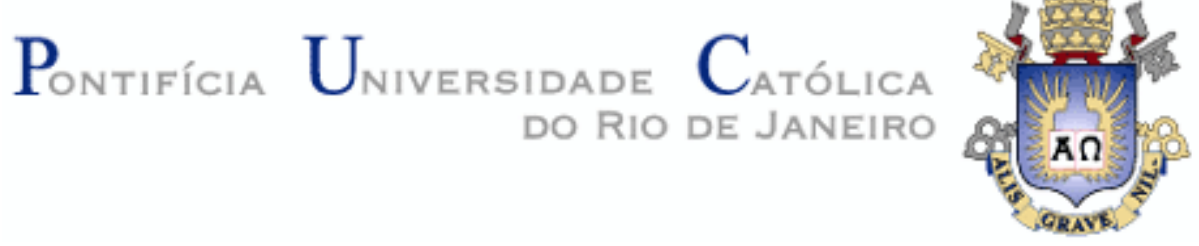

Vitor Eboli Lopes Paiva

\title{
Simulação de tensões residuais de soldagem e seu alívio por teste hidrostático
}

\section{Dissertação de Mestrado}

Dissertação apresentada como requisito parcial para obtenção do grau de Mestre pelo Programa de PósGraduação em Engenharia Mecânica do Departamento de Engenharia Mecânica do Centro Técnico Científico da PUC-Rio.

Orientador: Prof. José Luiz de França Freire 
Vitor Eboli Lopes Paiva

\title{
Simulação de tensões residuais de soldagem e seu alívio por teste \\ hidrostático
}

\begin{abstract}
Dissertação apresentada como requisito parcial para obtenção do grau de Mestre pelo Programa de Pós-Graduação em Engenharia Mecânica do Departamento de Engenharia Mecânica do Centro Técnico Científico da PUC-Rio. Aprovada pela comissão examinadora abaixo assinada.
\end{abstract}

Prof. José Luiz de França Freire Orientador Departamento de Engenharia Mecânica - PUC-Rio

Prof. Carlos Alberto de Almeida Departamento de Engenharia Mecânica - PUC-Rio

Prof. Valter Rocha dos Santos Departamento de Engenharia Química e de Materiais - PUC-Rio

Dr. Guilherme Victor Peixoto Donato CENPES - PETROBRAS

Prof. José Eugenio Leal Coordenador Setorial do Centro Técnico Científico - PUC-Rio 
Todos os direitos reservados. É proibida a reprodução total ou parcial do trabalho sem a autorização da universidade, do autor e do orientador.

\section{Vitor Eboli Lopes Paiva}

Graduou-se em engenharia mecânica em 2012 na Pontifícia Universidade Católica do Rio de Janeiro. Atua desde então na área de avaliação de integridade estrutural e análise de tensões com ênfase em simulação numérica utilizando elementos finitos.

Ficha Catalográfica

Paiva, Vitor Eboli Lopes

Simulação de tensões residuais de soldagem e seu alívio por teste hidrostático / Vitor Eboli Lopes Paiva; orientador: José Luiz de França Freire. - 2015.

275 f. : Il. (color) ; $30 \mathrm{~cm}$

Dissertação (mestrado)-Pontifícia Universidade Católica do Rio de Janeiro, Departamento de Engenharia Mecânica, 2015.

Inclui Bibliografia

1. Engenharia mecânica - Teses. 2. Tensões

Residuais. 3. Soldagem. 4. Método dos elementos finitos. 5. Gradientes de temperatura. 6. Alívio de tensões. I. Freire, José Luiz de França. II. Pontifícia Universidade Católica do Rio de Janeiro. Departamento de Engenharia Mecânica. III. Título. 


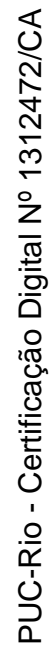

À meus pais, minha irmão, minhas avós e todos que torceram por mim. 


\section{Agradecimentos}

A Deus, pois sem ele não teria alcançado minhas metas.

A meus pais Geraldo e Maria pelo exemplo de caráter e de vida, que sempre foram para mim uma inspiração.

A meu irmão Fernando pelo companheirismo.

Ao meu Orientador, o professor José Luiz de França Freire, pela orientação e por todo o conhecimento compartilhado durante minha formação.

Aos professores Leonardo Dantas Rodrigues, da UFPA e Ronaldo Vieira, da PUC-Rio, pela ajuda na realização das medições experimentais utilizando a técnica de furo cego.

Ao Dr. Vladimir Ivanovitch Monine, pelo empréstimo dos espécimes estudados no Capítulo 5 e pelos dados das medições utilizando a técnica de difração de raios X.

Aos CNPq pelo apoio financeiro. 


\section{Resumo}

Paiva, Vitor Eboli Lopes; Freire, José Luiz de França. Simulação de tensões residuais de soldagem e seu alívio por teste hidrostático. Rio de Janeiro, 2015. 275p. Dissertação de Metrado - Departamento de Engenharia Mecânica, Pontifícia Universidade Católica do Rio de Janeiro.

A soldagem é o principal processo de união de componentes estruturais, sendo aplicado em larga escala na indústria. No entanto os ciclos térmicos existentes na soldagem geram nos componentes tensões e deformações residuais, que agem como solicitações pré-existentes, podendo ocasionar a falha prematura dos mesmos. As metodologias existentes para previsão das tensões residuais apenas quantificam conservadoramente esses esforços em um número limitado de geometrias. Nesse trabalho foi desenvolvida uma metodologia numérica usando o método de elementos finitos para a simulação da soldagem de componentes, com foco nas tensões, deformações e distorções causadas durante o processo. Os modelos estudados trataram da união de elementos planos, como chapas e painéis, da fabricação de elementos tubulares, como de dutos e de sua montagem em campo, e da união por soldagem das partes de um vaso de pressão. Foi estudada a influência de diversos parâmetros no comportamento da estrutura como: número de passes, velocidade de soldagem, comportamento do material, e influência do tratamento mecânico de alívio de tensões por meio da simulação de testes hidrostáticos aplicados aos componentes tubulares e ao vaso de pressão. No caso das placas unidas pela soldagem e dos tubos fabricados por este processo, a validade dos resultados obtidos foi feita por meio de medições experimentais realizadas com as técnicas de furo cego, corte elíptico e difração de raios X. Verificou-se uma boa concordância entre os resultados numéricos e experimentais, onde foi possível a obtenção de resultados experimentais para comparação. As simulações apontaram nos espécimes altos valores de tensões residuais, por vezes da ordem do limite de escoamento do material, sendo observada tração na região do cordão de solda e compressão em sua adjacência. Esse resultado é esperado uma vez que no cordão de solda são localizados os maiores gradientes de temperatura e as maiores restrições à expansão volumétrica. As simulações mostraram que a aplicação de um teste hidrostático tem como efeito benéfico para o componente a redistribuição das tensões residuais, com 
consequente diminuição das tensões residuais trativas nos cordões de solda. O grau do alívio das tensões é influenciado pelo valor da pressão de teste; sendo que, em geral, verificou-se que tanto maior a pressão de teste, tanto maior a redistribuição de tensões.

\section{Palavras-chave}

Tensões residuais; soldagem; método dos elementos finitos; gradientes de temperatura; alívio de tensões. 


\section{Abstract}

Paiva, Vitor Eboli Lopes; Freire, José Luiz de França (Advisor). Simulation of welding residual stress and its relief by hydrostatic test. Rio de Janeiro, 2015. 275p. MSc. Dissertation - Departamento de Engenharia Mecânica, Pontifícia Universidade Católica do Rio de Janeiro.

Welding is the main process to join structural components, being applied on a large scale and helping to increase productivity. However, the weld thermal cycles generate residual stresses and deformation, which act as pre-existing loads, and may cause premature failure. Existing methods only conservatively quantify these efforts on a limited number of geometries. In this work a numerical methodology was developed using the finite element method to simulate welding components, focusing on the stress, strains and distortions caused by process. The models studied dealt with the joining of elements such as plates and panels, the manufacturing of tubular elements such as pipelines and their assembly in the field, and the union by welding of parts of a pressure vessel.To understand the behavior of the structure the influence of various parameters were studied such as: number of weld beads, welding speed, material behavior, and the influence of a stress relief mechanical treatment through the simulation of hydrostatic tests applied to the tubular components and to the pressure vessel. In the two cases of the plates joined by welding and the pipes manufactured by this process, the validation of the results was performed by experimental measurements conducted using the blind hole, elliptical cut and X-ray diffraction techniques. Good agreement between the numerical and experimental results were verified, when was possible the knowledge of experimental results for comparison. The simulations indicated values of residual stress, sometimes in the order of the yield strength of the material, being observed traction in the weld bead and compression in its vicinity. This result is expected since that in the weld bead are located the largest temperature gradients and major restrictions on volume expansion. The simulations showed that the application of a hydrostatic test induces a beneficial effect to the component redistribution of residual stress, with consequent reduction of the tensile residual stresses in the weld beads. The degree of relief of tensile stress is influenced by the test pressure value; and, in general, it was found that the greater the test pressure, the greater the stress redistribution. 


\section{Keywords}

Residual Stress; welding; finite element method; temperature gradients; stress relief. 


\section{Sumário}

1 Introdução 30

1.1. Considerações Iniciais $\quad 30$

1.2. Objetivos 31

1.3. Trabalhos Importantes no Estudo das Tensões

Residuais Produzidas pela Soldagem 32

1.4. Software de Elementos Finitos Utilizado 40

1.5. Roteiro da Dissertação 41

2 Tensões Residuais 43

2.1. Tipos de Tensões Residuais 43

2.1.1. Tensões Residuais Macroscópicas 43

2.1.2. Tensões Residuais Microscópicas 44

2.1.3. Tensões Residuais Submicroscópicas 44

2.2. Influência das Tensões Residuais na Vida à

Fadiga dos Componentes Estruturais 45

2.3. Tensões Residuais na Soldagem 46

2.4. Técnicas de Medição de Tensões Residuais 48

2.4.1. Técnicas Destrutivas $\quad 49$

2.4.1.1. Técnica de Seccionamento 49

2.4.1.2. Técnica de Remoção de Camadas 50

2.4.1.3. Técnica do Anel Usinado 51

2.4.2. Técnicas Semi-destrutivas 51

2.4.2.1. Técnica do Furo Cego 52

2.4.3. Técnicas Não Destrutivas 54

2.4.3.1. Técnica de Difração de Raios X 54

2.4.3.2. Técnica de Ultra-som 55

2.4.3.3. Técnicas Magnéticas $\quad 56$

2.5. Métodos de Predição de Tensões Residuais 57

2.5.1. Método dos Elementos Finitos 57

2.5.2. Formulações Analíticas da Distribuição das Tensões Residuais $\quad 57$

2.5.2.1. Formulação de Masubuchi e Martin 58 
2.5.2.3. Formulação da API 579

2.6. Alívio de Tensões Residuais 61

2.6.1. Métodos de Alívio Térmicos 61

2.6.2. Métodos de Alívio Mecânicos 63

3 Análise Térmica do Processo de Soldagem 64

3.1. Fonte de Calor $\quad 67$

3.1.1. Temperatura do Cordão de Solda 71

3.1.2. Técnicas de "Morte" e "Nascimento" de Elementos 72

3.1.3. Soldagem com Múltiplos Cordões de Solda 73

3.1.4. Deposição do Cordão de Solda Levando em

Consideração os Efeitos da Velocidade

de Soldagem no Comportamento da Estrutura $\quad 75$

3.2. Transferência de Calor na Junta Soldada 76

3.2.1. Mecanismos de Troca de Calor $\quad 77$

3.2.1.1. Condução de Calor 78

3.2.1.2. Convecção 79

3.2.1.3. Radiação Térmica 82

3.3. Configurações do Modelo Térmico de Elementos Finitos 84

3.3.1. Propriedades do Material 84

3.3.1.1. Condutividade Térmica 84

3.3.1.2. Densidade 84

3.3.1.3. Calor Específico 85

3.3.2. Tipo de Elementos Utilizados 85

3.3.3. Malha $\quad 87$

3.3.4. Aplicação do Carregamento Térmico e Controle da Solução $\quad 88$

4 Análise Mecânica do Processo de Soldagem 89

4.1. Acoplamento Termomecânico 90

4.2. Plasticidade $\quad 91$

4.2.1. Comportamento Mecânico do Material 91 
4.2.2. Plasticidade no Software de Elementos Finitos 92

4.3. Campo de Tensões Durante a Soldagem 94

4.3.1. Desenvolvimento das Tensões Longitudinais 94

4.3.2. Desenvolvimento das Tensões Transversais 98

4.4. Campo de Tensões Residuais Após a Soldagem 99

4.4.1. Desenvolvimento das Tensões

Residuais Longitudinais $\quad 99$

4.4.2. Desenvolvimento das Tensões

Residuais Transversais

101

4.5. Desenvolvimento das Tensões Residuais

Considerando a Hipótese das Três Barras

103

4.5.1. Aplicação de um Tratamento de Alívio

de Tensões

105

4.6. Uso de um Gráfico Bilinear com uma Variação

de Temperatura Pequena

108

4.7. Influência de Múltiplos Cordões de Solda nas

Tensões Residuais

109

4.8. Influência da Velocidade de Soldagem nas

Tensões Residuais

110

4.9. Configurações do Modelo Estrutural de

Elementos Finitos

113

4.9.1. Propriedades do Material 113

4.9.1.1. Limite de Escoamento 113

4.9.1.2. Módulo de Elasticidade 114

4.9.1.3. Coeficiente de Expansão Térmica 114

4.9.2. Análise Mecânica Não Linear 115

4.9.3. Tipo de Elementos Utilizados 116

4.9.4. Malha 118

4.9.5. Aplicação do Carregamento Térmico,

Condições de Contorno e Controle da Solução 118

5 Soldagem de Elementos Planos $\quad 119$

5.1. Modelos Estudados 119

5.1.1. Malha do Modelo 123 
5.1.2. Configuração dos Passos Tempo

5.1.3. Condições de Contorno Térmicas 125

5.1.4. Condições de Contorno Mecânicas 125

5.2. Medições Experimentais 126

5.2.1. Técnica do Furo Cego 126

5.2.1.1. Preparação da Superfície 127

5.2.1.2. Colagem, Cabeamento e Teste das Rosetas $\quad 128$

5.2.1.3. Balanceamento e Calibração do Indicador 129

5.2.1.4. Alinhamento da Guia de Furação 129

5.2.1.5. Execução do Furo 130

5.2.1.6. Tratamento dos Dados

(Segundo a Norma ASTM E837) 131

5.2.2. Técnica de Difração de Raios-X 134

5.3. Resultados 137

5.3.1. Modelo das Chapas Livres $\quad 140$

5.3.2. Modelo das Chapas com Restrição 144

6 Soldagem de Elementos Tubulares 149

6.1. Processo de Fabricação UOE 150

6.2. Montagem no Campo 152

6.3. Modelos Estudados 153

6.4. Modelo Numérico da Fabricação do Tubo 154

6.4.1. Geometria do Modelo 155

6.4.2. Malha do Modelo 156

6.4.3. Configuração dos Passos Tempo 158

6.4.4. Condições de Contorno Térmicas 159

6.4.5. Condições de Contorno Mecânicas 159

6.4.6. Comportamento do Tubo Durante as

Etapas de Dobramento 160

6.4.7. Simulação dos Cordões de Solda 163

6.4.8. Medições Experimentais 163

6.4.9. Comparação de Resultados 164

6.5. Modelo Numérico da Montagem de Campo 182

6.5.1. Geometria do Modelo 183 
6.5.2. Malha do Modelo 184

6.5.3. Configuração dos Passos Tempo 185

6.5.4. Condições de Contorno Térmicas 187

6.5.5. Condições de Contorno Mecânicas 187

6.5.6. Resultados 188

7 Fabricação de Vasos de Pressão 205

7.1. Fabricação dos Vasos de Pressão 206

7.2. Vaso de Pressão Estudado 207

7.3. Modelo Numérico da Fabricação do Vaso 210

7.3.1. Geometria do Modelo 211

7.3.2. Malha do Modelo 213

7.3.3. Definição da Pressão de Teste Hidrostático 214

7.3.4. Análise de Tensões no Vaso Devido

à Pressão Interna 216

7.3.5. Configuração dos Passos Tempo 221

7.3.6. Condições de Contorno Térmicas 221

7.3.7. Condições de Contorno Térmicas 222

7.4. Resultados 222

8 Conclusões e Sugestões para Trabalhos Futuros 238

8.1. Conclusões 238

8.2. Sugestões para trabalhos futuros 239

8 Referências Bibliográficas $\quad 240$

$\begin{array}{ll}\text { Bibliografia Sugerida } & 248\end{array}$

Apêndice A - Comparação Entre Técnicas Experimentais de Medição de Tensões Residuais 249

Apêndice B - Modelos Analíticos de Fontes de Calor 250

B.1 Fonte de Calor Pontual 250

B.2 Fonte de Calor Superficial 251 
Apêndice C - Problema da Barra em Flexão Pura

Apêndice D - Comparação Entre as Soluções Analítica

e Numérica para o Problema das Três Barras

Apêndice $\mathrm{E}$ - Soldagem de um vaso de pressão

considerando uma curva bilinear e um gradiente de temperatura pequeno 


\section{Lista de figuras}

Figura 1.1: Comparação entre as tensões radiais

e circunferenciais residuais no disco

Figura 1.2: Comparação entre as tensões longitudinais medidas e as simuladas via MEF

Figura 1.3: Comparação das tensões longitudinais ao longo da superfície. 35

Figura 1.4: Forma do botão de solda no fim da soldagem,. 35

Figura 1.5: Tensões residuais medidas no tubo 36

Figura 1.6: Configuração do modelo de EF e tensões residuais equivalentes.

Figura 1.7: Configuração do modelo 3D de EF. 39

Figura 2.1: Distribuição das tensões residuais ao longo de vários grãos de um material policristalino e suas tensões separadas em macroscópicas, microscópicas e submicroscópicas.

Figura 2.2: (a) Tensão residual mostrada em um diagrama de Gerber; (b) Efeito da tensão residual trativa na tensão média; (c) Efeito da tensão residual compressiva na tensão média.

Figura 2.3: Curvas de fadiga para uma solda de topo de aço de baixo carbono: Curva 1 - sem tensões residuais; Curva 2 - com tensões residuais trativas (sem tratamentos de alívio de tensão); Curva 3 - com tensões residuais compressivas (após shot pening)

Figura 2.4: Perfil de tensões residuais na direção longitudinal e transversal de uma solda de topo

Figura 2.5: Distorções em componente com uma solda de topo devido à contração nas diversas direções.

Figura 2.6: Técnica de seccionamento aplicada em uma placa.

Figura 2.7: Técnica de seccionamento com corte transversal de uma chapa, (a) Estado original de tensões;

(b) Corte transversal; (c) Forças analíticas utilizadas para o calculo das tensões residuais. 
Figura 2.8: Parâmetros envolvidos na técnica de remoção de camadas.

Figura 2.9: Técnica do anel usinado acoplado com uma técnica ótica de medição de deformações, (a) antes da usinagem; (b) depois da usinagem.

Figura 2.10: Estado de tensões resultante do alívio provocado pela usinagem do furo.

Figura 2.11: Estado de tensões em um ponto $P(R, \alpha)$,

(a) antes da usinagem do furo; (b) depois da usinagem do furo.

Figura 2.12: Técnica do furo cego acoplada a técnicas experimentais de medição de tensão, (a-a') Moiré; (b) DIC; (c) Extensometria elétrica

Figura 2.13: Distâncias interplanares de grãos com diferentes orientações em um componente sem tensões.

Figura 2.14: Configurações esquemáticas da técnica de ultra-som, (a) através da espessura, pulso-eco;

(b) através da espessura, pitch-catch;

(c) pela superfície pitch-catch. 56

Figura 2.15: Estrutura dos domínios num material policristalino

Figura 2.16: Típicas Distribuições de tensão residuais de uma solda de topo: (a) Tensão longitudinal,

(b) Tensão transversal. 58

Figura 2.17: Distribuições de tensão residuais pela espessura de uma solda de topo segundo a norma BS7910: (a) Tensão longitudinal, (b) Tensão transversal.

Figura 2.18: Distribuições de tensão residuais pela superfície segundo a norma API 579 .

Figura 2.19: Tensões residuais em uma junta soldada:

a) sem reparo e sem tratamento de alívio; b) reparada sem tratamento de alívio; c) reparada com tratamento de alívio de tensões.

Figura 2.20: Distribuição de tensões em uma placa com solda de topo quando submetida a um carregamento externo.

Figura 3.1: Geometrias com distribuição de temperatura conhecida. 
Figura 3.2: Fluxograma para o estudo da soldagem.

Figura 3.3: Hipótese das três barras para simulação da soldagem.

Figura 3.4: Arco elétrico com eletrodo de tungstênio e gás de proteção de hélio em chapa de cobre resfriada por água.

Figura 3.5: Representação esquemática do arco elétrico e das formas de transferência de calor para a peça.

Figura 3.6: Cordão de solda representando a fonte de calor volumétrica no início da simulação e após 1 segundo transcorrido.

Figura 3.7: Resultados Térmicos obtidos com a formulação de Adam: a) Ciclos Térmicos; b) Isotérmicas das temperaturas.

Figura 3.8: Soldagem de duas chapas utilizando múltiplos passes: (a) Esquemático da sequência dos passes;

(b) Passe de raiz, único que não é desativado no início;

(c) Ativação do $2^{\circ}$ passe; (d) Ativação do $3^{\circ}$ passe;

(e) Ativação do $4^{\circ}$ passe. 74

Figura 3.9: Distribuição de temperaturas e comportamento de duas chapas soldadas com o cordão de solda sendo depositado aos poucos

Figura 3.10 - Correlação da máxima temperatura por região na ZAC. 77

Figura 3.11: Desenvolvimento de uma camada limite sob uma placa plana.

Figura 3.12: Elemento 3D SOLID90 86

Figura 3.13: Esquemático da percepção do contato entre as superfícies.

Figura 3.14: Elemento 3D SURF152.

Figura 3.15: Malha de elementos finitos de uma junta em "V".

Figura 4.1: Curvas tensão - deformação utilizadas:

a) Curva bilinear; b) Curva multilinear 92 
Figura 4.2: Representação esquemática do endurecimento isotrópico.

Figura 4.3: Representação da curva tensão deformação fornecida ao programa

Figura 4.4: Comportamento das tensões em um sólido prismático elementar: a) Diagrama tensão - deformação idealizado; b) Tensões longitudinais desenvolvidas ao longo do tempo; c) Curva da dilatação volumétrica do material; d) Ciclo térmico a que o prisma é submetido

Figura 4.5: Representação esquemática do desenvolvimento da temperatura e das tensões durante a soldagem de uma chapa: a) Esquemático do processo de soldagem;

b) Distribuição das tensões longitudinais pela chapa;

c) Distribuição de temperatura pela chapa.

Figura 4.6: Zonas plásticas de compressão e tração; Ciclos de tensão e deformação em campo de temperatura em regime permanente de uma fonte de calor móvel.

Figura 4.7: Representação esquemática do desenvolvimento das tensões durante a deposição de um cordão de solda em uma chapa: a) Esquemático do processo de soldagem;

b) Distribuição das tensões transversais pela chapa.

Figura 4.8: Tensões residuais longitudinais em uma chapa de:

a) Aço carbono; b) Aço martensítico; c) Aço austenítico.

Figura 4.9: Distribuição 3D das tensões residuais longitudinais em uma chapa.

Figura 4.10: Tensões residuais transversais em chapas:

a) com restrição transversal; b) sem restrição transversal. 102

Figura 4.11: Distribuição 3D das tensões residuais transversais de duas placas soldadas.

Figura 4.12: Representação esquemática da soldagem utilizando a hipótese das três barras. 103

Figura 4.13: Tensões na barra 1 e em uma das barras 2 após a soldagem.

Figura 4.14: Tensões no tratamento de alívio de tensão. 106

Figura 4.15: Tensões nas barras após o tratamento de alívio de tensão. 
Figura 4.16: Tensões residuais equivalentes (MPa) após a soldagem de um flange em um tubo utilizando uma curva bilinear e um gradiente térmico pequeno.

Figura 4.17: Representação esquemática da junta e tensões residuais equivalentes ( $\mathrm{MPa}$ ) na soldagem com múltiplos passes.

Figura 4.18: Soldagem de duas chapas pequenas com velocidade alta: a) Distribuição de temperaturas $\left({ }^{\circ} \mathrm{C}\right)$ na deposição do último segmento de cordão; b) Distribuição de tensões residuais longitudinais (MPa); c) Distribuição de tensões residuais equivalentes $(\mathrm{MPa})$.

Figura 4.19: Soldagem de duas chapas grandes com velocidade baixa: a) Distribuição de temperaturas $\left({ }^{\circ} \mathrm{C}\right)$ na deposição do último segmento de cordão; b) Distribuição de tensões residuais longitudinais (MPa); c) Distribuição de tensões residuais equivalentes (MPa).

Figura 4.20: Aplicação do método de Newton - Raphson a um incremento de carga.

Figura 4.21:Convergência do método de Newton - Raphson.

Figura 4.22: Elemento 3D SOLID186

Figura 5.1: Modelos das chapas estudas: a) Chapas sem soldagem; b) $1^{\circ}$ modelo, chapas livres; c) $2^{\circ}$ modelo, chapas com restrições ao deslocamento

Figura 5.2: Variação das propriedades térmicas e mecânicas do aço inoxidável Duplex 2205 com a temperatura.

Figura 5.3: Dimensões de uma das chapas.

Figura 5.4: Geometria do modelo das chapas para simulação da soldagem de topo.

Figura 5.5: Configurações da malha para as análises:

a) Malha; b) Histograma da qualidade dos elementos;

c) Histograma da razão de aspecto dos elementos.

Figura 5.6: Fluxograma com as etapas da aplicação da técnica do furo cego.

Figura 5.7: Disposição dos extensômetros elétricos nos modelos.

Figura 5.8: Cabeamento das rosetas. 128 
Figura 5.9: Condicionador de sinais Vishay P3.

Figura 5.10: Guia de furação e seu alinhamento.

Figura 5.11: Vista da roseta extensômetrica antes e depois da furação.

Figura 5.12: Configuração da roseta tipo A.

Figura 5.13: Esquema da medição por difração de raios X para: (a) $\psi=0$; (b) e $\psi>0$. 1 - tubo de raios $X ; 2$ e 3 - raio incidente e difratado; 4 - amostra analisada; 5 - perfil da linha de difração.

Figura 5.14: Funções $\theta_{\psi}=f\left(\operatorname{sen}^{2} \psi\right)$ no método de " $\left(\operatorname{sen}^{2} \psi\right)$ ". 136

Figura 5.15: Vista geral do aparelho de raios $X: 1-$ ampola de raios $X$; 2 - colimador ponteira; 3 - chapa de aço duplex medida; 4 - detector de raios X; 5 - bloco de controle de funcionamento de detector.

Figura 5.16: Distribuição de temperaturas na junta durante a deposição de cada passe de solda.

Figura 5.17: Temperaturas máximas ao longo do tempo na junta.

Figura 5.18: Distribuição de temperatura no instante de 15000 s.

Figura 5.19: Distribuição de tensões residuais: a)Tensões equivalentes; b) Tensões longitudinais;

c) Tensões transversais.

Figura 5.20: Distribuição de tensões residuais no Caminho 1 após a soldagem

Figura 5.21: Comparação das tensões residuais obtidas no Caminho 1 por diferentes métodos numéricos.

Figura 5.22: Comparação entre as tensões residuais medidas pela técnica furo cego e as simuladas via MEF no Caminho 1

Figura 5.23: Comparação entre as medições realizadas pela técnica furo cego e pela difração de raios $X$ no Caminho 1 
Figura 5.24: Distribuição de tensões residuais: a)Tensões equivalentes; b) Tensões longitudinais; c) Tensões transversais.

Figura 5.25: Distribuição de tensões residuais no Caminho 1 após a soldagem.

Figura 5.26: Comparação entre as tensões residuais medidas pela técnica furo cego e as simuladas via MEF no Caminho 1

Figura 5.27: Comparação entre as medições realizadas pela técnica furo cego e pela difração de raios $X$ no Caminho 1

Figura 6.1: Processo UOE: a) Prensagem das bordas da chapa; b) Prensa U;

Figura 6.2: Soldagem de campo de tubos, com dois soldadores utilizando eletrodo revestido.

Figura 6.3: Soldagem de tubos em alto mar utilizando um processo automatizado.

Figura 6.4: Variação das propriedades térmicas e mecânicas do aço API 5L X60 com a temperatura.

Figura 6.5: Geometria do modelo do tubo para simulação da soldagem e do teste hidrostático

Figura 6.6: Malha da análise considerando três barras:

a) Malha; b) Histograma da qualidade dos elementos;

c) Histograma da razão de aspecto dos elementos.

Figura 6.7: Malha da análise considerando múltiplos segmentos: a) Malha; b) Histograma da qualidade dos elementos; c) Histograma da razão de aspecto dos elementos

Figura 6.8: Modelo da conformação das bordas da chapa:

a) Estado inicial; b) Estado final após a prensagem;

c) Tensões efetivas no estado final; d) Deformações plásticas efetivas no estado final.

Figura 6.9: Modelo da conformação da chapa em U:

a) Estado inicial; b) Deslocamento vertical máximo do punção; c) Deslocamento horizontal dos roletes; d) Tensões efetivas no estado final; e) Deformações plásticas efetivas no estado final. 
Figura 6.10: Modelo da conformação da chapa em O:

a) Estado inicial; b) Deslocamento vertical máximo da matriz superior; c) Tensões efetivas no estado final; $d$ ) Deformações plásticas efetivas no estado final.

Figura 6.11: Comportamento na direção circunferencial durante as etapas de dobramento: a) Tensão circunferencial após a prensagem das bordas; a') Deformação circunferencial após a prensagem das bordas; b) Tensão circunferencial após a prensagem em U; b') Deformação circunferencial após a prensagem em U; c) Tensão circunferencial após a prensagem em O; c') Deformação circunferencial após a prensagem em O; d) Escala das tensões; d) Escala das deformações.

Figura 6.12: Rosetas extensométricas utilizadas na técnica do furo cego.

Figura 6.13: Extensômetro e cortes utilizados na técnica do furo elíptico.

Figura 6.14: Distribuição de temperaturas no tubo para o modelo das três barras no instante de 1s de simulação.

Figura 6.15: Distribuição de temperaturas na junta soldada para o modelo das três barras no instante de 1 s de simulação.

Figura 6.16: Temperatura em um ponto na superfície e centro do cordão de solda ao longo do tempo.

Figura 6.17: Evolução da distribuição de temperaturas no tubo para o modelo dos múltiplos segmentos.

Figura 6.18: Comparação da evolução da temperatura em um mesmo ponto nos dois modelos.

Figura 6.19: Distribuição de temperatura para ambos os modelos no instante de 5000s

Figura 6.20: Distribuição de tensões residuais considerando

a hipótese das três barras: a)Tensões equivalentes;

b) Tensões longitudinais; c) Tensões circunferenciais;

d) Tensões radiais.

Figura 6.21: Deslocamento na direção longitudinal após a soldagem, 5000s.

Figura 6.22: Distribuição de tensões residuais no Caminho 1 em 5000s para a hipótese das três barras. 
Figura 6.23: Comparação entre as distribuições de tensões

residuais nos Caminho 1 e Caminho 2.............................................172

Figura 6.24: Distribuições de tensões residuais ao longo

da espessura no Caminho 1: a) Longitudinal; b) Circunferencial;

c) Radial

Figura 6.25: Comparação das distribuições de tensões residuais obtidas através das hipóteses das três barras e dos múltiplos segmentos no Caminho 1

Figura 6.26: Tensões no tubo durante a realização do teste hidrostático de $90 \%$ de Sy na direção circunferencial.

Figura 6.27: Comparação da distribuição de tensões residuais antes e após a realização do teste hidrostático de $90 \%$ de Sy na direção circunferencial.

Figura 6.28: Comparação das distribuições de tensões residuais após a realização do teste hidrostático de $90 \%$ de Sy na direção circunferencial para as hipóteses das três barras e dos múltiplos segmentos no Caminho 1

Figura 6.29: Distribuição das tensões residuais no Caminho 3 antes, durante e após a realização do teste hidrostático para a hipótese dos múltiplos segmentos.

Figura 6.30: Variação das distribuições das tensões residuais após a aplicação dos diferentes testes hidrostáticos.

Figura 6.31: Comparação entre as tensões residuais medidas pelo furo cego e as simuladas via MEF no Caminho 1.

Figura 6.32: Comparação entre as tensões residuais medidas pelo furo elíptico e as simuladas via MEF no Caminho 1.

Figura 6.33: Geometria do modelo para simulação da soldagem circunferencial de campo e do teste hidrostático após a união.

Figura 6.34: Malha da análise considerando o único cordão:

a) Malha; b) Histograma da qualidade dos elementos;

c) Histograma da razão de aspecto dos elementos.

Figura 6.35: Malha da análise considerando múltiplos passes:

a) Malha; b) Histograma da qualidade dos elementos;

c) Histograma da razão de aspecto dos elementos. 185

Figura 6.36: Distribuição de temperaturas nos tubos para as duas hipóteses no instante de 1s de simulação. 
Figura 6.37: Temperatura no Ponto 1 ao longo do tempo para a hipótese do único cordão.

Figura 6.38: Distribuição de temperatura nos tubos para ambas as análises no instante de 5003s.

Figura 6.39: Distribuição de temperaturas na linha de transporte para a hipótese do único cordão no instante de 5004s de simulação.

Figura 6.40: Temperatura no Ponto 2 ao longo do tempo para a hipótese do único cordão.

Figura 6.41: Temperatura no Ponto 3 ao longo do tempo para a hipótese do único cordão.

Figura 6.42: Temperaturas máximas ao longo do tempo para a hipótese dos múltiplos cordões de solda.

Figura 6.43: Distribuição de temperaturas na junta para a hipótese do único cordão de solda.

Figura 6.44: Distribuição de temperaturas na junta para a hipótese dos múltiplos passes.

Figura 6.45: Distribuição de temperatura para ambas as análises no instante de 10018s

Figura 6.46: Comparação das distribuições de tensões equivalentes no modelo da fabricação do tubo com a hipótese das três barras e nos modelos de montagem de campo no tempo de 5000 s.

Figura 6.47: Distribuição de tensões residuais após a soldagem de campo considerando a hipótese do único cordão: a)Tensões equivalentes; b) Tensões longitudinais; c) Tensões circunferenciais; d) Tensões radiais.

Figura 6.48: Distribuição de tensões residuais no Caminho 4 em 10016s, para a hipótese do único cordão.

Figura 6.49: Distribuição de tensões residuais no Caminho 5 em 10016s, para a hipótese do único cordão.

Figura 6.50: Distribuição de tensões residuais no Caminho 6 em 10016s, para a hipótese do único cordão.

Figura 6.51: Distribuição de tensões nos Caminhos 4, 5 e 6 durante a realização do teste hidrostático de campo, para a hipótese do único cordão. 
Figura 6.52: Distribuição de tensões residuais antes e após a realização do teste hidrostático de campo no Caminho 4, para a hipótese do único cordão. 200

Figura 6.53: Distribuição de tensões residuais antes e após a realização do teste hidrostático de campo no Caminho 5, para a hipótese do único cordão.

Figura 6.54: Distribuição de tensões residuais antes e após a realização do teste hidrostático de campo no Caminho 6, para a hipótese do único cordão.

Figura 6.55: Comparação entre as distribuições de tensões residuais equivalentes para as duas hipóteses de união de campo no final da simulação. 202

Figura 6.56: Comparação das tensões residuais ao longo do Caminho 5, para as duas hipóteses analisadas no instante de $10018 \mathrm{~s}$ 203

Figura 6.57: Comparação das tensões residuais ao longo da espessura na junta circunferencial, para as duas hipóteses analisadas no instante de 10018s. 204

Figura 7.1: Desenho técnico do vaso VP-CTVP-E-01 parte 1..............207

Figura 7.2: Desenho técnico do vaso VP-CTVP-E-01 parte 2...............208

Figura 7.3: Variação das propriedades térmicas e mecânicas do aço 209

Figura 7.4: Numeração das juntas soldadas estudadas 209

Figura 7.5: Geometria do modelo do vaso com $1 / 2$ de simetrias, vista isométrica.

Figura 7.6: Geometria do modelo do vaso com $1 / 2$ de simetrias, vista frontal.

Figura 7.7: Formato das juntas soldadas estudadas ( ver

Figura 7.4 e Tabela 7.2).

Figura 7.8: Malha do modelo do vaso: a) Malha; b) Histograma da qualidade dos elementos; c) Histograma da razão de aspecto dos elementos.

Figura 7.9: Variáveis dimensionais do vaso usadas para a análise das tensões. 
Figura 7.10: Distribuição de tensões no vaso devido à pressão interna.

Figura 7.11: Comportamento do vaso devido à pressão interna em uma escala aumentada de 100 vezes.

Figura 7.12: Diagrama de corpo livre do vaso 220

Figura 7.13: Distribuição de temperaturas no vaso nos instantes de $1 \mathrm{~s}, 5001 \mathrm{~s}$, e 10001s respectivamente. 223

Figura 7.14: Temperaturas máximas ao longo do tempo. 224

Figura 7.15: Distribuição de temperaturas em de 5000s, 10000 s e 15000s. 225

Figura 7.16: Distribuição de tensões residuais: a)Tensões equivalentes;

Figura 7.17: Distribuição de tensões residuais no Caminho 1 em 15000s.

Figura 7.18: Distribuição de tensões residuais equivalentes no vaso durante a realização do $\mathrm{TH}$.

Figura 7.19: Tensões no vaso durante a realização do teste hidrostático 229

Figura 7.20: Comparação da distribuição de tensões residuais antes e após a realização do $\mathrm{TH}$

Figura 7.21: Distribuição de tensões residuais equivalentes no vaso após o $\mathrm{TH}$. 230

Figura 7.22: Comparação entre as tensões residuais nos pontos estudados antes e após o TH.

Figura 7.23: Comparação entres tensões residuais circunferenciais e longitudinais antes e após a realização de cada um dos testes hidrostático nos pontos $\mathrm{P} 1$, P2, P3, P4 e P5.

Figura 7.24: Comparação entres tensões residuais circunferenciais e longitudinais antes e após a realização de cada um dos testes hidrostático nos pontos $\mathrm{P} 6, \mathrm{P} 7$, P8, P9 e P10. 
Figura 7.25: Comparação entres tensões residuais circunferenciais e longitudinais antes e após a realização de cada um dos testes hidrostático nos pontos $\mathrm{P} 11, \mathrm{P} 12, \mathrm{P} 13$ e P14. . 


\section{Lista de tabelas}

Tabela 3.1: Eficiência de cada processo de soldagem. ..........................69

Tabela 3.2 - Valores típicos do coeficiente de convecção........................82

Tabela 5.1: Parâmetros de soldagem das chapas. ...............................120

Tabela 5.2: Propriedades do aço Duplex 2205 à temperatura ambiente.

Tabela 5.3: Duração de cada passo de tempo.....................................124

Tabela 5.4: Determinação dos coeficientes $\bar{a}$ e $\bar{b}$

para rosetas do Tipo $A$,

Tabela 5.5: Posicionamento do ângulo principal $\beta$, [12].......................133

Tabela 6.1: Propriedades do aço Duplex 2205 à

temperatura ambiente.

Tabela 6.2: Duração de cada passo de tempo......................................158

Tabela 6.3: Lista de pressões utilizadas na simulação

do teste hidrostático.

Tabela 6.4: Duração de cada passo de tempo. 186

Tabela 7.1: Propriedades do aço ASTM A515 Gr.60 à temperatura ambiente. 208

Tabela 7.2: Eficiência das Juntas Soldadas. 210

Tabela 7.3: Pressões máximas admissíveis para cada seção do vaso.

Tabela 7.4: Tensões longitudinais e circunferências para as pressões de projeto e de $\mathrm{TH}$.

Tabela 7.5: Valores das variáveis dimensionais.

Tabela 7.6: Comparação entre as tensões simuladas e calculadas analiticamente.

Tabela 7.7: Duração de cada passo de tempo. 221

Tabela 7.8: Tensões nos pontos estudados. 231

Tabela 7.9: Tensões nos pontos estudados para as

$\mathrm{P}_{\mathrm{TH}}$ iguais a $2 \mathrm{MPa}$ e $3.5 \mathrm{MPa}$ 


\section{Introdução}

\subsection{Considerações Iniciais}

A soldagem é o principal processo de união de metais, tendo papel fundamental em diferentes setores da indústria. Durante o processo de soldagem ocorre um aquecimento altamente não uniforme das partes a serem unidas. As seções da peça próximas ao aporte térmico são aquecidas até temperaturas extremamente elevadas e, em seguida, são resfriadas pela troca de calor entre a junta e o ambiente e entre a junta e as seções com temperaturas mais baixas. Os ciclos térmicos localizados induzem na estrutura soldada mudanças volumétricas produzindo tensões transientes e residuais. As tensões produzidas na soldagem e as deformações são fenômenos estreitamente relacionados. Durante o aquecimento e o resfriamento, deformações térmicas que ocorrem na junta e nas áreas adjacentes são caracterizadas por um comportamento elastoplástico do material.

As juntas soldadas são as regiões mais críticas da estrutura no que se refere a mecanismos de danos tais como: fadiga e trincas induzidas pelo ambiente, que se desenvolvem na presença de tensões residuais e de concentrações de tensão. As distorções causadas pela soldagem introduzem diversos problemas nas estruturas, como por exemplo: montagem problemática, perda de resistência e perda de qualidade. $\mathrm{O}$ conhecimento dos esforços atuantes nas juntas soldadas, causados por tensões residuais e/ou por carregamentos externos, tem como objetivo principal avaliar se a estrutura está operando dentro dos limites seguros. Assim é de suma importância o conhecimento do estado de tensões internas na junta soldada e nas condições que levam ao seu surgimento. 
Mesmo sabendo que as tensões residuais atuam de maneira decisiva na integridade estrutural de um componente mecânico, sua quantificação e consideração não é normalmente feita no projeto da estrutura. Isso se deve em parte ao fato das soluções analíticas usadas para quantificar as distribuições de tensões residuais em peças soldadas presentes na literatura só serem aplicadas a uma quantidade finita de geometrias, em geral chapas, e por serem por demais simplistas.

O método de elementos finitos (MEF) pode ser uma eficaz e eficiente ferramenta na previsão das tensões residuais geradas durante a soldagem, sendo capaz de prever tensões residuais e deformações no componente, tanto internamente como na superfície ao longo do tempo. Um dos diferencias da utilização do MEF é sua aplicabilidade a qualquer estrutura, podendo ser um modelo de simulação 2D ou 3D. Outros parâmetros como a aplicação de carregamentos e tratamentos de alívio de tensões após a soldagem também podem ser mensurados através desse método.

\subsection{Objetivos}

O objetivo principal desse trabalho foi desenvolver uma metodologia para simular e analisar a geração de tensões residuais produzidas pela soldagem em componentes com geometria complexa utilizando uma modelagem 3D por meio do MEF com propriedades térmicas e mecânicas variantes com a temperatura.

Também foram estudados os seguintes tópicos:

1) Desenvolvimento e teste de diferentes hipóteses para a simulação da soldagem, levando em consideração parâmetros como: velocidade de soldagem, número de passes de solda, diferentes aportes de calor, formato do cordão de solda e comportamento mecânico do material.

2) Estudo da influência da aplicação de diferentes tratamentos de alívio de tensões após o término da soldagem na distribuição das tensões residuais no componente.

3) Comparação entre medições experimentais obtidas através de diferentes técnicas e as tensões simuladas numericamente e calculadas analiticamente. 


\subsection{Trabalhos Importantes no Estudo das Tensões Residuais Produzidas pela Soldagem}

O trabalho aqui desenvolvido é a continuação de uma linha de pesquisa, que já vem sendo desenvolvida ao longo dos últimos anos, cujo objetivo é analisar a geração de tensões residuais em componentes submetidos a gradientes de temperatura.

A seguir serão apresentados os resumos de algumas publicações e trabalhos julgados relevantes para mostrar o panorama das pesquisas relacionadas ao tema estudado. Estes trabalhos foram julgados representativos das principais linhas de pesquisa desenvolvidas atualmente, que tem como propósito simular, medir e avaliar as tensões residuais que surgem em componentes soldados.

PAIVA, Vitor E. L., RODRIGUES, Leonardo D. e FREIRE, José L.F., em [60], desenvolveram um modelo numérico para analisar quantitativamente a distribuição e o comportamento das tensões residuais geradas a partir de gradientes de temperatura aplicados em um disco maciço, resultantes do aquecimento do seu ponto central.

Simulou-se através do software ANSYS, que utiliza o método de elementos finitos, o aquecimento e o resfriamento do disco a partir da imposição de um acréscimo de temperatura no seu ponto central. O cálculo e a análise das tensões e deformações causadas no disco foram feitos ao longo do tempo e levaram em consideração a plasticidade gerada pelos severos gradientes de temperatura. Neste trabalho as propriedades do material foram consideradas constantes com a temperatura.

Os resultados obtidos apontaram altos valores de tensões residuais no centro do disco, por vezes da ordem do limite de escoamento do material, Figura 1.1. Este é um resultado válido, pois no centro são localizados os maiores gradientes de temperatura e as maiores restrições à expansão volumétrica. 


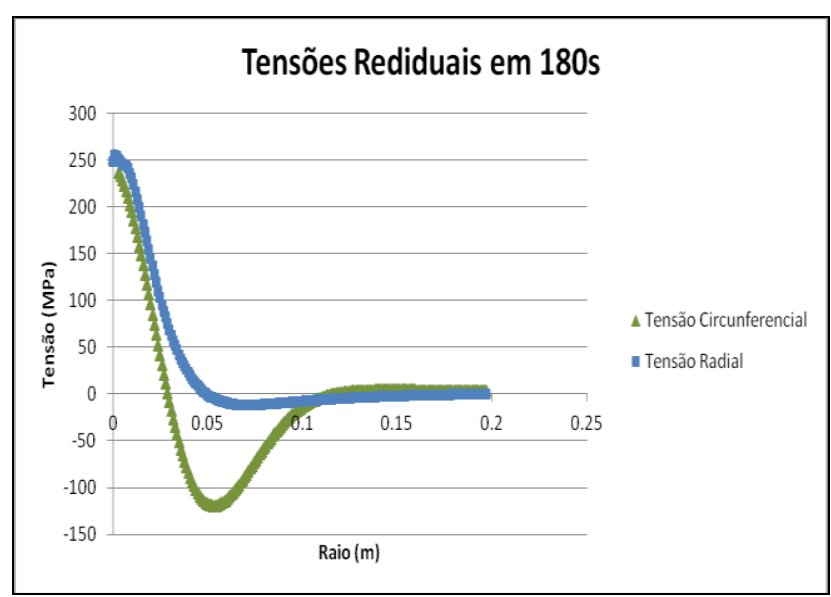

Figura 1.1: Comparação entre as tensões radiais e circunferenciais residuais no disco, [60].

PAIVA, Vitor E. L., RODRIGUES, Leonardo D., FREIRE, José L.F. e DELGADILLO, Gilmar W. R., em [54], analisaram as tensões residuais geradas a partir da soldagem longitudinal de fabricação em um tubo API 5L X60. Um modelo numérico foi desenvolvido e os resultados obtidos foram comparados com medições experimentais.

$\mathrm{Na}$ etapa numérica foi simulado o aquecimento e o resfriamento da região da união soldada. A solução do problema foi feita por meio do software ANSYS. O cálculo e a análise das tensões e deformações causadas na união soldada foram feitos ao longo do tempo e levaram em consideração a plasticidade gerada no material base e de solda, causada pelos elevados gradientes de temperatura, sendo considerada a variação das propriedades térmicas e mecânicas do material com a temperatura.

As soluções numéricas foram comparadas com resultados experimentais baseados em medições de tensões residuais que utilizaram os métodos extensométricos do furo cego e do corte retangular (furo elítico alongado).

Como não foi simulado o processo de dobramento do tubo, as tensões residuais determinadas numericamente são originárias apenas do processo de soldagem, não sendo possível comparar as tensões residuais circunferenciais medidas com as simuladas.

Foi possível prever a magnitude das tensões residuais longitudinais causadas pela soldagem de componentes. De um modo geral, as simulações e medições realizadas no tubo analisado apontaram altos valores de tensões residuais, por vezes da ordem do limite de escoamento do material, Figura 1.2. 
Esse resultado é válido, pois no cordão de solda são localizados os maiores gradientes de temperatura e as maiores restrições à expansão volumétrica.

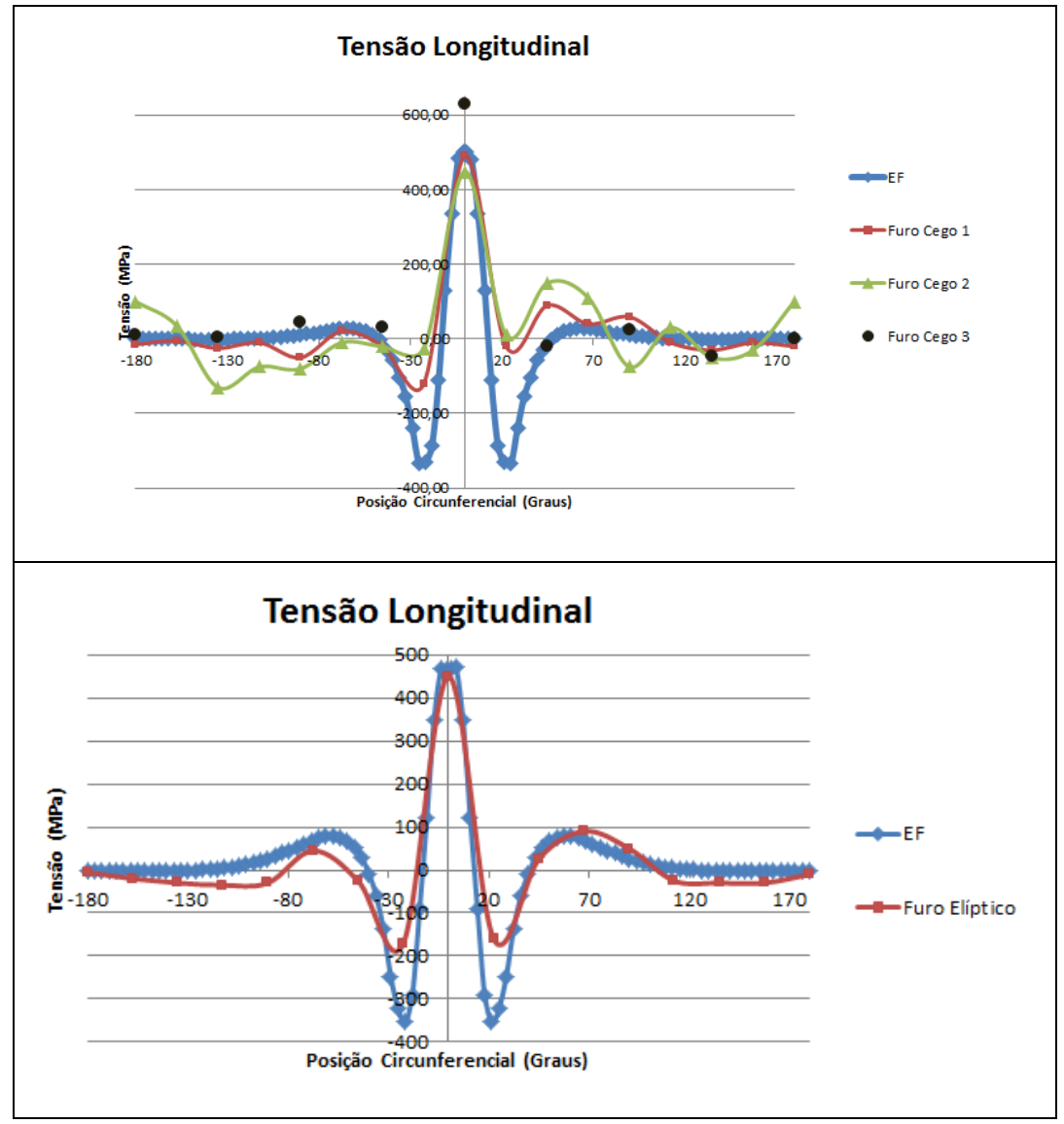

Figura 1.2: Comparação entre as tensões longitudinais medidas e as simuladas via MEF, [54].

WENTZ, André V., em [30], estudou técnicas numéricas, principalmente o MEF, para a simulação da soldagem por arco elétrico e por resistência elétrica. O trabalho apresenta uma extensa revisão bibliográfica sobre esse tipo soldagem, sua aplicabilidade e uso, bem como analisa os principais parâmetros envolvidos na simulação desse processo de soldagem.

Foram avaliadas as diferenças entre os modelos 2D e 3D, tendo-se optado por um modelo 2D, que considera a hipótese de estado plano de deformações e é numericamente mais simples.

Foram também desenvolvidos dois modelos para o estudo da soldagem; o primeiro trata da simulação da soldagem por arco elétrico, envolvendo uma análise térmica e mecânica, que é comparada com medições experimentais conduzidas por terceiros, Figura 1.3. O segundo simula uma solda ponto por resistência usando uma análise axissimétrica, Figura 1.4. 


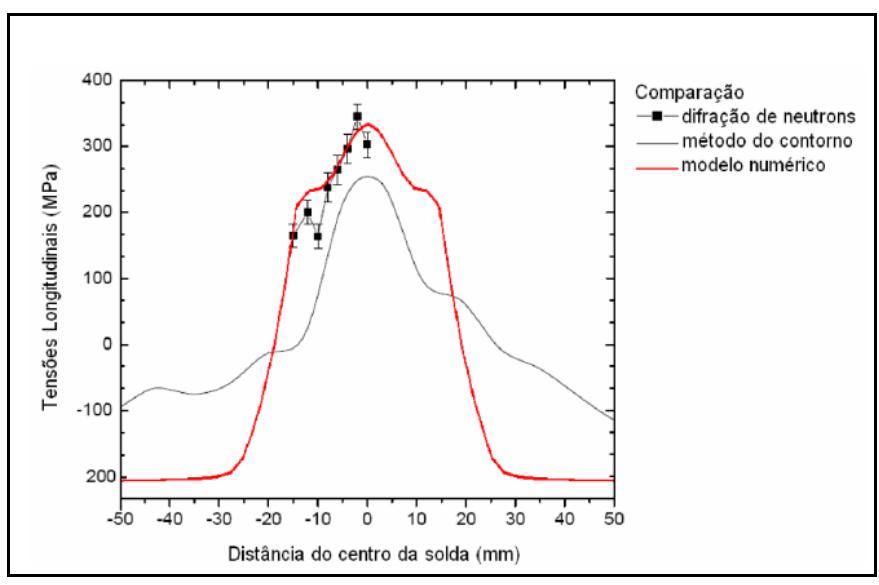

Figura 1.3: Comparação das tensões longitudinais ao longo da superfície, [30].

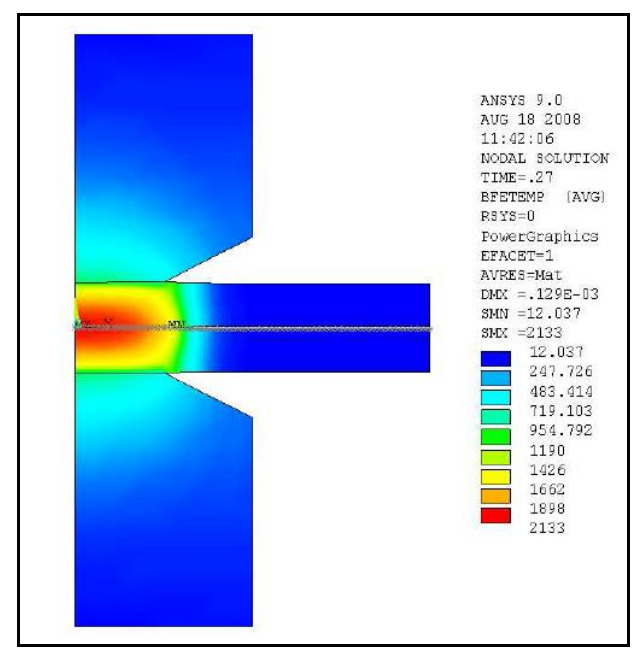

Figura 1.4: Forma do botão de solda no fim da soldagem, [30].

PILIPENKO, Artem., em [53], desenvolveu uma abordagem experimental, numérica e analítica para a análise de soldabilidade de painéis navais com soldagem multipasse, tendo como foco a investigação das tensões transientes e residuais produzidas pela soldagem e as distorções nas estruturas do casco do navio. A investigação baseiou-se principalmente na análise por elementos finitos. Algumas recomendações sobre técnicas de mitigação para reduzir a influência negativa da soldagem na estrutura foram dadas.

Foi desenvolvido um número de sistemas de simulação para análise de processo de soldagem com acoplamento termomecânico, levando em conta as condições de soldagem.

Duas técnicas de soldagem foram investigadas. O processo de soldagem com três eletrodos e um único passe de solda e a soldagem multipasse com um único eletrodo foram comparados em termos das suas características comuns e das tensões transientes e deformações produzidas. 
A exatidão de cada modelo de elementos finitos foi avaliada com base em resultados experimentais e analíticos. Várias técnicas que permitem reduzir as tensões e as deformações residuais também foram investigadas.

Uma revisão bibliográfica do fenômeno termomecânico da soldagem também foi conduzida.

RODRIGUES, Leonardo D., em [2], estudou as tensões residuais de fabricação em tubos para dutos, procurando encontrar meios para separar as tensões residuais daquelas causadas pelos esforços de trabalho e pelos esforços externos que agem em dutos enterrados, dentre os quais está a movimentação de solo.

Foram realizadas diversas medições experimentais em um tubo API 5L X60 e em um tubo API 5L X46, para determinar o perfil das tensões residuais de fabricação, sendo utilizadas duas técnicas diferentes, a técnica do furo cego e uma nova técnica de seccionamento desenvolvida no trabalho.

A partir das curvas de tensões residuais obtidas experimentalmente foram feitas recomendações para medições em campo e forneceram-se algumas metodologias para separação das tensões residuais dos valores totais medidos. As medições apontaram altos valores de tensões residuais, por vezes da ordem do limite de escoamento do material. Com base nos resultados obtidos, Figura 1.5, foi concluído que as tensões residuais circunferenciais e longitudinais variam muito ao longo do perímetro das seções analisadas.

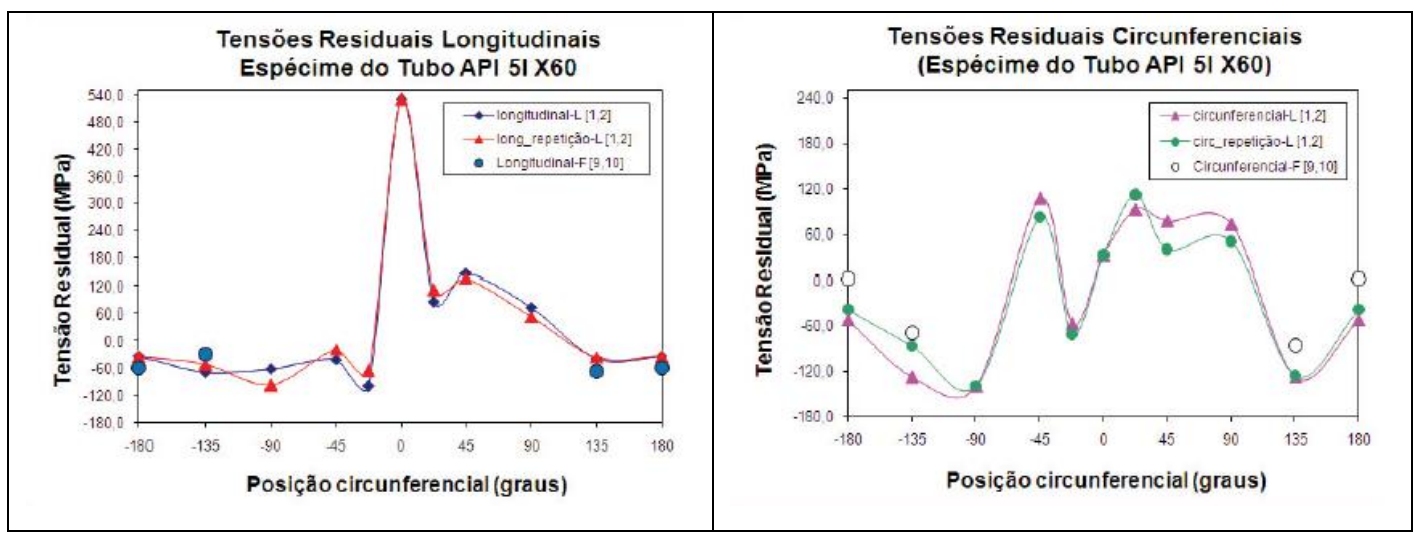

Figura 1.5: Tensões residuais medidas no tubo, [2]. 
DELGADILLO, Gilmar W. R., em [61], mediu e estudou as tensões em um tubo API 5L X60, submetido a esforços combinados de pressão interna, flexão e esforços axial, fazendo uso de rosetas extensométricas, que foram também usadas na medição de tensões residuais na técnica do furo cego.

Os resultados medidos com os extensômetros, antes e depois de se usinarem os furos cegos, foram comparados com deformações calculadas por meio de dois métodos: um analítico (Resistência de Materiais) e outro numérico (Elementos Finitos).

Para a realização dos experimentos foi desenvolvido um dispositivo para aplicação de carregamentos e medição das tensões. Esse dispositivo consiste em duas placas reforçadas soldadas nas extremidades do tubo, servindo como tampos para o tubo, sendo que uma delas contém uma tomada de pressão. As partes superiores das placas estão interligadas através de dois fusos com extremidades roscadas e que possibilitam a aplicações de forças axiais e momentos fletores no tubo. Os fusos são instrumentados com quatro extensômetros de resistência elétrica, ligados em ponte completa, para a medição das forças aplicadas.

Os resultados encontrados nas comparações revelaram exatidão satisfatória para os cálculos e medições empregados e validaram o uso do dispositivo de teste, tendo também mostrado que as tensões residuais longitudinais e circunferenciais no tubo variaram em torno de seu perímetro e de seu comprimento e possuem magnitudes por vezes muito próximas à resistência ao escoamento do tubo.

A partir dos resultados foi concluído que as medições de tensões residuais em laboratório não podem ser extrapoladas para aplicações a estudos em campo para determinação de cargas operacionais e geradas por movimento de solo, mesmo que o espécime do laboratório tenha materiais, dimensões e processo de fabricação semelhante ao do duto analisado.

XU, Shugen LIU, Guorong, ZHAO, Yanling, WANG, Jianjun., em [83], utilizaram o MEF para prever as tensões residuais na parede de um recipiente cilíndrico provocadas pelos múltiplos passes de solda depositados circunferencialmente na união das diversas seções de parede, Figura 1.6. 


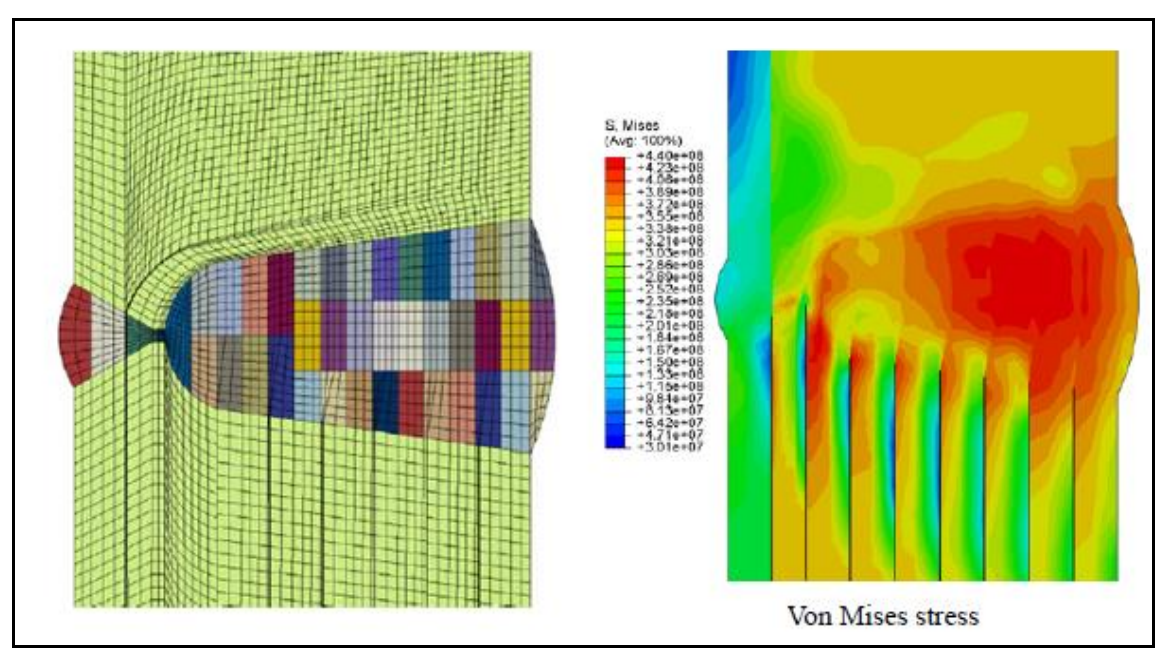

Figura 1.6: Configuração do modelo de EF e tensões residuais equivalentes, [83].

Os resultados numéricos mostraram que grandes magnitudes de tensões residuais são geradas na solda e nas suas proximidades (ZTA). Devido à diferença entre o material da camada interior, aço inoxidável, e da camada exterior, aço de baixa liga, foram encontradas distribuições heterogenias nas tensões. $\mathrm{O}$ espaçamento entre as camadas teve uma grande influência sobre a tensão residual na ZTA. Através de toda a espessura do recipiente com múltiplas camadas, a distribuição de tensões é descontínua.

\section{KU, Francis H., HICKS, Trevor G., MABE, William R., MILLER,} Jason R., em [78], foram desenvolvidas duas análises, uma 2D e outra 3D, para o estudo das tensões residuais induzidas pela soldagem circunferencial com múltiplos passos e velocidade controlada de um tubo Schedule 80 feito de aço inoxidável 304, Figura 1.7.

As análises investigaram as semelhanças e as diferenças entre as duas abordagens de modelagem em termos de tensões residuais e distorção axial causada pela soldagem da tubulação. A análise 2D é axissimétrica e avalia dois tipos de restrições diferentes, uma chamada fixo - fixo e outra chamada fixo livre. Enquanto que a análise 3D aproxima a não axissimetria por uma restrição fixo - livre.

Os resultados de temperatura entre as análises 2D e 3D são muito semelhantes. Apenas o modelo de análise 3D é capaz de simular o comportamento assimétrico da técnica de soldagem segmentada. O modelo 2D apresenta tensões circunferenciais similares às do modelo 3D. A distorção axial modelada na análise 3D é da mesma magnitude que a medida em laboratório em um protótipo. 


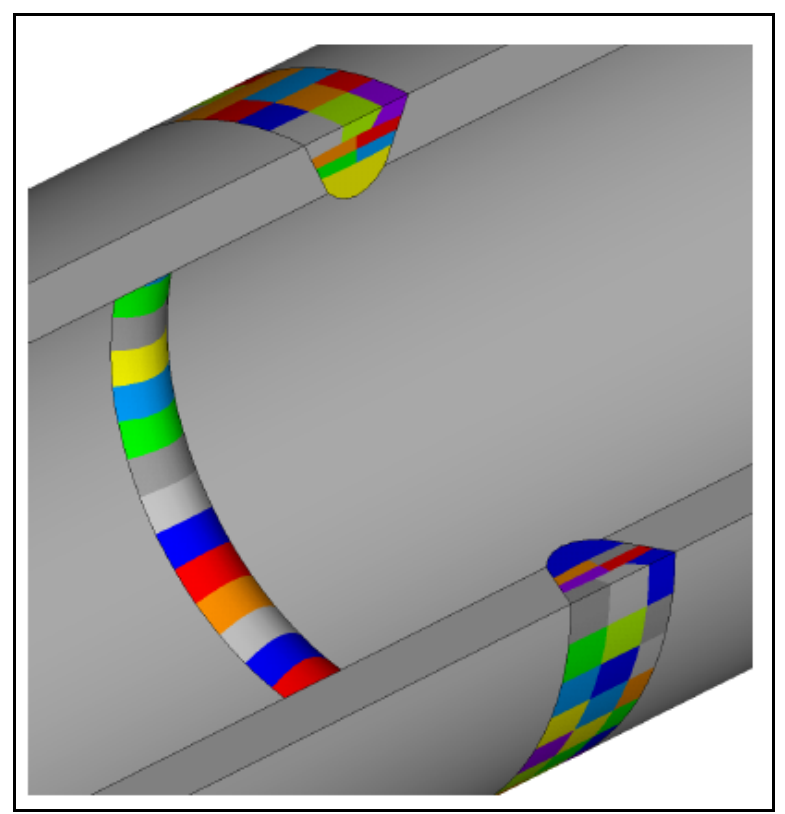

Figura 1.7: Configuração do modelo 3D de EF, [78].

DONG, Pingsha, SONG, Shaopin, ZHANG, Jinmiao, em [79],

realizaram uma avaliação detalhada dos perfis das tensões residuais prescritos nos códigos e normas amplamente utilizados, tais como a BS 7910 Apêndice Q, por meio da análise de alguns estudos em tensões residuais que se tornam disponíveis recentemente.

Foi apresentado um estudo de caso em que as medições de tensões residuais estão disponíveis para validação de um modelo de elementos finitos. Os perfis de tensão residual estipulados pela BS 7910 para soldas circunferenciais são avaliados nesse contexto.

Como resultado, uma série de áreas de melhoria no perfil de tensão residual foi identificada, valendo destacar:

1) $\mathrm{O}$ aporte de calor deve ser tratado como uma função contínua em vez de classificado discretamente como "baixo", "médio" e "alto".

2) $\mathrm{O}$ perfil de tensões residuais é melhor expresso em três termos fundamentais: distribuição de membrana, de flexão e auto-equilibrante.

3) As dimensões da geometria têm forte impacto na distribuição das tensões residuais pela peça; assim devem ser considerados no desenvolvimento dos perfis de tensões. 
YAGHI, A. H., HYDE, T. H., BECKER, A. A., SUN, W., em [80], desenvolveu um modelo de elementos finitos 2D para estudar as tensões residuais produzidas pela soldagem com múltiplos passes de dois tubos com materiais diferentes, um tubo de aço P92 e outro de uma liga à base de níquel (IN625).

Duas sub-rotinas foram definidas na análise estrutural de EF para simular as diferentes fases dos materiais envolvidos durante a soldagem, incluindo seu comportamento plástico e seu endurecimento, obtidos de ensaios de tração uniaxial dos materiais realizados em uma vasta gama de temperatura. A expansão térmica, incluindo os efeitos das transformações de fase, também foram numericamente modelados nas duas sub-rotinas.

\subsection{Software de Elementos Finitos Utilizado}

A modelagem por elementos finitos inicia com a discretização de uma geometria específica num número finito de elementos, de tal forma que cada elemento satisfaça, de modo individual, as condições de equilíbrio, e entre eles mesmos, sejam cumpridas as condições de compatibilidade com o contínuo.

A soldagem é um processo complexo, que envolve diferentes campos da engenharia, entretanto nesse trabalho a análise desse processo pode ser dividida em apenas duas partes, uma térmica e outra mecânica. A parte térmica trata da transferência de calor entre o aporte térmico e as partes unidas e da difusão do calor fornecido ao componente para seu interior e para o meio. A parte mecânica trata do comportamento mecânico da estrutura durante a aplicação dos gradientes de temperatura e do efeito de carregamentos externos aplicados após o término da soldagem, cujo objetivo é provocar um alívio de tensões.

Nos modelos desenvolvidos cada elemento é contornado por nós que os interconectam entre si e é caracterizado na parte térmica por uma matriz de temperaturas, que relaciona os gradientes de temperaturas com as temperaturas na peça. Já na parte mecânica eles são caracterizados por uma matriz de rigidez que relaciona as forças com as deformações. As matrizes de rigidez elementares constituem a matriz de rigidez global do componente. O carregamento externo (forças, pressão e tensões) é substituído por um sistema de forças equivalentes nos nós. 
Toda a análise numérica foi implementada no programa de elementos finitos ANSYS®, versão 14.5, mais especificamente no módulo "WorkBench". Para simular a parte térmica, utilizou-se a ferramenta "Transiente Térmico" do mesmo, e para a parte mecânica usou-se a ferramenta "Estrutural Permanente", onde para cada elemento é fornecida a história de temperatura no tempo. Também foram considerados os fenômenos não lineares como: não linearidades geométricas, não linearidade do material, grandes deslocamentos e grandes deformações.

\subsection{Roteiro da Dissertação}

A dissertação foi dividida em 8 capítulos, um que apresenta considerações gerais, seis de desenvolvimento e um de conclusões e recomendações. A seguir são indicados os aspectos mais importantes de cada capítulo:

Capítulo 1: apresenta considerações gerais sobre a dissertação e o tema estudado, indicando a estrutura do estudo e a rotina de desenvolvimento do trabalho.

Capítulo 2: faz um tratamento geral sobre tensões residuais. Os seguintes tópicos são apontados: diferentes conceitos, seus efeitos sobre os equipamentos, possíveis origens, principais mecanismos causadores e os processos no quais estão inclusos. São tratadas também as principais técnicas de medição.

Capítulo 3: analisa a parte térmica da soldagem, estudando como o calor é fornecido ao componente pela fonte de calor e a determinação da temperatura do cordão com base nos parâmetros de soldagem. Desenvolveu-se um procedimento para a simulação da deposição de múltiplos passes de solda e para deposição gradual do cordão de solda com base na velocidade de soldagem utilizando as técnicas de "morte" e "nascimento" de elementos. No final do capítulo são revisadas as principais configurações da simulação térmica. 
Capítulo 4: analisa a parte mecânica da soldagem, estudando o acoplamento entre o histórico de temperaturas simulado na parte térmica e o comportamento mecânico da estrutura. Foi estudada a evolução do campo de tensões durante e após a soldagem, sendo considerados dois tipos de comportamento do material. Desenvolveu-se uma análise analítica do modelo das três barras, que é usada para modelar a soldagem, e da influência de um tratamento mecânico de alívio de tensões. Investigou-se o uso de uma curva tensão - deformação bilinear com um pequeno gradiente térmico em uma simulação, bem como a influência de múltiplos passes de solda e da velocidade nas tensões residuais. No final do capítulo são revisadas as principais configurações da simulação mecânica.

Capítulo 5: apresenta o desenvolvimento de dois modelos numéricos para estudar a soldagem de elementos planos, os espécimes analisados consistiram em duas chapas com diferentes restrições ao deslocamento em suas bordas. As simulações numéricas foram comparadas com medições experimentais obtidas de duas técnicas diferentes e com formulações analíticas presentes na literatura.

Capítulo 6: apresenta o desenvolvimento de quatro modelos para estudar a soldagem de elementos tubulares. Os dois primeiros modelos tratam da fabricação de um duto, e os resultados numéricos são comparados a medições experimentais. Os dois últimos modelos tratam da montagem de campo de dois dutos fabricados segundo os mesmos parâmetros dos dois primeiros modelos. É investigada também a influência de diferentes tratamentos de alívio de tensões em espécimes tubulares.

Capitulo 7: apresenta o desenvolvimento de um modelo para o estudo das tensões residuais em um vaso de pressão após sua fabricação e após a aplicação de um teste hidrostático.

Capitulo 8: apresenta as conclusões e recomendações sobre os resultados obtidos no desenvolvimento do presente trabalho. 


\section{2}

\section{Tensões Residuais}

Tensões residuais consistem nas tensões que existem no interior de um componente na ausência de esforços ou gradientes de temperatura aplicados exteriormente. São auto-equilibrantes, qualquer perturbação como remoção de material ou aplicação de carregamentos térmicos ou mecânicos alteram o seu estado e causam sua redistribuição de modo que as tensões se equilibrem novamente, [1]. Uma vez que as tensões residuais existem na ausência uma solicitação externa, pode se afirmar que o sistema é auto-equilibrado se a força e o momento resultante destas tensões, em uma dada seção da peça forem nulos.

As tensões residuais surgem como uma resposta elástica a uma distribuição não homogênea de deformações não elásticas, que podem ser causadas por plasticidade, transformações de fase metalúrgica, expansão térmica, remoção de material, etc. Elas superpõem-se às tensões causadas pelas cargas de serviço, podendo ser benéficas ou prejudiciais às estruturas e equipamentos, dependendo de sua magnitude, direção e distribuição ao longo da estrutura.

\subsection{Tipos de Tensões Residuais}

Podem-se dividir as tensões residuais em diferentes tipos: tensões residuais macroscópicas, microscópicas e submicroscópicas. Essa classificação é referente à área de abrangência dessas tensões ao longo do grão e de seu contorno, [2].

\subsubsection{Tensões Residuais Macroscópicas}

Também chamadas de tensões residuais do Tipo I, são em geral homogêneas ao longo de grandes extensões de área, como por exemplo, diversos grãos do material, e se auto-equilibram com respeito ao corpo inteiro. Qualquer interferência no equilíbrio de forças e momentos em uma porção contendo tensões residuais macroscópicas terá como consequência a alteração de suas magnitudes. 
Processos que envolvem gradientes de deformação plástica, e/ou gradientes térmicos, como no caso da soldagem, são os principais causadores desse tipo de tensão residual, [3].

\subsubsection{Tensões Residuais Microscópicas}

Também chamadas de tensões residuais do Tipo II, são em geral homogêneas ao longo de pequenas áreas microscópicas, como por exemplo um grão ou parte dele, e se auto-equilibram ao longo de um pequeno conjunto de grãos. Mudanças macroscópicas das dimensões de um volume contendo tensões residuais microscópicas apenas serão observadas se perturbações distintas do equilíbrio ocorrem, [4].

\subsubsection{Tensões Residuais Submicroscópicas}

Também chamadas de tensões residuais do Tipo III, são não homogêneas ao longo de pequenas áreas submicroscópicas, como por exemplo, distâncias interatômicas dentro de uma pequena porção de um grão, e se auto-equilibram ao longo de pequenas porções do grão. Nenhuma mudança macroscópica acontecerá se o equilíbrio desses tipo de tensão residual for perturbado, [3]. Ocorrem nos materiais metálicos sujeitos a processos que produzam descontinuidades na rede cristalina como vazios, impurezas, falhas de empilhamento, entre outros, [4].

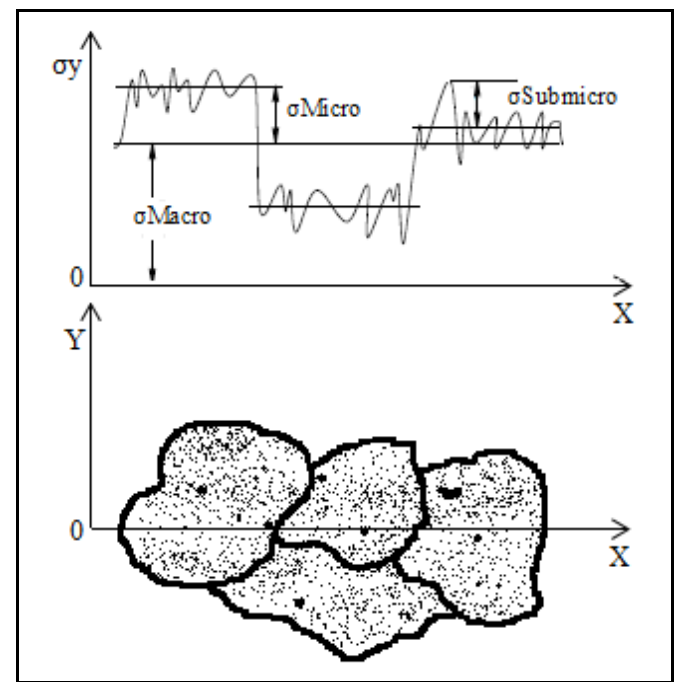

Figura 2.1: Distribuição das tensões residuais ao longo de vários grãos de um material policristalino e suas tensões separadas em macroscópicas, microscópicas e submicroscópicas. 


\subsection{Influência das Tensões Residuais na Vida à Fadiga dos Componentes Estruturais}

Embora as tensões residuais tenham efeito significativo na resistência e confiabilidade de peças e equipamentos, sua importância não é suficientemente levada em conta pelas normas e códigos vigentes. Isso ocorre porque a influência das tensões residuais na vida a fadiga de peças e elementos estruturais não depende apenas da magnitude das tensões, mas também das propriedades mecânicas dos materiais utilizados, dos parâmetros do carregamento cíclico e de outros fatores, [5]. Diversos critérios de projeto não consideram a existência de tensões residuais, admitindo que as únicas tensões atuantes na estrutura estão relacionadas com a sua operação.

Os efeitos das tensões residuais nos componentes podem ser benéficos ou maléficos dependendo da sua intensidade e da sua magnitude. Quando esses componentes são submetidos a carregamentos cíclicos, as tensões residuais são consideradas parcelas que compõem a tensão média, [6]. É possível quantificar os efeitos sobre a vida usando as relações de Gerber, ou Goodman, Figura 2.2.

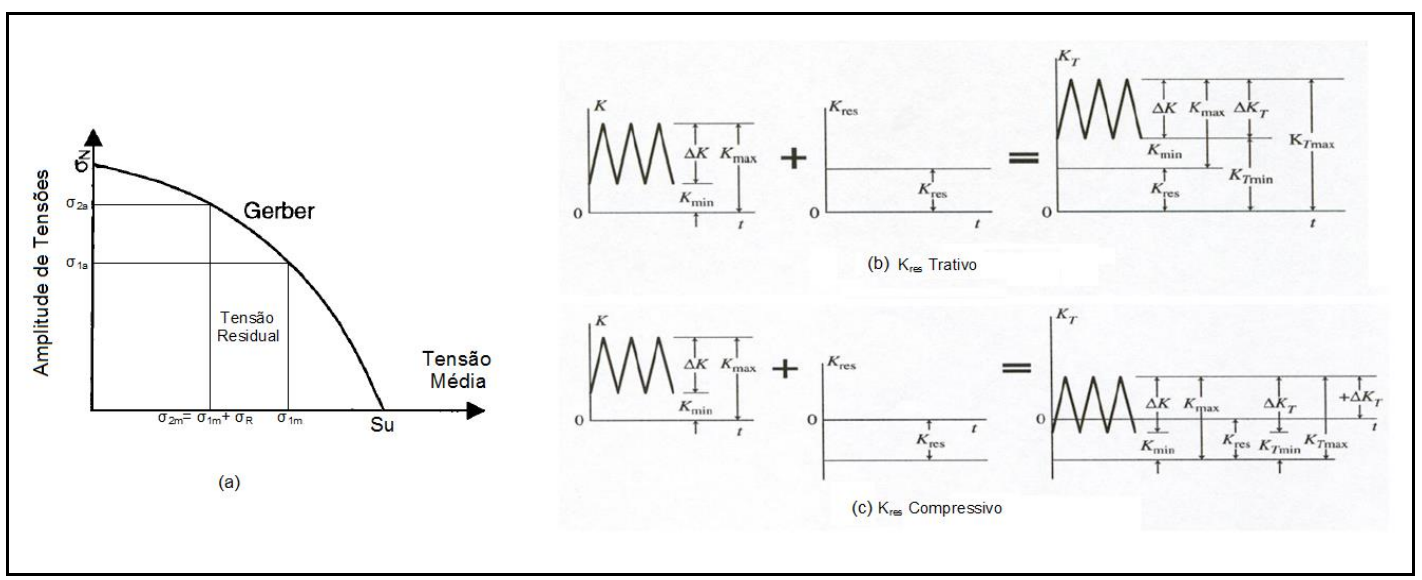

Figura 2.2: (a) Tensão residual mostrada em um diagrama de Gerber; (b) Efeito da tensão residual trativa na tensão média; (c) Efeito da tensão residual compressiva na tensão média.

A partir da Figura 2.2 pode se observar que a tensão residual trativa aumenta a magnitude da tensão média; assim para que a vida da estrutura permaneça inalterada, as amplitudes dos carregamentos devem ser reduzidas, caso contrário sua vida irá sofrer uma redução significativa, Figura 2.3. Se a tensão residual trativa for suficientemente elevada ela poderá até mesmo desencadear uma fratura estática durante a fadiga. 
Processos como tratamentos térmicos, martelamento, shot peening, laser peening e outros produzem tensões residuais compressivas, que por sua vez diminuem a magnitude da tensão média e aumentam a resistência à fadiga, sendo benéficas a estrutura [5].

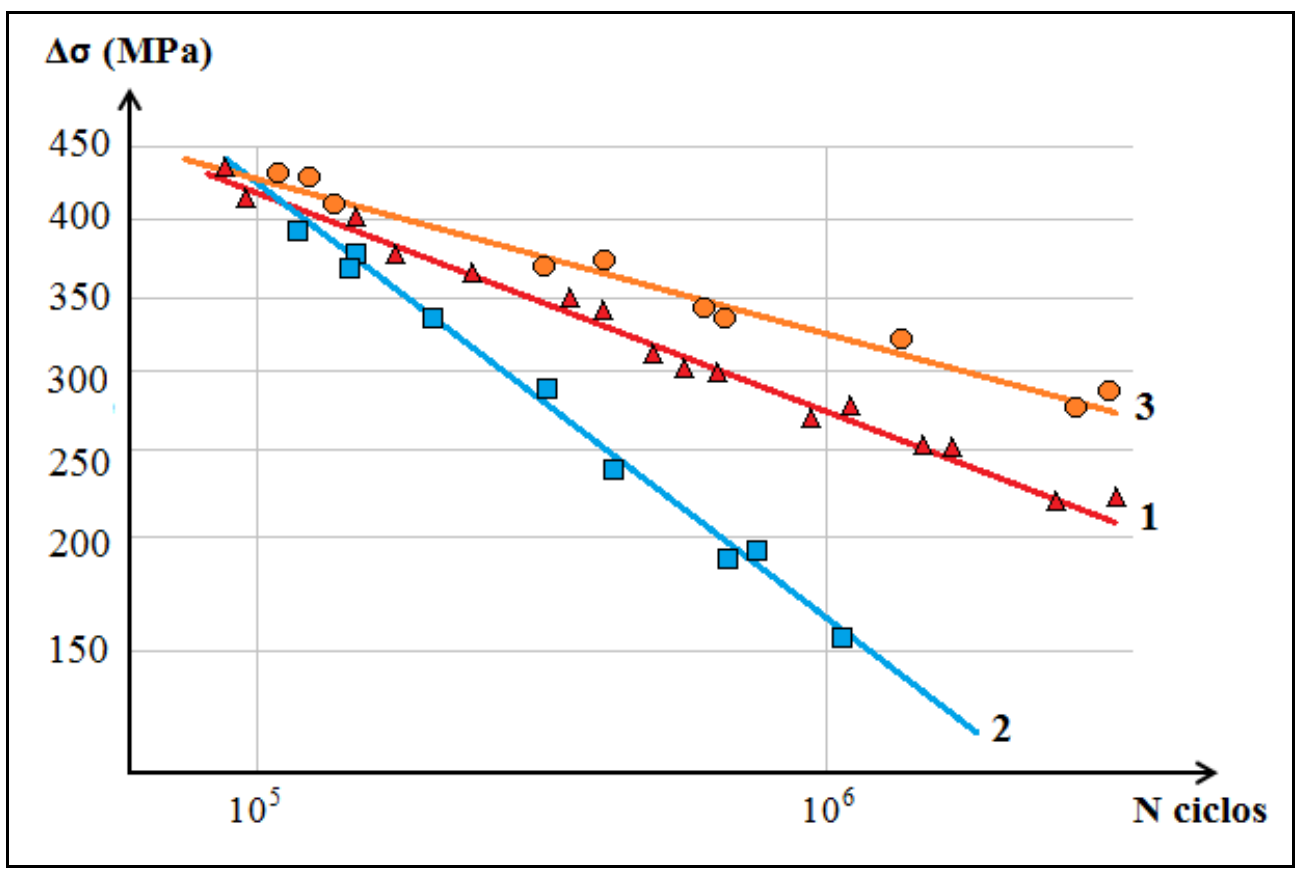

Figura 2.3: Curvas de fadiga para uma solda de topo de aço de baixo carbono: Curva 1 - sem tensões residuais; Curva 2 - com tensões residuais trativas (sem tratamentos de alívio de tensão); Curva 3 - com tensões residuais compressivas (após shot pening); [5].

\subsection{Tensões Residuais na Soldagem}

O processo de soldagem causa um severo aquecimento não uniforme nas partes a serem unidas. Regiões próximas ao arco elétrico são aquecidas até temperaturas de milhares de graus Celsius, e então resfriadas até toda peça retornar ao equilíbrio com o ambiente. $\mathrm{O}$ aquecimento localizado e subsequente resfriamento induzem mudanças volumétricas, gerando tensões e deformações no componente.

O desenvolvimento de tensões residuais pode ser explicado considerando o aquecimento e o resfriamento forçados da junta soldada e o fato dela assumir um comportamento elástico-plástico e deforma-se plasticamente de maneira não uniforme durante estes processos. As tensões residuais surgem devido à contração no resfriamento das regiões diferentemente aquecidas e plastificadas. 
Durante a soldagem as temperaturas no cordão de solda e adjacências atingem valores onde o módulo de elasticidade e o limite de escoamento do material são muito pequenos, facilitando o escoamento em altas temperaturas. Ao ser resfriado o material recupera sua rigidez, entretanto devido à presença de gradientes térmicos a contração se dá de maneira não uniforme.

Em uma junta soldada podem existir contrações longitudinais, transversais e angulares. As contrações longitudinais são em geral as mais importantes, pois a contração dos cordões de solda durante o resfriamento sofre mais restrição pelas partes soldadas nessa direção, [7]. A Figura 2.4 apresenta os perfis das tensões residuais nas direções longitudinal e transversal ao longo de uma chapa soldada pelo processo de arco submerso.

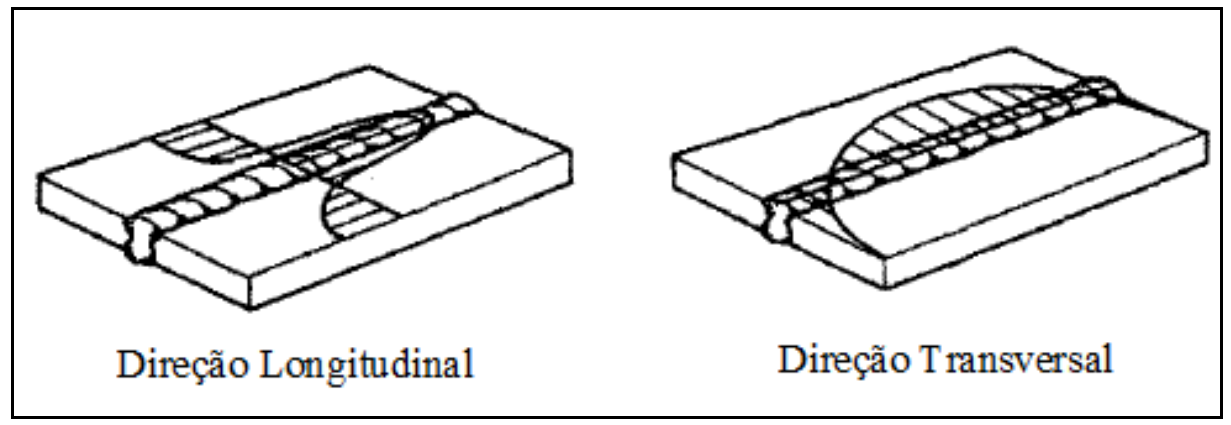

Figura 2.4: Perfil de tensões residuais na direção longitudinal e transversal de uma solda de topo, [7].

As contrações transversais dependem da restrição ao deslocamento das partes soldadas, do processo de soldagem escolhido, da velocidade do passe de solda, da largura do chanfro, e da geometria do cordão de solda, sendo minimizadas quando se utiliza um pequeno ângulo de chanfro; no entanto se esse ângulo for muito pequeno poderá dificultar a soldagem, [8].

A contração angular é causada pela contração transversal dos cordões de solda depositados na superfície, pois também existem gradientes de temperatura ao longo da espessura. Quanto maior for a quantidade de cordões de solda maior será a contração angular, [8].

Numa junta soldada a sequência se soldagem podem ter uma influência significativa sobre as tensões residuais, isso porque ao longo do comprimento do cordão as condições de restrição mudam, à medida que a solda depositada se solidifica atrás da poça de fusão, [8]. 
A Figura 2.5 mostra a influência das contrações nas diversas direções na distorção de um componente com uma solda de topo.

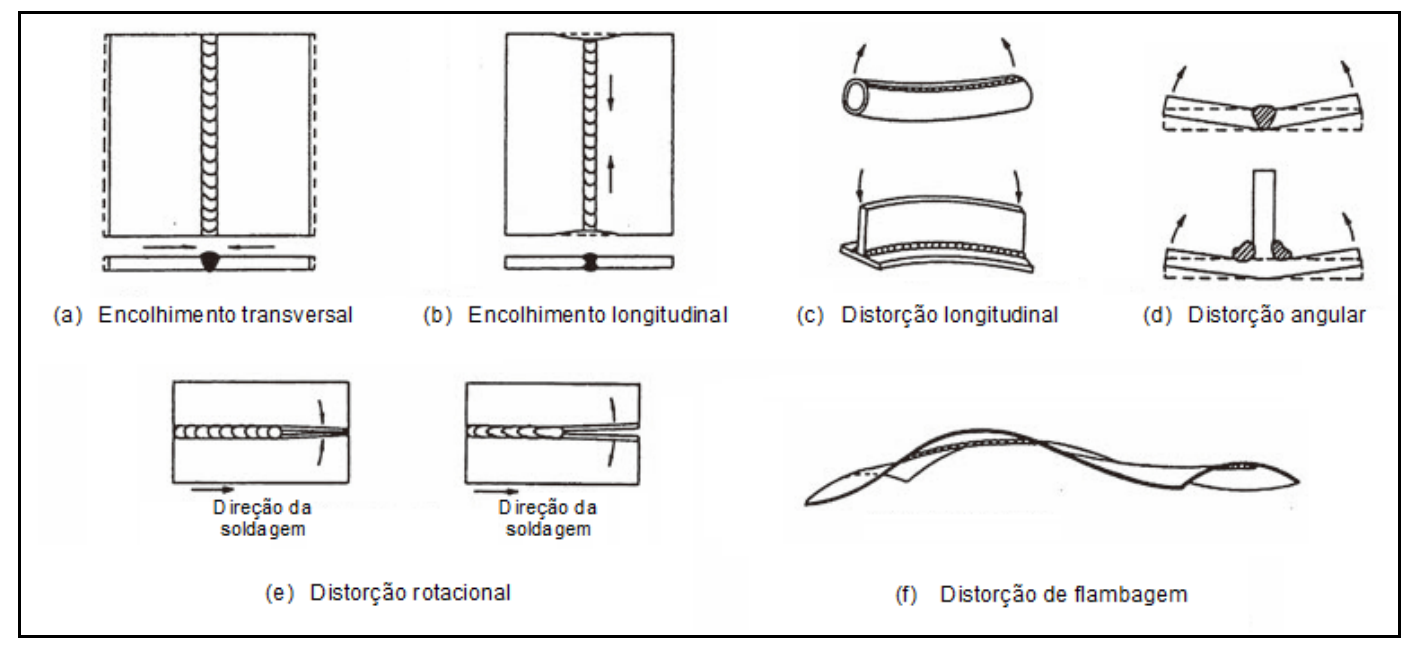

Figura 2.5: Distorções em componente com uma solda de topo devido à contração nas diversas direções.

As tensões residuais também podem ser decorrentes de transformações de fases. Os fenômenos de contração e transformação de fase se sobrepõem. A quantidade e sinal das tensões residuais dependem fortemente da temperatura na qual a transformação ocorre. No caso de aços, a transformação de austenita para ferrita, bainita ou martensita implica em expansão volumétrica, entretanto, as regiões vizinhas, mais frias e não transformadas impedem tal expansão, gerando tensões residuais. Quanto menor a temperatura de transformação, mais significativos os efeitos das transformações na tensão residual resultante, [8].

A magnitude das tensões residuais depende do grau de restrição ao deslocamento que estrutura oferece na direção considerada. Por vezes as tensões geradas são da ordem do limite de escoamento do material.

\subsection{Técnicas de Medição de Tensões Residuais}

A medição de tensões residuais requer cuidados específicos, não sendo possível utilizar as técnicas usuais de medição de tensões e deformações, que medem o incremento de deformação após a instalação dos sensores.

As técnicas de medição de tensões residuais se dividem em três tipos: destrutivas, semi-destrutivas e não destrutivas. Essas técnicas são classificadas de acordo com o nível de dano que induzem na estrutura a fim de quantificar as tensões residuais. Serão descritas a seguir as técnicas mais utilizadas atualmente. 


\subsubsection{Técnicas Destrutivas}

Esse conjunto de métodos se baseia na destruição do estado de equilíbrio local ou global das tensões residuais, através do seccionamento, usinagem, ou remoção de camadas do espécime, com a introdução de defeitos permanentes ou de considerável importância para a integridade do componente. A redistribuição das forças internas causa deformações, que são medidas para estimar o estado de tensões residuais no local considerado. As tensões residuais são calculadas a partir da deformação medida usando a teoria elástica em soluções analíticas.

\subsubsection{Técnica de Seccionamento}

Baseia-se na criação de superfícies livres, para possibilitar a redistribuição das tensões residuais na região seccionada e assim permitir a medição das deformações originadas. Essa técnica é melhor aplicada a espécimes onde a tensão longitudinal é a mais significativa, [9].

A exemplo, a distribuição de tensões residuais em uma chapa pode ser determinada medindo abertura das faces, $\delta$, criadas a partir de um corte longitudinal, como mostrado na Figura 2.6.

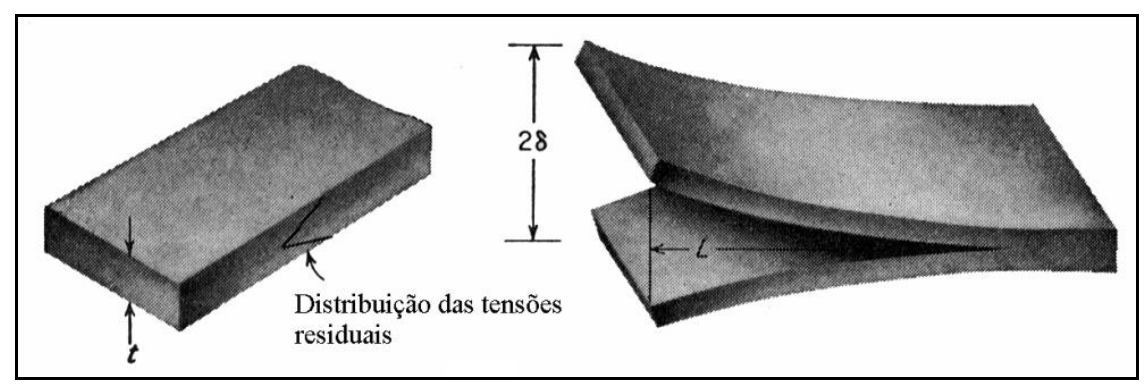

Figura 2.6: Técnica de seccionamento aplicada em uma placa.

A tensão longitudinal pode ser relacionada com a abertura da chapa pela seguinte expressão:

$$
\sigma_{l}=\frac{E \cdot t \cdot \delta}{2 \cdot L^{2} \cdot(1-v)}
$$

onde, E é o módulo de elasticidade do material, $v$ é o coeficiente de Poisson, t é a espessura da chapa e $\delta$ é a abertura medida. 
Embora essa técnica seja utilizada preferencialmente para medir a tensão longitudinal de componentes, ela também pode ser usada em conjunto com extensômetros para determinar a tensão residual transversal.

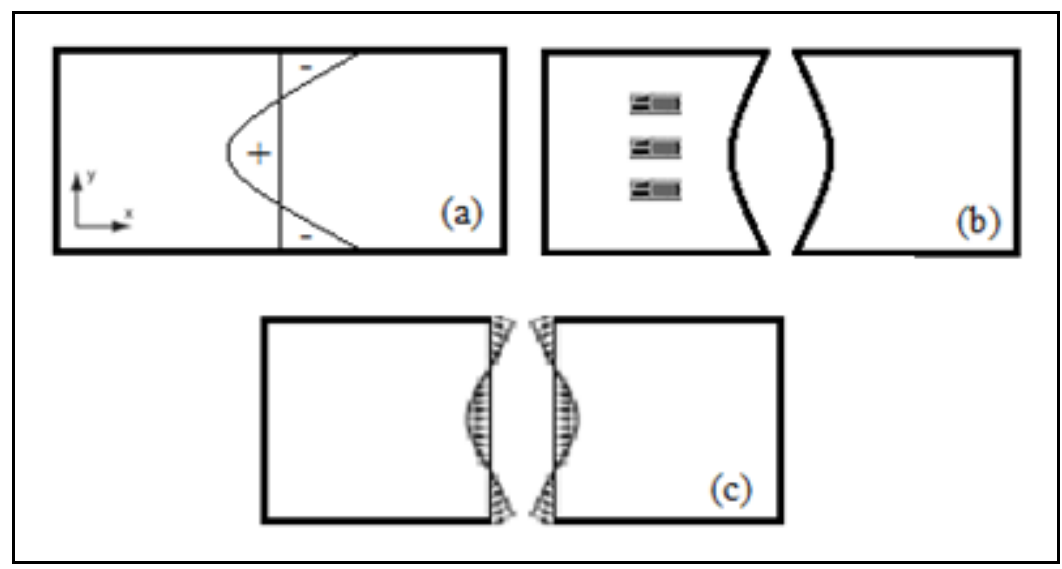

Figura 2.7: Técnica de seccionamento com corte transversal de uma chapa, (a) Estado original de tensões; (b) Corte transversal; (c) Forças analíticas utilizadas para o calculo das tensões residuais.

\subsubsection{Técnica de Remoção de Camadas}

Essa técnica é aplicada em geral a componentes planos, como revestimentos; consiste em medir a deflexão do espécime após a retirada de sucessivas camadas de material. Essa remoção de material é normalmente realizada através de usinagem química. Quanto se retira camadas superficiais do material o equilíbrio de forças e momentos internos é perturbado, fazendo com que a geometria do componente se altere para restabelecer o equilíbrio.

A deflexão medida no componente pode ser relacionada com as tensões residuais na camada retirada segundo a equação, [10]:

$$
\sigma_{\mathrm{e}}=\frac{E}{1-v}\left[-\frac{4 \mathrm{e}^{2}}{3 l^{2}} \cdot \frac{\partial f}{\partial \mathrm{e}}+8 \frac{\mathrm{e}}{l^{2}}\left(\mathrm{f}_{e i}-\mathrm{f}_{e f}\right)+\frac{8}{3 l^{2}} \int_{\text {ei }}^{\text {ef }} \mathrm{e}^{\prime} \mathrm{df}\right]
$$

onde, E é o módulo de elasticidade do material, $v$ é o coeficiente de Poisson, $e$ 'é a espessura do espécime antes da remoção de uma camada com espessura $d_{e}, e_{i}$ é a espessura inicial do espécime, antes da remoção de qualquer camada, $e_{f}$ é a espessura final do espécime, $l$ é o comprimento em qual a deflexão está sendo medida, $f$ é a deflexão medida, $d_{f}$ é a variação da deflexão causada pela retirada de uma camada de espessura $d e, f_{e i}$ é a deflexão inicial e fef é a deflexão final. 


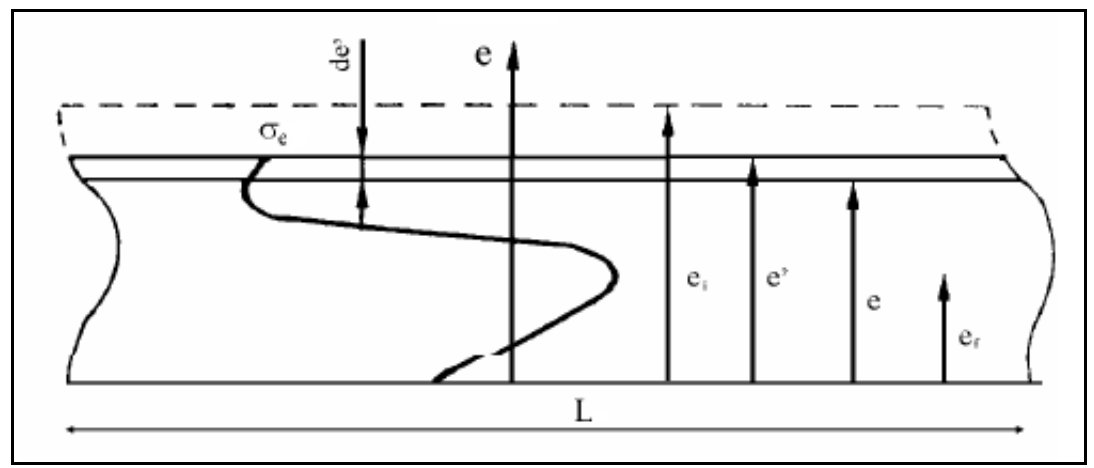

Figura 2.8: Parâmetros envolvidos na técnica de remoção de camadas.

\subsubsection{Técnica do Anel Usinado}

Essa técnica tem como princípio a medição das deformações em uma área central causadas pela usinagem de um anel externo à área de medição. Essa técnica é usada para avaliar o estado plano de tensões, entretanto usinagens adicionais de espessura podem fornecer informações adicionais para uma análise tridimensional, [11]. Podem ser usados rosetas ou sensores óticos para medir as tensões residuais locais.

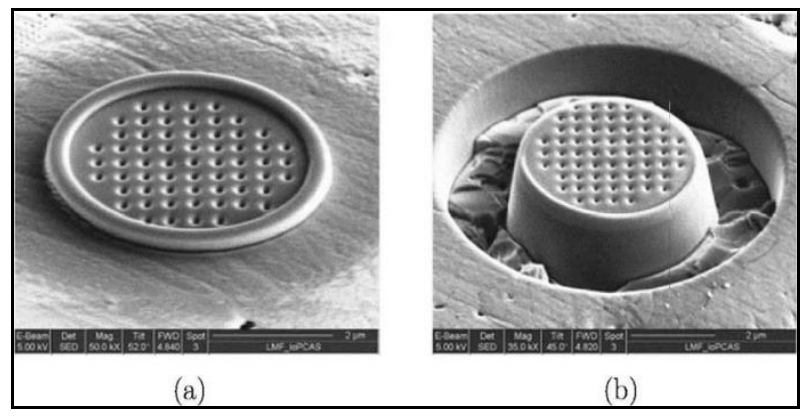

Figura 2.9: Técnica do anel usinado acoplado com uma técnica ótica de medição de deformações, (a) antes da usinagem; (b) depois da usinagem, [11].

A técnica do anel usinado tem uma vantagem sobre a técnica do furo cego, ela proporciona superfícies de deformação muito maiores. Porém, essa técnica é menos usada porque cria no modelo danos consideráveis e é muito menos conveniente de se implementar na prática.

\subsubsection{Técnicas Semi-destrutivas}

Semelhantes às técnicas destrutivas, se baseiam na destruição do estado de equilíbrio local das tensões residuais, através do seccionamento, usinagem, ou remoção de camadas do espécime; no entanto os defeitos causados não comprometem a integridade nem o funcionamento do equipamento. 
Muitos autores consideram a técnica do furo cego como uma técnica destrutiva, entretanto, segundo a norma ASTM E837-01:

"A técnica do furo cego é usualmente classificada como uma técnica semi-destrutiva, porque o dano que é causado é localizado e na maioria das vezes não influi significativamente na funcionalidade da estrutura. Como o furo cego causa dano à peça, essa técnica deve ser aplicada apenas a casos onde a estrutura é descartável, ou a introdução de pequeno furo não afetará significativamente sua operação.”, [12].

\subsubsection{Técnica do Furo Cego}

A técnica do furo cego é uma das mais utilizadas para a medição de tensões residuais, pois sua aplicação é relativamente fácil e tem excelente custo benefício se comparada a outras técnicas. A técnica consiste em usinar um pequeno furo na superfície do componente a ser analisado. A usinagem do furo provocará o alívio das tensões existentes que atuam nessa porção de material removido, provocando uma mudança nos estados de deformação nas regiões em torno do furo.

Não existe uma solução exata para a distribuição de tensões ao redor de um furo cego na teoria elástica. As soluções existentes usam constantes obtidas empiricamente; todavia pode se analisar o furo cego tendo como base uma placa com um furo passante, com tensões residuais uniformemente distribuídas.

Considerando uma chapa homogênea e isotrópica sob condições de tensão plana biaxial o estado de tensão residual original é chamado de $\sigma_{\text {res. }}$ A introdução de um furo de raio $\mathrm{R}_{0}$ altera a distribuição de tensões ao redor do mesmo. Segundo a solução de Kirsch a tensão residual pode ser determinada a partir da tensão medida depois da usinagem do furo, $\sigma$, e da tensão devida ao furo, $\sigma$ '”. A relaxação das tensões devida à introdução de um furo é, [13]:

$$
\sigma^{\prime \prime}-\sigma^{\prime}=\sigma_{r e s}
$$




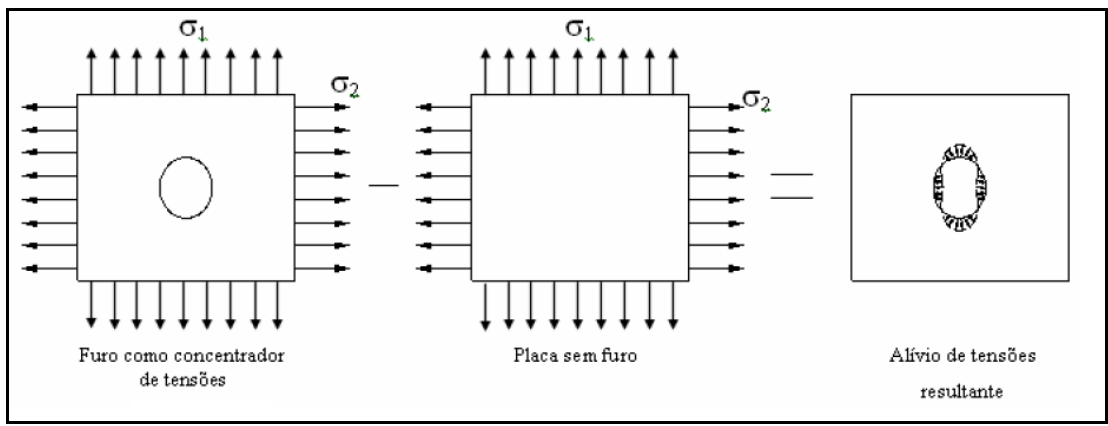

Figura 2.10: Estado de tensões resultante do alívio provocado pela usinagem do furo.

As tensões e direções principais residuais podem ser calculadas a partir da teoria elástica como:

$$
\begin{gathered}
\sigma_{\max }=\frac{\varepsilon_{1}+\varepsilon_{3}}{4 A}-\frac{1}{4 B} \sqrt{\left(\varepsilon_{3}-\varepsilon_{1}\right)^{2}+\left(\varepsilon_{3}+\varepsilon_{1}-2 \varepsilon_{2}\right)^{2}} \\
\sigma_{\min }=\frac{\varepsilon_{1}+\varepsilon_{3}}{4 A}+\frac{1}{4 B} \sqrt{\left(\varepsilon_{3}-\varepsilon_{1}\right)^{2}+\left(\varepsilon_{3}+\varepsilon_{1}-2 \varepsilon_{2}\right)^{2}} \\
\tan 2 \alpha=\frac{\varepsilon_{1}-2 \varepsilon_{2}+\varepsilon_{3}}{\varepsilon_{1}-\varepsilon_{3}}
\end{gathered}
$$

onde $\varepsilon_{1}, \varepsilon_{2}$ e $\varepsilon_{3}$ são as deformações medidas resultantes da introdução do furo cego, A e B são constantes determinadas empiricamente e $\alpha$ o ângulo da direção principal. A Figura 2.11 ilustra o estado de tensões em um ponto $P(R, \alpha)$ antes e depois da realização do furo cego.

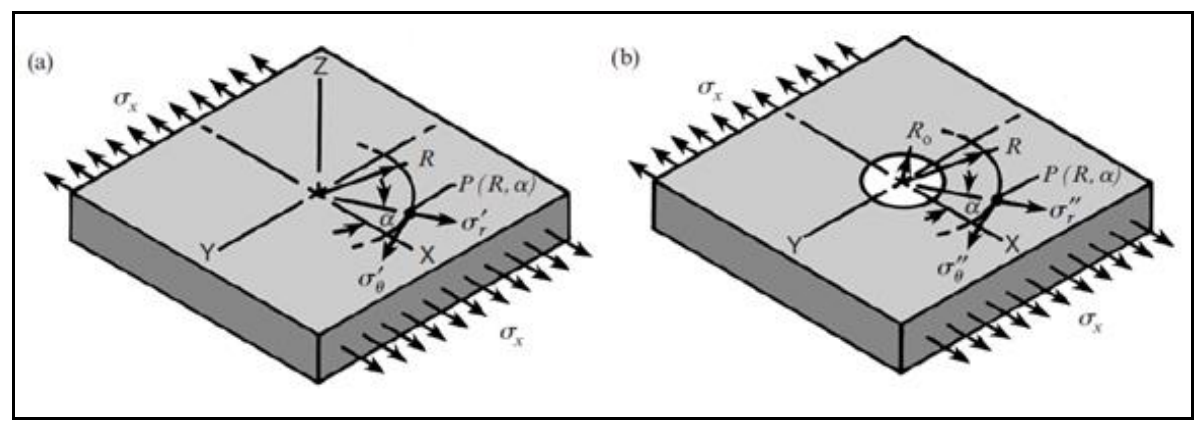

Figura 2.11: Estado de tensões em um ponto $\mathrm{P}(\mathrm{R}, \alpha)$, (a) antes da usinagem do furo; (b) depois da usinagem do furo. 
A técnica do furo cego deve estar associada a técnicas experimentais de medição de deformação. Dentre essas técnicas destacam-se as mais comuns, extensometria, correlação digital de imagem (DIC) e Moiré e técnica interferométrica. Na Figura 2.12 são mostrados exemplos da técnica do furo cego.

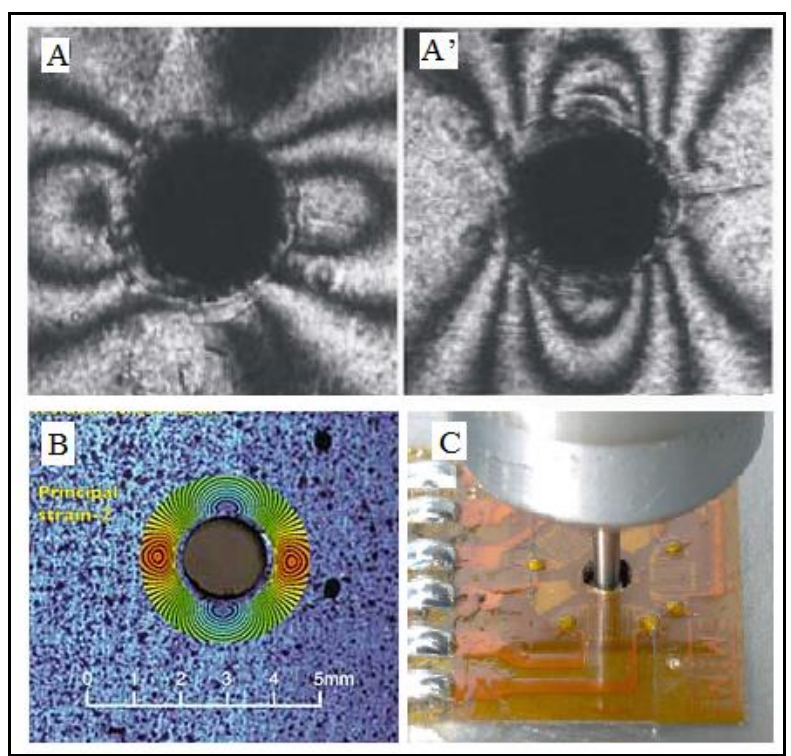

Figura 2.12: Técnica do furo cego acoplada a técnicas experimentais de medição de tensão, (a-a') Moiré; (b) DIC; (c) Extensometria elétrica [11].

\subsubsection{Técnicas Não Destrutivas}

As técnicas não destrutivas se baseiam nas relações existentes entre certas propriedades físicas ou cristalográficas e na perturbação que as tensões residuais causam nessas propriedades. Ao contrário das técnicas destrutivas e semi-destrutivas não causam defeitos nem comprometem a integridade do equipamento.

\subsubsection{Técnica de Difração de Raios X}

Essa técnica mede as distâncias entre os planos cristalinos, que são provocadas pelas tensões residuais. Em um material policristalino, com granulometria fina e isento de tensões, o espaçamento entre planos cristalinos não varia com a orientação desses planos. Medindo-se a variação das distâncias interplanares pode se determinas as tensões residuais atuantes, [14]. 


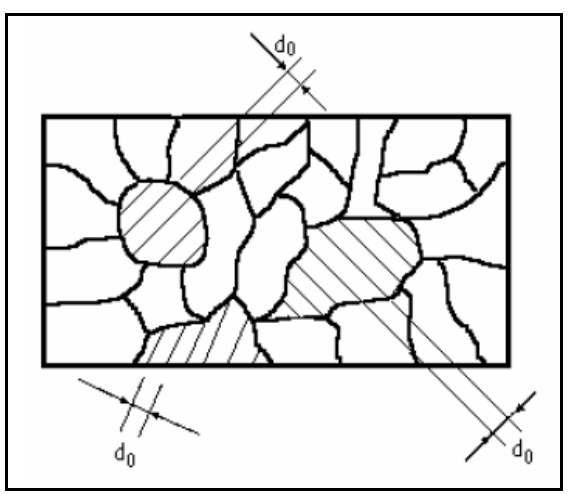

Figura 2.13: Distâncias interplanares de grãos com diferentes orientações em um componente sem tensões.

Quando um material cristalino é irradiado por um feixe de raios $\mathrm{X}$ monocromático com comprimento de onda $\lambda$, ocorre o espalhamento deste feixe pelos átomos que compõem o material. As intensidades dessas ondas se somam segundo uma interferência construtiva obedecendo a Lei de Bragg, segundo:

$$
2 \cdot d \cdot \sin \varphi=n \lambda
$$

onde $d$ é a distância interplanar, $\varphi$ é o ângulo entre feixe incidente e o plano difrator, $\lambda$ é o comprimento de onda e $n$ é um inteiro, chamado ordem de difração.

Se o comprimento de onde for constante, uma variação da distância entre planos provocada por uma tensão alterará o ângulo de difração. A deformação cristalográfica em função da variação das distâncias é:

$$
\varepsilon=\frac{\Delta d}{d_{0}}=-\cot g(\varphi) \cdot \Delta \varphi
$$

\subsubsection{Técnica de Ultra-som}

A técnica de ultra-som se baseia no efeito elasto-acústico, segundo esse princípio a velocidade de propagação de uma onde elástica em sólidos depende das tensões existentes no mesmo, [15]. A espessura da região da medição está estritamente relacionada com o comprimento que é utilizado, usualmente excedendo alguns milímetros. Ela atinge espaçamentos mais profundos do que a técnica de difração de raios $X$.

A variação da velocidade de propagação de ondas num meio devido a presença de tensões pode ser descrita como: 


$$
V=V_{0}+K \sigma
$$

onde $V_{0}$ é a velocidade de propagação de ondas num meio sem tensões, $\sigma$ é a tensão atuante, $K$ é a constante elasto-acústica, que depende do material, e $V$ é a velocidade de propagação no espécime tensionado.

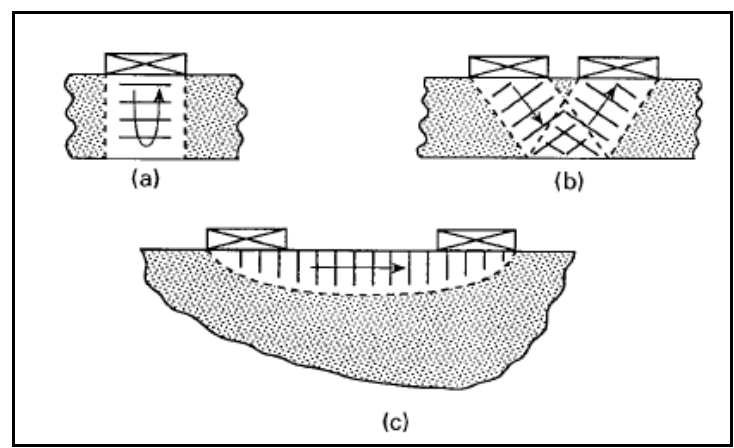

Figura 2.14: Configurações esquemáticas da técnica de ultra-som, (a) através da espessura, pulso-eco; (b) através da espessura, pitch-catch; (c) pela superfície pitch-catch.

\subsubsection{Técnicas Magnéticas}

São técnicas que se baseiam na relação magnetização-deformação e são aplicadas apenas a materiais ferromagnéticos. Dentre as técnicas existentes a mais utilizada é a técnica do ruído de Barkhause, que associa a mudança de microestrutura magnética com a presença de tensões residuais.

Os materiais ferromagnéticos são formados de regiões microscópicas magneticamente ordenadas, conhecidas por domínios. Cada domínio é magnetizado segundo direções cristalográficas preferenciais à magnetização, [16]. Na Figura 2.15 é mostrada a estrutura dos domínios em um material policristalino.

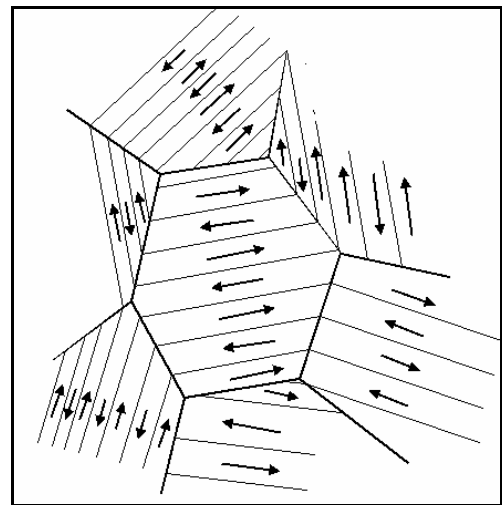

Figura 2.15: Estrutura dos domínios num material policristalino. 
Quando um campo magnético ou uma tensão é aplicada a um material ferromagnético a estrutura dos domínios se modifica, mudando suas dimensões ou rotacionando a direção dos vetores de magnetização. Essas mudanças causam alterações na magnetização média do componente, essas alterações são dependentes das tensões presentes e da microestrutura do material.

No Apêndice A as diferentes técnicas experimentais de medição de tensões residuais são comparadas levando em consideração aspectos técnicos, práticos e custos financeiros.

\subsection{Métodos de Predição de Tensões Residuais}

\subsubsection{Método dos Elementos Finitos}

O método de elementos finitos é uma técnica numérica usada para encontrar soluções aproximadas em problemas com valor de contorno para equações diferenciais parciais. Ele subdivide o domínio do problema em partes mais simples, chamados elementos finitos e utiliza métodos do calculo variacional para resolver o problema através da minimização de uma função de erro associada, [17].

O método dos elementos finitos é hoje a técnica de previsão de tensões residuais mais utilizada, sendo capaz de fornecer resultados confiáveis para estruturas complexas com diferentes geometrias. Essa técnica pode prever tensões residuais e deformações ao longo de um componente, tanto internamente como na superfície.

Nesse trabalho o MEF foi a principal ferramenta para a determinação das tensões residuais em componentes soldados.

\subsubsection{Formulações Analíticas da Distribuição das Tensões Residuais}

Existem diversas formulações para estimar a distribuição de tensões residuais na estrutura soldada, sendo algumas extremamente conservadoras. Em geral, nas formulações apenas a tensão residual longitudinal é estudada, devido à sua magnitude elevada, enquanto que a tensão residual transversal por sua vez é desprezada, devido a sua menor influência na vida da estrutura. Muitas dessas formulações foram obtidas através de observação empírica ou por simulações de elementos finitos comparados com dados experimentais. 


\subsubsection{Formulação de Masubuchi e Martin [18,19,20,21]}

De acordo com Masubuchi e Martin a distribuição de tensões residuais longitudinais $\left(\sigma_{\text {long }}\right)$ em uma solda de topo de duas placas pode ser aproximada pela equação:

$$
\sigma_{\text {long }}(y)=\sigma_{m}\left[1-\left(\frac{y}{b}\right)^{2}\right] \exp \left[-\frac{1}{2}\left(\frac{y}{b}\right)^{2}\right]
$$

onde $\sigma_{m}$ é a máxima tensão residual, que em geral é semelhante ao limite de escoamento do material. O parâmetro $b$ é a largura da zona em tração de $\sigma_{\text {long }}$, podendo ser aproximado como a largura do cordão de solda e y é a distância a partir do centro do cordão. Na Figura 2.16, é apresentada a distribuição de tensões residuais tipicamente encontradas em uma soldagem de topo de duas placas.

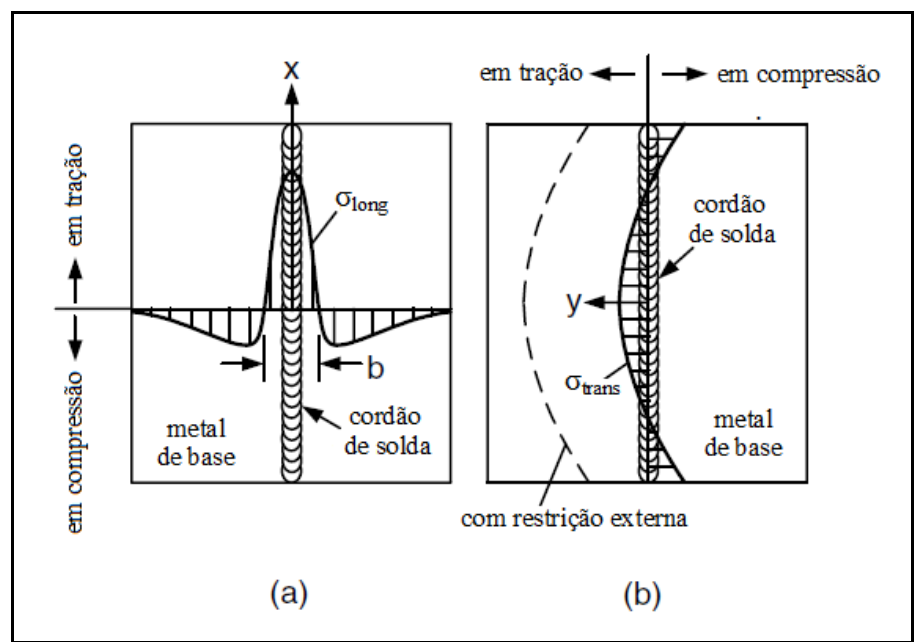

Figura 2.16: Típicas Distribuições de tensão residuais de uma solda de topo: (a) Tensão longitudinal, (b) Tensão transversal.

A distribuição da tensão residual transversal ao longo do comprimento da solda é mostrada na Figura 2.16b. As tensões de tração tem relativamente baixa magnitude e aparecem na parte do meio do cordão de solda, onde a contração térmica na direção transversal é retida pelo metal de base que está muito mais frio. As tensões de tração no meio do cordão são equilibradas por tensões de compressão nas extremidades da solda. 


\subsubsection{Formulação da BS7910 [22,79]}

O anexo Q da norma técnica BS7910 fornece informações sobre a distribuição de tensões residuais tipicamente encontradas ao longo da espessura em juntas soldadas. As distribuições são expressas em termos da profundidade, $z$, pela espessura da junta, $t$, e do limite de escoamento do material, $S_{y}$. A profundidade deve ser medida a partir da superfície do último cordão de solda depositado.

A tensão residual longitudinal para uma solda de topo é dada pela equação:

$$
\sigma_{\text {long }}(z)=S_{y}
$$

Os efeitos das restrições na estrutura na direção longitudinal não são levados em consideração para o calculo dessa tensão, tendo uma distribuição uniforme ao longo da espessura, Figura 2.17a.

A tensão residual transversal pode variar bastante ao longo da espessura, como mostrado na Figura $2.17 \mathrm{~b}$, podendo, para casos sem restrições, ser mensurada pela equação:

$$
\sigma_{\text {trans }}(z)=S_{y} \cdot\left[0.9415-0.0319\left(\frac{z}{t}\right)-8.3394\left(\frac{z}{t}\right)^{2}+8.660\left(\frac{z}{t}\right)^{3}\right]
$$

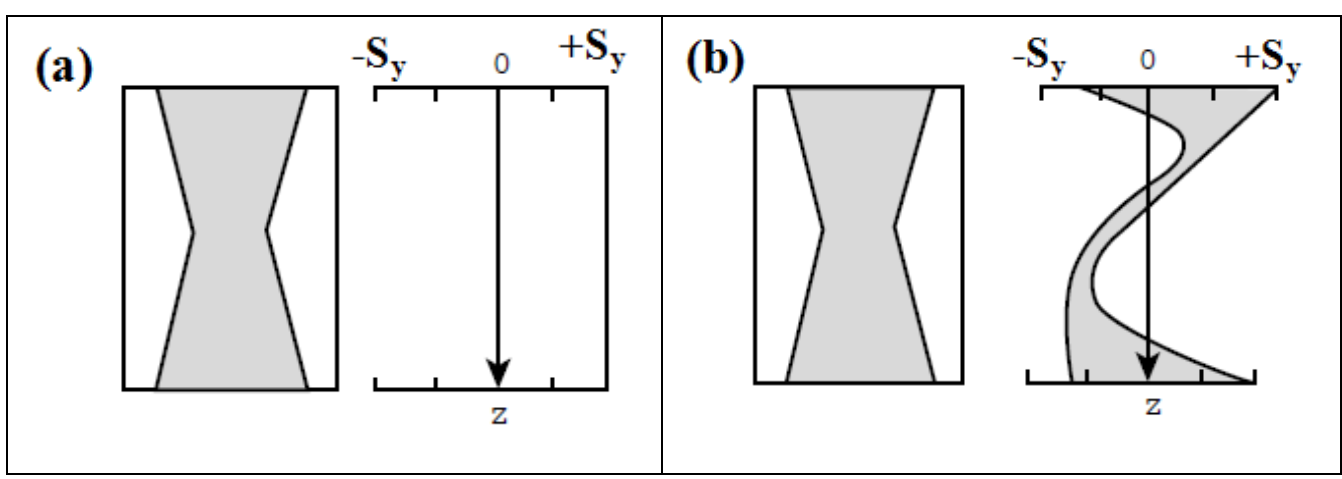

Figura 2.17: Distribuições de tensão residuais pela espessura de uma solda de topo segundo a norma BS7910: (a) Tensão longitudinal, (b) Tensão transversal, [22].

\subsubsection{Formulação da API 579 [23]}

Um procedimento para determinar e avaliar a magnitude e a distribuição de tensões residuais em juntas soldadas é fornecido no anexo E da norma API 579. 
As distribuições de tensões residuais fornecidas nessa norma tratam das tensões na junta como soldada ("as-welded") e também após um tratamento de alívio de tensões.

A fim de estimar a magnitude da distribuição de tensões residuais na junta soldada, deve-se fazer uma estimativa do limite de escoamento real do material. $\mathrm{Na}$ ausência de dados experimentais o limite real pode ser estimado segundo a equação abaixo, que eleva o limite real acima do especificado por norma.

$$
S_{y}^{r}=S_{y}+69 M P a
$$

Uma função paramétrica é utilizada para descrever a distribuição de tensões residuais superficiais na direção longitudinal do cordão de solda. A tensão longitudinal pode ser calculada pelas equações:

$$
\begin{aligned}
& \sigma_{\text {long }}(y)=S_{y}^{r} \cdot R_{r} \quad \text { para } \quad|y| \leq \frac{w}{2}
\end{aligned}
$$

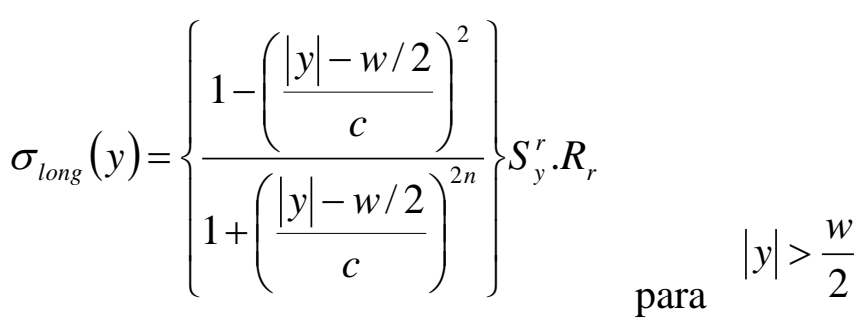

onde $R_{r}$ é um parâmetro que traduz a redução da tensão residual caso seja aplicado algum tratamento de alívio de tensões, y é a coordenada local definida ao longo da superfície do componente, $w$ é a largura do cordão de solda, $c$ é um parâmetro de comprimento, sendo proporcional a $\sqrt{r \cdot t}$ para tubos ou a espessura, $t$, para placas e $n$ é um parâmetro de integração, podendo ser 2,3,4 ou 5 dependendo da geometria da junta e da direção da tensão residual.

Na Figura 2.18, é apresentada a distribuição de tensões residuais superficiais na direção do cordão de solda em uma placa e em uma casca cilíndrica. 


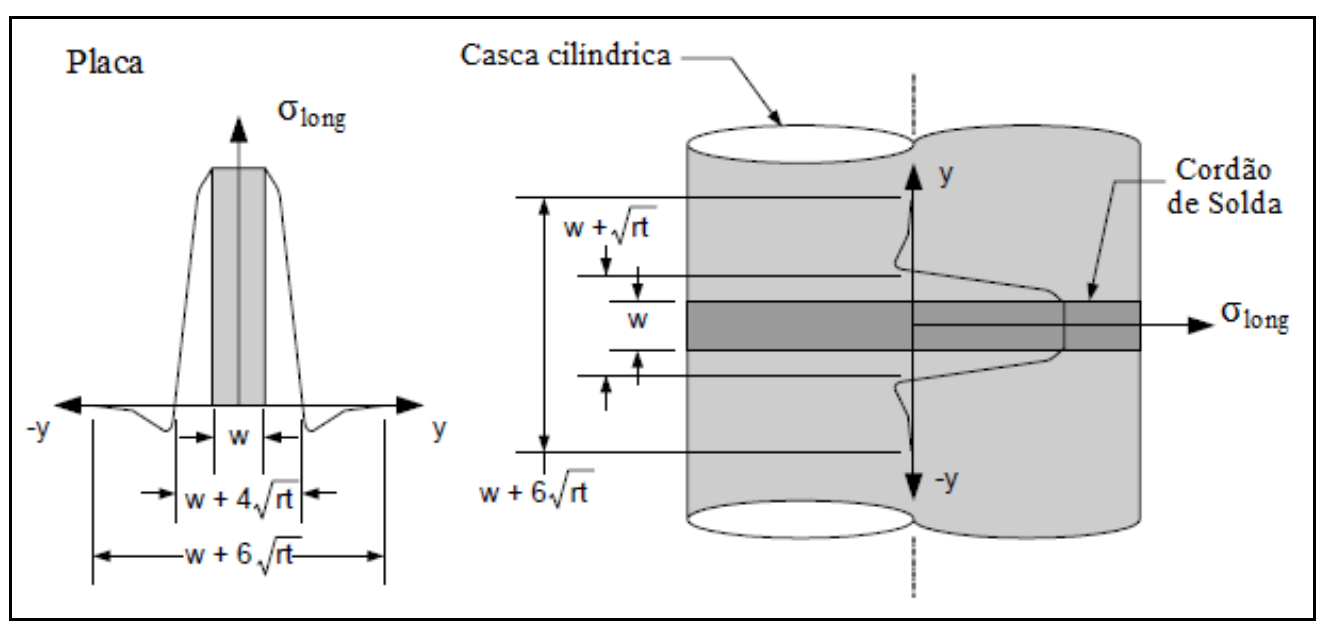

Figura 2.18: Distribuições de tensão residuais pela superfície segundo a norma API 579.

\subsection{Alívio de Tensões Residuais}

Em geral a resistência à fadiga das juntas soldadas é consideravelmente mais baixa que a resistência à fadiga do metal de base. Pode-se contornar esse problema otimizando o projeto da junta, escolhendo o tipo mais adequado de junta, que possui maior resistência à fadiga, e posicionando as juntas em zonas da estrutura com menores tensões nominais. Entretanto nem sempre é possível recorrer a essas soluções; por exemplo, é impossível em uma estrutura complexa eliminar todas as soldas de canto.

Assim é desejável utilizar outros métodos que permitam melhorar o desempenho à fadiga. Esses métodos têm por finalidade introduzir tensões compressivas ou reduzir a magnitude das tensões trativas presentes na junta e em suas adjacências. A seguir serão apresentadas algumas técnicas de aprimoramento da vida da estrutura, sendo divididos entre métodos de alívio térmicos e não térmicos (ou mecânicos).

\subsubsection{Métodos de Alívio Térmicos}

O método de alívio térmico mais comum é o pós-aquecimento da junta soldada. Ele é um tratamento térmico que visa à redução e redistribuição das tensões residuais que tenham sido introduzidas pela soldagem. 
O grau de relaxamento das tensões residuais depende do tipo de material, da sua composição, da temperatura de pico (máxima) em que se realiza o pós-aquecimento e do tempo em que a junta permanece nessa temperatura. É comumente considerado no pós-aquecimento que a junta deve permanecer na temperatura de pico durante uma hora para cada $25,4 \mathrm{~mm}$ de espessura embora em certos casos, um mínimo tempo de permanência deve ser especificado.

$\mathrm{O}$ aquecimento da junta após a soldagem reorganiza a estrutura cristalina do material, transformando à de metaestável em estável. A temperatura de pico pode variar entre uma faixa de $350^{\circ} \mathrm{C}$ até $650^{\circ} \mathrm{C}$ e a junta é resfriada lentamente até a temperatura ambiente. Além da redução e redistribuição das tensões residuais, o pós-aquecimento em temperaturas elevadas permite a ocorrência de alguma têmpera, precipitação ou efeitos de envelhecimento. Estas alterações metalúrgicas podem reduzir a dureza da estrutura como soldada, melhorar a ductilidade e a reduzir os riscos de ruptura frágil. Em alguns aços, no entanto, os processos de envelhecimento e precipitação podem causar deterioração das propriedades mecânicas.

A Figura 2.19, mostra a redução de tensões residuais em uma junta que foi reparada após a realização de um pós-aquecimento, [24].

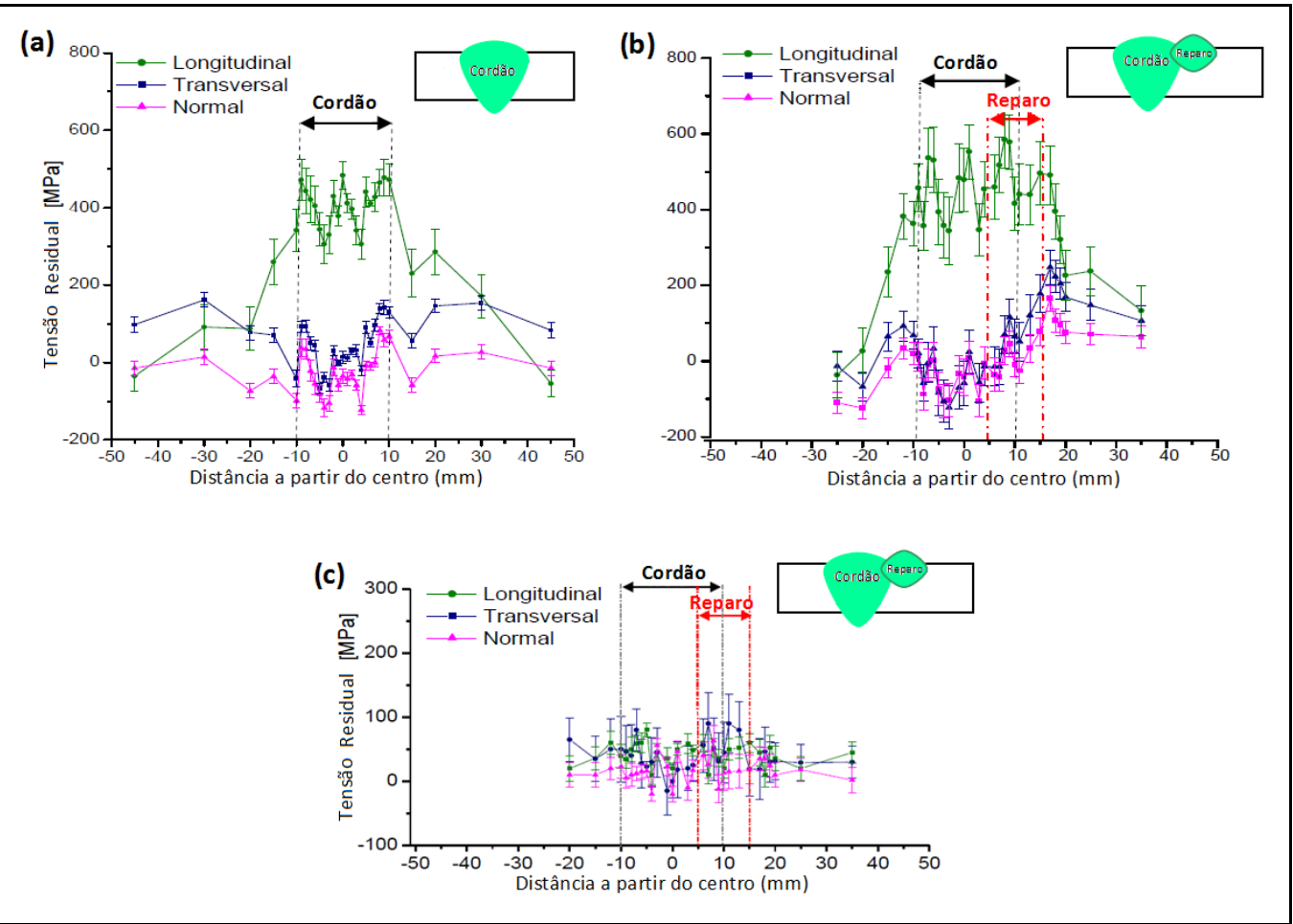

Figura 2.19: Tensões residuais em uma junta soldada: a) sem reparo e sem tratamento de alívio; b) reparada sem tratamento de alívio; c) reparada com tratamento de alívio de tensões, [24]. 


\subsubsection{Métodos de Alívio Mecânicos}

Dentre os métodos mecânicos de alívio de tensões residuais pode-se citar como os mais comumente empregados o jateamento de granalha (shot peening), o martelamento, os testes hidrostáticos e o laser peening. Nesses métodos de alívio de tensão, carregamentos externos são aplicados na estrutura soldada. Com a introdução desses carregamentos externos partes da estrutura se deformam plasticamente e, consequentemente, uma redução considerável das tensões residuais é alcançada quando a carga aplicada é removida.

O mecanismo de redistribuição de tensões pode ser explicado pela Figura 2.20, onde é mostrado o comportamento de uma solda de topo com tensões residuais quando submetida a um carregamento externo uniforme.

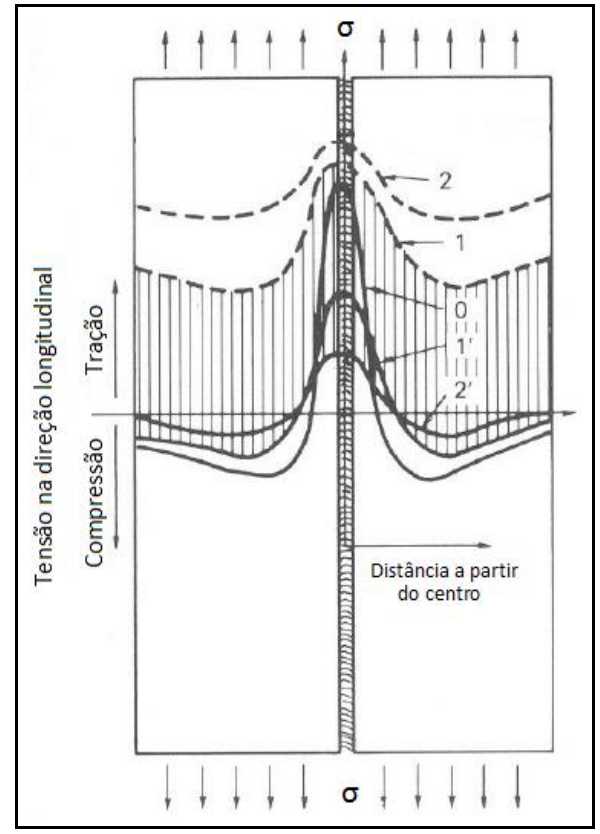

Figura 2.20: Distribuição de tensões em uma placa com solda de topo quando submetida a um carregamento externo.

A curva-0 mostra a distribuição da tensão residual longitudinal no estado soldado. A curva-1 mostra a distribuição de tensões quando é aplicada $\sigma_{l}$ e a curva-1' é a distribuição de tensão após $\sigma_{1}$ ter sido aplicada e libertada. A curva-2 mostra o aumento de tensão de tração para $\sigma_{2}$ e a curva-2' é a distribuição de tensão após $\sigma_{2}$ ter sido aplicada e libertada. 


\section{3 Análise Térmica do Processo de Soldagem}

Em muitas aplicações práticas da soldagem é desejável conhecer a distribuição de temperaturas na junta, em relação à posição, ao tempo e às condições de soldagem. Nos processos de soldagem a junta precisa ser aquecida até uma temperatura adequada, trabalhando-se com fontes de calor localizadas e de elevada temperatura. O aquecimento localizado e não uniforme causa distorções na estrutura e para compreender os estados de tensão e deformação originados é necessário propor soluções analíticas e numéricas para a distribuição de temperatura na estrutura.

Ao longo do tempo as principais técnicas para solução dos problemas de transferência de calor foram mudando com o aumento da capacidade computacional. As soluções analíticas foram introduzidas à aproximadamente 70 anos atrás e as soluções baseadas nos métodos numéricos, como diferenças finitas e elementos finitos, foram propostas há 40 anos. Nos últimos anos o método dos elementos finitos (MEF) se tornou a técnica mais popular e eficiente para resolução de problemas de transferência de calor.

Este trabalho trata do estudo da soldagem por fusão. Assim uma gama de diferentes processos de soldagem são compreendidos. Entre os principais tem-se: soldagem por eletroescória (ESW), soldagem por arco submerso (SAW), soldagem por eletrodo revestido (SMAW), soldagem por gás inerte ou ativo (MIG/MAG) e soldagem com eletrodo de tungstênio (GTAW). Esses processos se baseiam na fusão do metal de base e do metal de solda para formar a junta soldada.

As equações que governam o fluxo de calor em um sólido isotrópico são lineares. Esse fato torna possível encontrar soluções analíticas que dão as distribuições de temperatura para um número de diferentes configurações e tamanhos diferentes de fonte de calor. Os modelos utilizados nas derivações são normalmente de forma simplificada; por exemplo, se presume que o calor é emitido a partir de um ponto, ao longo de uma linha, ou através de um plano. 
Fontes de calor reais têm dimensões finitas e as distribuições de temperatura reais da soldagem desviam consideravelmente das calculadas a partir de expressões teóricas, [25]. A criação de um modelo analítico para o estudo da troca de calor na soldagem consiste no desenvolvimento de uma formulação matemática que melhor descreve a distribuição de temperaturas no corpo estudado. Os modelos analíticos estão condicionados a geometrias específicas. Estruturas complexas são aproximadas por geometrias com distribuição de temperatura conhecida. Na Figura 3.1, são mostradas algumas das geometrias que possuem soluções para a distribuição de temperatura.

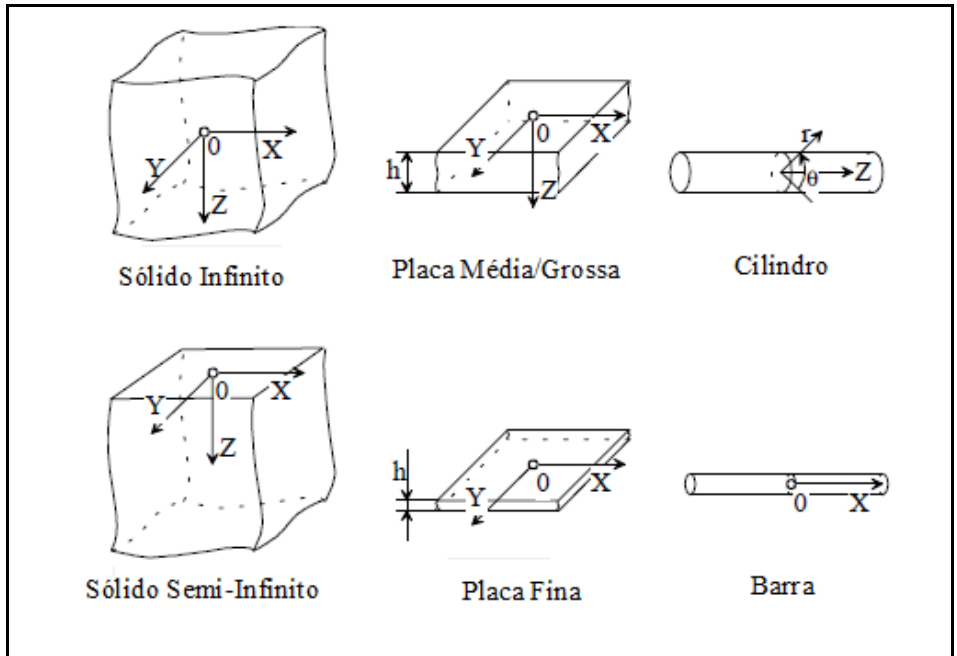

Figura 3.1: Geometrias com distribuição de temperatura conhecida.

Para resolver os diferentes problemas de transferência de calor com geometrias complexas e sem solução analítica conhecida uma variedade de modelos de elementos finitos pode ser empregada. A modelagem por elementos finitos se inicia com a discretização da geometria em questão em um número finito de elementos, de modo que cada elemento satisfaça, de modo individual, as condições de equilíbrio e, entre eles mesmos, sejam cumpridas as condições de compatibilidade geométrica do sistema.

Cada elemento é composto por um conjunto de nós, que se conectam entre si e com os nós dos demais elementos. A discretização da geometria em elementos permite resolver o problema de transferência de calor mediante o uso de um sistema de equações não lineares, resolvidas por métodos incrementais e interativos. 
O próximo passo é a escolha do tipo de análise, permanente ou transiente. Em seguida é a escolha do modelo para a fonte de calor, que pode variar sua dimensão, posição e duração. O último passo é a aplicação das condições de contorno da análise, mecanismos de troca de calor, restrições e condições de préaquecimento. A Figura 3.2 mostra o diagrama de fluxo para o desenvolvimento do modelo da soldagem.

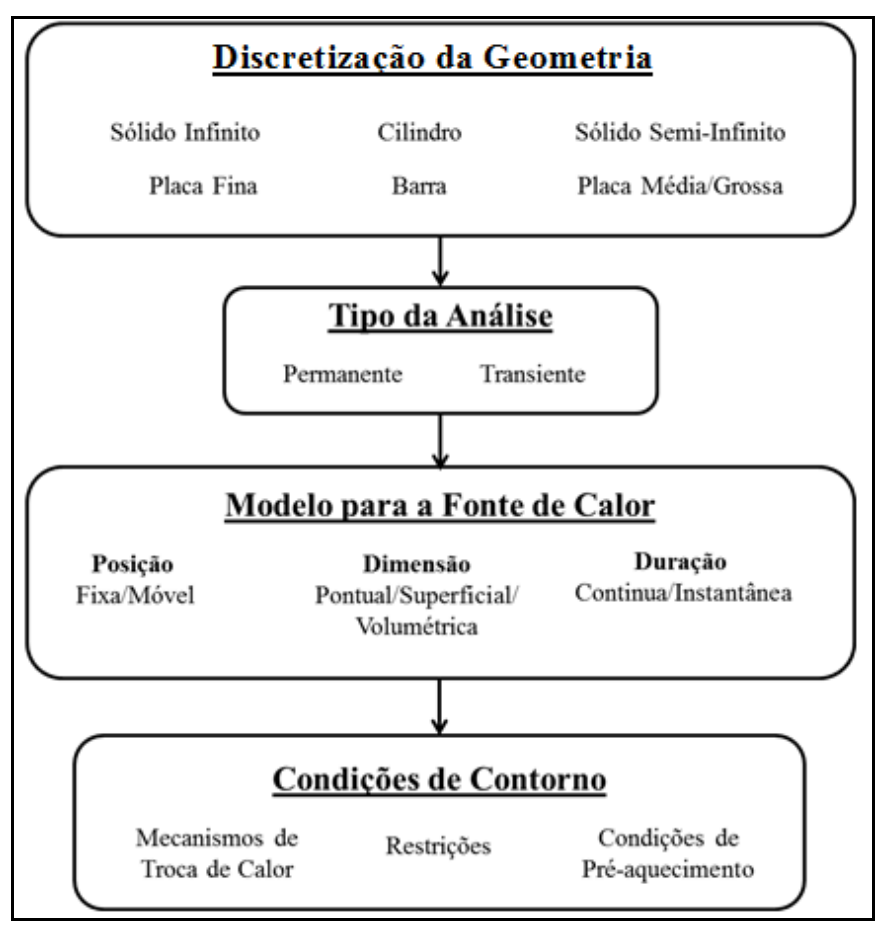

Figura 3.2: Fluxograma para o estudo da soldagem.

O modelo tridimensional (3D) transiente, que leva em consideração os efeitos de tamanho e de assimetria da geometria ao longo do tempo, foi escolhido para a simulação do processo de soldagem por ser o mais próximo do real.

Para simulação da soldagem foi adotada a hipótese das três barras, onde o cordão de solda e as partes unidas pela solda são representadas por barras em paralelo, como mostrado na Figura 3.3. Todas as três barras estão inicialmente à temperatura ambiente. A barra do meio é aquecida individualmente, dilatando-se até atingir o mesmo comprimento das demais barras, passando a estar ligada ao bloco rígido superior. A partir desse momento a barra do meio tende a se contrair devido à perda de temperatura para o meio gerando um estado de tensões residuais na estrutura. $\mathrm{O}$ desenvolvimento das tensões residuais provocadas pelos ciclos térmicos da soldagem utilizando a hipótese das três barras será estudado no capítulo 4. 


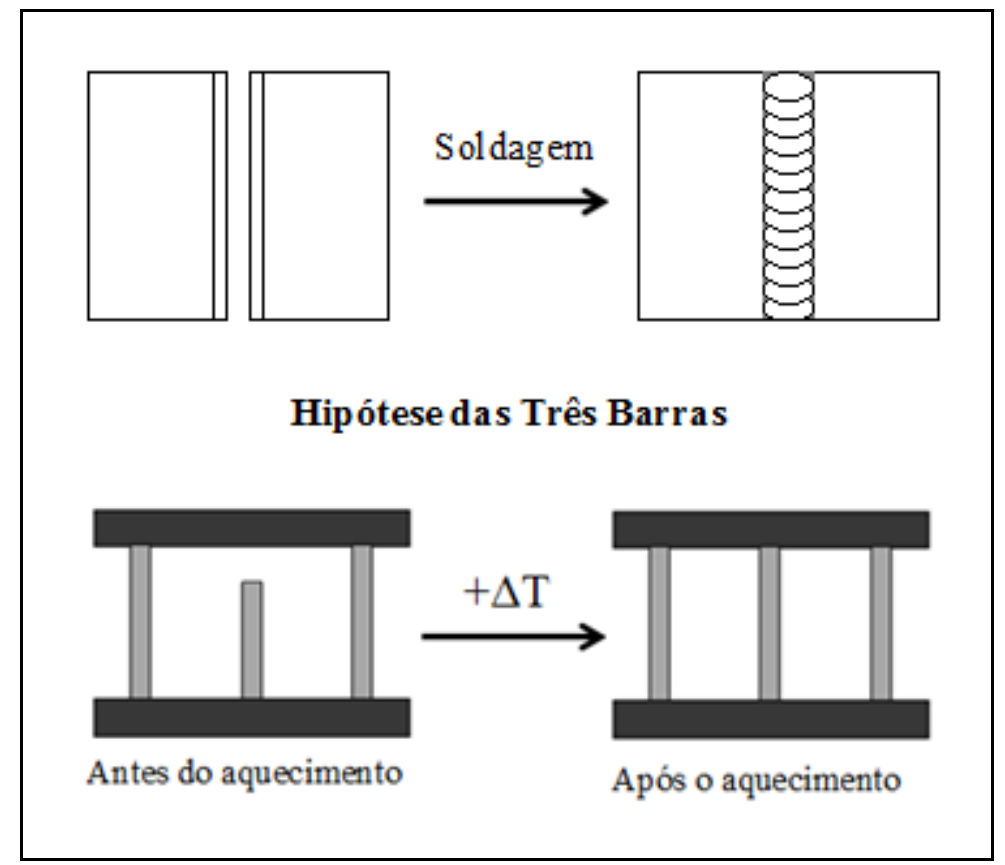

Figura 3.3: Hipótese das três barras para simulação da soldagem.

O fluxo de calor na soldagem pode ser dividido em duas etapas: fornecimento de calor à junta e dissipação desse calor pelo componente e para o ambiente. A seguir será estudado o fenômeno da transferência de calor na soldagem e os parâmetros que a influenciam.

\subsection{Fonte de Calor}

O arco elétrico é a fonte de calor mais utilizada na soldagem por fusão de materiais metálicos, pois apresenta uma concentração adequada de energia para fusão do metal de solda e de base, além de ser de fácil utilização e ser de baixo custo. O arco elétrico consiste de uma descarga elétrica constante, através de um gás ionizado chamado de plasma, a alta temperatura, capaz de fundir e unir os metais de solda e de base, [26].

A Figura 3.4 mostra um arco elétrico com eletrodo de tungstênio e gás de proteção de hélio em chapa de cobre resfriada por água. 


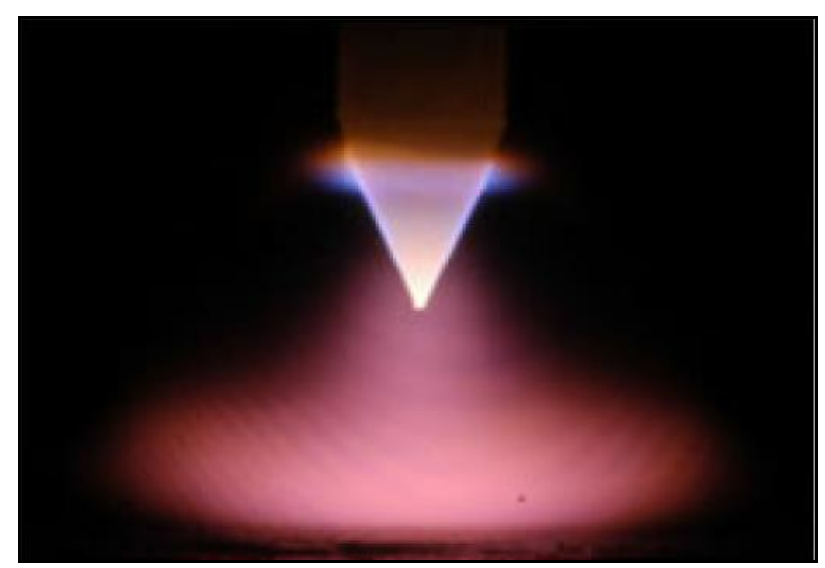

Figura 3.4: Arco elétrico com eletrodo de tungstênio e gás de proteção de hélio em chapa de cobre resfriada por água, [27].

A transferência de calor do arco elétrico para a peça acontece principalmente através de três formas, como mostrado na Figura 3.5. A primeira forma acontece na conexão arco-peça, onde o calor é transferido por condução da coluna de plasma para a junta formando a poça de fusão. Quanto maior for a corrente elétrica, maior será o calor transferido para a superfície da poça de fusão. É razoável assumir que mais de $80 \%$ de toda tensão do arco é consumida na conexão arco-peça e arco-eletrodo.

A segunda forma da transferência do calor para a peça é representada pelo calor carregado por gotas de material fundido indo do eletrodo para a poça de fusão. Esta quantidade do calor representa de 20 a $30 \%$ da energia total de soldagem, dependendo do material e do tipo da transferência metálica. Uma parcela do calor carregado pelas gotas é perdida para o ambiente devido aos respingos e à evaporação metálica.

A terceira forma envolve a energia da coluna de plasma que é entregue para a peça, principalmente na área adjacente à poça de fusão. A radiação da coluna de plasma é uma forma de transferir o calor, especialmente fora da conexão arcopeça, devido à alta temperatura dentro dessa região. Entretanto, o jato de plasma também carrega energia do plasma para a peça através da convecção forçada e difusão. Assim, uma parcela do calor da coluna de plasma se perde para o ambiente, por radiação predominantemente e convecção. Mas uma parcela significante desta perda de calor da coluna de plasma vai para a peça, não sendo considerada como perda. Isso acontece por convecção, uma vez que a camada correspondente do gás aquecido não ionizado em torno também carrega a energia, [28]. 


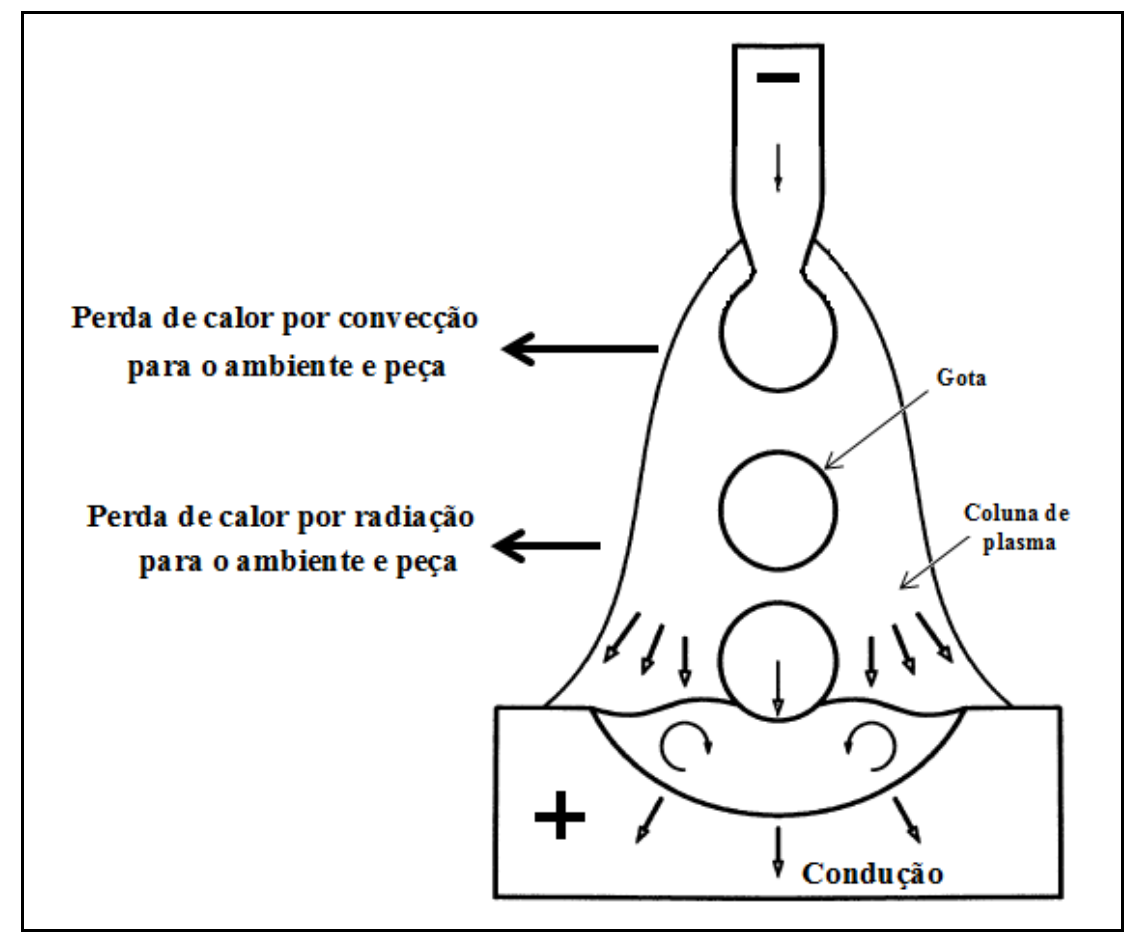

Figura 3.5: Representação esquemática do arco elétrico e das formas de transferência de calor para a peça.

Pode se assumir que toda a energia elétrica do arco é convertida em energia térmica, no entanto nem toda energia é usada para aquecer o metal de base e o de solda. Uma parte dessa energia é perdida por dissipação para o meio. Logo a eficiência do processo de soldagem pode ser expressa em função da energia fornecida à peça, da voltagem e da corrente utilizadas, assim tem-se:

$$
Q=\eta \cdot U \cdot I
$$

onde $\eta$ é a eficiência do arco elétrico, $U$ é a voltagem do arco, $I$ é a corrente do arco e $Q$ é o fluxo de calor líquido fornecida a peça.

Devido às características únicas de cada processo de soldagem a eficiência de cada processo é diferente dos demais. Os valores das eficiências são mostrados na Tabela 3.1 a seguir.

Tabela 3.1: Eficiência de cada processo de soldagem, [26].

\begin{tabular}{|c|c|c|c|c|c|}
\hline Processo & SAW & SMAW & $\begin{array}{c}\text { GTAW } \\
\text { (CC-) }\end{array}$ & $\begin{array}{c}\text { GTAW } \\
(\mathbf{C C}+)\end{array}$ & MIG/MAG \\
\hline $\begin{array}{c}\text { Eficiência } \\
(\boldsymbol{\eta})\end{array}$ & $0.85-0.98$ & $0.70-0.90$ & $0.50-0.80$ & $0.20-0.98$ & $0.75-0.95$ \\
\hline
\end{tabular}


A maioria dos modelos analíticos de fontes de calor propostos na literatura utilizam a distribuição normal (gaussiana) para representar a distribuição do fluxo de calor, com os maiores fluxos no centro da distribuição. Os modelos são diferenciados pelas suas dimensões espaciais; fonte pontual, superficial e volumétrica. Maiores informações sobre os modelos analíticos de fonte de calor podem ser encontradas no Apêndice B.

O modelo de aporte térmico que melhor se adequa a esse estudo é a distribuição volumétrica do calor, sendo representado pelo cordão de solda, como mostrado na Figura 3.6. Considerou-se que todo calor é transferido para a peça através do cordão de solda, que é depositado a uma temperatura uniforme e em geral em torno da temperatura de fusão do material. A fonte foi modelada como um corpo "quente" que é depositado de uma só vez, considerando a hipótese das três barras, trocando calor com a peça e o meio até todo o sistema alcançar o equilíbrio térmico.

A fim de compensar a parcela de calor transferida para a peça através da condução de calor da coluna de plasma para a junta, que não é simulada, é razoável assumir que durante o primeiro segundo (1s) de simulação o cordão de solda não sofre influência das condições de contorno, não trocando calor com o ambiente, mas apenas com a peça.

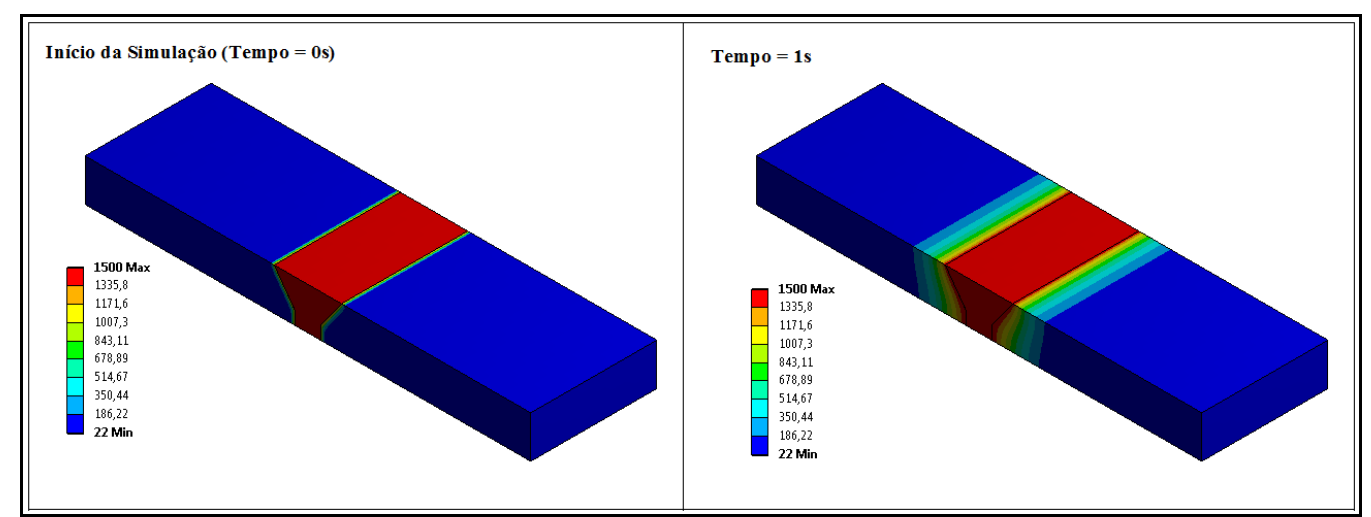

Figura 3.6: Cordão de solda representando a fonte de calor volumétrica no início da simulação e após 1 segundo transcorrido. 


\subsubsection{Temperatura do Cordão de Solda}

A temperatura que o cordão de solda apresenta no instante em que é depositado influenciará severamente o comportamento mecânico da estrutura. Pode-se estimar a temperatura inicial do cordão de solda utilizando a formulação de Adam, [29], que tem como base as equações para a distribuição de temperatura em placas planas desenvolvidas por Rosenthal. Formulações analíticas para a distribuição de temperaturas na soldagem podem ser encontradas no Apêndice B.

Adam propôs as seguintes equações para calcular a temperatura de pico, $T_{p}$, adotada como a temperatura inicial do cordão, na superfície das chapas (coordenada $z$ igual a zero) a uma distância $Y$ distante da zona fundida (medida ao longo da direção normal).

Para o modelo bidimensional (chapas finas), tem-se:

$$
\frac{1}{T_{p}-T_{0}}=\frac{4.13 \mathrm{VYg} \rho c}{Q}+\frac{1}{T_{m}+T_{0}}
$$

Para o modelo tridimensional (chapas grossas), tem-se:

$$
\frac{1}{T_{p}-T_{0}}=\frac{5.44 \pi k \alpha}{Q V}\left[2+\left(\frac{V Y}{2 \alpha}\right)^{2}\right]+\frac{1}{T_{m}+T_{0}}
$$

onde $T_{p}$ é a temperatura de pico, $T_{0}$ é a temperatura de pré-aquecimento, $T_{m}$ é a temperatura de fusão do metal, $g$ é a espessura, $\rho$ é a massa específica, $c$ é o calor específico, $\alpha$ é a difusividade térmica, $k$ é a condutividade do material, $Q$ é o aporte térmico (obtido a partir da equação 3.1), $V$ é a velocidade de soldagem e $Y$ é a distancia na direção $y$.

A Figura 3.7 mostra a distribuição e o histórico de temperaturas em uma placa grossa de aço SAE 1018 soldada com uma velocidade de $2.4 \mathrm{~mm} / \mathrm{s}$ e com um aporte de $3200 \mathrm{~W}$, obtidos utilizando a formulação de Adam, [29]. 


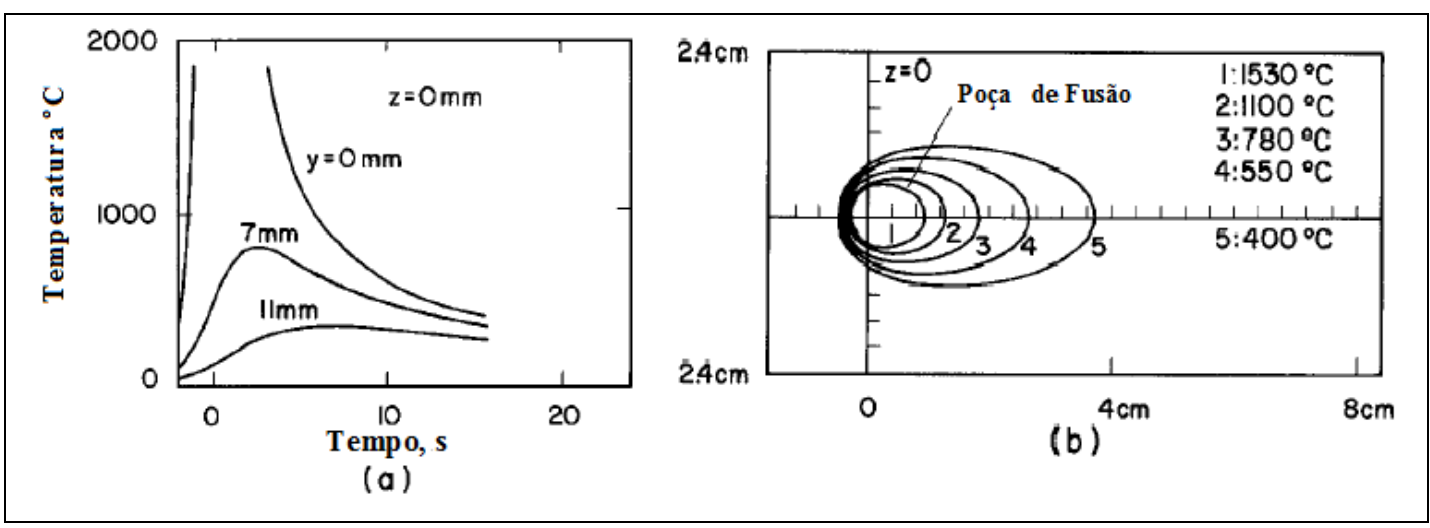

Figura 3.7: Resultados Térmicos obtidos com a formulação de Adam: a) Ciclos Térmicos; b) Isotérmicas das temperaturas.

$\mathrm{Na}$ ausência de dados como corrente, tensão elétrica, velocidade de soldagem e tipo de processo de soldagem é razoável assumir sem prejuízo para a simulação que o cordão de solda foi depositado na temperatura de fusão do metal de base, [30, 31].

\subsubsection{Técnicas de "Morte" e "Nascimento" de Elementos}

Se uma porção de material é retirada ou adicionada de um sistema, alguns elementos em seu modelo podem tornar-se "inexistentes" ou "existentes" respectivamente. As opções de "morte" e "nascimento" de elementos podem ser usadas para desativar ou reativar elementos selecionados em tais casos. No software ANSYS, os comandos EKILL e EALIVE são usados respectivamente para cada uma dessas operações.

Para conseguir o efeito de "morte" do elemento, o software ANSYS, na verdade, não remove os elementos "mortos". Em vez disso, ele os desativa, multiplicando sua rigidez ou condutividade, dependendo do tipo de simulação, por um severo fator de redução. Este fator é definido como $10^{-6}$ por padrão, mas pode ser alterado nas configurações do software. Carregamentos aplicados ao elemento associado com elementos desativados são zerados, no entanto, eles ainda fazem parte do vetor de carregamentos. Da mesma forma, a massa, o amortecimento, o calor específico, e outras propriedades são zerados em elementos desativados. A massa e energia de elementos desativados não são incluídas nas somas durante a simulação. A deformação do elemento também é definida como zero assim que esse elemento é morto. 
Da mesma forma, quando os elementos "nascem", eles não são realmente adicionados ao modelo, eles são simplesmente reativados. No início da análise deve-se criar todos os elementos, incluindo aqueles que irão "nascer" em fases posteriores da análise. Não se pode criar novos elementos. Para adicionar um elemento, primeiro se deve desativá-lo, em seguida, reativá-lo no instante apropriado.

Quando um elemento é reativado, a sua rigidez, massa, carregamentos e outros irão retornar aos seus valores originais. Os elementos que são reativados não possuem histórico de deformações ou temperaturas de instantes anteriores a sua reativação. No entanto, a deformação inicial, definida como uma constante real (para elementos do tipo treliças, como LINK1), não serão afetados pelas operações de "nascimento" e "morte". Além disso, a menos que os efeitos de grande deformação estejam ativados, alguns tipos de elementos serão reativados em sua configuração geométrica original (efeitos de grande deformação devem ser incluídos para obter resultados significativos). As deformações térmicas são calculadas para elementos recém-ativados com base na temperatura do passo em que se ativou o elemento e na temperatura de referência. Assim, elementos recém-nascidos submetidos a cargas térmicas podem não estar livres de tensões, o que é esperado na soldagem, [32, 33, 34].

\subsubsection{Soldagem com Múltiplos Cordões de Solda}

É possível criar uma poça de fusão de qualquer tamanho, simplesmente aumentando a taxa de transferência de calor para a estrutura. No entanto a poça de fusão pode se tornar difícil de controlar à medida que cresce, e o tamanho de grão pode se tornar indesejavelmente grande. Por isso, é usual limitar o tamanho ou a penetração da solda em torno de um tamanho de $20 \mathrm{~mm}$. Para estruturas que necessitem de maior penetração utilizam-se múltiplos passos de soldagem, [25].

A soldagem com múltiplos passes consiste em sucessivas camadas superpostas de cordão de solda apresentando uma multiplicidade de zonas afetadas pelo calor. Esse tipo de soldagem é utilizada no reparo de peças com defeitos e quando a espessura da peça for elevada. Neste caso, a união dos componentes não pode ser realizada com apenas um único passe. 
Cada passe de solda representa um aporte de calor independente. Para simular a sequência de deposição de passes deve-se usar as técnicas de "morte" e "nascimento" de elementos. Todos os passes com exceção do primeiro passe ou de raiz devem ser desativados no início da simulação. À medida que a simulação se desenvolve os passos subsequentes são ativados, em ordem, até o término da soldagem.

Na Figura 3.8, é apresentada a soldagem com múltiplos passes de duas chapas com considerável espessura, sendo utilizados 4 passes. Inicialmente os passes 2, 3 e 4 foram desativados e no decorrer da simulação cada passe foi ativado segundo o histórico de simulação.
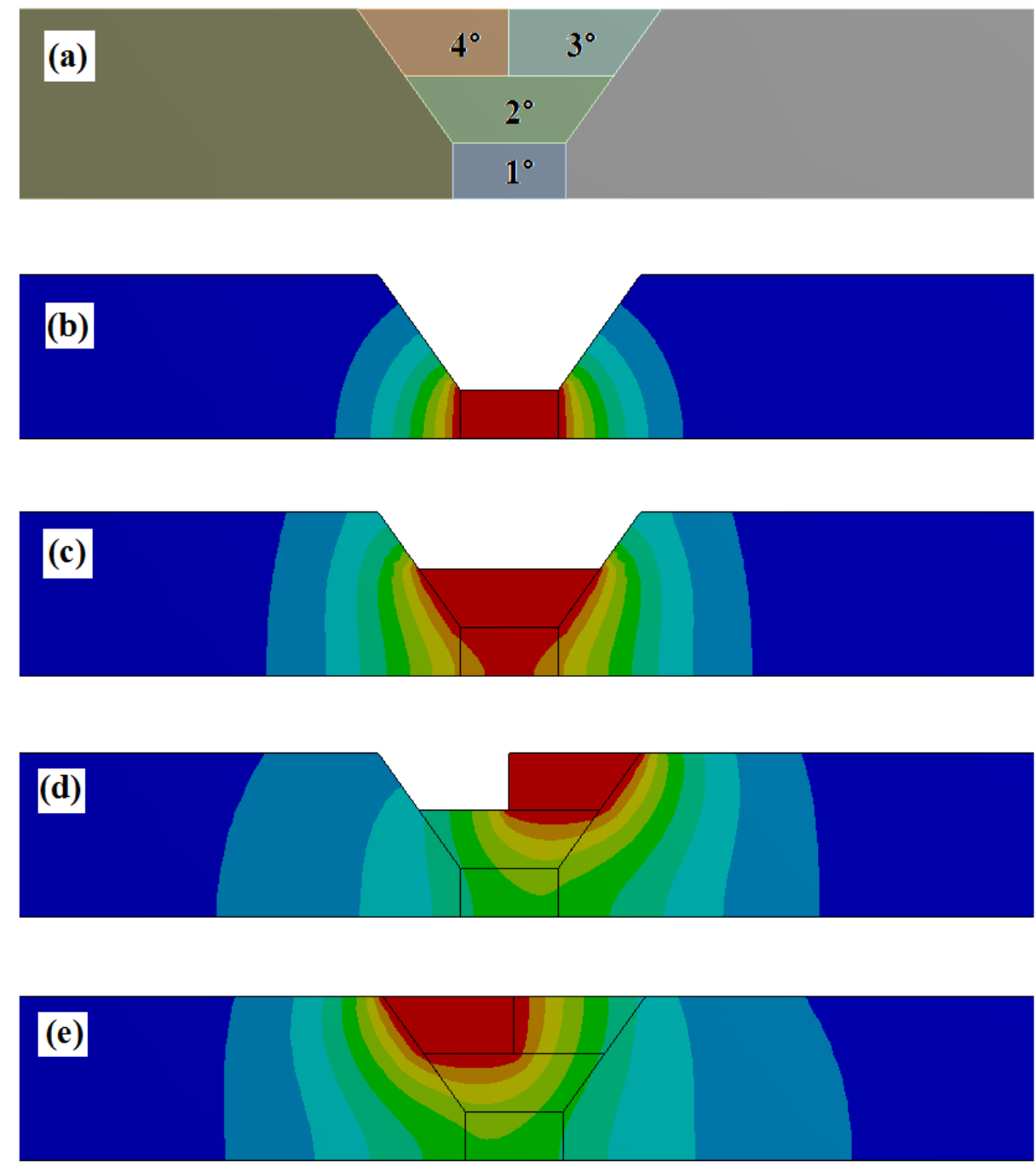

Figura 3.8: Soldagem de duas chapas utilizando múltiplos passes: (a) Esquemático da sequência dos passes; (b) Passe de raiz, único que não é desativado no início; (c) Ativação do $2^{\circ}$ passe; (d) Ativação do $3^{\circ}$ passe; (e) Ativação do $4^{\circ}$ passe. 


\subsubsection{Deposição do Cordão de Solda Levando em Consideração os Efeitos da Velocidade de Soldagem no Comportamento da Estrutura}

A velocidade de soldagem representa a velocidade de deslocamento do arco elétrico ao longo do comprimento da junta. A penetração e o tamanho do cordão de solda serão influenciados pela velocidade de soldagem.

Como citado na seção 2.3 do capítulo 2, a sequência de soldagem influencia significativamente as tensões residuais, uma vez que ao longo do comprimento do cordão as condições de restrição mudam, à medida que a solda depositada se solidifica atrás da poça de fusão. A velocidade de soldagem será determinante no comportamento das distorções na estrutura, causadas pelo encolhimento devido à solidificação do material e pelas contrações térmicas.

Uma aproximação mais realista da simulação da deposição do cordão de solda consiste em considerar que em vez do cordão ser depositado de uma só vez, como uma única barra (hipótese das três barras), ele é depositado aos poucos. $\mathrm{O}$ cordão de solda passa a ser representado por várias barras menores, essa conjectura leva em consideração a influência da velocidade de soldagem na geometria da peça após a soldagem.

Semelhante à soldagem com múltiplos passes utiliza-se as técnicas de "morte" e "nascimento" de elementos para simular a deposição do cordão. A primeira seção do cordão, primeira barra, não é desativada, em seguida as demais barras são ativadas conforme a relação entre velocidade de soldagem e o tempo decorrido de simulação.

A Figura 3.9 mostra a distribuição de temperatura e o comportamento de duas chapas soldadas em diferentes instantes de tempo, onde o cordão de solda foi depositado aos poucos segundo uma velocidade de soldagem predeterminada. 


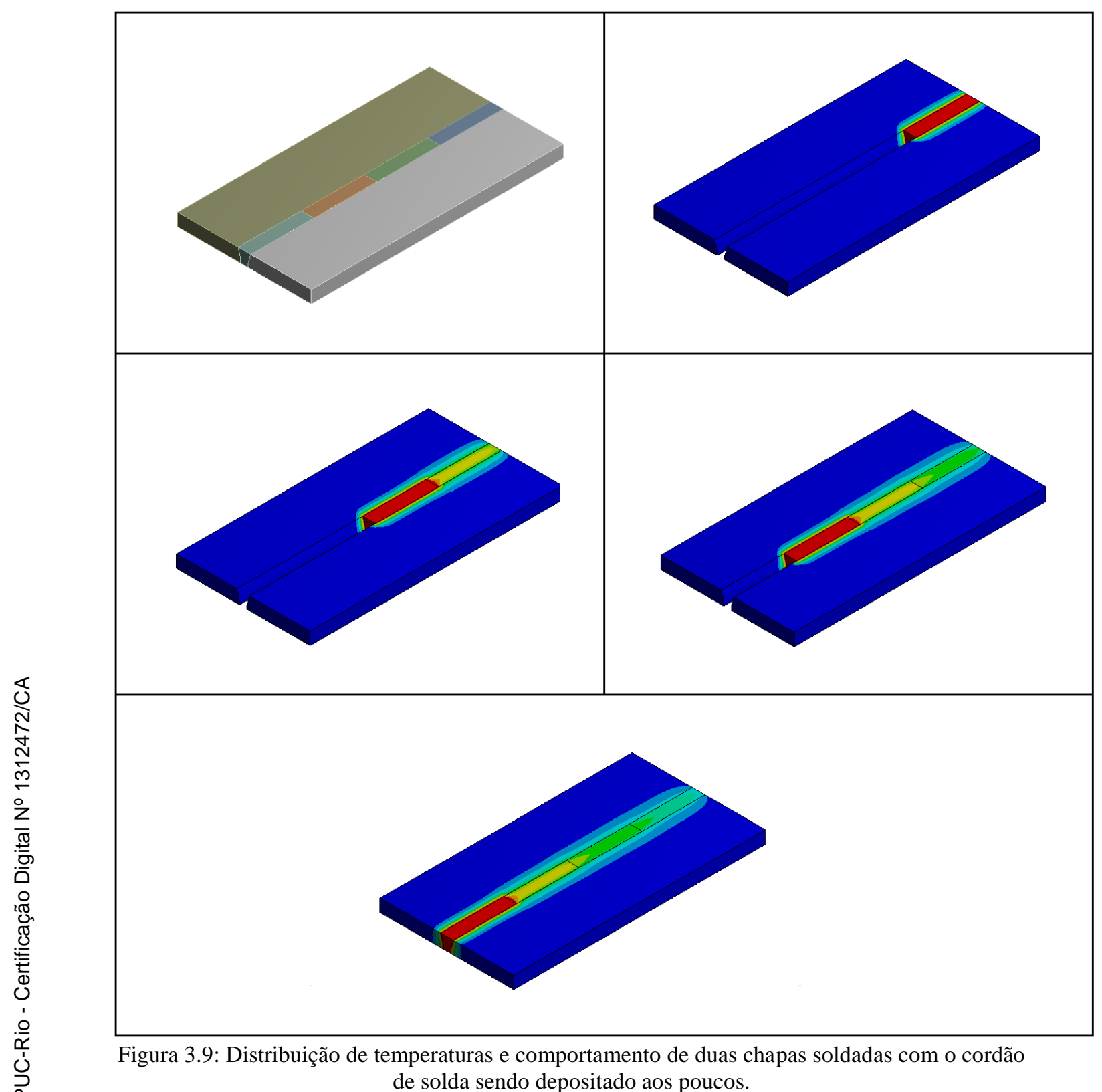

\subsection{Transferência de Calor na Junta Soldada}

O calor fornecido pelo aporte de calor produz na junta um histórico de temperaturas complexo, onde as temperaturas variam em função da posição, do tempo e das características do processo de soldagem empregado. Esses ciclos térmicos, a que a peça é submetida, provocam mudanças da microestrutura do material, tensões térmicas e deformações. Portanto compreender e estimar as temperaturas na estrutura é de fundamental importância, pois o comportamento dos componentes submetidos a um processo de soldagem depende significativamente dos fenômenos de transferência de calor. 


\subsubsection{Mecanismos de Troca de Calor}

Existem quatro modos básicos de transporte de calor: condução, convecção, mudança de fase e radiação. A zona fundida, ZF, e as regiões adjacentes ao metal de solda, ZTA, são submetidas a ciclos térmicos cujas temperaturas de pico diminuem à medida que se afasta do eixo central da solda. Essas temperaturas sofrem uma brusca variação devido à perda de calor, podendo haver modificações estruturais em relação ao material original, como mostrado na Figura 3.10.

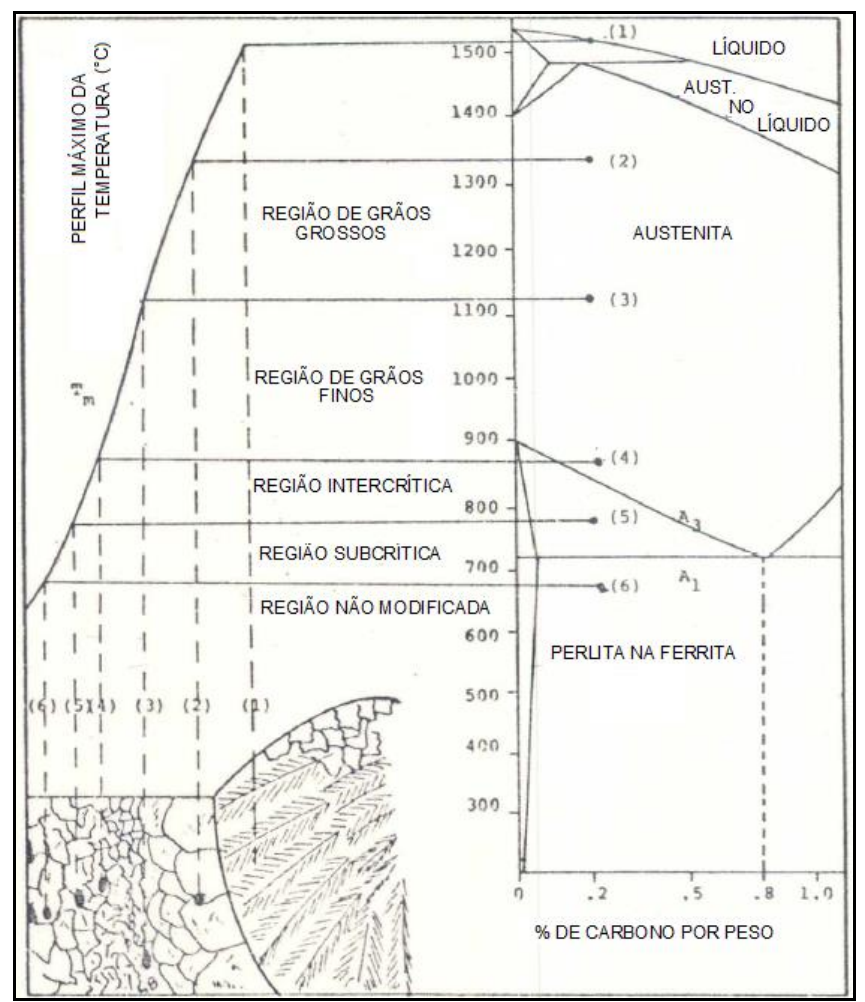

Figura 3.10 - Correlação da máxima temperatura por região na ZAC, [35].

$\mathrm{Na}$ soldagem, o calor presente na ZF é dissipado para o meio e para o interior da peça até que toda a estrutura retorne ao equilíbrio térmico. $\mathrm{O}$ calor dissipado pela condução para o interior do componente faz surgir a ZTA, onde a temperatura de pico se encontra abaixo da temperatura de solidus, no entanto sendo suficientemente elevada e capaz de causar mudanças microestruturais no material. Os gradientes térmicos que surgem ao longo do componente são consequência direta da condutividade térmica do material.

Após o término da soldagem ocorre o resfriamento do componente até a temperatura ambiente, causado pela troca de calor com o meio externo, uma vez que a condução funciona apenas como mecanismo difusor de calor pela peça. 
A convecção é a forma mais importante de transferência de calor entre a peça e o meio. O tempo de resfriamento e a microestrutura do material dependem em grande parte dos parâmetros da convecção. A convecção se caracteriza pela troca de calor entre um corpo com temperatura acima da ambiente e um fluido escoando à temperatura ambiente sobre esse corpo.

De forma menos significante se comparada à convecção, mas ainda importante para o resfriamento da peça, a radiação térmica transfere calor de superfícies com elevada temperatura, como é o caso da $\mathrm{ZF}$, para o meio através da irradiação de ondas eletromagnéticas.

\subsubsection{Condução de Calor}

A condução de calor é o transporte difusivo de energia térmica, sendo uma condição intrínseca a qualquer problema de troca de calor entre corpos ou regiões onde existam gradientes térmicos. A taxa de calor trocado no interior da estrutura é influenciada diretamente pela condutividade térmica do material da estrutura.

Em casos específicos, como a soldagem de chapas longas e delgadas em posições longe das extremidades, [36], a condução de calor em uma das duas coordenadas espaciais da seção transversal da chapa pode ser desprezada, podendo se aproximar o fluxo na peça de calor por uma análise unidimensional.

A condução de calor para o caso unidimensional pode ser escrita através da Lei de Fourier:

$$
q=-k \cdot A \cdot \frac{\partial T}{\partial x}
$$

onde $A$ é a área da seção transversal, $q$ é o fluxo de calor na direção $x, k$ é a condutividade térmica e $d T / d x$ é o gradiente de temperatura, que pelo fato de ser negativo causa a inserção do sinal negativo na equação (3.4) para representar um fluxo de calor positivo.

Em geral a análise unidimensional permanente é por demais simplista para tratar do processo de soldagem, assim surge a necessidade de estudar o problema da transferência de calor no interior do componente em função do tempo e da posição. 
A equação para a transferência de calor tridimensional de um sólido sujeito apenas à condução no tempo, que é derivada da lei de Fourier para condução de calor e da lei de conservação de energia, onde toda energia que entra na peça pelo aporte térmico tem que ser dissipada no interior da mesma, é da forma:

$$
\rho c \frac{\partial T}{\partial t}=\frac{\partial}{\partial x}\left(k \frac{\partial T}{\partial x}\right)+\frac{\partial}{\partial y}\left(k \frac{\partial T}{\partial y}\right)+\frac{\partial}{\partial z}\left(k \frac{\partial T}{\partial z}\right)+\dot{q}
$$

onde $\rho$ é a densidade em função da temperatura, $c$ é o calor específico em função da temperatura, $k$ é a condutividade térmica em função da, $\dot{q}$ é o calor gerado por unidade de volume, $T$ é a temperatura e $t$ o tempo. Como as propriedades do material variam em função da temperatura esta análise se torna não linear.

Essa equação estabelece que, em qualquer ponto do meio, a taxa de energia líquida transferida por condução para o interior do sólido somada à taxa volumétrica de geração de energia térmica deve ser igual à taxa de variação da energia térmica armazenada no interior desse sólido, [37].

\subsubsection{Convecção}

A convecção descreve a transferência de calor entre uma superfície e um fluido em movimento sobre essa superfície, sendo uma condição de contorno da modelagem térmica. As condições de contorno representam as condições de interação entre a junta soldada e as regiões que a cercam. A convecção é regida por uma variável conhecida como coeficiente local de convecção que é determinada com base nas temperaturas do fluido e da junta.

\subsection{Convecção Forçada}

Para entender esse mecanismo de troca de calor é necessário introduzir o conceito de camada limite, Figura 3.11. Considere o escoamento de um fluido sobre uma superfície plana. Quando as partículas do fluido entram em contato com a superfície, elas passam a ter velocidade zero. Essas partículas em contanto passam a retardar o movimento das partículas das camadas adjacentes e assim sucessivamente até uma distância da superfície onde esse efeito se torna desprezível. 
Semelhante à camada limite de velocidade descrita anteriormente existe a camada limite térmica, que se desenvolve quando as temperaturas entre o fluido em movimento e a superfície diferem. As partículas em contato com a superfície da placa alcançam o equilíbrio térmico na temperatura da superfície. Por sua vez essas partículas trocam energia com as partículas situadas em camadas mais distantes da placa até que todo o sistema se encontre à mesma temperatura. Como, em geral, o processo de soldagem se realiza exposto ao ambiente, o sistema retorna ao equilíbrio térmico quando atinge a temperatura ambiente, [38].

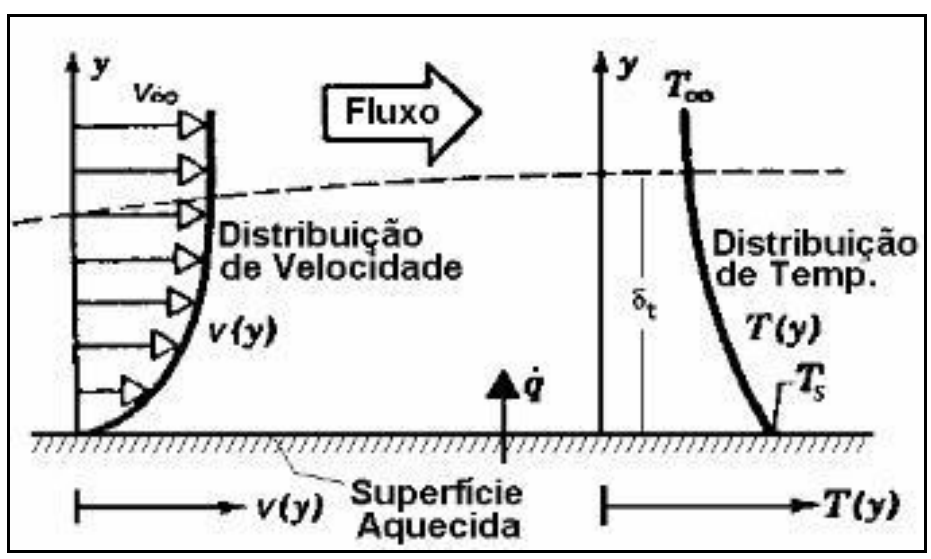

Figura 3.11: Desenvolvimento de uma camada limite sob uma placa plana.

Para um fluxo tridimensional genérico existem seis incógnitas em qualquer instante numa dada posição; são elas as três componentes de velocidade, a pressão, a temperatura, e densidade do fluido. Para propriedades constantes do fluido, o fluxo de calor não depende das temperaturas, podendo ser obtido de forma independente. Com o fluxo de calor conhecido, a equação de energia subsequentemente fornece a variação de temperatura.

A determinação do fluxo de calor e do campo de temperaturas permite o cálculo do coeficiente local de troca de calor por convecção:

$$
h=\frac{-\left.k_{f}(\partial T / \partial y)\right|_{s}}{T_{s}-T_{\infty}}
$$

onde $k_{f}$ é a condutividade térmica do fluido, $T_{s}$ é a temperatura da superfície e $T_{\infty}$ é a temperatura do meio. Essa expressão é adequada porque, na superfície, não há movimento do fluido e a transferência de energia ocorre apenas por condução. 
Essa é a representação adimensional conhecida como número de Nusselt:

$$
N u=\frac{h \cdot L}{k_{f}}
$$

onde $L$ é o comprimento característico.

O fluxo de calor local trocado pela superfície pode ser representado como:

$$
q^{\prime \prime}=h\left(T_{s}-T_{\infty}\right)
$$

\subsection{Convecção Natural}

O movimento de um fluido por convecção natural é devido às forças de empuxo no interior do fluido, enquanto na convecção forçada ele é imposto externamente. A flutuação é devida à presença combinada de um gradiente de massa específica do fluido e uma força de corpo que é proporcional à massa específica, [39]. A situação mais comum para o aparecimento de um gradiente de massa específica no fluido é causado por um gradiente de temperatura na superfície da peça, como no caso da soldagem.

Para a obtenção de um coeficiente de convecção natural correlaciona-se o número de Nusselt com o número de Rayleigh e com o número de Prandtl, segundo:

$$
\overline{N u}_{L}=\left\{0.825+\frac{0.387 \cdot R a_{L}{ }^{1 / 6}}{\left[1+(0.492 / \mathrm{Pr})^{9 / 16}\right]^{8 / 27}}\right\}^{2}
$$

onde $R_{a L}$ é o número de Rayleigh e Pr é o número de Prandtl.

O número de Rayleigh é dado pela equação:

$$
R a_{L}=\frac{g \beta\left(T_{s}-T_{\infty}\right) L^{3}}{\alpha v}
$$

onde $g$ é a aceleração da gravidade, $\beta$ é o coeficiente de expansão térmica, $L$ é o comprimento característico, $\alpha$ é a difusividade térmica e $v$ é viscosidade cinemática do fluido. 
O número de Prandtl é determinado empiricamente e depende da temperatura do fluido. Utilizando o número médio de Nusselt calculado acima, equação 3.14 , e aplicando a equação 3.12 pode-se obter um coeficiente de convecção médio, segundo:

$$
\bar{h}=\frac{\overline{N u}_{L} \cdot k_{f}}{L}
$$

A fim de simplificar a simulação da soldagem, o escoamento do fluido sobre a superfície da junta tanto na convecção forçada quanto na natural não é simulado. Ao invés disso introduz-se no modelo de elementos finitos uma condição de contorno de convecção, que representa o escoamento do fluido. Essa condição de contorno atua sobre a superfície da geometria com um coeficiente de convecção calculado pela equação 3.6 ou pela equação 3.11 , dependendo do caso, podendo ainda ser retirado da literatura para casos amplamente estudados onde se desconhece a temperatura do fluido.

Na tabela 3.2, são apresentados valores típicos, obtidos da literatura, [40], para o coeficiente de convecção em situações onde se conhece a fase do fluido e as características do seu escoamento sobre a superfície da estrutura.

Tabela 3.2 - Valores típicos do coeficiente de convecção, [40].

\begin{tabular}{|c|c|c|}
\hline Tipo de Convecção/Fluido & Líquido & Gás \\
\hline Natural & $\mathrm{h}=50-1000 \mathrm{~W} / \mathrm{m}^{2} \mathrm{~K}$ & $\mathrm{~h}=5-25 \mathrm{~W} / \mathrm{m}^{2} \mathrm{~K}$ \\
\hline Forçada & $\mathrm{h}=50-20000 \mathrm{~W} / \mathrm{m}^{2} \mathrm{~K}$ & $\mathrm{~h}=25-250 \mathrm{~W} / \mathrm{m}^{2} \mathrm{~K}$ \\
\hline Ebulição (mudança de fase) & \multicolumn{2}{|c|}{$\mathrm{h}=2500-100000 \mathrm{~W} / \mathrm{m}^{2} \mathrm{~K}$} \\
\hline
\end{tabular}

\subsubsection{Radiação Térmica}

A transferência de calor por radiação compreende a energia trocada na forma de ondas eletromagnéticas, sendo também uma condição de contorno da modelagem térmica. Ao contrário da condução de calor, as ondas eletromagnéticas não necessitam de um meio de propagação. Outra diferença entre esses mecanismos de troca de calor é a dependência com a temperatura. Enquanto os fluxos de calor na condução e convecção são lineares o fluxo de calor da radiação tende a ser proporcional à quarta potência. Por essa razão a radiação costuma ser a forma predominante de troca de calor em superfícies a altas temperaturas, [41]. 
A radiação térmica é negligenciada em muitas análises de troca de calor entre a junta soldada e o meio ambiente, pois o cordão de solda só permanece em temperatura elevada por pouco tempo, sendo a convecção a principal fonte de troca de calor com o meio. Entretanto a radiação é a forma dominante de transferência de calor do arco elétrico para a junta soldada.

A radiação que é emitida pela superfície tem sua origem na energia térmica do material limitada pela superfície. A taxa na qual a energia é liberada por unidade de área é denominada poder emissivo da superfície, $E$, segundo a equação:

$$
E=\varepsilon \sigma T_{s}^{4}
$$

onde $T_{s}$ é a temperatura absoluta da superfície, $\sigma$ é a constante de StefanBoltzmann e $\varepsilon$ é a emissividade da superfície, que varia na faixa $0 \leq \varepsilon \leq 1$, que depende das características do material e da superfície emissora.

Existe um limite superior para o poder emissivo, que é previsto pela Lei de Stefan-Boltzmann, com $E_{b}$ sendo o poder emissivo do corpo negro, segundo a equação:

$$
E_{b}=\sigma T_{s}^{4}
$$

O fluxo de calor transferido por radiação entre duas superfícies pode ser determinado com base na Lei de Stefan-Boltzmann e no conceito do fator de forma, que é a fração da radiação que deixa uma superfície e é interceptada por outra, tendo-se:

$$
q^{\prime \prime}=\sigma \varepsilon A_{s} F_{s-v i z}\left(T_{s}^{4}-T_{v i z}^{4}\right)
$$

onde $A_{s}$ é a área da superfície irradiadora, $F_{s-v i z}$ é o fator de forma da superfície quente e do meio e $T_{v i z}$ é a temperatura na vizinhança da superfície quente.

No modelo de elementos finitos a radiação é definida como uma condição de contorno da simulação, definindo cada cordão de solda como superfície emissora com uma emissividade característica do seu material constituinte. 


\subsection{Configurações do Modelo Térmico de Elementos Finitos}

Esse estudo tem como base a análise dos resultados obtidos de modelos em 3D. A modelagem em 3D permitire quantificar a influência de parâmetros como: a assimetria das regiões da geometria, as contrações dos extremos dos cordões de solda, e a deposição do cordão de solda segundo uma velocidade de soldagem. Estes parâmetros não podem ser quantificados sem o uso de hipóteses e simplificações nos modelos em 2D.

Abaixo são apresentadas as características mais relevantes de desenvolvimento nos modelos 3D simulados nesse trabalho.

\subsubsection{Propriedades do Material}

As propriedades físicas dos materiais aqui estudados são de fundamental importância para determinar adequadamente a distribuição de temperaturas durante o processo de soldagem. Considerou-se que as propriedades variam de acordo com a temperatura, o que torna essa análise não linear. Também foi assumido que tanto o metal de base quanto o metal de solda são feitos do mesmo material. Embora essa suposição não reflita a realidade ela não acarreta erros para simulação, uma vez que propriedades similares para o metal de base e do metal de solda são desejadas na soldagem de partes homogêneas, [42]. As principais propriedades que afetam a simulação térmica são: a condutividade de calor $(k)$, a densidade $(\rho)$ e o calor específico $(c)$.

\subsubsection{Condutividade Térmica}

A condutividade térmica quantifica a habilidade dos materiais de conduzir energia térmica. A condutividade térmica é uma característica específica de cada material, e depende tanto do nível de impurezas presente no material como da temperatura na qual esse se encontra. A condução de energia térmica nos metais diminui à medida que a temperatura aumenta como ocorre na soldagem.

\subsubsection{Densidade}

A densidade de um corpo define-se como o quociente entre a massa e o volume desse corpo. A densidade dos metais durante a soldagem varia muito pouco com a variação da temperatura. 
No caso dos aços essa variação é em torno de $300 \mathrm{~kg} / \mathrm{m}^{3}$. Pode-se então desprezar essa variação e assumir a densidade como uma variável constante. O aumento de temperatura na soldagem provoca uma diminuição da densidade, uma vez que a fase líquida dos metais é menos densa.

\subsubsection{Calor Específico}

O calor específico é muito importante para o estudo da soldagem, pois quantifica a quantidade de calor necessária para variar a temperatura do corpo aquecido. O fluxo de calor para junta durante a soldagem faz com que o calor específico do material aumente, diminuindo a quantidade de calor necessária para ocasionar a fusão do metal de solda com o metal de base. O calor latente de fusão é considerado na simulação como uma parcela do calor específico e incorporado diretamente nesse no intervalor de temperatura onde ocorre a mudança de fase, [43].

\subsubsection{Tipo de Elementos Utilizados}

No software ANSYS, escolheu-se o elemento sólido tridimensional SOLID90, [44], Figura 3.12, para a simulação do interior das estruturas soldadas. A característica principal desse elemento sólido utilizado é a sua capacidade de condução de calor. Esse elemento tem vinte nós com um único grau de liberdade em cada nó, a temperatura. Os elementos SOLID90 têm compatibilidade de formas de temperatura e são adequados para modelar geometrias curvas, sendo aplicados a uma análise tridimensional permanente ou transiente.

No software utilizado existem dois tipos principais de elementos sólidos para os modelos propostos: os com variante prismática e tetraédrica, que possuem melhor desempenho quando utilizado em malhas regulares e os com variante prismática, piramidal e tetraédrica que tem ótimo desempenho, inclusive quando utilizado em malhas irregulares. Escolheu-se o tipo do elemento baseado na geometria estudada. 


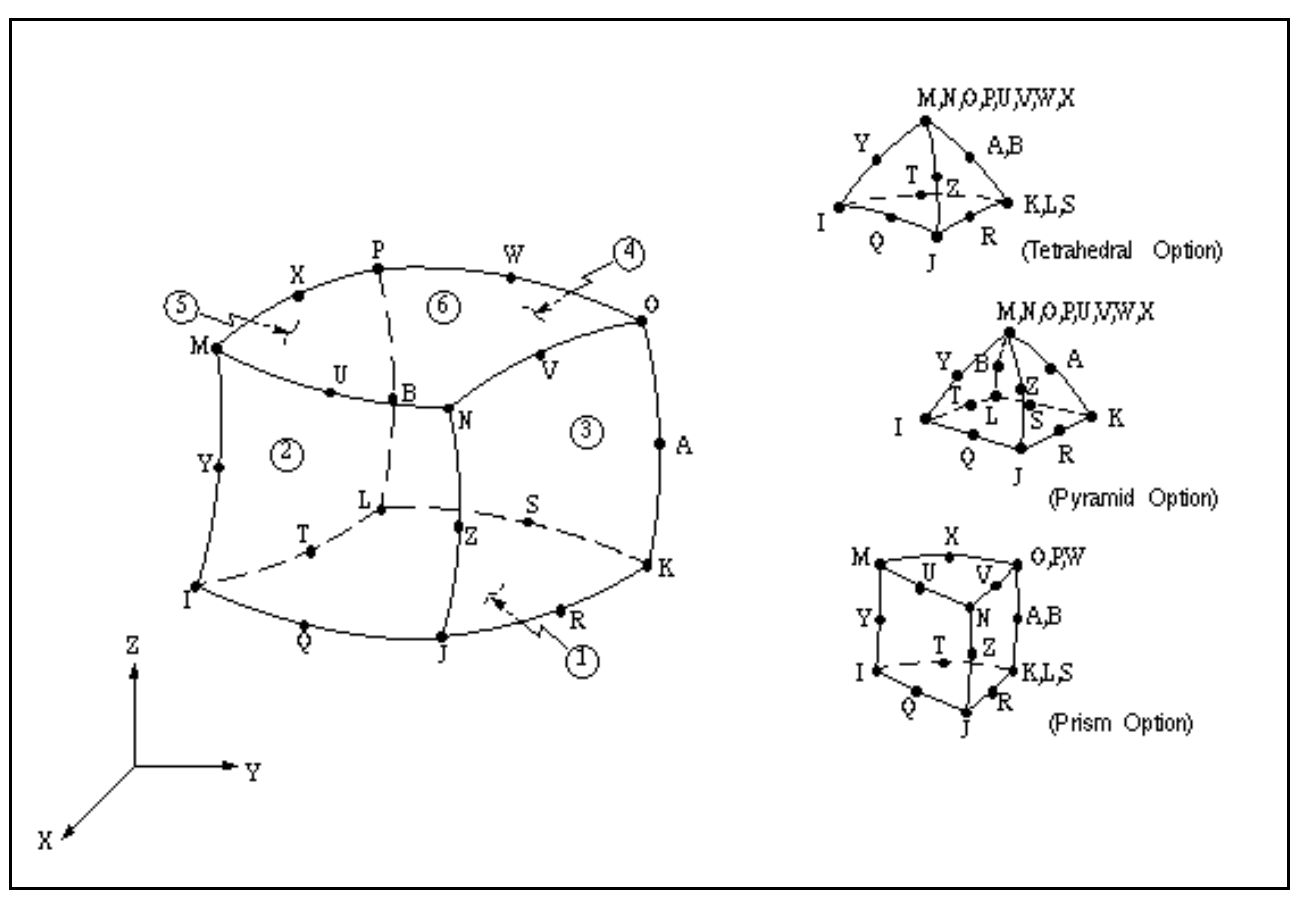

Figura 3.12: Elemento 3D SOLID90.

As superfícies em 3D de contato das partes a serem unidas, que estão em contado com o cordão de solda, foram modeladas usando o elemento de contato rígido TARGE170, [45]. Esse elemento é utilizado para representar superfícies "alvo" para os respectivos elementos de contato do outro corpo, estando associados ao elemento CONTA174, [46]. Os elementos de contado sobrepõem-se aos elementos sólidos, descrevendo as fronteiras da estrutura.

A área de contato do cordão foi modelada utilizando o elemento CONTA174. Semelhante ao elemento TARGE170, esse tipo de elemento se localiza na superfície dos elementos sólidos (SOLID90) do cordão de solda, tendo as mesmas características geométricas da face sólida a que está conectado.

O tipo de contato entre o metal de base e o metal de solda foi definido como sendo BONDED. Essa condição considera que ambas as superfícies em contato estão “coladas", não podendo se separar. As superfícies estarão unidas independente de vazios, penetração, carregamentos e comportamento de outras peças, [48]. A Figura 3.13 mostra um desenho esquemático de como ocorre o contato e de como se dá a percepção de uma superfície de contato por outra. 


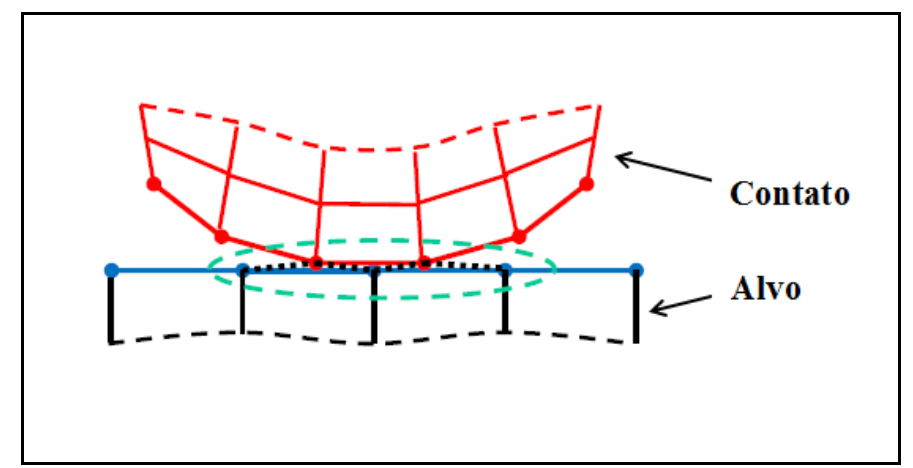

Figura 3.13: Esquemático da percepção do contato entre as superfícies.

Foi usado também o elemento SURF152, [47], Figura 3.14, que é utilizado para efeitos de superfície. Ele tem de quatro a nove nós se posicionando sobre uma área de uma face 3D de qualquer elemento térmico sólido e é usado para simular os efeitos de troca de calor por convecção e radiação do corpo aquecido para o meio.

O algoritmo utilizado para formulação dos contatos foi o PURE PENALTY (método das penalidades, padrão do software), em que se substitui um problema com restrições por uma série de problemas sem restrições.

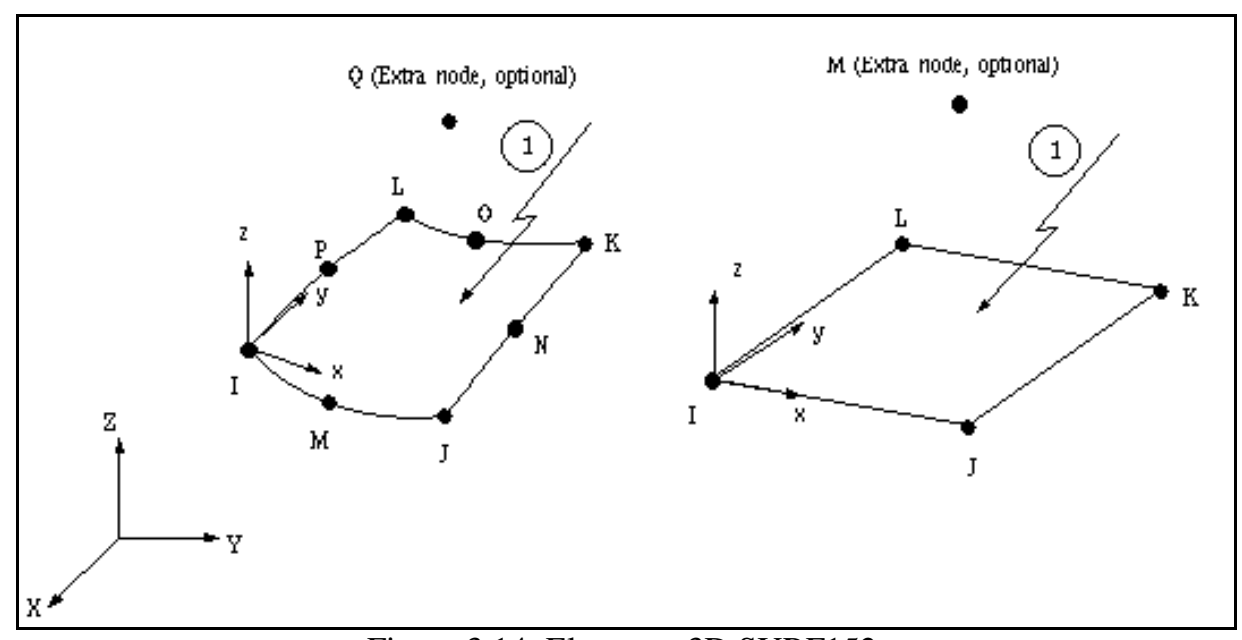

Figura 3.14: Elemento 3D SURF152.

\subsubsection{Malha}

Foram utilizadas nos modelos estudados tanto malhas regulares quanto malhas irregulares, dependendo da geometria. Entretanto é uma característica de ambas as malhas o refinamento na região da ZTA, para que se possa simular com exatidão a troca de calor na junta. Regiões distantes do cordão de solda foram modeladas com o menor número possível de elementos para que não se prejudique os resultados, a fim de se reduzir o custo computacional. 
Uma análise da sensibilidade da malha, bem como uma análise da qualidade dos elementos deve ser realizada para garantir a confiabilidade dos resultados. A Figura 3.15 mostra a malha de elementos finitos de uma junta com chanfro em formato de V.

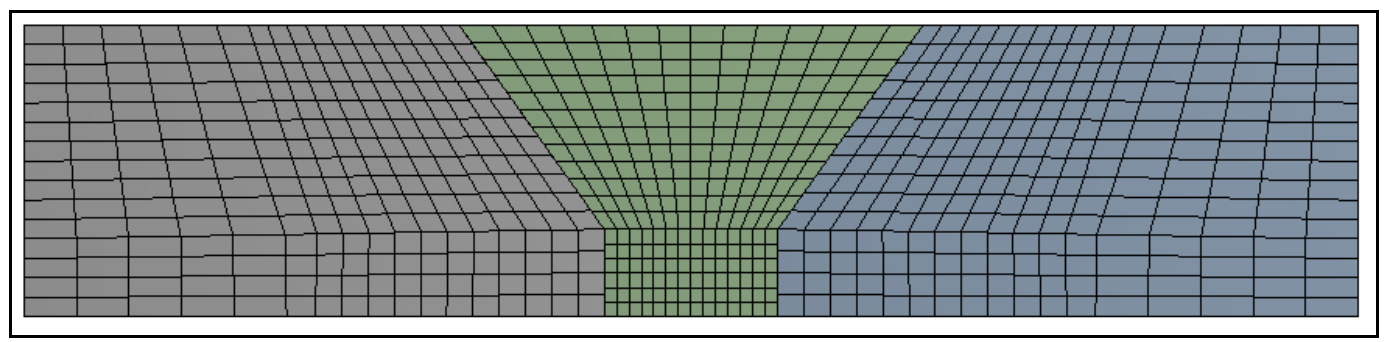

Figura 3.15: Malha de elementos finitos de uma junta em "V".

\subsubsection{Aplicação do Carregamento Térmico e Controle da Solução}

Para simulação da deposição de cada cordão de solda (como uma única barra) ou seção de cordão (múltiplas barras) foram usados 15 passos, assim o número total de passos da simulação depende do número de cordões e de seção simuladas. Cada passo foi dividido em mil sub-passos, podendo realizar até mil interações por sub-passo segundo a necessidade do software para atingir a convergência. $O$ primeiro passo ou o passo onde se inicia a deposição do cordão de solda tem duração fixa, igual a um segundo (1s). A duração dos demais passos é incremental até o tempo final de simulação ou da temperatura de interpasse.

Como citado anteriormente, no passe onde se inicia a deposição do cordão de solda não são aplicadas condições de contorno na peça; desta maneira a junta não troca calor com o meio por um segundo para compensar os efeitos da condução do arco para a junta. A partir do segundo passo são aplicadas as condições de contorno na estrutura até o final do décimo quinto passo. Quando existem múltiplos passes de solda ou múltiplas seções de cordão as condições de contorno aplicadas no segundo passo de simulação são suprimidas durante o passo de deposição e reativadas no passo seguinte. Esse procedimento é realizado a cada nova deposição até que a simulação termine. 


\section{4}

\section{Análise Mecânica do Processo de Soldagem}

Durante a soldagem o desenvolvimento do campo de tensões e deformações é caracterizado por um comportamento elastoplástico do material, condições transientes de temperatura com elevadas temperaturas de pico e gradientes térmicos severos. A ocorrência das tensões transientes e residuais é decorrência da variação desigual de volume dos elementos estruturais. A cinemática do campo de tensões durante a soldagem é um processo de desenvolvimento de tensões que tem a duração de todo o período de soldagem e do subsequente resfriamento.

$\mathrm{O}$ aquecimento localizado da junta soldada e seu resfriamento causam mudanças volumétricas, gerando tensões e deformações no componente. A contração durante o resfriamento das regiões diferentemente aquecidas e plastificadas provoca o surgimento de um campo de tensões permanentes que se auto-equilibram. Devido às altas magnitudes de temperatura o módulo de elasticidade e o limite de escoamento do material se tornam muito pequenos, facilitando a plastificação do material. À medida que o material é resfriado ele vai recuperando sua rigidez, no entanto por causa dos gradientes térmicos a contração se dá de maneira não uniforme.

Podem existir contrações longitudinais, transversais e angulares. As contrações longitudinais são as mais importantes, pois nessa direção a contração dos cordões de solda durante o resfriamento sofre maior restrição pelas partes soldadas. A magnitude das tensões residuais depende do grau de restrição ao deslocamento que estrutura oferece na direção considerada.

Como já citado anteriormente para simulação da soldagem foi adotada a hipótese das três barras, onde o cordão de solda e as partes unidas pela solda são representados por barras em paralelo. Foi utilizado um modelo tridimensional (3D) transiente, que leva em consideração os efeitos de tamanho e de assimetria da geometria ao longo do tempo, bem como considera a dependência das propriedades do material com a temperatura. 
O conhecimento do histórico de distribuição de temperaturas na junta em relação à posição, e por consequência o conhecimento dos gradientes térmicos é de extrema importância para determinar o comportamento mecânico da estrutura soldada. É usado um modelo de elementos finitos estrutural que acopla as soluções de um modelo transiente térmico previamente simulado.

\subsection{Acoplamento Termomecânico}

$\mathrm{Na}$ modelagem de problemas que envolvem fenômenos mecânicos e térmicos, comumente tratam-se as respostas térmica e mecânica de forma separada, assumindo que uma não tem influência sobre a outra. Essas modelagens são conhecidas como desacopladas e fornecem soluções satisfatórias para problemas que não apresentam gradientes de temperatura consideráveis e/ou deformação. Entretanto na soldagem essa simplificação não pode ser considerada, pois há a presença de severos gradientes de temperatura e deformação, sendo necessário considerar o acoplamento entre dois modelos, um térmico e outro mecânico, chamado de acoplamento termomecânico.

Os aspectos fenomenológicos da soldagem envolvem o acoplamento entre diferentes processos físicos e sua descrição é bastante complexa. Existem três acoplamentos: térmico, transformação de fase e mecânico. Semelhante a alguns autores, [49], nesses trabalho não será considerada a influência das transformações de fase no comportamento mecânico da estrutura após a realização da soldagem.

Os modelos estudados nesse trabalho são baseados na termodinâmica dos processos irreversíveis [50]. Essa formulação considera que o estado termodinâmico de um ponto de uma peça pode ser caracterizado através de um conjunto finito de variáveis de estado. São consideradas diversas variáveis de estado na soldagem, sendo duas delas definidas como variáveis observáveis, e são diretamente mensuráveis, a temperatura, T, e a deformação total, ${ }^{\varepsilon_{i j}}$. Também são consideradas variáveis internas como: a deformação plástica, ${ }^{\varepsilon_{i j}^{p}}$, a deformação elástica, ${ }^{\varepsilon_{i j}^{e}}$, e a componente térmica, ${ }_{i j}^{t h}$. A fonte de calor foi modelada diretamente como um carregamento na simulação mecânica. 
A formulação da equação constitutiva para a plasticidade é obtida assumindo uma decomposição aditiva das deformações, podendo ser escrita como:

$$
\varepsilon_{i j}=\varepsilon_{i j}^{e}+\varepsilon_{i j}^{p}+\varepsilon_{i j}^{t h}
$$

\subsection{Plasticidade}

Supondo-se que um elemento de um material é submetido a um estado de tensões com sua magnitude gradualmente aumentada, a deformação inicial do elemento é inteiramente elástica e a forma original do elemento é recuperada no descarregamento completo. A partir de certas condições críticas das tensões aplicadas (tensões superiores à tensão de escoamento), deformações plásticas (ou permanentes) começam a surgir no elemento. O limite do comportamento elástico, sob qualquer combinação possível de tensões é definido pelo critério de escoamento. Esse comportamento é verificado não só para um carregamento direto a partir de um estado de equilíbrio, mas também quando ocorre um recarregamento de um elemento submetido anteriormente a um descarregamento a partir de um estado plástico [51].

É necessária uma série de idealizações para definir o limite de escoamento. Neste trabalho, em primeiro lugar, presume-se que as condições de carga são tais que as taxas de deformação e os efeitos térmicos podem ser negligenciados. Também são desprezados o efeito Bauschinger e os loops de histerese, adotando-se a hipótese de endurecimento isotrópico.

O material é considerado isotrópico, de modo que as suas propriedades em cada ponto são as mesmas em todas as direções. Há uma simplificação imediata e útil resultante do fato experimental que o escoamento é praticamente inalterado por uma tensão hidrostática uniforme ou compressiva.

\subsubsection{Comportamento Mecânico do Material}

O comportamento do material utilizado na simulação por elementos finitos pode ser modelado de diferentes maneiras. A sua escolha deve ser baseada nos resultados esperados da simulação. Nesse trabalho utilizaram-se dois tipos de curvas tensão - deformação: bilinear e multilinear. 
A curva bilinear, Figura 4.1a, é composta por dois segmentos de reta. O primeiro segmento representa a porção elástica da curva e sua inclinação é caracterizada pelo módulo de elasticidade. O segundo segmento de reta representa a porção elastoplástica e é caracterizada pelo módulo Tangente do material. O limite de escoamento é definido na interseção das duas retas.

Por sua vez a curva multilinear, Figura 4.1 b, é mais próxima da curva real do material. Ela é formada por múltiplos segmentos de reta. Quanto maior o número de segmentos mais representativa da realidade é a curva. Semelhante à curva bilinear, o primeiro segmento representa a porção elástica e sua inclinação é caracterizada pelo módulo de elasticidade. Os demais segmentos definem o comportamento plástico.

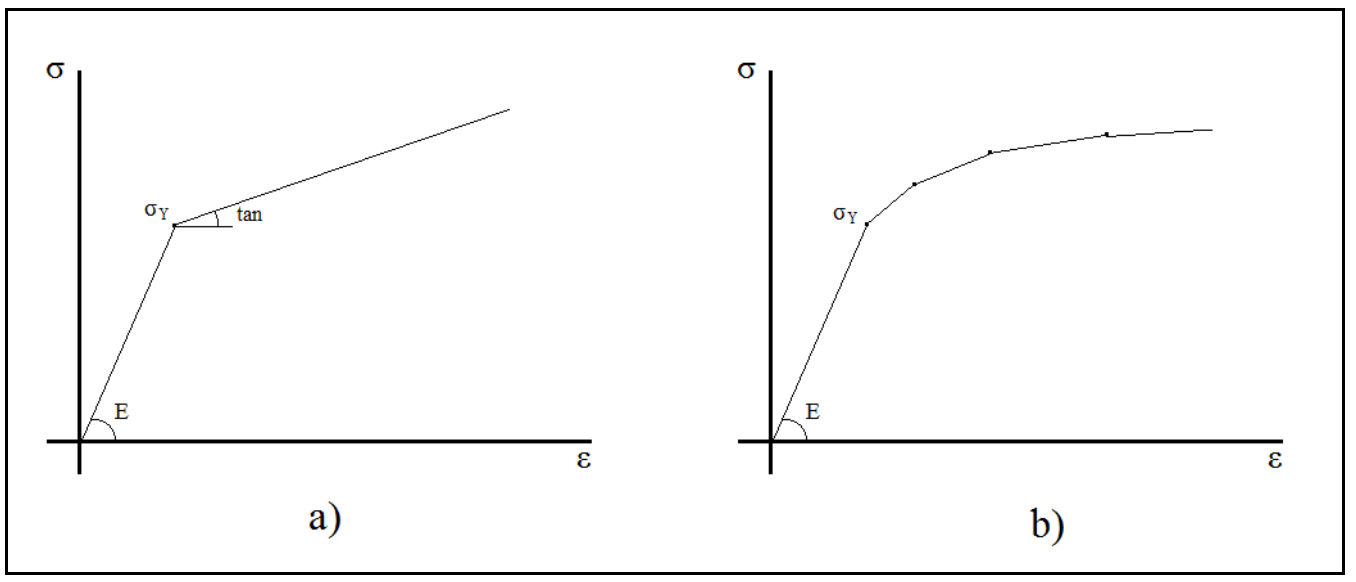

Figura 4.1: Curvas tensão - deformação utilizadas: a) Curva bilinear; b) Curva multilinear.

\subsubsection{Plasticidade no Software de Elementos Finitos}

Ao deformar plasticamente um sólido e, em seguida, descarregá-lo e, em seguida, novamente carregá-lo de modo a induzir ainda mais deformações plásticas, a sua resistência terá aumentado. Isto é conhecido como endurecimento por deformação.

O material começa a escoar no momento que o tensor desviatório atinge a superfície de escoamento. O tamanho e a forma da superfície de escoamento dependem da história total de deformações do componente. Existem duas hipóteses para quantificar o endurecimento do material: o endurecimento isotrópico e o endurecimento cinemático [52]. 
Nesse trabalho foi apenas estudado o endurecimento isotrópico, que considera o material como isotrópico e desconsidera o efeito Bauschinger. O endurecimento isotrópico considera que a superfície de escoamento expande-se uniformemente quando o material é deformado plasticamente, Figura 4.2. O termo isotrópico se refere a uma dilatação uniforme da superfície de escoamento.

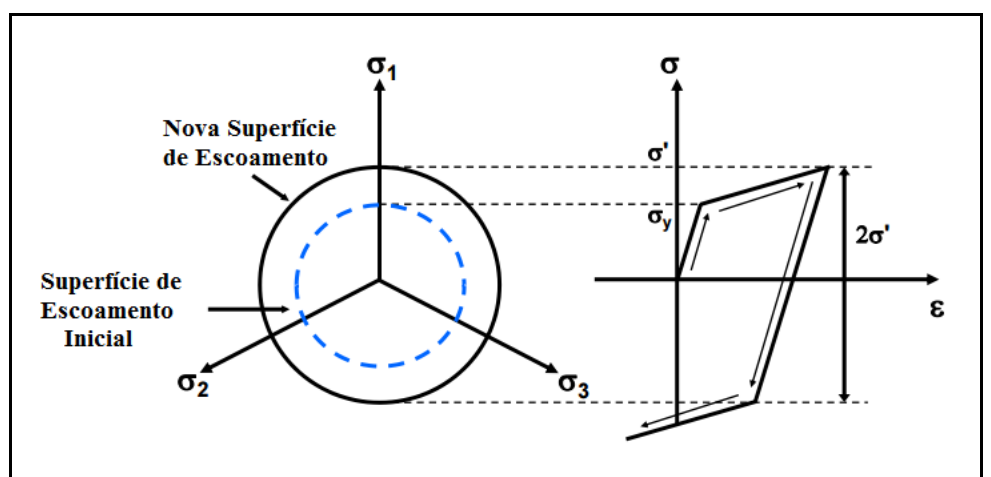

Figura 4.2: Representação esquemática do endurecimento isotrópico, [52].

O comportamento elastoplástico do componente pode ser descrito segundo a equação:

$$
\sigma_{\text {total }}=\frac{\sigma}{E}+K \varepsilon_{p l}{ }^{n}
$$

onde $K$ é o coeficiente de resistência e $n$ é o expoente de encruamento.

Para simular o comportamento elastoplástico do material é fornecida ao software a curva de tensão - deformação real, sem a parcela elástica da curva. Deve-se subtrair a parte elástica da curva, onde o primeiro ponto fornecido é o limite de proporcionalidade com deformação plástica igual a zero. A Figura 4.3 exemplifica a curva fornecida ao programa. 


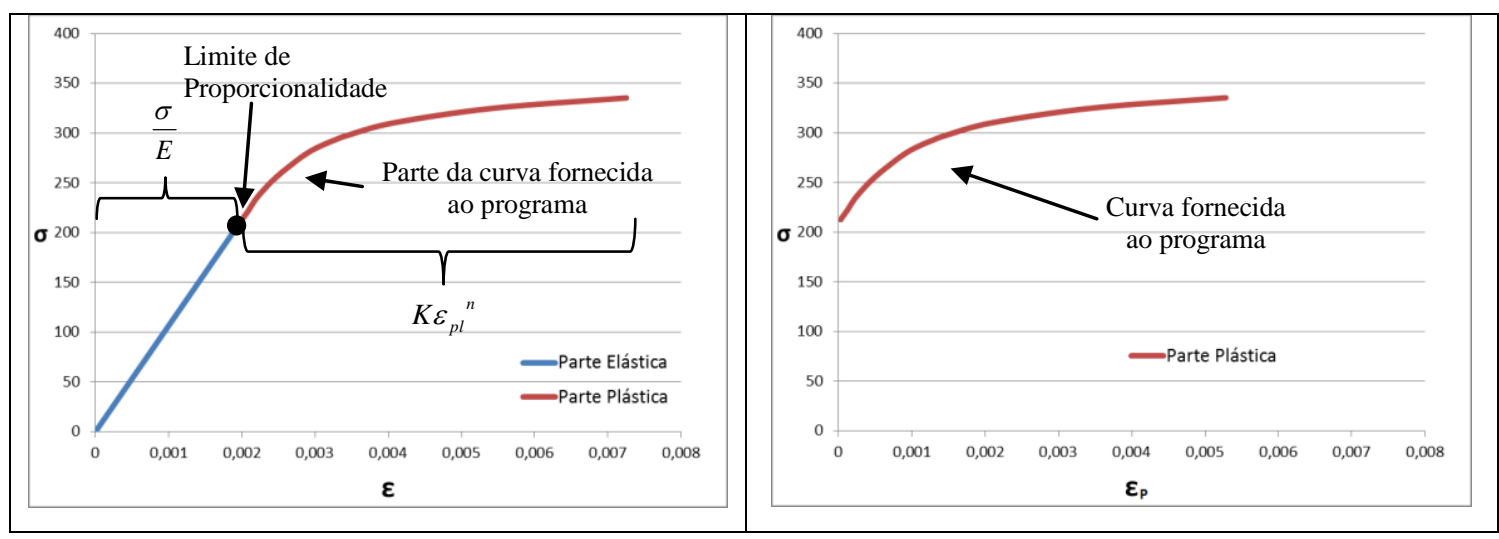

Figura 4.3: Representação da curva tensão - deformação fornecida ao programa.

A fim de mostrar o comportamento elastoplástico de um componente foi simulada a flexão de uma barra de seção transversal quadrática sujeita à flexão pura, onde os carregamentos aplicados causam deformações plásticas e tensões residuais. Maiores informações sobre essa simulação podem ser encontradas no Apêndice C.

\subsection{Campo de Tensões Durante a Soldagem [53]}

\subsubsection{Desenvolvimento das Tensões Longitudinais}

\section{- Elemento próximo ao cordão de solda}

Considerando um ciclo térmico genérico, assim como o mostrado na Figura 4.4a-d, um sólido elementar é escolhido para monitorar o desenvolvimento das tensões. Assume-se também que a espessura não tem considerável influência sobre o campo de tensões, pois os gradientes térmicos através dela podem ser negligenciados sem prejuízo. A temperatura interna do prisma elementar é considerada constante por causa do seu volume ser infinitesimal.

Em geral, a estrutura soldada é suficientemente rígida para manter a deformação total ao longo da direção da soldagem (nesse caso $\varepsilon_{x}$ ) significantemente menor que a deformação térmica livre, sem restrições ao deslocamento, $\varepsilon^{T}$.

Essas hipóteses são verdadeiras para elementos situados perto do cordão de solda. Por isso pode se assumir que o prisma não muda suas dimensões na direção $x$. Ao mesmo tempo, durante o aquecimento e o resfriamento a tensão longitudinal, ${ }^{\sigma_{x}}$, aparece na estrutura. 
Para fins de simplificação considera-se o caso de tensão unidimensional, onde a tensão transversal, ${ }^{\sigma_{y}}$, é igual a zero (na direção y os elementos podem ser deformar livre de tensões). Assim na direção longitudinal, sentido da soldagem, $\sigma_{x} \neq 0, \varepsilon_{x}=0$, mas na direção transversal $\sigma_{y}=0, \varepsilon_{y} \neq 0$.

Para analisar os ciclos de tensão nos elementos, informações sobre a expansão volumétrica do material, por causa das elevadas temperaturas e o diagrama tensão - deformação do mesmo são necessárias. Desprezando as mudanças estruturais no material, pode-se aproximar a dilatação volumétrica por uma linha reta, Figura 4.4c, onde o coeficiente de expansão térmica é constante.

O diagrama tensão - deformação real pode ser substituído por um diagrama idealizado, onde a parte elástica da curva forma um ângulo de $45^{\circ}$ com o eixo $\varepsilon^{e p}$, Figura 4.4a.

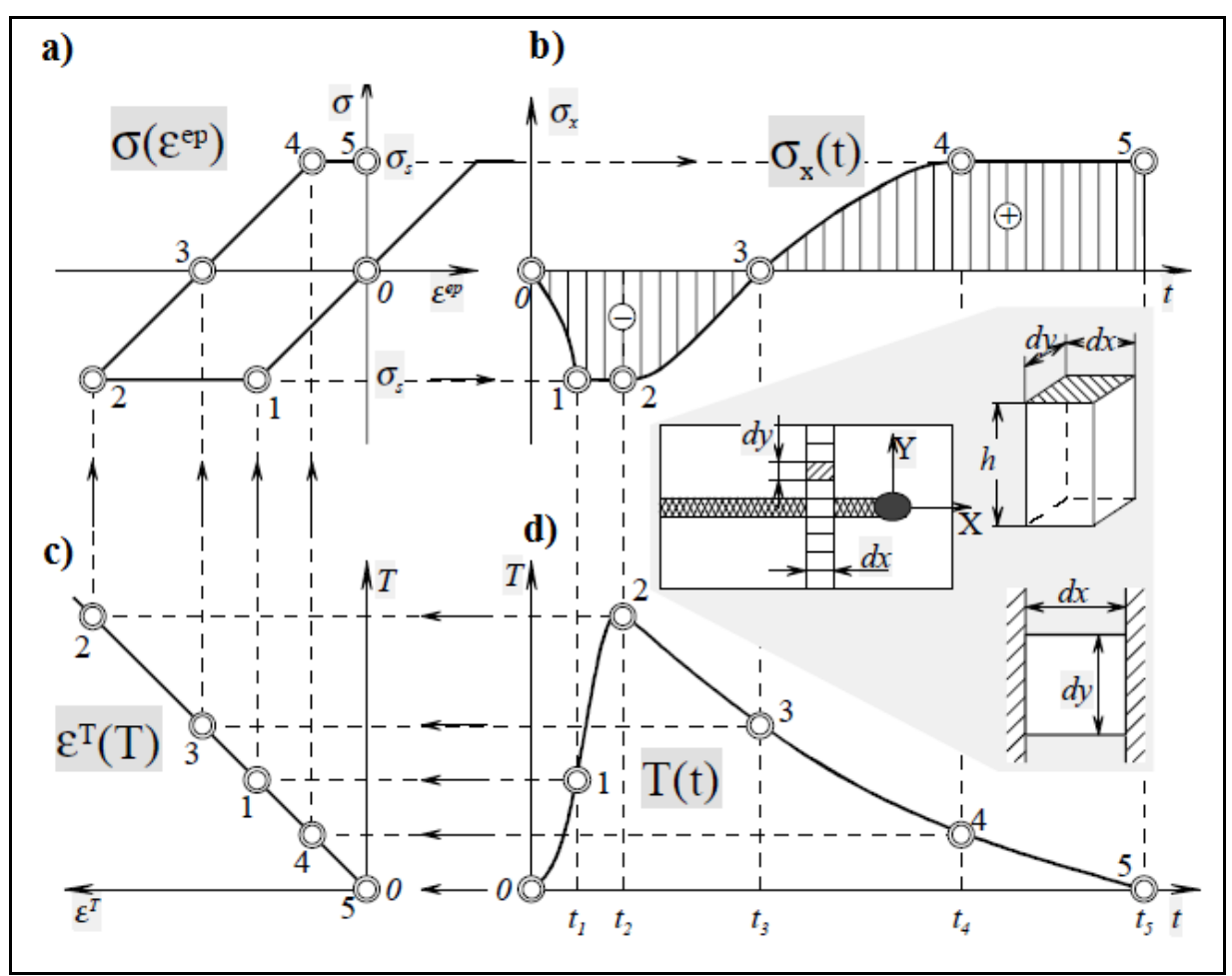

Figura 4.4: Comportamento das tensões em um sólido prismático elementar: a) Diagrama tensão deformação idealizado; b) Tensões longitudinais desenvolvidas ao longo do tempo; c) Curva da dilatação volumétrica do material; d) Ciclo térmico a que o prisma é submetido, [53]. 
Analisando a Figura 4.4, no tempo ${ }^{t_{1}}$ a temperatura $T_{1}$ é caracterizada pelo ponto 1. A partir desse ponto uma linha horizontal, caracterizando a expansão térmica correspondente a $T_{1}$, pode determinar o ponto 1 na curva de dilatação térmica. Para o caso de um prisma rígido na direção $\mathrm{x}$, a $\varepsilon^{T}{ }_{1}$ irá determinar a expansão térmica livre. Traçando uma linha reta vertical outro ponto 1 é obtido no diagrama $\sigma\left(\varepsilon^{e p}\right)$, esse ponto é caracterizado por $\sigma_{x}$ e $\varepsilon^{e}{ }_{x}$ em $t_{1}$ e coincide com o momento no tempo que $\sigma_{x}$ atinge o limite de escoamento, ${ }^{\sigma_{Y}}$. Assim pode se aferir o ponto 1 na curva de tensão por tempo pela interseção das retas traçadas a partir da curva do ciclo térmico e do diagrama de tensão - deformação do material.

Os demais pontos da curva tensão por tempo podem ser obtidos da mesma maneira. O ponto 2 corresponde a máxima temperatura no ciclo térmico e à máxima deformação plástica compressiva.

Depois de $t_{2}$ o resfriamento e por consequência o descarregamento tem início e perdura até ${ }^{t_{3}}$. Em ${ }^{t_{3}}$, a tensão elástica e a deformação são ambas iguais a zero. De ${ }^{t_{3}}$ até $t_{4}$ a tensão elástica cresce. Ao atingir $t_{4}$ o sólido volta a se deformar plasticamente, mas desta vez em tração. O tempo $t_{5}$ corresponde ao estado de equilíbrio da temperatura com a temperatura do ambiente.

A Figura 4.5 apresenta uma representação esquemática da temperatura e da distribuição tensão longitudinal resultante que ocorrem durante depois de um cordão de solda em uma chapa. O arco elétrico é representado por uma seta, que esta se movendo no eixo $x$ com velocidade $v$.

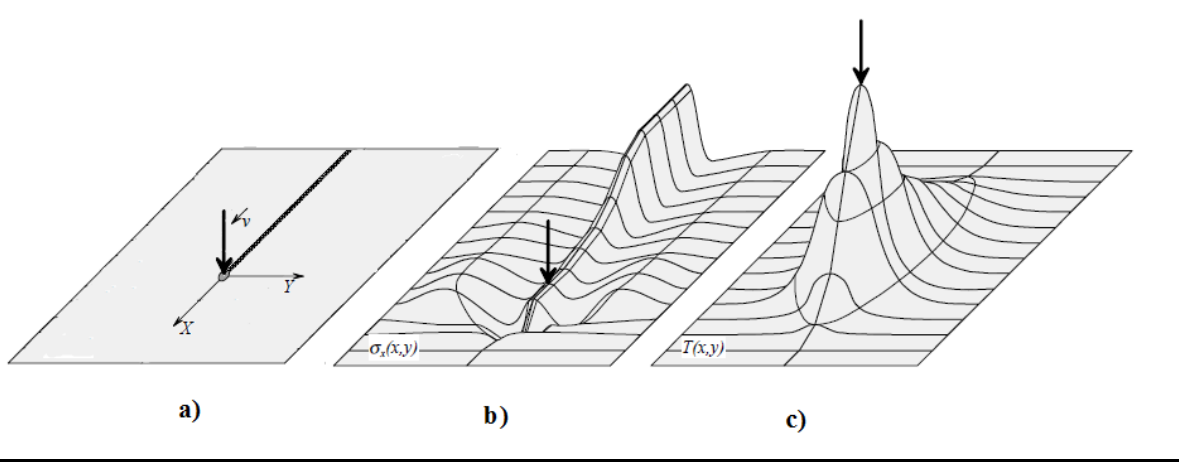

Figura 4.5: Representação esquemática do desenvolvimento da temperatura e das tensões durante a soldagem de uma chapa: a) Esquemático do processo de soldagem; b) Distribuição das tensões longitudinais pela chapa; c) Distribuição de temperatura pela chapa. 
Em posições longe da fonte de calor a temperatura é constante e igual a do ambiente, assim a tensão é igual a zero em todos esses pontos.

Movendo no sentido negativo do eixo $x$ até atingir o ponto onde a temperatura começa a se elevar, os pontos próximos ao cordão começam a apresentar compressão na direção longitudinal. Esta compressão muda para uma ascensão rápida da tensão longitudinal. A taxa de variação da tensão é proporcional ao gradiente de temperatura à frente do aporte de calor. Isso ocorre porque o limite de escoamento diminui drasticamente com o aumento de temperatura.

A tensão em regiões localizadas próximas ao aporte é compressiva, visto que a expansão nessas áreas é restringida pelo material ao seu redor, que tem temperatura menor. Entretanto, a tensão em áreas distantes do aporte é trativa equilibrando a tensão compressiva das áreas perto do cordão de solda.

Em posições no cordão de solda atrás do aporte térmico, a temperatura cai suficientemente para o material voltar a ser rígido para resistir à deformação causa pela mudança de temperatura. Devido ao resfriamento as áreas contraem e surgem tensões de tração.

Após o término da soldagem a temperatura decresce e equaliza com o ambiente. Tensões residuais longitudinais de tração com magnitude elevada, próximas ao limite de escoamento do material, aparecem na solda e em suas adjacências. Enquanto em regiões distantes da solda a tensão é compressiva.

Na Figura 4.6, é mostrada uma representação da distribuição da zona plástica para um caso em regime permanente de temperatura causada por uma fonte de calor móvel.

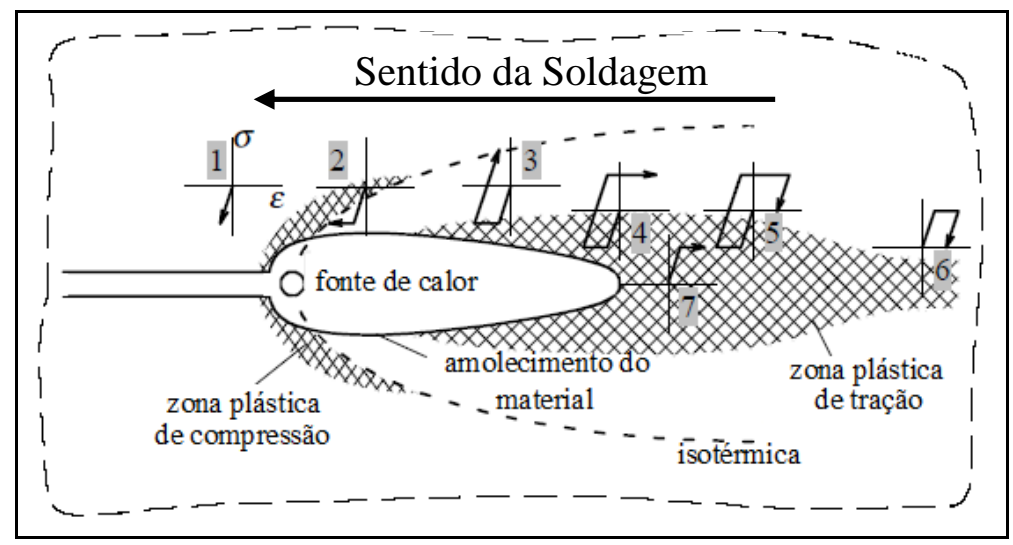

Figura 4.6: Zonas plásticas de compressão e tração; Ciclos de tensão e deformação em campo de temperatura em regime permanente de uma fonte de calor móvel, [53]. 
Os pontos 1, 2 e 3 estão situados em uma mesma linha ao longo da horizontal, representando a evolução consecutiva da tensão em uma posição situada a certa distância do centro da solda. Primeiro o material é exposto a uma compressão elástica (ponto 1), então atinge o limite de escoamento sofrem deformação plástica (ponto 2), e então segue-se por um descarregamento elástico (ponto 3).

Embora sejam parecido os ponto 5 e 6 são diferentes, o ponto 6 após atingir certo compressão elástica e plástica foi "recozido" pela isoterma de amolecimento do material.

O ponto 7 está sobre o cordão de solda e não existia até se depositar, o cordão estando apenas sujeito apenas a deformações elásticas e plásticas de tração.

\subsubsection{Desenvolvimento das Tensões Transversais}

A Figura 4.7 apresenta uma representação esquemática da evolução da tensão transversal resultante que ocorre numa chapa soldada longitudinalmente. O arco elétrico, que esta se movendo no eixo x com velocidade v, é representado por uma seta.

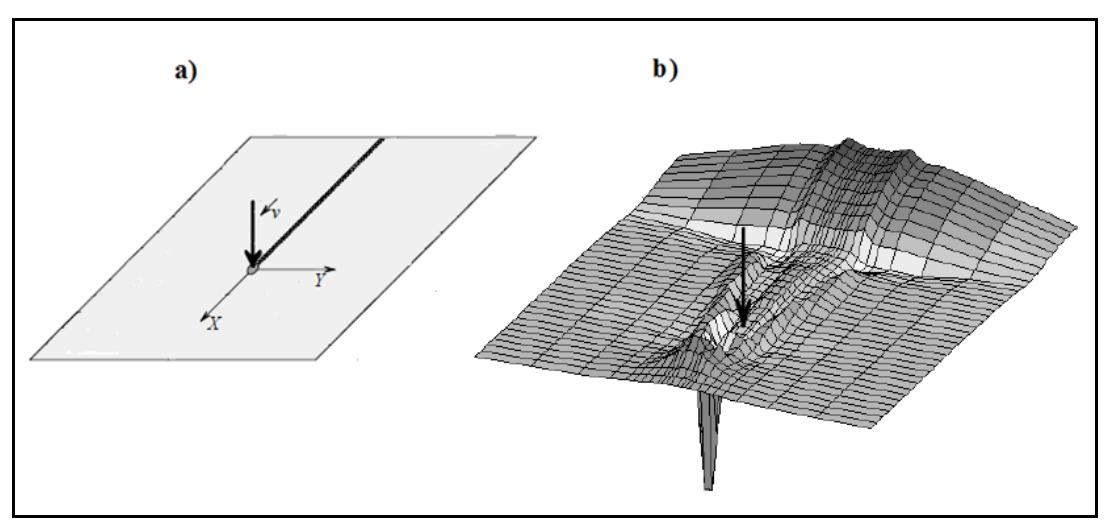

Figura 4.7: Representação esquemática do desenvolvimento das tensões durante a deposição de um cordão de solda em uma chapa: a) Esquemático do processo de soldagem; b) Distribuição das tensões transversais pela chapa, [53].

O comportamento das tensões transversais é similar ao comportamento das tensões longitudinais, durante o início do resfriamento. Longe da fonte de calor, a tensão é igual a zero por causa da ausência de perturbação e gradientes de temperatura. Próximo do aporte térmico há uma região em forma de "calombo" com tensão trativa enquanto a temperatura ainda é igual a zero. 
Ao atingir temperaturas elevadas essa região para de se comportar em compressão atingindo o limite de escoamento. Com o aumento das temperaturas e o decréscimo do limite de escoamento, as tensões transversais se tornam quase nulas.

A região altamente comprimida a frente da fonte de calor explica a formação do "calombo". A tensão transversal deve estar em auto-equilíbrio com a seção longitudinal. Logo a região em tração tem por finalidade a manutenção do equilíbrio evitando a compressão indesejada na área em torno dos elementos aquecidos da estrutura, que estão tentando expandir.

Em posições atrás do aporte a temperatura cai consideravelmente, fazendo com que o material recupere sua rigidez e resista à deformação causada pelos gradientes térmicos. Devido ao resfriamento as áreas próximas a solda contraem e causam o gradual aumento das tensões trativas.

\subsection{Campo de Tensões Residuais Após a Soldagem}

\subsubsection{Desenvolvimento das Tensões Residuais Longitudinais}

A tensão residual longitudinal máxima ocorre no cordão de solda e é em geral semelhante ao limite de escoamento do material em temperatura ambiente. À medida que se afasta do cordão de solda, a tensão longitudinal relaxa e se torna compressiva nas áreas adjacentes. Embora na maioria dos casos a distribuição da tensão residual longitudinal tenha o comportamento semelhante à Figura 4.8a, esse comportamento pode variar dependendo da composição do material, das taxas de resfriamento e do estado inicial que a estrutura se encontra antes da soldagem.

Por exemplo, aços austeníticos têm coeficientes de expansão térmica maiores que aços carbonos comuns. Para esses aços o "amolecimento" ocorre a temperaturas mais elevadas, se comparados a aços de baixo carbono. Assim, comparativamente, os aços austeníticos sofrem tensões térmicas maiores. 


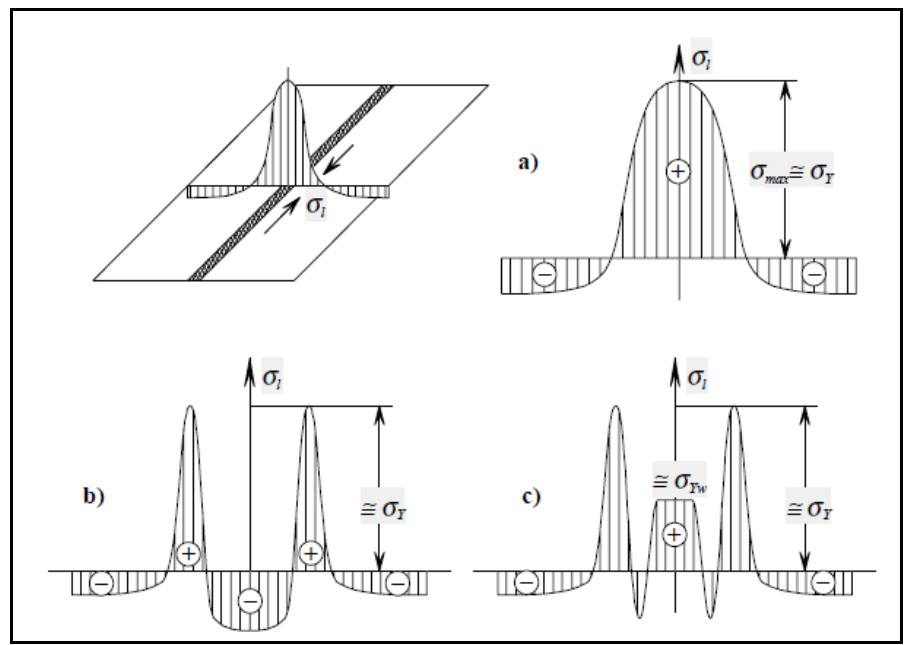

Figura 4.8: Tensões residuais longitudinais em uma chapa de: a) Aço carbono; b) Aço martensítico; c) Aço austenítico, [53].

O comprimento da zona de deformação plástica depende dos parâmetros de soldagem, das propriedades do material e da rigidez da estrutura. As propriedades mais importantes do material são: o limite de escoamento, o módulo de elasticidade e o coeficiente de expansão térmica. Quanto maior o limite de escoamento mais estreita é a zona de deformação plástica, entretanto quanto maior for o módulo de elasticidade e coeficiente de expansão térmica mais ampla ela será.

Os principais parâmetros de soldagem são o fluxo de calor por unidade de comprimento e a velocidade de soldagem. Durante a soldagem, quanto maior for o fluxo de calor maior será a zona plástica. Aumentando a velocidade de soldagem e mantendo se constante o fluxo resulta na redução do comprimento da zona de deformação plástica.

Na Figura 4.9 é apresentada a distribuição 3D das tensões longitudinais em uma chapa soldada. 


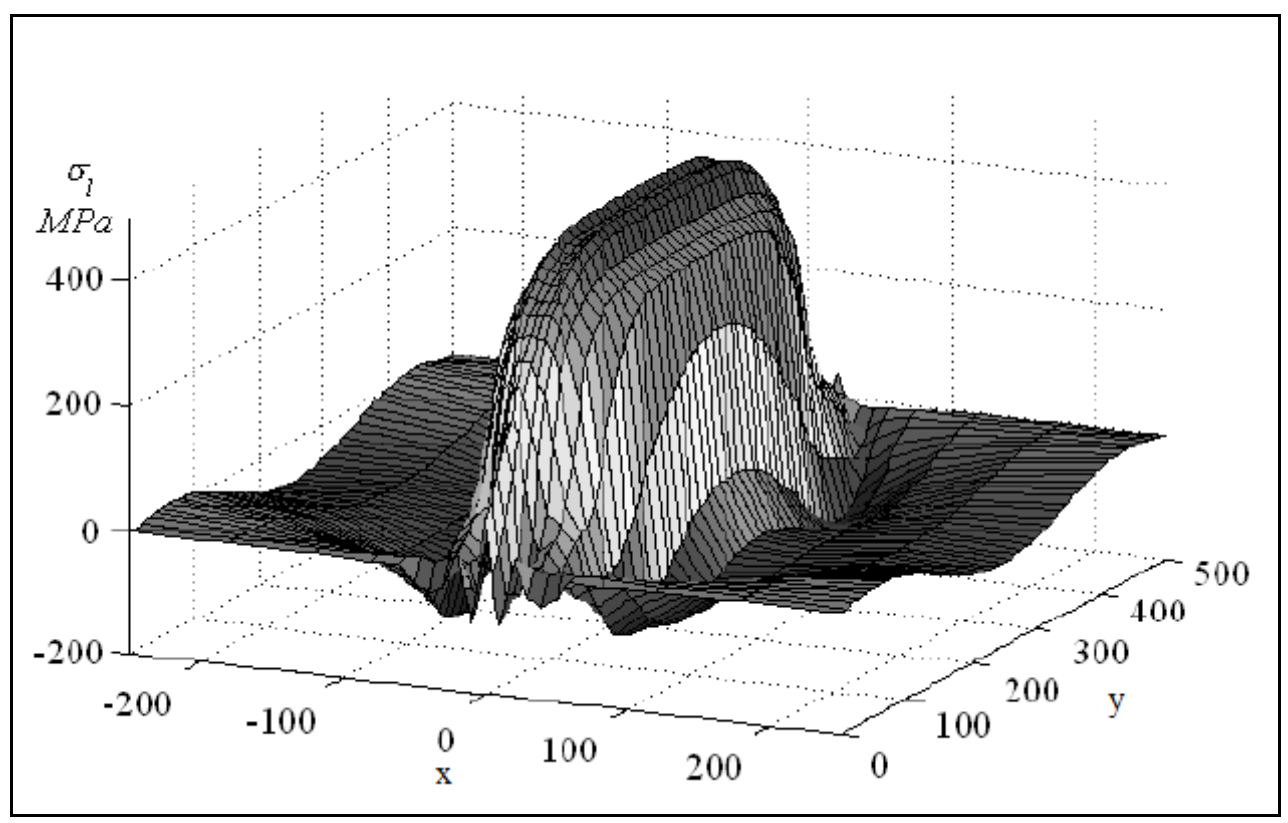

Figura 4.9: Distribuição 3D das tensões residuais longitudinais em uma chapa, [53].

\subsubsection{Desenvolvimento das Tensões Residuais Transversais}

Após a estrutura soldada ser resfriada e retornar ao equilíbrio com o ambiente, por causa das contrações transversais e longitudinais aparecem na estrutura tensões residuais transversais. Se a estrutura não tem restrições ao deslocamento (livre), a tensão transversal não apresenta magnitude elevada.

A Figura 4.10a apresenta as tensões resíduas transversais ocorrentes em duas chapas com restrições ao deslocamento na direção transversal.

Durante a soldagem de estruturas delgadas com uma elevada velocidade de soldagem, as extremidades de movem em direção uma da outra durante o resfriamento. A contração longitudinal tem a tendência de dobrar a estrutura, como consequência a tensão residual surgirá, como mostrado na Figura 4.10b, ao longo da linha de centro.

Se a velocidade de soldagem é suficientemente baixa para o metal de solda resfriar-se até a temperatura em que o material é capaz de resistir a carregamentos e isso ocorrer não muito longe do aporte de calor, então o final do cordão de solda terá tensão trativa, como mostrado na Figura 4.10c. 


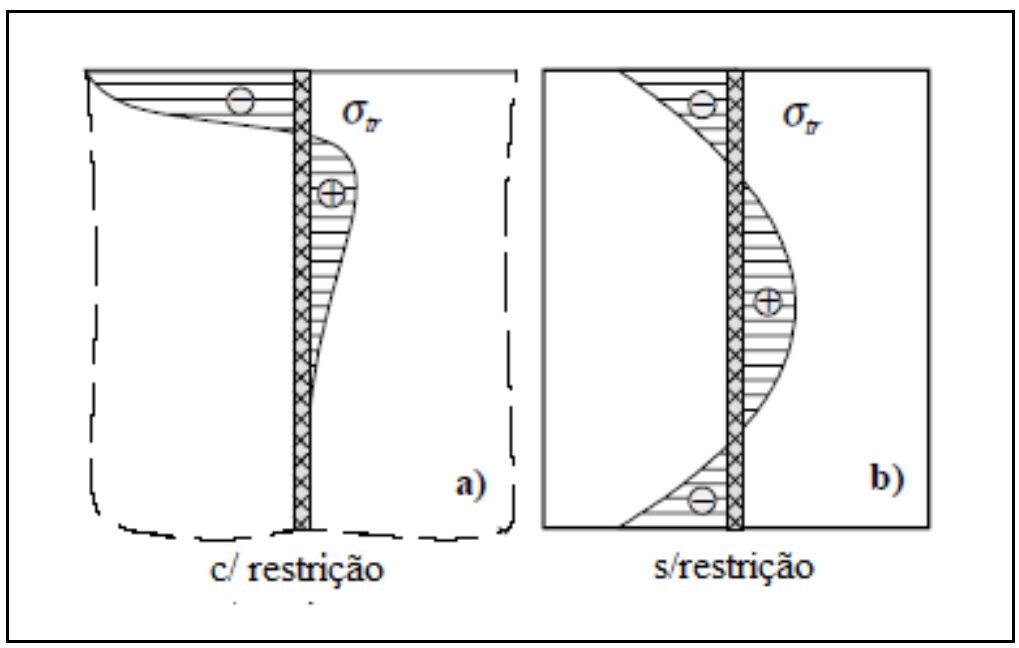

Figura 4.10: Tensões residuais transversais em chapas: a) com restrição transversal; b) sem restrição transversal, [53].

$\mathrm{Na}$ Figura 4.11, é mostrado a distribuição 3D das tensões residuais transversais de duas placas soldadas. Pode se perceber que os picos de tensão residual transversal estão localizados próximos às extremidades do cordão.

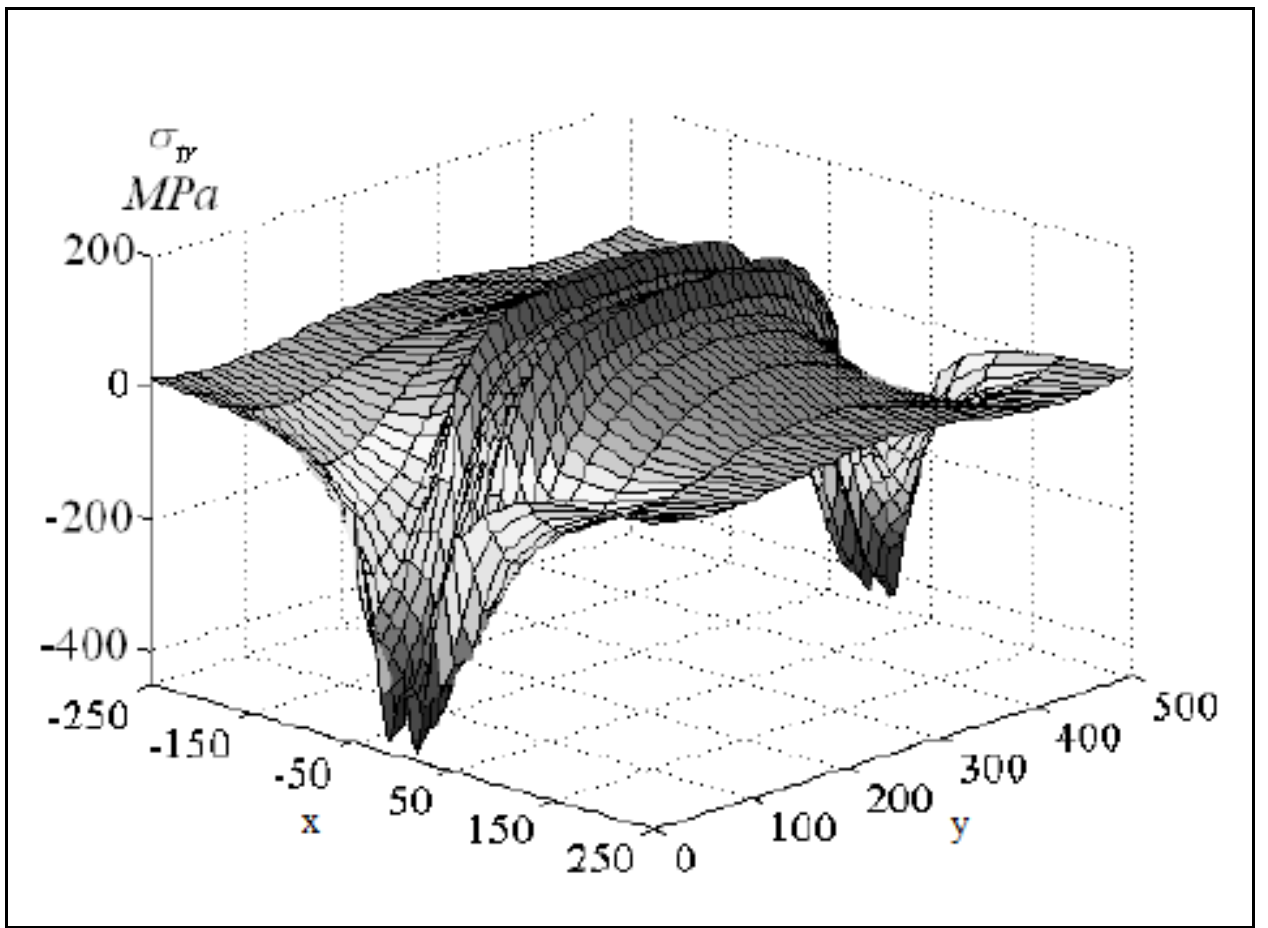

Figura 4.11: Distribuição 3D das tensões residuais transversais de duas placas soldadas, [53]. 


\subsection{Desenvolvimento das Tensões Residuais Considerando a Hipótese das Três Barras}

O desenvolvimento de tensões residuais pode ser explicado considerando o aquecimento e o resfriamento forçado. A Figura 4.12, mostra três barras com mesma área (que podem ser assumidas como molas em paralelo, sendo a do meio menor que as demais, enquanto as dos extremos estão ligadas a dois blocos rígidos), [26, 29,54].

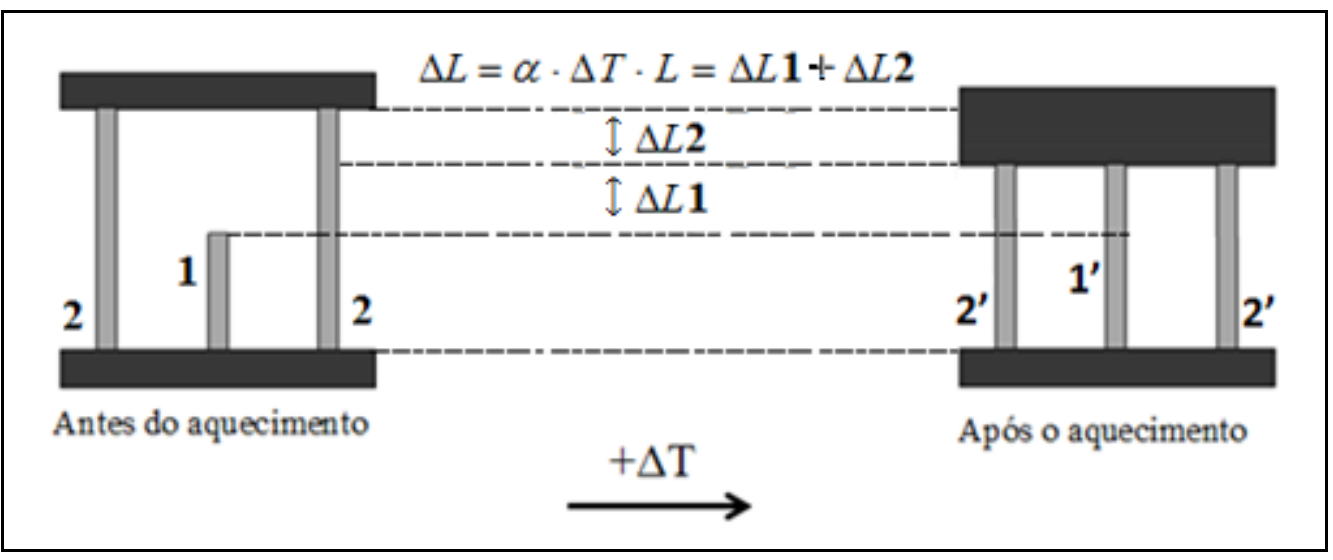

Figura 4.12: Representação esquemática da soldagem utilizando a hipótese das três barras.

Todas as três barras estão inicialmente à temperatura ambiente. A barra do meio é aquecida individualmente, dilatando-se até atingir o mesmo comprimento das demais barras, passando a estar ligada ao bloco rígido superior. A partir desse momento a barra do meio tende a se contrair devido à perda de temperatura para $\mathrm{o}$ meio, apresentando tensão trativa, enquanto as barras laterais, devido ao equilíbrio de forças, apresentam tensões compressivas. Assume-se que as barras são feitas de um material com comportamento elasto perfeitamente plástico.

Para que haja equilíbrio, o somatório de forças deve ser nulo e deve existir compatibilidade de deslocamentos; assim:

$$
\begin{gathered}
P_{1}{ }^{\prime}+2 P_{2}{ }^{\prime}=0 \\
\alpha \cdot \Delta T \cdot L=\Delta L=\Delta L_{1}{ }^{\prime}+\Delta L_{2}{ }^{\prime} \\
\alpha \cdot \Delta T=\frac{\Delta L_{1}{ }^{\prime}}{L}+\frac{\Delta L_{2}{ }^{\prime}}{L}=\varepsilon_{1}{ }^{\prime}+\varepsilon_{2}{ }^{\prime}
\end{gathered}
$$


Supondo que contração térmica faz com que a barra do centro se deforme plasticamente enquanto as barras dos extremos se deformam elasticamente, o somatório de forças e a compatibilidade de deslocamentos são:

$$
\left\{\begin{array}{c}
\sigma_{1}{ }^{\prime} \cdot A_{1}-2 \cdot \sigma_{2}{ }^{\prime} \cdot A_{2}=0 \\
\varepsilon_{Y} \cdot E \cdot A_{1}-2 \cdot \varepsilon_{2}{ }^{\prime} \cdot E \cdot A_{2}=0 \quad \therefore \quad \varepsilon_{2}{ }^{\prime}=\frac{A_{1}}{2 A_{2}} \cdot \varepsilon_{Y} \\
\varepsilon_{1}{ }^{\prime}=\varepsilon_{Y}+\Delta \varepsilon_{1}{ }^{\prime} \\
\varepsilon_{1}{ }^{\prime}+\varepsilon_{2}{ }^{\prime}=\alpha \cdot \Delta T
\end{array}\right.
$$

Substituindo as equações 4.6 e 4.7 em 4.8 , tem-se:

$$
\varepsilon_{Y}+\Delta \varepsilon_{1}{ }^{\prime}+\frac{A_{1}}{2 A_{2}} \cdot \varepsilon_{Y}=\alpha \cdot \Delta T
$$

Isolando o termo $\Delta \varepsilon_{1}{ }^{\prime}$, tem-se:

$$
\Delta \varepsilon_{1}{ }^{\prime}=\alpha \cdot \Delta T-\varepsilon_{Y} \cdot\left[1+\frac{A_{1}}{2 A_{2}}\right]
$$

As tensões $\sigma_{1}$ ' e $\sigma_{2}$ ' são calculadas a partir das respectivas deformações, sabendo que o material é perfeitamente plástico. Na Figura 4.13, são mostradas as tensões nas barras após a soldagem. 


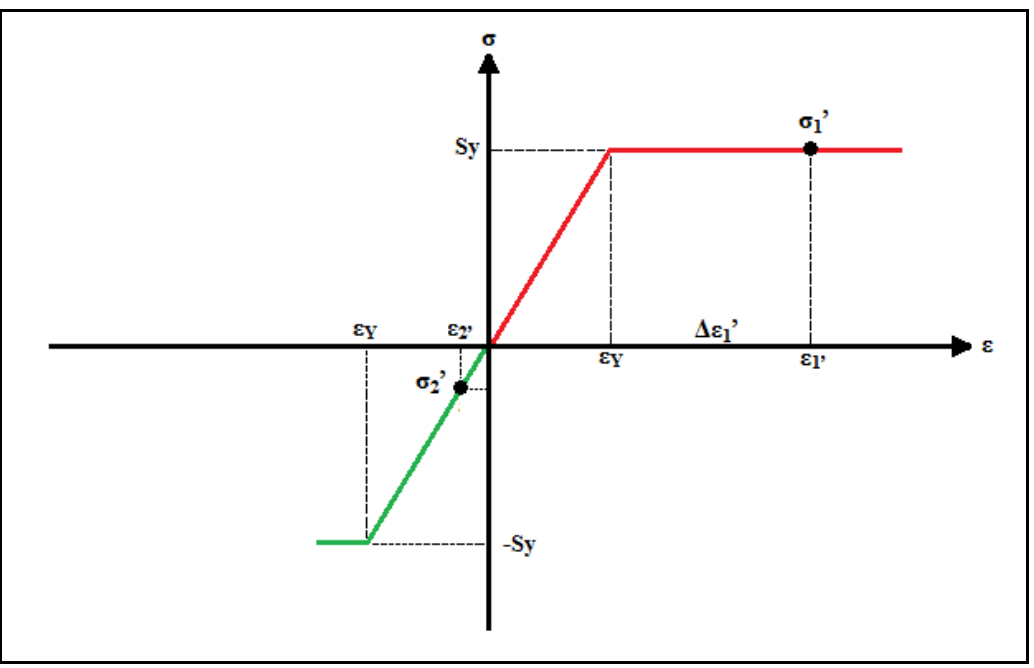

Figura 4.13: Tensões na barra 1 e em uma das barras 2 após a soldagem.

\subsubsection{Aplicação de um Tratamento de Alívio de Tensões}

A fim de reduzir a magnitude de tensão da barra central aplica-se no conjunto uma força trativa, que levará as barras laterais ao escoamento. Após o descarregamento dessa força ocorrerá um alívio de tensões.

Essa força, chamada de $P_{e x t}$, é capaz de levar as barras laterais até o limite de escoamento e por consequência deformar plasticamente ainda mais a barra central.

Pelo equilíbrio a força $P_{\text {ext }}$ será:

$$
P_{e x t}=P_{1}^{\prime \prime}+P_{2}^{\prime \prime}
$$

$\mathrm{P}_{1}$ ” será igual a zero, porque a contribuição da barra central (barra 1) é zero, isso ocorre devido a barra 1 já estar escoada.

A tensão nas barras laterais (barras 2) devido a $P_{\text {ext }}$ será:

$$
\sigma_{2}^{\prime \prime}=\frac{P_{2}^{\prime \prime}}{2 A_{2}}+\sigma_{2}{ }^{\prime}=\frac{P_{e x t}}{2 A_{2}}-S_{Y} \cdot \frac{A_{1}}{2 A_{2}}=S_{Y}
$$

Assim,

$$
P_{e x t}=S_{Y} \cdot 2 A_{2}\left[1+\frac{A_{1}}{2 A_{2}}\right]
$$

A acréscimo de deformação na barra 1 será:

$$
\Delta \varepsilon_{1} "=\varepsilon_{Y} \cdot\left[1+\frac{A_{1}}{2 A_{2}}\right]
$$


Como todas as barras se deslocam juntas sob o carregamento do teste de alivio de tensão $\left(P_{\text {ext }}\right)$, todas tem o mesmo acréscimo de deformação, logo:

$$
\Delta \varepsilon_{2}{ }^{\prime \prime}=\Delta \varepsilon_{1} "
$$

Na Figura 4.14, são mostradas as tensões causadas pelo tratamento de alívio de tensões.

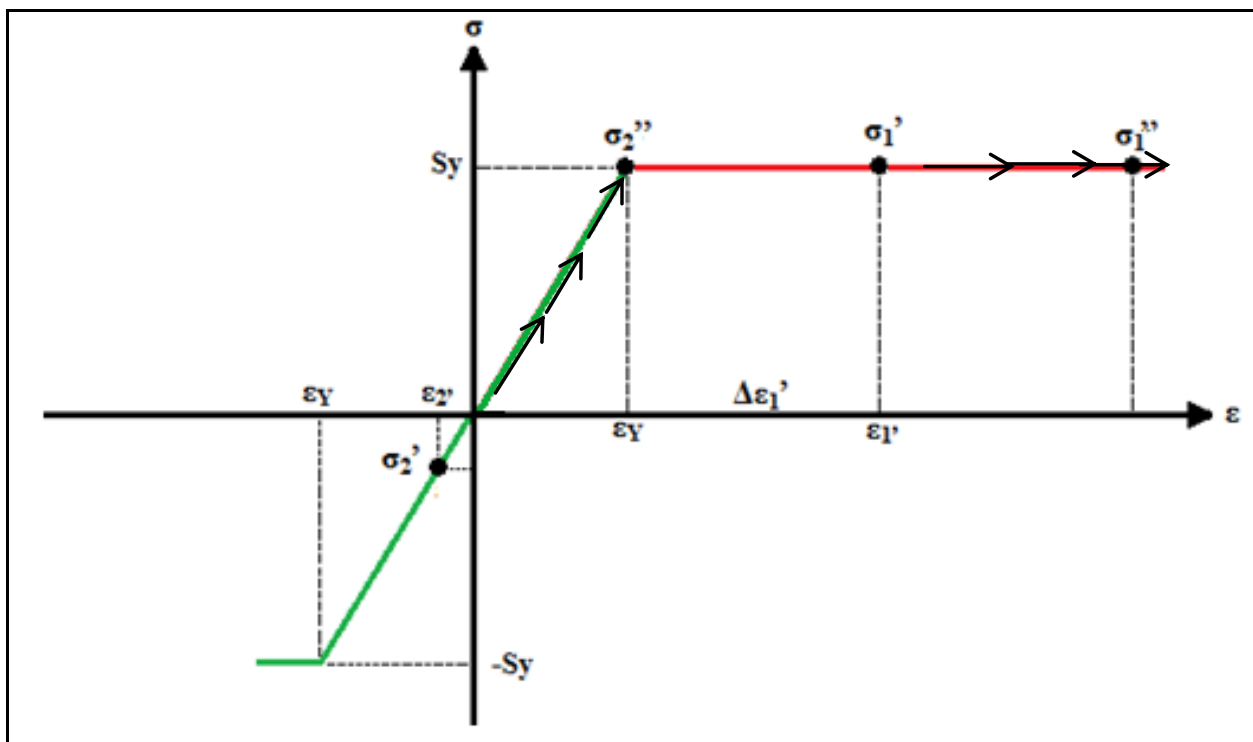

Figura 4.14: Tensões no tratamento de alívio de tensão.

Descarregando elasticamente a força do teste de alívio, tem-se:

$$
P_{d e s c}=P_{e x t}=P_{d e s c 1}+P_{d e s c 2}
$$

O descarregamento ocorre segundo iguais deslocamentos (deformações iguais):

$$
\begin{gathered}
\Delta \varepsilon_{\text {desc } 1}=\Delta \varepsilon_{\text {desc } 2} \\
\frac{\sigma_{\text {desc } 1}}{E}=\frac{\sigma_{\text {desc } 2}}{E} \rightarrow \frac{P_{\text {desc } 1}}{A_{1} \cdot E}=\frac{P_{\text {desc } 2}}{2 \cdot A_{2} \cdot E}
\end{gathered}
$$

Isolando o termo $\mathrm{P}_{\text {desc } 1}$,

$$
P_{\text {desc1 }}=P_{\text {desc } 2} \cdot \frac{A_{1}}{2 \cdot A_{2}}
$$

Substituindo a equação 4.19 na equação 4.16, tem-se:

$$
P_{\text {desc }}=S_{Y} \cdot 2 A_{2}\left[1+\frac{A_{1}}{2 A_{2}}\right]=P_{d e s c 1}+P_{d e s c 2}=P_{d e s c 2} \cdot\left[1+\frac{A_{1}}{2 A_{2}}\right]
$$




$$
\therefore P_{\text {desc } 2}=\frac{S_{Y} \cdot 2 A_{2}\left[1+\frac{A_{1}}{2 A_{2}}\right]}{1+\frac{A_{1}}{2 A_{2}}}
$$

As tensões de descarregamento nas barras são:

$$
\begin{gathered}
\sigma_{\text {desc } 2}=S_{Y} \cdot\left[1+\frac{A_{1}}{2 A_{2}}\right] \frac{2 A_{2}}{2 A_{2}+A_{1}} \\
\sigma_{\text {desc } 1}=\frac{S_{Y} \cdot\left[1+\frac{A_{1}}{2 A_{2}}\right]}{1+\frac{A_{1}}{2 A_{2}}}
\end{gathered}
$$

Consequentemente as variações de deformação após o descarregamento são:

$$
\begin{aligned}
\Delta \varepsilon_{\text {desc } 1} & =\frac{S_{Y}}{E} \\
\Delta \varepsilon_{\text {desc } 2} & =\frac{S_{Y}}{E}
\end{aligned}
$$

A Figura 4.15, apresenta as tensões nas barras após o tratamento de alívio de tensões.

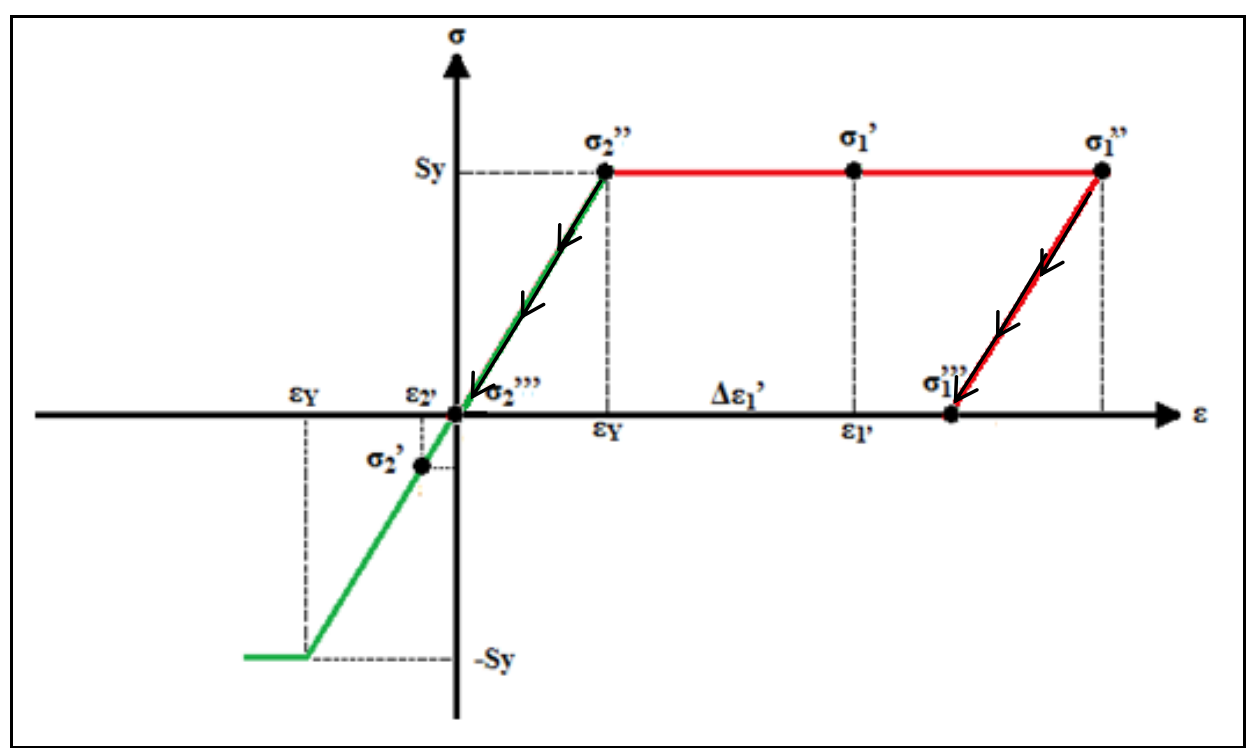

Figura 4.15: Tensões nas barras após o tratamento de alívio de tensão.

No Anexo D foi comparado esse equacionamento analítico para as tensões residuais nas três barras com uma simulação numérica com as mesmas variáveis. 


\subsection{Uso de um Gráfico Bilinear com uma Variação de Temperatura Pequena}

Como mostrado no item anterior o comportamento das tensões na soldagem em um material com uma curva tensão - deformação bilinear elástica-perfeitamente plástica depende fortemente da variação de temperatura (gradiente térmico) que é imposta.

Enquanto na soldagem as temperaturas de pico estão em torno dos $1500{ }^{\circ} \mathrm{C}$, utilizando valores de temperatura bem menores e gráfico bilinear é possível recriar o comportamento das tensões residuais da soldagem. Em geral pode-se utilizar uma temperatura de pico a partir de $300^{\circ} \mathrm{C}$.

Essa simplificação não traduz por completo o comportamento real da estrutura soldada, porém seu uso é capaz de fornecer uma informação qualitativa do comportamento da estrutura. Essa ferramenta é principalmente útil em estruturas complexas, pois simplifica a simulação e fornece resultados qualitativos confiáveis.

Na Figura 4.16, são mostradas as tensões residuais equivalentes após a soldagem de um flange em um tubo, ambos com limite de escoamento igual a $250 \mathrm{MPa}$ e módulo de elasticidade igual a $200 \mathrm{GPa}$, quando utilizado uma curva bilinear e um gradiente térmico baixo, de $300^{\circ} \mathrm{C}$.

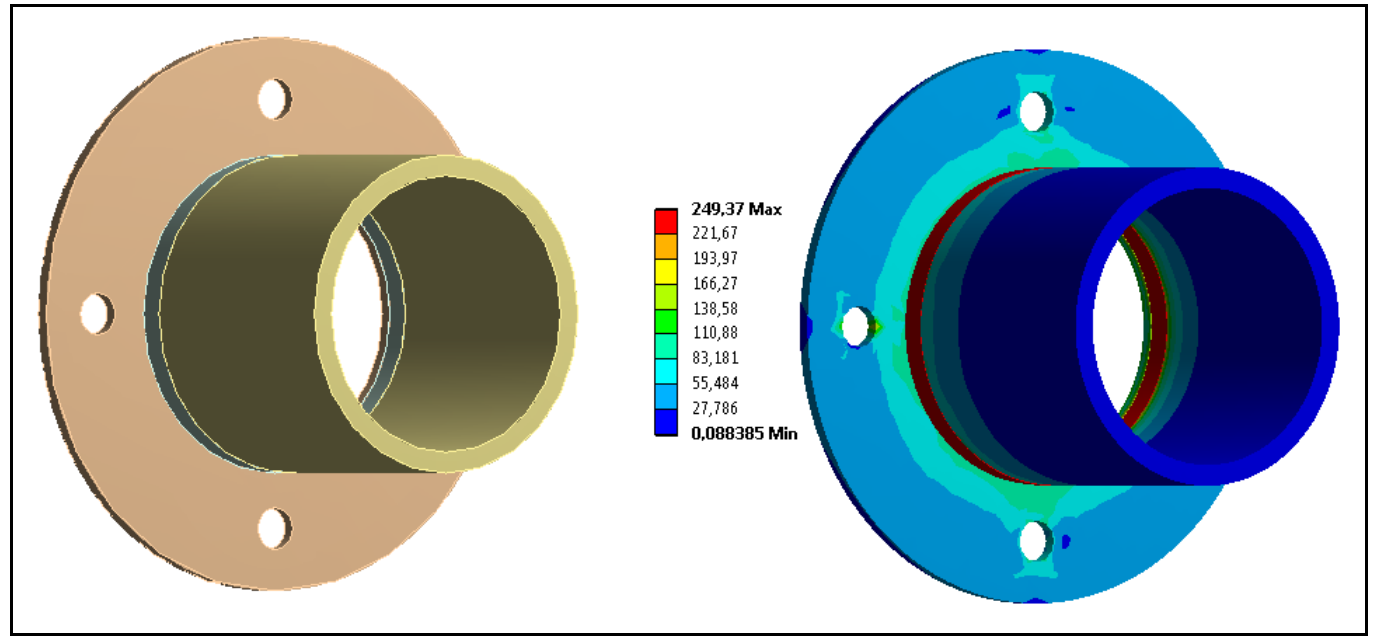

Figura 4.16: Tensões residuais equivalentes (MPa) após a soldagem de um flange em um tubo utilizando uma curva bilinear e um gradiente térmico pequeno. 


\subsection{Influência de Múltiplos Cordões de Solda nas Tensões Residuais}

Em geral o metal de solda produzido pela soldagem por fusão tem uma granulação grosseira. Os ciclos térmicos provocados pela sobreposição de cordões de solda sobre os cordões previamente depositados podem funcionar como um tratamento de revenimento.

Assumindo que o ciclo térmico de deposição não tem influência sobre a microestrutura da junta soldada, não ocorrendo transformação microestrutural, pode-se assumir que a deposição de um novo cordão de solda sobre um antigo age como um tratamento de alivio mecânico provocado por um ciclo térmico.

Ao ser depositado, à temperatura próxima de fusão do material, o novo cordão tende a se contrair devido a perde de calor para o ambiente e para o meio, contudo essa contração é restringida pelo cordão de solda antigo e pelas partes a serem unidas.

Assim o novo cordão de solda passa a provocar uma força trativa sobre o antigo, [80], e semelhante ao que mostrado no item 4.5.1, esse carregamento de tração faz com que o antigo cordão tenha uma deformação plástica positiva.

Quando a junta retorna ao equilíbrio com o ambiente o novo cordão de solda passa a ter uma tensão trativa consideravelmente maior que a do cordão de solda antigo, pois esse sofreu um alívio mecânico de tensões residuais.

$\mathrm{Na}$ Figura 4.17, são mostradas as tensões residuais equivalentes de uma junta unida por múltiplos cordões de solda, observando-se a diminuição da magnitude das tensões ao longo da espessura.

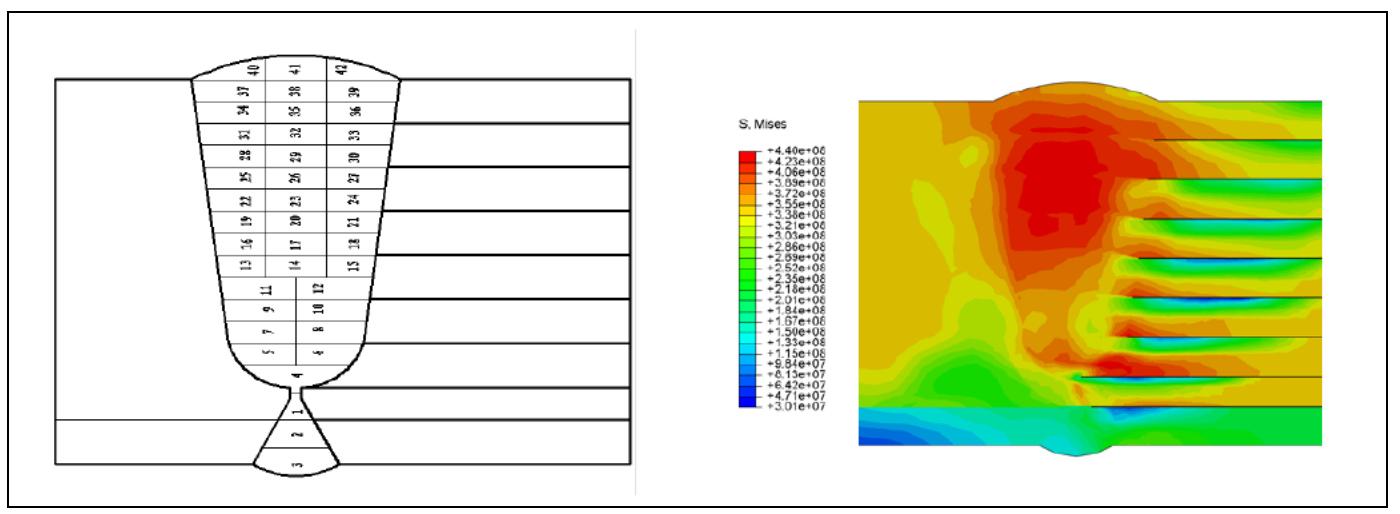

Figura 4.17: Representação esquemática da junta e tensões residuais equivalentes $(\mathrm{Pa})$ na soldagem com múltiplos passes, [83]. 


\subsection{Influência da Velocidade de Soldagem nas Tensões Residuais}

A velocidade de soldagem tem um papel importante no nível de tensões residuais que a peça apresenta após a soldagem. A geometria do cordão de solda e o calor fornecido à junta dependem diretamente da velocidade de deposição.

Como citado na capitulo anterior, usando as técnicas de "morte" e "nascimento" de elementos, o cordão de solda pode ser representado por várias barras menores. A velocidade de soldagem é caracterizada pelo tempo de ativação desses segmentos de cordão.

No que se refere ao comportamento mecânico da estrutura soldada com os efeitos da velocidade, existem dois modos de influência distintos. Um é quando a velocidade de soldagem tem pouca influência sobre deformações existentes, é o caso de estruturas pequenas e/ou com uma velocidade de soldagem considerada alta. O outro é quando a estrutura é grande e/ ou apresenta velocidade de soldagem pequena.

Quando a peça tem pequenas dimensões e/ou a velocidade de soldagem é alta os segmentos que representam a deposição do cordão não influenciam os demais. Neste caso quando um novo segmento de cordão é depositado o antigo ainda está à elevada temperatura, desta forma ambos não apresentam rigidez consideráveis, embora tenham entre si gradientes térmicos. Essa diferença de temperaturas, no entanto, não tem muita importância no comportamento entre os dois segmentos de cordão, [78].

Na Figura 4.18, é mostrada a soldagem de duas chapas de pequenas dimensões com velocidade alta. Pode se perceber que as tensões que surgem após a soldagem tem o comportamento típico esperado, semelhante ao que se encontraria caso fosse utilizada uma única barra. 
a)

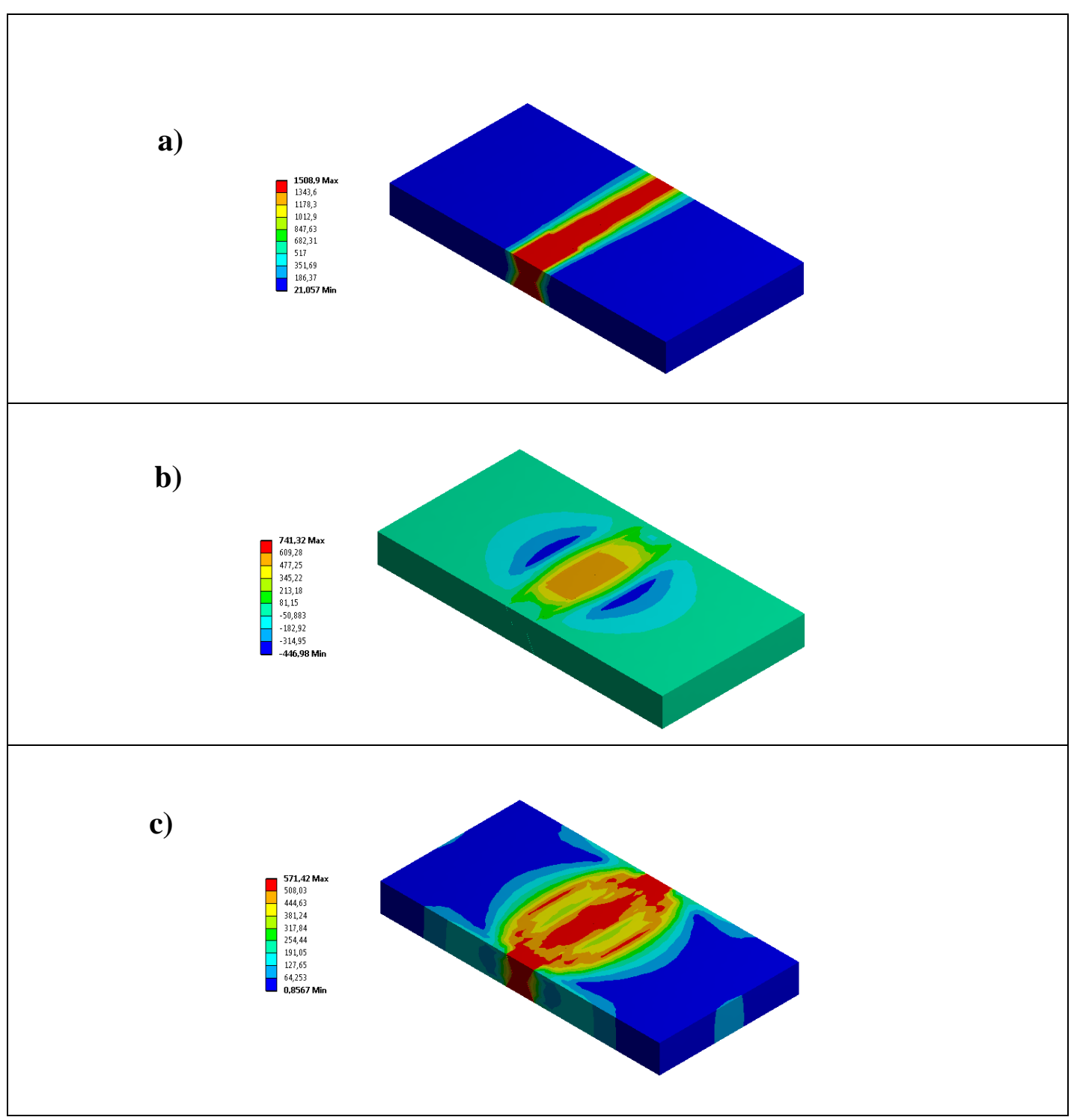

Figura 4.18: Soldagem de duas chapas pequenas com velocidade alta: a) Distribuição de temperaturas $\left({ }^{0} \mathrm{C}\right)$ na deposição do último segmento de cordão; b) Distribuição de tensões residuais longitudinais (MPa); c) Distribuição de tensões residuais equivalentes (MPa).

Se a estrutura tiver dimensões consideráveis e/ou baixa velocidade de soldagem os segmentos que representam a deposição do cordão tem considerável influenciam sobre os demais. À medida que um segmento de cordão depositado esfria o próximo segmento depositado atua sobre o anterior como um carregamento mecânico. Isso acontece porque o antigo segmento recuperou alguma rigidez, o que faz com que a tendência a se contrair do novo segmento seja percebida como um carregamento mecânico, análogo ao caso de múltiplos cordões de solda. 
Na Figura 4.19, é mostrada a soldagem de duas chapas de grandes dimensões com velocidade baixa. Pode se perceber que as tensões que surgem após a soldagem não tem o comportamento típico, havendo uma redistribuição das tensões ao longo das chapas.

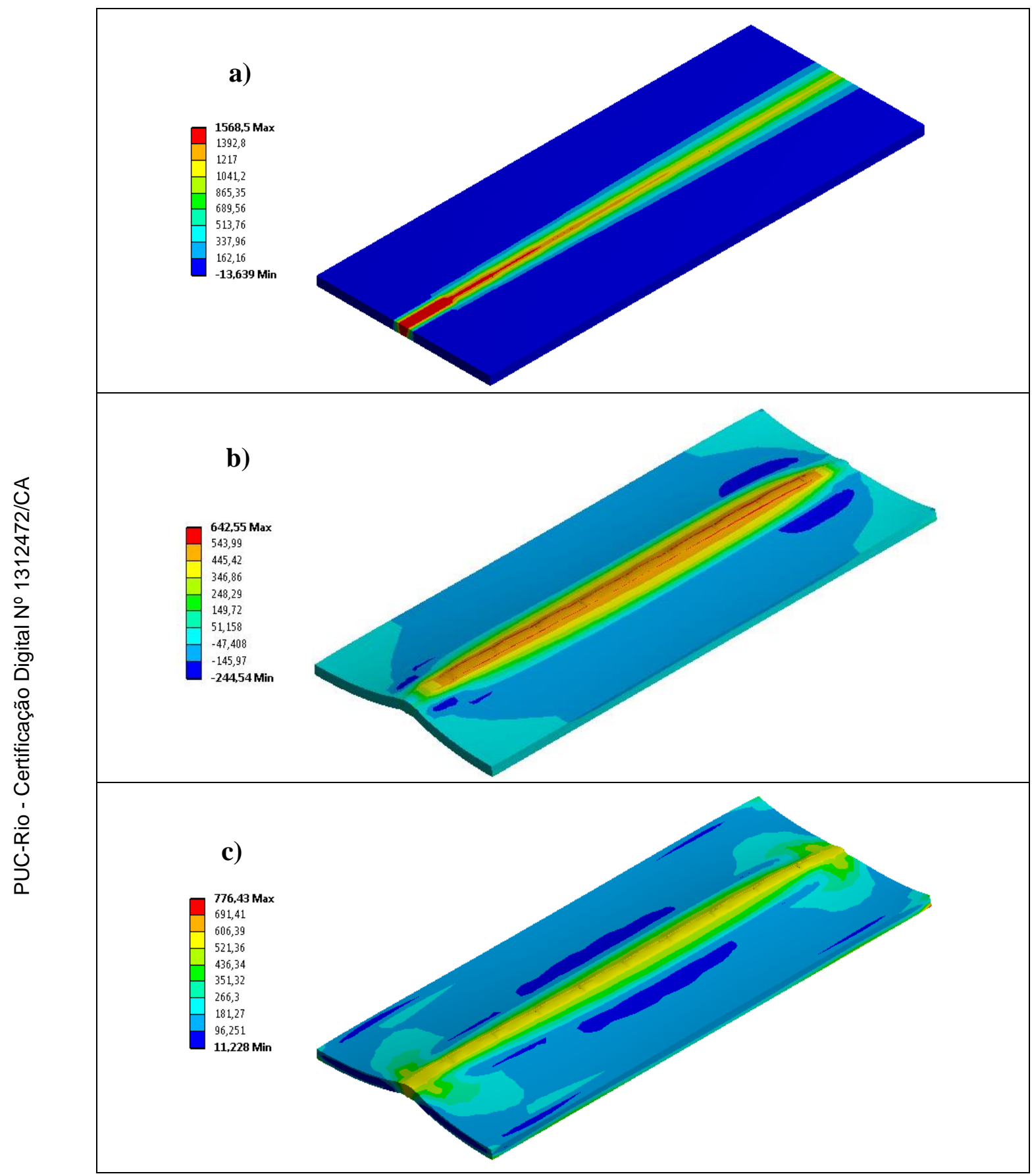

Figura 4.19: Soldagem de duas chapas grandes com velocidade baixa: a) Distribuição de temperaturas $\left({ }^{0} \mathrm{C}\right)$ na deposição do último segmento de cordão; b) Distribuição de tensões residuais longitudinais $(\mathrm{MPa})$; c) Distribuição de tensões residuais equivalentes (MPa). 


\subsection{Configurações do Modelo Estrutural de Elementos Finitos}

Semelhante ao modelo térmico, o modelo mecânico utiliza uma modelagem 3D, que permite analisar a assimetria da geometria, as contrações dos extremos dos cordões de solda e as influências de múltiplos passes e da deposição do cordão de solda segundo uma velocidade de soldagem no comportamento da estrutura. Estes parâmetros não podem ser quantificados pelos modelos em 2D.

Abaixo são apresentadas as características mais relevantes de desenvolvimento nos modelos 3D simulados nesse trabalho.

\subsubsection{Propriedades do Material}

As propriedades mecânicas dos materiais estudados dependem estreitamente da temperatura em que se encontram, assim é necessário conhecer o histórico dos gradientes térmicos que a estrutura apresenta durante a soldagem. A determinação do comportamento mecânico da junta está ligada a suas propriedades.

Considerou-se que as propriedades variam de acordo com a temperatura, o que torna essa análise não linear. Também foi assumido que tanto o metal de base quanto o metal de solda são feitos do mesmo material. As transformações microestruturais que ocorrem durante e após a soldagem não foram levadas em conta, logo a variação de volume decorrente dessas transformações não foi considerada.

As principais propriedades que afetam a simulação estrutural são: o limite de escoamento $\left(S_{y}\right)$, o módulo de elasticidade $(E)$ e o coeficiente de expansão térmica $(\alpha)$.

\subsubsection{Limite de Escoamento}

O limite de escoamento de um material é definido como a tensão no ensaio de tração em que o material começa a deformar-se plasticamente. Antes de atingir o limite de escoamento o material se deforma elasticamente e após ser descarregado retorna ao seu formato original quando o carregamento não é capaz de ultrapassar esse limite. Existem diversos critérios que quantificam o escoamento do material, sendo os mais importantes os critérios de Tresca e o de von Mises. Uma vez que o limite de escoamento é ultrapassado, uma parcela da deformação se torna permanente. 
A tensão onde ocorre o escoamento depende tanto da taxa de deformação e, mais significativamente, da temperatura na qual a deformação ocorre. $\mathrm{O}$ aumento da temperatura interna do material afeta sua rigidez. De um modo geral, o aumento da temperatura faz diminuir o limite de escoamento, a dureza e o módulo de elasticidade dos materiais.

Em temperaturas elevadas, como é o caso da soldagem, o material se comporta como "amolecido", o que facilita sua deformação plástica.

\subsubsection{Módulo de Elasticidade}

O módulo de elasticidade é um número que mensura a resistência de um material a se deformar elasticamente, quando este é carregado. O módulo de elasticidade é definido pela inclinação da curva de tensão - deformação na região de deformação elástica do ensaio de tração. Um material será mais rígido quando tiver um maior módulo de elasticidade.

Como citado anteriormente, com o aumento de temperatura os módulos de elasticidade dos materiais tendem a diminuir.

\subsubsection{Coeficiente de Expansão Térmica}

A expansão térmica é a tendência do material a aumentar em volume, em resposta a uma mudança na temperatura. Todos os materiais têm essa tendência.

Quando um corpo é aquecido, suas partículas começam a se mover e se tornar ativas mantendo assim uma maior separação média entre elas. O grau de expansão dividido pela mudança de temperatura é chamado de coeficiente de expansão térmica do material e, geralmente, varia com a temperatura.

O coeficiente de expansão térmica descreve como o tamanho de um objeto muda com uma alteração na temperatura. Especificamente, ele mede a variação fracional do tamanho por grau variado na temperatura, a uma pressão constante. Com o aumento de temperatura esse coeficiente tende a aumentar.

O coeficiente de expansão térmica volumétrica é o coeficiente de expansão térmica mais básico. Em geral, os materiais se expandem ou contraem quando há mudanças de temperatura, com expansão ou contração que ocorre em todas as direções. 
Para materiais isotrópicos, os coeficientes lineares e de superfície podem ser calculados a partir do coeficiente de expansão volumétrico tomando a raiz quadrada ou raiz cúbica do volume do coeficiente de expansão térmica.

\subsubsection{Análise Mecânica Não Linear [55]}

A análise por elementos finitos pode ser tão complexa quanto se deseje. Entretanto, o tempo de processamento aumenta com o nível de complexidade. Processos que envolvam plasticidade, não linearidade geométrica e contatos requerem abordagens não lineares.

Uma análise não linear por elementos finitos utiliza métodos iterativos incrementais na procura da menor diferença entre as forças internas e externas. $\mathrm{O}$ método mais utilizado é o Newton - Raphson, que se baseia na implementação de incrementos de carga em várias iterações de equilíbrio, atingindo gradualmente a condição de equilíbrio com pequenos erros.

$\mathrm{Na}$ Figura 4.20, apresenta a execução da solução iterativa, com quatro iterações, de Newton - Raphson para um incremento de carregamento.

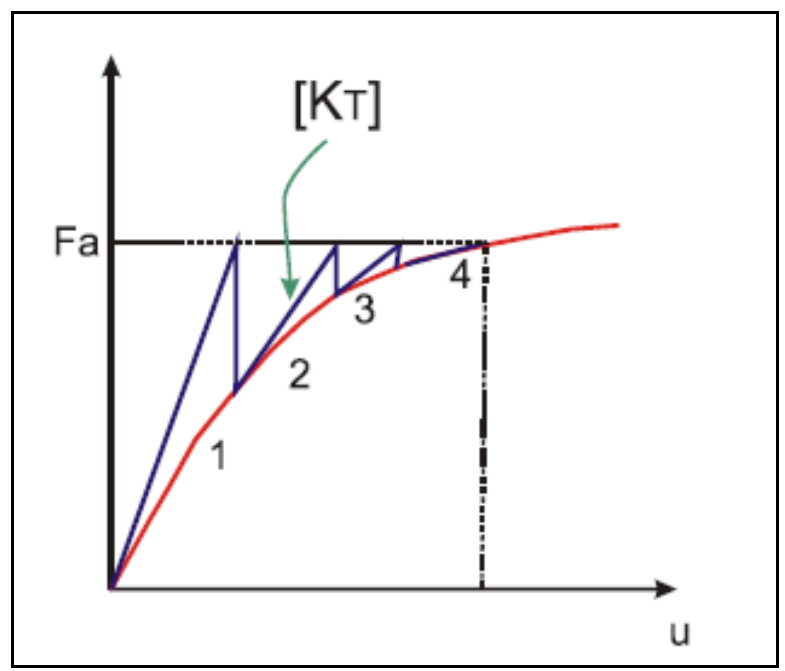

Figura 4.20: Aplicação do método de Newton - Raphson a um incremento de carga.

Essa solução segue a equação:

$$
[K T]\{\Delta u\}=\left\{F_{a}\right\}-\left\{F_{n r}\right\}
$$

onde $K T$ é a matriz de rigidez tangencial, $\{\Delta u\}$ é o incremento de deslocamento, $\left\{F_{a}\right\}$ é o vetor de carga aplicada e $\left\{F_{n r}\right\}$ é o vetor de força interna resultante. 
A matriz de rigidez tangencial é atualizada a cada iteração de carregamento e é definida como:

$$
[K T]=\left[K_{i n c}\right]+\left[K_{u}\right]+\left[K_{\sigma}\right]-\left[K_{a}\right]
$$

onde $\left[K_{i n c}\right]$ é a matriz tangencial principal, $[K u]$ é a matriz de deslocamento inicial, $\left[K_{\sigma}\right]$ é a matriz de tensão e $[\mathrm{Ka}]$ é a matriz de carga inicial.

A solução converge quando $\left\{F_{a}\right\}=\left\{F_{n r}\right\}$. Assim a convergência $R$ é definida por:

$$
\{R\}=\left\{F_{a}\right\}-\left\{F_{n r}\right\}
$$

A Figura 4.21, mostra a convergência do método de Newton - Raphson.

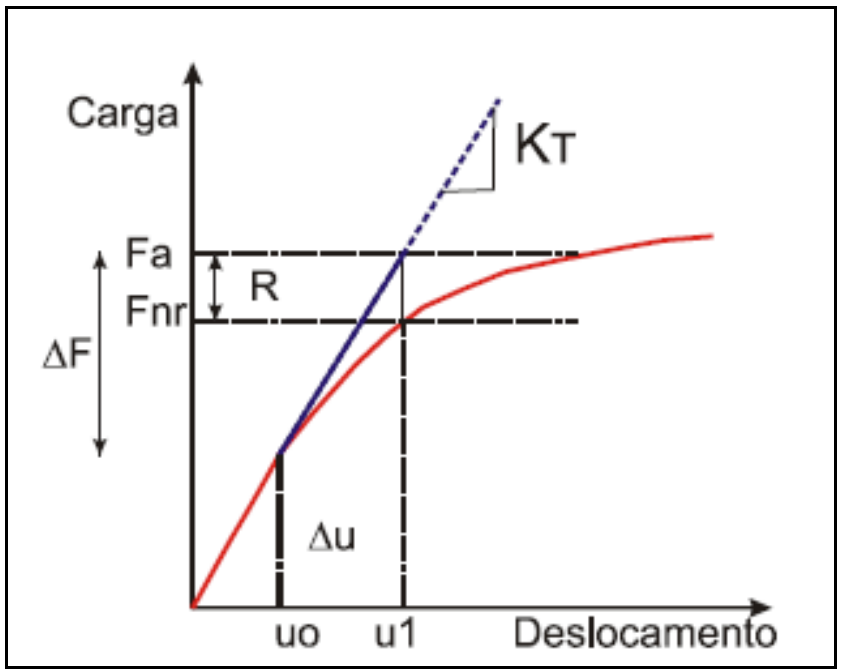

Figura 4.21:Convergência do método de Newton - Raphson.

A vantagem do método de Newton - Raphson é que para a matriz de rigidez tangencial o método tem uma taxa quadrática de convergência. Em cada iteração o erro na solução é proporcional ao quadrado do erro anterior.

\subsubsection{Tipo de Elementos Utilizados}

Utilizou-se o elemento sólido SOLID186, [56], Figura 4.22, para a simulação do interior das estruturas soldadas. A característica principal desse elemento sólido utilizado é a sua capacidade de suportar grandes deformações. No software utilizado existem dois tipos principais de elementos sólidos para o modelo proposto: elementos de oito nós e três graus de liberdade por nó (com variante prismática e tetraédrica, que possui melhor desempenho quando utilizado 
em malhas regulares) e elementos de vinte nós, com três graus de liberdade por nó (com variante prismática, piramidal e tetraédrica e ótimo desempenho, inclusive quando utilizado em malhas irregulares).

O tipo do elemento foi escolhido baseado na geometria estudada. O elemento considera também o efeito da plasticidade e grandes deslocamentos.

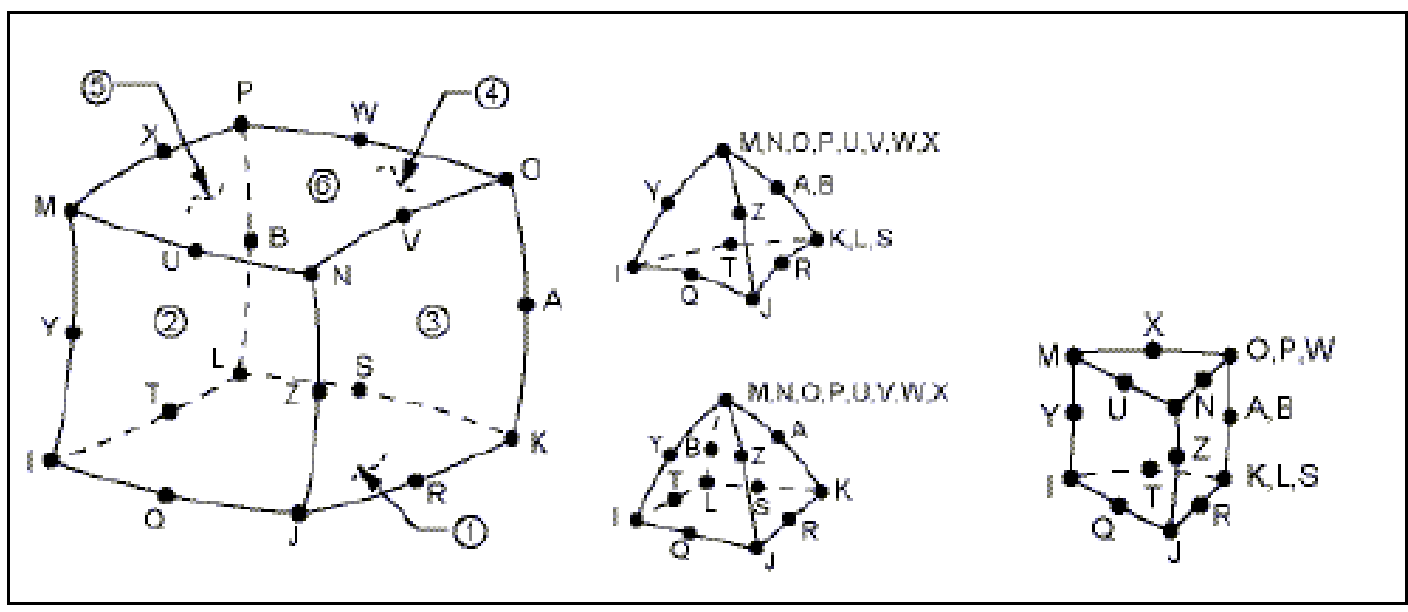

Figura 4.22: Elemento 3D SOLID186.

Semelhante ao modelo térmico as superfícies em 3D de contato das partes a serem unidas, que estão em contado com o cordão de solda, foram modeladas usando o elemento de contato rígido TARGE170, que representa as superfícies "alvo" para os respectivos elementos de contato do outro corpo, estando também associados ao elemento CONTA174.

Foi usado também o elemento COMBIN14 que tem aplicação longitudinal ou torcional em uma, duas ou três dimensões. A opção de mola-amortecedor longitudinal o torna em um elemento de tensão-compressão uniaxial com até três graus de liberdade em cada nó. A opção de mola-amortecedor de torção o torna em um elemento puramente rotacional com três graus de liberdade em cada nó.

A interação entre o metal de base e o metal de solda foi definida como sendo BONDED, sendo considerado que ambas as superfícies em contato estão “coladas", não podendo se separar.

O algoritmo utilizado para formulação dos contatos foi o PURE PENALTY, que substitui um problema com restrições por uma série de problemas sem restrições. 


\subsubsection{Malha}

Foi buscada uma semelhança entre as malhas dos modelos térmicos e mecânicos, utilizando-se preferencialmente malhas iguais para os dois. Assim é uma característica das duas malhas o refinamento na região da ZTA, para que se possa simular com exatidão o comportamento da junta. As regiões distantes do cordão de solda foram modeladas com um número pequeno de elementos, que não afete as soluções. Uma análise da sensibilidade da malha, bem como uma análise da qualidade dos elementos deve ser realizada para garantir a confiabilidade dos resultados. Foram utilizadas nos modelos estudados tanto malhas regulares quanto malhas irregulares, dependendo da geometria.

\subsubsection{Aplicação do Carregamento Térmico, Condições de Contorno e Controle da Solução}

A configuração do tempo do modelo mecânico é exatamente igual ao do modelo térmico, o tempo onde ocorre cada passo deve ser igual em ambos os modelos. A fonte de calor foi modelada diretamente como um carregamento térmico na simulação estrutural, logo é necessário que o histórico de temperaturas na peça seja carregado na análise mecânica antes do início da simulação.

Em acordo com o modelo térmico para cada cordão de solda (como uma única barra) ou seção de cordão (múltiplas barras) foram usados 15 passos, assim o número total de passos da simulação depende do número de cordões e de seção simuladas. Cada passo foi dividido em mil sub-passos, podendo realizar até mil interações por sub-passo segundo a necessidade do software para convergir.

As condições de contorno são aplicadas logo no início da simulação, seja restringindo ou não o deslocamento de superfícies, pontos ou arestas.

No caso da existência de um tratamento mecânico de alivio de tensões o número de passos da simulação deve ser aumentado. Assim a simulação do alívio pode ser entendida como uma simulação dentro de outra. Após o fim dos passos da soldagem, se acrescentam os passos para simular o alívio. O carregamento de alívio deve ser desativado durante a soldagem, para que não haja interferência entre as simulações. Já as condições de contorno podem ou não ser mantidas, a depender do caso. 


\section{5 Soldagem de Elementos Planos}

A soldagem de elementos planos representa o principal tipo de união de geometrias. Essas peças podem ser painéis, chapas, barras entre outros. Por exemplo, temos o transporte marítimo que é reconhecido como uma das principais formas de transporte de bens e pessoas. A construção naval teve um grande impulso ao longo do século XX, principalmente durante o período entre guerras, quando o tempo de produção de um navio decaiu de quatro anos para apenas oito semanas. Essa evolução tremenda na produção se deve a introdução da soldagem como principal método de união, substituindo o uso de rebites.

A soldagem na produção é um fator determinante e está diretamente relacionada com o custo de produção e com a qualidade, representando de 20 a $30 \%$ do tempo de produção e $10 \%$ do custo total.

\subsection{Modelos Estudados}

Para o estudo da soldagem de elementos planos foram analisadas a união de chapas grossas através de modelos experimentais e modelos matemáticos (analíticos e numéricos). A definição de chapas finas ou espessas faz referência à influência da espessura na distribuição de temperaturas pela peça, assim em chapas finas a distribuição de calor tem um comportamento bidimensional enquanto em chapas espessas o calor apresenta uma distribuição não uniforme que deve ser levada em consideração ao longo da espessura. As chapas estudadas apresentam $13.8 \mathrm{~mm}$ de espessura, sendo necessários múltiplos passes para o preenchimento da junta. 
Foram examinados dois modelos diferentes, o primeiro analisa as tensões residuais geradas após a soldagem de topo para a união de duas chapas livres, sem restrições ao deslocamento em qualquer direção, e o segundo analisa o comportamento de após a soldagem de topo para a união de duas chapas com restrições ao deslocamento nas direções vertical e horizontal, como mostrado pela Figura 5.1.

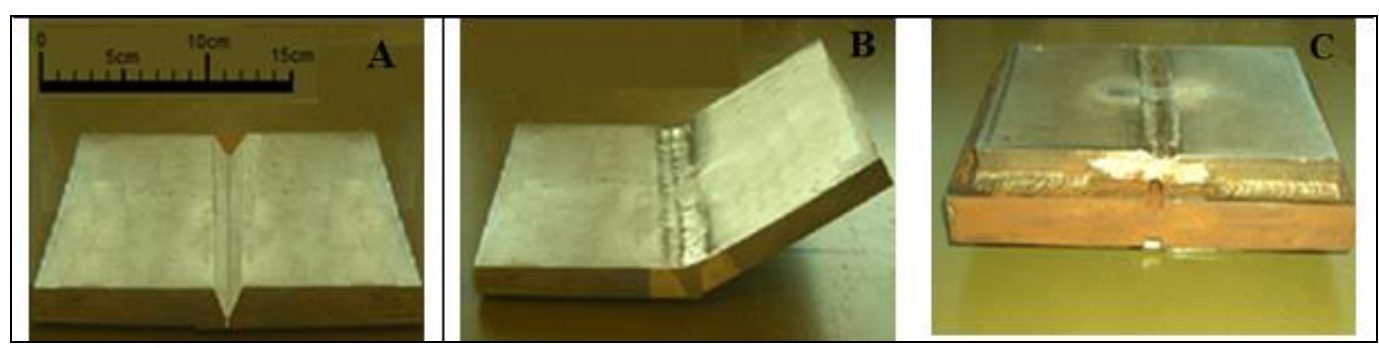

Figura 5.1: Modelos das chapas estudas: a) Chapas sem soldagem; b) $1^{\circ}$ modelo, chapas livres; c) $2^{\circ}$ modelo, chapas com restrições ao deslocamento.

Para o preenchimento das juntas foram utilizados 16 passes de solda, 2 de raiz e 14 de preenchimento. O processo de soldagem escolhido para confecção dos modelos experimentais foi o GTAW e os parâmetros de soldagem estão descritos na Tabela 5.1.

Tabela 5.1: Parâmetros de soldagem das chapas.

\begin{tabular}{|c|c|}
\hline Parâmetro & Característica \\
\hline Limpeza & Escovamento \\
\hline \multirow{2}{*}{ Metal de base } & $\begin{array}{c}\text { Aço Inoxidável Duplex 2205 (UNS } \\
\text { S32205) }\end{array}$ \\
\hline Classificação AWS do metal de adição & ER 2209 \\
\hline Temperatura de pré-aquecimento $\left({ }^{0} \mathrm{C}\right)$ & 27 \\
\hline Temperatura de interpasse $\left({ }^{\circ} \mathrm{C}\right)$ & 70 \\
\hline Eletrodo & Toriado $(2 \%$, EW Th-2) - \\
& 3.2 mm de diâmetro \\
\hline Posição de soldagem & Topo \\
\hline Gás de proteção & Ar- $99,9 \%$ de pureza), \\
\hline Purga (Ar + 2,5\% N2) \\
\hline Vazão do gás de proteção $(\mathrm{L} / \mathrm{min})$. & 15 \\
\hline Diâmetro do metal de adição $(\mathrm{mm})$ & 1.2 \\
\hline Velocidade $(\mathrm{m} / \mathrm{s})$ & 0.03 \\
\hline Tensão $(\mathrm{V})$ & 12 \\
\hline Corrente $(\mathrm{A})$ & 170 \\
\hline Aporte de calor $(\mathrm{kJ} / \mathrm{mm})$ & 0.5 \\
\hline
\end{tabular}


Os modelos numéricos desenvolvidos simulam a deposição dos cordões de solda utilizando a hipótese das três barras, onde cada cordão é assumido como uma barra inteira depositada de uma única vez. Foram utilizadas as técnicas de morte e nascimento de elementos para simular a deposição dos múltiplos passes de solda.

Os modelos analíticos se basearam nas formulações analíticas para predição das distribuições das tensões residuais apresentadas no item 2.5.2 do Capítulo 2.

Em ambos os modelos os resultados numéricos e analíticos obtidos foram comparados com medições experimentais obtidas através de duas técnicas diferentes, difração de raios $\mathrm{X}$ e furo cego.

Foi considerado nas simulações que tanto o metal de base como o de solda são feitos do mesmo material, o aço inoxidável Duplex 2205 (UNS S32205). As propriedades do material à temperatura ambiente bem como outros dados estão mostrados na Tabela 5.2 e a Figura 5.2 apresenta a variação das propriedades térmicas e mecânicas utilizadas para simulação com a temperatura. Essas propriedades foram extraídas de referências da literatura, [57,58,59].

Tabela 5.2: Propriedades do aço Duplex 2205 à temperatura ambiente.

\begin{tabular}{|c|c|c|}
\hline Propriedade & Símbolo & $\begin{array}{c}\text { Valor na temperatura } \\
\text { ambiente }\end{array}$ \\
\hline Limite de escoamento & $S_{y}$ & $509 \mathrm{MPa}$ \\
\hline Coeficiente de expansão térmica & $\alpha$ & $1.310^{-5} \mathrm{C}$ \\
\hline Módulo de elasticidade & $E$ & $200 \mathrm{GPa}$ \\
\hline Condutividade térmica & $k$ & $49.38 \mathrm{~W} / \mathrm{m}^{20} \mathrm{C}$ \\
\hline Calor específico & $c$ & $491.06 \mathrm{~J} / \mathrm{kg}{ }^{0} \mathrm{C}$ \\
\hline Densidade & $\rho$ & $7850 \mathrm{~kg} / \mathrm{m}^{3}$ \\
\hline
\end{tabular}

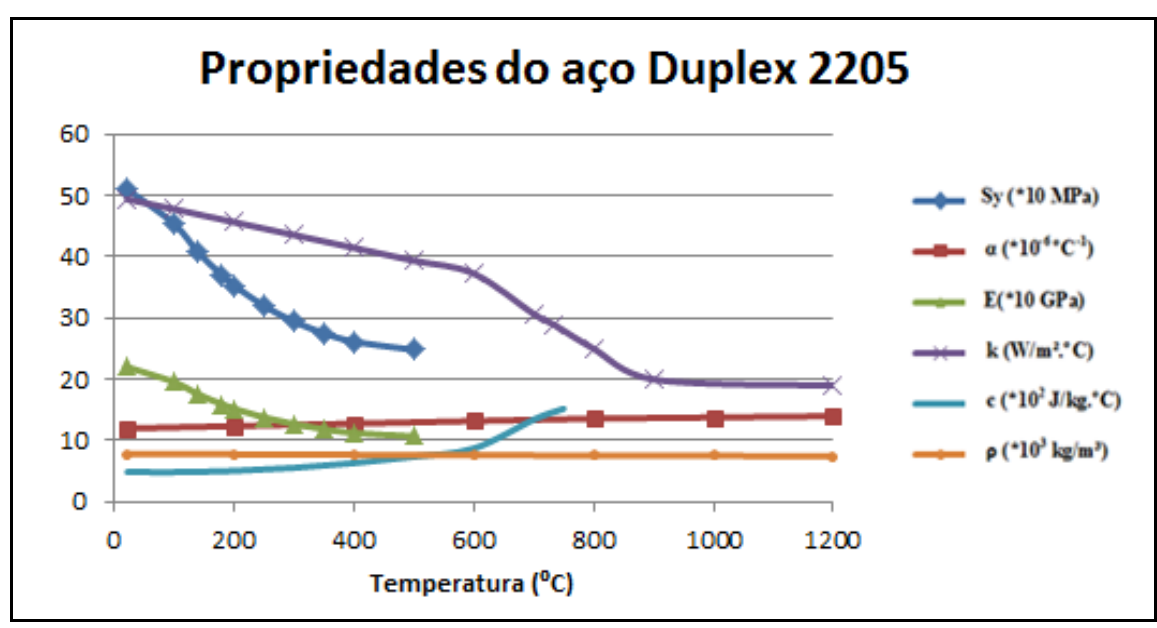

Figura 5.2: Variação das propriedades térmicas e mecânicas do aço inoxidável Duplex 2205 com a temperatura. 
A Figura 5.3 apresenta as dimensões de uma das chapas soldadas. O espécime plano utilizado tem o ângulo de bizel igual a $35^{\circ}, 13.8 \mathrm{~mm}$ de espessura, $98 \mathrm{~mm}$ de largura, $100 \mathrm{~mm}$ de profundidade, $2 \mathrm{~mm}$ de nariz e comprimento de fresta igual a $5 \mathrm{~mm}$.

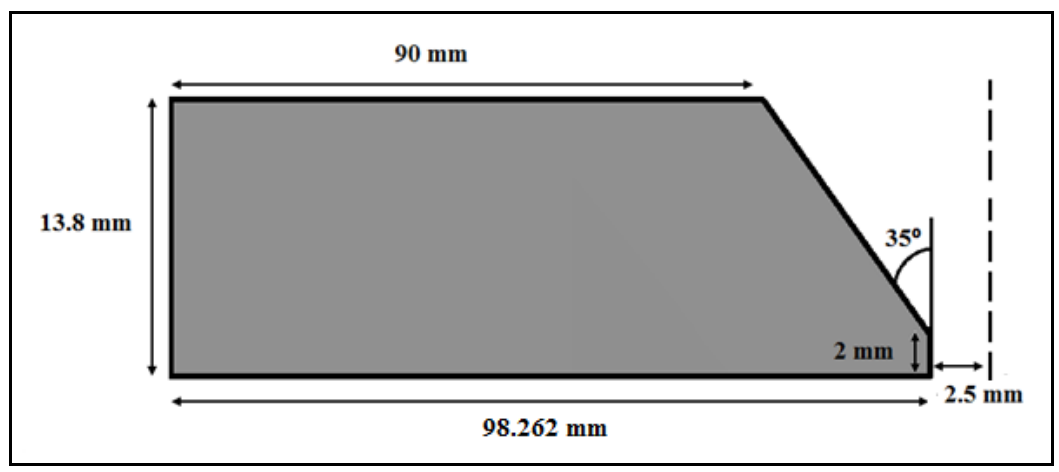

Figura 5.3: Dimensões de uma das chapas.

A Figura 5.4 mostra a geometria utilizada nos modelos numéricos. A geometria dos modelos numéricos apresenta $1 / 2$ de simetria no comprimento, com restrições aos deslocamentos nas faces de simetria ( $u z=0$ no plano xy).

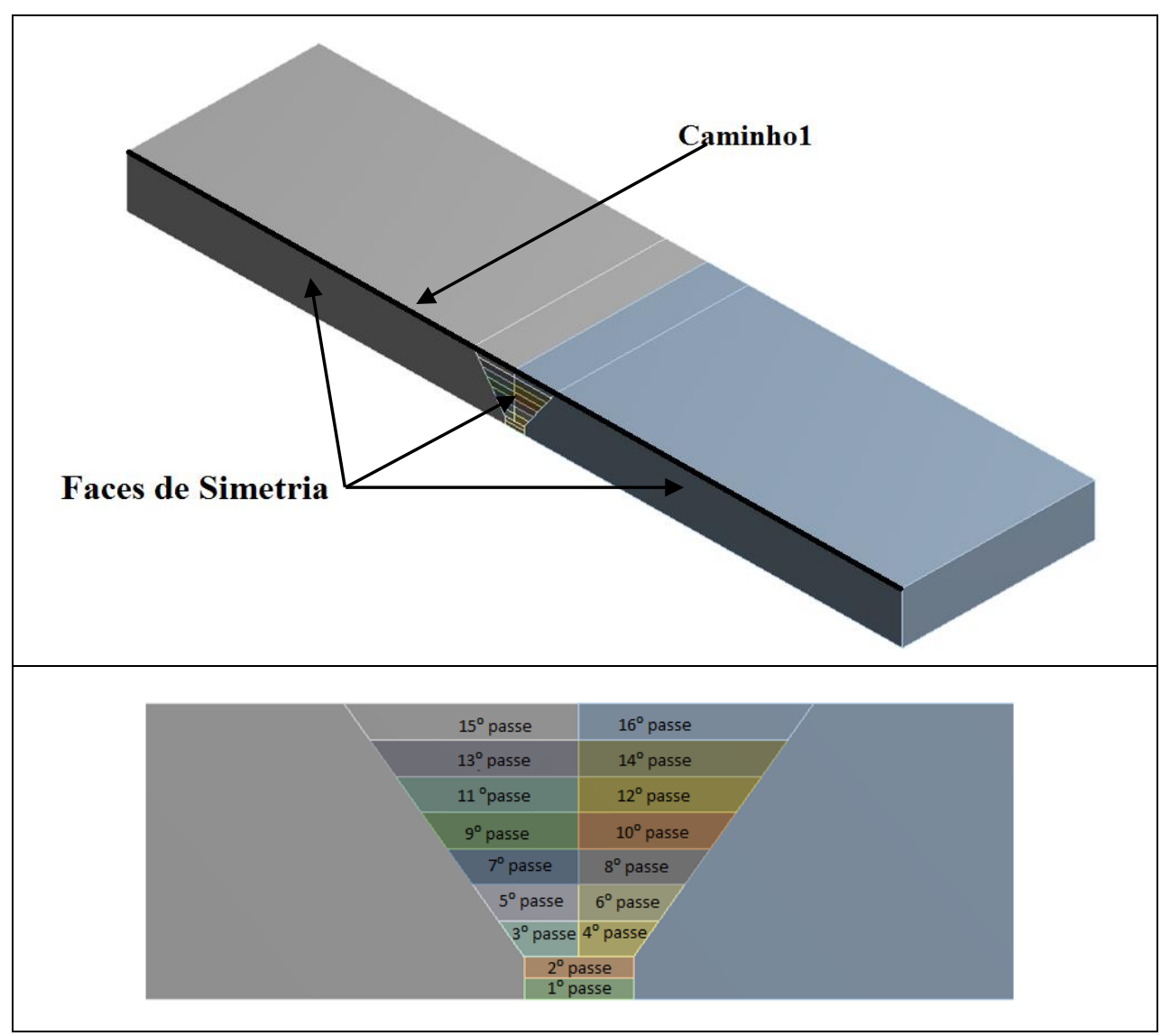

Figura 5.4: Geometria do modelo das chapas para simulação da soldagem de topo. 


\subsubsection{Malha do Modelo}

As análises foram baseadas nas malhas mostradas nas Figuras 5.5, sendo que ambas as malhas das partes térmica e mecânica foram iguais em cada tipo de simulação, a fim de facilitar a comutação de resultados.

A malha considerada nas análises tem 11502 nós e 1888 elementos. O fator qualidade dos elementos, que mede a qualidade de cada elemento, tem valor mínimo igual a 0.35 e valor máximo igual a 0.95 e uma média para todos os elementos igual a 0.78 , com um desvio padrão de 0.11. A razão de aspecto mínima foi de 1.22 e a máxima foi de 5.0, com média igual a 1.76 e desvio padrão de 0.62. Na Figura 5.5 é mostrada a malha e os fatores de qualidade da mesma.

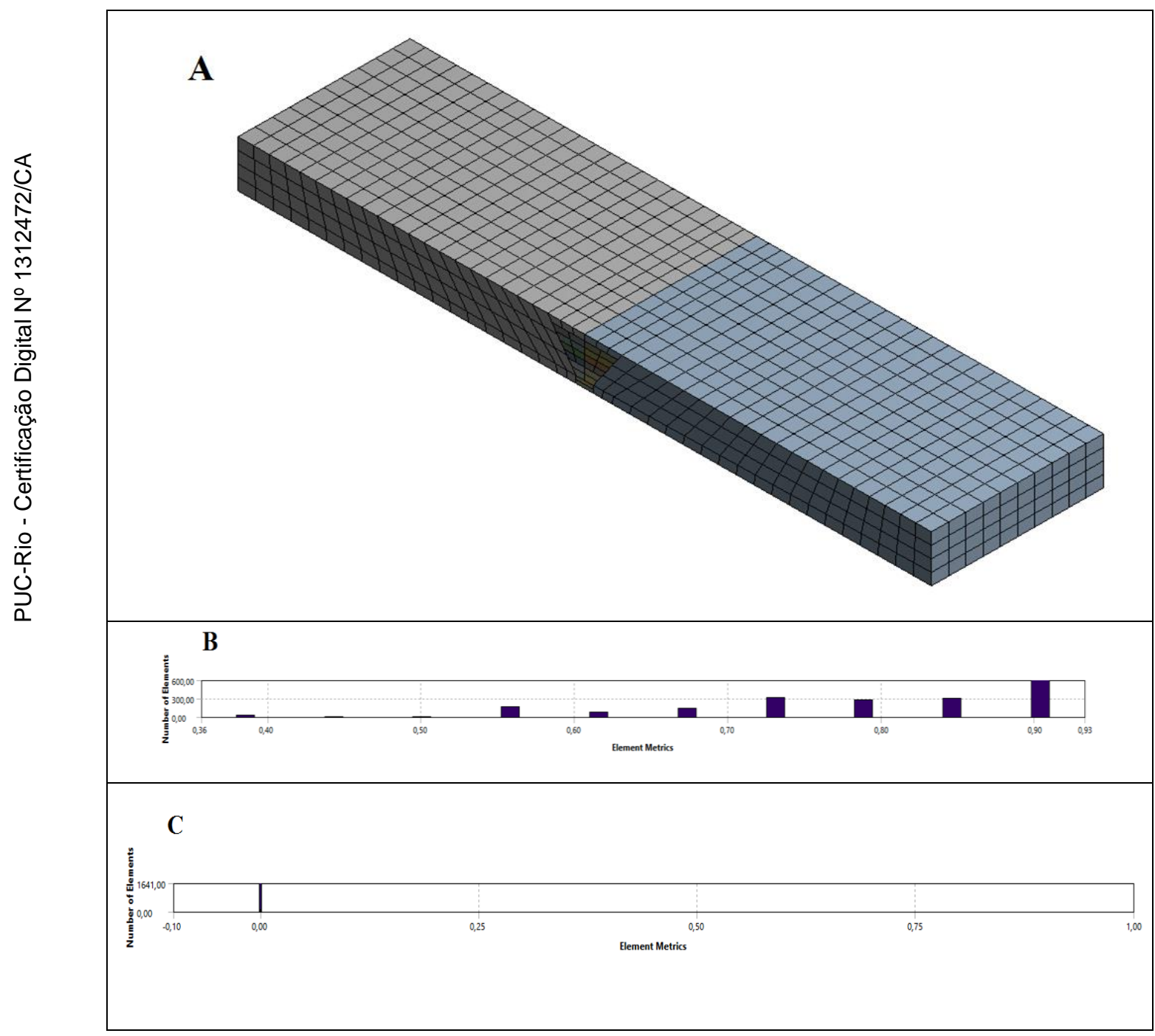

Figura 5.5: Configurações da malha para as análises: a) Malha; b) Histograma da qualidade dos elementos; c) Histograma da razão de aspecto dos elementos. 


\subsubsection{Configuração dos Passos Tempo}

Foram usados 80 passos de tempo para ambas as simulações, sem restrições e com restrições ao deslocamento. A simulação da deposição de cada passe de solda tem a duração de $1 \mathrm{~s}$ e ocorre durante um passo de tempo. Abaixo, a Tabela 5.3 correlaciona cada passo de tempo com sua duração e com o evento que ocorre nele para ambos os tipos de simulação.

Tabela 5.3: Duração de cada passo de tempo.

\begin{tabular}{|c|c|c|c|c|c|c|c|}
\hline Passo & Duração (s) & $\begin{array}{c}\text { Tempo ao Final do } \\
\text { Passo (s) }\end{array}$ & Evento & Passo & Duração (s) & $\begin{array}{c}\text { Tempo ao Final do } \\
\text { Passo (s) }\end{array}$ & Evento \\
\hline $1^{0}$ & 1 & 1 & $\begin{array}{c}\text { Deposição do } \\
1^{0} \text { cordão }\end{array}$ & $41^{0}$ & 1 & 4001 & $\begin{array}{c}\text { Deposição do } \\
9^{0} \text { cordão }\end{array}$ \\
\hline $2^{0}$ & 1 & 2 & \multirow{4}{*}{ Troca de calor } & $42^{0}$ & 1 & 4002 & \multirow{4}{*}{ Troca de calor } \\
\hline $3^{0}$ & 1 & 3 & & $43^{0}$ & 1 & 4003 & \\
\hline $4^{0}$ & 1 & 4 & & $44^{0}$ & 1 & 4004 & \\
\hline $5^{0}$ & 496 & 500 & & $45^{0}$ & 496 & 4500 & \\
\hline $6^{0}$ & 1 & 501 & $\begin{array}{l}\text { Deposição do } \\
2^{0} \text { cordão }\end{array}$ & $46^{0}$ & 1 & 4501 & $\begin{array}{c}\text { Deposição do } \\
10^{0} \text { cordão }\end{array}$ \\
\hline $7^{0}$ & 1 & 502 & \multirow{4}{*}{ Troca de calor } & $47^{0}$ & 1 & 4502 & \multirow{4}{*}{ Troca de calor } \\
\hline $8^{0}$ & 1 & 503 & & $48^{0}$ & 1 & 4503 & \\
\hline $9^{0}$ & 1 & 504 & & $49^{0}$ & 1 & 4504 & \\
\hline $10^{0}$ & 496 & 1000 & & $50^{0}$ & 496 & 5000 & \\
\hline $11^{0}$ & 1 & 1001 & $\begin{array}{l}\text { Deposição do } \\
3^{0} \text { cordão }\end{array}$ & $51^{0}$ & 1 & 5001 & $\begin{array}{c}\text { Deposição do } \\
11^{0} \text { cordão }\end{array}$ \\
\hline $12^{0}$ & 1 & 1002 & \multirow{4}{*}{ Troca de calor } & $52^{0}$ & 1 & 5002 & \multirow{4}{*}{ Troca de calor } \\
\hline $13^{0}$ & 1 & 1003 & & $53^{0}$ & 1 & 5003 & \\
\hline $14^{0}$ & 1 & 1004 & & $54^{0}$ & 1 & 5004 & \\
\hline $15^{0}$ & 496 & 1500 & & $55^{0}$ & 496 & 5500 & \\
\hline $16^{0}$ & 1 & 1501 & $\begin{array}{l}\text { Deposição do } \\
4^{0} \text { cordão }\end{array}$ & $56^{0}$ & 1 & 5501 & $\begin{array}{c}\text { Deposição do } \\
12^{0} \text { cordão }\end{array}$ \\
\hline $17^{0}$ & 1 & 1502 & \multirow{4}{*}{ Troca de calor } & $57^{0}$ & 1 & 5502 & \multirow{4}{*}{ Troca de calor } \\
\hline $18^{0}$ & 1 & 1503 & & $58^{0}$ & 1 & 5503 & \\
\hline $19^{0}$ & 1 & 1504 & & $59^{0}$ & 1 & 5504 & \\
\hline $20^{0}$ & 496 & 2000 & & $60^{0}$ & 496 & 6000 & \\
\hline $21^{0}$ & 1 & 2001 & $\begin{array}{l}\text { Deposição do } \\
5^{0} \text { cordão }\end{array}$ & $61^{0}$ & 1 & 6001 & $\begin{array}{c}\text { Deposição do } \\
13^{0} \text { cordão }\end{array}$ \\
\hline $22^{0}$ & 1 & 2002 & \multirow{2}{*}{ Troca de calor } & $62^{0}$ & 1 & 6002 & \multirow{2}{*}{ Troca de calor } \\
\hline $25^{0}$ & 496 & 2500 & & $65^{0}$ & 496 & 6500 & \\
\hline $26^{0}$ & 1 & 2501 & $\begin{array}{l}\text { Deposição do } \\
6^{0} \text { cordão }\end{array}$ & $66^{0}$ & 1 & 6501 & $\begin{array}{c}\text { Deposição do } \\
14^{0} \text { cordão }\end{array}$ \\
\hline $27^{0}$ & 1 & 2502 & \multirow{4}{*}{ Troca de calor } & $67^{0}$ & 1 & 6502 & \multirow{4}{*}{ Troca de calor } \\
\hline $28^{0}$ & 1 & 2503 & & $68^{0}$ & 1 & 6503 & \\
\hline $29^{0}$ & 1 & 2504 & & $69^{0}$ & 1 & 6504 & \\
\hline $30^{0}$ & 496 & 3000 & & $70^{0}$ & 496 & 7000 & \\
\hline $31^{0}$ & 1 & 3001 & $\begin{array}{l}\text { Deposição do } \\
7^{0} \text { cordão }\end{array}$ & $71^{0}$ & 1 & 7001 & $\begin{array}{c}\text { Deposição do } \\
15^{0} \text { cordão }\end{array}$ \\
\hline $32^{0}$ & 1 & 3002 & \multirow{4}{*}{ Troca de calor } & $72^{0}$ & 1 & 7002 & \multirow{4}{*}{ Troca de calor } \\
\hline $33^{0}$ & 1 & 3003 & & $73^{0}$ & 1 & 7003 & \\
\hline $34^{0}$ & 1 & 3004 & & $74^{0}$ & 1 & 7004 & \\
\hline $35^{0}$ & 496 & 3500 & & $75^{0}$ & 496 & 7500 & \\
\hline $36^{0}$ & 1 & 3501 & $\begin{array}{c}\text { Deposição do } \\
8^{0} \text { cordão } \\
\end{array}$ & $76^{0}$ & 1 & 7501 & $\begin{array}{c}\text { Deposição do } \\
16^{0} \text { cordão } \\
\end{array}$ \\
\hline $37^{0}$ & 1 & 3502 & \multirow{4}{*}{ Troca de calor } & $77^{0}$ & 1 & 7502 & \multirow{4}{*}{ Troca de calor } \\
\hline $38^{0}$ & 1 & 3503 & & $78^{0}$ & 1 & 7503 & \\
\hline $39^{0}$ & 1 & 3504 & & $79^{0}$ & 1 & 7504 & \\
\hline $40^{\circ}$ & 496 & 4000 & & $80^{\circ}$ & 7496 & 15000 & \\
\hline
\end{tabular}




\subsubsection{Condições de Contorno Térmicas}

As temperaturas nas juntas soldadas ao longo do tempo foram analisadas através de uma análise de transferência de calor transiente, onde o calor é transmitido através da condução e convecção. Na análise não foram considerados os efeitos da radiação, pois dentre os mecanismos de transferência de calor presentes no processo de soldagem os que mais impactam na acurácia do modelo numérico são os processos de condução e convecção, [30, 53, 60].

Os aportes de calor das soldagens foram modelados diretamente como carregamentos da simulação térmica. Cada passe de solda se inicia com o cordão de solda sendo depositado como uma condição de temperatura. Como os parâmetros de soldagem são conhecidos pode-se determinar a temperatura de deposição a partir da equação 3.3, assumindo que a distância na direção $y(Y)$ é igual à zero. A temperatura em que os cordões de solda são depositados tem valor igual a $2089^{\circ} \mathrm{C}$.

Após o término de cada passe são aplicadas as condições de contorno térmicas nos espécimes, uma convecção, que é aplicada às faces exteriores com exceção da face em contato com a superfície de apoio, igual a $30 \mathrm{~W} / \mathrm{m}^{2} \mathrm{~K}$, até que toda a chapa entre em equilíbrio com a temperatura ambiente de $22{ }^{\circ} \mathrm{C}$. A condução é uma condição de contorno intrínseca da análise, sendo regida pela condutividade térmica, calor especifico e densidade do material.

Ambos os modelos numéricos seguiram a mesma simulação térmica, uma vez que eles apenas se diferenciam quanto às condições de contorno mecânicas.

\subsubsection{Condições de Contorno Mecânicas}

A variação das temperaturas ao longo do tempo na junta obtida na análise térmica transiente é transformada em um carregamento térmico no modelo estrutural. Durante a soldagem as tensões e deformações originadas no processo são caracterizadas por um comportamento elastoplástico do metal, propriedades mecânicas variantes com a temperatura e gradientes térmicos muito severos. 
No primeiro modelo não foram aplicadas restrições ao deslocamento. Durante a soldagem as chapas estão livres para se deslocar e deformar em qualquer direção. Já no segundo modelo nas faces inferiores, em contato com a superfície de apoio, o deslocamento foi fixado em zero, para simular a présoldagem de fixação do modelo experimental.

Como não foram aplicadas restrições ao deslocamento no primeiro modelo utilizou-se a opção de "Weak Springs" que impede o movimento de corpo rígido da peça.

\subsection{Medições Experimentais}

Para medição das tensões residuais provenientes da soldagem de união das chapas foram empregadas duas técnicas experimentais de medição, a do furo cego e a da difração de raios $X$.

\subsubsection{Técnica do Furo Cego}

Essa técnica é aplicada para determinar o perfil de tensões residuais em casos onde o comportamento do material estudado é isotrópico linear - elástico. A técnica do furo cego faz uso de extensômetros elétricos para determinar o estado plano de tensões na superfície de medição do material, fornecendo medições pontuais, que são referentes à porção de material removida da peça. A introdução do furo na peça com tensões residuais provoca alívio e redistribuição destas. Os dados obtidos experimentalmente são depois tratados por uma série de equações segundo a norma ASTM E837 para a determinação das distribuições de tensões residuais na superfície do espécime.

A Figura 5.6 apresenta o fluxograma com as etapas de execução do método do furo cego. A seguir cada uma das etapas e suas influências dentro do processo para a obtenção de uma medição confiável serão mais bem estudadas. 


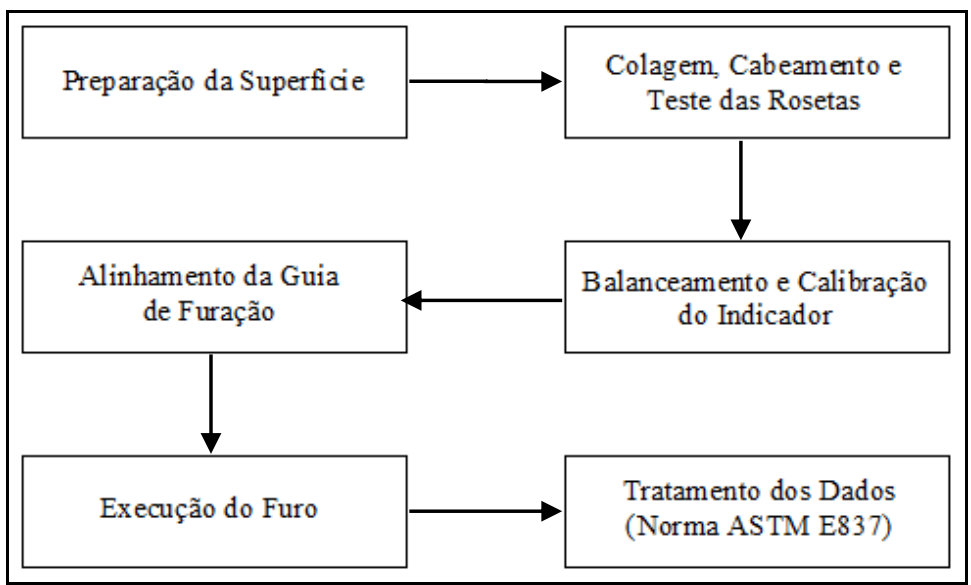

Figura 5.6: Fluxograma com as etapas da aplicação da técnica do furo cego.

Os extensômetros elétricos usados foram do tipo PA - $06-062 \mathrm{RE}-120 \mathrm{~L}$, com fator extensométrico igual a $2.13 \pm 1 \%$ fabricados pela EXCEL SENSORES. Foram utilizados um total de 7 rosetas por modelo, sendo uma posicionado sobre o cordão de solda e outras três de cada lado da solda até à borda das chapas, todos posicionadas sobre o mesmo eixo transversal. A Figura 5.7 mostra a disposição dos extensômetros nos modelos.

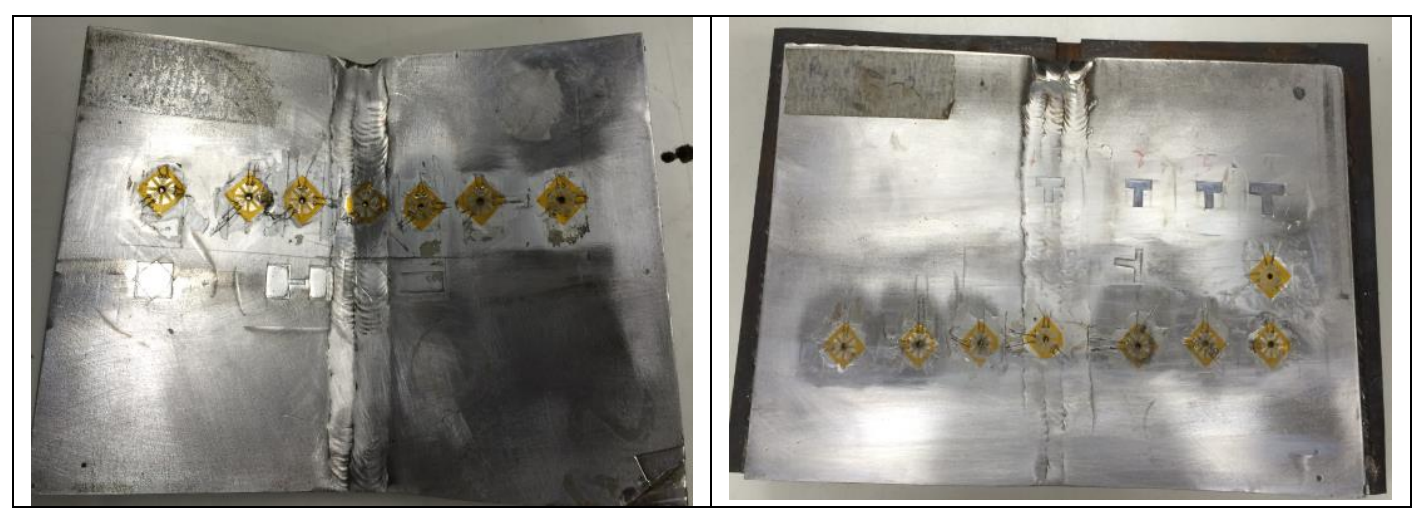

Figura 5.7: Disposição dos extensômetros elétricos nos modelos.

\subsubsection{Preparação da Superfície}

Nesta etapa as superfícies onde as rosetas extensométricas serão coladas deverão ser lixadas e limpas. A preparação das superfícies deve adotar metodologias com o menor grau de agressividade possível à superfície das chapas. O lixamento demasiado para limpar e homogeneizar as superfícies de medição pode provocar alteração e redistribuição das tensões residuais pré-existentes. Antes da colagem das rosetam, as superfícies devem ser limpas com uma substancia solvente (nesse trabalho foi utilizada acetona pura) para eliminação de qualquer impureza que dificulte a colagem. 


\subsubsection{Colagem, Cabeamento e Teste das Rosetas}

Com as superfícies de medição devidamente retificadas e sem nenhuma impureza, as rosetas são coladas segundo instruções do fabricante de forma a garantir que as deformações ocorridas na superfície sob as grades de medição de seus extensômetros sejam totalmente lidas. Também é importante considerar a coincidência entre as direções longitudinal e transversal das chapas com as direções 1 e 3 da roseta, a fim de facilitar os cálculos. Para a colagem das rosetas foi usado o adesivo Loctite 496, à base de cianoacrilato, e uma proteção de uma camada simples de silicone neutro.

Após a colagem é realizado o cabeamento dos terminais dos extensômetros por meio de soldagem para ligá-los ao indicador de deformações. Os terminais são soldados a cabos blindados de 3 fios tio AWG 26, Figura 5.8. Os cabos são ligados às pontes de Wheatstone (Tipo 1/4) de um condicionador de sinais Vishay P3.

Para validar a colagem e a soldagem dos cabos, as três resistências entre os fios ligados aos extensômetros são medidas e comparadas com o valor dado pelo fabricante da roseta (neste caso $120 \Omega$ ). Também se verifica o isolamento entre eles e a superfície de medição. A resistência entre as rosetas e as superfícies deve ser maior que $200 \mathrm{M} \Omega$.

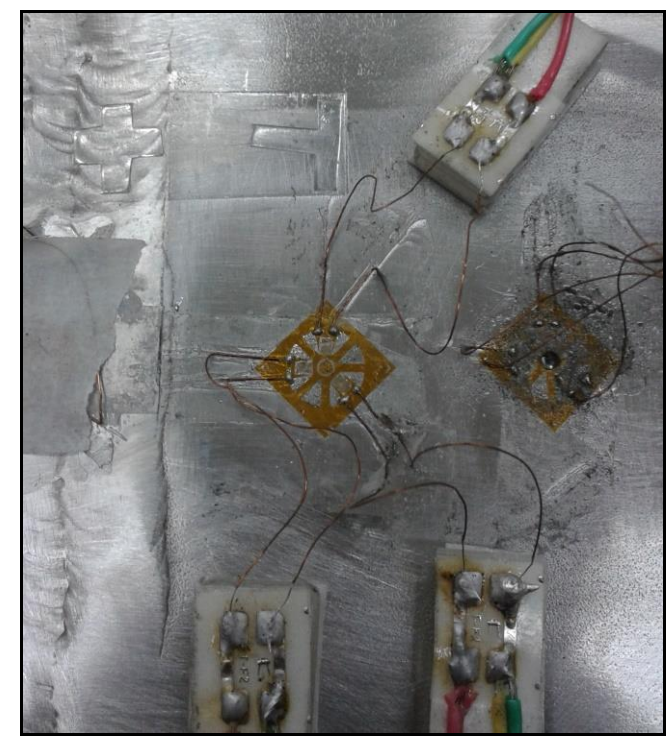

Figura 5.8: Cabeamento das rosetas. 


\subsubsection{Balanceamento e Calibração do Indicador}

Se os testes com as rosetas mostrarem a adequação de sua instalação, os três extensômetros são ligados às pontes de Weatstone do condicionador de sinais. As Pontes são balanceadas e os sistemas de medição dos extensômetros são calibrados com o auxílio de uma resistência padrão.

A Figura 5.9 apresenta o condicionador de sinais Vishay P3.

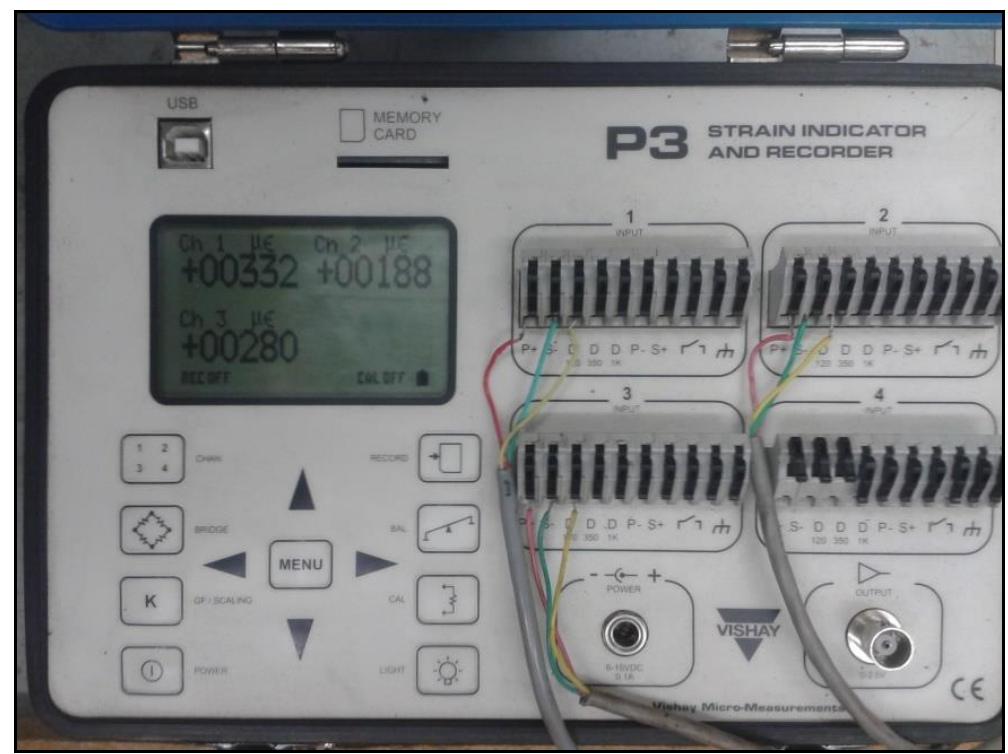

Figura 5.9: Condicionador de sinais Vishay P3.

\subsubsection{Alinhamento da Guia de Furação}

Qualquer excentricidade na furação pode acarretar erros consideráveis na deformação medida. Para excentricidades de cerca de $10 \%$ do raio do furo (algo em torno de oito centésimos de milímetro), pode-se chegar a erros de até $5 \%$ no cálculo das tensões $[2,61]$.

A guia de furação é acoplada a um tripé, que deve ser colado na superfície da medição com o mesmo cuidado com que se cola a roseta. Com o auxílio de uma lupa e uma mesa de translação acoplada ao tripé é possível tornar a guia de furação concêntrica à roseta, Figura 5.10. 


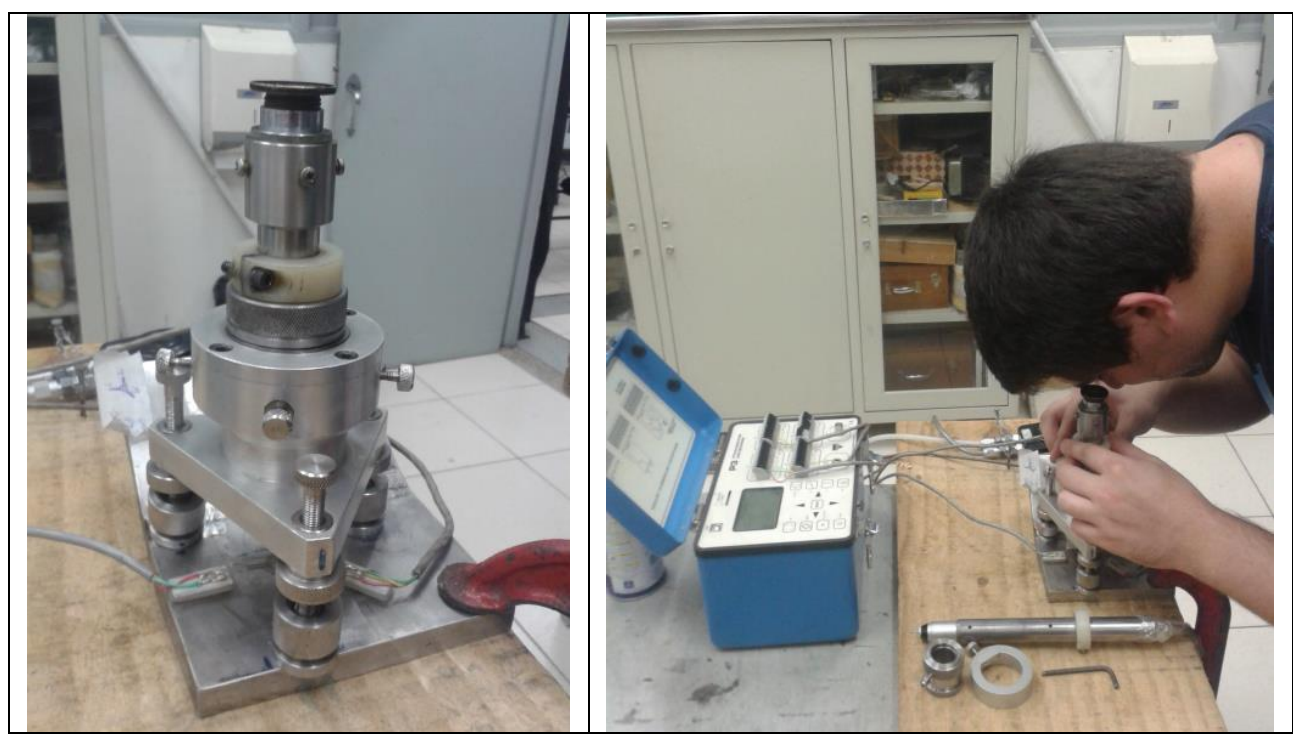

Figura 5.10: Guia de furação e seu alinhamento.

\subsubsection{Execução do Furo}

Após centralização da guia, a lupa é retirada para dar lugar à ferramenta de furação. O processo de furação pode introduzir tensões maiores que as existentes. Estas tensões são, normalmente, trativas e são provocadas pela camada de material deformada plasticamente ou alterada estruturalmente [62].

Dentre os principais parâmetros que afetam as tensões geradas pela execução do furo estão: a qualidade da geometria do furo cilíndrico usinado e a velocidade de rotação na furação [2].

Em [2] foi estudado os efeitos da velocidade de furação, sendo apresentado um estudo sobre as tensões originadas a partir da furação em altíssima rotação (acima de 400.000 RPM usando uma turbina a ar) e as geradas na usinagem do furo com uma furação à baixa rotação (abaixo de 1000 RPM). Assumiu-se que a furação a altíssimas rotações gera tensões menores do que com rotações baixas. Entretanto, em [84] foram testados os métodos com altíssima e baixa rotações e concluiu-se que os dois métodos têm a mesma eficiência para a execução do furo de forma incremental.

A ferramenta recomendada é a Fresa de Topo e a mais usada é a do tipo Cônica Invertida, tal como a que foi a usada nas medições desta tese e está mostrada na Figura 5.11. O incremento de profundidade de furação escolhido foi igual a $0.05 \mathrm{~mm}$, esse valor foi escolhido devido a dureza elevada do aço trabalhado de forma a minimizar o desgaste da ferramenta, e a profundidade final do furo, h, foi igual a $2 \mathrm{~mm}$. 


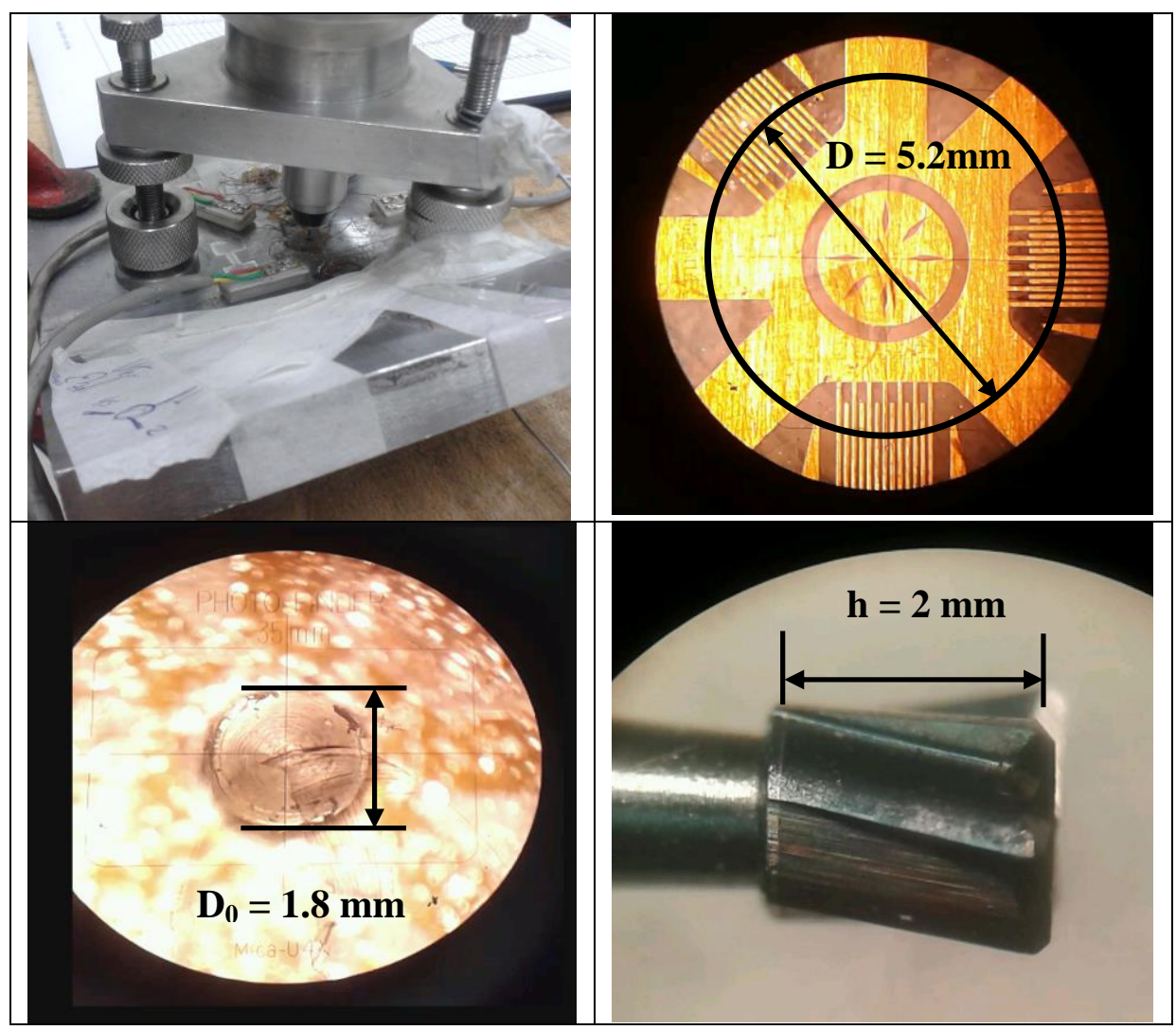

Figura 5.11: Vista da roseta extensômetrica antes e depois da furação.

\subsubsection{Tratamento dos Dados (Segundo a Norma ASTM E837)}

Depois da usinagem dos furos cegos, as deformações lidas devem ser tratadas por uma série de equações a fim de se determinar as tensões principais nominais presentes na peça em cada ponto medido antes da furação.

As tensões longitudinais e transversais podem ser calculadas com base nas tensões principais e nas posições angulares relativas às normais aos planos, onde essas tensões atuam. O procedimento e as equações para usados foram retirados da norma ASTM E837 -13a.

Quando as tensões residuais obtidas pela técnica do furo cego alcançam valores acima da metade da resistência ao escoamento do material (0.5 Sy), as medições apresentam um erro. Isso porque, com valores elevados, o material começa a escoar na borda do furo devido à concentração de tensões gerada por ele, invalidando o uso dos coeficientes de alívio a e b , que foram determinados para o regime elástico, relacionando linearmente as deformações medidas com as tensões existentes.

A Figura 5.12 apresenta a configuração da roseta do tipo $A$ utilizada para as medições. 


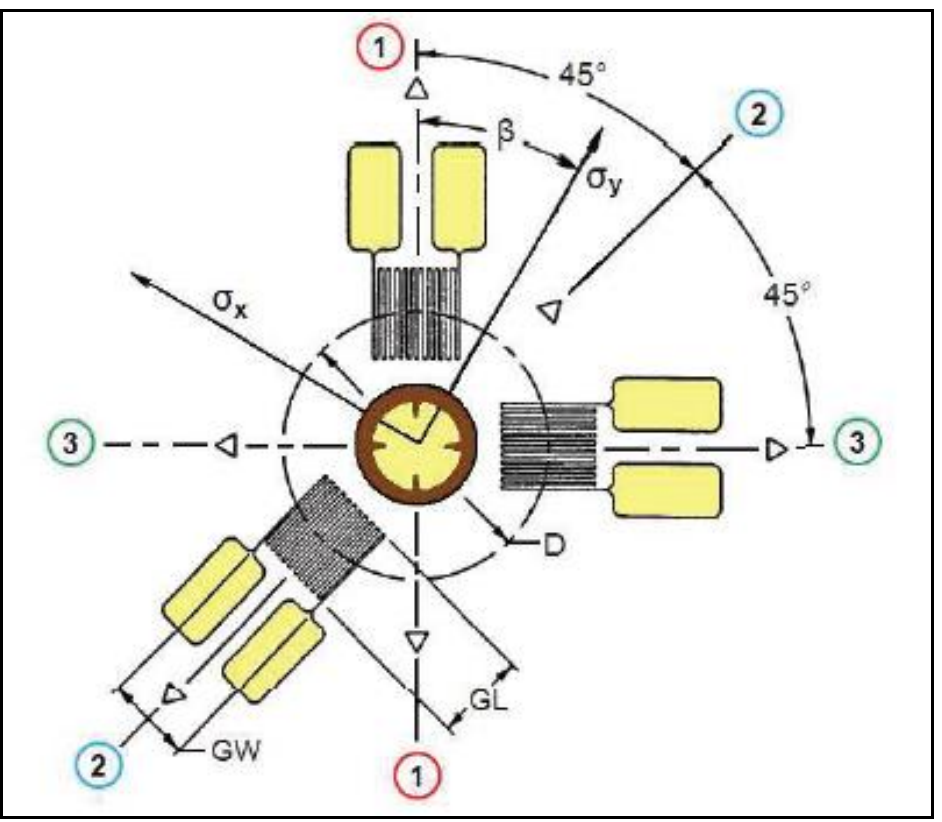

Figura 5.12: Configuração da roseta tipo A.

O cálculo das tensões e planos principais segue os seguintes passos:

Primeiro calcula-se as combinações das deformações para cada incremento segundo as equações:

$$
\begin{gathered}
p=\frac{\left(\varepsilon_{3}+\varepsilon_{1}\right)}{2} \\
q=\frac{\left(\varepsilon_{3}-\varepsilon_{1}\right)}{2} \\
t=\frac{\left(\varepsilon_{3}+\varepsilon_{1}-2 \varepsilon_{2}\right)}{2}
\end{gathered}
$$

O próximo passo é a determinação dos coeficientes de alívio $\bar{a}$ e $\bar{b}$ com

\begin{tabular}{|c|c|c|c|c|c|c|c|c|c|c|c|c|}
\hline \multirow{2}{*}{$\begin{array}{l}\text { Roseta } \\
\text { Tipo A }\end{array}$} & \multicolumn{6}{|c|}{$a$} & \multicolumn{6}{|c|}{$b$} \\
\hline & \multicolumn{6}{|c|}{$\mathrm{D}_{0} / \mathrm{D}$} & \multicolumn{6}{|c|}{$\mathrm{D}_{0} / \mathrm{D}$} \\
\hline $\mathrm{h} / \mathrm{D}$ & 0,030 & 0,031 & 0,035 & 0,040 & 0,045 & 0,050 & 0,030 & $\mathbf{0 , 0 3 1}$ & 0,035 & 0,040 & 0,045 & 0,050 \\
\hline 0 & 0,000 & 0,000 & 0,000 & 0,000 & 0,000 & 0,000 & 0,000 & 0,000 & 0,000 & 0,000 & 0,000 & 0,000 \\
\hline 0.05 & 0,027 & 0,029 & 0,037 & 0,049 & 0,063 & 0,080 & 0,051 & 0,055 & 0,069 & 0,090 & 0,113 & 0,140 \\
\hline 0.10 & 0,059 & $\mathbf{0 , 0 6 3}$ & 0,081 & 0,108 & 0,138 & 0,176 & 0,118 & 0,126 & 0,159 & 0,206 & 0,255 & 0,317 \\
\hline 0.15 & 0,085 & 0,091 & 0,115 & 0,151 & 0,192 & 0,238 & 0,180 & 0,192 & 0,239 & 0,305 & 0,375 & 0,453 \\
\hline 0.20 & 0,101 & 0,108 & 0,137 & 0,177 & 0,223 & 0,273 & 0,227 & 0,241 & 0,299 & 0,377 & 0,459 & 0,545 \\
\hline 0.25 & 0,110 & $\mathbf{0 , 1 1 7}$ & 0,147 & 0,190 & 0,238 & 0,288 & 0,259 & 0,275 & 0,339 & 0,425 & 0,513 & 0,603 \\
\hline 0.30 & 0,113 & 0,120 & 0,151 & 0,195 & 0,243 & 0,293 & 0,279 & 0,296 & 0,364 & 0,454 & 0,546 & 0,638 \\
\hline 0.35 & 0,113 & 0,120 & 0,151 & 0,195 & 0,242 & 0,292 & 0,292 & 0,309 & 0,379 & 0,472 & 0,566 & 0,657 \\
\hline 0.40 & 0,111 & 0,149 & 0,149 & 0,192 & 0,239 & 0,289 & 0,297 & 0,315 & 0,387 & 0,482 & 0,576 & 0,668 \\
\hline Passante & 0,090 & & 0,122 & 0,160 & 0,203 & 0,249 & 0,288 & & 0,377 & 0,470 & 0,562 & 0,651 \\
\hline
\end{tabular}
base na Tabela 5.4, abaixo, para cada incremento.

Tabela 5.4: Determinação dos coeficientes $\bar{a}$ e $\bar{b}$ para rosetas do Tipo A, [12] . 
Depois se calculam os termos $P, Q$ e $T$, que são respectivamente a tensão isotrópica (equivalente-biaxial), a tensão cisalhante em $45^{\circ}$ e a tensão cisalhante máxima, segundo as equações abaixo:

$$
\begin{gathered}
P=-E\left[\frac{\left(\sum \bar{a} \cdot p\right)}{\left(\sum \bar{a}^{2}\right) \cdot(1+v)}\right] \\
Q=-E\left[\frac{\left(\sum \bar{b} \cdot q\right)}{\left(\sum \bar{b}^{2}\right)}\right] \\
T=-E\left[\frac{\left(\sum \bar{b} \cdot t\right)}{\left(\sum \bar{b}^{2}\right)}\right]
\end{gathered}
$$

onde $\Sigma$ indica o somatório das quantidades indicadas para cada profundidade do furo.

Calcula-se agora o ângulo $\beta$ que indica a direção das tensões principais em relação ao extensômetro da posição 1 , sendo positivo no sentido horário. As direções das tensões principais coincidem ou ficam muito próximas as direções longitudinal e transversal, isto é, $\beta$ com valor próximo de $0^{\circ}$ ou $90^{\circ}$. Dessa maneira a equação 5.7 e a Tabela 5.5 são utilizadas para o cálculo e análise do ângulo $\beta$.

$$
\beta=\frac{1}{2} \arctan \left(\frac{-T}{-Q}\right)=\frac{1}{2}\left(\frac{\sum \bar{b} \cdot t}{\sum \bar{b} \cdot q}\right)
$$

Tabela 5.5: Posicionamento do ângulo principal $\beta$, [12].

\begin{tabular}{|c|c|c|c|}
\hline & $\mathbf{Q}>\mathbf{0}$ & $\mathbf{Q = 0}$ & $\mathbf{Q}<\mathbf{0}$ \\
\hline $\mathbf{T}<\mathbf{0}$ & $45^{0}<\beta<90^{0}$ & $45^{0}$ & $0^{0}<\beta<450^{0}$ \\
\hline $\mathbf{T}=\mathbf{0}$ & $90^{0}$ & Não definido & $0^{0}$ \\
\hline $\mathbf{T}>\mathbf{0}$ & $-90^{0}<\beta<-45^{0}$ & $-45^{0}<\beta<90^{0}$ & $-45^{0}<\beta<0^{0}$ \\
\hline
\end{tabular}

Para determinar as tensões longitudinais e transversais, sabendo que a posição longitudinal coincide com o extensômetro 1 na Figura 5.12, são usadas as seguintes equações: 


$$
\begin{gathered}
\sigma_{\text {reslong }}=\frac{\sigma_{\max }+\sigma_{\min }}{2}+\frac{\sigma_{\max }-\sigma_{\min }}{2} \cos (2(-\beta)) \\
\sigma_{\text {restrans }}=\frac{\sigma_{\text {max }}+\sigma_{\min }}{2}-\frac{\sigma_{\text {max }}-\sigma_{\min }}{2} \cos (2(-\beta))
\end{gathered}
$$

\subsubsection{Técnica de Difração de Raios-X}

Nessa técnica a tensão na rede cristalina é medida e a tensão residual associada é determinada a partir das constantes elásticas assumindo uma distorção linear elástica do plano cristalino da estrutura. Uma vez que os raios $\mathrm{X}$ colidem sobre uma determinada área na amostra, muitos grãos e cristais irão contribuir para a medição. O número exato depende do tamanho de grão e geometria do feixe.

Embora se considere que a medição nessa técnica seja realizada na superfície da peça, os raios X penetram certa distância para dentro do material: a profundidade de penetração depende do ânodo, do material e do ângulo de incidência. Assim a tensão medida é, essencialmente, a média ao longo de alguns microns de profundidade sob a superfície do espécime. [63].

O principal método utilizado para realização de medições de tensões por difração de raios X é o método de "sen² $\psi$ " que se baseia na medição do ângulo de difração que é caracterizado pela posição angular da linha de difração [14, 64]. A Figura 5.13 mostra o esquema das medidas pelo método de "sen ${ }^{2} \psi$ ".

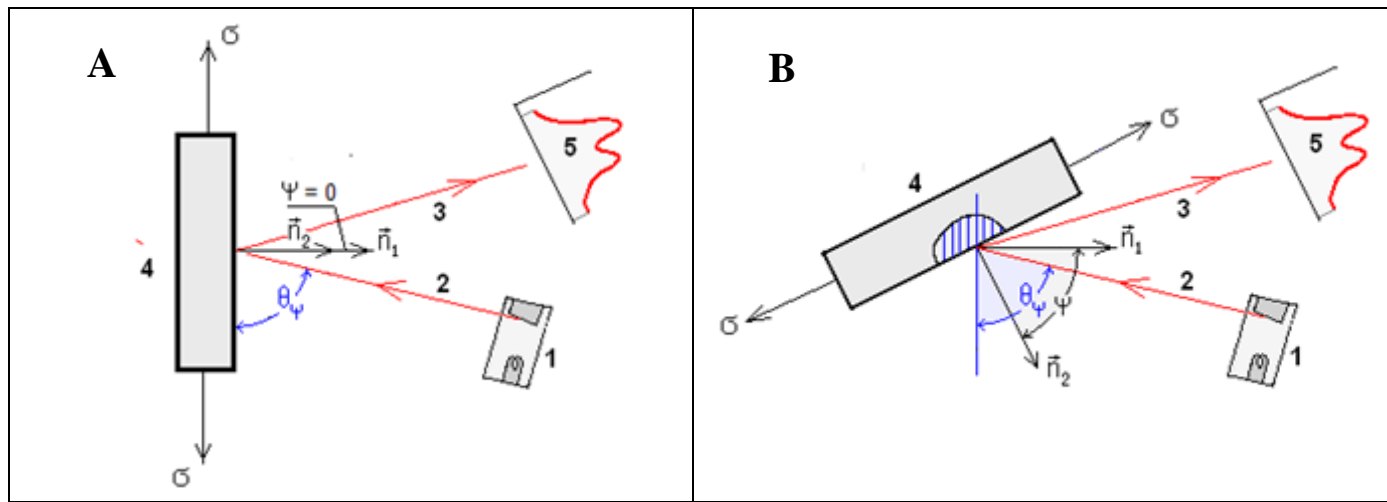

Figura 5.13: Esquema da medição por difração de raios X para: (a) $\psi=0$; (b) e $\psi>0$.

1 - tubo de raios X; 2 e 3 - raio incidente e difratado; 4 - amostra analisada; 5 - perfil da linha de difração. 
A principal equação deste método é a equação da teoria de elasticidade para deformação $\varepsilon_{\phi, \psi}$ em direção arbitrária [65]. No caso do sistema de coordenadas polares e do estado de tensões bidimensionais, esta equação pode ser escrita como:

$$
\varepsilon_{\varphi, \psi}=\frac{1+v}{E} \sigma_{\varphi} \operatorname{sen}^{2} \psi-\frac{v}{E}\left(\sigma_{\max }+\sigma_{\min }\right)
$$

onde $\varphi$ e $\psi$ são os ângulos azimutal e polar respectivamente, $E$ e $v$ são as constantes de elasticidade do material, $\sigma_{\max }$ e $\sigma_{\min }$ são tensões principais e $\sigma_{\varphi}$ é a componente da tensão medida.

A deformação $\varepsilon_{\phi, \psi}$ também pode ser expressa em termos da difração de raios X, através da lei de Bragg segundo a equação, mostrada no Capítulo 2:

$$
2 \cdot d \cdot \operatorname{sen} \theta=\lambda
$$

onde $d$ é a distância interplanar da rede cristalina, $\theta$ é o ângulo de difração e $\lambda$ é o comprimento de onda. Após a diferenciação da lei de Bragg pode-se obter a expressão para deformação $\varepsilon_{\phi, \psi}$ igual a:

$$
\varepsilon_{\varphi, \psi}=\frac{\Delta d}{d}=-\cot g(\theta) \cdot \Delta \theta=-\cot g(\theta) \cdot\left(\theta_{\psi}-\theta_{0}\right)
$$

A partir da combinação das equações 5.10 e 5.12 pode-se obter a equação para o ângulo de difração $\theta_{\psi}$ mostrado na Figura 5.13, que é o ângulo entre o raio incidente ou difratado e o plano cristalino:

$$
\theta_{\psi}=\theta_{0}+\sigma_{\varphi} \frac{(1+v)}{E} \frac{\operatorname{sen}^{2} \psi}{\operatorname{ctg} \theta}-\frac{v}{E}\left(\sigma_{\max }+\sigma_{\min }\right)
$$

De acordo com equação $5.13, \theta_{\psi}$ é uma função linear com relação a $\operatorname{sen}^{2} \psi$ e a partir da tangente desta função determina-se o valor da tensão $\sigma \varphi$ segundo a equação:

$$
\sigma_{\varphi}=\frac{E}{1+v} \operatorname{ctg} \theta\left(\theta_{\psi=90}-\theta_{\psi=0}\right)
$$

onde $(\theta \psi=90-\theta \psi=0)$ é o valor da tangente de inclinação da linha reta da função $\theta_{\psi}=f\left(\operatorname{sen}^{2} \psi\right)$. A Figura 5.13 ilustra o gráfico do ângulo de difração $\theta_{\psi}$ em função de $\operatorname{sen}^{2} \psi$ dada pela equação 5.13 para várias tensões $\sigma_{\varphi}$. 


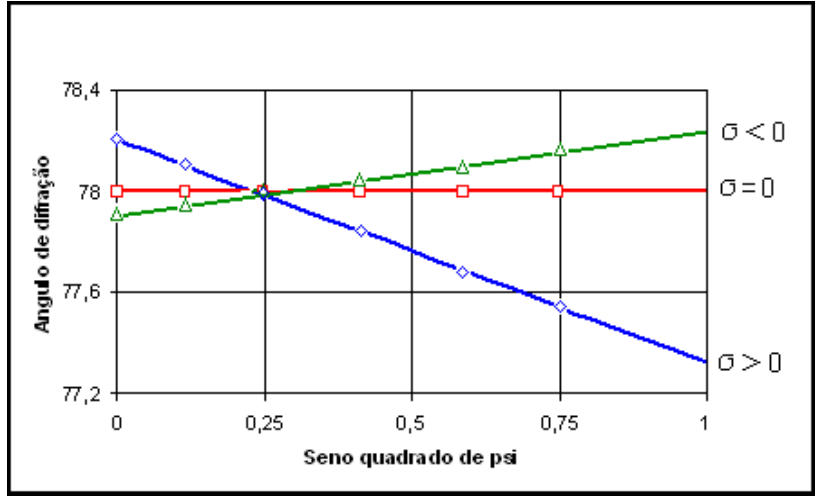

Figura 5.14: Funções $\theta_{\psi}=\mathrm{f}\left(\operatorname{sen}^{2} \psi\right)$ no método de "( $\left.\operatorname{sen}^{2} \psi\right)$ ".

As variações do ângulo $\psi$ são obtidas através da inclinação do feixe de raios $\mathrm{X}$ que incide na superfície da amostra analisada.

Utilizando os valores de constantes elásticas, a formula final para cálculo de tensões medidas pode ser escrita como:

$$
\sigma_{\varphi}=-k \cdot\left(\theta_{\psi=90}-\theta_{\psi=0}\right)
$$

A Figura 5.15 apresenta a vista geral do aparelho de raios $\mathrm{X}$ utilizado nas medições.

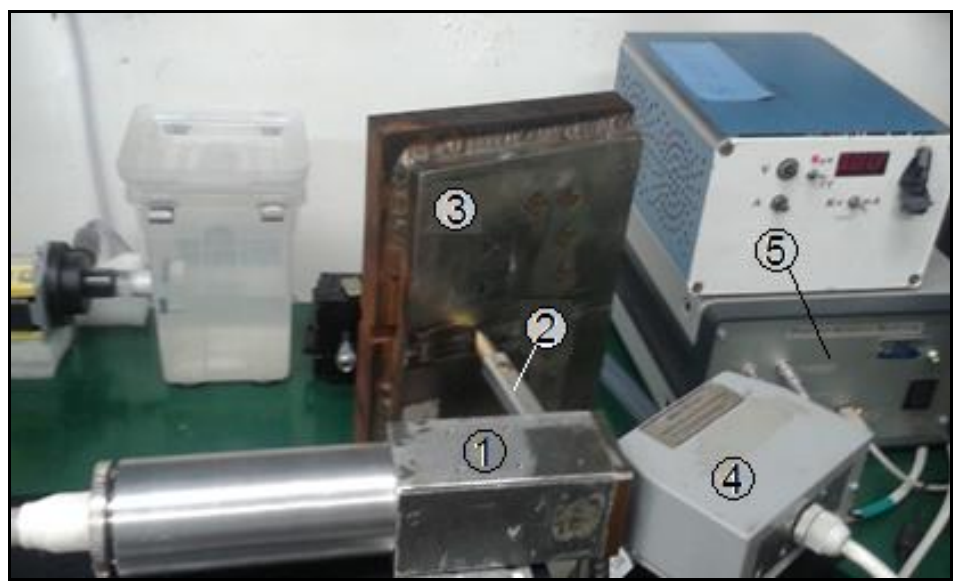

Figura 5.15: Vista geral do aparelho de raios X: 1 - ampola de raios X; 2 - colimador ponteira; 3 - chapa de aço duplex medida; 4 - detector de raios X; 5 - bloco de controle de funcionamento de detector. 


\subsection{Resultados}

Embora os modelos estudados nesse capítulo sejam diferentes entre si, assumiu-se que eles apresentam a mesma historia térmica, ambos com 16 passes de solda e com as mesmas condições de contorno. Assim foi desenvolvida apenas uma simulação térmica para os dois.

$\mathrm{O}$ aquecimento e o resfriamento das chapas durante sua união pela soldagem foram modelados utilizando as variáveis apresentadas no item 5.1.4 e a hipótese das três barras. A fonte de calor durante a deposição de cada cordão de solda foi modelada como um carregamento térmico, sendo considerado que todo o calor é transferido para as chapas através de cada cordão.

Para simular a deposição sequencial dos 16 cordões de solda foram usadas as técnicas de "morte" e "nascimento" de elementos. Todos os elementos constituintes dos cordões de solda com exceção do passe de raiz foram "desligados" para que os ciclos térmicos dos primeiros cordões não influenciassem os demais.

Na deposição de cada cordão de solda foi considerado que cada um deles já se encontra dilatado e à temperatura de $2089^{\circ} \mathrm{C}$, essa temperatura foi calculada com base no item 3.1.1. e nas informações fornecidas pela Tabela 5.1. À medida que a simulação transcorre eles passam a trocar calor com o meio e com as demais regiões das chapas. O calor é dissipado por convecção para o ambiente através de um coeficiente de convecção e para o interior do modelo através de um coeficiente de condução dependente da temperatura.

O tempo de deposição dos cordões de solda é igual a 1s, durante esse tempo o cordão não perde calor, apenas o transfere para as chapas a fim de compensar a parcela não simulada que seria transferida pelo arco elétrico.

Na Figura 5.16 é apresenta distribuição de temperaturas na junta durante a deposição sequencial dos múltiplos cordões de solda. Os ciclos térmicos provocados pela sobreposição de cordões de solda sobre os cordões previamente depositados funcionam como um tratamento de alívio mecânico, como citado no item 4.6. 


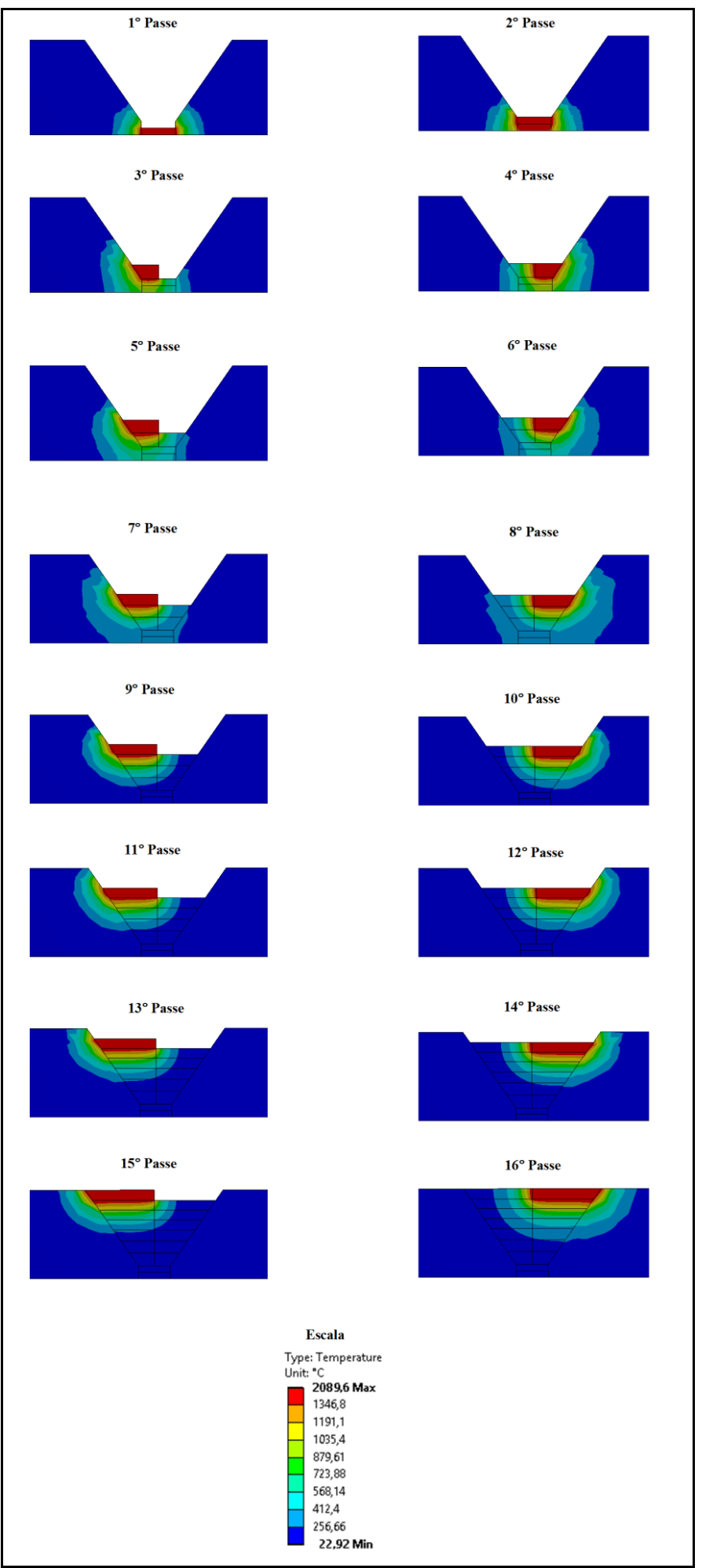

Figura 5.16: Distribuição de temperaturas na junta durante a deposição de cada passe de solda.

A Figura 5.17 apresenta as temperaturas máximas em toda a análise ao longo do tempo. Cada pico de temperatura representa a deposição de um novo passe de solda. O tempo médio para a temperatura máxima entrar em equilíbrio com o ambiente é de 500s, sendo 15000s o instante de tempo em que toda a linha se encontra a $22{ }^{\circ} \mathrm{C}$. 


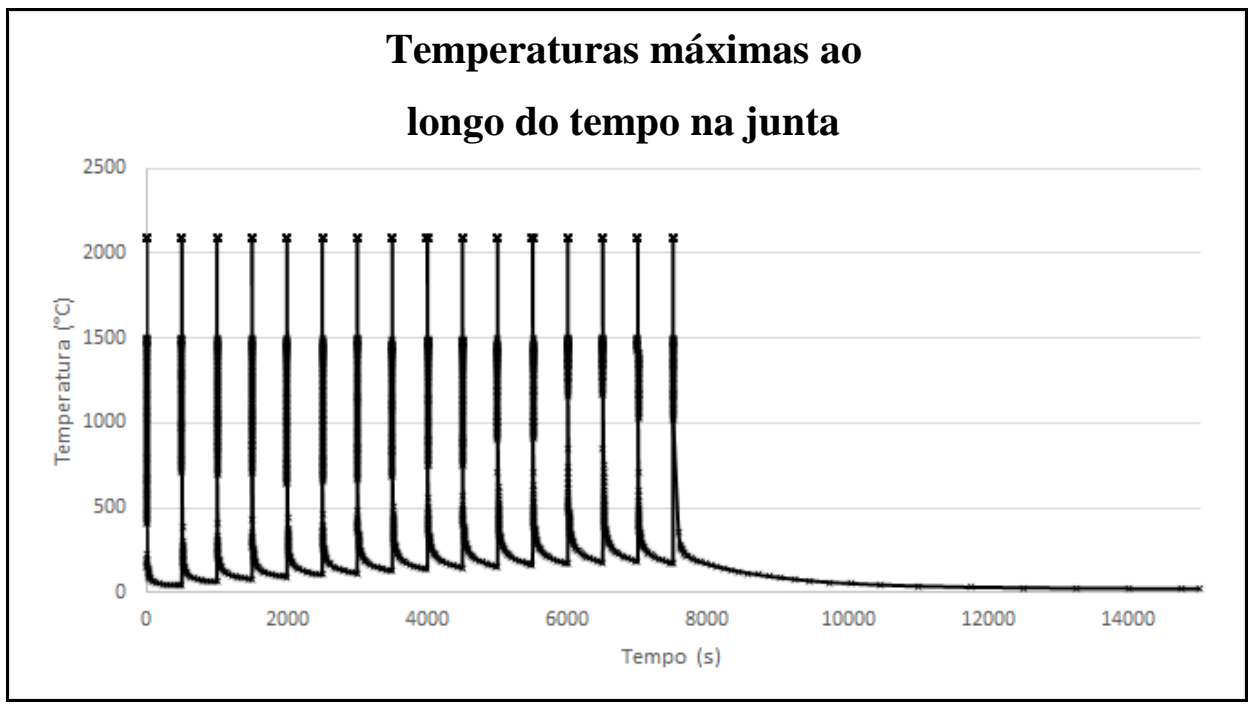

Figura 5.17: Temperaturas máximas ao longo do tempo na junta.

Quando a análise atinge 15000s todo o calor fornecido as chapas durante as soldagens se dissipou para o meio e todo o espécime retorna ao equilíbrio térmico com a temperatura ambiente de $22^{\circ} \mathrm{C}$, como mostrado na Figura 5.18.

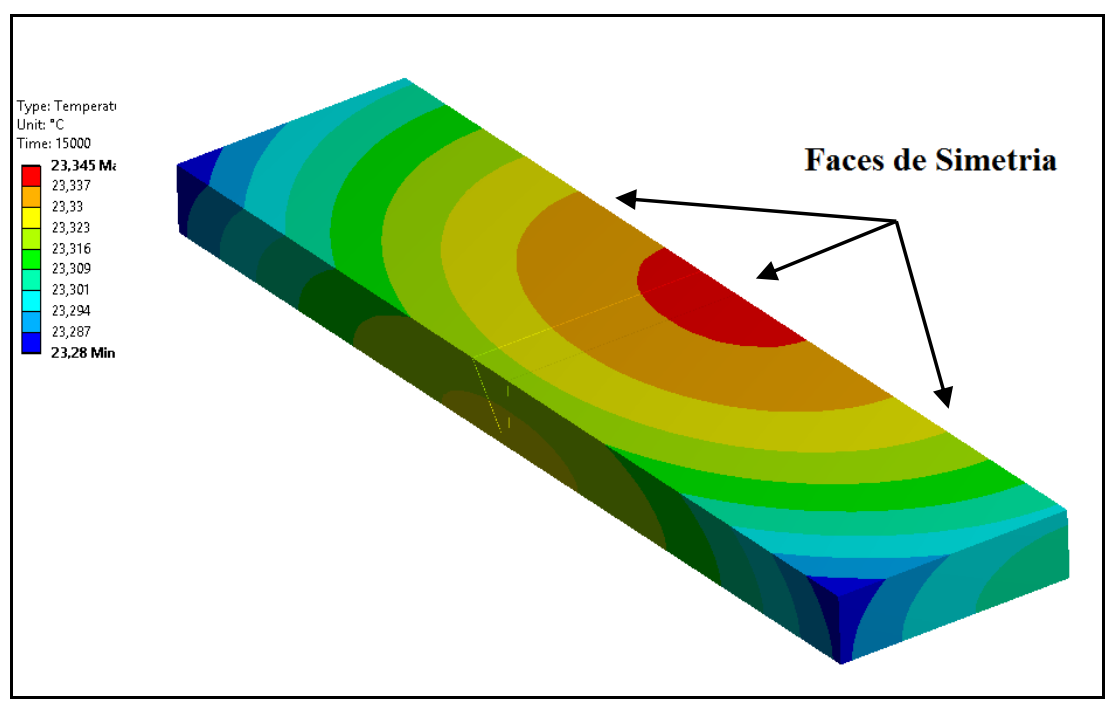

Figura 5.18: Distribuição de temperatura no instante de 15000s.

Os gradientes de temperaturas e as restrições ao deslocamento fazem surgir tensões residuais nas chapas após a soldagem. A soldagem provoca nas chapas mudanças volumétricas não uniformes, que por sua vez geram tensões e deformações. A contração durante o resfriamento das regiões diferentemente aquecidas e plastificadas provoca o surgimento de um campo de tensões residuais que se auto-equilibram. A seguir será analisado cada modelo separadamente para melhor visualização dos resultados. 


\subsubsection{Modelo das Chapas Livres}

Nesse modelo as chapas são soldadas sem a aplicação de restrições ao seu deslocamento, observa-se que à medida que cada passe de solda é depositado a distorção angular aumenta. As distribuições de tensões estão diretamente relacionadas a essa condição de contorno.

Na Figura 5.19 são apresentadas as distribuições de tensões residuais após a soldagem no instante de 15000 s.

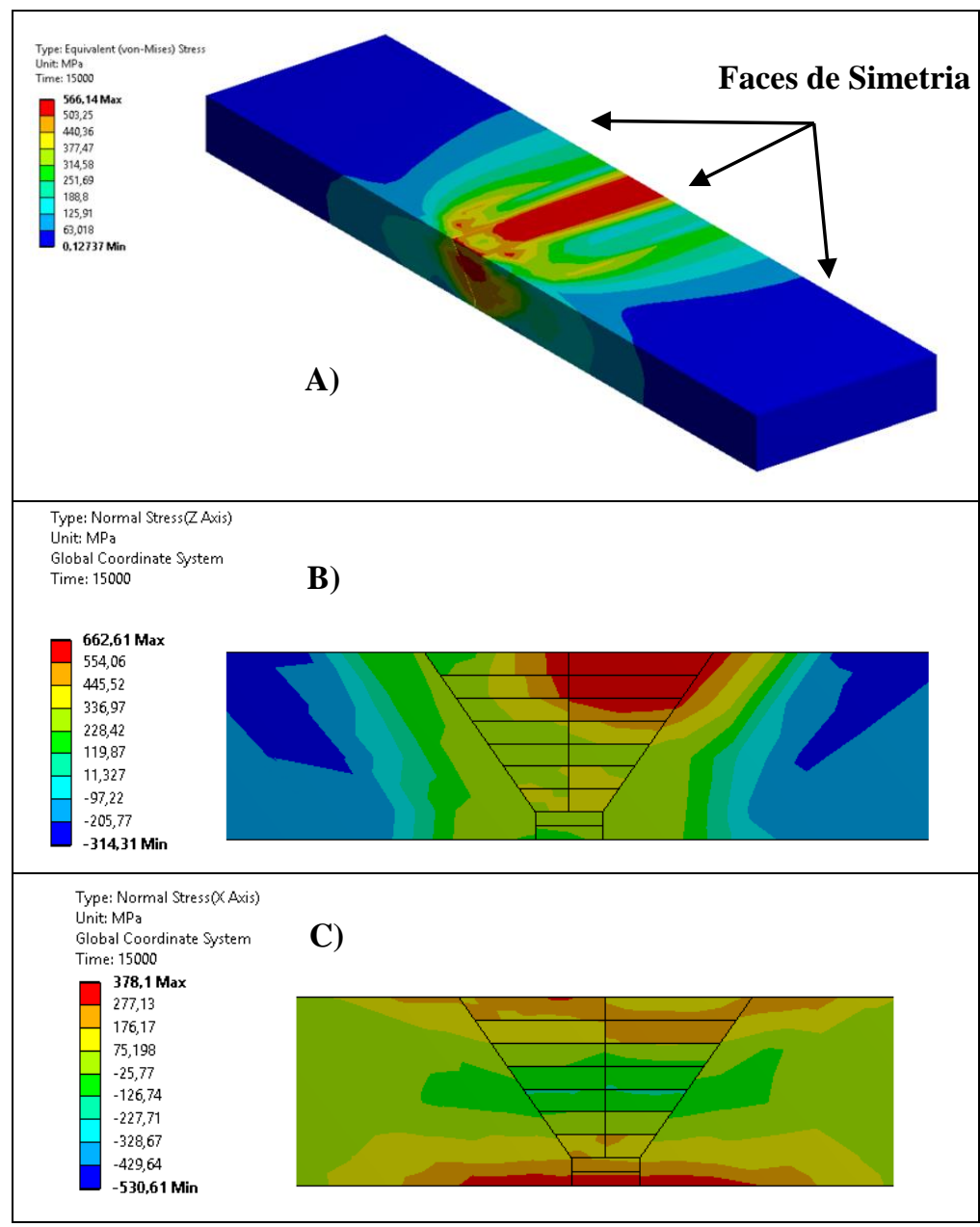

Figura 5.19: Distribuição de tensões residuais: a)Tensões equivalentes; b) Tensões longitudinais; c) Tensões transversais.

A tensão equivalente residual, Figura 5.19a, na superfície do último cordão depositado tem magnitude semelhante ao limite de escoamento do material das chapas. Cada novo cordão depositado passa a agir sobre os demais como um tratamento de alívio mecânico. Percebe-se que o $16^{\circ}$ passe de solda causa um alívio na magnitude das tensões do $15^{\circ}$ passe, assim como também há um alívio de tensões ao longo da espessura da junta. 
As distorções na borda das chapas causadas pelas soldagens provocam uma mudança no comportamento das tensões nessa região. Devido ao comprimento considerável do espécime pode se assumir que as tensões na região central se comportam segundo a hipótese de deformações planas.

As tensões residuais longitudinais, Figura 5.19b, são auto-equilibrantes, sendo trativas na junta soldada e compressivas na ZTA. Os níveis elevados de tensões, às vezes com valores maiores que o limite de escoamento do material, se devem ao fato das maiores restrições a expansão e contração estarem na direção longitudinal. Como citado anteriormente há um alívio nos níveis das tensões ao longo da espessura da junta.

A ausência de restrições durante a soldagem governa o comportamento das tensões residuais transversais, Figura 5.19c. Na região da junta elas apresentam valores trativos, no entanto com magnitudes mais baixas que as observadas na direção longitudinal. Como as chapas estão livres para de deformar os níveis de tensão na direção transversal são uma consequência dessa condição. A medida que se distancia do centro da junta as tensões tendem a zero, pois a contração nessa direção não é muito severa. A tensão transversal deve estar em autoequilíbrio com a seção longitudinal, a região em tração tem por finalidade a manutenção desse equilíbrio.

A Figura 5.20 apresenta as distribuição de tensões residuais ao longo do Caminho 1 (Figura 5.4) em 15000s.

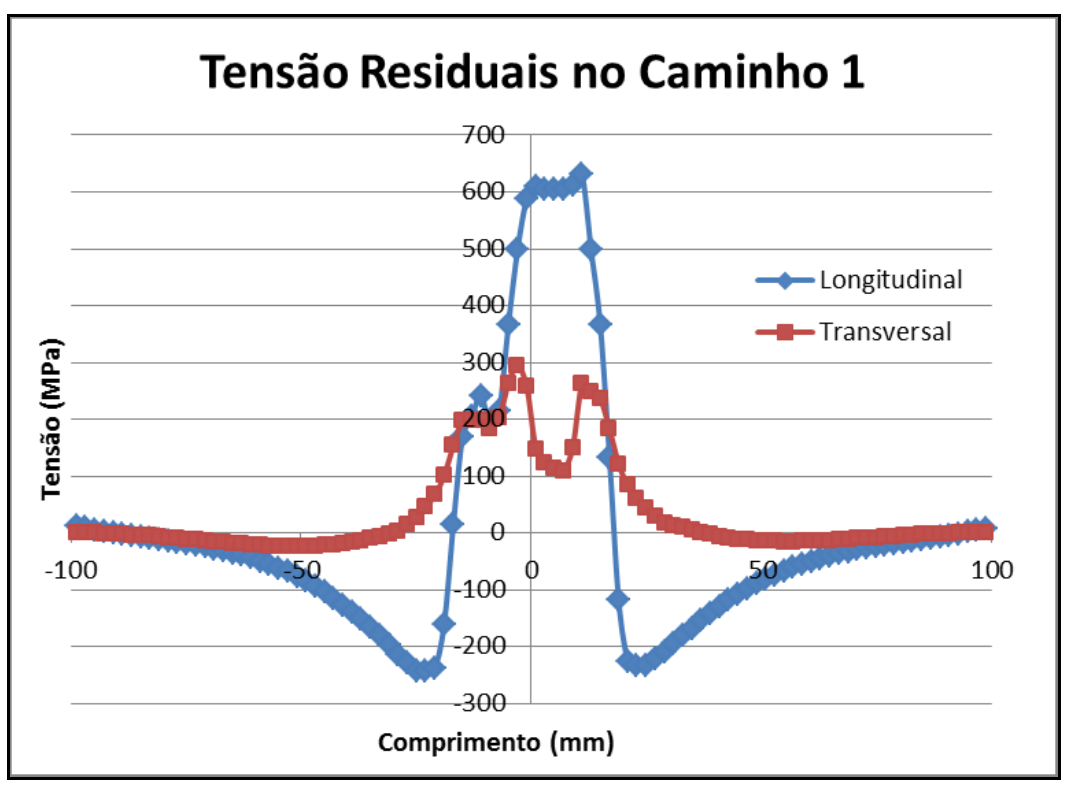

Figura 5.20: Distribuição de tensões residuais no Caminho 1 após a soldagem. 
A Figuras 5.21 mostra a comparação entre as tensões residuais longitudinais calculadas analiticamente, através da formulação de Masubuchi e Martin e pela formulação da API 579 apresentadas no Capítulo 2, e as tensões simuladas pelo MEF no Caminho 1. Todos os três métodos de previsão de tensões residuais apresentaram resultados semelhantes para o Caminho 1, tração na junta e compressão nas adjacências.

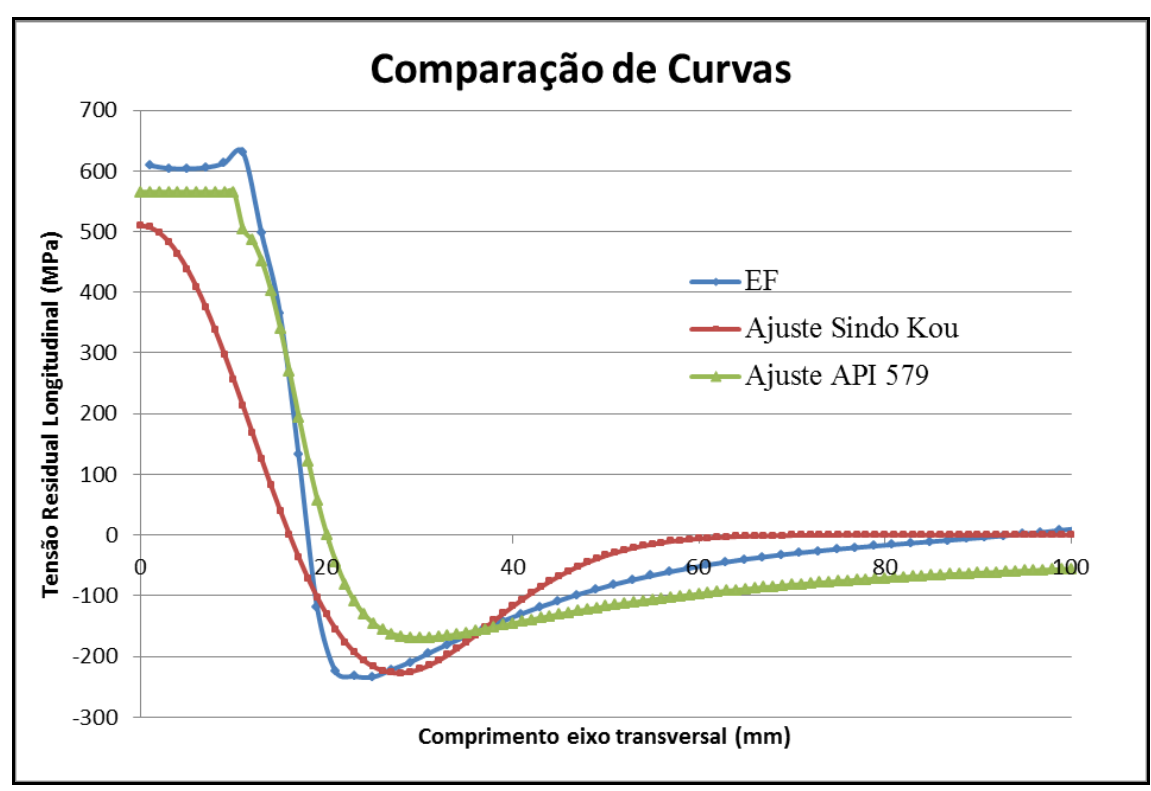

Figura 5.21: Comparação das tensões residuais obtidas no Caminho 1 por diferentes métodos numéricos.

A Figuras 5.22 mostra a comparação entre as tensões residuais medidas utilizando a técnica do furo cego com profundidade de $2 \mathrm{~mm}$, onde o gradiente de tensões não é tão alto, e as tensões simuladas pelo MEF no Caminho 1. 


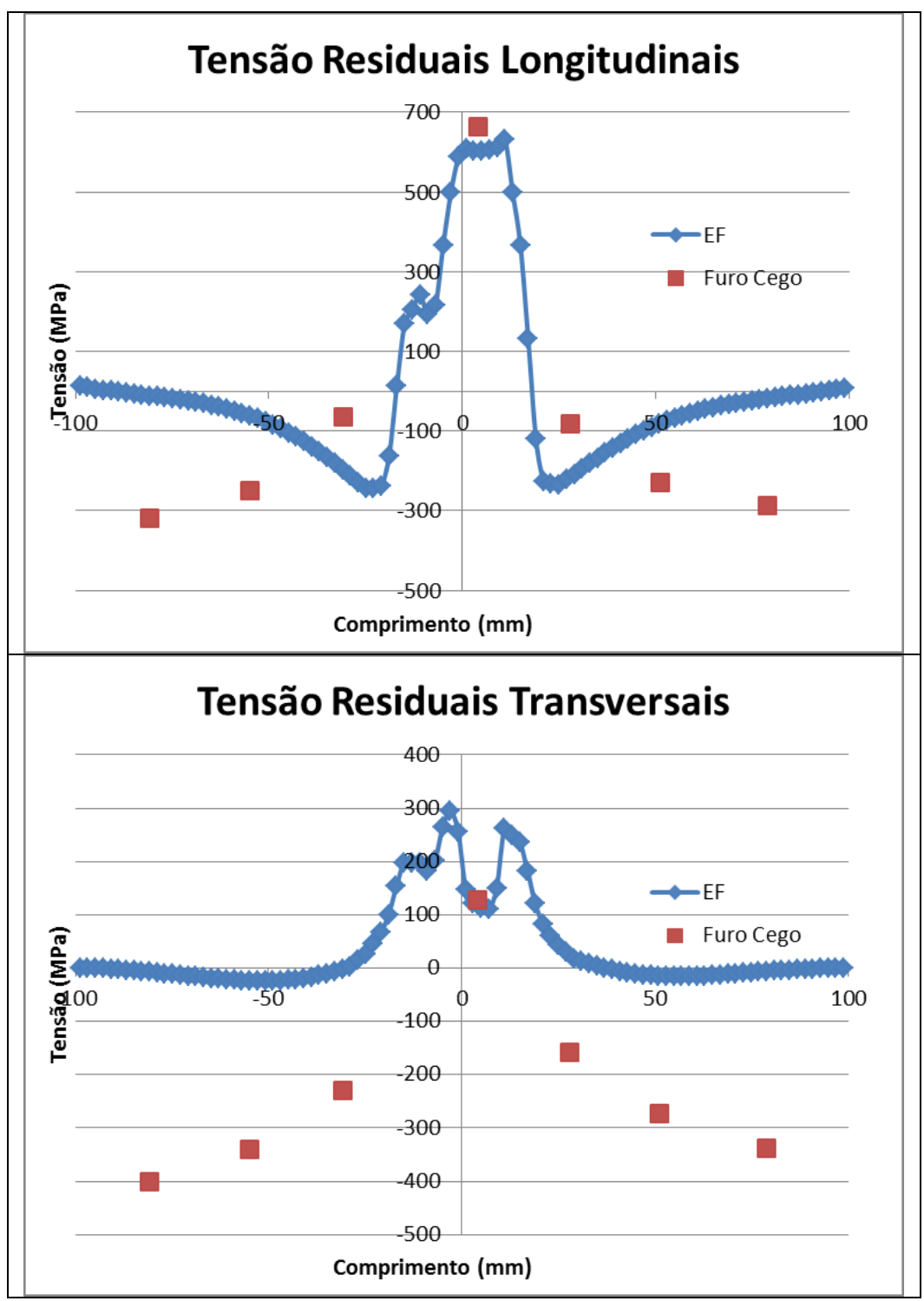

Figura 5.22: Comparação entre as tensões residuais medidas pela técnica furo cego e as simuladas via MEF no Caminho 1.

Observando as Figura 5.22, acima, percebe-se uma concordância entre os resultados das tensões na região da junta soldada, isso porque as tensões geradas a partir do processo de soldagem se sobrepõem as tensões residuais geradas pelos processos de fabricação das chapas, como: laminação, corte e outros.

Embora as distribuições de tensões simuladas e medidas apresentem formatos parecidos seus valores fora da região da soldagem são bastante diferentes. Como as chapas estão livres para se mover durante a soldagem e a deposição dos cordões de solda tem maior influência na região central, uma vez que as tensões a partir de $50 \mathrm{~mm}$ em qualquer direção tendem a zero, pode se notar que os processos de fabricação produzem nas chapas tensões residuais compressivas. 
A Figura 5.23 mostra a comparação entre as tensões residuais medidas utilizando a técnica do furo cego, com profundidade de $0.25 \mathrm{~mm}$, e medidas pela difração de raios $\mathrm{X}$ no Caminho $1^{1}$. A profundidade de analise do furo cego igual a $0.25 \mathrm{~mm}$ foi escolhida considerando o fato da difração de raios $\mathrm{X}$ realizar medições apenas nas primeiras camadas do material, cerca de dezenas de micrometros. Assim a comparação dos resultados com os da profundidade de $2 \mathrm{~mm}$ seria imprecisa.

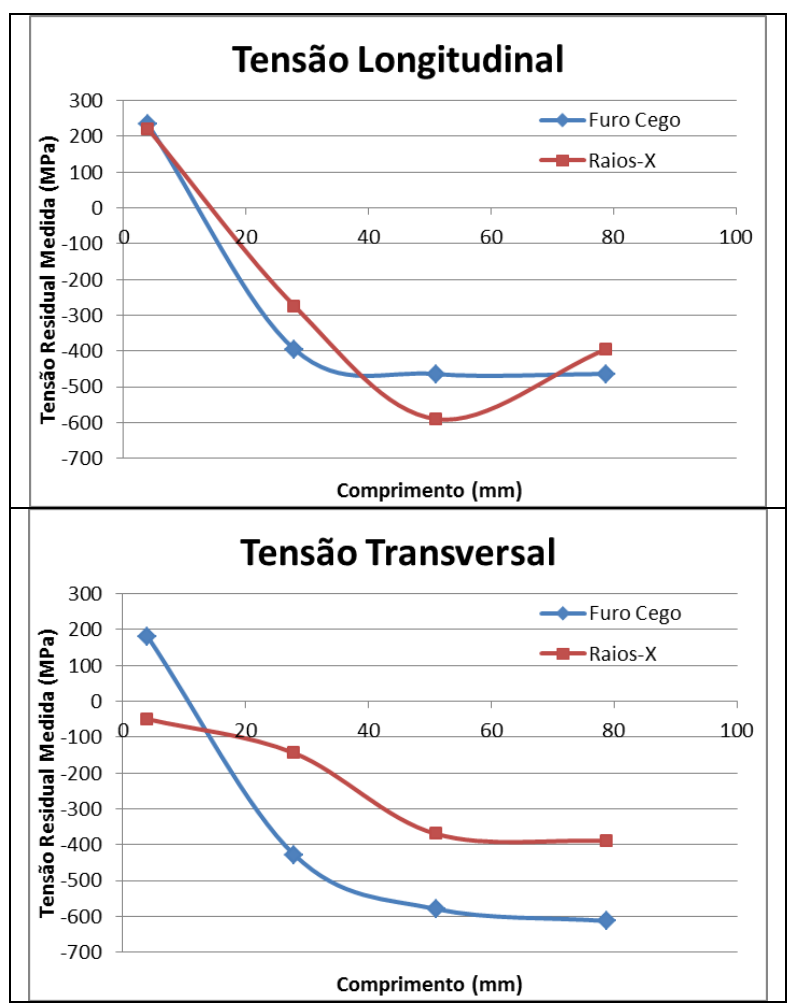

Figura 5.23: Comparação entre as medições realizadas pela técnica furo cego e pela difração de raios X no Caminho 1.

\subsubsection{Modelo das Chapas com Restrição}

Esse modelo considera que as chapas durante sua soldagem não podem se deslocar horizontalmente nem verticalmente, por causa das restrições aos deslocamentos das faces inferiores em contato com a superfície de apoio. A distorção angular do modelo é muito pequena, podendo ser desprezada. As distribuições de tensões estão diretamente ligadas a essa condição de contorno.

${ }^{1}$ Os resultados de difração de raios $\mathrm{X}$ foram determinados pelo Dr. Vladimir Monine, no laboratório de Fotomecânica da PUC-Rio, no período de 2013 à 2015. 
Na Figura 5.24 são apresentadas as distribuições de tensões residuais após a soldagem no instante de 15000s.

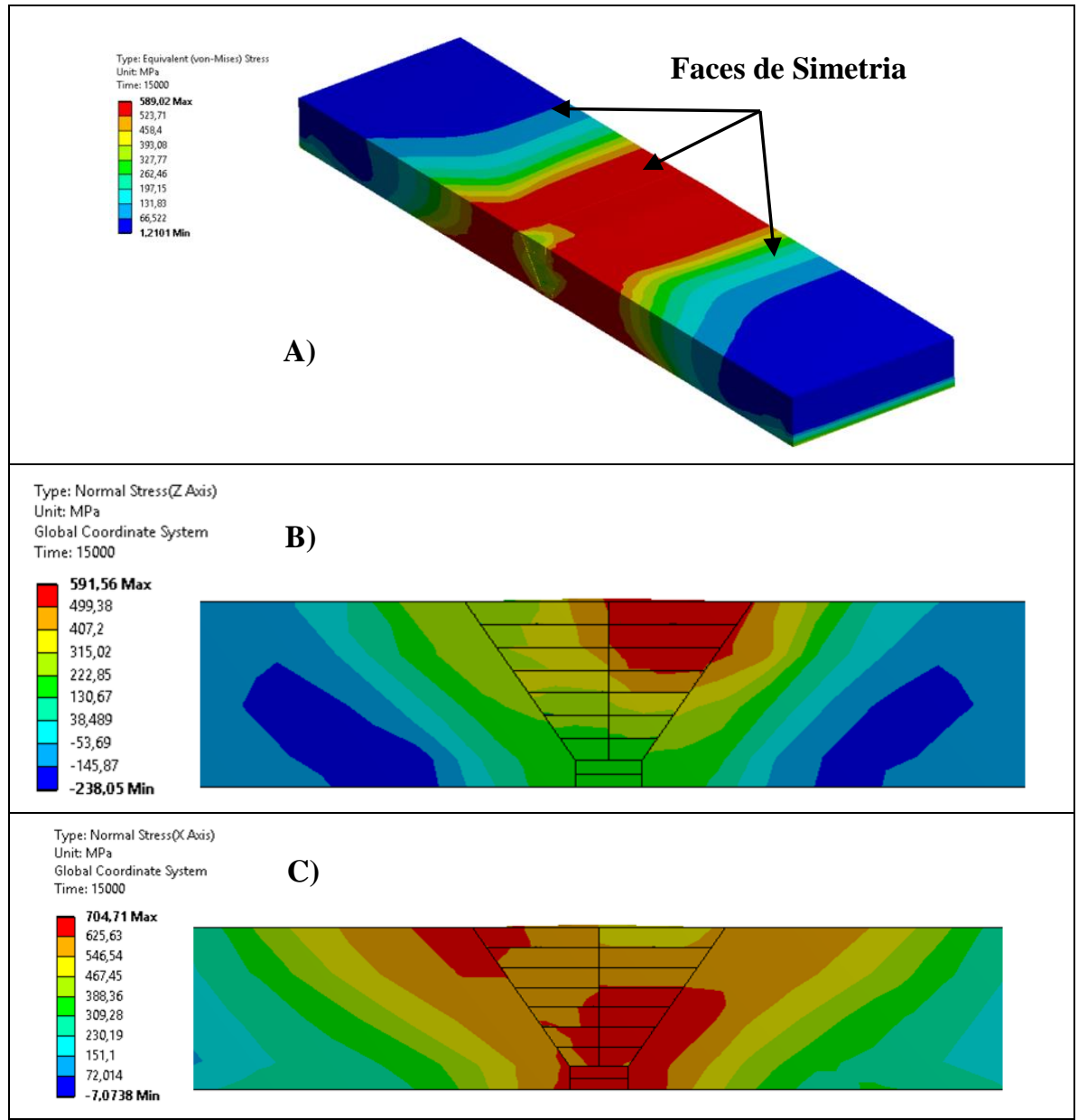

Figura 5.24: Distribuição de tensões residuais: a)Tensões equivalentes; b) Tensões longitudinais;

c) Tensões transversais.

A tensão equivalente residual (von Mises), Figura 5.24a, em quase toda região da junta tem magnitude semelhante ao limite de escoamento do material. O comportamento das tensões e deformações nas chapas após a soldagem é uma consequência da fixação dos deslocamentos das mesmas. Cada novo cordão depositado além de agir sobre os demais como um tratamento de alívio mecânico, tem a tendência de distorcer angularmente o modelo, as tensões residuais originadas são uma resposta à condição de contorno imposta.

As tensões residuais longitudinais, Figura 5.24b, são auto-equilibrantes, sendo trativas na junta soldada e compressivas na ZTA. Ao contrário do modelo das chapas livres, a região com maior compressão esta localizada na porção inferior das chapas ao lado da junta, isso porque as chapas tendem a se distorcer na forma de um $\mathrm{V}$ invertido. 
As restrições durante a soldagem governam o comportamento das tensões residuais transversais, Figura 5.24c. Na região da junta elas apresentam valores trativos, com magnitudes às vezes maiores que as observadas na direção longitudinal. Como as chapas não estão livres para se deformar, os níveis de tensão na direção transversal são uma consequência direta dessa condição. À medida que se distancia do centro da junta, as tensões tendem a zero, pois a contração nessa região não é muito severa.

A Figura 5.25 apresenta as distribuição de tensões residuais ao longo do Caminho 1 em 15000s.

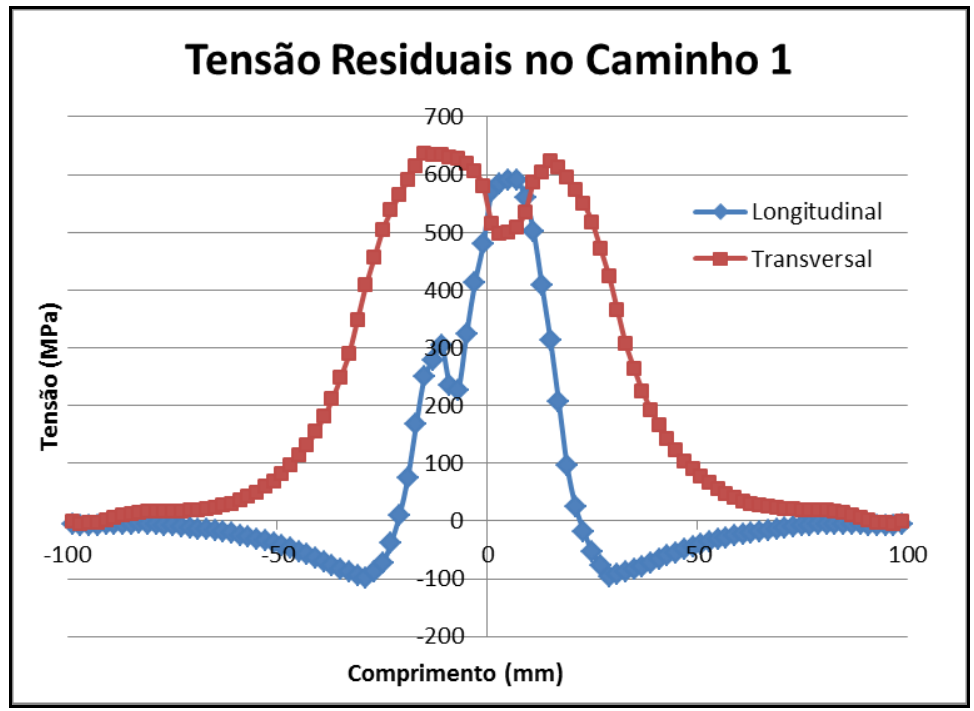

Figura 5.25: Distribuição de tensões residuais no Caminho 1 após a soldagem.

Observando a Figura 5.25, pode-se dizer que as tensões residuais longitudinais sempre são trativas na junta e compressivas na ZTA, independente da condição de contorno aplicada no modelo. O comportamento das tensões longitudinais depende das restrições à expansão e contração da direção longitudinal, qualquer outra restrição tem pouco efeito no seu comportamento, o que pode ser observado comparando as Figuras 5.20 e 5.25.

Já o comportamento das tensões transversais é seriamente afetado pelas restrições ao deslocamento das faces inferiores, quase todo o modelo apresenta tensões trativas elevadas.

A Figuras 5.26 mostra a comparação entre as tensões residuais medidas utilizando a técnica do furo cego com profundidade de $2 \mathrm{~mm}$ e as tensões simuladas pelo MEF no Caminho 1 . 


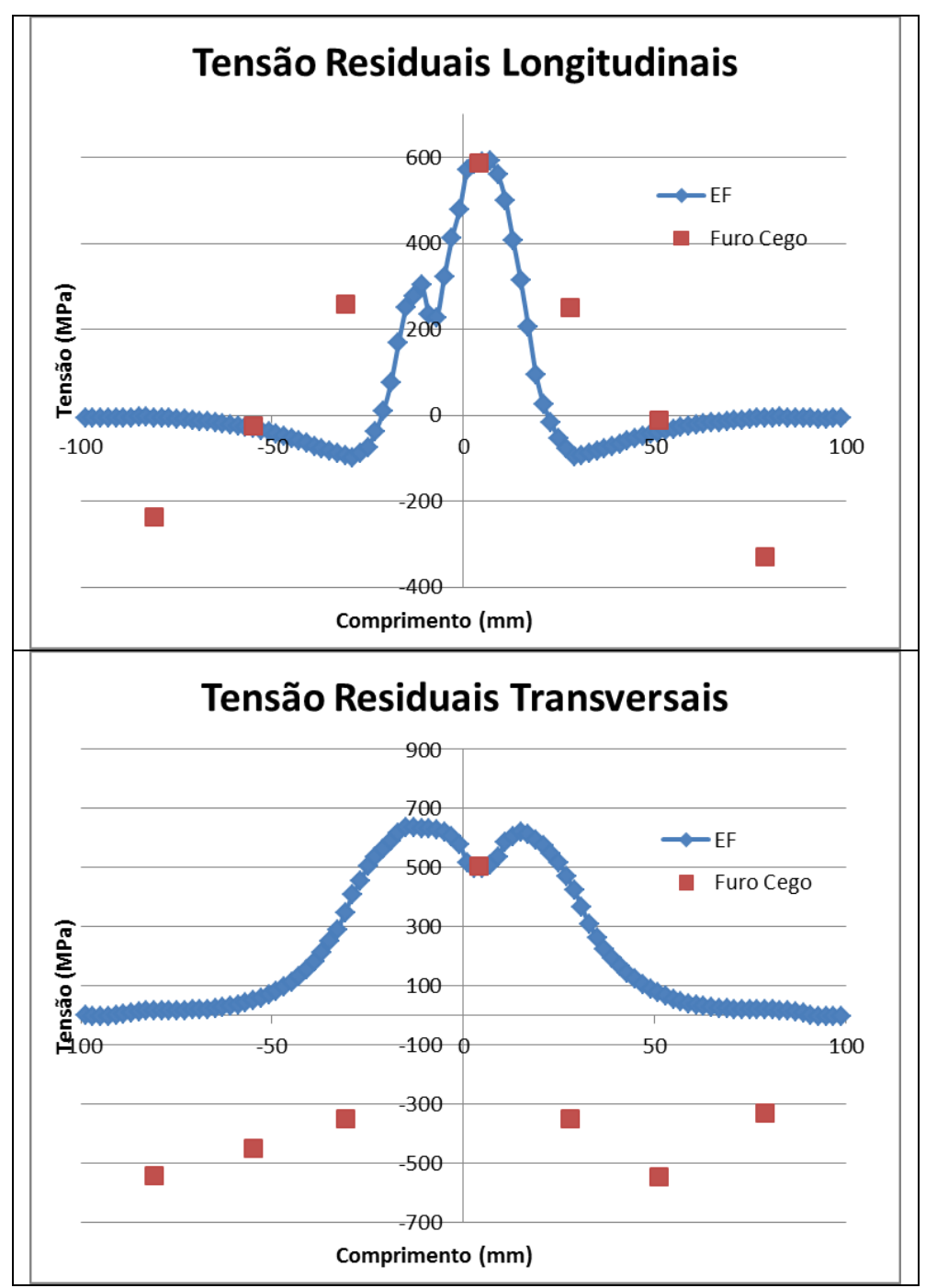

Figura 5.26: Comparação entre as tensões residuais medidas pela técnica furo cego e as simuladas via MEF no Caminho 1.

Observando as Figura 5.26, acima, percebe-se uma concordância entre os resultados das tensões na região da junta soldada. Embora as distribuições de tensões simuladas e medidas apresentem valores fora da região da soldagem bastante diferentes, esse comportamento já era esperado devido as tensões residuais de fabricação.

A Figura 5.27 mostra a comparação entre as tensões residuais medidas utilizando a técnica do furo cego, com profundidade de $0.25 \mathrm{~mm}$, e medidas pela difração de raios $\mathrm{X}$ no Caminho $1^{2}$.

${ }^{2}$ Os resultados de difração de raios X foram determinados pelo Dr. Vladimir Monine, no laboratório de Fotomecânica da PUC-Rio, no período de 2013 à 2015. 


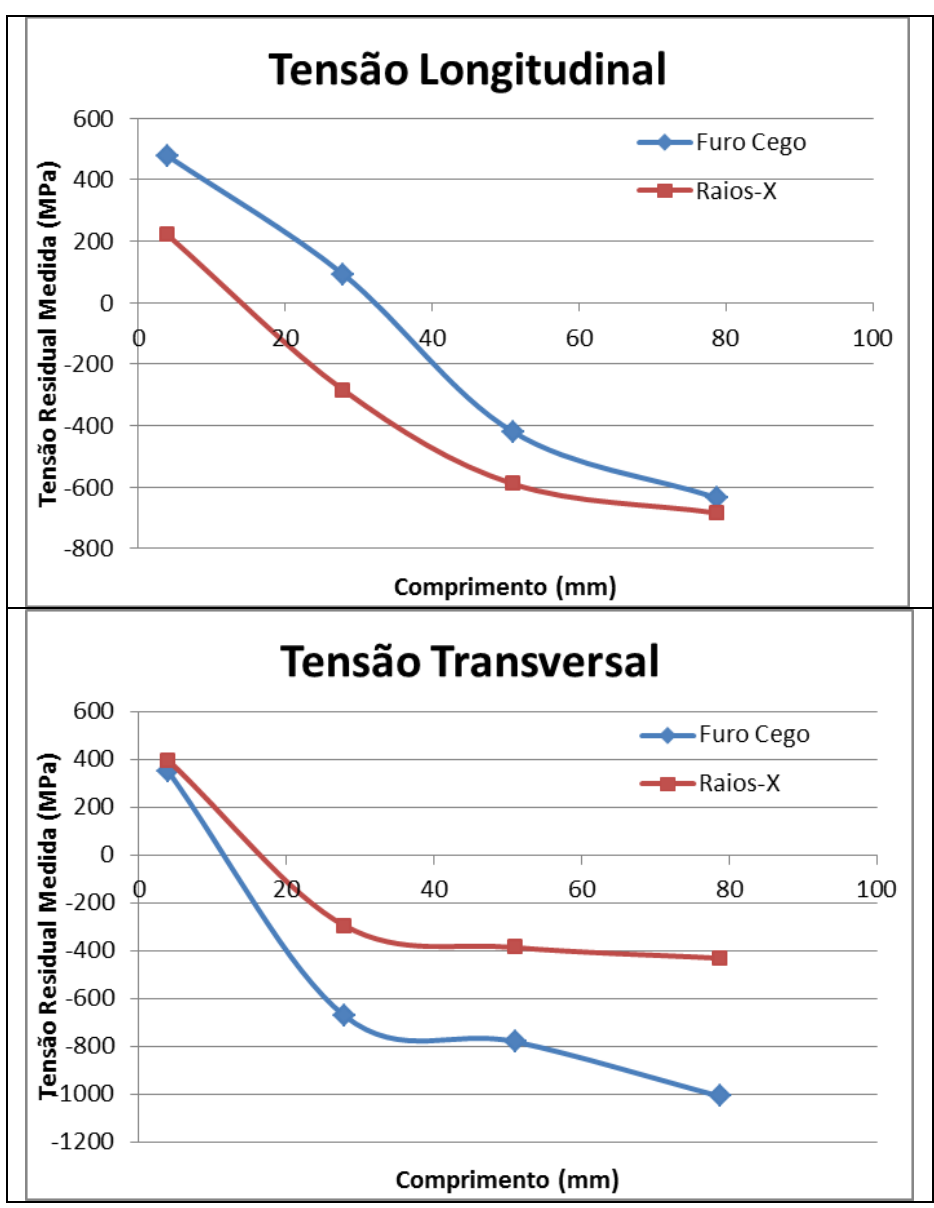

Figura 5.27: Comparação entre as medições realizadas pela técnica furo cego e pela difração de raios X no Caminho 1. 


\section{6 Soldagem de Elementos Tubulares}

Dutos e tubulações representam a principal forma de se transportar produtos líquidos ou gasosos entre dois pontos. Para determinados volumes e distâncias, o transporte de produtos combustíveis por dutos, quando comparado com outros modais de transporte, geralmente se apresenta como alternativa econômica mais vantajosa, confiável e segura, [66].

Os tubos de grande diâmetro usados para transporte de gás e óleo são comumente fabricados a partir da conformação a frio de placas de aço através do processo UOE. A placa é fresada e virolada ao longo de suas bordas, depois prensada em forma de $\mathrm{U}$, e em seguida é prensada novamente em uma forma de $\mathrm{O}$, em duas matrizes semicirculares. $\mathrm{O}$ tubo é soldado para fechar o $\mathrm{O}$, e por fim expandido circunferencialmente, para obter-se uma forma circular com diâmetro e suas variações dentro de especificações de tolerância de fabricação.

Os tubos podem ser também fabricados pelo processo ERW, onde a chapa é desbobinada formando tubos de meio rolo e então soldada por resistência elétrica em alta frequência. Ao contrário do processo anterior, no processo ERW não há restrições de diâmetro para os tubos produzidos, o diâmetro depende do ângulo em que as chapas são desbobinadas na máquina. Semelhante ao processo UOE os tubos passam por calibragens dimensionais e ensaios não destrutivos.

Os processos de fabricação descritos anteriormente são usados para fabricar tubos com costura. O processo que fabrica tubos sem costura é chamado de processo Mannesmann e é o principal processo de fabricação de tubos sem costura. A formação do tubo por esse processo é dada a partir de uma barra circular maciça de aço, que é empurrada por dois cilindros oblíquos que o rotacionam e transladam contra um mandril fixo. Obtém-se um tubo bruto, que sofrerá conformação de acabamento através de laminadores perfiladores. Este processo de fabricação provoca rugosidade na parte interna do tubo. 
A fabricação e montagem dos dutos e tubulações envolvem em geral processos de soldagem, unindo chapas para formar os tubos ou unindo seções tubulares diferentes para formar linhas de transporte. Nesse trabalho serão estudados apenas os tubos fabricados a parir do processo UOE, que é o mais utilizado na produção de dutos para a indústria do petróleo e gás. Embora o foco desse estudo seja os dutos de oleodutos e gasodutos, o conhecimento aqui desenvolvido se aplica a qualquer soldagem longitudinal ou circunferencial de tubulações metálicas e de elementos com formato circular.

\subsection{Processo de Fabricação UOE $[66,67]$}

Boa parte dos tubos com diâmetros maiores que 16 polegadas, usados no transporte de óleo, gás e derivados, são geralmente conformados à frio através do processo UOE. O processo UOE começa aparando as extremidades laterais da chapa por fresamento para ajustar sua largura, que depende do diâmetro do tubo a ser fabricado. Simultaneamente as extremidades são chanfradas para formar um chanfro em formato de $\mathrm{X}$ para a soldagem e também viroladas para permitir fechamento e forma circular adequados no processo de soldagem longitudinal

$\mathrm{Na}$ primeira etapa de conformação mecânica as extremidades laterais são prensadas em formato circular com uma extensão para formação das virolas. (Figura 6.1a). Na prensa U a chapa é alinhada nos suportes de dobramento e em seguida o punção U move-se para baixo e curva todo o comprimento da chapa em três pontos (Figura 6.1b). A chapa agora em formato de calha é levada para prensa $\mathrm{O}$, que consiste de duas matrizes semicirculares rígidas (Figura 6.1c). Para tubos de diferentes diâmetros trocam-se as matrizes para obter o diâmetro de dobramento de interesse.

Após deixar a prensa $\mathrm{O}$, o tubo segue para o equipamento de selamento, onde roletes dispostos na circunferência externa do tubo alinham as extremidades a serem soldadas. O selamento é realizado por um passe fino e continuo de soldagem, utilizando o processo MIG ou MAG com gás $\mathrm{CO}_{2}$. Esse pequeno passe, executado pela face externa e localizado na raiz do chanfro, tem como objetivo fechar o tubo mantendo os topos laterais alinhados, além de servir como base para a futura soldagem realizada por arco submerso. Toda a solda de selamento deve ser refundida pela soldagem de costura segundo a norma API 5L. 
Terminado a selagem é realizado primeiramente a soldagem interna do tubo pelo processo de arco submerso com a junta longitudinal do tubo na posição 6:00h. Depois, em outra máquina, o tubo é girado de $180^{\circ}$ e a solda externa é realizada. $\mathrm{O}$ processo de arco submerso utilizado nessas soldagens é automático e tem alta taxa de deposição, pois envolve a utilização de diversos arcos simultâneos, processo Tandem (Figura 6.1d).

Após a soldagem o tubo segue para a remoção do excesso de fluxo. A solda sofre inspeção para detectar eventuais defeitos de deposição de material. Em seguida o tubo sofre uma expansão a frio, realizada por um mandril especial (Figura 6.1e). O mandril expande radialmente movendo-se na direção longitudinal até que todo o tubo tenha sido trabalhado. A expansão tem por função garantir a circularidade do tubo.

Cada segmento de tubo passa por um teste hidrostático a uma pressão interna especificada pelo comprador ou por norma de fabricação. A pressão de teste deve provocar uma tensão circunferencial de $60,75,85$ ou $90 \%$ da resistência mínima ao escoamento especificada para o tubo. $\mathrm{O}$ trabalho a frio pelo qual passam os tubos UOE introduz mudanças no comportamento tensãodeformação do material, principalmente na direção circunferencial.

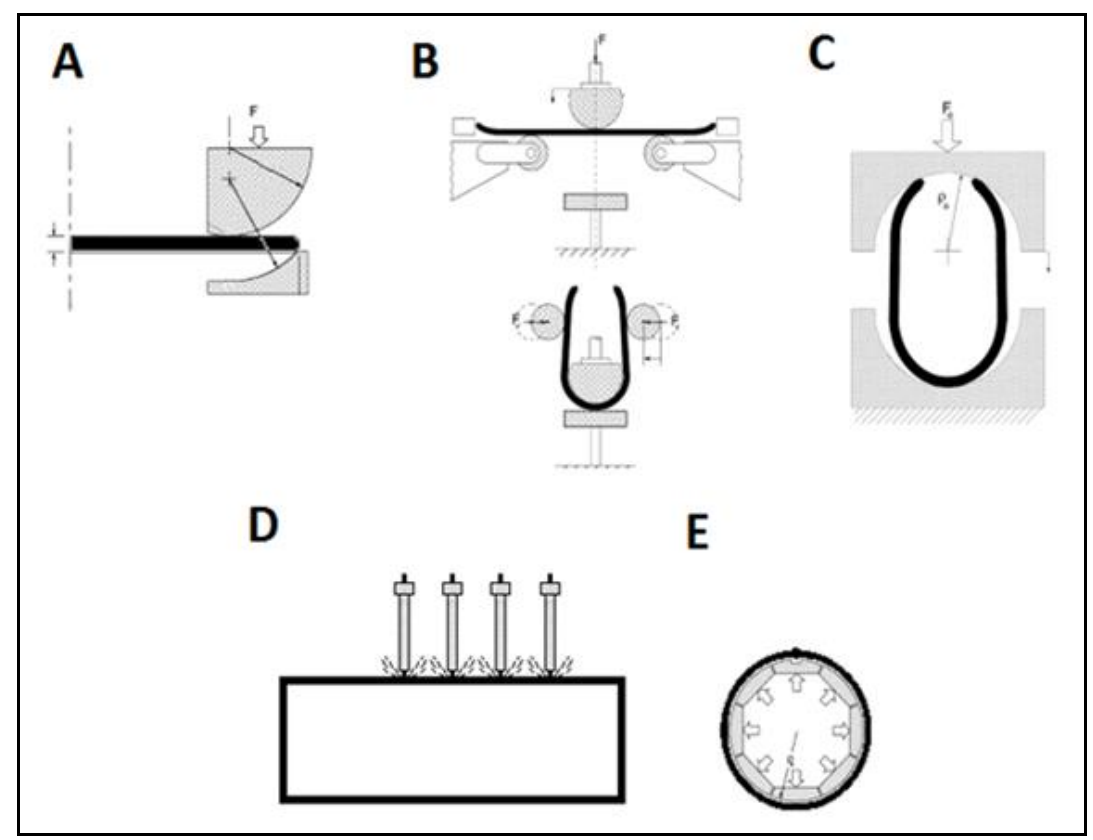

Figura 6.1: Processo UOE: a) Prensagem das bordas da chapa; b) Prensa U;

c) Prensa O; d) Soldagem por arco submerso; e) Expansão à frio. 


\subsection{Montagem no Campo [66]}

Os dutos de transporte de petróleo e gás podem ser terrestres ou marinhos, embora o processo de instalação nesses ambientes seja completamente diferente entre si, há semelhanças na fase de união para formação das linhas de transporte.

A montagem terrestre a grosso modo segue as seguintes fases: determinação do traçado; abertura de pista; transporte, distribuição de tubos; curvamento; soldagem; revestimento; abaixamento; cobrimento da vala; teste hidrostático.

A fase seguinte à distribuição e curvamento dos tubos é a soldagem, que deve ser realizada de acordo com as normas ASME B 31.4 e ASME B 31.8. O processo de soldagem mais utilizado é a solda elétrica com eletrodo revestido, porém em casos especiais outros processos também podem ser usados. Os procedimentos de soldagem a serem utilizados devem ser qualificados pela norma API STD 1104. Para complemento, pode ser usada a qualificação pela norma ASME Seção IX.

Quando se utiliza o processo com eletrodo revestido, são realizados diversos passes de solda para a união completa dos tubos. Inicialmente se realiza um passe de raiz e demais passes de preenchimento, o último passe é um passe de acabamento. O número de passes é especificado no procedimento executado, bem como todas as características do processo, como consumíveis e equipamentos. São necessários dois soldadores trabalhando simultaneamente em cada passe, um em cada lado do tubo, Figura 6.2.

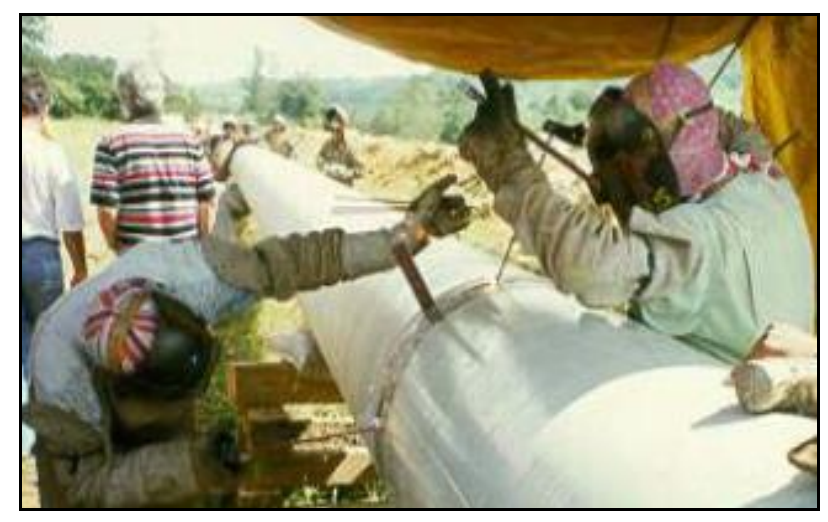

Figura 6.2: Soldagem de campo de tubos, com dois soldadores utilizando eletrodo revestido. 
Na montagem marinha, as linhas são construídas dentro de embarcações até serem lançadas no mar ou são construídas em terra e transportadas já montadas. $\mathrm{Na}$ construção em alto mar, a construção das linhas se a semelha a produção segundo o fordismo, onde há uma estação responsável pela realização de cada etapa. Devido às altas taxas de lançamento dos dutos, o processo de soldagem utilizado deve ter altas taxas de deposição, assim utilizam-se processos preferencialmente automatizados, Figura 6.3.

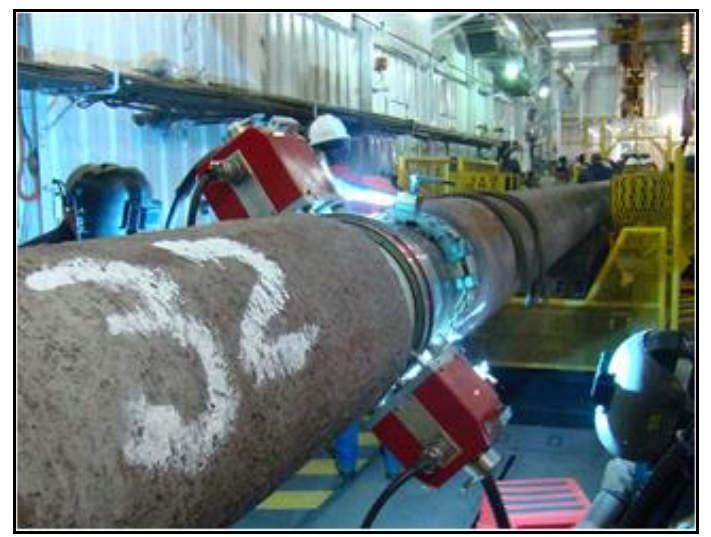

Figura 6.3: Soldagem de tubos em alto mar utilizando um processo automatizado.

\subsection{Modelos Estudados}

Foram desenvolvidos dois modelos para o estudo do comportamento mecânico em espécimes tubulares. O primeiro analisa as tensões residuais geradas no tubo a partir de cada processo envolvido na sua fabricação e o segundo analisa o comportamento de dois tubos quando estes são unidos em campo para a formação de uma linha de transporte sem o efeito de curvamentos a frio.

No primeiro modelo os resultados numéricos obtidos foram comparados com medições experimentais obtidas da literatura. O segundo modelo tem como ênfase a união de campo. Entretanto para simular corretamente o comportamento da linha de transporte foi necessário repetir a simulação do primeiro modelo antes de se iniciar a soldagem de campo.

Foi considerado que todos os tubos estudados são feitos do mesmo material, o aço API 5L X60. As propriedades do material à temperatura ambiente bem como outros dados estão mostrados na Tabela 6.1 e a Figura 6.4 apresenta a variação das propriedades térmicas e mecânicas utilizadas para simulação com a temperatura. Essas propriedades foram extraídas de referências da literatura, $[58,59,68]$. 
Tabela 6.1: Propriedades do aço Duplex 2205 à temperatura ambiente.

\begin{tabular}{|c|c|c|}
\hline Propriedade & Símbolo & $\begin{array}{c}\text { Valor na temperatura } \\
\text { ambiente }\end{array}$ \\
\hline Limite de escoamento & $S_{y}$ & $420 \mathrm{MPa}$ \\
\hline $\begin{array}{c}\text { Coeficiente de expansão } \\
\text { térmica }\end{array}$ & $\alpha$ & $1.210^{-5}{ }^{0} \mathrm{C}$ \\
\hline Módulo de elasticidade & $E$ & $200 \mathrm{GPa}$ \\
\hline Condutividade térmica & $k$ & $49.38 \mathrm{~W} / \mathrm{m}^{2}{ }^{0} \mathrm{C}$ \\
\hline Calor específico & $c$ & $491.06 \mathrm{~J} / \mathrm{kg}{ }^{0} \mathrm{C}$ \\
\hline Densidade & $\rho$ & $7850 \mathrm{~kg} / \mathrm{m}^{3}$ \\
\hline
\end{tabular}

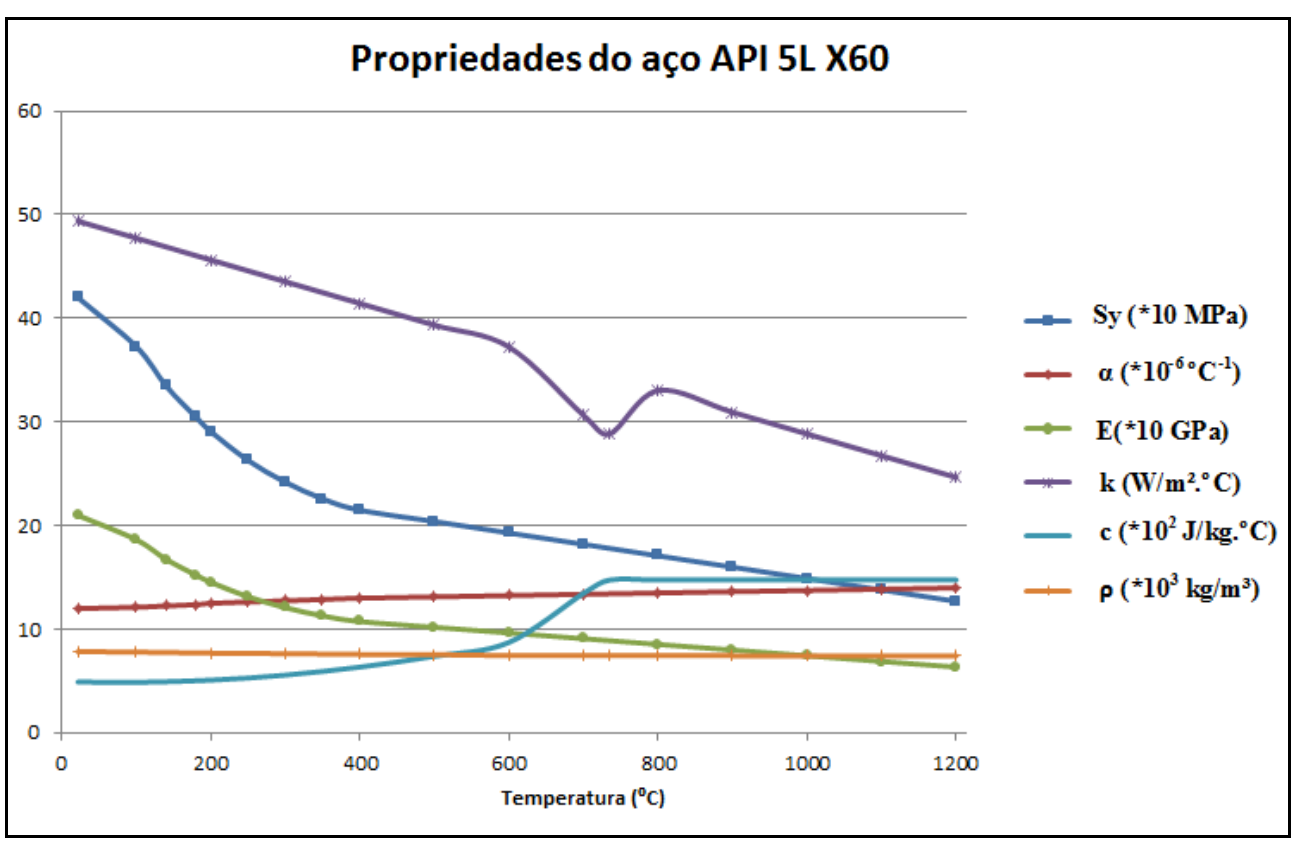

Figura 6.4: Variação das propriedades térmicas e mecânicas do aço API 5L X60 com a temperatura.

\subsection{Modelo Numérico da Fabricação do Tubo}

Este modelo trata do comportamento de um tubo fabricado a partir do processo UOE. Foi estudada a influência de cada etapa nas tensões residuais, o comportamento da chapa durante as fases de dobramento para criação do tubo foi obtido da literatura. No entanto as etapas da soldagem e da expansão à frio foram simuladas pelo MEF.

O cordão de solda foi simulado utilizando duas hipóteses diferentes; a hipótese das três barras e a das múltiplas barras formando o cordão. Também foram testadas diferentes pressões no teste hidrostático, a fim de avaliar o alívio de tensões. 


\subsubsection{Geometria do Modelo}

O espécime tubular utilizado tem diâmetro igual a $323.85 \mathrm{~mm}$ (12 3/4”), 9.7 $\mathrm{mm}$ de espessura e $500 \mathrm{~mm}$ de comprimento. A junta soldada tem o formato de $\mathrm{X}$, e ambos os cordões interno e externo foram assumidos como um só. A largura de ambos os cordões de solda foi de $20 \mathrm{~mm}$ e o ângulo do $\mathrm{X}$ foi de $25.8^{0}$. Uma vez que o passe de selamento do tubo é refundido durante o processo Tandem este não foi considerado, não tendo sido simulado. A Figura 6.5 mostra a geometria do modelo simulado.

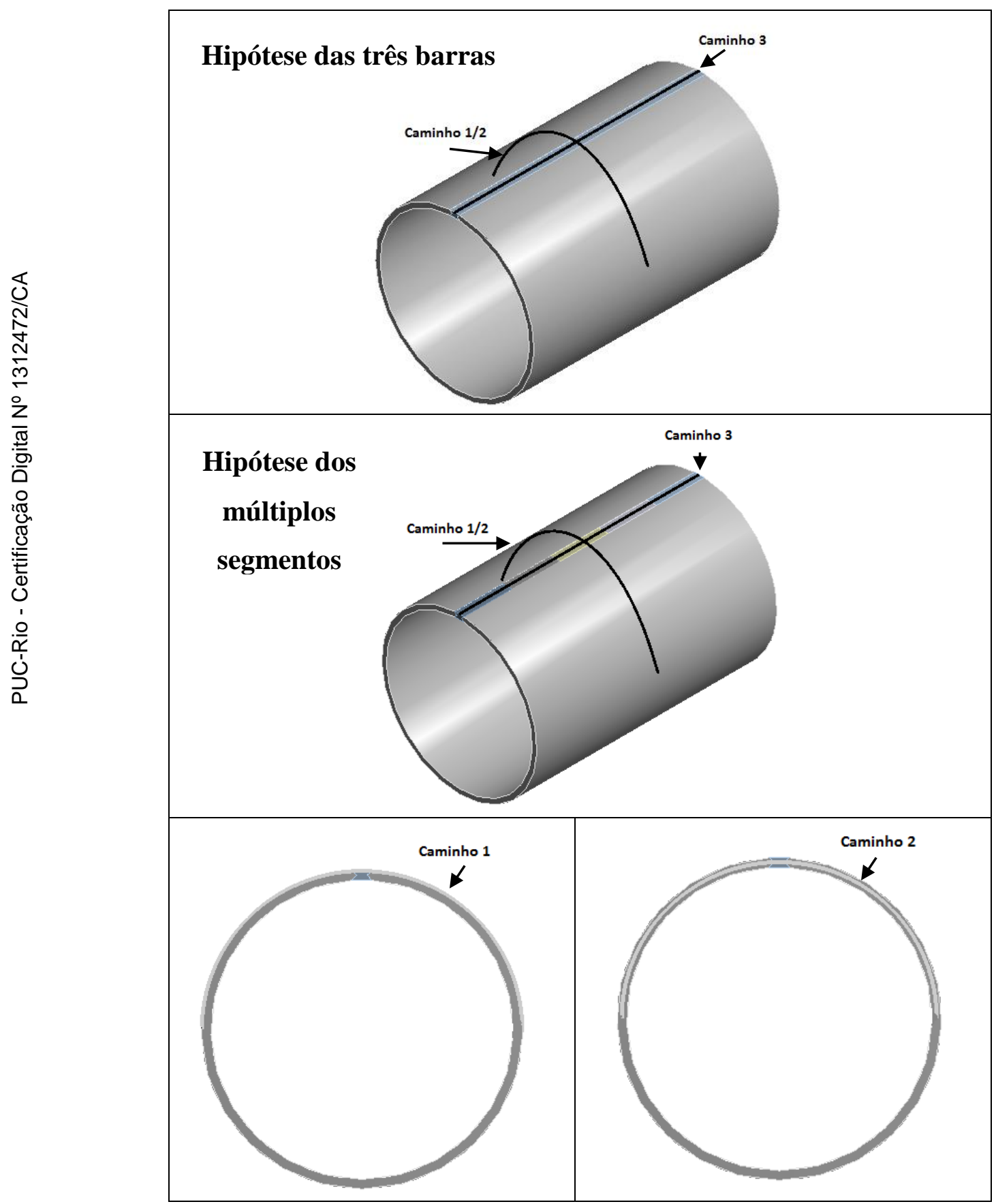

Figura 6.5: Geometria do modelo do tubo para simulação da soldagem e do teste hidrostático. 


\subsubsection{Malha do Modelo}

As análises foram baseadas nas malhas mostradas nas Figuras 6.6 e 6.7, sendo que ambas as malhas das partes térmica e mecânica foram iguais em cada tipo de simulação, a fim de facilitar a comutação de resultados.

A malha da análise, considerando a hipótese das três barras, tem 35567 nós e 4990 elementos. O fator qualidade dos elementos, que mede a qualidade de cada elemento, tem valor mínimo igual a 0.27 e valor máximo igual a 0.99 e uma média para todos os elementos igual a 0.86 , com um desvio padrão de 0.12 . A razão de aspecto mínima foi de 1.02 e a máxima foi de 8.16 , com média igual a 1.38 e desvio padrão de 0.85 . Na Figura 6.6 são mostradas a malha e os fatores de qualidade da mesma.

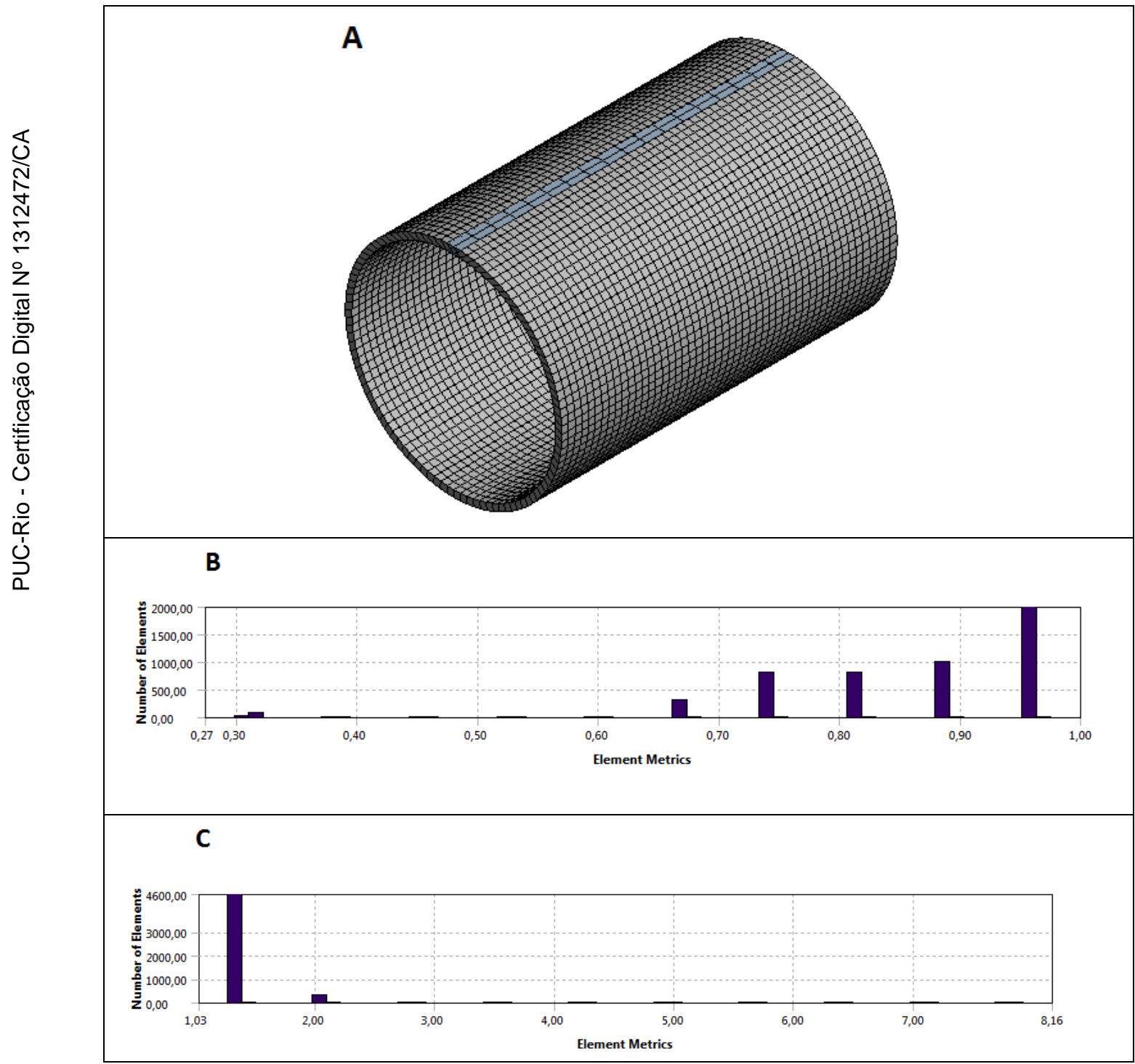

Figura 6.6: Malha da análise considerando três barras: a) Malha; b) Histograma da qualidade dos elementos; c) Histograma da razão de aspecto dos elementos. 
A malha da análise, considerando a hipótese de múltiplos segmentos, tem 38393 nós e 5468 elementos. O fator qualidade dos elementos, que mede a qualidade de cada elemento, tem valor mínimo igual a 0.15 e valor máximo igual a 0.99 e uma média para todos os elementos igual a 0.81 , com um desvio padrão de 0.20. A razão de aspecto mínima foi de 1.02 e a máxima foi de 22.75 , com média igual a 1.83 e desvio padrão de 2.16. Na Figura 6.7 são mostradas a malha e os fatores de qualidade da mesma.

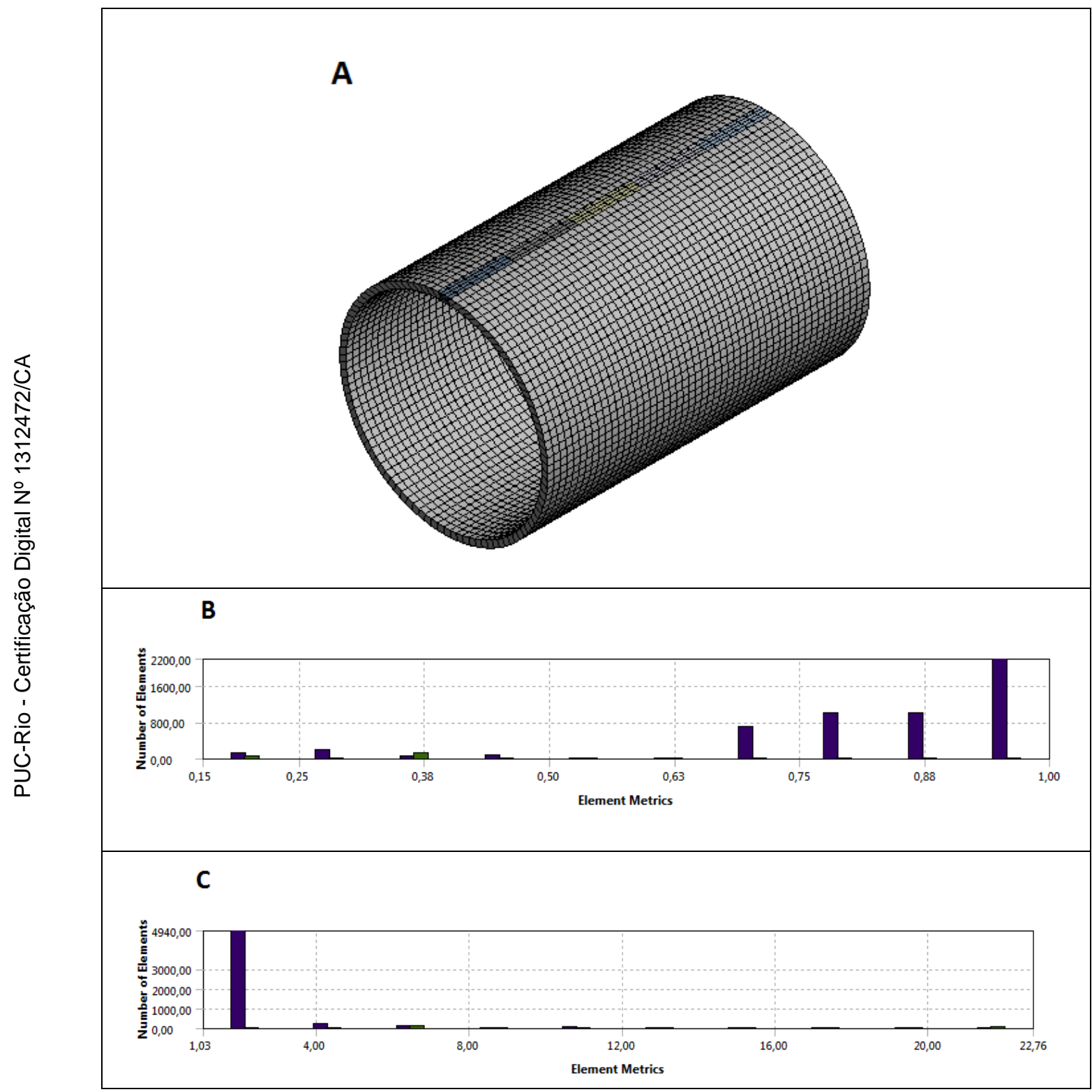

Figura 6.7: Malha da análise considerando múltiplos segmentos: a) Malha; b) Histograma da qualidade dos elementos; c) Histograma da razão de aspecto dos elementos. 


\subsubsection{Configuração dos Passos Tempo}

Foram usados 18 passos de tempo para ambos os tipos de simulação, três barras e múltiplos segmentos. Na simulação com o cordão de solda representado por uma única barra, o primeiro passo representa a deposição do cordão e tem a duração de 1s. Na simulação com múltiplos segmentos de cordão, a deposição de cada segmento tem a duração de 1s e ocorre durante um passo. Os três últimos passos de tempo são utilizados para simular o teste hidrostático que os tubos passam na fabricação. Abaixo, a Tabela 6.2 correlaciona cada passo de tempo com sua duração e com o evento que ocorre nele para ambos os tipos de simulação.

Tabela 6.2: Duração de cada passo de tempo.

\begin{tabular}{|c|c|c|c|c|}
\hline Passo & Duração (s) & $\begin{array}{c}\text { Tempo ao Final do } \\
\text { Passo (s) }\end{array}$ & $\begin{array}{l}\text { Evento - } \\
\text { três barras }\end{array}$ & $\begin{array}{c}\text { Evento - } \\
\text { múltiplos segmentos } \\
\end{array}$ \\
\hline $1^{0}$ & 1 & 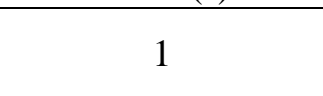 & Deposição do cordão & $\begin{array}{l}\text { Deposição de cordão/ } \\
\text { Troca de calor }\end{array}$ \\
\hline $2^{0}$ & 1 & 2 & \multirow{14}{*}{ Troca de calor } & $\begin{array}{l}\text { Deposição de cordão/ } \\
\text { Troca de calor }\end{array}$ \\
\hline $3^{0}$ & 1 & 3 & & $\begin{array}{c}\text { Deposição de cordão/ } \\
\text { Troca de calor }\end{array}$ \\
\hline $4^{0}$ & 1 & 4 & & $\begin{array}{l}\text { Deposição de cordão/ } \\
\text { Troca de calor }\end{array}$ \\
\hline $5^{0}$ & 1 & 5 & & $\begin{array}{c}\text { Deposição de cordão/ } \\
\text { Troca de calor } \\
\end{array}$ \\
\hline $6^{0}$ & 1 & 6 & & \multirow{10}{*}{ Troca de calor } \\
\hline $7^{0}$ & 1 & 7 & & \\
\hline $8^{0}$ & 1 & 8 & & \\
\hline $9^{0}$ & 1 & 9 & & \\
\hline $10^{0}$ & 1 & 10 & & \\
\hline $11^{0}$ & 1 & 11 & & \\
\hline $12^{0}$ & 1 & 12 & & \\
\hline $13^{0}$ & 1 & 13 & & \\
\hline $14^{0}$ & 1 & 14 & & \\
\hline $15^{0}$ & 4986 & 5000 & & \\
\hline $16^{0}$ & 1 & 5001 & $\begin{array}{c}\text { Início do Teste } \\
\text { Hidrostático }\end{array}$ & $\begin{array}{c}\text { Início do Teste } \\
\text { Hidrostático }\end{array}$ \\
\hline $17^{0}$ & 1 & 5002 & $\begin{array}{l}\text { Pressão Máxima do } \\
\text { Teste Hidrostático }\end{array}$ & $\begin{array}{l}\text { Pressão Máxima do } \\
\text { Teste Hidrostático }\end{array}$ \\
\hline $18^{0}$ & 1 & 5003 & $\begin{array}{c}\text { Final do Teste } \\
\text { Hidrostático }\end{array}$ & $\begin{array}{c}\text { Final do Teste } \\
\text { Hidrostático }\end{array}$ \\
\hline
\end{tabular}




\subsubsection{Condições de Contorno Térmicas}

As temperaturas na junta soldada ao longo do tempo podem ser previstas por uma análise de transferência de calor transiente, onde o calor pode ser transmitido através da condução e convecção. $\mathrm{Na}$ análise não foram considerados os efeitos da radiação, pois dentre os mecanismos de transferência de calor presentes no processo de soldagem os que mais impactam na acurácia do modelo numérico são os processos de condução e convecção, [30, 53, 60].

A fonte de calor foi modelada diretamente como um carregamento da simulação térmica. A soldagem se inicia com o cordão de solda sendo depositado na temperatura de fusão do metal, como uma condição de temperatura. Essa temperatura arbitrária do cordão de solda foi escolhida uma vez que se desconhecem os parâmetros de soldagem. Na hipótese das três barras, onde o cordão é depositado de uma só vez, é usada apenas uma condição de temperatura, porém na hipótese de múltiplos segmentos são usadas cinco condições de temperatura, uma para cada segmento.

Em seguida são aplicadas as condições de contorno térmicas no tubo, convecção no interior do tubo igual a $10 \mathrm{~W} / \mathrm{m}^{2} \mathrm{~K}$ e no exterior igual a $25 \mathrm{~W} / \mathrm{m}^{2} \mathrm{~K}$, esse valores foram escolhidos com base na Tabela 3.2 , até que todo o tubo entre em equilíbrio com a temperatura ambiente de $22{ }^{\circ} \mathrm{C}$. Foram escolhidos dois coeficientes de convecção distintos a fim de simular com melhor exatidão as condições de soldagem durante a fabricação. A condução é uma condição de contorno intrínseca da análise, sendo regida pela condutividade térmica, calor especifico e densidade do material.

\subsubsection{Condições de Contorno Mecânicas}

A história de temperaturas obtida na análise térmica transiente é transformada em um carregamento térmico no modelo estrutural. Durante a soldagem as tensões e deformações originadas no processo são caracterizadas por um comportamento elastoplástico do metal, propriedades mecânicas variantes com a temperatura e gradientes térmicos muito severos.

Não foram aplicadas ao tubo restrições ao deslocamento, entretanto utilizouse a opção de "Weak Springs" que impede o movimento de corpo rígido. 
Nos três últimos passos ocorre o teste hidrostático, sendo a pressão máxima atingida no passo do meio. Para ambas as hipóteses foi utilizada a pressão de alívio que causa uma tensão circunferencial de $90 \%$ de SMYS. No entanto, para fins de comparação foi utilizada para a hipótese das três barras as pressões que causam tensões circunferenciais iguais a $85 \%, 75 \%$ e $60 \%$ do SMYS do material.

\subsubsection{Comportamento do Tubo Durante as Etapas de Dobramento [69]}

A primeira etapa do processo de fabricação é a prensagem das bordas da chapa, durante esse processo, a ferramenta superior é mantida fixa e a ferramenta inferior se move na direção vertical conformando as bordas. A Figura 6.8 apresenta o modelo de elementos finitos utilizados e as tensões e deformações efetivas ao final dessa etapa.

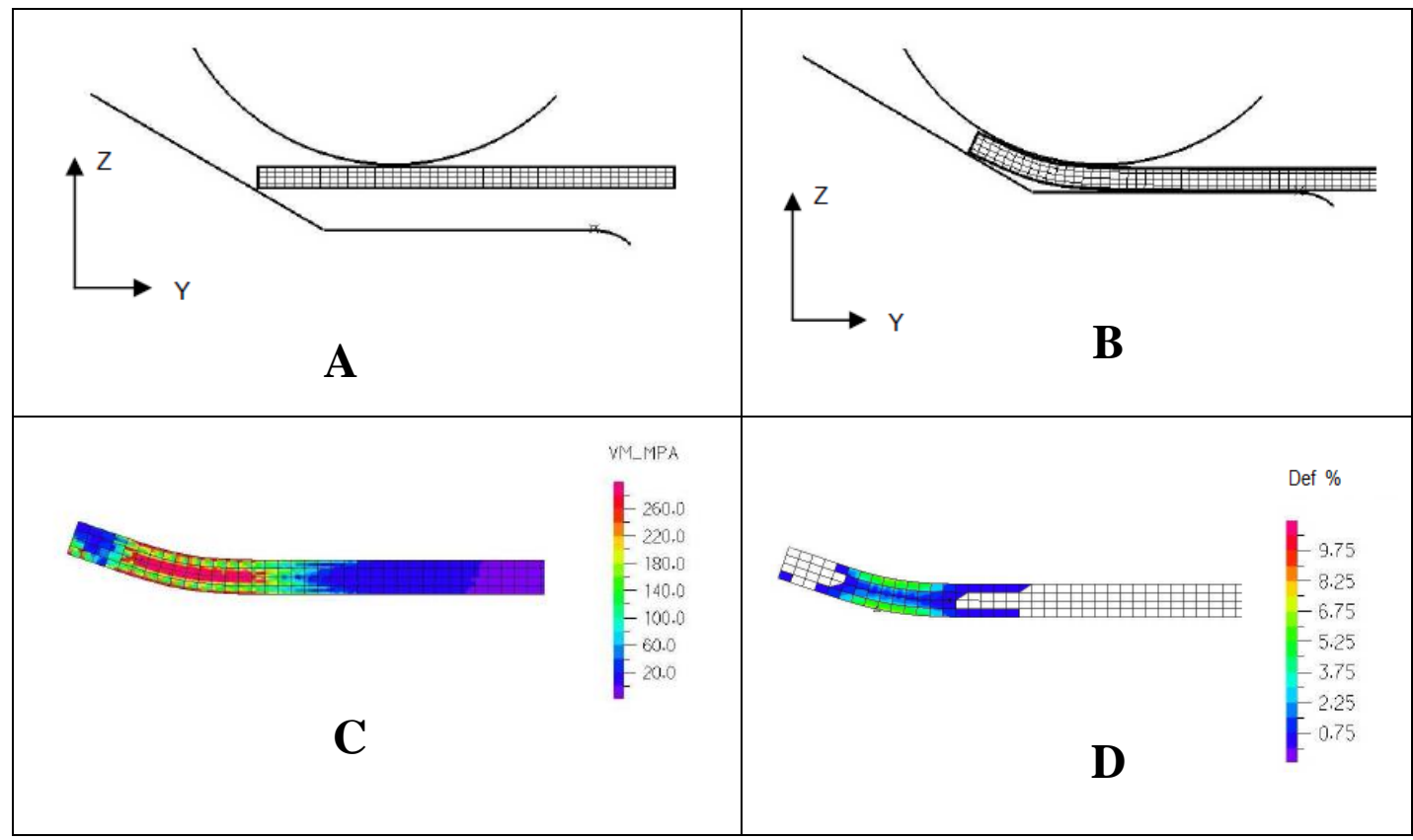

Figura 6.8: Modelo da conformação das bordas da chapa: a) Estado inicial; b) Estado final após a prensagem; c) Tensões efetivas no estado final; d) Deformações plásticas efetivas no estado final.

A próxima etapa é a prensagem em $\mathrm{U}$, onde a chapa se transforma em $\mathrm{U}$. Um punção se desloca verticalmente conformando a chapa entre dois roletes, após o punção atingir sua máxima condição de deslocamento esses roletes se deslocam na horizontal dando a forma final do U. A Figura 6.9 apresenta o modelo de elementos finitos utilizados e as tensões e deformações efetivas ao final dessa etapa. 


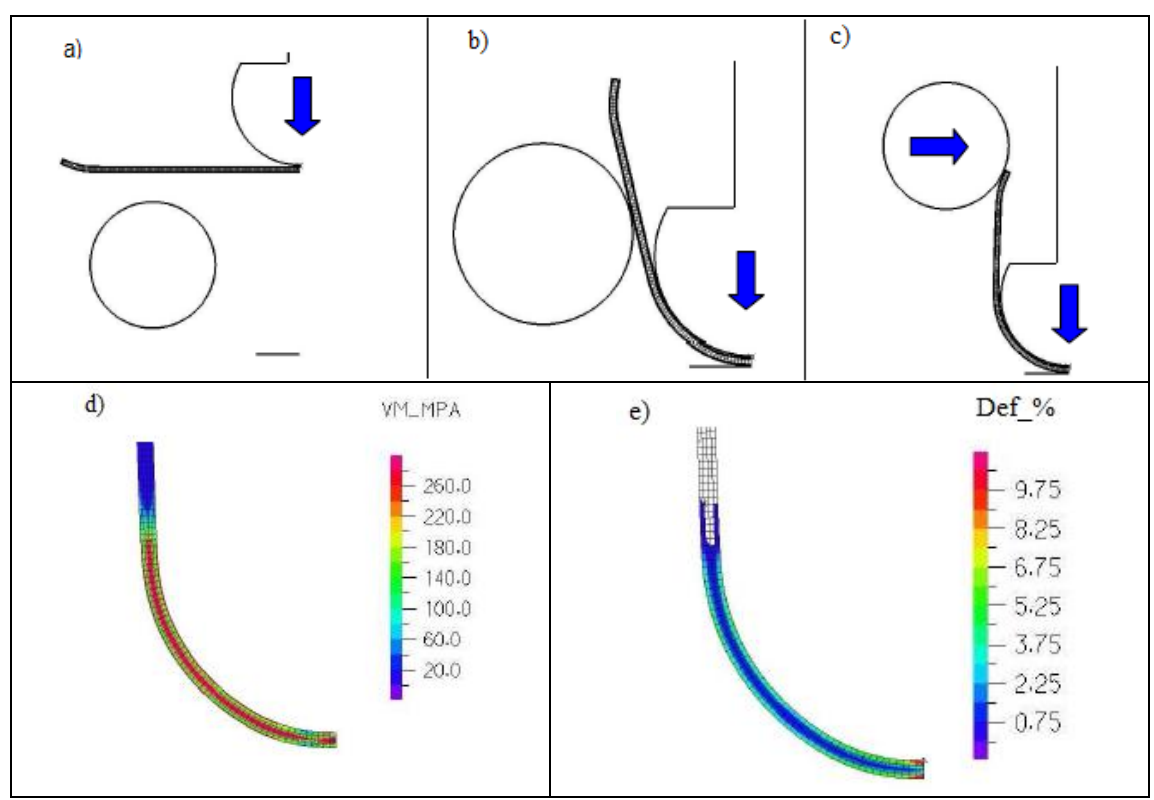

Figura 6.9: Modelo da conformação da chapa em U: a) Estado inicial; b) Deslocamento vertical máximo do punção; c) Deslocamento horizontal dos roletes; d) Tensões efetivas no estado final; e) Deformações plásticas efetivas no estado final.

A etapa que se segue é a prensagem em $\mathrm{O}$, que consiste de uma compressão circunferencial para formar o $\mathrm{O}$ a partir do $\mathrm{U}$ obtido anteriormente. $\mathrm{O} \mathrm{U}$ é colocado em uma matriz fixa em formato de semicírculo e outra matriz móvel, também em forma de semicírculo, se desloca na vertical conformando e formando o O. A Figura 6.10 apresenta o modelo de elementos finitos utilizados e as tensões e deformações efetivas ao final dessa etapa.

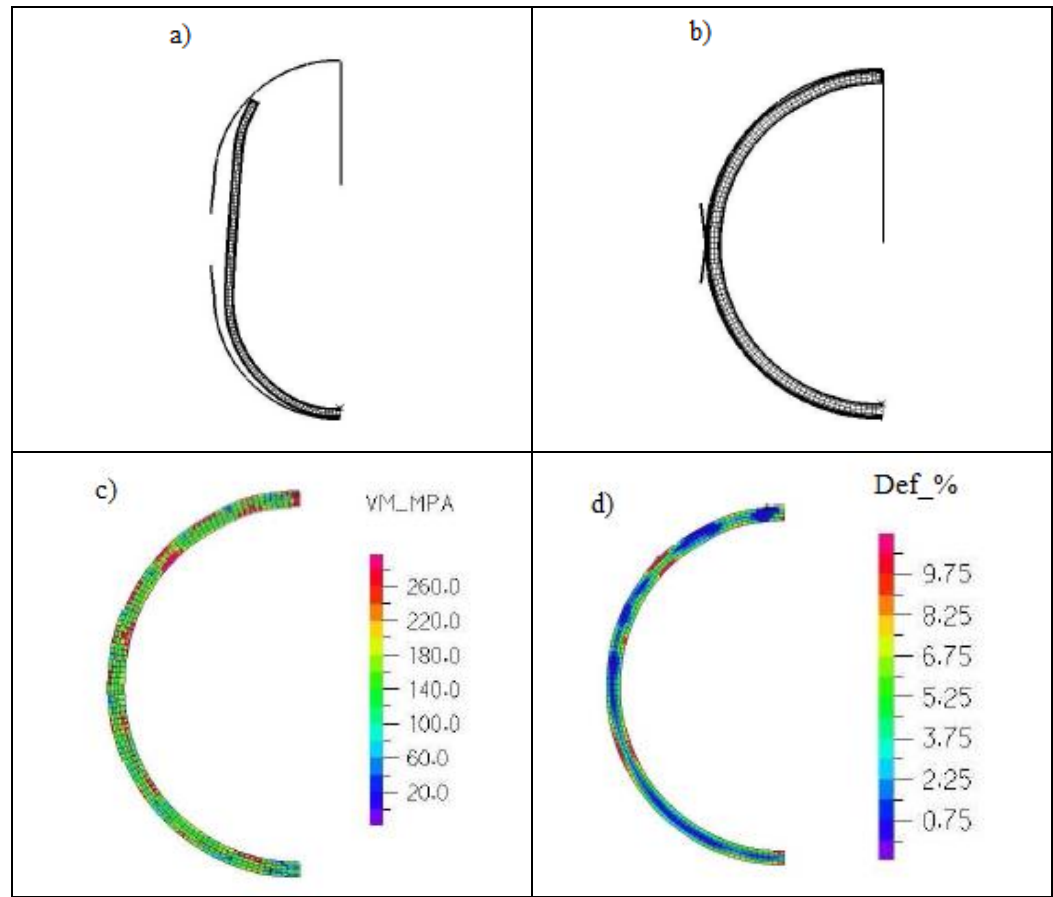

Figura 6.10: Modelo da conformação da chapa em O: a) Estado inicial; b) Deslocamento vertical máximo da matriz superior; c) Tensões efetivas no estado final; d) Deformações plásticas efetivas no estado final. 
A conformação da chapa para formação do tubo tem maior influência na direção circunferencial do mesmo. Durante esses processos as tensões circunferenciais são mais críticas do que as demais nas outras direções, porém essas tensões apresentam magnitudes relativamente baixas se comparadas às tensões na direção longitudinal que surgem após a soldagem. Assim não há prejuízo para análise nem para os modelos numéricos desconsiderar os efeitos das etapas de dobramento nas tensões residuais longitudinais. Entretanto a comparação entre as medições experimentais, que posteriormente serão descritas, e as tensões circunferenciais obtidas numericamente ainda é valida. A Figura 6.11 apresenta as tensões e deformações circunferenciais em cada etapa de dobramento.

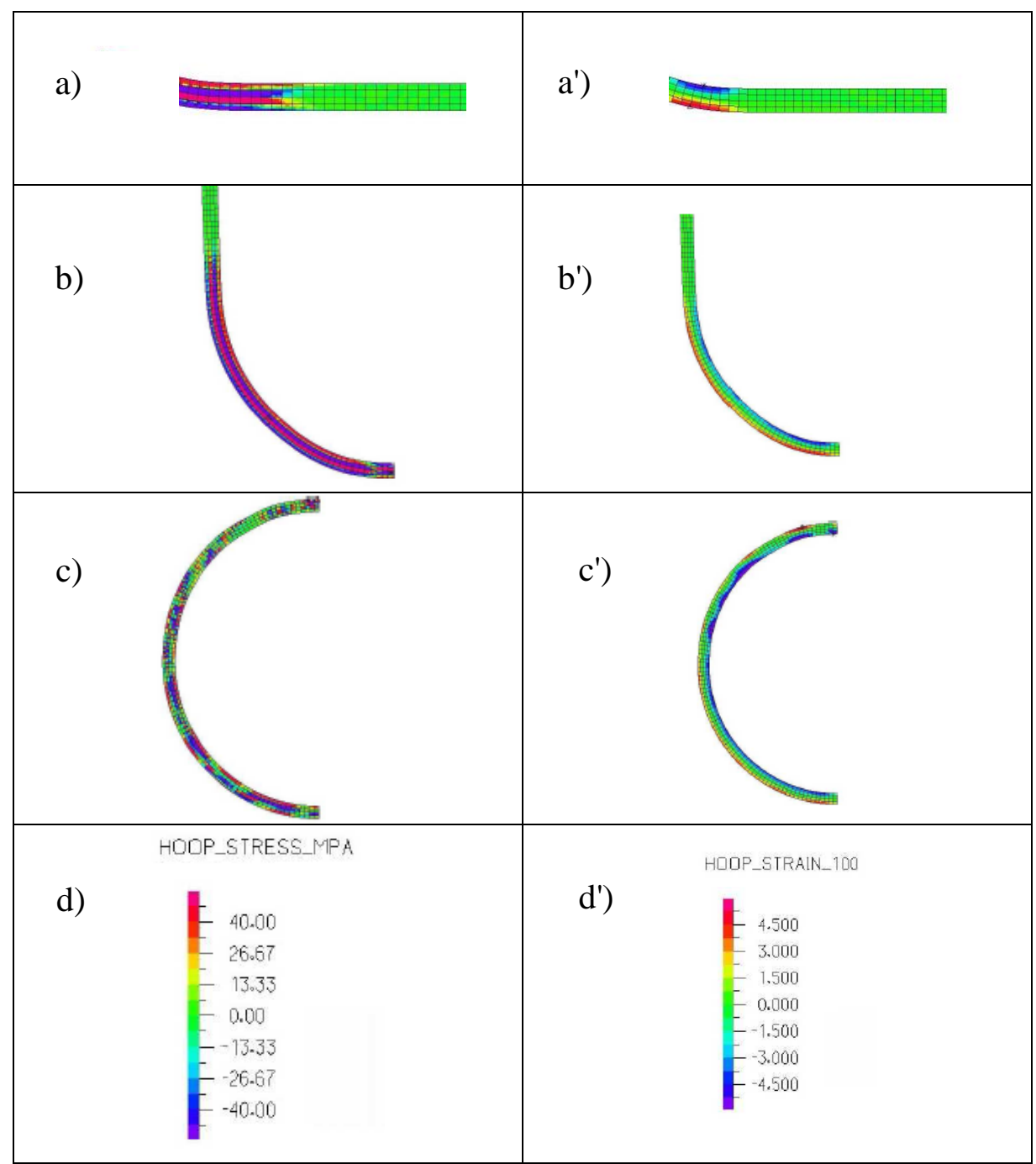

Figura 6.11: Comportamento na direção circunferencial durante as etapas de dobramento: a) Tensão circunferencial após a prensagem das bordas; a') Deformação circunferencial após a prensagem das bordas; b) Tensão circunferencial após a prensagem em U; b') Deformação circunferencial após a prensagem em U; c) Tensão circunferencial após a prensagem em O; c') Deformação circunferencial após a prensagem em O; d) Escala das tensões; d) Escala das deformações. 


\subsubsection{Simulação dos Cordões de Solda}

$\mathrm{O}$ aquecimento e o resfriamento durante a soldagem de fabricação do tubo foram modelados utilizando as variáveis apresentadas no item 6.4.4. Também se assumiu que todo a aporte térmico se dá através do cordão de solda para o interior do tubo, sendo analisadas e comparadas as curvas da temperatura em função do tempo para pontos localizados na superfície do espécime.

Inicialmente o cordão de solda já se encontra dilatado e à temperatura de fusão do metal. À medida que a simulação transcorre ele passa a trocar calor com o meio e com as demais regiões do tubo. Assim na proporção que o cordão de solda é resfriado ele será forçado a voltar ao seu tamanho inicial, passando a estar tracionado enquanto as demais regiões vizinhas passarão a ficar comprimidas, de forma a equilibrar o somatório de forças no tubo.

\subsubsection{Medições Experimentais}

Os dados experimentais foram retirados de [2,61]. Essas referências mediram as tensões residuais em espécimes tubulares X60 que nunca entraram em operação.

Para medição das tensões residuais provenientes da fabricação do tubo foram empregadas duas técnicas de medição extensométricas, a do furo cego e a do furo elíptico. A técnica do furo cego, Figura 6.12, é uma das mais utilizadas na medição de tensões residuais e consiste na usinagem de um furo (cego ou passante) que provoca uma modificação no estado de tensão interna no componente, este se traduzindo na introdução de deslocamentos e consequentes deformações na vizinhança do furo, como apresentado nos capítulos 2 e 5 .

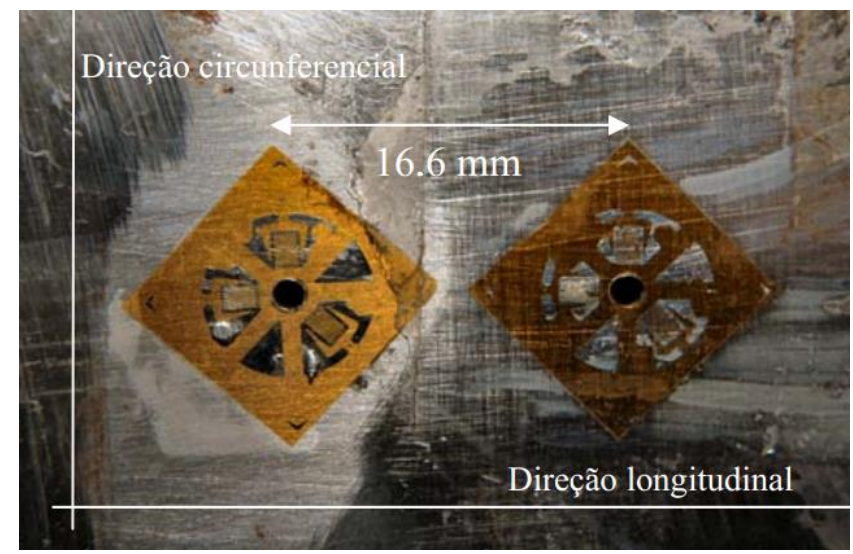

Figura 6.12: Rosetas extensométricas utilizadas na técnica do furo cego. 
Já a técnica do furo elíptico é uma técnica de seccionamento que baseia na extensão da técnica do furo cego. Em vez de um furo circular, faz-se um corte ou sulco retangular longo que é modelado analiticamente por uma elipse onde um dos semi-eixos é muito grande em relação ao outro semi-eixo. Em resumo, a técnica consiste na usinagem de cortes longos na superfície da peça, Figura 6.13, que aliviam as tensões causadas pelo material retirado e provocam variações nas deformações existentes na vizinhança do corte, [70,71].

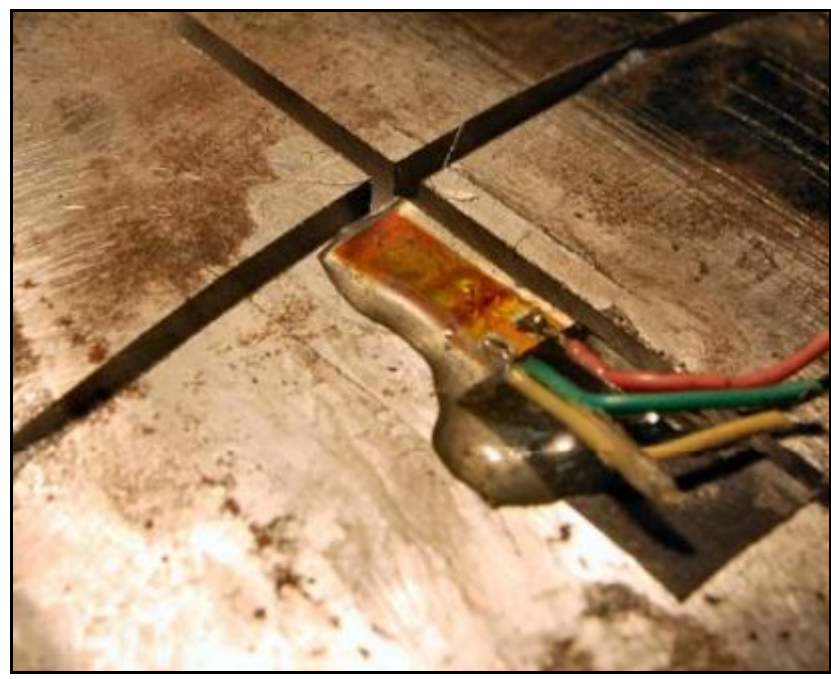

Figura 6.13: Extensômetro e cortes utilizados na técnica do furo elíptico.

Foram colados extensômetros (uniaxiais com $5 \mathrm{~mm}$ de base de medida ou rosetas próprias para furo cego com extensômetros com $3.2 \mathrm{~mm}$ de base de medida) na superfície externa do tubo ao logo de seções circunferenciais, com origem a partir do cordão de solda, nas posições zero (cordão de solda), $22.5^{\circ}$, $45^{\circ}, 90^{\circ}$ e sucessivamente até completar o seu perímetro. Foram realizados três conjuntos de medições utilizando a técnica do furo cego e apenas um conjunto de medições utilizando a técnica do furo elíptico.

\subsubsection{Comparação de Resultados}

O calor é dissipado por convecção para o ambiente através de dois coeficientes de troca de calor por convecção, sendo um externo e um interno, e também para seu interior através de um coeficiente de condução, que é variável com a temperatura. 
O processo de aquecimento é compreendido entre o início da simulação e o momento (1s após o início da deposição do cordão para a hipótese das três barras e 1s após o início da deposição do último segmento de cordão para a hipótese de múltiplos segmentos) quando o cordão passa a estar sujeito às condições de contorno térmicas. A partir do momento que cessa a deposição do cordão de solda o calor é dissipado para o interior do tubo, aquecendo as demais regiões e fazendo surgir variações de temperatura entre regiões adjacentes, gerando assim gradientes térmicos e consequentemente tensões térmicas.

Embora as análises da fabricação do tubo aqui estudadas sejam diferentes entre si, ambos apresentam resultados de comportamento térmico e mecânico semelhantes.

Na Figura 6.14 é apresentada a distribuição de temperaturas no tubo para o modelo das três barras no instante de 1s de simulação, logo após o término da soldagem e início da troca de calor para o meio.

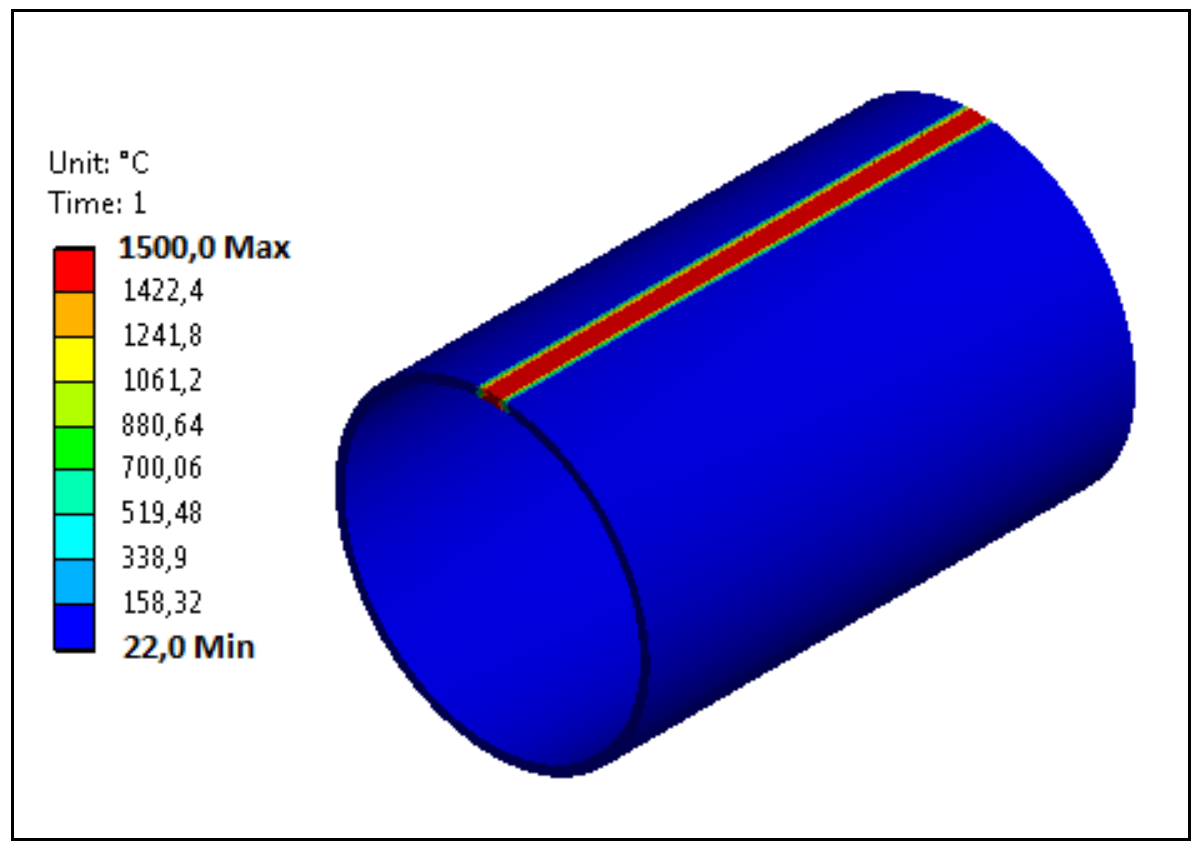

Figura 6.14: Distribuição de temperaturas no tubo para o modelo das três barras no instante de 1 s de simulação. 
Pode se perceber que as temperaturas das regiões adjacentes ao cordão de solda são bastante elevadas. Essa distribuição de temperaturas altas no entorno do cordão de solda tem como finalidade compensar a parcela de calor trocada entre a junta e a coluna de plasma. Os gradientes de temperatura formadas na região da junta fazem surgir no entorno do metal de solda a ZTA, como mostrado na Figura 6.15, que apresenta a distribuição de temperaturas na junta em 1s de simulação.

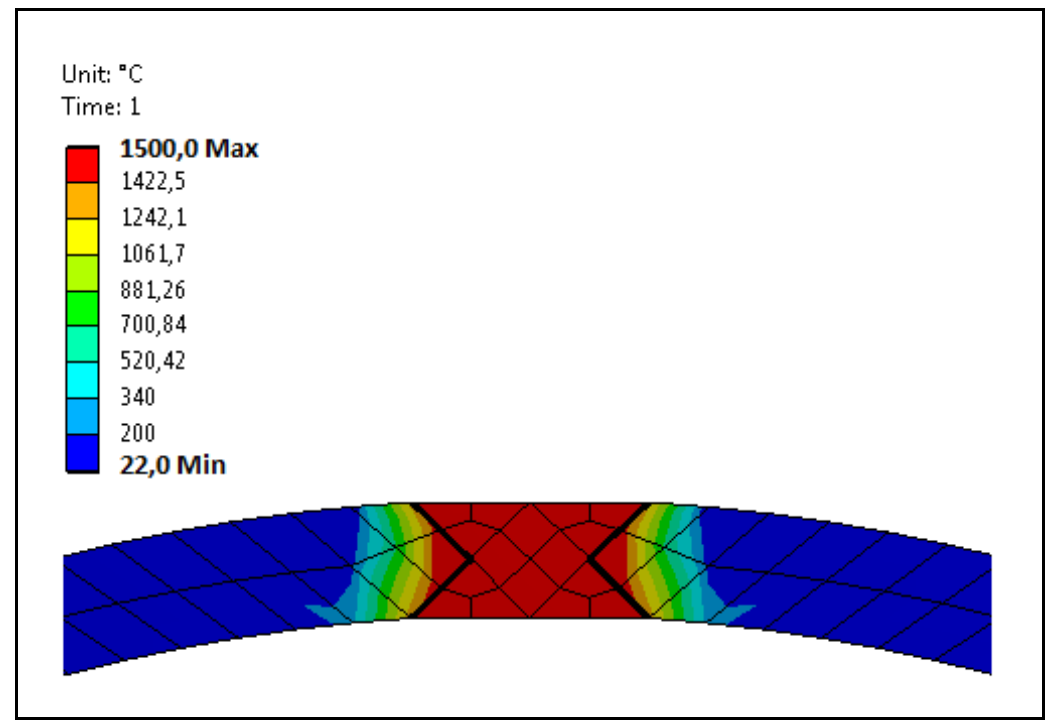

Figura 6.15: Distribuição de temperaturas na junta soldada para o modelo das três barras no instante de 1 s de simulação.

Na Figura 6.16 é mostrada a evolução da temperatura em um ponto localizado na superfície externa do tudo e na região central do cordão de solda longo do tempo, após o cordão de solda ter sido depositado e subsequentemente resfriado por duas convecções, uma externa e outra interna.

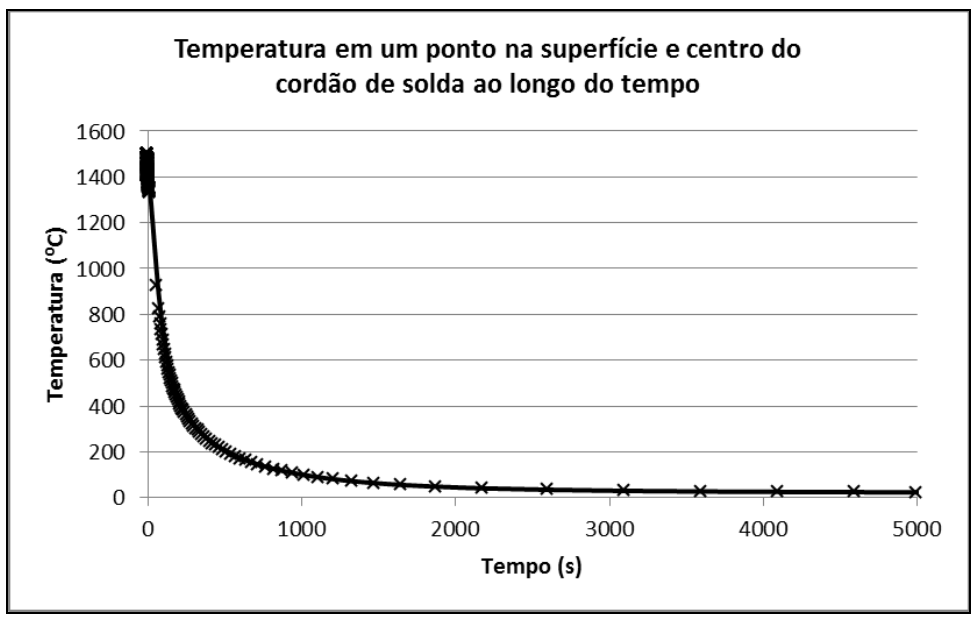

Figura 6.16: Temperatura em um ponto na superfície e centro do cordão de solda ao longo do tempo. 
Analisando o modelo com múltiplos segmentos de cordão de solda, a Figura 6.17 apresenta evolução da distribuição de temperaturas no tubo em cada instante de deposição de um segmento de cordão, desde a deposição do primeiro segmento, início da simulação, até o quinto e último segmento.

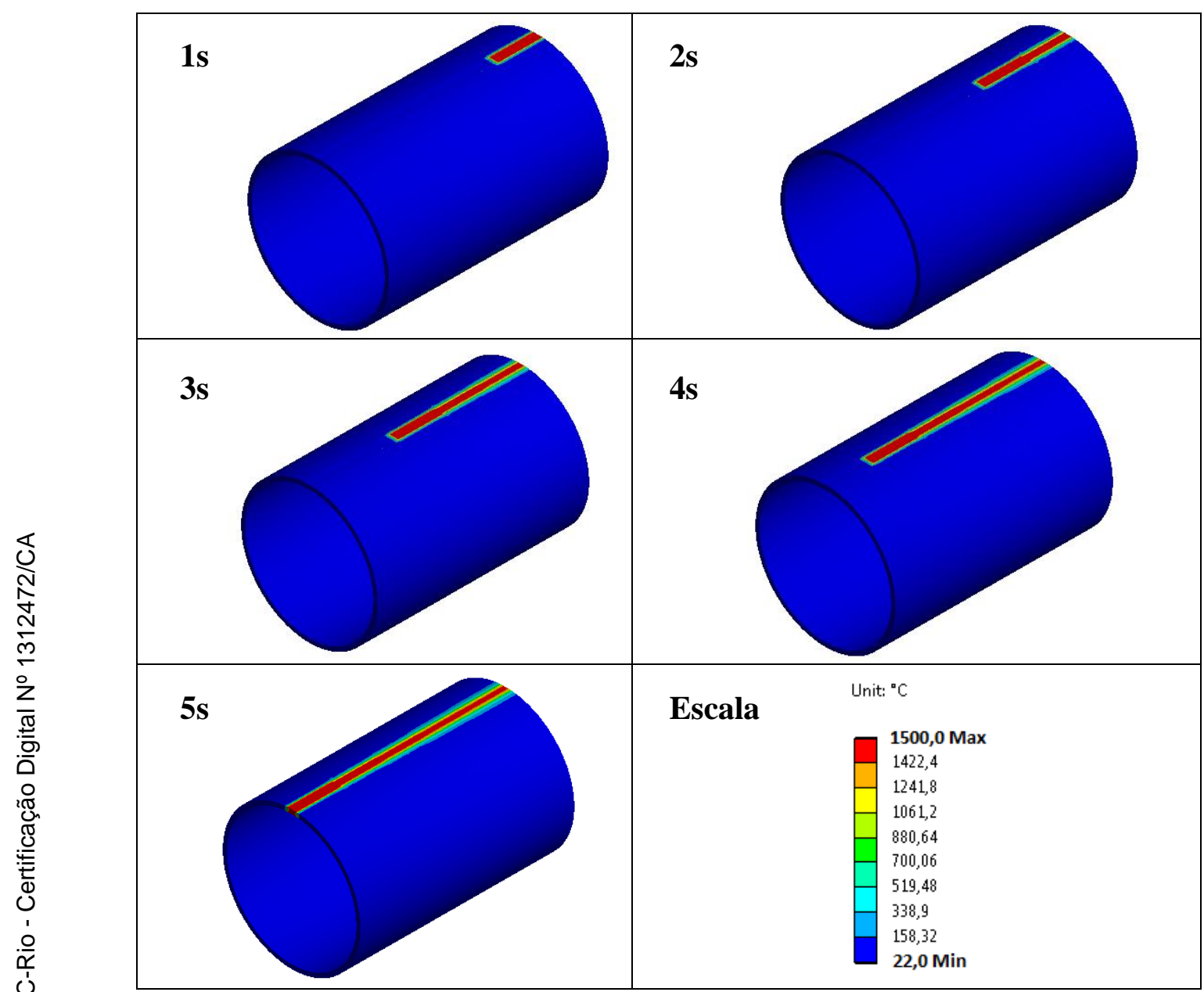

Figura 6.17: Evolução da distribuição de temperaturas no tubo para o modelo dos múltiplos segmentos.

Como a velocidade de soldagem na deposição dos diversos segmentos é extremamente alta, $600 \mathrm{~cm} / \mathrm{min}$, os modelos com múltiplos segmentos de cordão e com o cordão inteiro não apresentam diferenças significativas. Entretanto pode se perceber que já no instante igual a $5 \mathrm{~s}$, deposição do ultimo segmento, a distribuição de temperaturas no entorno do primeiro segmento de cordão apresenta magnitude bem menor que a inicial. Embora nesse caso a influência da velocidade de soldagem seja pequena, ela provoca uma variação da distribuição de tensões na peça se comparado com o modelo das três barras, que tem aplicação única no tempo. 
Comparando a evolução da temperatura de um mesmo ponto localizado na superfície externa e no centro do cordão, como mostrado na Figura 6.18, observase que a temperatura tem o mesmo comportamento, dessa forma pode se dizer que os modelos são bastante parecidos se comparados termicamente.

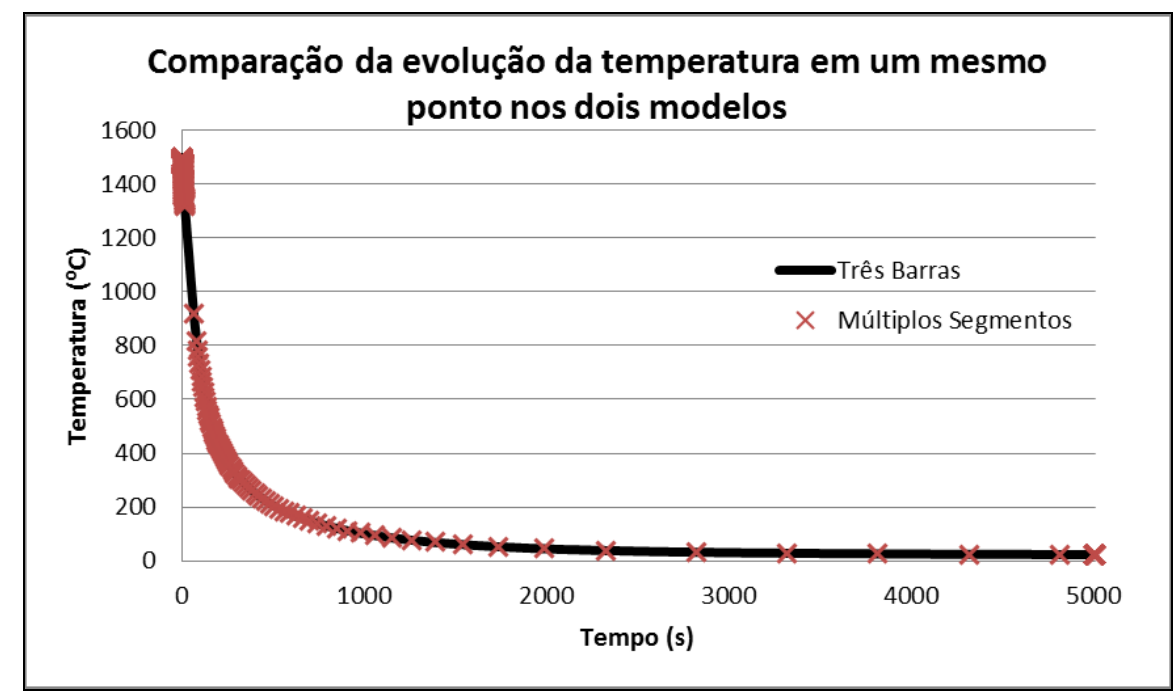

Figura 6.18: Comparação da evolução da temperatura em um mesmo ponto nos dois modelos.

Quando as simulações atingem 5000s todo o calor fornecido ao tubo durante a soldagem se dissipou para o meio e todo o espécime retorna ao equilíbrio térmico com a temperatura ambiente de $22^{\circ} \mathrm{C}$, assim como mostrado na Figura 6.19 .

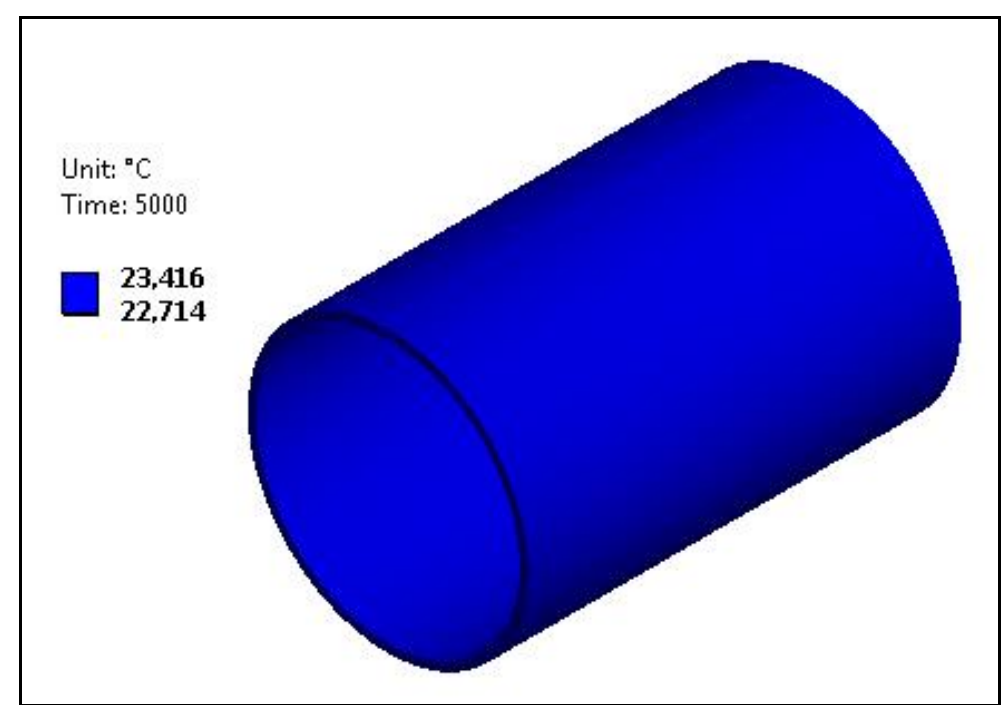

Figura 6.19: Distribuição de temperatura para ambos os modelos no instante de 5000s. 
Os severos gradientes de temperaturas e as restrições ao deslocamento das regiões próximas ao cordão de solda fazem surgir tensões residuais no tubo após a soldagem. $\mathrm{O}$ aquecimento localizado durante a soldagem e o resfriamento causam mudanças volumétricas não uniformes, que por sua vez geram tensões e deformações no tubo. A contração durante o resfriamento das regiões diferentemente aquecidas e plastificadas provoca o surgimento de um campo de tensões permanentes que se auto-equilibram.

A Figura 6.20 apresenta as distribuições das tensões residuais no tubo após a soldagem de fabricação, no instante de 5000s, considerando a hipótese das três barras.

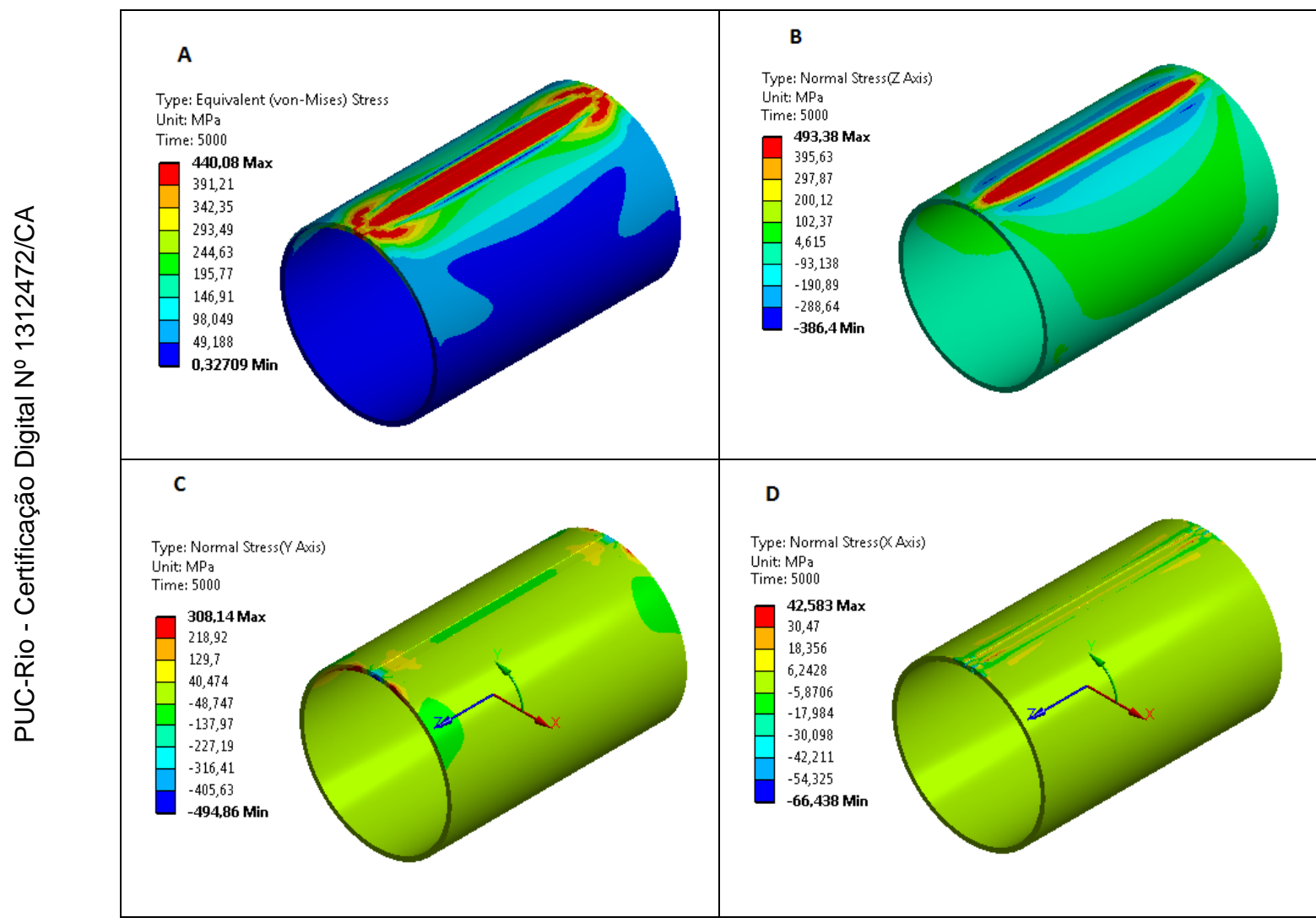

Figura 6.20: Distribuição de tensões residuais considerando a hipótese das três barras: a)Tensões equivalentes; b) Tensões longitudinais; c) Tensões circunferenciais; d) Tensões radiais.

A tensão equivalente residual, Figura $6.20 \mathrm{a}$, no cordão de solda tem magnitude similar ao limite de escoamento do material do tubo. No cordão de solda e em seu entorno estão localizadas as maiores tensões equivalentes, enquanto que nas regiões mais distantes da junta as tensões são aproximadamente zero. Observa-se também que as distorções nas bordas do cordão provocam uma mudança no comportamento das tensões nessas regiões. 
Devido ao comprimento considerável do tubo pode se dizer que as tensões na região central se comportam segundo a hipótese de deformações planas.

As tensões residuais longitudinais após a soldagem de fabricação, Figura 6.20b, são as principais componentes no cálculo da tensão equivalente. As tensões nessa direção são auto-equilibrantes, sendo trativas no cordão de solda e compressivas na ZTA. Esses níveis elevados de tensões se devem ao fato das maiores restrições à expansão e à contração do cordão depositado estarem na direção longitudinal do tubo.

Embora as tensões circunferenciais apresentem magnitudes elevadas nas bordas do cordão, no resto do tubo sua magnitude não é elevada, ficando entre 40 MPa e -60 MPa. Como o principal esforço a que o tubo é submetido quando pressurizado se encontra na direção circunferencial, o fato das tensões residuais nessa direção serem baixas não é maléfico para a integridade do mesmo.

As tensões residuais radiais do tubo são irrelevantes e podem ser desprezadas uma vez que tem níveis de tensão máximo em torno de $42 \mathrm{MPa}$ em tração. A contração nessa direção é muito pequena não influenciando no comportamento do tubo.

A Figura 6.21 apresenta os deslocamentos que ocorrem nas bordas na direção longitudinal após a soldagem. Percebe-se que as bordas tendem a se contrair o que provoca uma alteração da distribuição de tensões nessas regiões, como mostrado na Figura 6.20.

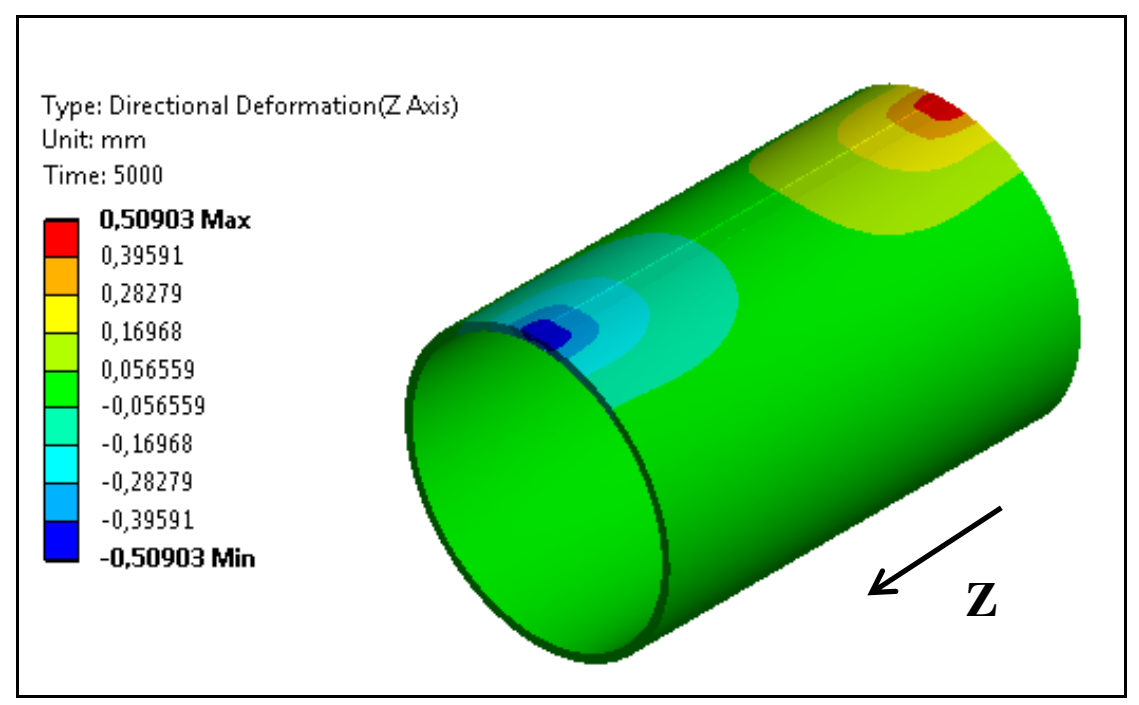

Figura 6.21: Deslocamento na direção longitudinal após a soldagem, 5000s. 
A Figura 6.22 apresenta as distribuição de tensões residuais ao longo do Caminho 1 em 5000s para a hipótese das três barras.

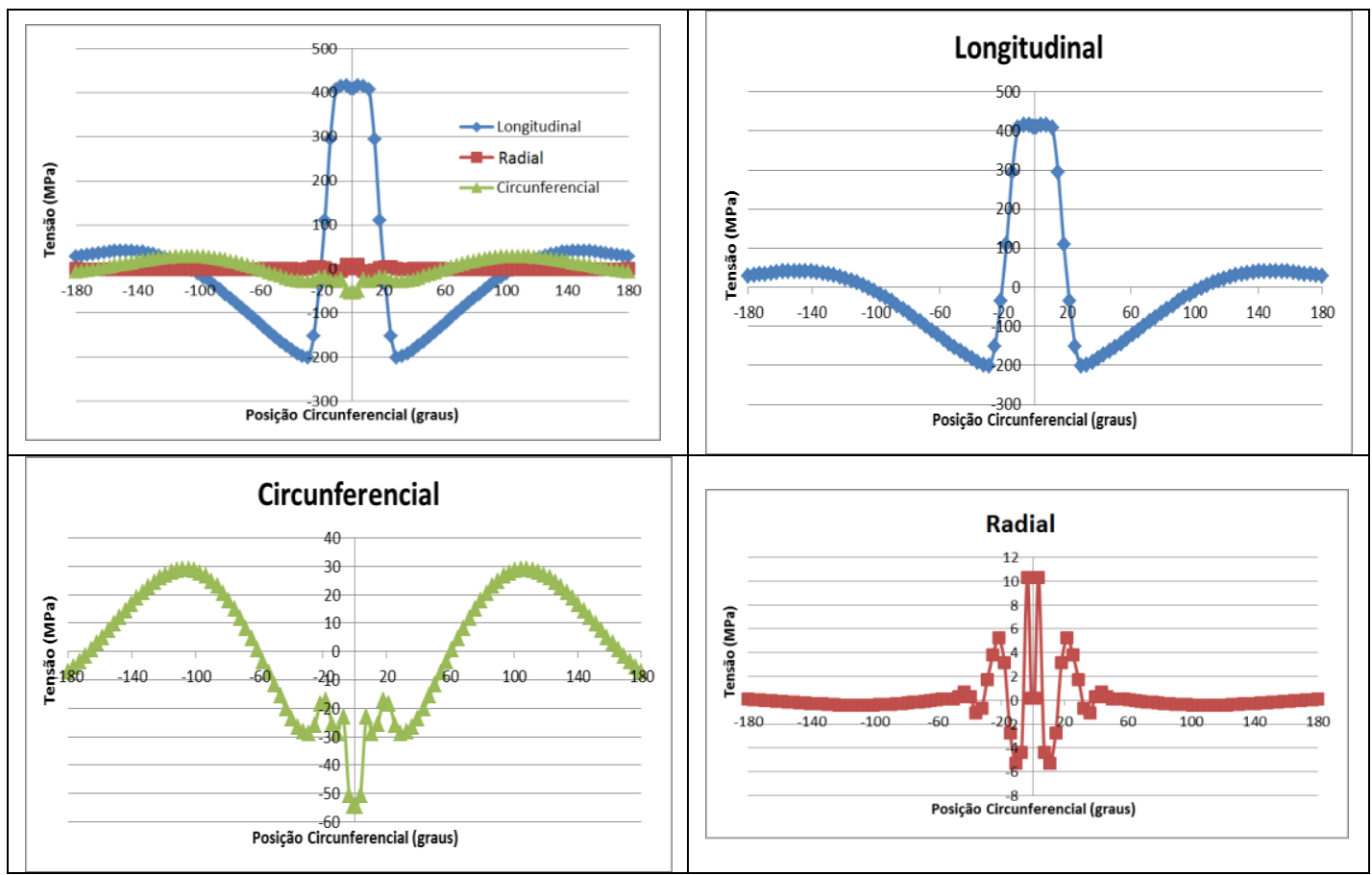

Figura 6.22: Distribuição de tensões residuais no Caminho 1 em 5000s para a hipótese das três barras.

Analisando a Figura 6.22, pode se notar que a tensão na direção longitudinal se comparada com as demais é a mais significativa após a soldagem. Ela é trativa no cordão de solda e compressiva nas adjacências. A tensão circunferencial é compressiva na região do cordão de solda e trativa nas demais posições do tubo. Já a tensão radial é muito pequena e localizada na região do cordão de solda.

A distribuição das tensões residuais na superfície externa e interna do tubo apresentam valores similares na direção longitudinal, isso se deve a geometria da junta em forma de $\mathrm{X}$. Porém as tensões circunferenciais no meio da espessura diferem das da superfície, como pode ser percebido na Figura 6.23, onde são comparadas as distribuições de tensões residuais no centro, Caminho 2, e na superfície do tubo, Caminho 1, para a hipótese das três barras. 


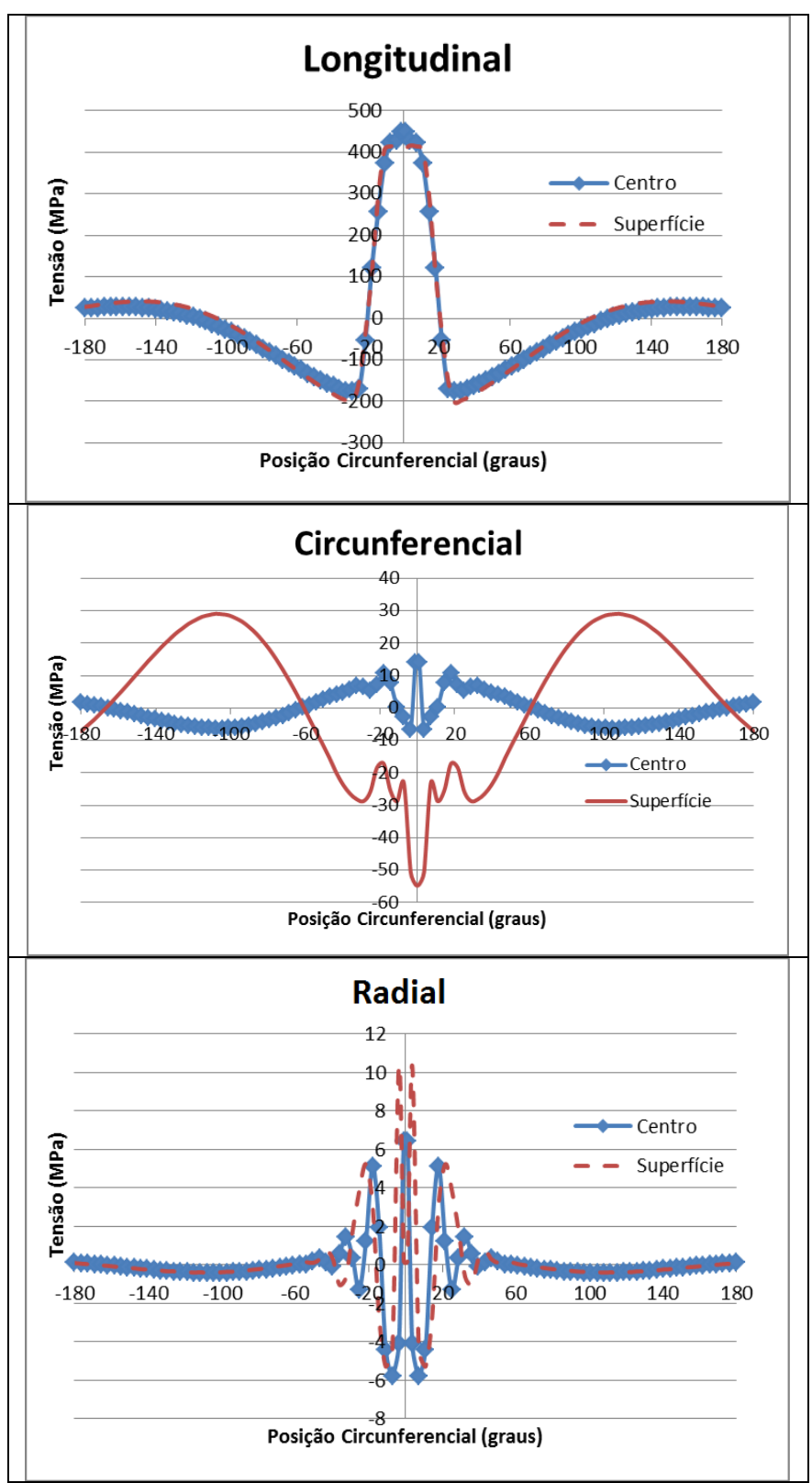

Figura 6.23: Comparação entre as distribuições de tensões residuais nos Caminho 1 e Caminho 2.

As distribuições das tensões residuais são praticamente iguais com exceção da circunferencial, entretanto embora as distribuições no centro e na superfície sejam diferentes suas magnitudes são relativamente pequenas. Essa similaridade de distribuições no centro e na superfície se deve a espessura do tubo ser relativamente pequena, $9.7 \mathrm{~mm}$. Isto pode ser comprovado analisando a Figura 6.24, que mostra a variação das tensões residuais ao longo da espessura do tubo no Caminho 1 no instante de 5000s. 


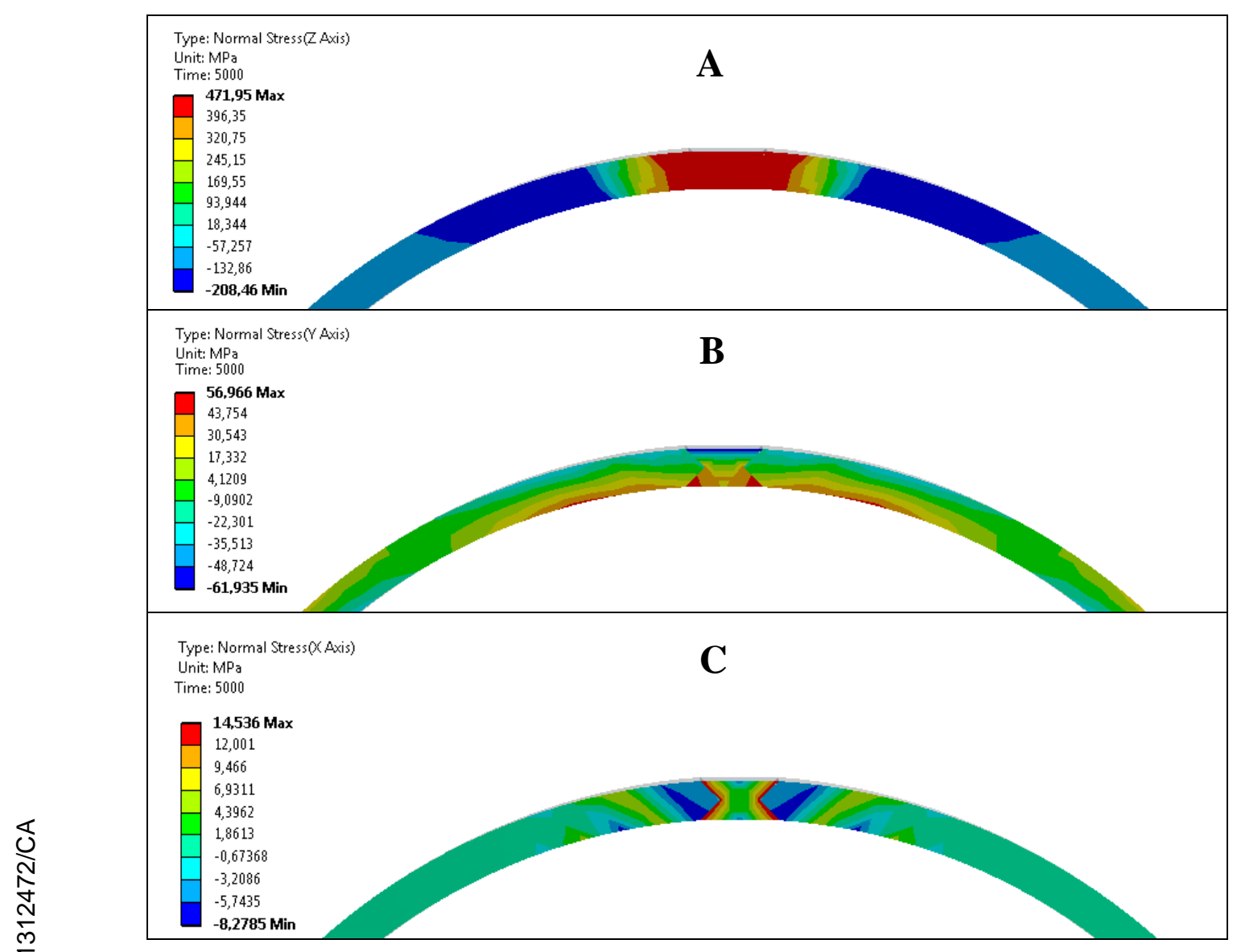

Figura 6.24: Distribuições de tensões residuais ao longo da espessura no Caminho 1: a) Longitudinal; b) Circunferencial; c) Radial.

A Figura 6.25 apresenta a comparação das tensões residuais obtidas através da hipótese das três barras e da hipótese dos múltiplos segmentos no Caminho 1. 


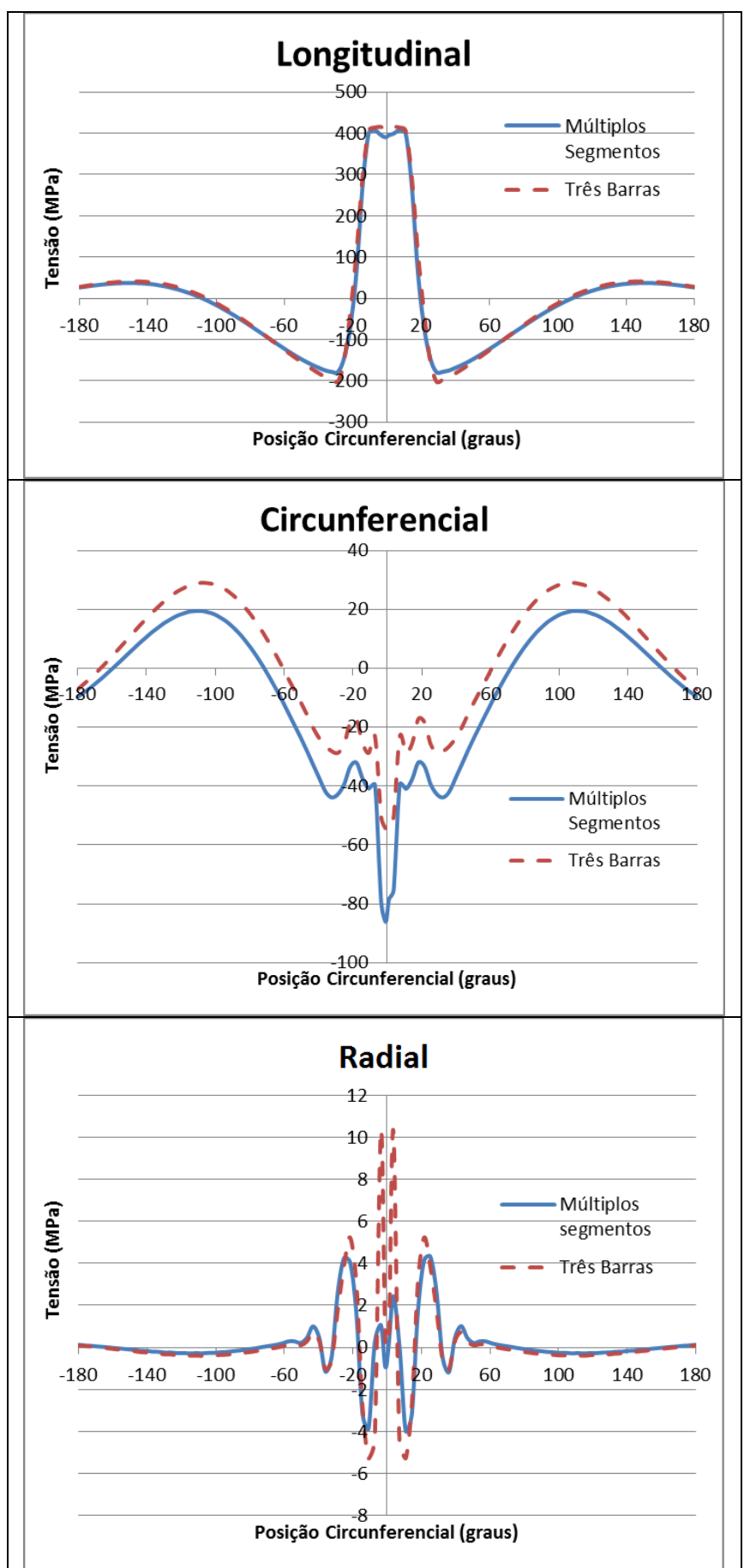

Figura 6.25: Comparação das distribuições de tensões residuais obtidas através das hipóteses das três barras e dos múltiplos segmentos no Caminho 1 .

Semelhante ao que já foi comentado sobre a distribuição de temperaturas, as distribuições de tensões residuais para a hipótese das três barras e para a hipótese dos múltiplos segmentos são bastante semelhantes, fora pequenas diferenças. Desta maneira pode se assumir que a soldagem com velocidades elevadas pode ser aproximada, sem prejuízo, por um cordão de solda inteiro, hipótese das três barras. 
A aplicação do teste hidrostático, $\mathrm{TH}$, provoca um esforço na direção circunferencial do espécime, que depende da pressão aplicada. As pressões testadas são apresentadas na Tabela 6.3, abaixo.

Tabela 6.3: Lista de pressões utilizadas na simulação do teste hidrostático.

\begin{tabular}{|c|c|c|}
\hline $\begin{array}{c}\text { Pressão do teste } \\
\text { hidrostático (MPa) }\end{array}$ & $\begin{array}{c}\text { Tensão provocada } \\
\text { na direção } \\
\text { circunferencial } \\
\text { (MPa) }\end{array}$ & $\begin{array}{c}\text { Porcentagem do limite de } \\
\text { escoamento à temperatura } \\
\text { ambiente atingido pela } \\
\text { tensão circunferencial (\%) }\end{array}$ \\
\hline 22.6 & 378 & 90 \\
\hline 21.4 & 357 & 85 \\
\hline 18.9 & 315 & 75 \\
\hline 15.1 & 252 & 60 \\
\hline
\end{tabular}

A Figura 6.26 apresenta as distribuições de tensões no tubo durante a realização do teste hidrostático com pressão que causa $90 \%$ do escoamento na direção circunferencial, considerando a hipótese das três barras. Essa pressão que causa $90 \%$ do escoamento na direção circunferencial é a mais utilizada atualmente na fabricação de dutos para a indústria do petróleo, todavia a pressão pode ser alterada dependendo do projeto.

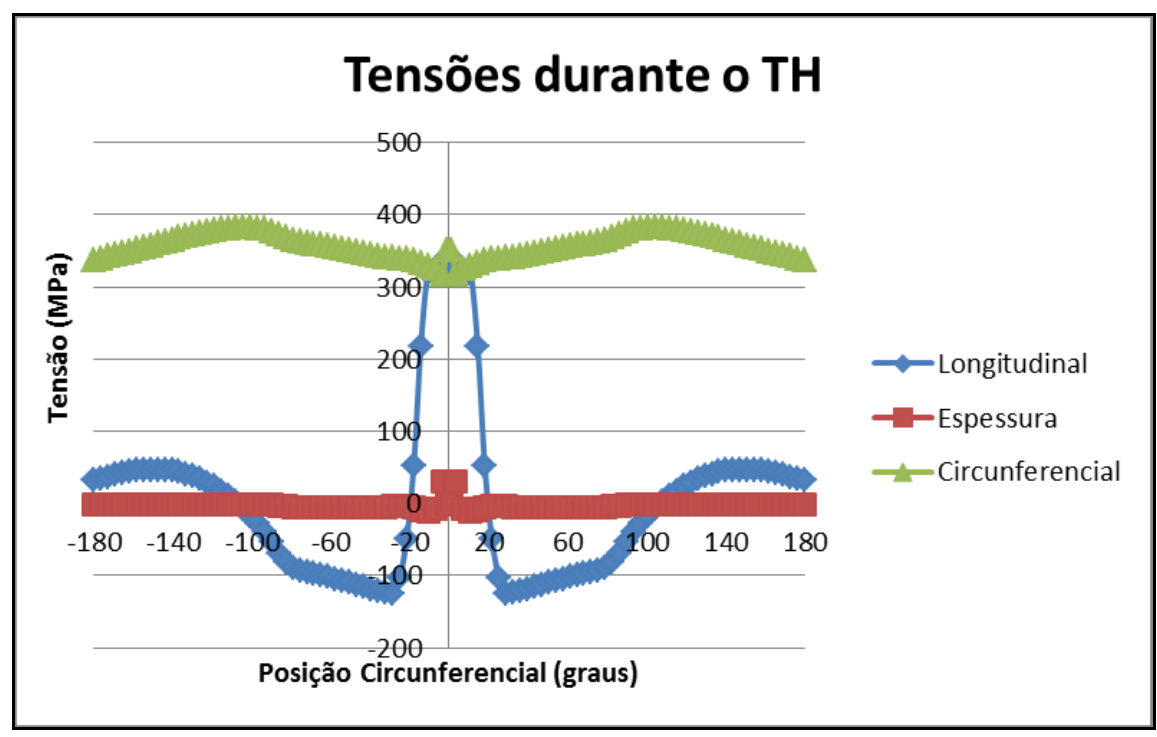

Figura 6.26: Tensões no tubo durante a realização do teste hidrostático de $90 \%$ de Sy na direção circunferencial.

Durante o teste hidrostático a influência da pressão nas demais direções fora a circunferencial é muito pequena, o teste hidrostático causa tensões circunferenciais que são duas vezes maiores que as longitudinais. 
Na Figura 6.27 são comparadas as distribuições das tensões residuais antes da realização do teste hidrostático e após a despressurização e fim do alívio de tensões que provoca uma tensão de $90 \%$ do escoamento na direção circunferencial no Caminho 1.

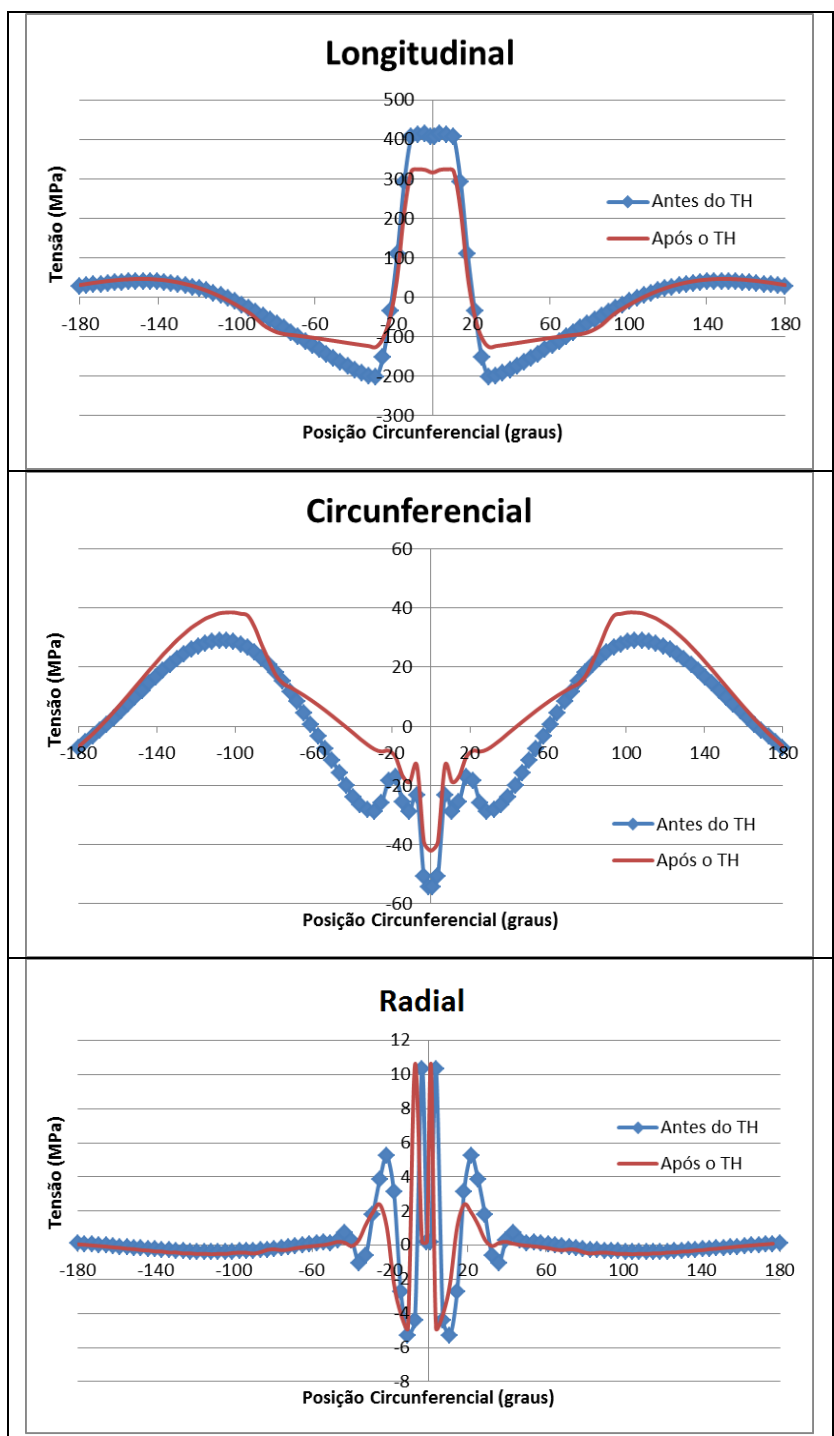

Figura 6.27: Comparação da distribuição de tensões residuais antes e após a realização do teste hidrostático de $90 \%$ de Sy na direção circunferencial.

A maior influência do alívio de tensões ocorre na direção circunferencial, uma vez que a maior tensão provocada pelo alívio ocorre nessa direção. Embora a maior tensão ocorra nessa direção, há uma diminuição da magnitude de tração no cordão de solda na direção longitudinal e o mesmo ocorre com os níveis de compressão nas adjacências do cordão de solda, ao longo da espessura o comportamento também é semelhante. 
Se considerarmos a hipótese dos múltiplos segmentos, o tubo se comporta após o alívio de forma semelhante à hipótese das três barras, como mostrado pela Figura 6.28.

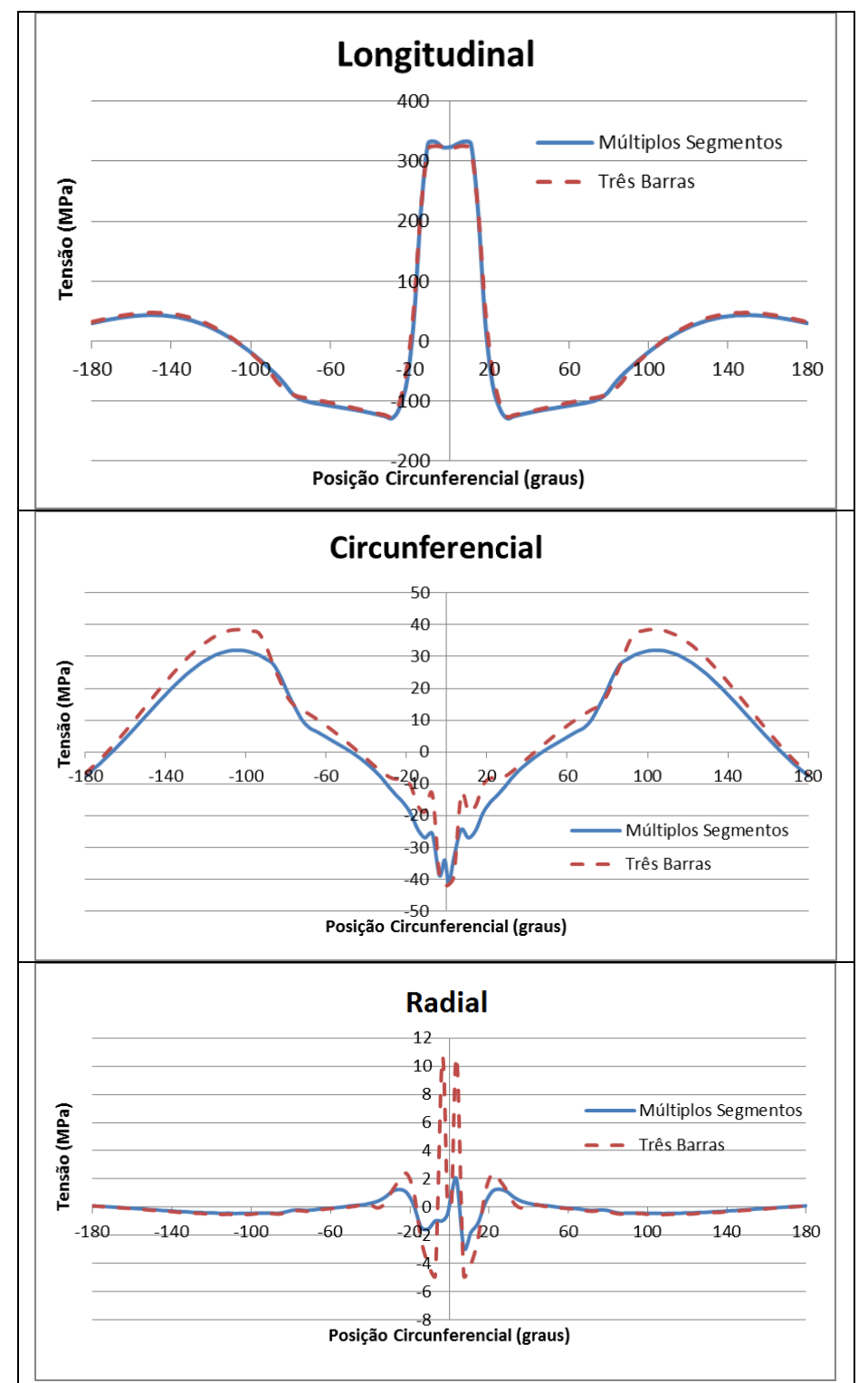

Figura 6.28: Comparação das distribuições de tensões residuais após a realização do teste hidrostático de $90 \%$ de Sy na direção circunferencial para as hipóteses das três barras e dos múltiplos segmentos no Caminho 1.

A Figura 6.29 apresenta as distribuições de tensões residuais na superfície do cordão de solda, Caminho 3, antes, durante e após o teste hidrostático para a hipótese dos múltiplos segmentos de cordão. 


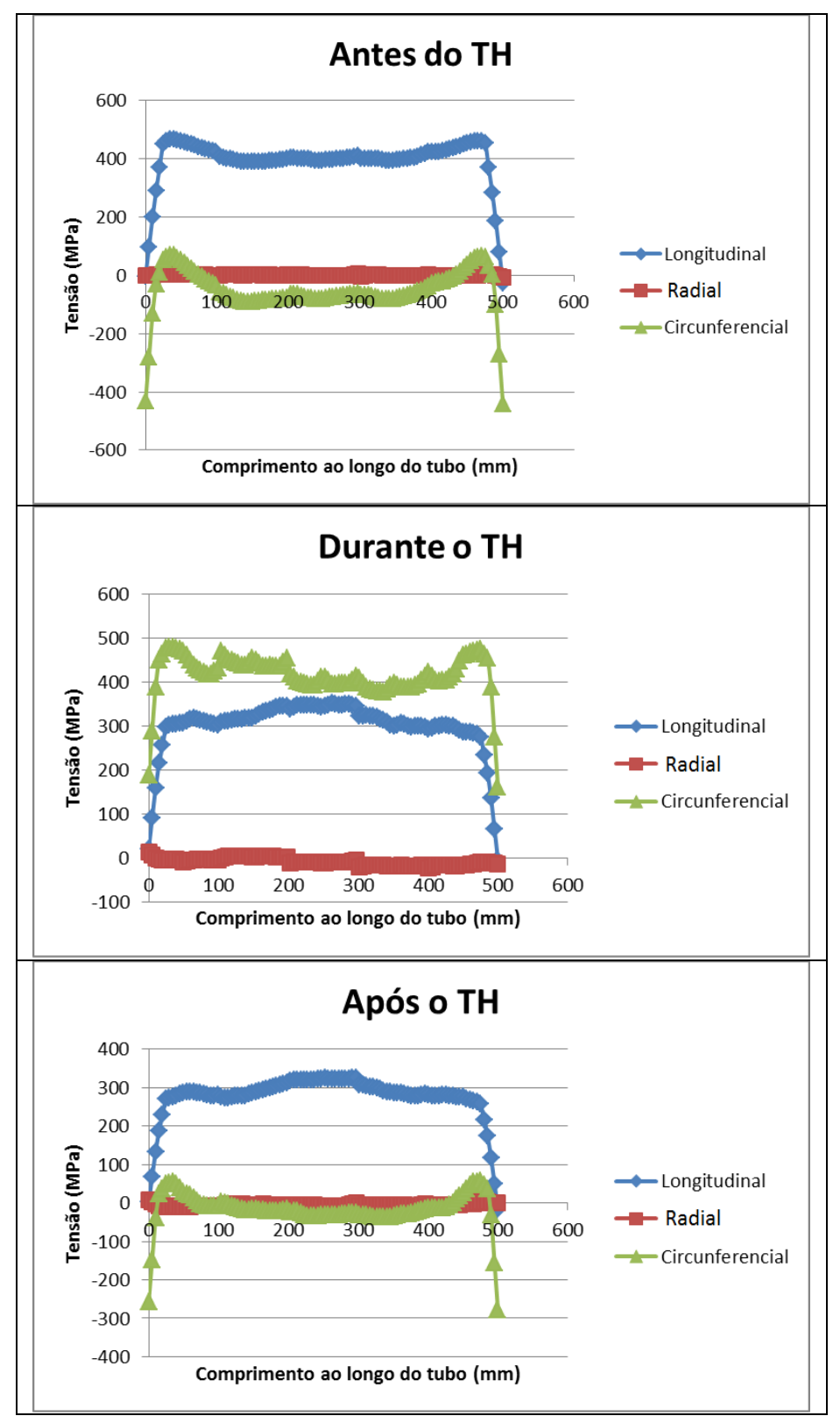

Figura 6.29: Distribuição das tensões residuais no Caminho 3 antes, durante e após a realização do teste hidrostático para a hipótese dos múltiplos segmentos.

A distribuição de tensões residuais ao longo do comprimento do tubo na hipótese dos múltiplos segmentos é uniforme com exceção da região das bordas. As distribuições de tensões ao longo dos segmentos de cordão seguem o mesmo padrão já que a velocidade de soldagem utilizada tem pouca influência na alteração da distribuição.

Para compreender melhor a eficácia e a influência do teste hidrostático no comportamento do tubo foram testadas diferentes pressões, fornecidas pela Tabela 6.3. A Figura 6.30 apresenta a variação das distribuições das tensões residuais após a realização do teste hidrostático para cada pressão específica. 


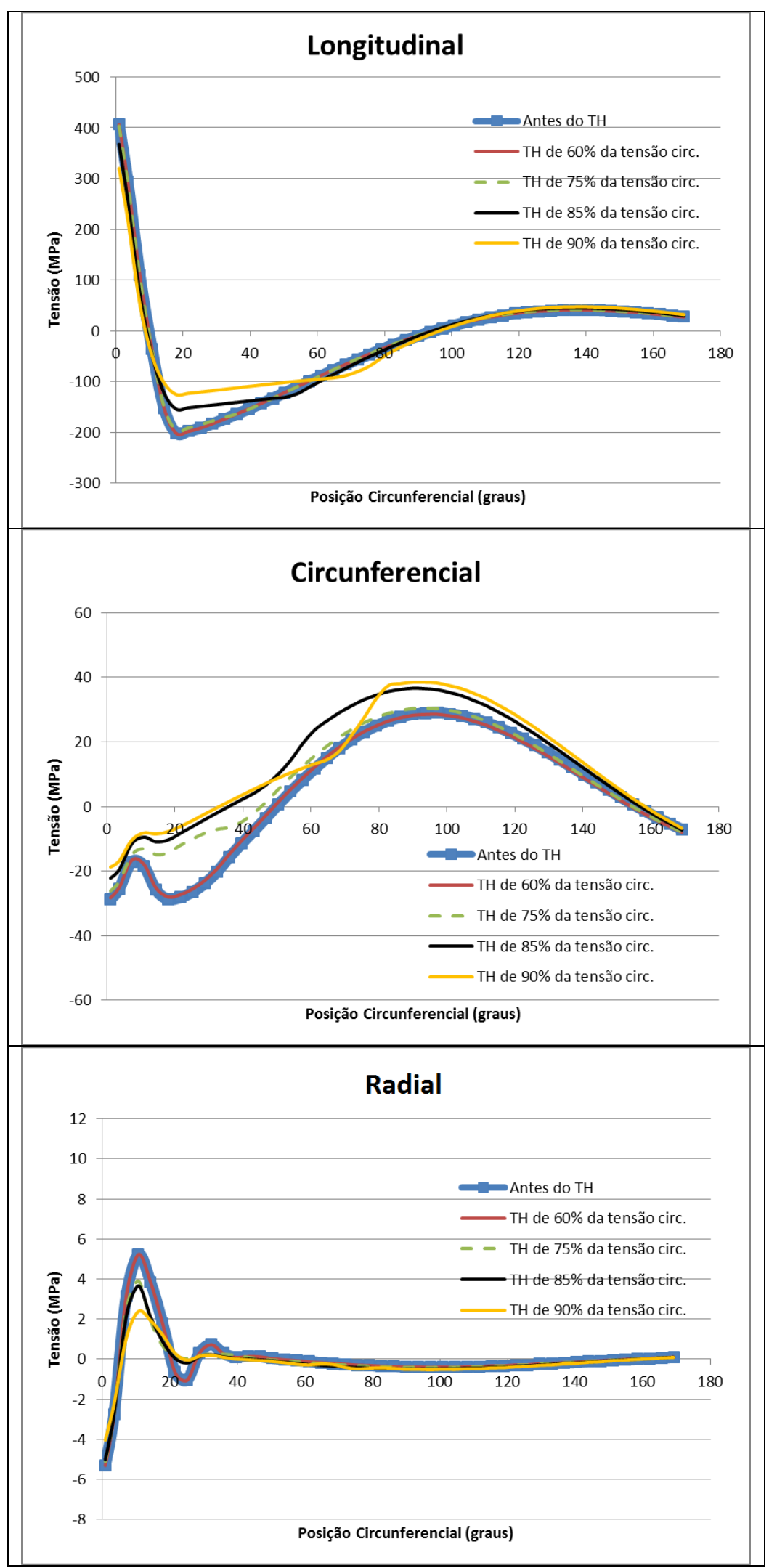

Figura 6.30: Variação das distribuições das tensões residuais após a aplicação dos diferentes testes hidrostáticos. 
A influência do teste de alívio de tensões na direção longitudinal da solda é relativamente pequena. No cordão de solda há uma diminuição da magnitude trativa, e o mesmo ocorre na compressão das zonas adjacentes ao cordão. Nas regiões mais distantes da junta o teste não provoca nenhuma alteração no comportamento.

É na direção circunferencial onde ocorre a maior variação das tensões após o teste. Há uma diminuição da compressão no cordão de solda e um acréscimo de tração nas regiões mais distantes. A realização de um teste hidrostático em um componente com soldas longitudinais não é benéfico às suas tensões circunferenciais, uma vez que ocorre acréscimo das tensões trativas e diminuição das compressivas. Entretanto pelo fato das tensões circunferenciais apresentarem baixas magnitudes esse efeito pode ser relevado já que o teste tem como função não só o alívio, mas também garantir a estanqueidade do tubo.

Na direção radial há uma diminuição da tração, porém os níveis de tensão nessa direção são muito pequenos o que faz com que o alívio possa ser desprezado.

Analisando a Figura 6.30, pode se concluir que as tensões residuais após o teste com pressão de $60 \%$ de escoamento na direção circunferencial são iguais às anteriores da realização do mesmo. Assim qualquer teste realizado com essa pressão ou com pressões menores que essa não provoca nenhuma alteração na distribuição de tensões residuais. O teste hidrostático tem pouca influência sobre o comportamento das tensões causadas pelas soldas longitudinais, o que é corroborado pela pouca variação das tensões longitudinais após os testes.

As Figuras 6.31 e 6.32 mostram a comparação entre as tensões residuais medidas utilizando a técnicas experimentais e as tensões simuladas pelo método dos elementos finitos no Caminho 1 para a hipótese das três barras após o teste o teste hidrostático que causa uma tensão de $60 \%$ de escoamento na direção circunferencial. 


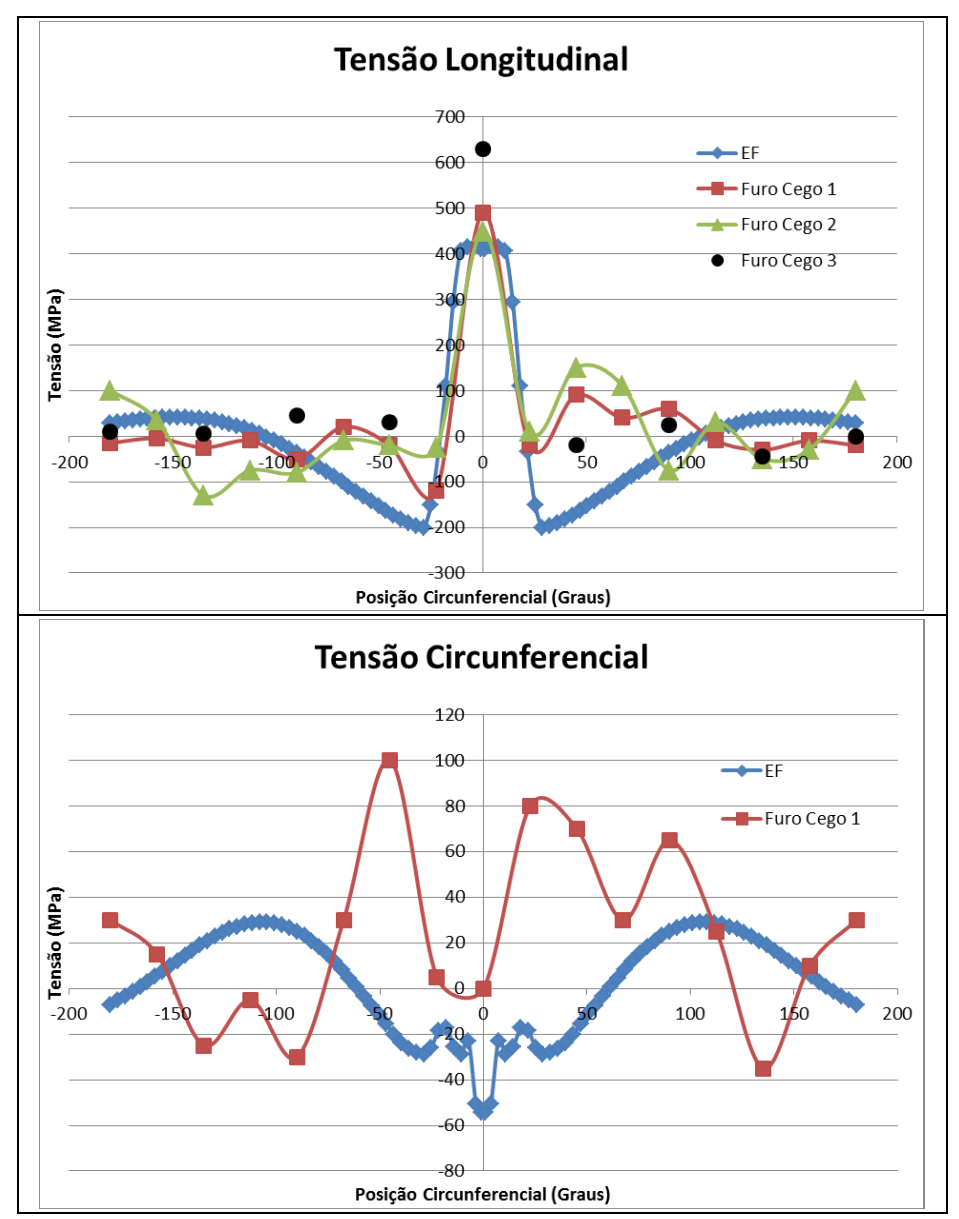

Figura 6.31: Comparação entre as tensões residuais medidas pelo furo cego e as simuladas via MEF no Caminho 1.

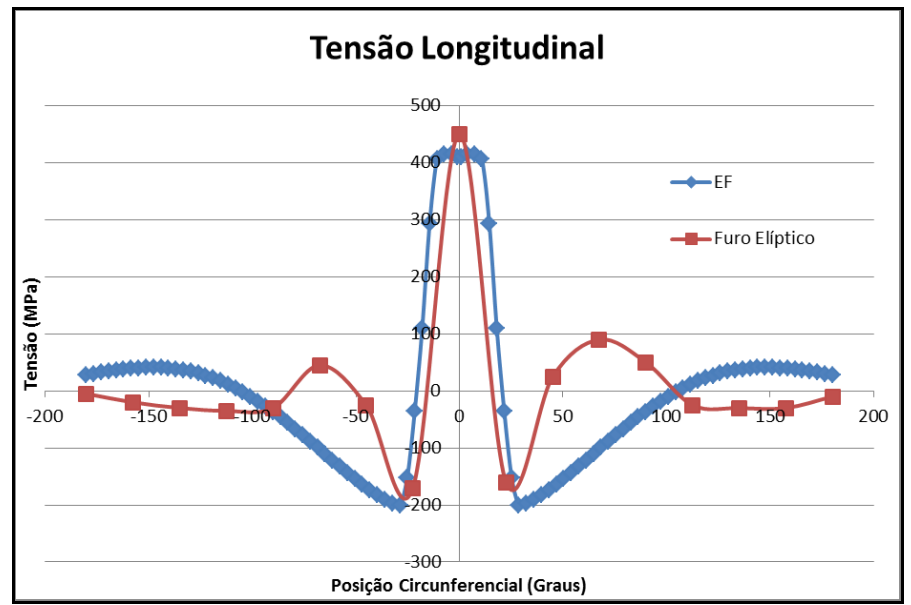

Figura 6.32: Comparação entre as tensões residuais medidas pelo furo elíptico e as simuladas via MEF no Caminho 1.

Como as medições experimentais foram realizadas em espécimes cujas condições de fabricação e inspeção são desconhecidas, optou-se por comparar os resultados experimentais com os obtidos numericamente após um teste hidrostático que provoca pouca influência na redistribuição de tensões. 
No cordão de solda (posição $0^{\circ}$ ) a tensão residual na direção longitudinal do tubo atingiu a magnitude do limite de escoamento do material e em uma medição (Furo Cego 3) apresentou um valor a cima desse limite. Embora o método do furo cego seja adequado para tensões até dois terços do limite de escoamento, valores acima deste limite devem ser considerados como representativos de tensões altas. As regiões adjacentes ao cordão de solda (posições entre $15^{\circ}$ e $40^{\circ}$ aproximadamente) apresentam tensões compressivas.

As medições realizadas utilizando furo elíptico apresentaram resultados semelhantes aos numéricos. Deve-se notar que as medições com furo elíptico precisam ser feitas com cortes de profundidades maiores (para este caso, $7 \mathrm{~mm}$ no mínimo) para que o alívio de tensões alcance toda a grade de medição do extensômetro. Já as medições com furo cego são realizadas com uma profundidade de 2 a $3 \mathrm{~mm}$.

Como na modelagem por elementos finitos não foi simulado o processo de dobramento do tubo, as tensões residuais determinadas numericamente são originárias apenas do processo de soldagem, não sendo assim razoável comparar de forma acurada as tensões residuais circunferenciais medidas com as simuladas, como se percebe analisando a Figura 6.31.

\subsection{Modelo Numérico da Montagem de Campo}

Este modelo trata do comportamento de dois tubos fabricado pelo do processo UOE e unidos em campo por uma soldagem circunferencial. A fim de simular corretamente o comportamento dos tubos, a fabricação destes também foi simulada. Assim o modelo numérico da fabricação de tubo foi repetido nas duas seções que representam os tubos a serem unidos antes da simulação da união circunferencial. A soldagem longitudinal de fabricação foi simulada como um único cordão de solda depositado de uma só vez, através da hipótese das três barras.

Também foi estudada a influência de duas hipóteses diferentes para a simulação da união circunferencial, a hipótese do único cordão e a dos múltiplos passes de solda (três passes), na variação das distribuições de tensões ao longo da espessura. Todos os cordões de solda foram simulados considerando a hipótese das três barras. Foram testadas apenas duas pressões de teste hidrostático, uma na 
fabricação, 60\% do escoamento, e outra após a soldagem de campo, 90\% do escoamento.

\subsubsection{Geometria do Modelo}

Os espécimes tubulares utilizados para simular os tubos tem diâmetro igual a $323.85 \mathrm{~mm}\left(12 \frac{3 / 4}{}\right.$ "), $9.7 \mathrm{~mm}$ de espessura e $250 \mathrm{~mm}$ de comprimento. A junta soldada longitudinal, de fabricação, tem o formato de $\mathrm{X}$, e ambos os cordões interno e externo foram assumidos como um só. A largura de ambos os cordões de solda foi de $20 \mathrm{~mm}$ e o ângulo do $\mathrm{X}$ foi de $25.8^{\circ}$. A junta circunferencial, de campo, tem formato de $\mathrm{V}$, e o ângulo do $\mathrm{V}$ foi de $90^{\circ}$. A Figura 6.33 mostra a geometria do modelo simulado.

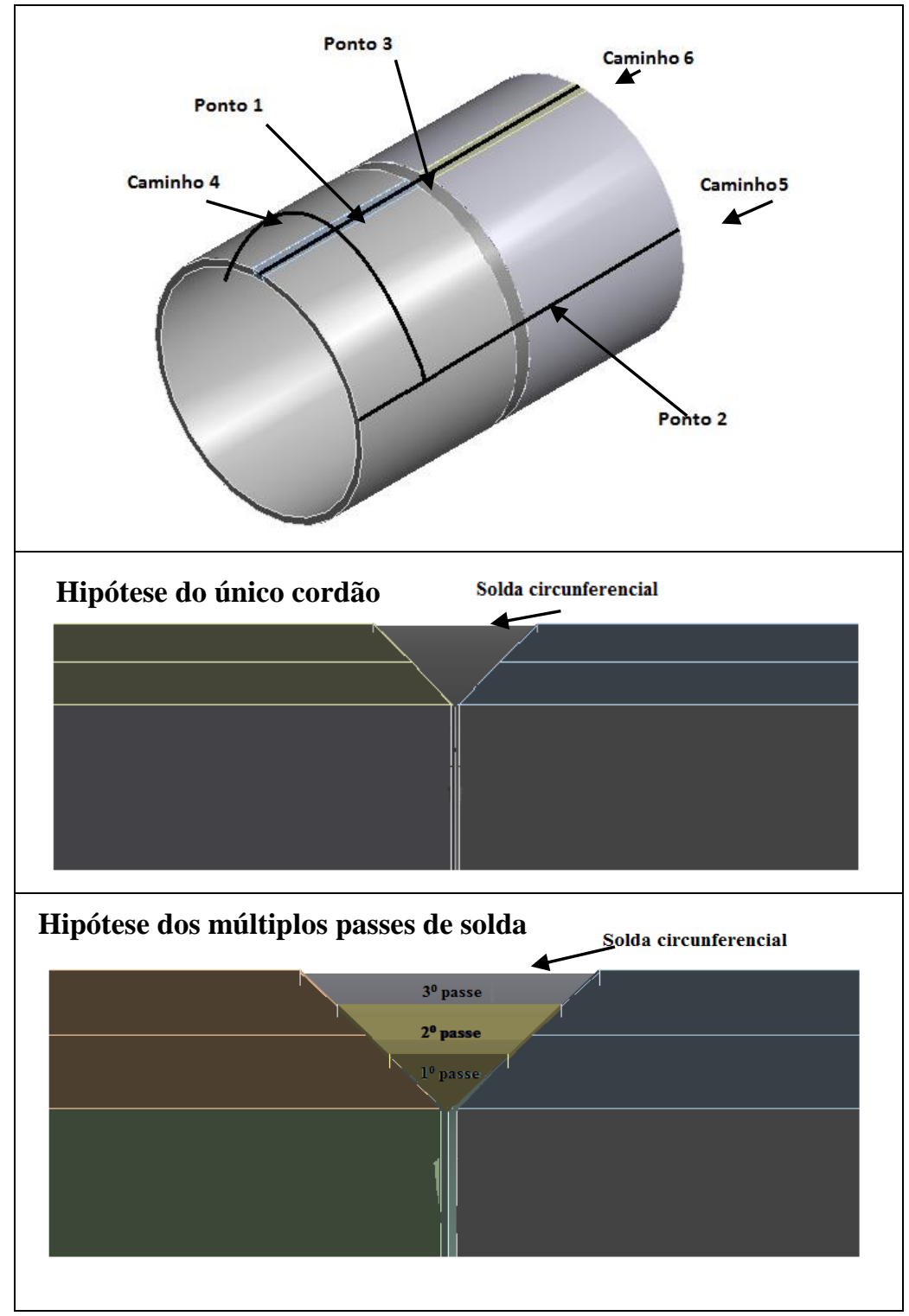

Figura 6.33: Geometria do modelo para simulação da soldagem circunferencial de campo e do teste hidrostático após a união. 


\subsubsection{Malha do Modelo}

As análises foram baseadas nas malhas mostradas nas Figuras 6.33 e 6.34, sendo que ambas as malhas das partes térmica e mecânica foram iguais em cada tipo de simulação, a fim de facilitar a comutação de resultados.

A malha da análise considerando a hipótese do único cordão circunferencial tem 32843 nós e 15623 elementos. O fator qualidade dos elementos, que mede a qualidade de cada elemento, tem valor mínimo igual a 0.11 e valor máximo igual a 0.99 e uma média para todos os elementos igual a 0.81 , com um desvio padrão de 0.08. A razão de aspecto mínima foi de 1.20 e a máxima foi de 36.40 , com média igual a 1.89 e desvio padrão de 0.52 . Na Figura 6.34 são mostradas a malha e os fatores de qualidade da mesma.

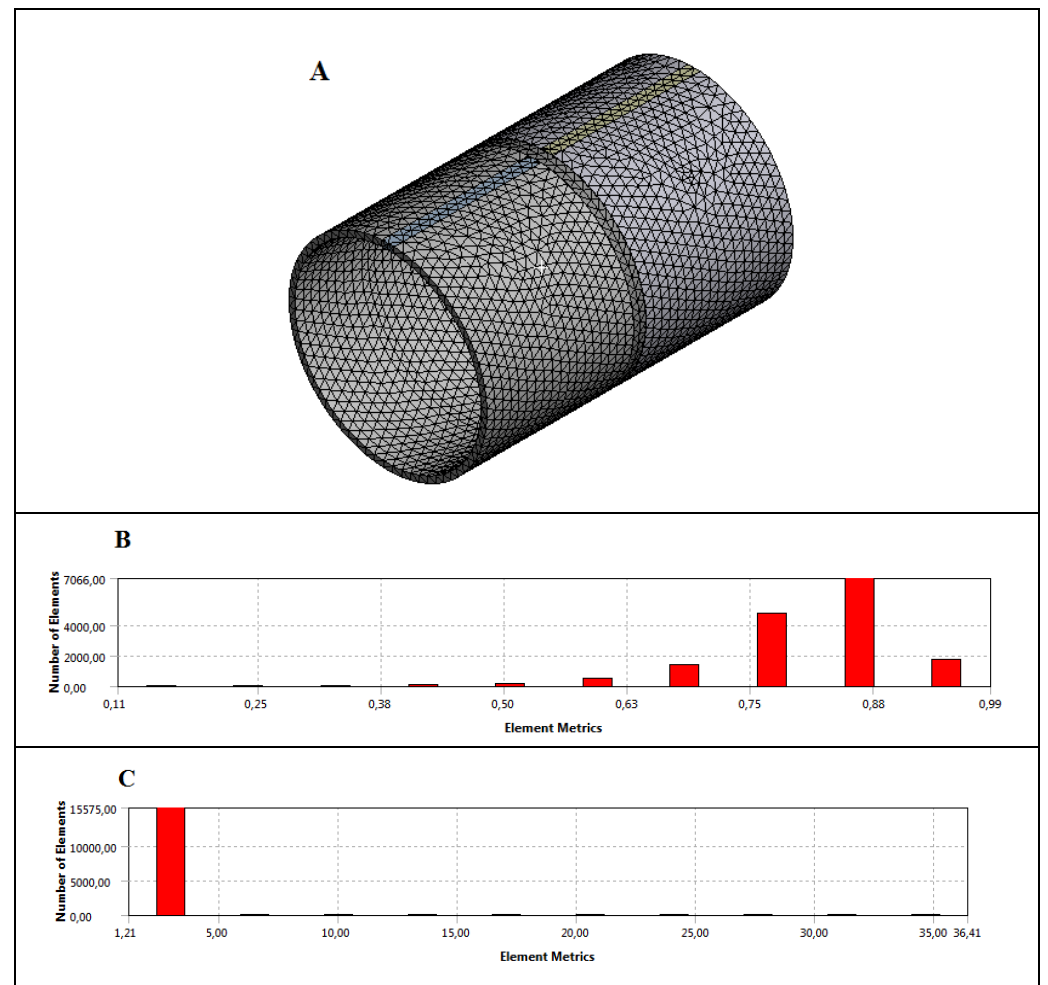

Figura 6.34: Malha da análise considerando o único cordão: a) Malha; b) Histograma da qualidade dos elementos; c) Histograma da razão de aspecto dos elementos.

A malha da análise considerando a hipótese dos múltiplos passes de solda tem 39423 nós e 16245 elementos. O fator qualidade dos elementos, que mede a qualidade de cada elemento, tem valor mínimo igual a 0.11 e valor máximo igual a 0.99 e uma média para todos os elementos igual a 0.80 , com um desvio padrão de 0.10. A razão de aspecto mínima foi de 1.20 e a máxima foi de 36.40 , com média igual a 1.96 e desvio padrão de 0.65 . Na Figura 6.35 são mostradas a malha e os fatores de qualidade da mesma. 


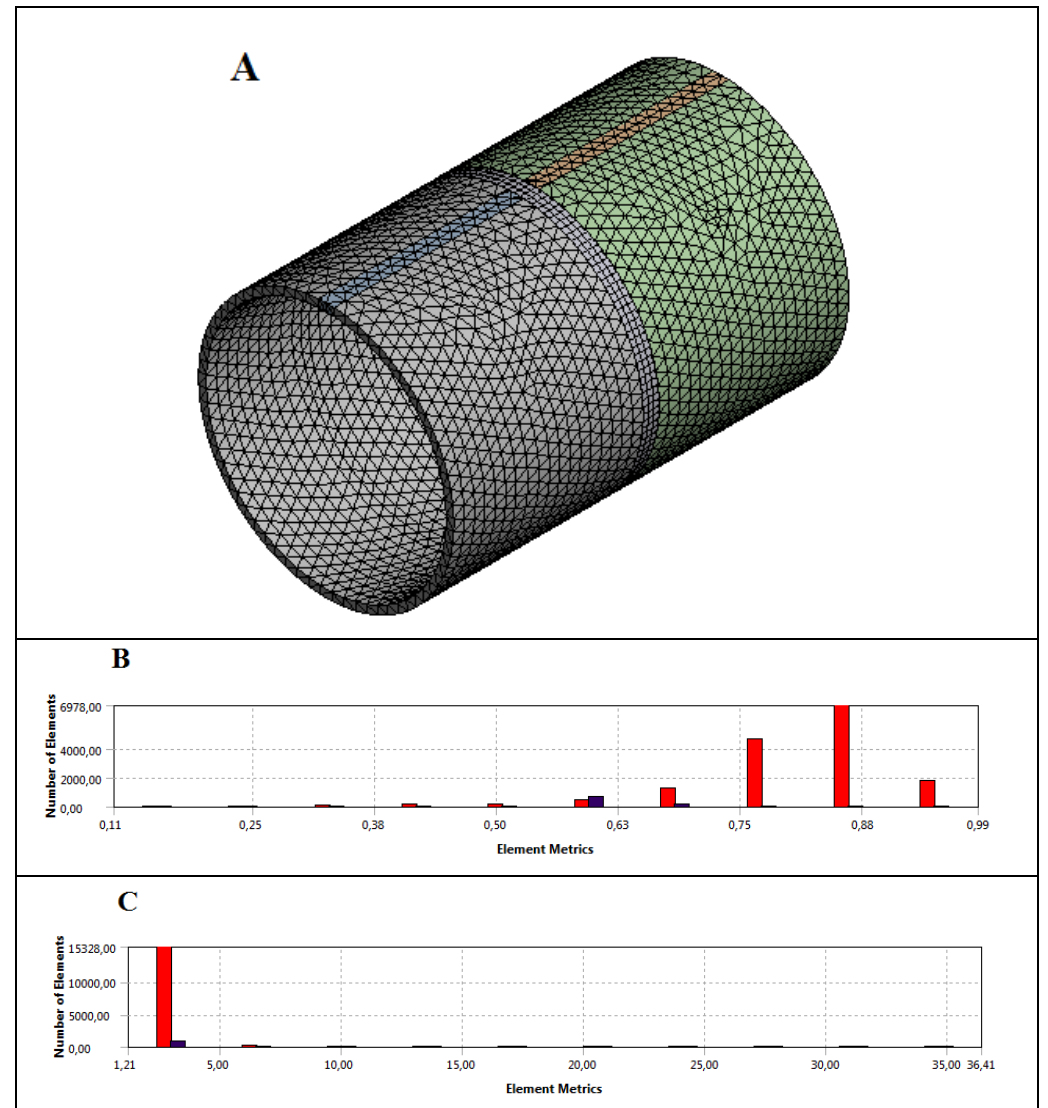

Figura 6.35: Malha da análise considerando múltiplos passes: a) Malha; b) Histograma da qualidade dos elementos; c) Histograma da razão de aspecto dos elementos.

\subsubsection{Configuração dos Passos Tempo}

Foram usados 26 e 36 passos de tempo para as análises que consideram a hipótese do único cordão e múltiplos passes respectivamente. Ambas as análises são iguais até o $18^{\circ}$ passo, término do teste hidrostático de fabricação, a partir desse ponto elas se diferenciam no número de passos utilizados para simular cada passe de solda circunferencial.

$\mathrm{Na}$ simulação da fabricação dos tubos os cordões de solda são representados por uma única barra, o primeiro passo representa a deposição do cordão e tem a duração de 1s. Na simulação com um único cordão circunferencial, a deposição do cordão ocorre no $19^{\circ}$ passo e tem a duração de $1 \mathrm{~s}$.

Para a simulação com múltiplos passes as deposições dos cordões ocorrem nos $19^{\circ}, 24^{\circ}$ e $29^{\circ}$ passos com duração de 1 s cada um. Nos três últimos passos de tempo é simulado o teste hidrostático de campo. A Tabela 6.4 correlaciona cada passo de tempo com sua duração e com o evento que ocorre nele para as duas análises. 
Tabela 6.4: Duração de cada passo de tempo.

\begin{tabular}{|c|c|c|c|c|c|c|}
\hline \multirow[b]{2}{*}{ Passo } & \multicolumn{3}{|c|}{ Hipótese das três barras } & \multicolumn{3}{|c|}{ Hipótese dos múltiplos passes } \\
\hline & Duração (s) & $\begin{array}{l}\text { Tempo ao } \\
\text { Final do } \\
\text { Passo (s) }\end{array}$ & Evento & $\begin{array}{c}\text { Duração } \\
\text { (s) }\end{array}$ & $\begin{array}{c}\text { Tempo ao Final } \\
\text { do Passo (s) }\end{array}$ & Evento \\
\hline $1^{0}$ & 1 & 1 & $\begin{array}{l}\text { Deposição dos } \\
\text { cordões } \\
\text { longitudinais }\end{array}$ & 1 & 1 & $\begin{array}{l}\text { Deposição dos } \\
\text { cordões } \\
\text { longitudinais }\end{array}$ \\
\hline $2^{0}$ & 1 & 2 & - & 1 & 2 & - \\
\hline $3^{0}$ & 1 & 3 & - & 1 & 3 & - \\
\hline $4^{0}$ & 1 & 4 & - & 1 & 4 & - \\
\hline $5^{0}$ & 1 & 5 & - & 1 & 5 & - \\
\hline $6^{0}$ & 1 & 6 & - & 1 & 6 & - \\
\hline $7^{0}$ & 1 & 7 & - & 1 & 7 & - \\
\hline $8^{0}$ & 1 & 8 & - & 1 & 8 & - \\
\hline $9^{0}$ & 1 & 9 & - & 1 & 9 & - \\
\hline $10^{0}$ & 1 & 10 & - & 1 & 10 & - \\
\hline $11^{0}$ & 1 & 11 & - & 1 & 11 & - \\
\hline $12^{0}$ & 1 & 12 & - & 1 & 12 & - \\
\hline $13^{0}$ & 1 & 13 & - & 1 & 13 & - \\
\hline $14^{0}$ & 1 & 14 & - & 1 & 14 & - \\
\hline $15^{0}$ & 4986 & 5000 & - & 4986 & 5000 & - \\
\hline $16^{0}$ & 1 & 5001 & Início do TH & 1 & 5001 & Início do TH \\
\hline $17^{0}$ & 1 & 5002 & $\begin{array}{c}\text { Pressão } \\
\text { Máxima do TH }\end{array}$ & 1 & 5002 & $\begin{array}{c}\text { Pressão Máxima } \\
\text { do TH }\end{array}$ \\
\hline $18^{0}$ & 1 & 5003 & Final do TH & 1 & 5003 & Final do TH \\
\hline $19^{0}$ & 1 & 5004 & $\begin{array}{l}\text { Deposição do } \\
\text { cordão } \\
\text { circunferencial }\end{array}$ & 1 & 5004 & $\begin{array}{c}\text { Deposição do } \\
1^{0} \text { passe } \\
\text { circunferencial }\end{array}$ \\
\hline $20^{\circ}$ & 1 & 5005 & - & 1 & 5005 & - \\
\hline $21^{0}$ & 1 & 5006 & - & 1 & 5006 & - \\
\hline $22^{0}$ & 1 & 5007 & - & 1 & 5007 & - \\
\hline $23^{0}$ & 5008 & 10015 & - & 1000 & 6007 & - \\
\hline $24^{0}$ & 1 & 10016 & Início do TH & 1 & 6008 & $\begin{array}{c}\text { Deposição do } \\
2^{0} \text { passe } \\
\text { circunferencial } \\
\end{array}$ \\
\hline $25^{0}$ & 1 & 10017 & $\begin{array}{c}\text { Pressão } \\
\text { Máxima do TH }\end{array}$ & 1 & 6009 & 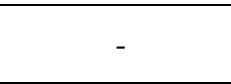 \\
\hline $26^{0}$ & 1 & 10018 & Final do TH & 1 & 6010 & - \\
\hline $27^{0}$ & & & & 1 & 6011 & \\
\hline $28^{0}$ & & & & 1000 & 7011 & - \\
\hline $29^{0}$ & & & & 1 & 7012 & $\begin{array}{l}\text { Deposição do } \\
3^{0} \text { passe } \\
\text { circunferencial }\end{array}$ \\
\hline $30^{\circ}$ & & & & 1 & 7013 & - \\
\hline $31^{0}$ & & & & 1 & 7014 & - \\
\hline $32^{0}$ & & & & 1 & 7015 & - \\
\hline $33^{0}$ & & & & 3000 & 10015 & - \\
\hline $34^{0}$ & & & & 1 & 10016 & Início do TH \\
\hline $35^{0}$ & & & & 1 & 10017 & $\begin{array}{c}\text { Pressão Máxima } \\
\text { do TH }\end{array}$ \\
\hline $36^{0}$ & & & & 1 & 10018 & Final do TH \\
\hline
\end{tabular}




\subsubsection{Condições de Contorno Térmicas}

As simulações da fabricação dos tubos seguem os mesmos parâmetros do item 6.4.4. O aporte de calor foi modelado como um carregamento na simulação térmica. A soldagem se inicia com o cordão de solda sendo depositado na temperatura de fusão do metal, como uma condição de temperatura. A temperatura do cordão de solda foi escolhida igual a temperatura de fusão do material uma vez que se desconhecem as variáveis da soldagem. Após a deposição dos cordões longitudinais, são aplicadas as condições de contorno térmicas nos tubos, convecção no interior do tubo igual a $10 \mathrm{~W} / \mathrm{m}^{2} \mathrm{~K}$ e no exterior igual a 25 $\mathrm{W} / \mathrm{m}^{2} \mathrm{~K}$, não sendo considerados os efeitos da radiação térmica. Essas condições de contornos ficam ativas até os tubos trocarem todo o calor e retornarem ao equilíbrio com a temperatura ambiente de $22{ }^{\circ} \mathrm{C}$ em $5003 \mathrm{~s}$.

Nas simulações da montagem de campo a deposição dos cordões ou do único cordão circunferencial obedece à configuração apresentada na Tabela 6.4. Cada cordão se comporta como uma única barra, entretanto na hipótese dos múltiplos passes, três cordões são usados para formar a junta soldada. Em ambas as hipóteses são aplicadas condições de contorno térmicas a partir do $19^{\circ}$ passo, uma convecção externa igual a $50 \mathrm{~W} / \mathrm{m}^{2} \mathrm{~K}$ e outra interna de $20 \mathrm{~W} / \mathrm{m}^{2} \mathrm{~K}$, com finalidade de simular as condições de contorno do ambiente da soldagem em campo.

\subsubsection{Condições de Contorno Mecânicas}

A história de temperaturas que foi obtida na análise térmica transiente é transformada em um carregamento térmico no modelo estrutural. Os gradientes provocam severas deformações plásticas no modelo.

Não foram aplicadas ao tubo restrições ao deslocamento nos tubos, porém foi utilizada a condição de "Weak Springs" para impedir o movimento de corpo rígido.

Nos passos $16^{\circ}, 17^{\circ}$ e $18^{\circ}$ ocorre o teste hidrostático de fabricação, sendo a pressão máxima atingida no passo do meio, e nos três últimos passos de cada análise foi realizado o teste hidrostático de campo. As pressões utilizadas em ambas as análises foram as mesmas, 60\% do SMYS na direção circunferencial no teste de fabricação e $90 \%$ do SYMS na direção circunferencial no teste de campo. 


\subsubsection{Resultados}

O comportamento dos tubos durante sua fabricação é o mesmo apresentado pelo item 6.4.8 para a hipótese das três barras, no entanto a fabricação é apenas metade da simulação e dura até o instante de 5003s.

A transferência de calor para o meio e pelos tubos foi modelada utilizando as variáveis apresentadas no item 6.5.4. Todo o aporte térmico se dá através do cordão de solda, inicialmente os cordões se encontram dilatados e à temperatura de fusão do metal, à medida que a simulação transcorre ele passa a trocar calor com o meio e com as demais regiões do tubo. O calor é trocado por convecção para o ambiente através de dois pares de coeficientes de troca de calor por convecção, dois de fabricação e dois de campo.

A Figura 6.36 apresenta a distribuição de temperaturas nos tubos para a análise do único cordão circunferencial no instante de 1s de simulação, logo após o término da soldagem de fabricação e início da transferência de calor para o meio. Entretanto, essa Figura também representa a distribuição de temperaturas em 1s para a análise dos múltiplos passes, já que nesse instante as duas análises são iguais.

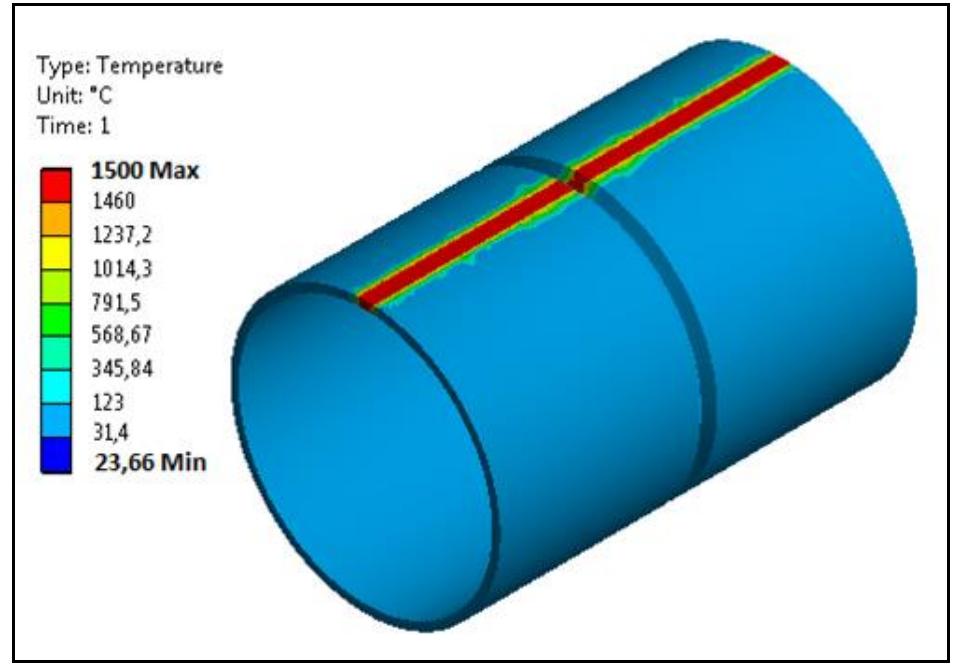

Figura 6.36: Distribuição de temperaturas nos tubos para as duas hipóteses no instante de 1s de simulação.

Pode se perceber que a Figura 6.36 é semelhante à Figura 6.14, as temperaturas das regiões próximas aos cordões de solda longitudinais são bastante elevadas, essa distribuição de temperaturas altas no entorno do cordão de solda tem como função compensar o calor trocado entre a junta e a coluna de plasma. 
Na Figura 6.37 é mostrada a evolução da temperatura no Ponto 1, localizado na superfície externa do tubo e na região central do cordão de solda longitudinal, ao longo do tempo para a hipótese do único cordão. O calor presente no cordão é trocado com o meio e difundido para o interior do tubo até o instante de 5003s, quando a temperatura entra em equilíbrio com a temperatura ambiente. Após esse instante, ocorre a deposição do cordão de solda circunferencial, a dissipação do calor contido nesse cordão provoca um pequeno aquecimento do material localizado no Ponto 1, como é mostrado pela curva a partir do instante de 5003s. A temperatura nesse ponto retorna ao equilíbrio no tempo de $10018 \mathrm{~s}$ de simulação.

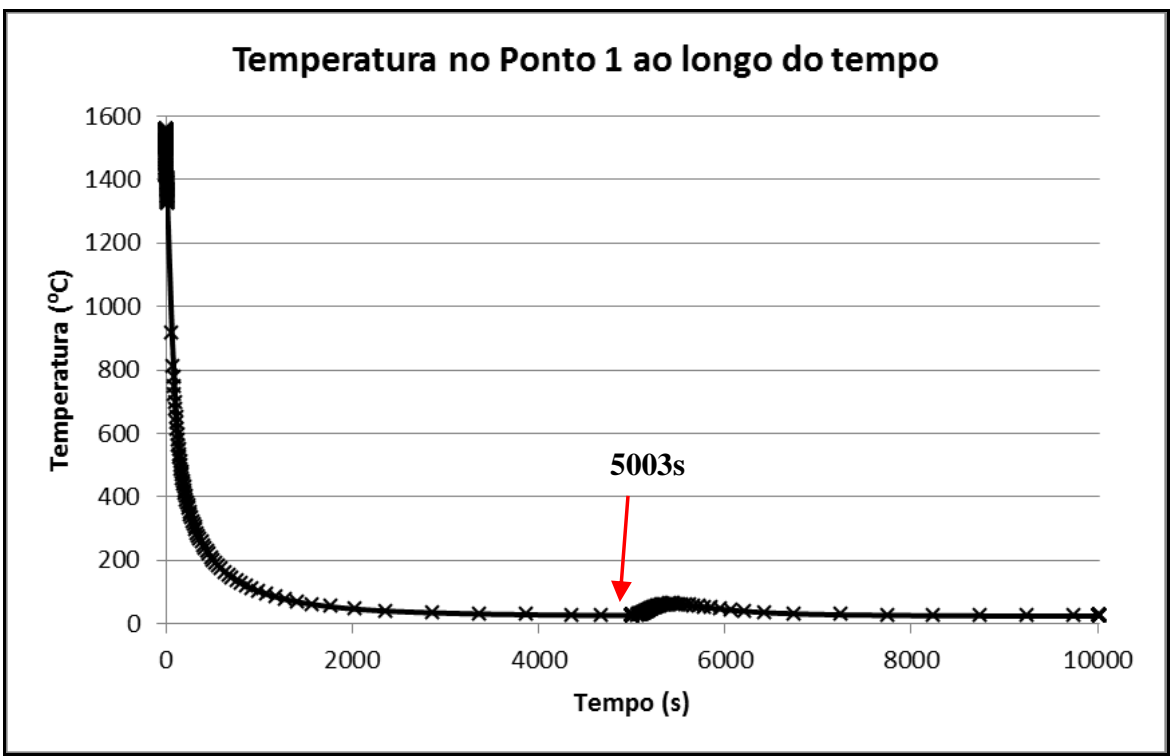

Figura 6.37: Temperatura no Ponto 1 ao longo do tempo para a hipótese do único cordão.

Quando as simulações atingem 5003s todo o calor fornecido aos tubos durante a soldagem de fabricação se dissipou para o meio e os espécimes estão em equilíbrio térmico com o ambiente á temperatura de $22^{\circ} \mathrm{C}$, assim como mostrado na Figura 6.38. 


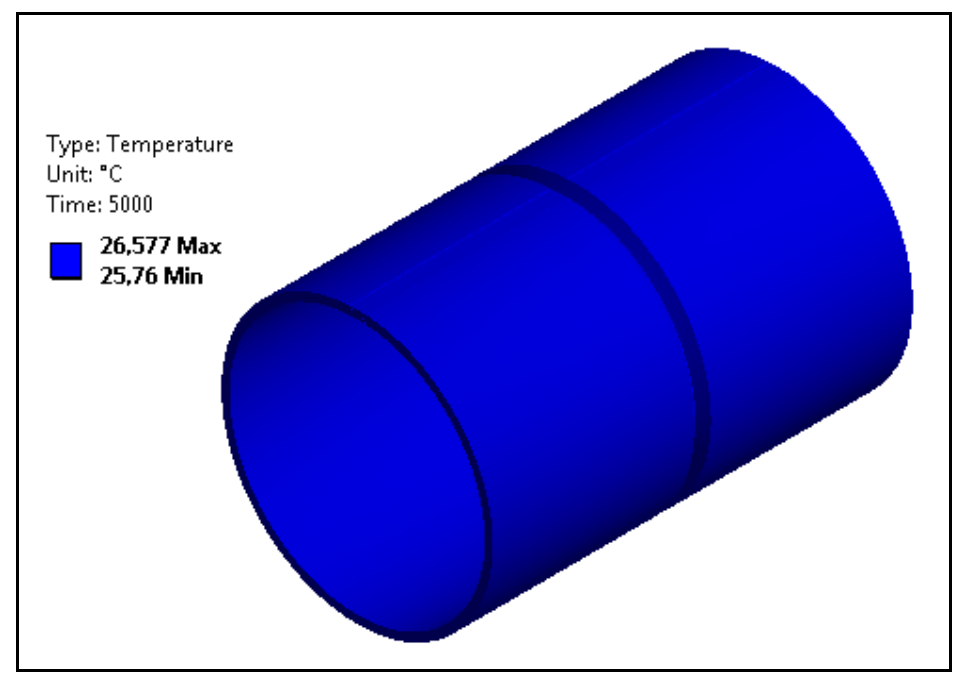

Figura 6.38: Distribuição de temperatura nos tubos para ambas as análises no instante de 5003s.

Na análise que utiliza a hipótese do único cordão de solda circunferencial, que une as seções tubulares, a deposição da solda ocorre de uma só vez, toda a junta é preenchida simultaneamente pelo metal de solda. Essa consideração que todo o cordão é depositado ao mesmo tempo não gera prejuízo para a simulação visto que na prática são usados dois arcos elétricos ao mesmo tempo para evitar empenamentos e diminuir o tempo de soldagem.

A Figura 6.39 apresenta a distribuição de temperaturas na linha de transporte para a análise do único cordão circunferencial no instante de 5004s de simulação, logo após o término da soldagem de campo e início da transferência de calor para o meio.

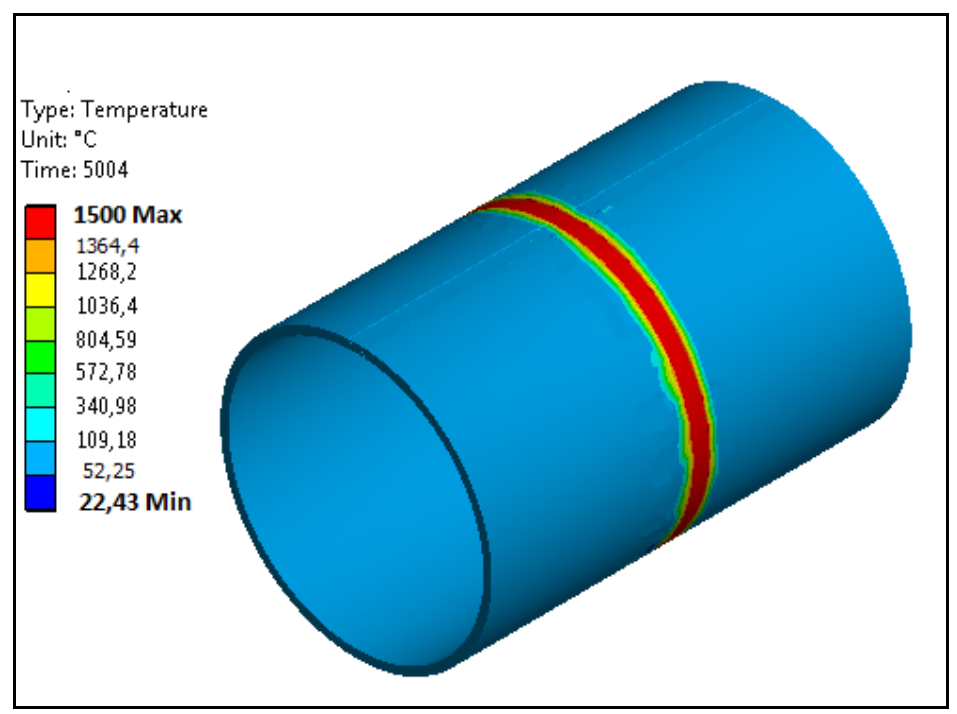

Figura 6.39: Distribuição de temperaturas na linha de transporte para a hipótese do único cordão no instante de 5004s de simulação. 
Semelhante aos cordões longitudinais, as regiões próximas ao cordão circunferencial apresentam temperaturas bastante elevadas e são responsáveis pela formação de uma nova ZTA, que modifica a existente próxima aos cordões longitudinais.

A Figura 6.40 mostra a evolução da temperatura no Ponto 2, localizado na superfície externa do cordão de solda circunferencial, ao longo do tempo para a hipótese do único cordão. Como a união circunferencial ocorre apenas no $19^{0}$ passo de simulação não existe histórico de temperaturas para esse ponto em instantes anteriores à soldagem de campo, assim os valores partem de 5004 no eixo das abscissas. A temperatura nesse ponto retorna ao equilíbrio no tempo de 10018s de simulação, após todo o calor contido no cordão ser dissipado.

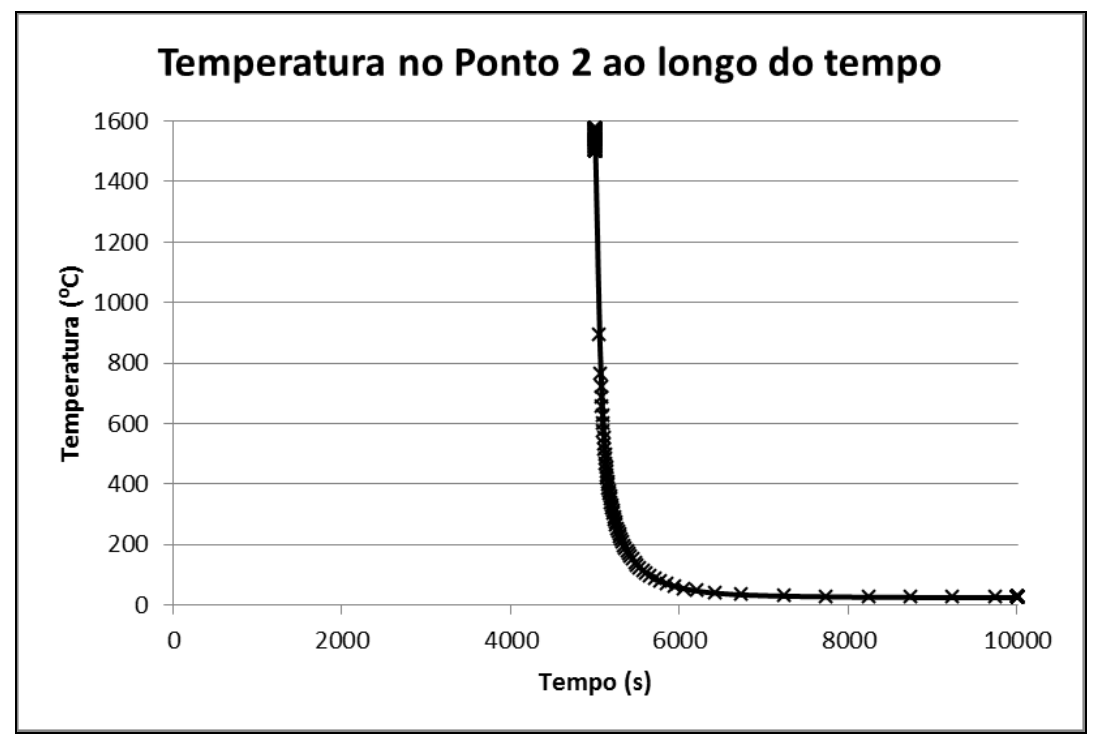

Figura 6.40: Temperatura no Ponto 2 ao longo do tempo para a hipótese do único cordão.

Analisando o Ponto 3, localizado na superfície de um dos cordões longitudinais, mas no entanto próximo a união circunferencial, percebe-se que quando a soldagem de campo acontece as regiões próximas são aquecidas até temperaturas da ordem de $500{ }^{0} \mathrm{C}$, como mostrado pela Figura 6.41. Esse aquecimento provoca o surgimento de uma ZTA no entorno do cordão circunferencial, e também a modificação da ZTA formada a partir das soldagens de fabricação. 


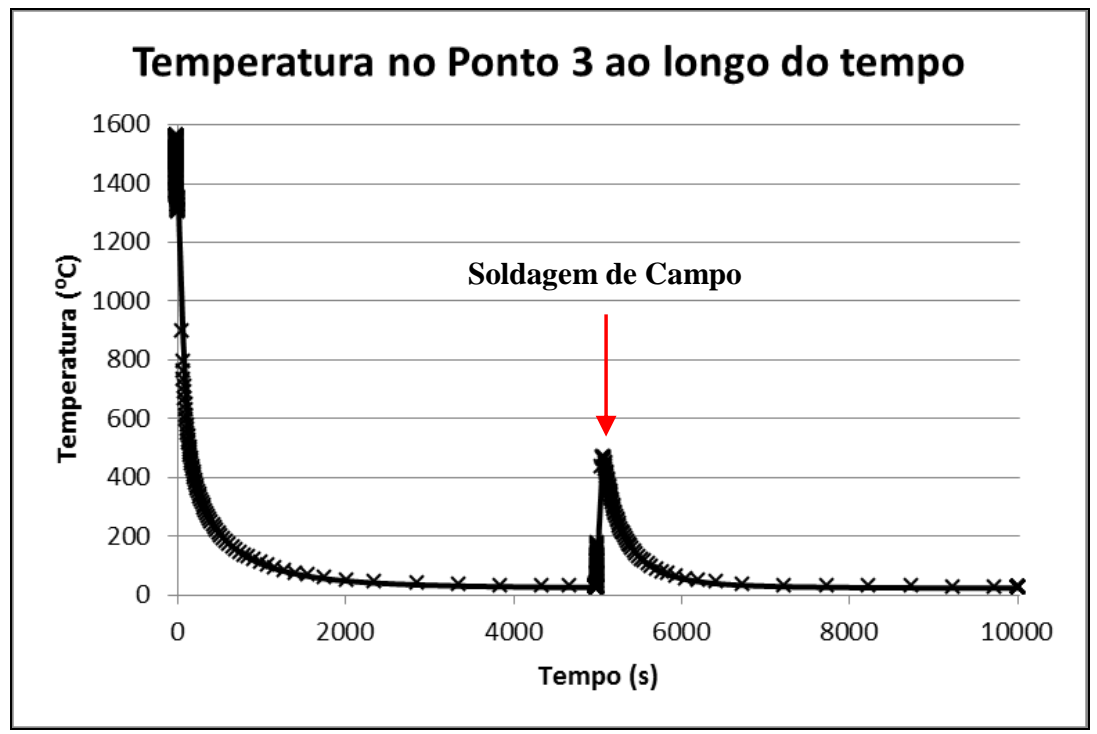

Figura 6.41: Temperatura no Ponto 3 ao longo do tempo para a hipótese do único cordão.

Na hipótese dos múltiplos passes de solda para formação da junta, cada novo passe depositado provoca um novo aquecimento, visto que são três aportes diferentes. Deste modo os gradientes térmicos e o comportamento mecânico da linha de transporte montada a partir da hipótese do único cordão e a partir da hipótese dos múltiplos cordões serão diferentes entre si.

A Figura 6.42 apresenta as temperaturas máximas em toda a análise ao longo do tempo para a hipótese dos múltiplos cordões. Cada pico de temperatura representa a deposição de um novo passe de solda. O tempo médio para a temperatura máxima entrar em equilíbrio com o ambiente é de 1000s, sendo 10018 s o instante de tempo em que toda a linha se encontra a $22{ }^{\circ} \mathrm{C}$.

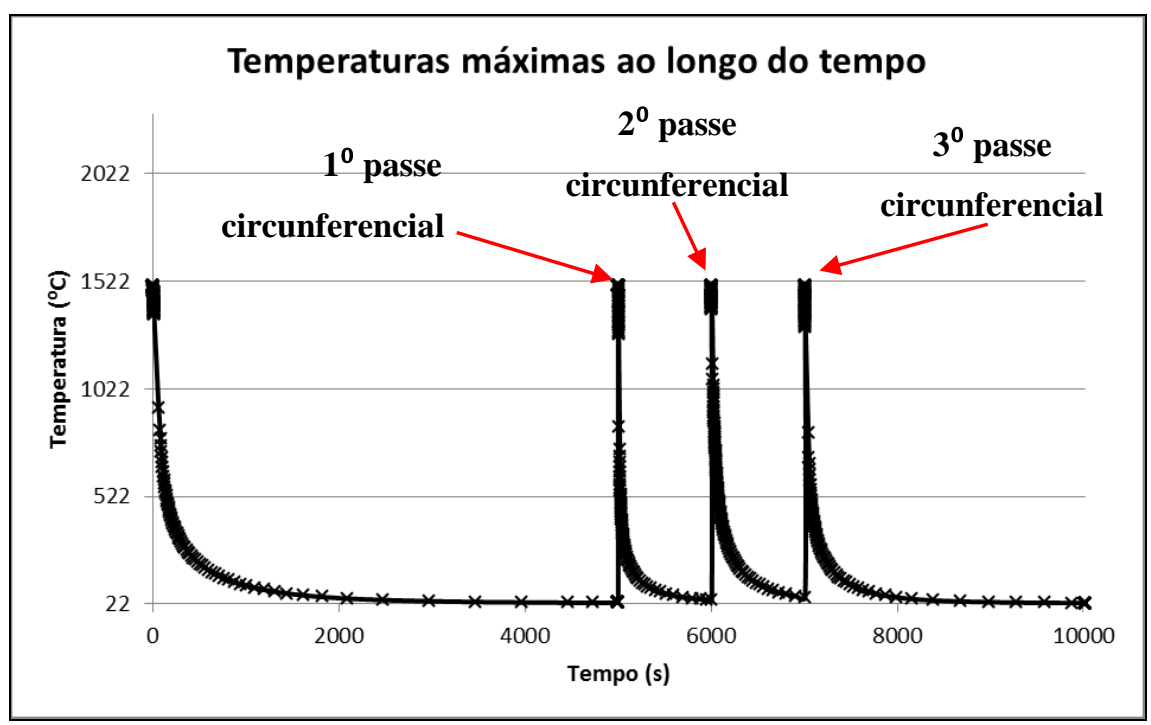

Figura 6.42: Temperaturas máximas ao longo do tempo para a hipótese dos múltiplos cordões de solda. 
As Figuras 6.43 e 6.44 apresentam a distribuição de temperaturas na junta durante a soldagem circunferencial para as hipóteses do único cordão e dos múltiplos passes respectivamente. Os ciclos térmicos provocados pela sobreposição de cordões de solda sobre os cordões previamente depositados funcionam como um tratamento de revenimento. A deposição de um novo cordão de solda sobre um antigo age como um tratamento de alívio mecânico, como citado no item 4.6.

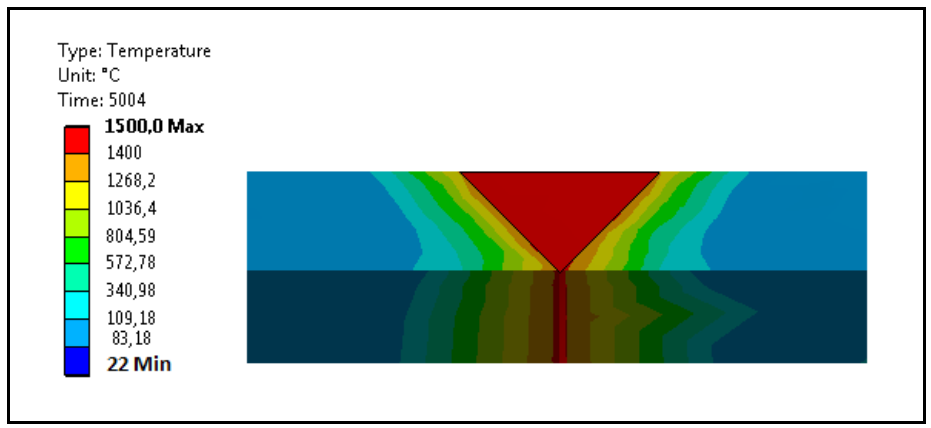

Figura 6.43: Distribuição de temperaturas na junta para a hipótese do único cordão de solda.

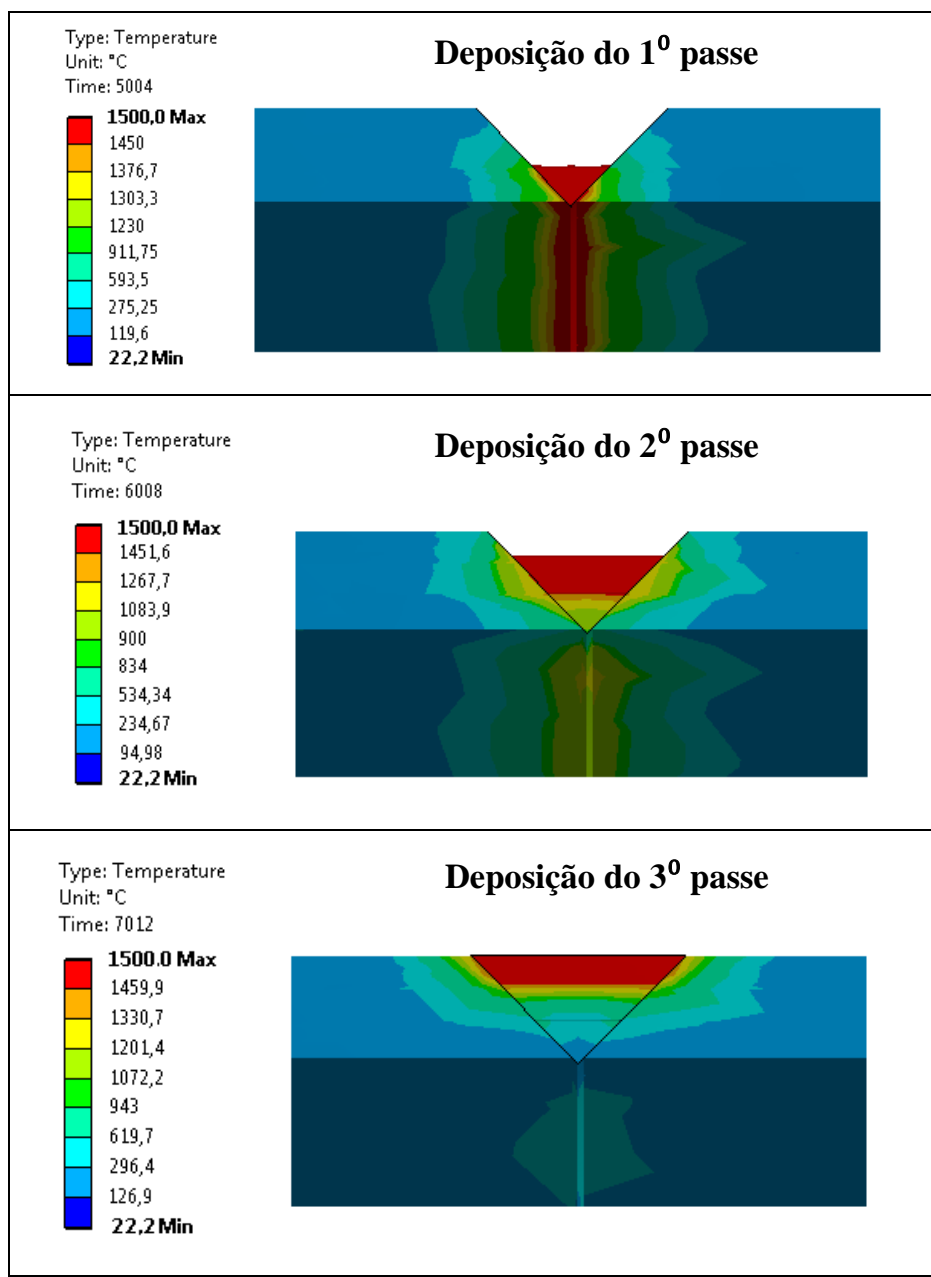

Figura 6.44: Distribuição de temperaturas na junta para a hipótese dos múltiplos passes. 
Comparando as Figuras acima, observa-se que os gradientes térmicos produzidos pela deposição de um único cordão são bem mais severos do que os gerados a partir da deposição gradual de diversos passes de solda. Consequentemente são esperadas maiores magnitudes de tensões residuais para a hipótese do único cordão de solda circunferencial

Quando as análises atingem 10015s todo o calor fornecido a linha durante as soldagens se dissipou para o meio e todo o espécime retorna ao equilíbrio térmico com a temperatura ambiente de $22^{\circ} \mathrm{C}$, como mostrado na Figura 6.45.

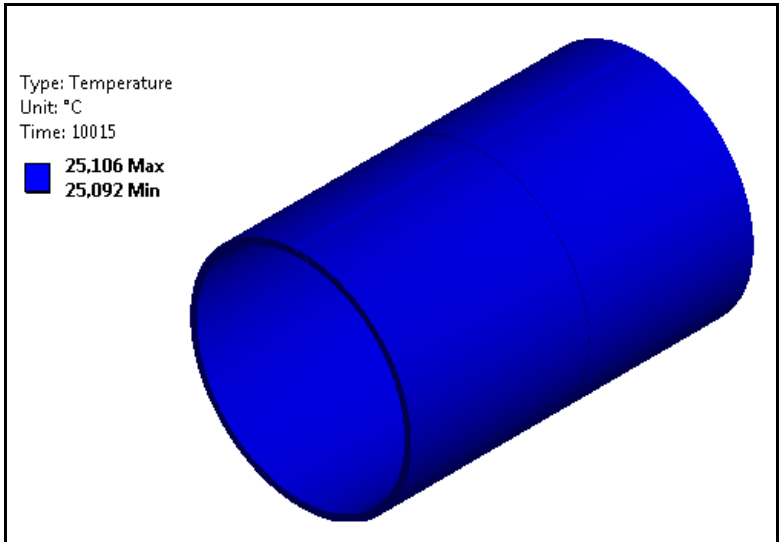

Figura 6.45: Distribuição de temperatura para ambas as análises no instante de 10018s.

O comportamento mecânico dos tubos, que serão unidos para formação da linha de transporte, após a soldagem longitudinal de fabricação é similar ao comportamento do tubo simulado no modelo da fabricação com a hipótese das três barras. A Figura 6.46, abaixo, compara as tensões residuais equivalentes nos modelos para o instante de tempo onde ocorre o equilíbrio térmico. Percebe-se que embora os espécimes tenham comprimentos diferentes, a distribuição de tensões nas bordas e na região central dos dois modelos é semelhante.

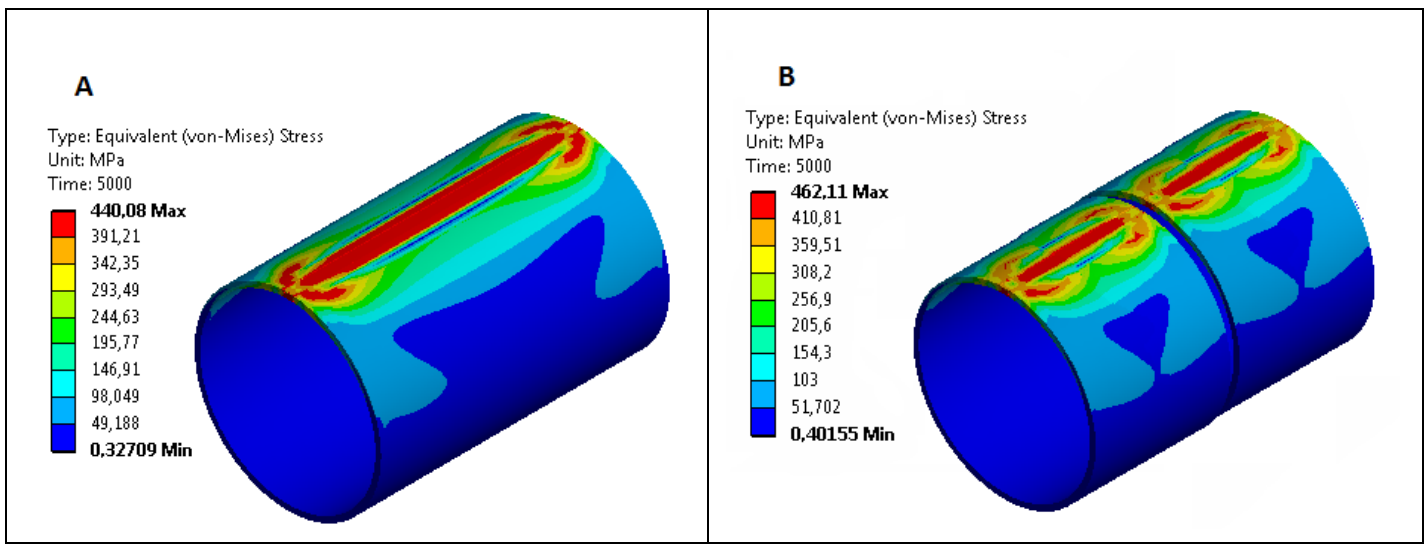

Figura 6.46: Comparação das distribuições de tensões equivalentes no modelo da fabricação do tubo com a hipótese das três barras e nos modelos de montagem de campo no tempo de 5000s. 
$\mathrm{Na}$ soldagem de campo os gradientes térmicos que surgem durante o processo de união provocam principalmente na direção circunferencial deformações plásticas acentuadas. Essa direção é a que representa a maior resistência ao deslocamento das áreas diferentemente aquecidas durante a soldagem circunferencial. Pode-se dizer que essa direção é a direção longitudinal da soldagem, pois considerando a hipótese das três barras, cada tubo representa uma das barras da extremidade e o cordão a barra do meio, assim a soldagem acontece na direção longitudinal das barras.

A Figura 6.47 apresenta as distribuições das tensões residuais na linha de transporte após a soldagem de campo, no instante de 10016s, considerando a hipótese do único cordão.

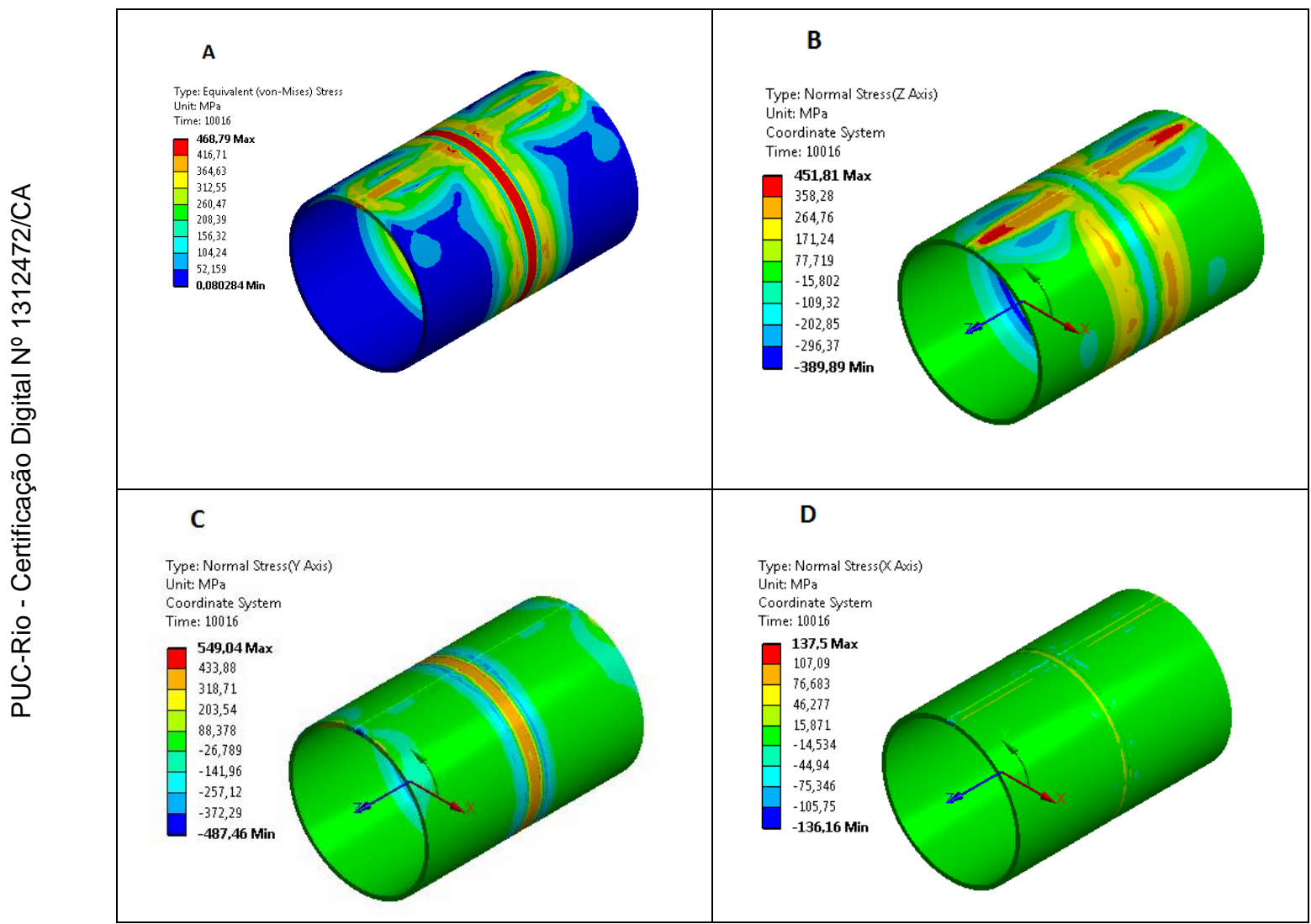

Figura 6.47: Distribuição de tensões residuais após a soldagem de campo considerando a hipótese do único cordão: a)Tensões equivalentes; b) Tensões longitudinais; c) Tensões circunferenciais;

d) Tensões radiais.

A tensão equivalente residual, Figura 6.47 a, no cordão circunferencial tem magnitude igual ao limite de escoamento do material. Próximo aos cordões de solda e em seu entorno estão localizadas as maiores tensões equivalentes, enquanto que nas regiões mais distantes das juntas as tensões são aproximadamente zero. 
A deposição do cordão circunferencial provoca uma redistribuição de tensões residuais nos tubos nas regiões adjacentes a junta circunferencial.

As tensões residuais longitudinais após a soldagem de campo, Figura $6.47 \mathrm{~b}$, tem valores elevados, próximos ao limite de escoamento, nos cordões longitudinais, porém nesses cordões a região próxima à junta circunferencial sofreu um alívio de tensões provocado pelos ciclos térmicos da soldagem de campo.

As tensões residuais circunferenciais são as que apresentam as maiores magnitudes após a soldagem de campo. Como citado anteriormente é na direção circunferencial que existem as maiores restrições as deformações impostas pela soldagem, logo as maiores tensões residuais irão surgir nessa orientação.

As tensões residuais radiais da linha são baixas e podem ser desconsideradas na análise. As deformações nessa direção são muito pequenas não influenciando no comportamento do tubo.

A Figura 6.48 apresenta as distribuição de tensões residuais ao longo do Caminho 4 em 10016s, após terminado o processo de fabricação dos tubos e terminada a soldagem de campo, para a hipótese do único cordão.

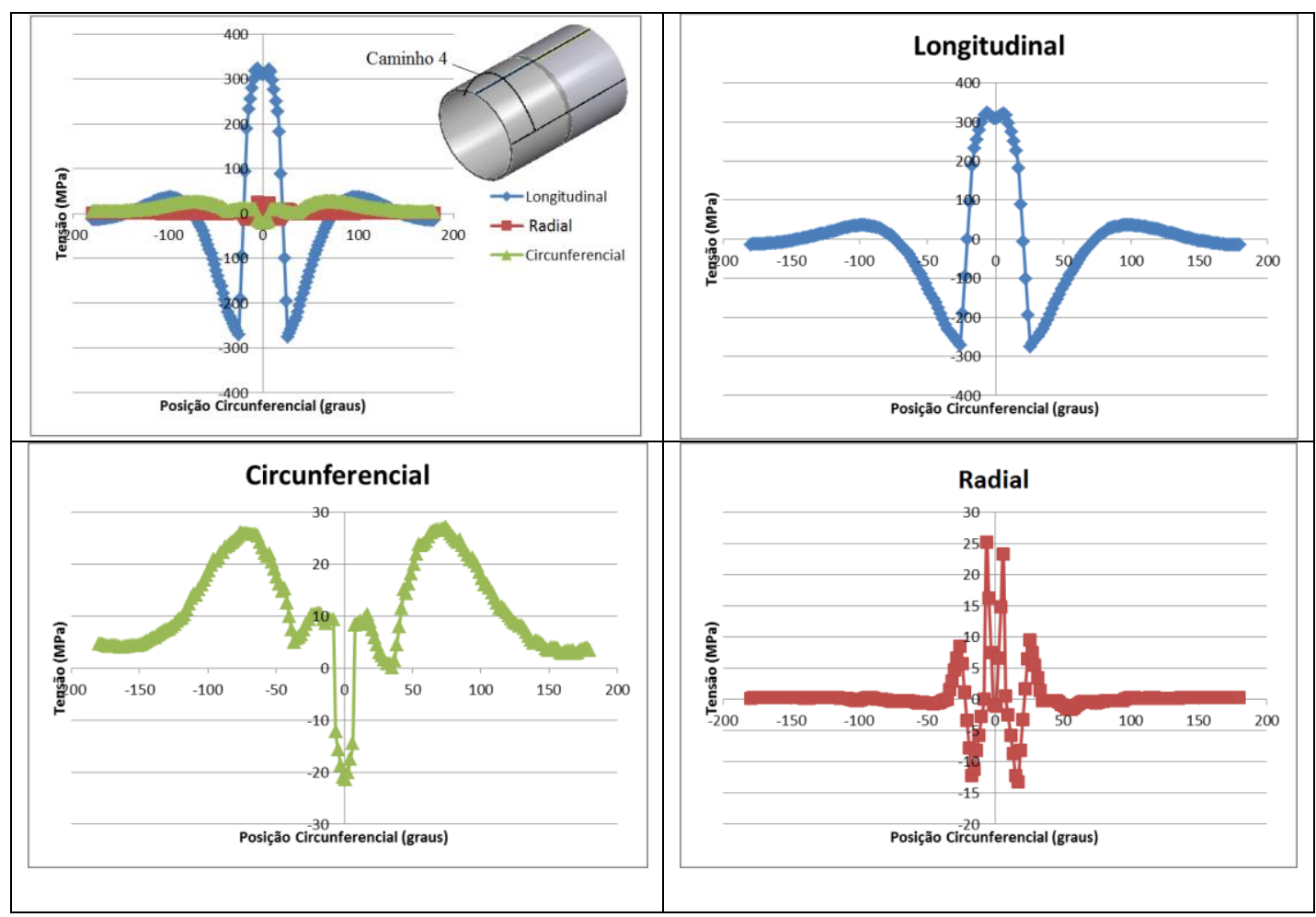

Figura 6.48: Distribuição de tensões residuais no Caminho 4 em 10016s, para a hipótese do único cordão. 
Analisando a Figura 6.48, pode se concluir que no Caminho 4, posição mais distante da junta circunferencial, a soldagem de campo tem pouca influência na distribuição de tensões residuais geradas pela fabricação do tubo. A tensão na direção longitudinal se comparada com as demais é a mais significativa, ela é trativa no cordão de solda longitudinal e compressiva nas suas adjacências. A tensão circunferencial, é compressiva na região do cordão de solda e trativa nas demais posições do tubo. Já tensão radial é muito pequena e localizada na região do cordão de solda. Essas distribuiç̧ões de tensões residuais são semelhantes às apresentadas na Figura 6.22.

A Figura 6.49 apresenta as distribuição de tensões residuais ao longo do Caminho 5, em 10016s, para a hipótese do único cordão de solda. A tensão residual circunferencial nesse caminho apresenta magnitude trativa no cordão de solda e compressiva em sua vizinhança. Por sua vez a tensão longitudinal passa a se comportar como a tensão circunferencial nos cordões longitudinais durante a fabricação dos tubos, apresentando compressão no cordão e tração nas suas proximidades.

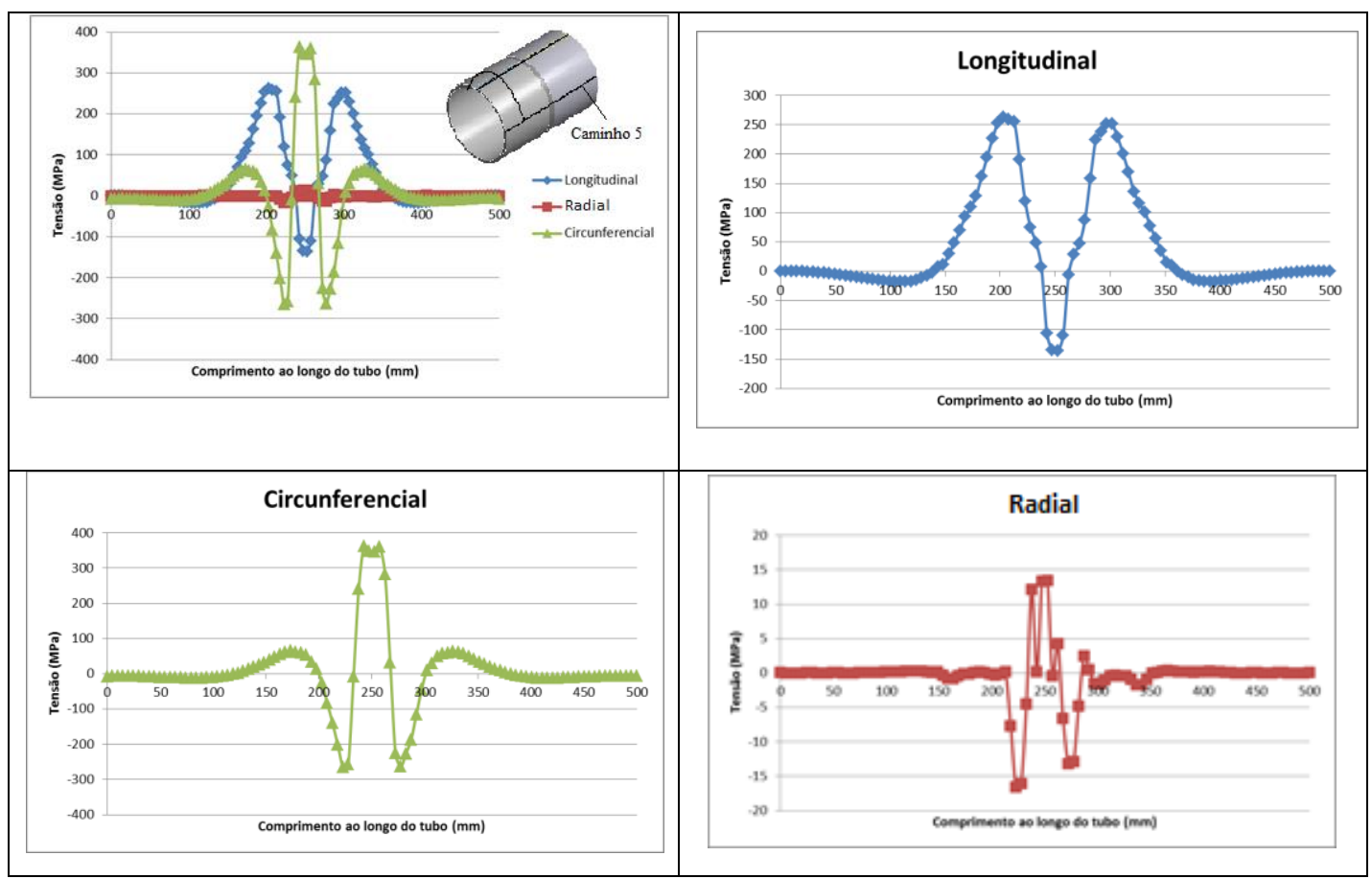

Figura 6.49: Distribuição de tensões residuais no Caminho 5 em 10016s, para a hipótese do único cordão. 
A Figura 6.50 apresenta as distribuição de tensões residuais ao longo do Caminho 6, em 10016s, para a hipótese do único cordão de solda. Observa-se que a soldagem circunferencial provoca um alívio de tensões longitudinais nos cordões longitudinais, posto que na região central as tensões decrescem para valores abaixo do limite de escoamento do material. Na direção circunferencial as tensões são trativas na união circunferencial e compressivas auto-equilibrantes nos tubos.

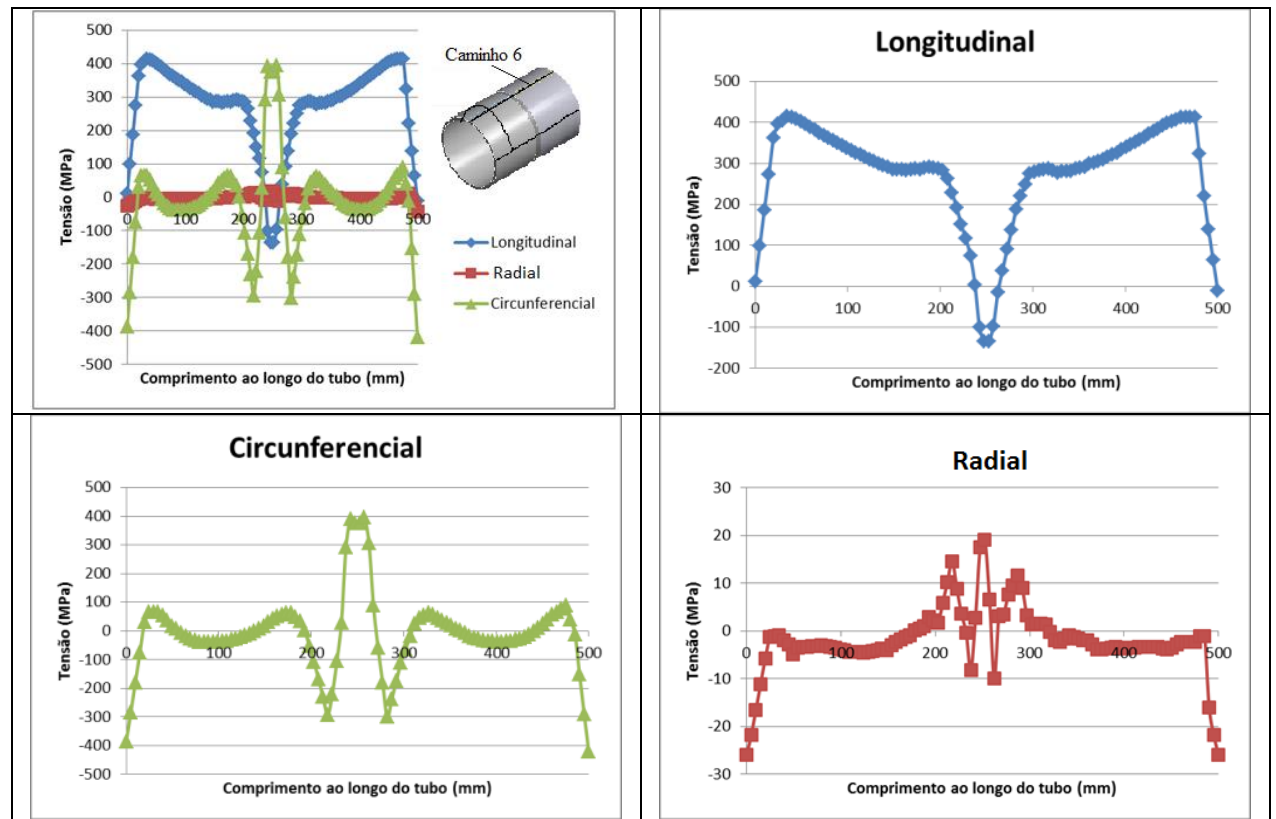

Figura 6.50: Distribuição de tensões residuais no Caminho 6 em 10016s, para a hipótese do único cordão.

No instante de tempo de 10017 s é realizado o teste hidrostático de campo que tem por finalidade testar a integridade e a estanqueidade da linha. A pressão escolhida para o teste hidrostático provoca um esforço igual a $90 \%$ do limite de escoamento na direção circunferencial, tendo valor igual a $22.64 \mathrm{MPa}$.

A Figura 6.51 apresenta as distribuições de tensões na linha durante a realização do teste hidrostático com pressão que causa $90 \%$ do escoamento na direção circunferencial, considerando a hipótese do único cordão, para os Caminhos 4, 5 e 6. 


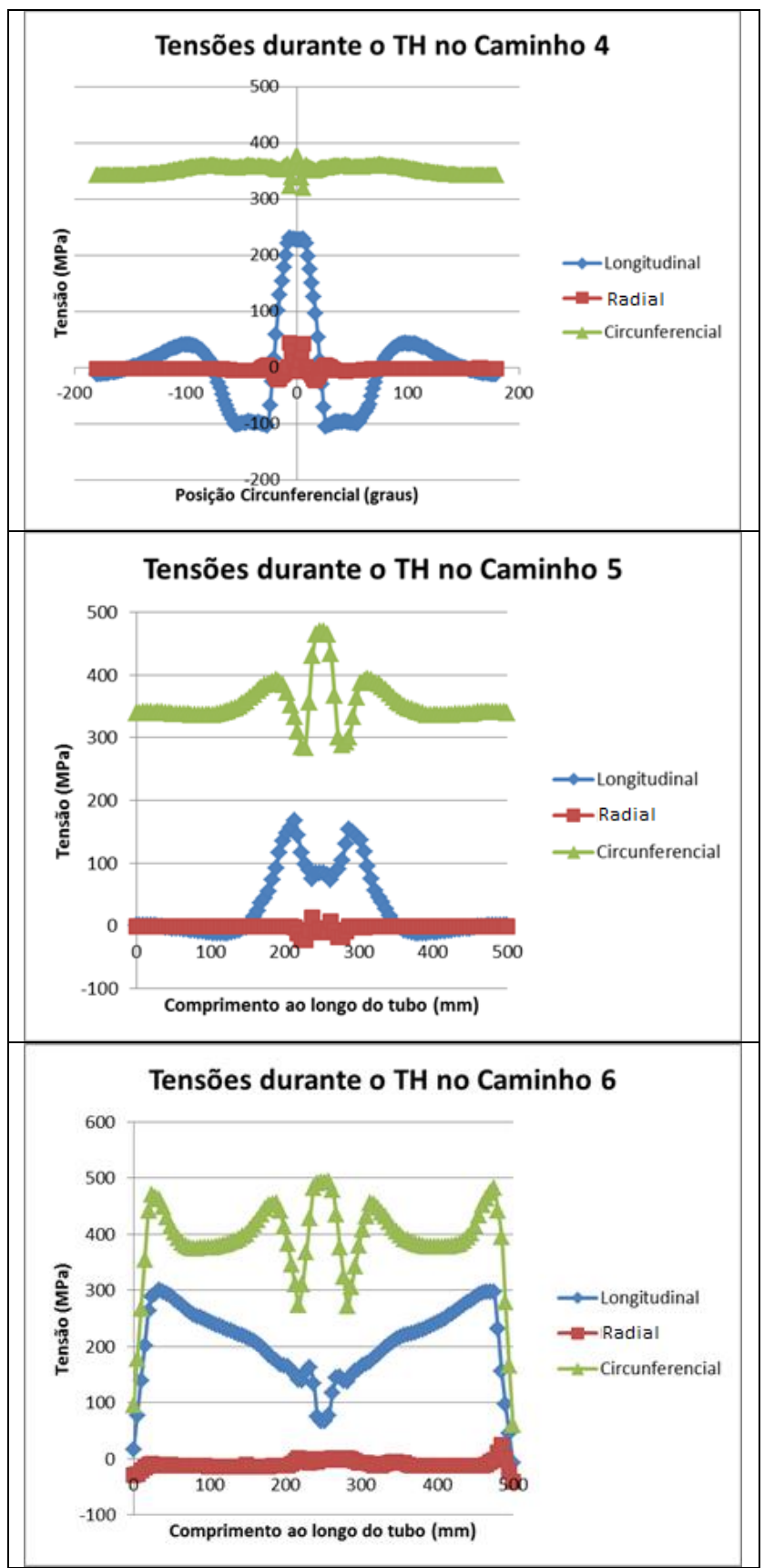

Figura 6.51: Distribuição de tensões nos Caminhos 4, 5 e 6 durante a realização do teste hidrostático de campo, para a hipótese do único cordão.

Em todos os caminhos a tensão circunferencial é a que sofre maior influência da pressão interna, atingindo valores próximos ao limite de ruptura do material, logo é nessa direção que é esperado o maior alívio de tensões.

A Figura 6.52 apresenta as tensões residuais antes e depois da realização do teste hidrostático de campo no Caminho 4, para a hipótese do único cordão. 


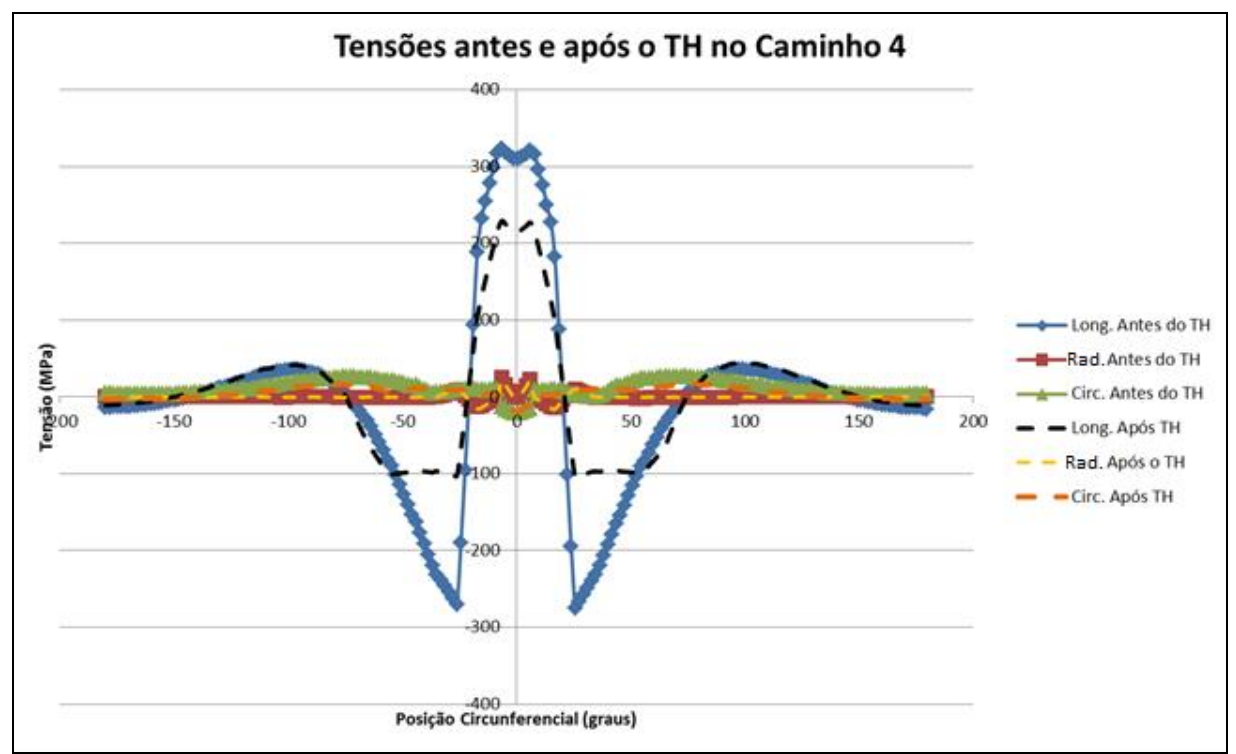

Figura 6.52: Distribuição de tensões residuais antes e após a realização do teste hidrostático de campo no Caminho 4, para a hipótese do único cordão.

Embora a tensão longitudinal não seja a mais afetada pelo teste hidrostático, ela é a que apresenta o maior alívio, cerca de $100 \mathrm{MPa}$ no cordão de solda. Vale ressaltar que esse é o segundo alívio mecânico que esse Caminho sofreu ao longo da simulação. As tensões longitudinais no cordão, após a soldagem de fabricação, apresentavam magnitudes em torno do limite de escoamento do material, no entanto após esse segundo teste hidrostático apresentam valores equivalentes à metade do limite de escoamento do material. Embora o alívio de tensões também ocorra nas direções circunferencial e radial devido a suas baixas magnitudes suas distribuições não tem influencia considerável no comportamento da linha.

A Figura 6.53 apresenta as tensões residuais antes e depois da realização do teste hidrostático de campo no Caminho 5, para a hipótese do único cordão. 


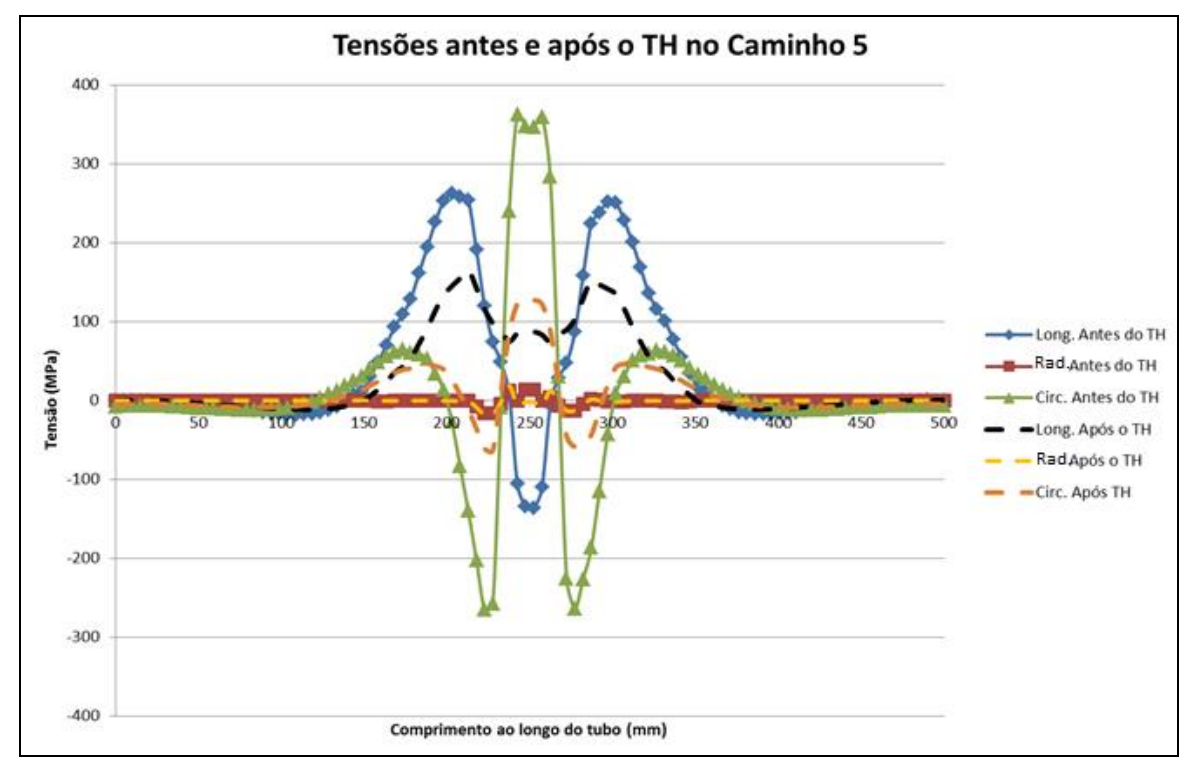

Figura 6.53: Distribuição de tensões residuais antes e após a realização do teste hidrostático de campo no Caminho 5, para a hipótese do único cordão.

No Caminho 5, a tensão circunferencial é a que sofre o maior alívio de tensões após o teste hidrostático, cerca de $220 \mathrm{MPa}$ no cordão de solda. As demais tensões residuais nesse caminho também sofrem uma redução considerável com o teste hidrostático.

A Figura 6.54 apresenta as tensões residuais antes e depois da realização do teste hidrostático de campo no Caminho 6, para a hipótese do único cordão.

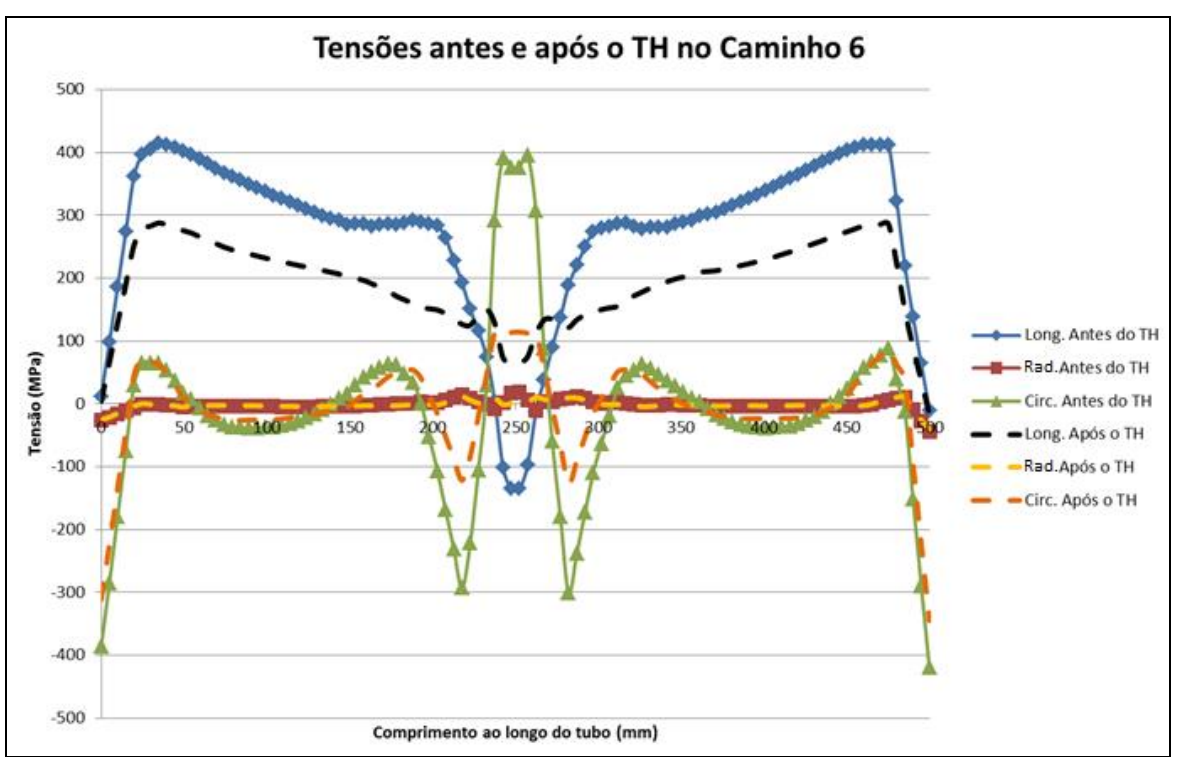

Figura 6.54: Distribuição de tensões residuais antes e após a realização do teste hidrostático de campo no Caminho 6, para a hipótese do único cordão. 
Semelhante ao Caminho 5, o Caminho 6 também sofre grande influência do teste hidrostático de campo, 90\% de SMYS . As tensões residuais no cordão de solda sofrem grande redução após a despressurização, entretanto nas bordas das linhas as tensões ainda atingem níveis consideravelmente altos.

As hipóteses do único cordão de solda e dos múltiplos passes produzem na linha distribuições de tensões residuais diferentes entre si, contudo essas diferenças não são acentuadas, como se percebe comparando as distribuições de tensões residuais equivalentes após o fim da simulação, Figura 6.55. O comportamento da linha nas duas hipóteses é bastante similar, inclusive a escala da magnitude das tensões.

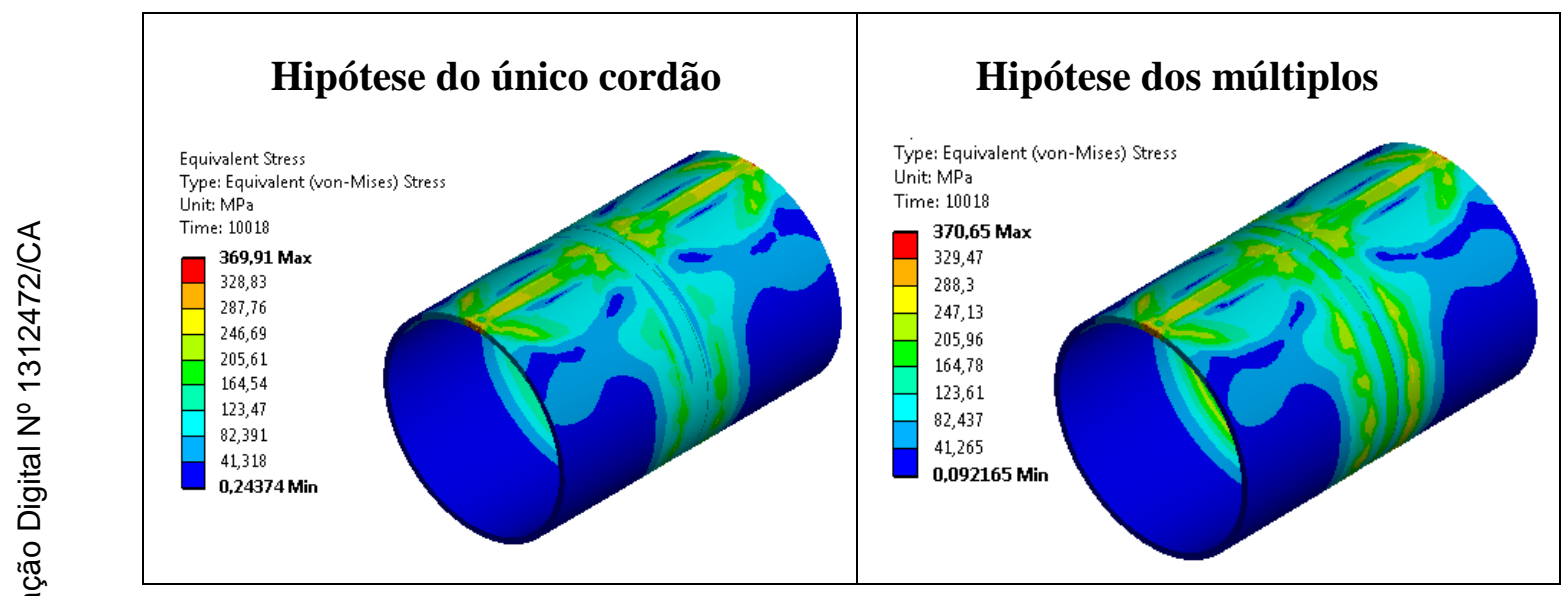

Figura 6.55: Comparação entre as distribuições de tensões residuais equivalentes para as duas hipóteses de união de campo no final da simulação.

A Figura 6.56 compara as tensões residuais superficiais ao longo do caminho 5 para as duas hipóteses estudadas para a realização soldagem circunferencial, no instante de tempo igual a 10018s. 


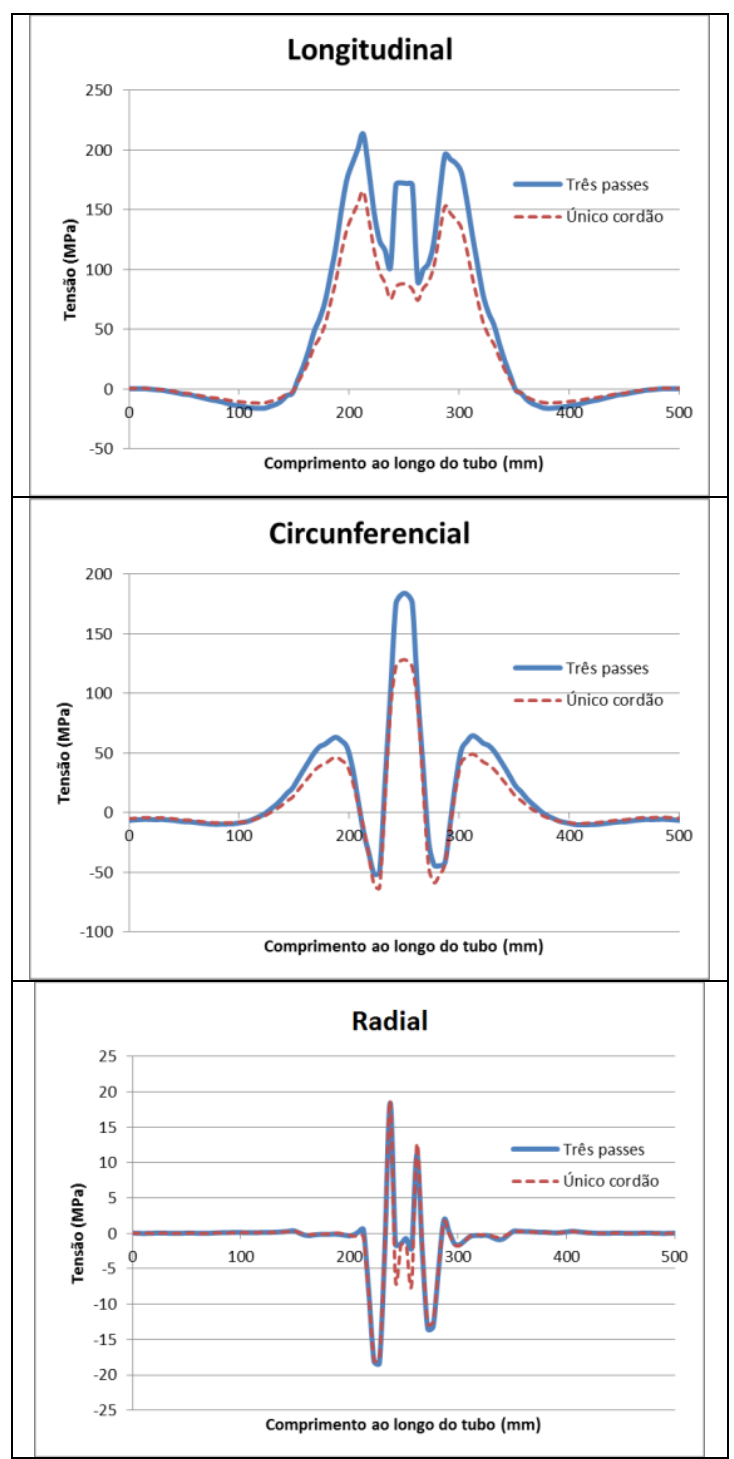

Figura 6.56: Comparação das tensões residuais ao longo do Caminho 5, para as duas hipóteses analisadas no instante de 10018s.

As tensões residuais superficiais têm magnitudes ligeiramente superiores na hipótese dos múltiplos passes de solda, isso se deve aos ciclos térmicos provocados pela sequência de soldagem a que a junta é submetida. Na soldagem com múltiplos passes a distorção angular, causada pelos diversos ciclos de temperatura, aumenta com a espessura da peça de trabalho por causa do aumento da quantidade de metal de solda depositado e, por conseguinte, há um aumento na contração térmica da junta e nas suas tensões residuais.

A Figura 6.57 apresenta a comparação entre as tensões residuais o longo da espessura na junta circunferencial no instante de 10018s para as duas hipóteses. 


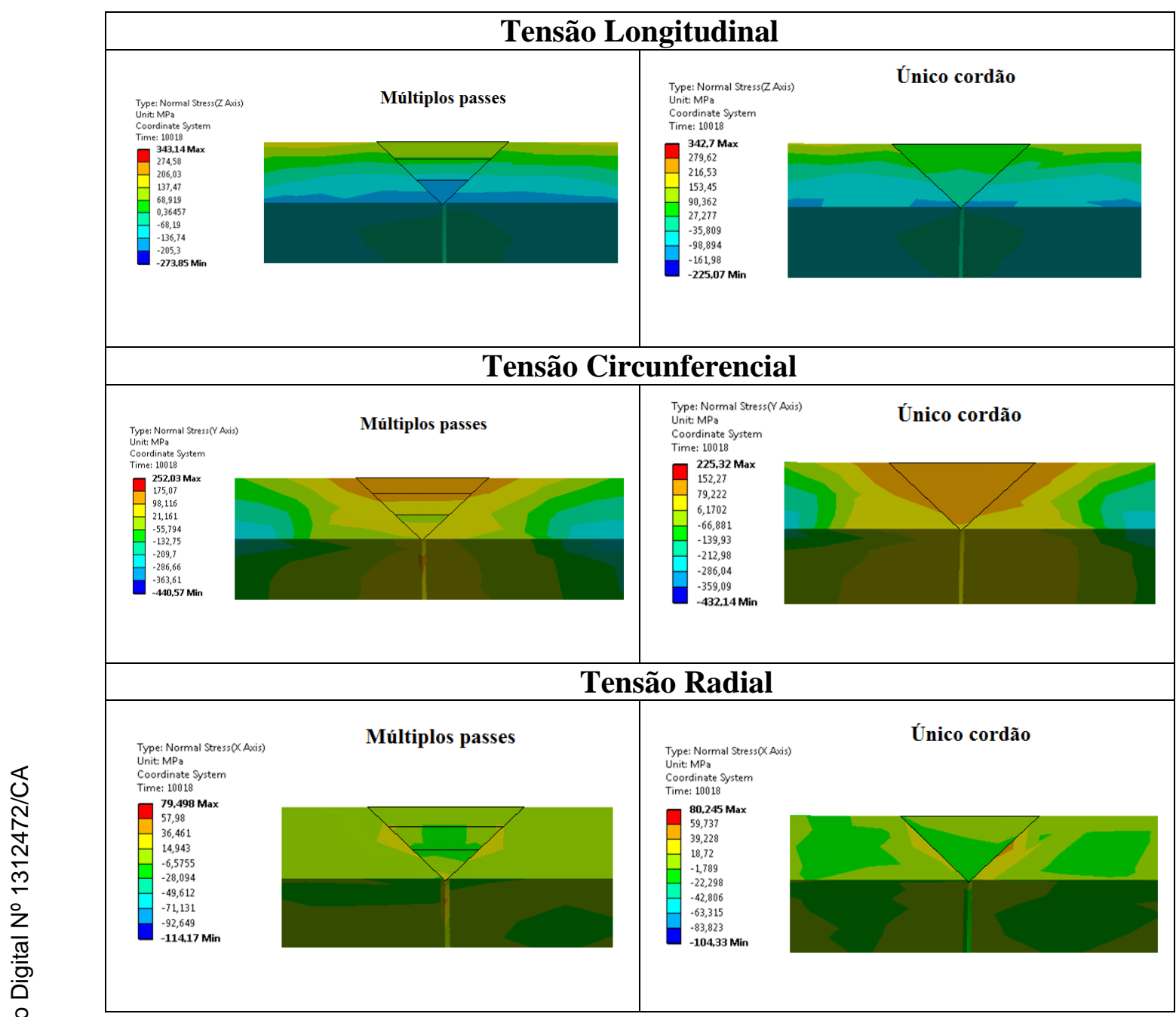

Figura 6.57: Comparação das tensões residuais ao longo da espessura na junta circunferencial, para as duas hipóteses analisadas no instante de $10018 \mathrm{~s}$.

Analisando a Figura 6.57, percebe-se que as distribuições de tensões residuais longitudinais e radiais são semelhantes no comportamento e em magnitude. Entretanto, as tensões na direção circunferencial apresentam comportamento bastante dissimilar. A hipótese dos múltiplos passes apresenta magnitude mais elevada se comparada a do único cordão. As tensões radiais na hipótese do único cordão são mais elevadas, isso se deve aos revenimentos que ocorrem na hipótese dos múltiplos passes e ao gradiente térmico ao longo da espessura mais elevado na hipótese do único cordão. 


\section{7}

\section{Fabricação de Vasos de Pressão}

Vasos de pressão são recipientes estanques, de qualquer tipo, dimensões, formato ou finalidade, capazes de conter um fluido pressurizado. Sua fabricação deve satisfazer a normas técnicas específicas bem como receber inspeções periódicas para propósitos de segurança. Em termos de projeto, são classificados como tanques de armazenamento os reservatórios submetidos a uma pressão relativa inferior a $0.1 \mathrm{Mpa}$, os quais são projetados de acordo com o código API 620; vasos pressurizados (ou despressurizados) acima desta pressão relativa seguem o código ASME, [72].

Contrariamente ao que acontece com quase todos os outros equipamentos, máquinas e estruturas, a grande maioria dos vasos de pressão não é um item de linha de fabricação de alguma indústria; salvo raras exceções, os vasos são projetados e construídos por encomenda para atender cada caso específico. Assim o estudo do comportamento de cada vaso de pressão produzido é de fundamental importância.

Em geral os vasos de pressão projetados de acordo com o código ASME, seção VIII, Divisão 1 são projetados a partir de regras e não requerem uma avaliação detalhada de todas as tensões. A Divisão 1 do código ASME não considera explicitamente os efeitos das tensões combinadas, nem fornece métodos para quantificar essas tensões. No entanto a Divisão 2 do mesmo código apresenta guias específicos para o cálculo das tensões, como elas são combinadas e como elas são admitidas para cada categoria de tensão combinada. Na Divisão 2 se projeta por análise, enquanto na Divisão 1 se utilizam regras, [73].

A Divisão 2 considera as tensões em um estado triaxial, enquanto a Divisão 1 considera um estado biaxial de tensões combinadas e usa a teoria da máxima tensão cisalhante. 


\subsection{Fabricação dos Vasos de Pressão [74]}

Quase todos os vasos são fabricados a partir de chapas de aço, ligadas entre si por soldagem. A soldagem também é empregada para fixação de todas as outras partes que constituem a parede de pressão do vaso, bem como para muitas das peças não pressurizadas do vaso, tanto internas como externas.

É obrigatório que todas as soldas de emenda de chapas no casco e nos tampos dos vasos de pressão sejam de topo, com penetração total e facilmente radiografáveis. Esses requisitos das soldas na parede de pressão são uma exigência geral de todas as normas. Sempre que possível essas soldas devem ser feitas pelos dois lados. Em vasos de pequeno diâmetro, onde não é possível se realizar a soldagem pelo lado interno, pode ser feita apenas a soldagem externa. $\mathrm{O}$ código ASME, Seção VIII, Divisão 2 exige a soldagem por ambos os lados em todas as soldas de topo em aços de alta resistência. Para soldas fora da parede de pressão do vaso, como soldas de ligação aos suportes do vaso ou a outros acessórios ou estruturas externas, a penetração total nunca é exigida, embora sempre que for conveniente essas soldas devem ter penetração total.

Deve ser observado que em cascos cilíndricos e cônicos as soldas longitudinais são as mais solicitadas, estando sujeitas ao dobro de esforço das soldas circunferenciais, devendo por isso receber maior cuidado no projeto e durante a execução.

Devido ao ciclo térmico da soldagem todas as soldas causam contrações e deformações no material que resultam em tensões residuais. Considera-se que as tensões residuais nos vasos de pressão podem ser sensivelmente diminuídas pelo tratamento térmico de alívio de tensões após a soldagem, e é por esse motivo que esse tratamento é exigido para espessuras grandes ou para vasos sujeitos à fratura frágil ou à corrosão sob tensão.

No projeto de um vaso de pressão pode-se reduzir as contrações das soldas e por consequência as tensões residuais, adotando-se, tanto quanto possível, soldas simétricas e com chanfro de menor abertura compatível com a exigência de penetração total e de qualidade do passe de raiz da solda. O projeto adequando da junta é fundamental para a redução das tensões residuais geradas pela soldagem. 


\subsection{Vaso de Pressão Estudado}

O vaso de pressão estudado nesse trabalho foi o VP-CTVP-E-01, com desenho e especificações apresentados nas Figuras 7.1 e 7.2 e na Tabela 1. O projeto deste vaso (determinação das espessuras de seus componentes estruturais) foi desenvolvido e apresentado em [75]. O corpo principal do vaso será construído através de chapas calandradas unidas por soldagem.

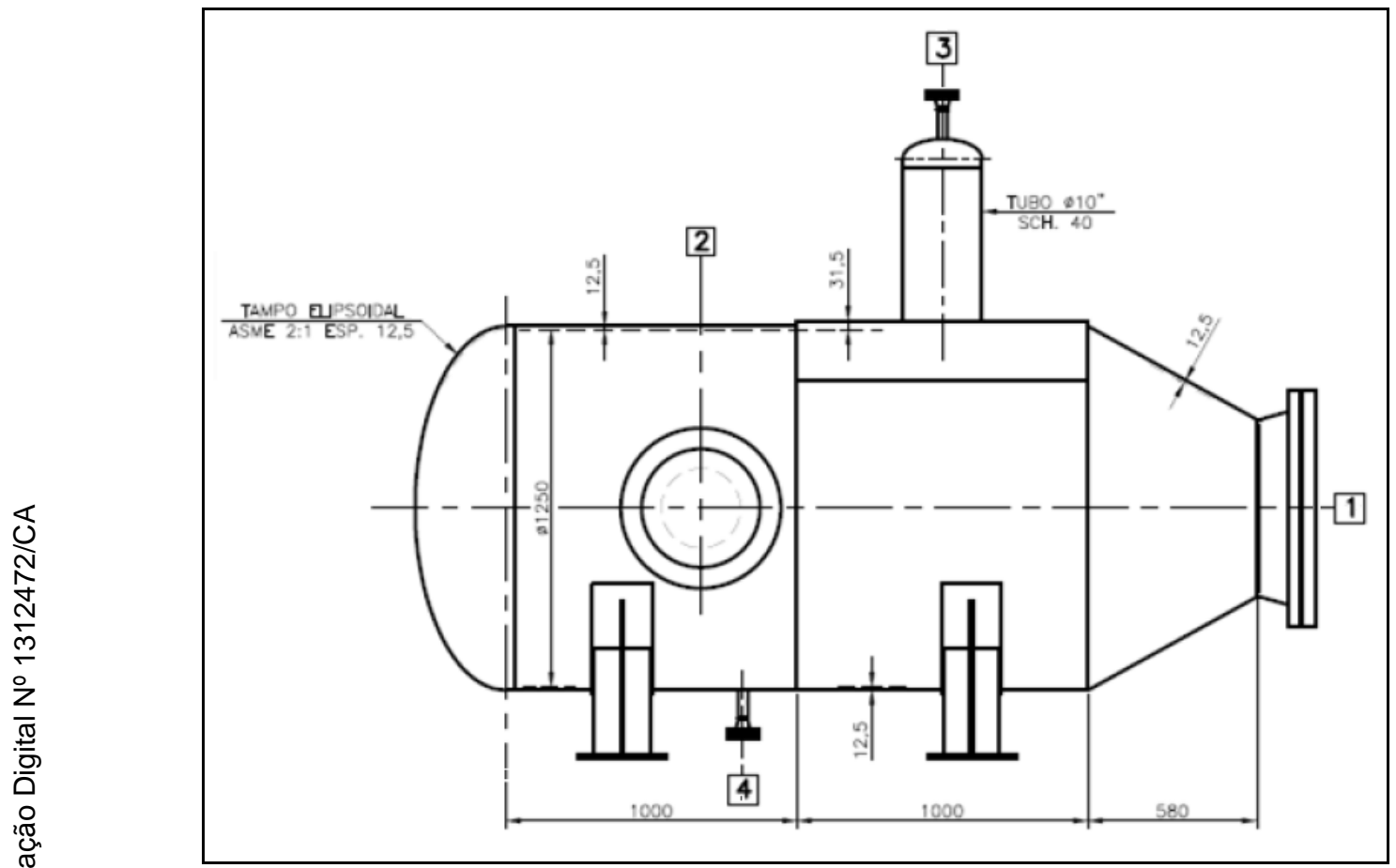

Figura 7.1: Desenho técnico do vaso VP-CTVP-E-01 parte 1. [75] 


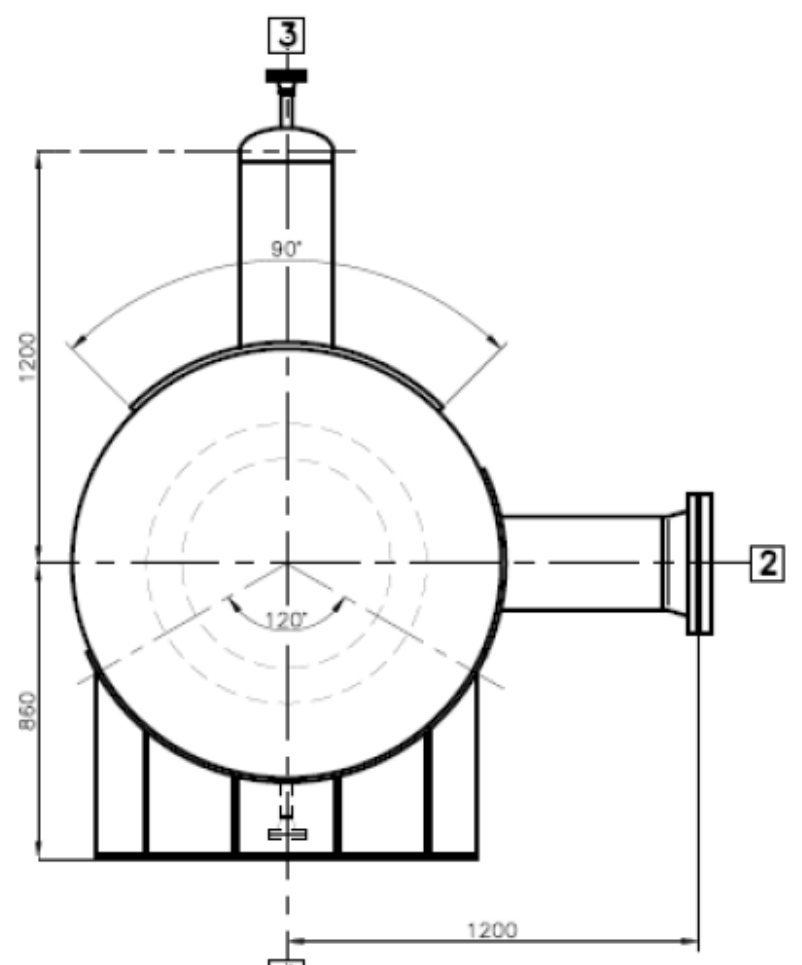

4

\begin{tabular}{|c|c|c|c|c|c|c|c|}
\hline \multicolumn{7}{|c|}{ BOCAIS } \\
\hline POS. & DIAM. & QT & CLASSE & TIPO & FACE & SCH. & SE RVIÇO \\
\hline 1 & $24^{\prime \prime}$ & 1 & 150 & WN & RF & - & BOCA DE VISITA \\
\hline 2 & $10^{\prime \prime}$ & 1 & 150 & WN & RF & 40 & ENTRADA \\
\hline 3 & $1^{\prime \prime}$ & 1 & 150 & WN & RF & 40 & VENT. \\
\hline 4 & $1^{\prime \prime}$ & 1 & 150 & WN & RF & 40 & DRENO \\
\hline
\end{tabular}

Figura 7.2: Desenho técnico do vaso VP-CTVP-E-01 parte 2. [75]

Considera-se que todo o vaso é feito do mesmo material, o aço ASTM A516 Gr. 60. Propriedades do material à temperatura ambiente bem como outros dados estão mostrados na Tabela 7.1. A Figura 7.3 apresenta a variação das propriedades térmicas e mecânicas utilizadas com a temperatura. Essas propriedades foram extraídas de referências da literatura $[58,59,76]$.

Tabela 7.1: Propriedades do aço ASTM A515 Gr.60 à temperatura ambiente.

\begin{tabular}{|c|c|c|}
\hline Propriedade & Símbolo & $\begin{array}{c}\text { Valor na temperatura } \\
\text { ambiente }\end{array}$ \\
\hline Limite de escoamento & $S_{y}$ & $220 \mathrm{MPa}$ \\
\hline $\begin{array}{c}\text { Coeficiente de expansão } \\
\text { térmica }\end{array}$ & $\alpha$ & $1.210^{-5}{ }^{0} \mathrm{C}$ \\
\hline Módulo de elasticidade & $E$ & $200 \mathrm{GPa}$ \\
\hline Condutividade térmica & $k$ & $49.38 \mathrm{~W} / \mathrm{m}^{2}{ }^{0} \mathrm{C}$ \\
\hline Calor específico & $c$ & $491.06 \mathrm{~J} / \mathrm{kg}{ }^{0} \mathrm{C}$ \\
\hline Densidade & $\rho$ & $7850 \mathrm{~kg} / \mathrm{m}^{3}$ \\
\hline Módulo da tangente & $M o d . T g$ & $2000 \mathrm{MPa}$ \\
\hline
\end{tabular}




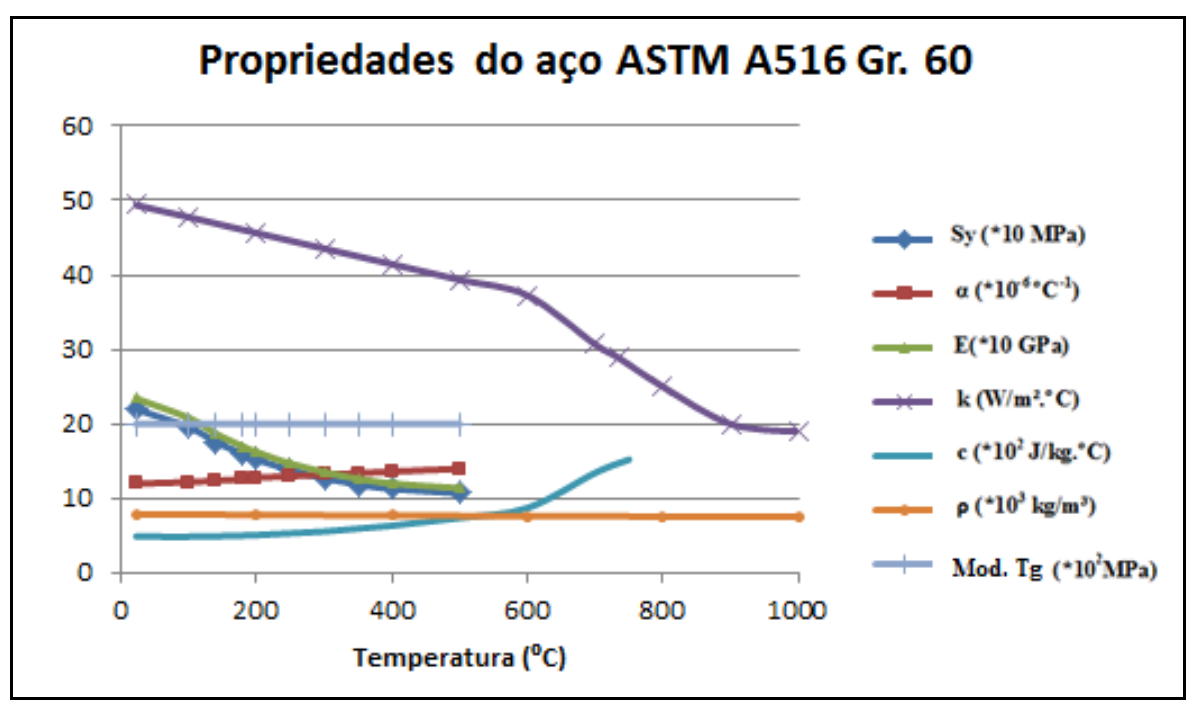

Figura 7.3: Variação das propriedades térmicas e mecânicas do aço ASTM A516 Gr. 60 com a temperatura.

As juntas soldadas estudadas neste artigo foram numeradas segundo a Figura 7.4, abaixo.

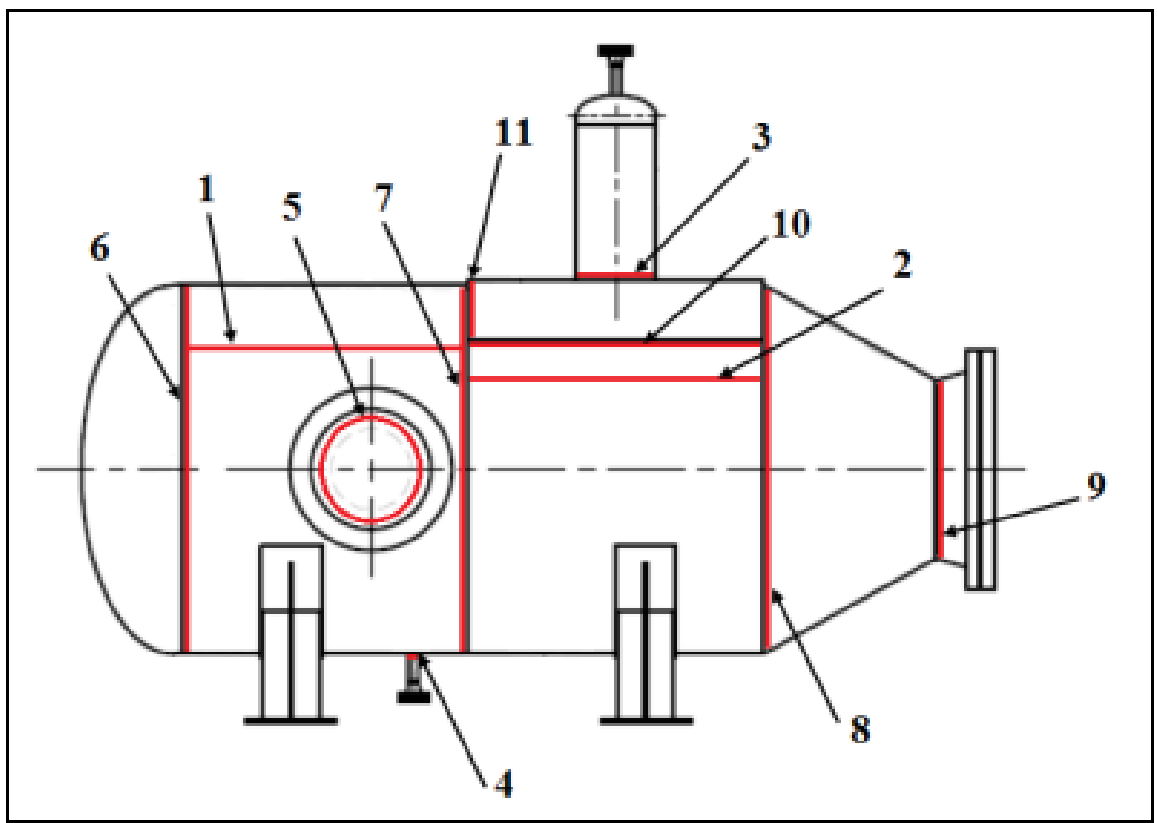

Figura 7.4: Numeração das juntas soldadas estudadas.

As eficiências das juntas soldadas foram determinadas a partir da tabela UW-12, baseando-se na categoria das juntas e na forma de inspeção especificada. Seus valores estão na Tabela 7.2. 
Tabela 7.2: Eficiência das Juntas Soldadas.

\begin{tabular}{|c|c|c|c|}
\hline $\mathbf{N}^{\mathbf{0}}$ da Junta & Categoria & Tipo de União & $\mathbf{E}$ \\
\hline 1 & A & Topo, duplo filete & 0.85 \\
\hline 2 & A & Topo, duplo filete & 0.85 \\
\hline 3 & B & Topo, único filete & 0.80 \\
\hline 4 & D & Canto & N/A \\
\hline 5 & D & Canto & N/A \\
\hline 6 & A & Topo, duplo filete & 0.85 \\
\hline 7 & A & Topo, duplo filete & 0.85 \\
\hline 8 & A & Topo, duplo filete & 0.85 \\
\hline 9 & C & Topo, duplo filete & 0.80 \\
\hline 10 & D & Canto & N/A \\
\hline 11 & A & Topo, duplo filete & 0.85 \\
\hline
\end{tabular}

\subsection{Modelo Numérico da Fabricação do Vaso}

Para o estudo do comportamento mecânico do vaso de pressão seu material foi representado por uma curva tensão-deformação multilinear. Foram realizadas duas análises transientes: uma térmica e outra estrutural, que simularam as execuções dos diversos cordões de solda do vaso e determinaram as tensões residuais geradas nas soldagens. No apêndice E esse mesmo vaso de pressão foi simulado usando uma curva tensão - deformação bilinear com a aplicação de um pequeno gradiente de temperatura, como no item 4.5 do capítulo 4 .

Todas as juntas soldadas foram simuladas utilizando a hipótese das três barras, onde os cordões de solda e as partes unidas pelas soldas foram representados por barras em paralelo, não tendo sido considerados os efeitos da velocidade de soldagem e a influência de múltiplos passes de solda nas juntas. Em resumo, cada cordão de solda foi representado por uma única barra e a soldagem foi realizada em um único passe. Neste trabalho, as tensões residuais geradas pela calandragem das chapas não foram consideradas.

As tensões residuais nas seções constituintes do vaso geradas pela calandragem das chapas foram desprezadas. Essas tensões são consideráveis na direção circunferencial do vaso, e se originaram durante a flexão na calandragem das chapas, entretanto os processos de soldagem se sobrepõem ao curvamento das chapas, fazendo com que as principais tensões residuais no vaso sejam consequência das soldagens de fabricação.

Após a determinação das tensões residuais causadas pela soldagem do vaso, foi realizado um teste hidrostático. 
A pressão de teste hidrostático pode ser determinada de duas maneiras de acordo com as determinações da UG-99 [75]. Seu valor mínimo é definido pela equação (7.1), que será apresentada mais à frente, ou através do item UG-32 [75], onde a pressão de teste é a menor pressão admissível entre os componentes levando em consideração a sobre-espessura de corrosão.

\subsubsection{Geometria do Modelo}

A geometria do modelo de elementos finitos do vaso estudado obedece aos desenhos técnicos apresentados nas Figuras 7.1 e 7.2, utilizando-se 1/2 de simetria e restrições aos deslocamentos nas faces de simetria ( $u x=0$ no plano yz). A espessura do costado cilíndrico é de $12.5 \mathrm{~mm}$ e a espessura do reforço no bocal de ventilação, bocal número 3, é de $19 \mathrm{~mm}$. Todas as juntas soldadas foram consideradas inteiriças, configurando uma barra contínua com o formato da junta. As Figura 7.5 e 7.6 mostram a geometria utilizada para simulação. Na Figura 7.6 estão explicitados o Caminho 1 e os pontos P1 a P14, que serão usados adiante como caminho ou pontos para os quais as tensões determinadas nas análises do MFE serão mostradas.

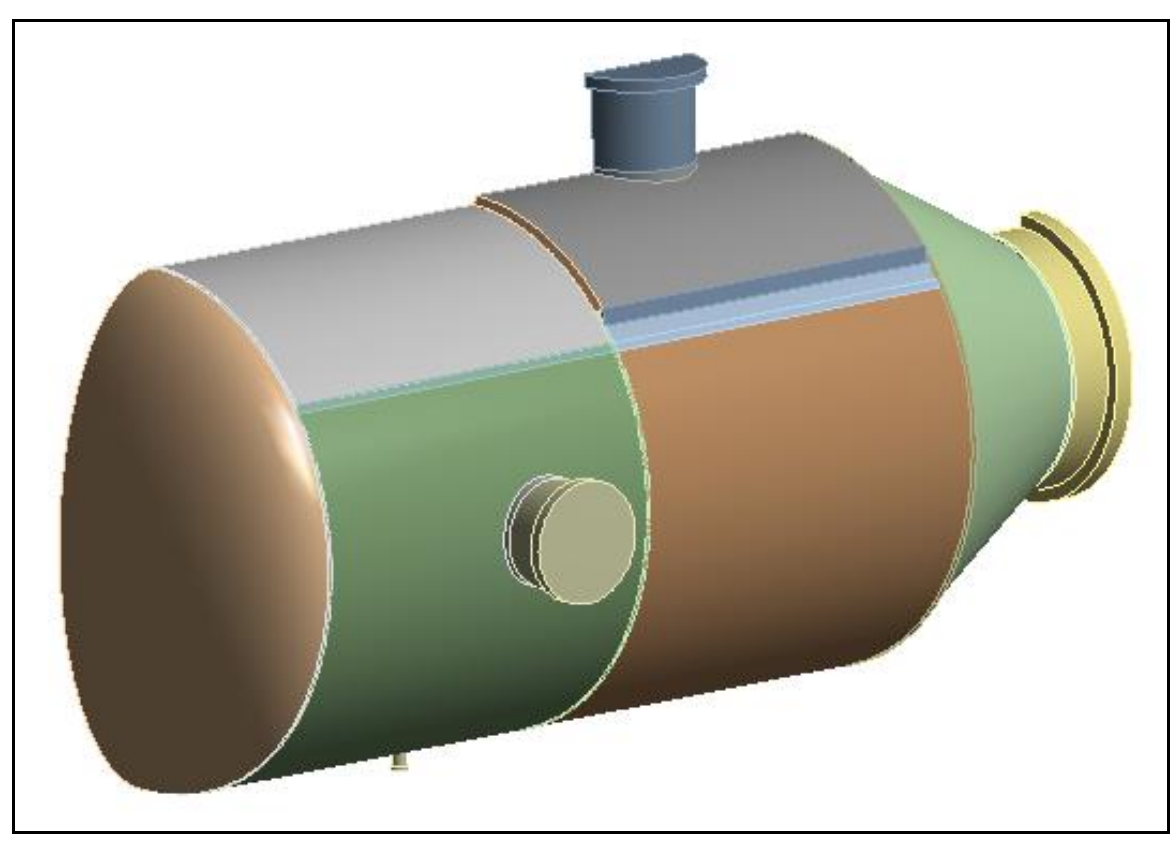

Figura 7.5: Geometria do modelo do vaso com $1 / 2$ de simetrias, vista isométrica. 


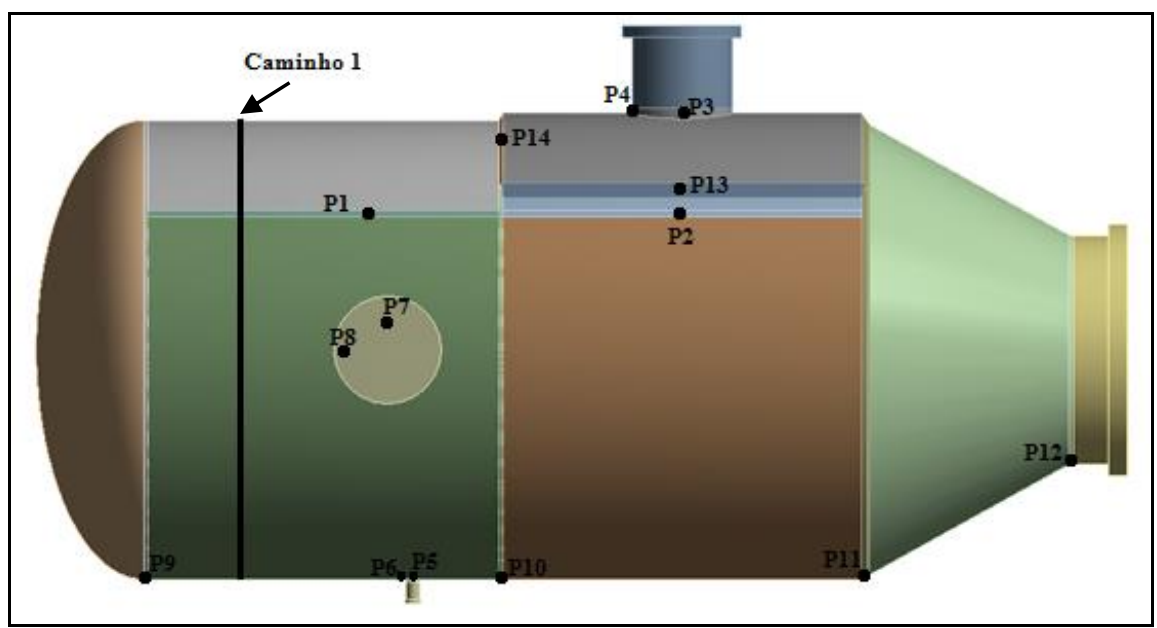

Figura 7.6: Geometria do modelo do vaso com $1 / 2$ de simetrias, vista frontal.

Todas as juntas soldadas (Figura 7.4 e Tabela 7.2) foram consideradas inteiriças, como uma única barra, e seguem os formatos mostrados na Figura 7.7.

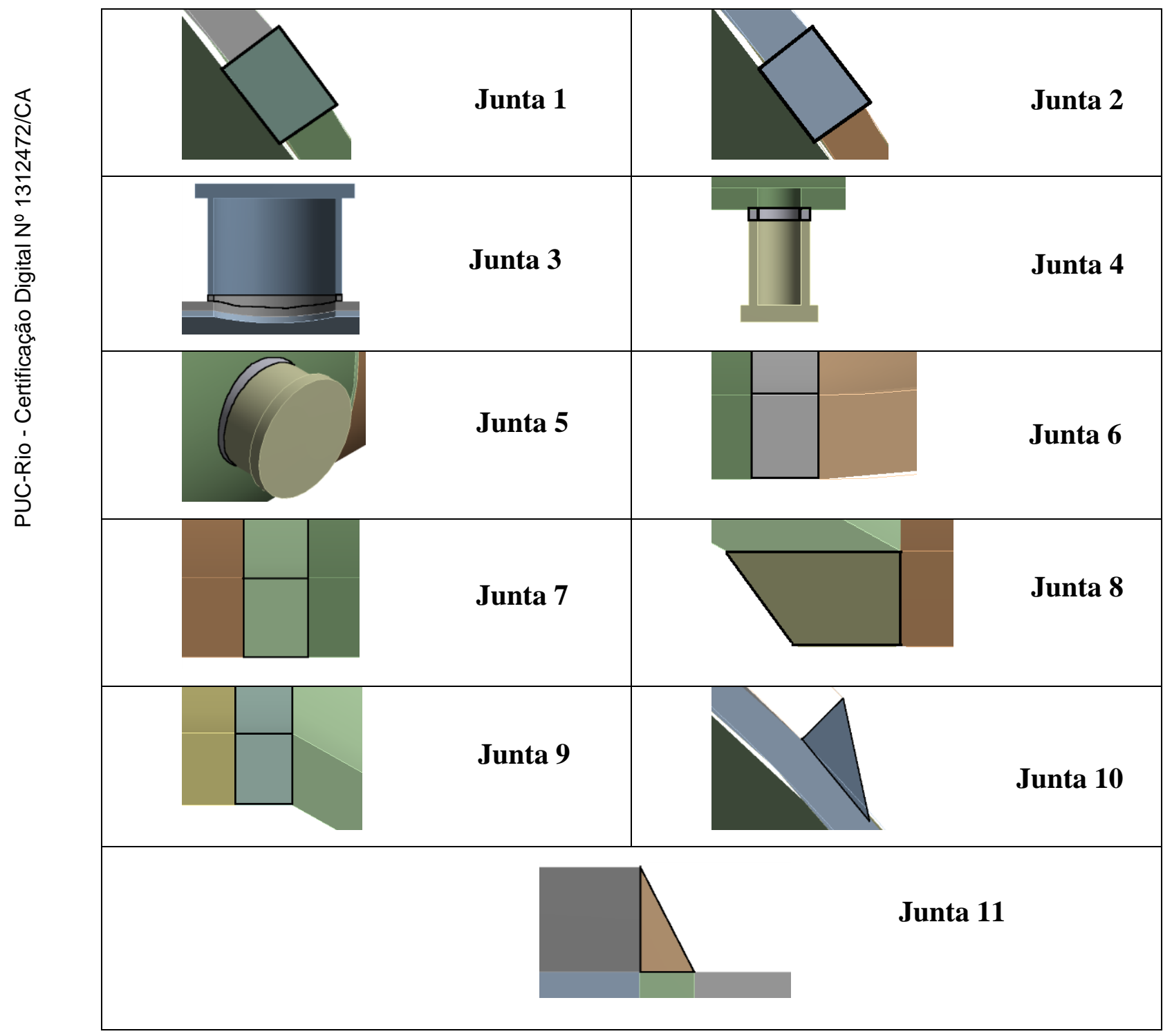

Figura 7.7: Formato das juntas soldadas estudadas ( ver Figura 7.4 e Tabela 7.2). 


\subsubsection{Malha do Modelo}

As análises foram baseadas na malha mostrada na Figura 7.8, sendo que todas as malhas das partes térmica e mecânica são iguais, a fim de facilitar a comutação e comparação de resultados. A malha adotada tem 20825 nós e 3937 elementos. O fator que mede a qualidade de cada elemento tem valor mínimo igual a 0.05 , valor máximo igual a 0.98 e uma média para todos os elementos igual a 0.41 , com um desvio padrão de 0.17 . A razão de aspecto mínima foi de 1.31 e a máxima foi de 37.07, com média igual a 4.85 e desvio padrão de 2.34 .

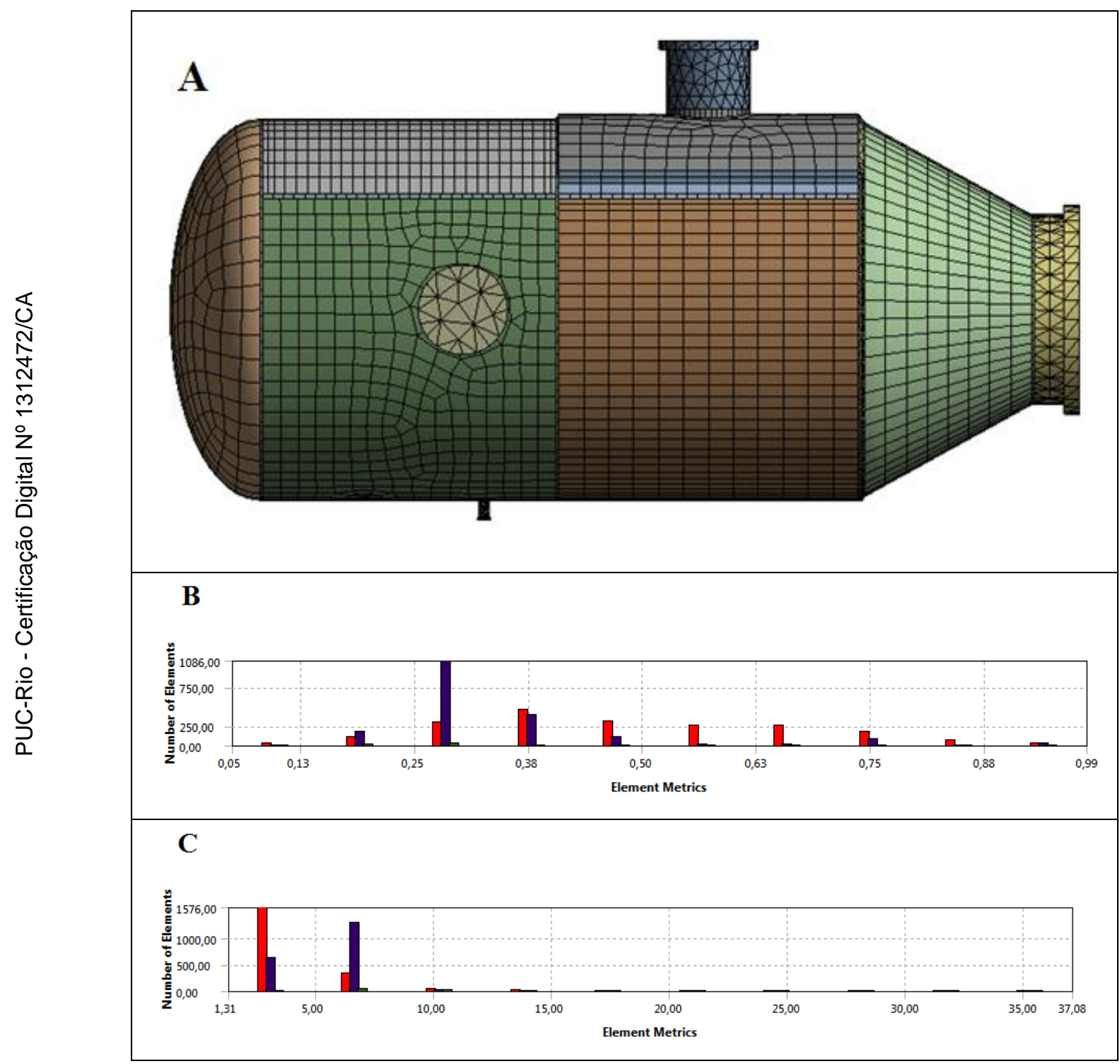

Figura 7.8: Malha do modelo do vaso: a) Malha; b) Histograma da qualidade dos elementos; c) Histograma da razão de aspecto dos elementos. 


\subsubsection{Definição da Pressão de Teste Hidrostático}

A execução de um teste hidrostático é usada para a verificação da estanqueidade do vaso e de sua integridade estrutural depois de completada sua fabricação e montagem. O teste hidrostático é também considerado como um processo de alívio de tensões, uma vez que deve provocar escoamento em alguns pontos onde as tensões residuais são altas e assim redistribuir estas tensões para as regiões de materiais adjacentes, uma característica garantida pela obrigatoriedade da compatibilidade de deslocamentos.

É conveniente que a pressão do teste hidrostático seja a maior possível, mas compatível com a segurança da parte mais fraca do vaso. Essa pressão é superior à pressão de projeto e também à pressão máxima de trabalho admissível do vaso. Assim durante o teste hidrostático o material dos pontos mais solicitados do vaso ficará submetido a uma tensão acima de sua tensão admissível. Essa situação pode ser admitida com segurança pelo fato do teste hidrostático ser realizado durante um pequeno espaço de tempo e por uma única vez ou por um pequeno número de vezes durante a vida do vaso.

O valor da pressão de teste hidrostático é também estabelecido pelas normas de projeto, porque essa pressão poderá ser tanto maior quanto for o coeficiente de segurança adotado pela norma para a fixação da tensão admissível. Para os vasos construídos de acordo com o código ASME, Seção VIII, Divisão 1 (2010), a pressão de teste deve ser no mínimo $30 \%$ maior que a pressão máxima de trabalho admissível (PMTA) do vaso, correspondente à espessura corroída, conforme o parágrafo UG-99 dessa norma. A pressão poderá também ser $30 \%$ maior que a PMTA do vaso novo e frio. Quando a PMTA não for calculada permite-se que a pressão de teste seja descrita pela equação, [74,75]:

$$
P_{T H}=1.3 \cdot P_{\mathrm{Pr} o j} \cdot \frac{S_{c}}{S_{h}}
$$

onde $P_{P r o j}$ é a pressão de projeto, $S_{c}$ é a tensão admissível do material na temperatura ambiente e $S_{h}$ é a tensão admissível do material na temperatura de trabalho. 
Para o presente caso, a temperatura de teste é igual à temperatura ambiente, não havendo diferença nos valores da tensão admissível do material na temperatura de projeto e na temperatura de teste, assim:

$$
\frac{S_{c}}{S_{h}}=1
$$

A pressão de projeto do vaso foi calculada em [75], sendo escolhido o menor valor dentre os calculados para cada seção do vaso, como mostrados na Tabela 7.3.

Tabela 7.3: Pressões máximas admissíveis para cada seção do vaso, [75].

\begin{tabular}{|c|c|}
\hline Seção & Pressão Máxima de Projeto (MPa) \\
\hline Tampo Elipsoidal & 1.762 \\
\hline Casco Cilíndrico & 1.747 \\
\hline Costado Cônico & 1.441 \\
\hline Bocal & 2.130 \\
\hline
\end{tabular}

Analisando todas as pressões calculadas determina-se que a PMAT será igual a $1.441 \mathrm{MPa}$. Com isso através da equação 1, obtém-se a pressão mínima de teste hidrostático:

$$
P_{T H}=1.3 \cdot P_{\operatorname{Pr} o j}=1.874 \mathrm{MPa}
$$

Valores de tensões circunferenciais e longitudinais calculados via MEF para as pressões de projeto e pressão de teste para os diversos pontos P1 a P14 marcados na Figura 7.6 estão apresentados na Tabela 7.4.

Pode-se verificar que os valores estão abaixo da tensão admissível (121 MPa) quando a pressão de projeto atua e abaixo da tensão de escoamento para a pressão de teste. Nas próximas seções os valores de tensões residuais serão calculados para todos os pontos das juntas soldadas e então será aplicada novamente a pressão de teste hidrostático para o conhecimento do estado final de tensões e verificação da influência deste teste nas tensões residuais resultantes do processo de soldagem. 
Tabela 7.4: Tensões longitudinais e circunferências para as pressões de projeto e de TH.

\begin{tabular}{|c|c|c|c|c|}
\hline \multirow{2}{*}{ Ponto } & \multicolumn{2}{|c|}{ Pressão de Projeto } & \multicolumn{2}{c|}{ Pressão de TH } \\
\cline { 2 - 5 } & $\boldsymbol{\sigma}_{\text {Long. }}($ MPa) & $\boldsymbol{\sigma}_{\text {Circ. }}$ (MPa) & $\boldsymbol{\sigma}_{\text {Long. }}$ (MPa) & $\boldsymbol{\sigma}_{\text {Circ. }}$ (MPa) \\
\hline P1 & 37.00 & 63.84 & 48.13 & 83.03 \\
\hline P2 & 44.17 & 85.79 & 57.42 & 111.59 \\
\hline P3 & -4.77 & 18.11 & -6.23 & 23.55 \\
\hline P4 & 88.16 & 91.59 & 114.67 & 119.13 \\
\hline P5 & 43.17 & 62.21 & 56.11 & 80.90 \\
\hline P6 & 11.71 & 46.04 & 15.26 & 59.90 \\
\hline P7 & -4.22 & 51.92 & -5.37 & 67.41 \\
\hline P8 & 95.24 & 172.65 & 73.20 & 206.18 \\
\hline P9 & 24.97 & -11.51 & 32.48 & -14.98 \\
\hline P10 & 36.88 & 70.68 & 47.95 & 91.91 \\
\hline P11 & -90.71 & -52.88 & -117.96 & -68.77 \\
\hline P12 & 55.31 & 69.37 & 71.94 & 90.22 \\
\hline P13 & 19.83 & 7.45 & 25.78 & 9.71 \\
\hline P14 & -1.21 & 25.74 & -1.57 & 33.47 \\
\hline
\end{tabular}

\subsubsection{Análise de Tensões no Vaso Devido à Pressão Interna}

Com finalidade de validar o modelo numérico da fabricação do vaso foi realizada uma simulação estática do comportamento mecânico do vaso sujeito a uma pressão interna que é igual à pressão de teste hidrostático.

A Figura 7.9 apresenta as variáveis dimensionais utilizadas para a análise de esforços no vaso.

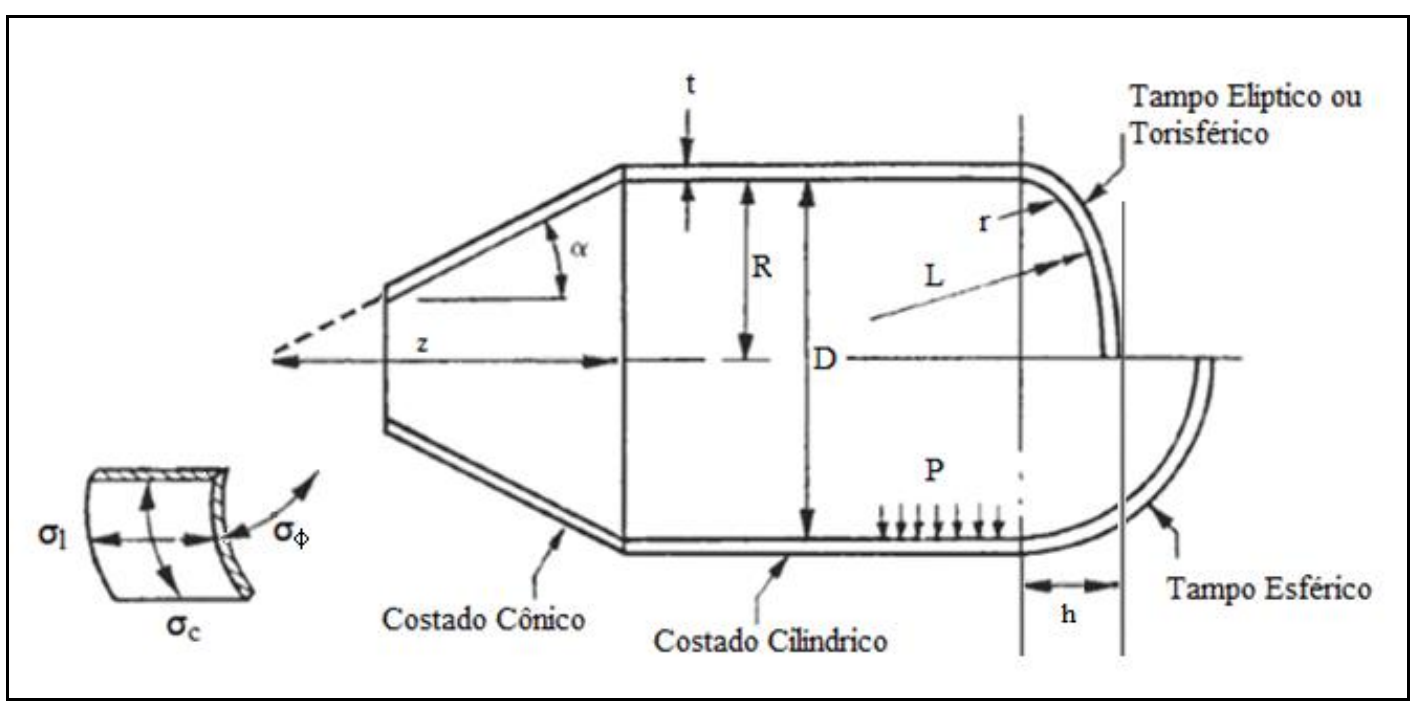

Figura 7.9: Variáveis dimensionais do vaso usadas para a análise das tensões. 
As coordenadas utilizadas para descrever a geometria do vaso tiram vantagem da sua simetria axial. É natural alinhar uma coordenada ao longo do eixo do vaso (isto é, na direção longitudinal). Para analisar o estado de tensão na parede do vaso, uma segunda coordenada é então alinhada ao longo da direção da curvatura do vaso. Com essa escolha de coordenadas axissimétricas não há tensões de cisalhamento, as tensões circunferencial, $\sigma c$, e a tensão longitudinal, $\sigma$, são as tensões principais.

A equação 7.2, apresentada abaixo, correlaciona as tensões principais na parede do vaso de pressão na seção cilíndrica.

$$
\sigma_{c}=2 \sigma_{l}=\frac{P \cdot R}{t}
$$

Na seção cônica as tensões na parede do vaso são definidas com base no semi-ângulo subentendido pelo cone, $\alpha$. A equação 7.3 apresenta as tensões na parede nessa seção.

$$
\sigma_{c}=2 \sigma_{l}=\frac{P \cdot z \cdot \operatorname{tg}(\alpha)}{t}
$$

As tensões no centro do tampo elipsoidal podem ser calculadas pelas equações 7.4 e 7.5 .

$$
\begin{gathered}
\sigma_{c}=\sigma_{\phi}=\frac{P \cdot R^{2}}{2 \cdot t \cdot h} \\
\sigma_{l}=P
\end{gathered}
$$

A Tabela 7.5 apresenta os valores das variáveis dimensionais utilizadas para o calculo das tensões no vaso.

Tabela 7.5: Valores das variáveis dimensionais.

\begin{tabular}{|c|c|c|c|c|c|c|}
\hline $\mathbf{P}(\mathbf{M P a})$ & $\mathbf{R}(\mathbf{m m})$ & $\mathbf{t}(\mathbf{m m})$ & $\boldsymbol{\alpha}($ graus) & $\operatorname{tg}(\boldsymbol{\alpha})$ & $\begin{array}{c}\mathbf{Z}-\mathbf{n o} \\
\text { centro }(\mathbf{m m})\end{array}$ & $\mathbf{h}(\mathbf{m m})$ \\
\hline 1.874 & 625 & 12.5 & 28.91 & 0.55 & 841.83 & 300 \\
\hline
\end{tabular}

Na tabela 7.6 são comparadas as tensões calculadas analiticamente pelas equações 7.2, 7.3, 7.4 e 7.5, e as simuladas numericamente em posições próximas as regiões nominais. 
Tabela 7.6: Comparação entre as tensões simuladas e calculadas analiticamente.

\begin{tabular}{|c|c|c|c|c|c|c|}
\hline \multirow{2}{*}{ Seção } & \multicolumn{3}{|c|}{ Tensões Analíticas (MPa) } & \multicolumn{3}{c|}{ Tensões Numéricas (MPa) } \\
\cline { 2 - 7 } & $\boldsymbol{\sigma}_{\mathbf{I}}$ & $\boldsymbol{\sigma}_{\mathbf{c}}$ & $\boldsymbol{\sigma}_{\phi}$ & $\boldsymbol{\sigma}_{\mathbf{l}}$ & $\boldsymbol{\sigma}_{\mathbf{c}}$ & $\boldsymbol{\sigma}_{\phi}$ \\
\hline Costado Cilíndrico & 46.85 & 93.70 & - & 43.63 & 93.77 & - \\
\hline $\begin{array}{c}\text { Costado Cônico - } \\
\text { Centro }\end{array}$ & 34.84 & 69.70 & - & 33.63 & 87.77 & - \\
\hline $\begin{array}{c}\text { Tampo } \\
\text { Elipsoidal }\end{array}$ & 1.874 & 97.60 & 97.60 & 1.72 & 108.84 & 107.81 \\
\hline
\end{tabular}

A Figura 7.10 apresenta as distribuições de tensões que foram simuladas numericamente no vaso submetido a uma pressão interna constante.

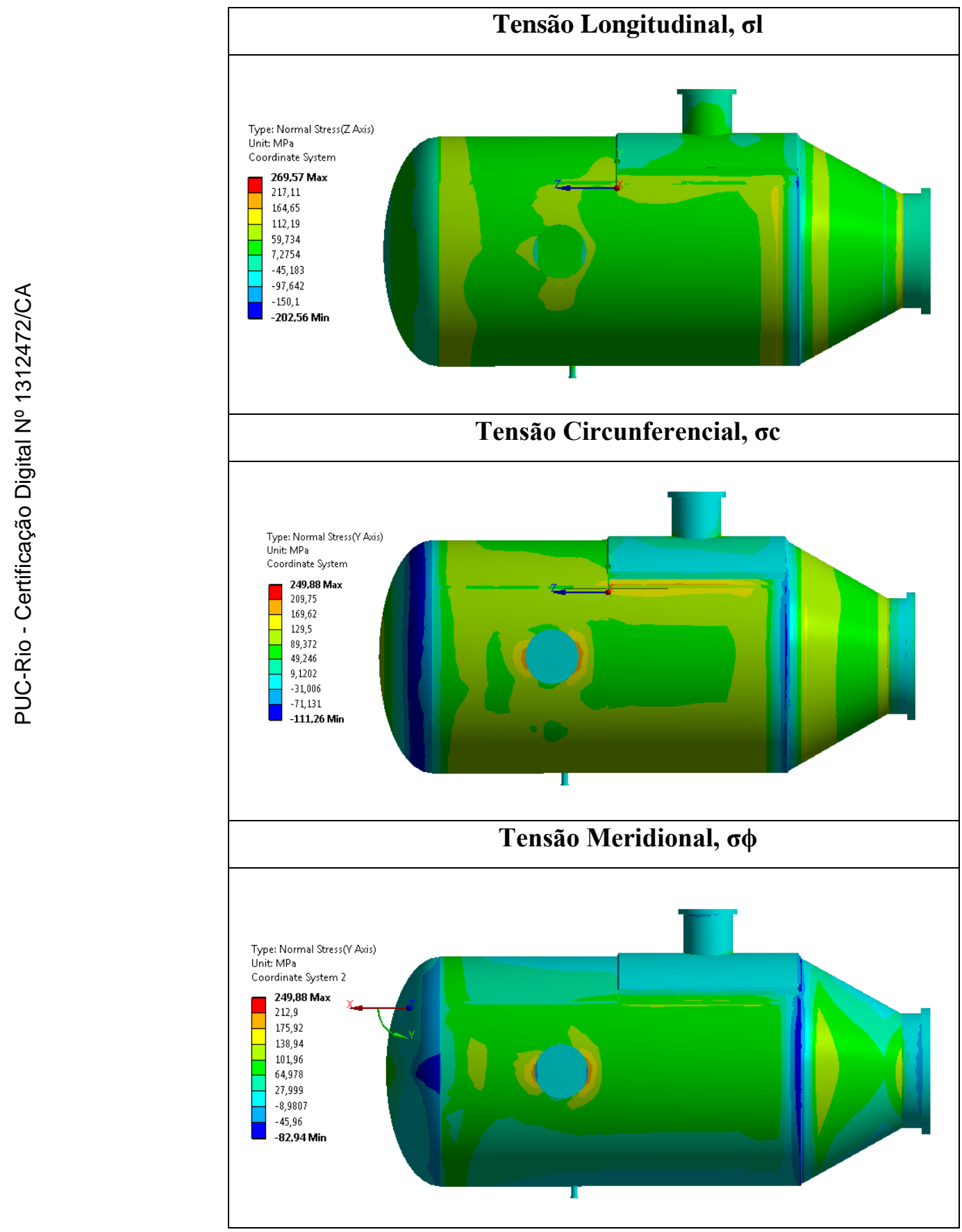

Figura 7.10: Distribuição de tensões no vaso devido à pressão interna. 
Analisando a Tabela 7.6 e a Figura 7.10, embora os valores calculados analiticamente e numericamente sejam bastante semelhantes nas regiões analisadas, em outras seções do vaso como nas regiões de transição entre o costado cilíndrico e o cônico, e entre o tampo elipsoidal e o costado cilíndrico as tensões calculadas pelos dois métodos são diferentes.

Esse comportamento do vaso se deve a diferença das rigidezes dessas seções, a Figura 7.11 apresenta comportamento do vaso quando submetido à pressão interna em uma escala aumentada de 100 vezes.

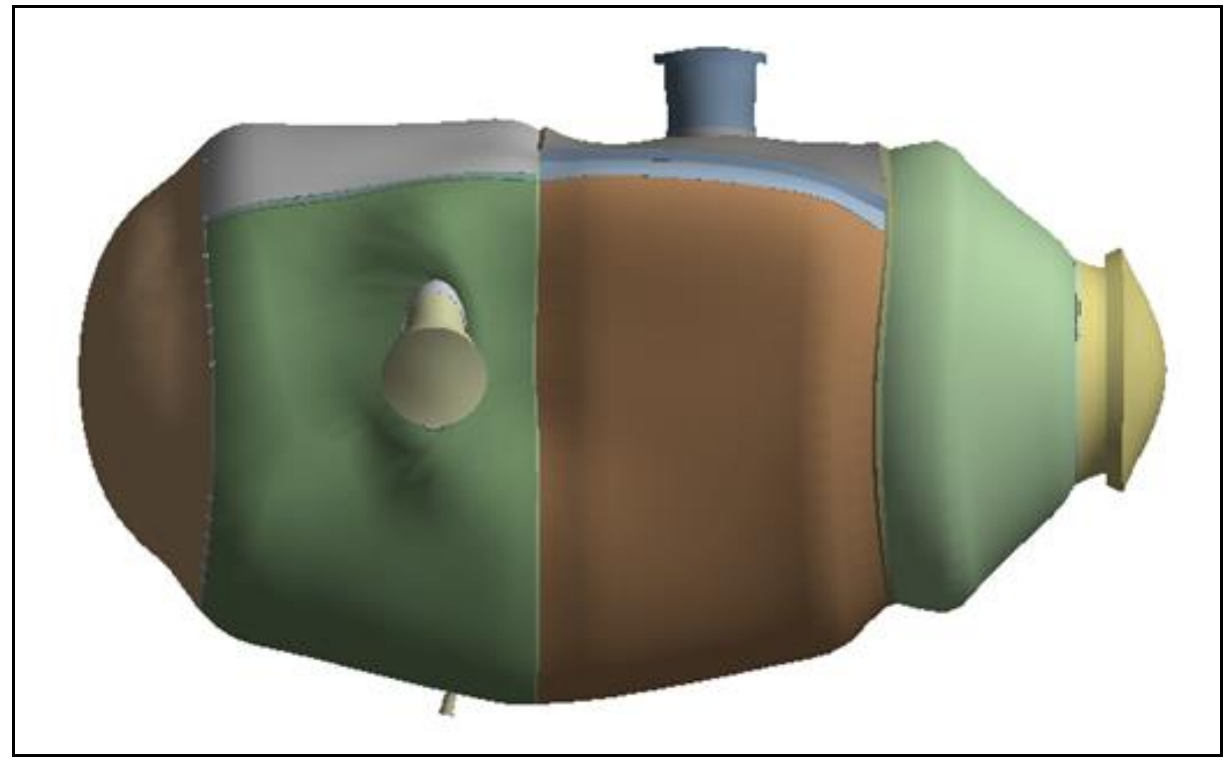

Figura 7.11: Comportamento do vaso devido à pressão interna em uma escala aumentada de 100 vezes.

Com base na Figura 7.11, percebe-se que nas regiões de transição de geometria, o costado cilíndrico tende a se deformar mais do que o tampo e do que região cônica, assim nessas regiões deve haver um equilíbrio entre as seções através da compatibilidade de deformações.

Quando uma seção se deforma deve fazê-lo de tal forma que as deformações dos elementos adjacentes de material sejam compatíveis uns com os outros e com todas as condições de apoio externo, ou seja, devem se encaixar em sua forma deformada sem quaisquer lacunas ou sobreposições.

As tensões na parede dos vasos de pressão ocorrem devido a diferentes tipos de carregamentos, dependendo do propósito do vaso e das diversas influencias externas a que o vaso é sujeito durante sua vida. A pressão interna é a que tem a maior influência sobre no nível das tensões nas paredes, por isso todos os outros tipos de carregamentos são consideradas menos importantes. 
As forças internas que ocorrem nas paredes do vaso podem ser, em determinadas condições, determinadas pela sobreposição dos dois tipos de carregamentos, de membrana e de momento. Na tensão de membrana, presume-se que apenas forças normais ocorrem na parede, enquanto as forças de cisalhamento e os momentos fletores não são considerados. Na fase de projeto, os vasos de pressão devem ser fabricados de modo que a tensão verdadeira seja aproximadamente a mesma que a tensão de membrana a fim de evitar a flexão das paredes e altas tensões à flexão.

A Figura 7.12 apresenta o diagrama de corpo livre e a equações compatibilidade de esforços nas seções do vaso.

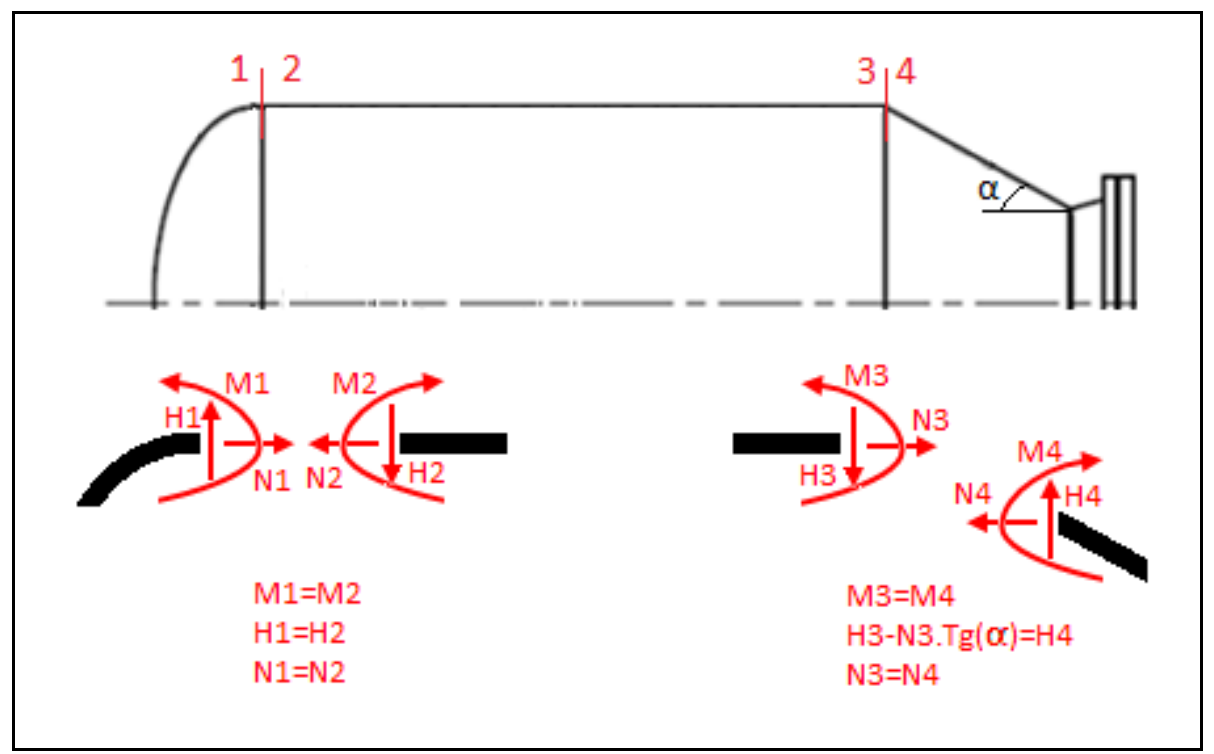

Figura 7.12: Diagrama de corpo livre do vaso.

O comportamento nas regiões de transição de geometria pode ser explicado devido à ocorrência de flexões, uma vez que está se superpondo um estado de tensão de membrana. Como a espessura é constante em todo o vaso, a pressão interna provoca uma flexão, para causar equilíbrio e compatibilidade, causando essa heterogeneidade de tensões.

Para que haja um estado de tensão de membrana no vaso de pressão, a espessura do costado cilíndrico deve ser maior do que a espessura do tampo e do costado cônico. Na configuração atual o estado de tensão de membrana prevalece na maior parte do costado e do tampo do vaso de pressão, mas não nas junções, [77]. 


\subsubsection{Configuração dos Passos Tempo}

Foram usados 23 passos de tempo para as análises de tensões relativas ao processo de soldagem e ao processo de teste hidrostático. Os primeiros 20 passos representaram os processos de soldagem, realizados em três etapas diferentes e relativas aos cordões de soldas 1 a 5,6 a 9 e 10 a 11 . Os três últimos eventos de tempo se referem ao teste hidrostático. A Tabela 7.7 correlaciona cada passo de tempo com sua duração e com o evento que ocorre nele.

Tabela 7.7: Duração de cada passo de tempo.

\begin{tabular}{|c|c|c|c|}
\hline $\begin{array}{l}\text { Passo de } \\
\text { Tempo }\end{array}$ & Duração (s) & Tempo ao Final do Passo (s) & Evento \\
\hline $1^{0}$ & 1 & 1 & $\begin{array}{l}\text { Deposição dos cordões nas } \\
\text { juntas } n^{0} 1,2,3,4 \text { e } 5\end{array}$ \\
\hline $2^{0}$ & 1 & 2 & \multirow{6}{*}{ Troca de calor } \\
\hline $3^{0}$ & 1 & 3 & \\
\hline $4^{0}$ & 1 & 4 & \\
\hline $5^{0}$ & 1 & 5 & \\
\hline $6^{0}$ & 1 & 6 & \\
\hline $7^{0}$ & 4994 & 5000 & \\
\hline $8^{0}$ & 1 & 5001 & $\begin{array}{c}\text { Deposição dos cordões nas } \\
\text { juntas } n^{0} 6,7,8 \text { e } 9\end{array}$ \\
\hline $9^{0}$ & 1 & 5002 & \multirow{6}{*}{ Troca de calor } \\
\hline $10^{0}$ & 1 & 5003 & \\
\hline $11^{0}$ & 1 & 5004 & \\
\hline $12^{0}$ & 1 & 5005 & \\
\hline $13^{0}$ & 1 & 5006 & \\
\hline $14^{0}$ & 4994 & 10000 & \\
\hline $15^{0}$ & 1 & 10001 & $\begin{array}{c}\text { Deposição dos cordões nas } \\
\text { juntas } n^{0} 10 \text { e } 11\end{array}$ \\
\hline $16^{0}$ & 1 & 10002 & \multirow{5}{*}{ Troca de calor } \\
\hline $17^{0}$ & 1 & 10003 & \\
\hline $18^{0}$ & 1 & 10004 & \\
\hline $19^{0}$ & 1 & 10005 & \\
\hline $20^{0}$ & 1 & 10006 & \\
\hline $21^{0}$ & 4994 & 15000 & Início do TH \\
\hline $22^{0}$ & 1 & 15001 & Pressão Máxima do TH \\
\hline $23^{0}$ & 1 & 15002 & Final do TH \\
\hline
\end{tabular}

\subsubsection{Condições de Contorno Térmicas}

As temperaturas nas juntas soldadas ao longo do tempo são calculadas por uma análise de transferência de calor transiente, onde o calor pode ser transmitido apenas através da condução e convecção, sendo que os efeitos da radiação não são considerados. 
Os aportes de calor das soldagens foram modelados diretamente como carregamentos da simulação térmica. Cada soldagem se inicia com o cordão de solda sendo depositado na temperatura de fusão do metal, como uma condição de temperatura. Essa temperatura de deposição foi escolhida igual ao ponto de fusão do material uma vez que ainda não foram especificados os parâmetros de soldagem do vaso.

Em seguida foram aplicadas as condições de contorno térmicas no vaso, uma convecção no exterior do vaso igual a $30 \mathrm{~W} / \mathrm{m}^{2}{ }^{0} \mathrm{C}$ e outra no interior igual a $10 \mathrm{~W} / \mathrm{m}^{2}{ }^{0} \mathrm{C}$, até que todo o vaso entrasse em equilíbrio com a temperatura ambiente de $22^{\circ} \mathrm{C}$. A condução também é considerada no modelo, sendo uma condição de contorno intrínseca da análise, regida pela condutividade térmica, calor específico e densidade do material.

\subsubsection{Condições de Contorno Térmicas}

O histórico de temperaturas obtida na análise térmica transiente foi transformado em um carregamento térmico no modelo estrutural para a determinação do estado de tensões e deformações do vaso. Não foram simulados os suportes do vaso, entretanto utilizou-se a opção de "Weak Springs", que impede o movimento de corpo rígido. Nos três últimos passos ocorre o teste hidrostático, sendo a pressão máxima atingida no passo do meio. Foi utilizada a pressão de alívio igual a $130 \%$ da pressão de projeto.

\subsection{Resultados}

Os ciclos térmicos durante a soldagem de fabricação do vaso foram modelados utilizando as variáveis apresentadas no item 7.3.6. Os cordões de solda, quando depositados, se encontram dilatados e à temperatura de fusão do metal. À medida que a simulação transcorre eles passam a trocar calor com o meio e com as demais regiões do vaso. Quando cada cordão de solda é resfriado ele é forçado a voltar ao seu tamanho inicial, gerando deformações plásticas distribuídas heterogeneamente neles e no material adjacente do vaso e, por consequência, tensões residuais. 
O calor proveniente das soldagens é dissipado por convecção para o ambiente e por condução pelas chapas por meio de um coeficiente de condução, que varia com a temperatura.

Na Figura 7.13 é apresentada a distribuição de temperaturas no vaso para o modelo nos instantes após o término das soldagens e início da troca de calor para o meio.

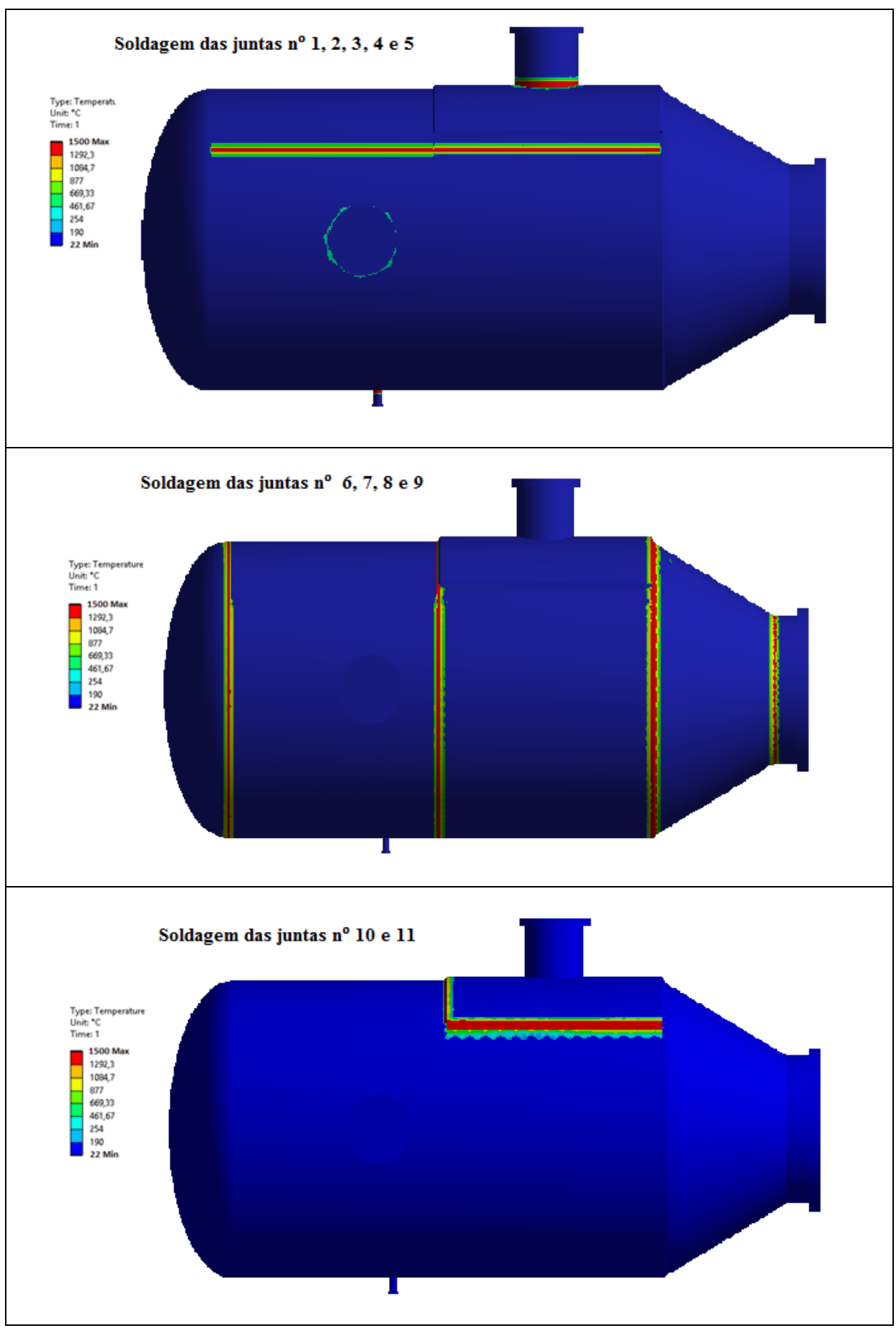

Figura 7.13: Distribuição de temperaturas no vaso nos instantes de $1 \mathrm{~s}, 5001 \mathrm{~s}$, e $10001 \mathrm{~s}$ respectivamente. 
Na Figura 7.14 são apresentas as temperaturas máximas em toda a análise ao longo do tempo. Cada pico de temperatura representa a deposição dos passes de solda nos instantes de $1 \mathrm{~s}, 5001 \mathrm{~s}$ e $10001 \mathrm{~s}$. O tempo médio para a temperatura máxima entrar em equilíbrio com o ambiente é de 5000s, sendo 15002 s o instante de tempo em que todo o vaso se encontra a $22{ }^{\circ} \mathrm{C}$.

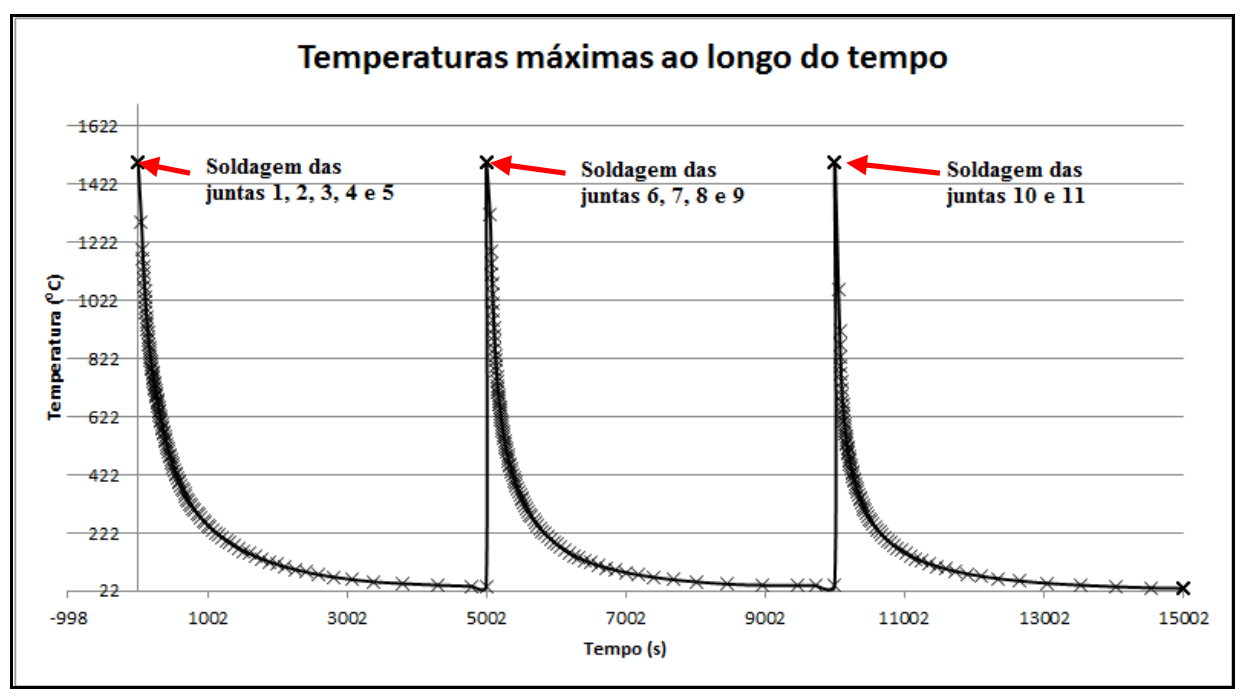

Figura 7.14: Temperaturas máximas ao longo do tempo.

$\mathrm{Na}$ análise transiente o calor é trocado aos poucos com o ambiente e com as regiões adjacentes às juntas soldadas, os gradientes térmicos avançando para regiões mais afastadas das juntas. Cada segmento de soldagem, que é representado por cada pico da Figura 7.14, leva em torno de 5000s para entrar em equilíbrio com o ambiente.

A realização de cada novo segmento de soldagem tem influência no comportamento do anterior, pois os novos ciclos térmicos influem sobre o comportamento das juntas já depositadas, seja de forma global ou localizada, através de novos ciclos térmicos nas regiões em contado, como por exemplo, é o caso da influência das juntas 10 e 11 sob as juntas 2 e 7 e das regiões de contato entre as juntas 1 e 6,1 e 7,2 e 7 e 2 e 8 .

Quando a análise transiente atinge 5000s, 10000s, e 15000s todo o calor fornecido ao vaso durante os segmentos de soldagem se dissipou para o meio e pelo espécime, que retorna ao equilíbrio térmico com a temperatura ambiente de $22^{\circ} \mathrm{C}$, como mostrado na Figura 7.15. 


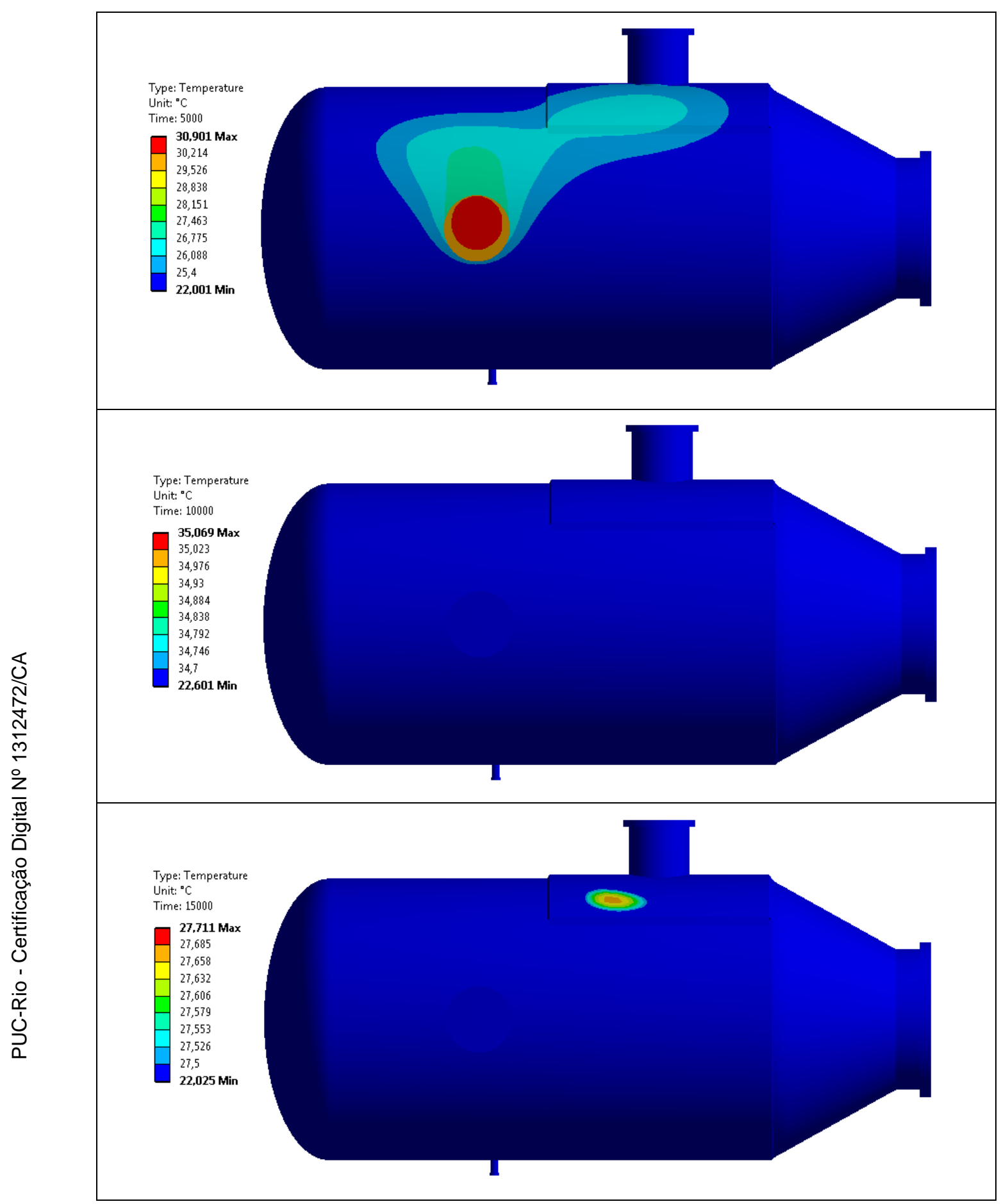

Figura 7.15: Distribuição de temperaturas em de 5000s, 10000s e 15000s.

Os severos gradientes de temperaturas ao longo do vaso e as restrições ao deslocamento das regiões próximas aos cordões de solda fazem surgir tensões residuais após a soldagem. O aquecimento localizado durante as soldagens e o resfriamento causam mudanças volumétricas não uniformes, que por sua vez provocam tensões e deformações. A contração durante o resfriamento das regiões 
diferentemente aquecidas e plastificadas provoca o surgimento de um campo de tensões permanentes que se auto-equilibram.

As tensões residuais longitudinais e circunferenciais após a soldagem são similares no sentido de que são trativas na superfície dos cordões na direção da maior restrição à deformação, apresentando valores semelhantes ao limite de escoamento do material.

Nessa análise o calor se difunde por todo o vaso, criando gradientes térmicos, mesmo que de pequena magnitude, por toda a geometria. As distribuições de tensões que aparecem são decorrência direta dessas variações de temperaturas nessas regiões ao longo do tempo.

A Figura 7.16 apresenta as distribuições das tensões residuais no vaso após a soldagem de fabricação, no instante de 15000s.

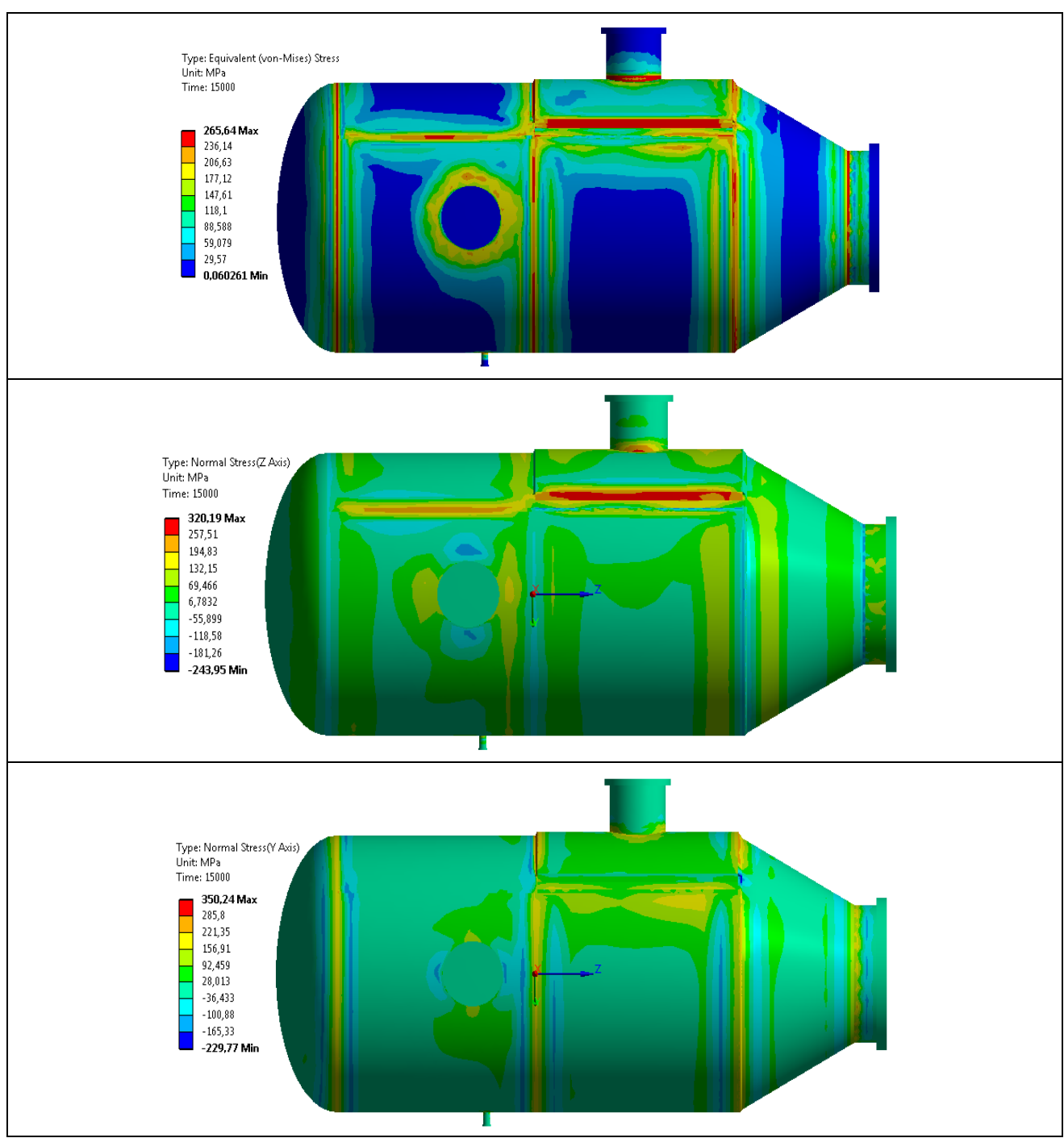

Figura 7.16: Distribuição de tensões residuais: a)Tensões equivalentes;

b) Tensões longitudinais; c) Tensões circunferenciais. 
Observando a Figura 7.16a, percebe-se que a tensão residual equivalente tem valores nas juntas semelhantes ao limite de escoamento, entretanto em algumas seções esse limite é ultrapassado, sendo um efeito do comportamento multilinear do material. As tensões residuais se distribuem por todo o vaso, não ficando restritas às juntas.

As tensões residuais longitudinais após a soldagem de fabricação, Figura 7.16b, apresentam valores máximos trativos nas juntas 1,2 e 10, e nos pontos P3, P5 e P7, e compressivos na ZTA. Esses níveis elevados de tensões se devem as restrições à expansão e contração das regiões diferentemente aquecidas e resfriadas durante a fabricação.

As tensões residuais circunferenciais, Figura 7.16c, também apresentem magnitudes elevadas próximas ao limite de escoamento; no entanto esses valores estão localizados nas juntas circunferenciais. As regiões correspondentes as ZTAs circunferenciais se encontram em compressão a fim de equilibrar as tensões geradas pela soldagem.

As tensões na direção radial são pequenas e podem ser desprezadas. A contração nessa direção é muito pequena não influenciando no comportamento do vaso.

A Figura 7.17 apresenta as distribuições das tensões residuais no vaso ao longo do Caminho 1 após a soldagem de fabricação no instante de 15000s.

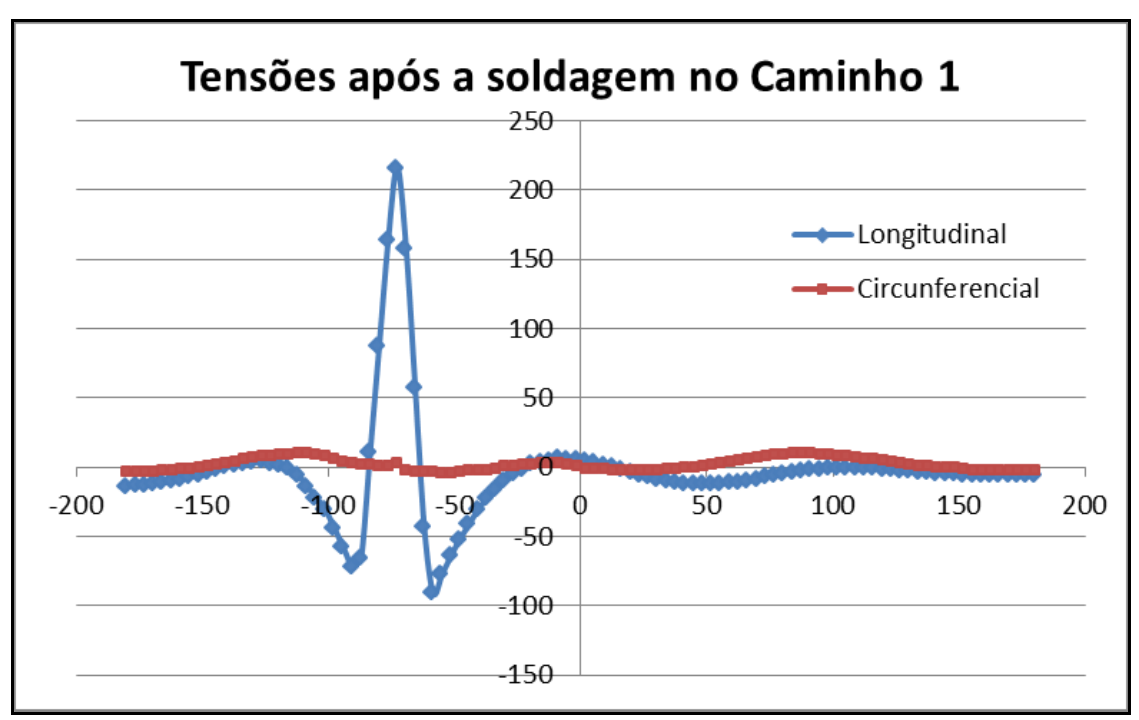

Figura 7.17: Distribuição de tensões residuais no Caminho 1 em 15000s. 
O Caminho 1 corta a junta1 na posição de -73 graus. Nessa posição a tensão residual longitudinal é máxima trativa, e as tensões nas adjacências são compressivas e auto-equilibrantes.

As tensões residuais circunferenciais têm magnitudes baixas, variando numa faixa de -10 a $7 \mathrm{MPa}$, e também sofrem influência da realização das soldagens das juntas 5 e 6.

Após o término das soldagens é aplicado no vaso um teste hidrostático. A pressão de teste foi calculada no item 7.3.3 e é igual a 1.874 MPa. A Figura 7.18 apresenta as distribuições de tensões equivalentes no vaso durante a realização do teste hidrostático com pressão igual a $130 \%$ da pressão de projeto.

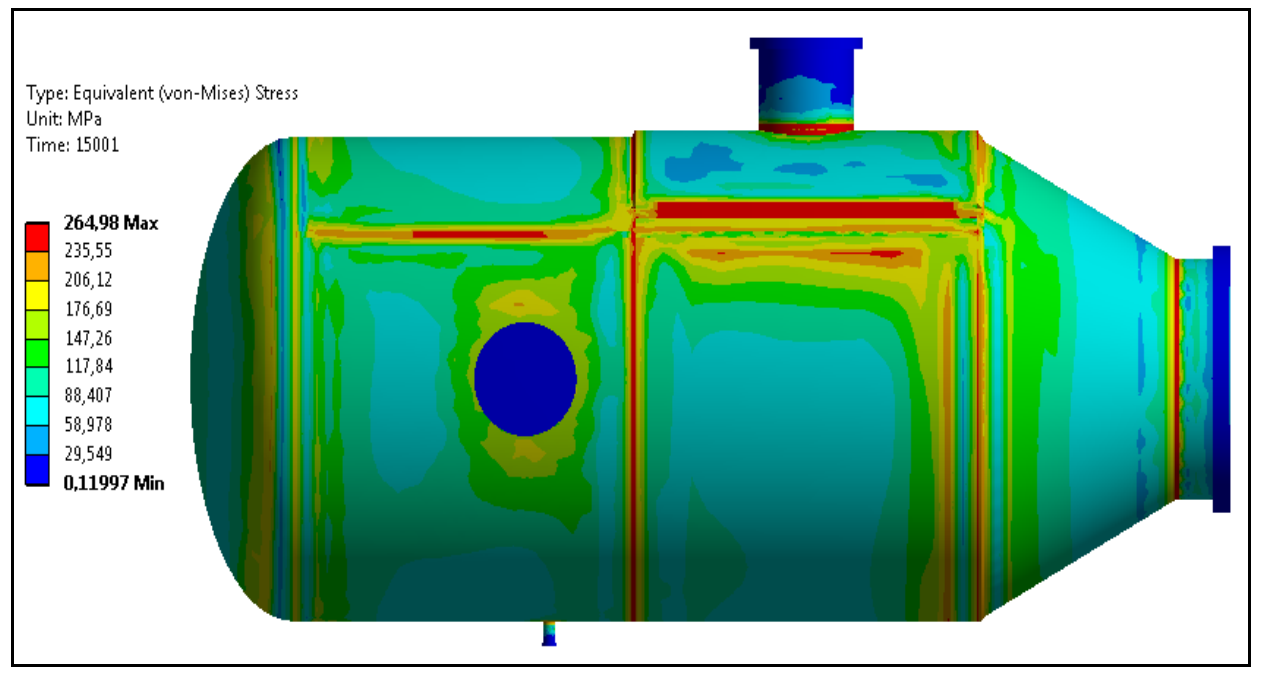

Figura 7.18: Distribuição de tensões residuais equivalentes no vaso durante a realização do TH.

Durante o teste hidrostático a influência da pressão nas demais direções fora a circunferencial é muito pequena; nas regiões nominais do costado cilíndrico o teste hidrostático causa tensões circunferenciais que são duas vezes maiores que as longitudinais.

A Figura 7.19 apresenta as distribuições de tensões ao longo do Caminho 1 do vaso durante a realização do teste hidrostático. 


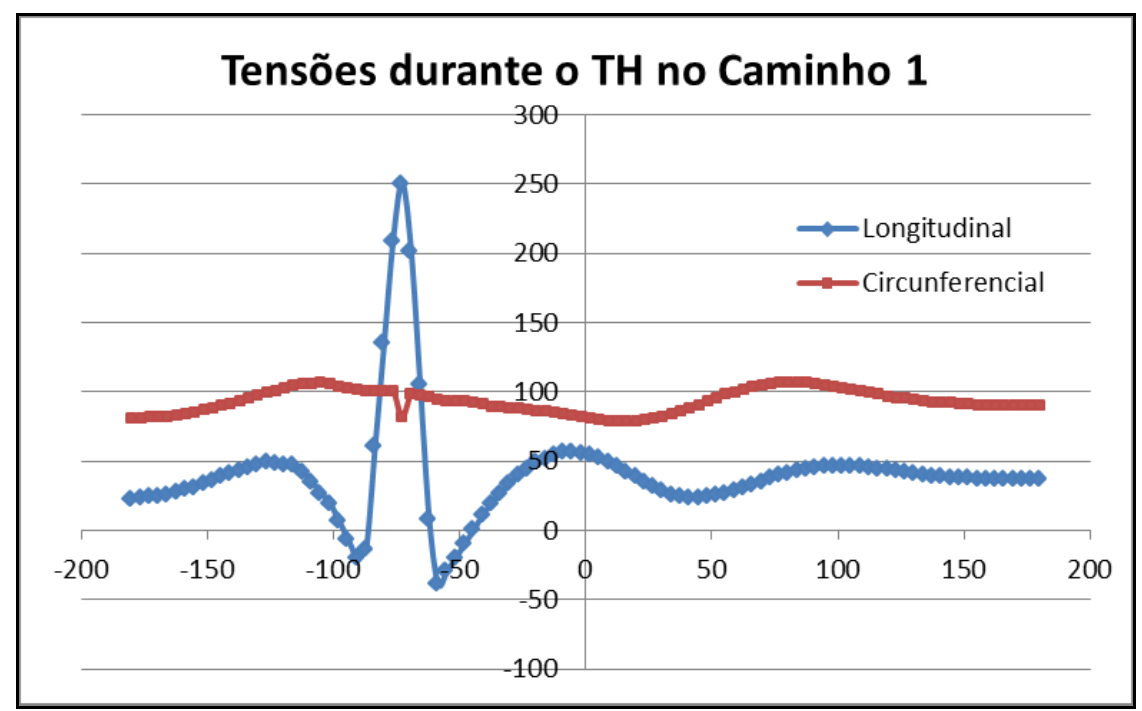

Figura 7.19: Tensões no vaso durante a realização do teste hidrostático.

Na Figura 7.20 são comparadas as distribuições das tensões residuais antes da realização do teste hidrostático e após a despressurização e fim do alívio de tensões no Caminho 1. $\mathrm{P}_{\mathrm{TH}}$

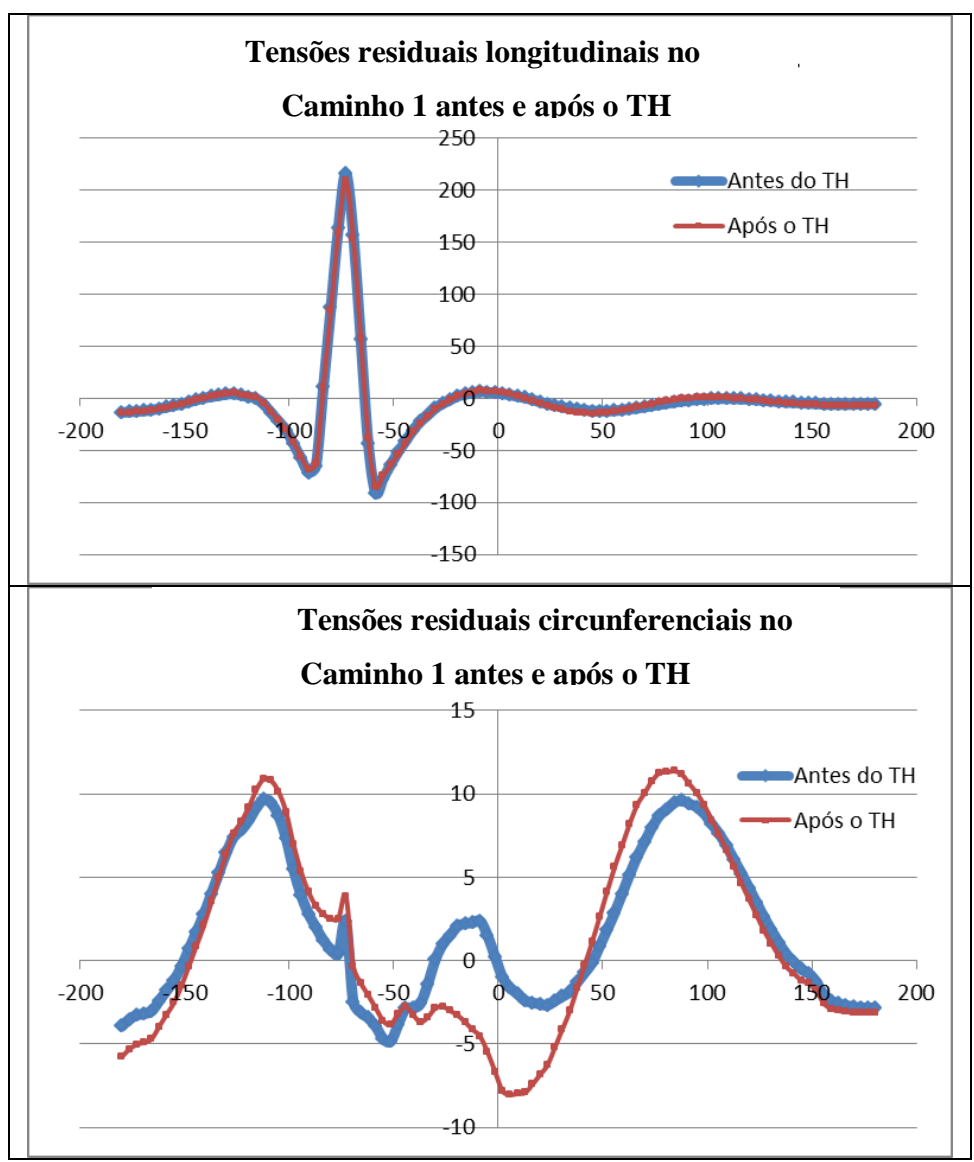

Figura 7.20: Comparação da distribuição de tensões residuais antes e após a realização do TH. 
Nesse caminho a maior influência do alívio de tensões, mesmo que pequena, ocorre na direção circunferencial, uma vez que a maior tensão provocada pelo teste hidrostático ocorre nessa direção. O teste hidrostático tem pouco efeito sobre as juntas longitudinais, como mostrado pela Figura 7.20.

$\mathrm{Na}$ Figura 7.21 é apresentada as distribuições das tensões residuais equivalentes após a realização do teste hidrostático.

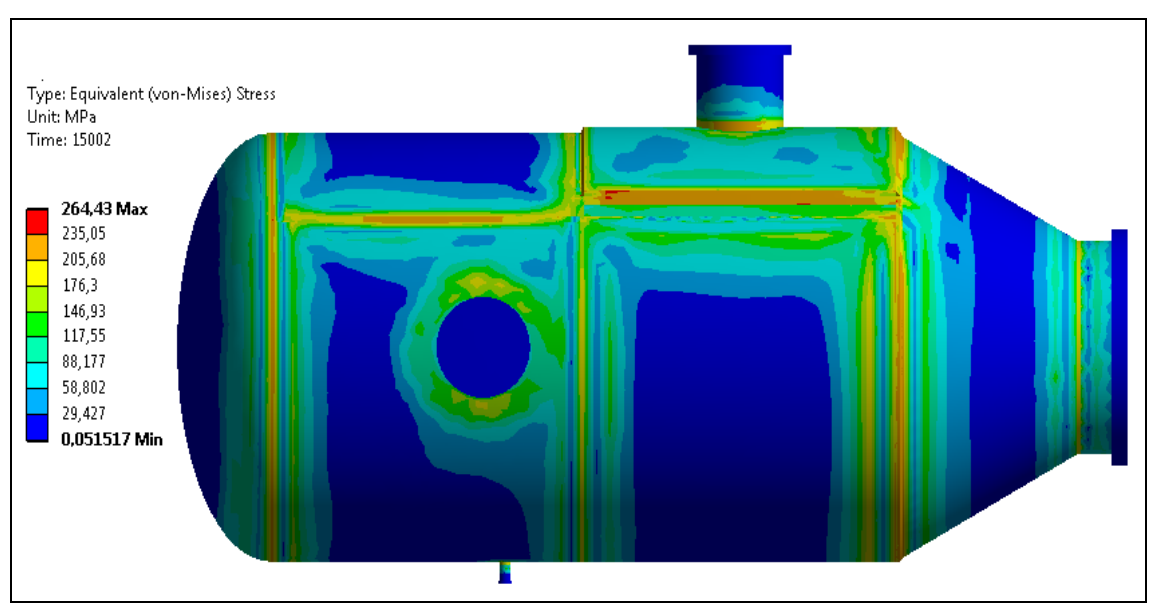

Figura 7.21: Distribuição de tensões residuais equivalentes no vaso após o TH.

Analisando a Figura 7.21, observa-se o alívio de tensões é maior nas juntas circunferenciais do que nas longitudinais, no entanto nem todas as juntas circunferenciais sofrem um alívio considerável após a realização do teste hidrostático. Devido à compatibilidade de deslocamentos, que deve existir no vaso durante a pressurização, as tensões nas juntas 6 e 8, regiões de mudança de geometria, não sofrem alteração, continuando as mesma anteriores ao teste hidrostático.

A Tabela 7.8 e a Figura 7.22 apresentam as tensões residuais antes, durante e após a realização do teste de alívio de tensões nos pontos estudados. As tensões circunferenciais e longitudinais nos pontos localizados nos costados cilíndrico e cônico do vaso foram: direção circunferencial é a direção tangente ao diâmetro do vaso; direção longitudinal é a direção do eixo longitudinal do vaso. As tensões circunferenciais e longitudinais nos pontos localizados nos bocais foram analisadas segundo o seguinte sistema de eixos de referência: direção circunferencial é a direção tangente ao diâmetro do bocal; direção longitudinal é a direção do eixo longitudinal do bocal. 
Tabela 7.8: Tensões nos pontos estudados.

\begin{tabular}{|c|c|c|c|c|c|c|}
\hline \multirow{2}{*}{ Instante } & \multicolumn{2}{|c|}{$\begin{array}{c}\text { Após a } \\
\text { Soldagem }\end{array}$} & \multicolumn{2}{c|}{ Durante o TH } & \multicolumn{2}{c|}{ Após o TH } \\
\hline Ponto/Tensão (MPa) & Circ. & Long. & Circ. & Long. & Circ. & Long. \\
\hline P1 & 2.78 & 239.55 & 81.38 & 272.72 & 2.77 & 226.02 \\
\hline P2 & 39.83 & 168.9 & 142.44 & 219.25 & 45.43 & 166.88 \\
\hline P3 & 250.35 & 59.39 & 249.78 & 51.44 & 229.39 & 58.70 \\
\hline P4 & 218.34 & -50.90 & 266.95 & 35.91 & 164.06 & -30.17 \\
\hline P5 & 208.47 & -19.02 & 226.85 & 26.15 & 166.03 & 1.45 \\
\hline P6 & 203.52 & -19.42 & 234.12 & 20.35 & 170.28 & 15.40 \\
\hline P7 & 218.34 & -22.54 & 235.44 & -7.44 & 180.07 & 4.06 \\
\hline P8 & 137.12 & -135.75 & 248.08 & 22.34 & 53.51 & -37.67 \\
\hline P9 & 171.31 & -109.59 & 140.07 & -63.23 & 152.85 & -101.88 \\
\hline P10 & 176.56 & -103.41 & 241.31 & -7.35 & 148.85 & -55.15 \\
\hline P11 & 146.88 & -125.28 & 55.60 & -188.16 & 108.47 & -117.47 \\
\hline P12 & 178.46 & -104.00 & 250.44 & 0.37 & 159.9 & -52.65 \\
\hline P13 & 46.79 & 265.26 & 50.36 & 265.28 & 36.60 & 239.24 \\
\hline P14 & 248.88 & -8.03 & 250.82 & -5.99 & 215.37 & -5.43 \\
\hline
\end{tabular}

Analisando a tabela acima, pode se verificar que os pontos P1, P2 e P13 apresentam tensões residuais longitudinais após a soldagem com valores próximos ao limite de escoamento do material devido à restrição a expansão nessa direção. Analogamente, os pontos P3, P4, P5, P6, P7, P6, P7, P8, P9, P10, P11, P12 e P14 apresentam tensões circunferenciais com valores próximos ao limite de escoamento do material, pois a restrição à expansão nesses pontos se dá na orientação circunferencial.

Com a aplicação do teste hidrostático há uma alteração nos estados de tensão do vaso, as regiões do vaso tem um acréscimo de deformações trativas. Após a despressurização do vaso as tensões residuais são redistribuídas em novos estados de equilíbrio. Os pontos P9 e P11 sofrem pouca variação em seus valores de tensões residuais, sendo que esse comportamento se deve as flexões que existem nessas regiões, que tem por finalidade manter a compatibilidade de deslocamentos nas regiões com transição de geometria. Assim, mesmo com a aplicação de um alívio de tensões esse pontos mantem seu valores de tensões residuais inalterados, independente da pressão de teste aplicada. As juntas mais críticas para análise da vida à fadiga são aquelas localizadas em regiões onde a geometria do vaso é variável. 
Os demais pontos localizados em juntas circunferências apresentam uma redução do nível de tensões residuais circunferências em torno de 19\%, enquanto que a redução das magnitudes nos pontos situados em juntas longitudinais é de apenas $5 \%$. O teste hidrostático tem pouca influência em outras direções fora a circunferencial, como mostrado na Figura 7.22. Esse fato se deve as tensões provocadas pelo tratamento de alívio serem relativamente baixas, sendo menores que o limite de escoamento do material.

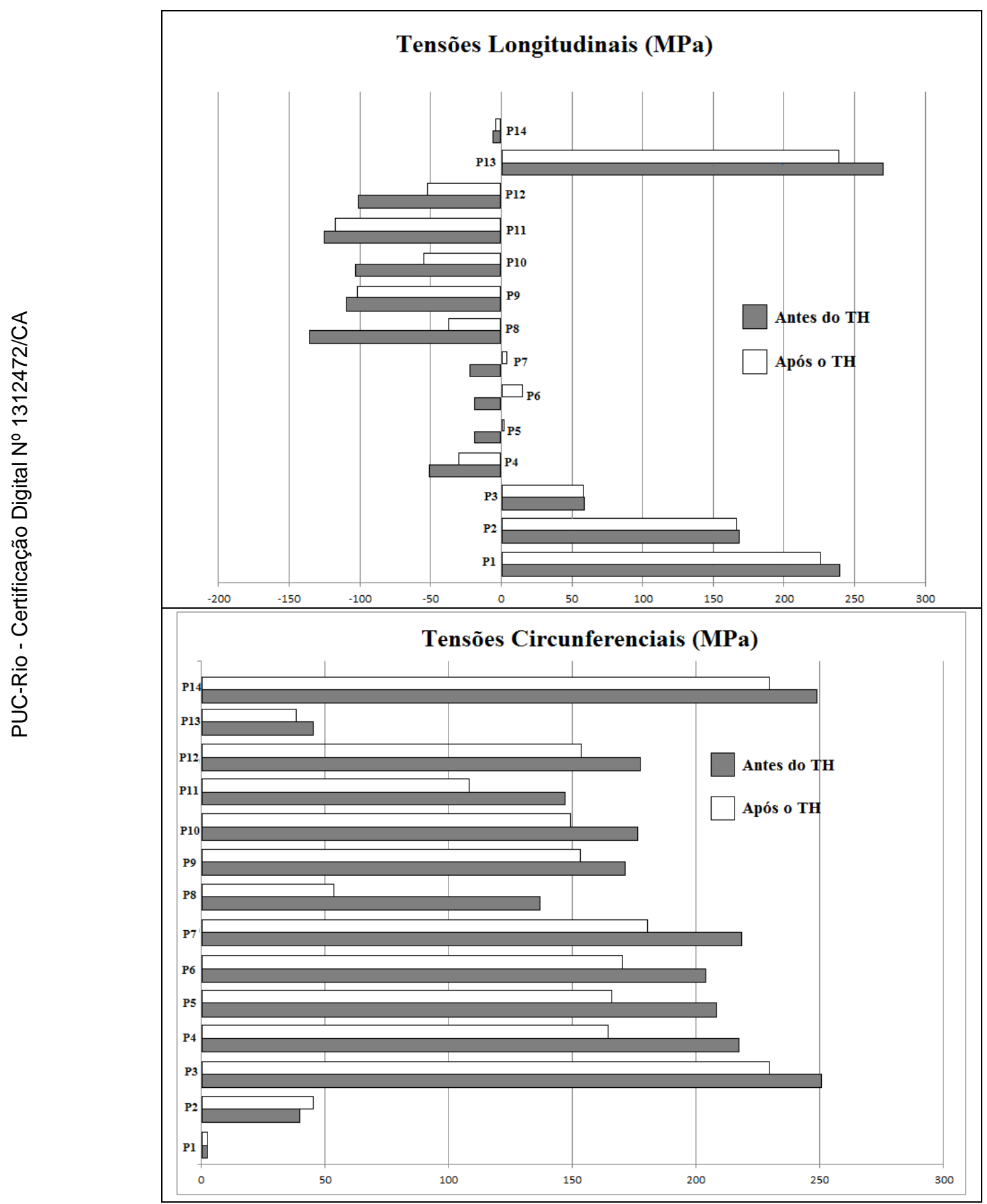

Figura 7.22: Comparação entre as tensões residuais nos pontos estudados antes e após o TH. 
Além da pressão de teste igual a $1.874 \mathrm{MPa}$ foram testadas outras duas pressões, uma igual a $2.0 \mathrm{MPa}(138.74 \%$ da pressão de projeto) e outra igual a 3.5 MPa (242.78\% da pressão de projeto). Essas duas outras pressões de teste hidrostático foram escolhidas de maneira a estudar a influência do teste de hidrostático no alívio de tensões.

A pressão de teste igual a $3.5 \mathrm{MPa}$ teve esse valor escolhido, pois é o menor valor de pressão que inicia o escoamento do cortado cilíndrico na direção circunferencial. Assim como o costado apresenta um estado de tensões residuais menores que as demais regiões do vasão, durante a aplicação do teste essas demais regiões apresentam tensões acima do limite de escoamento do material. Já a pressão igual $2 \mathrm{MPa}$ foi escolhida por ser um valor intermediário entre a menor e maior pressão.

Semelhante a Tabela 7.8 a Tabela 7.9 apresenta as tensões residuais antes, e após a realização dos novos testes de alívio de tensões nos pontos estudados.

Tabela 7.9: Tensões nos pontos estudados para as $\mathrm{P}_{\mathrm{TH}}$ iguais a $2 \mathrm{MPa}$ e $3.5 \mathrm{MPa}$.

\begin{tabular}{|c|c|c|c|c|c|c|}
\hline & & & \multicolumn{4}{|c|}{ Pressão do TH } \\
\hline & & & \multirow{2}{*}{\multicolumn{2}{|c|}{$\begin{array}{c}2 \mathrm{MPa} \\
\text { Após o TH }\end{array}$}} & \multirow{2}{*}{\multicolumn{2}{|c|}{$\begin{array}{c}\text { 3.5 MPa } \\
\text { Após o TH }\end{array}$}} \\
\hline Instante & \multicolumn{2}{|c|}{$\begin{array}{c}\text { Após a } \\
\text { Soldagem }\end{array}$} & & & & \\
\hline Ponto/Tensão (MPa) & Circ. & Long. & Circ. & Long. & Circ. & Long. \\
\hline $\mathrm{P} 1$ & 2.78 & 239.55 & 2,26 & 204,78 & $-12,18$ & 103,34 \\
\hline $\mathrm{P} 2$ & 39.83 & 168.9 & 22,11 & 157,29 & $-45,57$ & 3,52 \\
\hline P3 & 250.35 & 59.39 & 211,17 & 43,15 & 45,15 & $-157,15$ \\
\hline $\mathrm{P} 4$ & 218.34 & -50.90 & 124,17 & $-21,79$ & 5,04 & 48,78 \\
\hline P5 & 208.47 & -19.02 & 136,81 & 6,99 & $-32,76$ & 6,97 \\
\hline P6 & 203.52 & -19.42 & 150,12 & 35,63 & 159,85 & 150,61 \\
\hline $\mathrm{P} 7$ & 218.34 & -22.54 & 164,59 & 40,05 & 76,66 & $-24,87$ \\
\hline P8 & 137.12 & -135.75 & $-26,08$ & $-12,8$ & $-104,64$ & $-57,08$ \\
\hline P9 & 171.31 & -109.59 & 135,67 & $-84,94$ & $-59,27$ & 94,31 \\
\hline $\mathrm{P} 10$ & 176.56 & -103.41 & 122,48 & $-27,52$ & 34,36 & 2,84 \\
\hline P11 & 146.88 & -125.28 & 81,69 & $-105,11$ & $-113,03$ & $-12,06$ \\
\hline $\mathrm{P} 12$ & 178.46 & -104.00 & 132,95 & $-29,61$ & 39,54 & 22,96 \\
\hline $\mathrm{P} 13$ & 46.79 & 265.26 & 5,26 & 212,3 & -45 & 129,36 \\
\hline P14 & 248.88 & -8.03 & 196,32 & $-4,25$ & 129,2 & $-7,05$ \\
\hline
\end{tabular}

Nas Figuras 7.23, 7.24 e 7.25 são comparadas as tensões residuais circunferenciais e longitudinais antes e após a realização de cada teste hidrostático. 


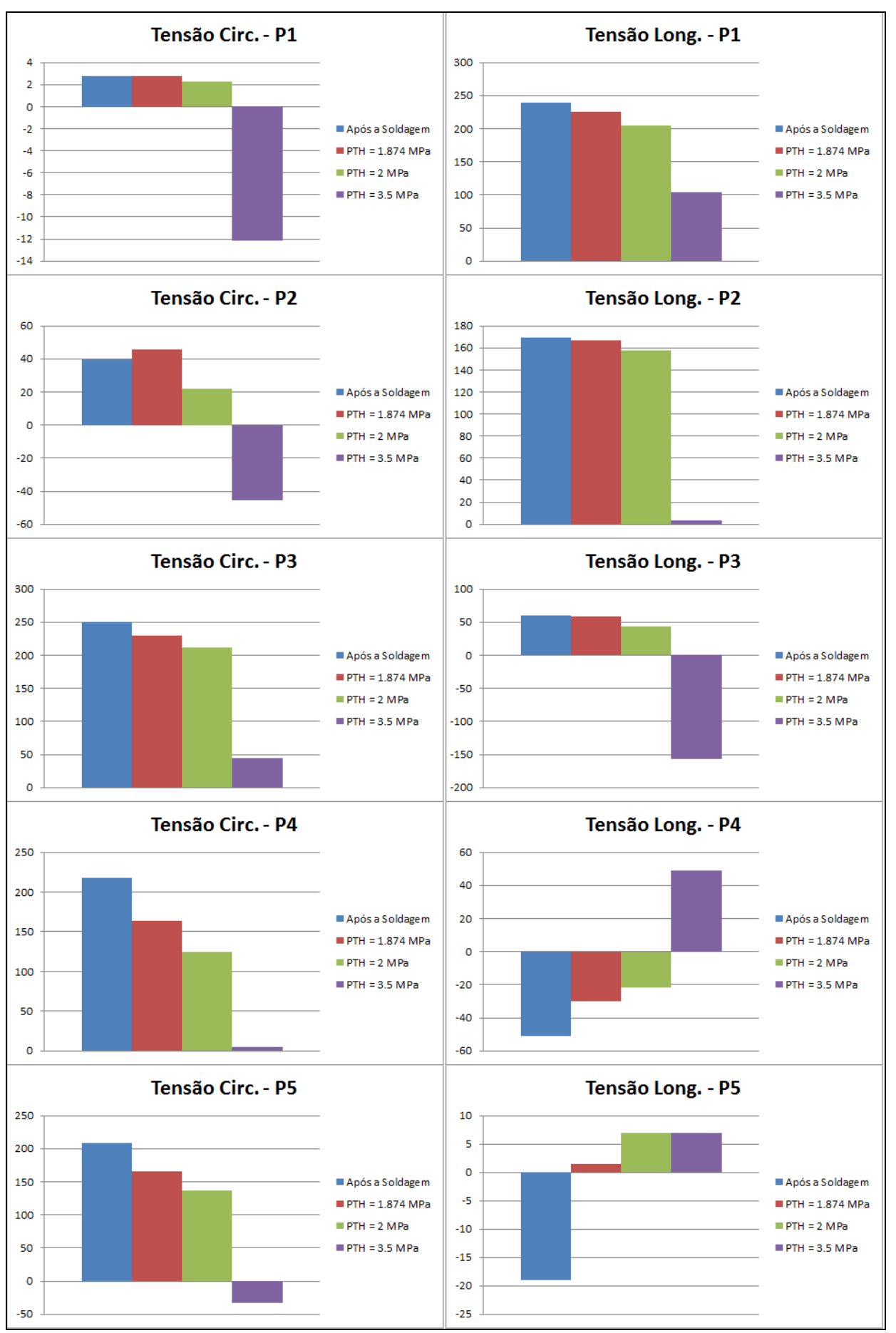

Figura 7.23: Comparação entres tensões residuais circunferenciais e longitudinais antes e após a realização de cada um dos testes hidrostático nos pontos $\mathrm{P} 1, \mathrm{P} 2, \mathrm{P} 3, \mathrm{P} 4$ e P5. 


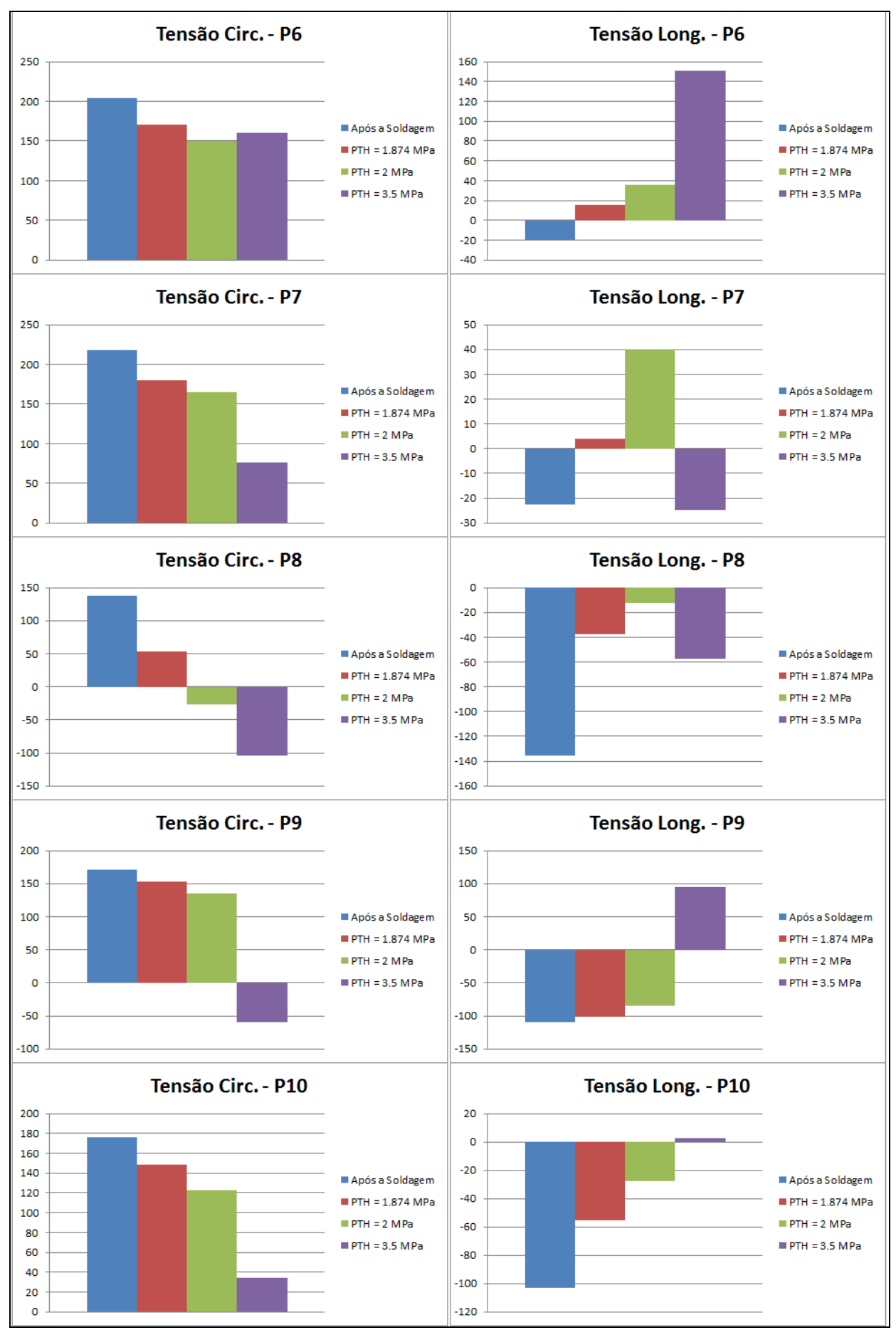

Figura 7.24: Comparação entres tensões residuais circunferenciais e longitudinais antes e após a realização de cada um dos testes hidrostático nos pontos P6, P7, P8, P9 e P10. 


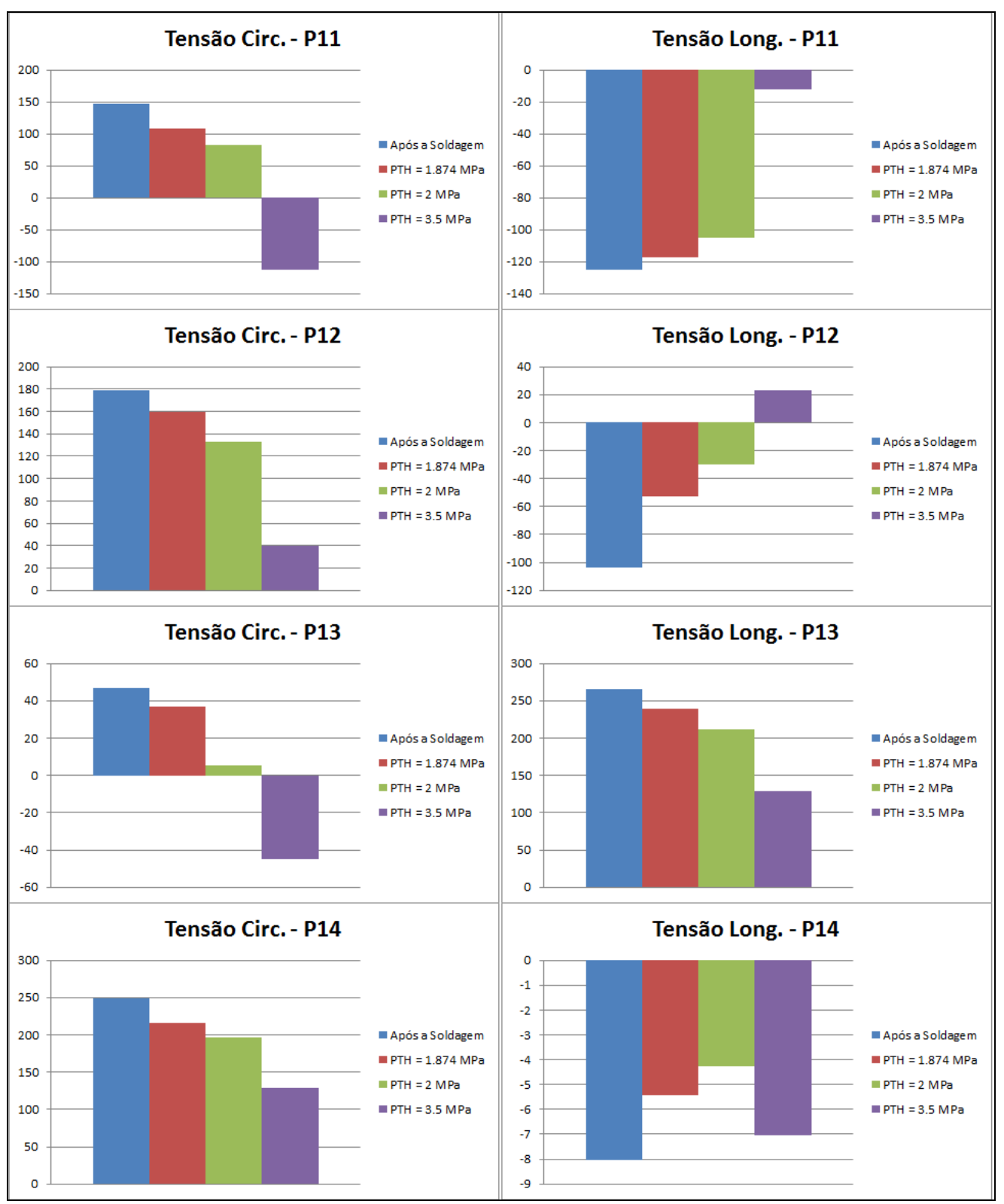

Figura 7.25: Comparação entres tensões residuais circunferenciais e longitudinais antes e após a realização de cada um dos testes hidrostático nos pontos $\mathrm{P} 11, \mathrm{P} 12, \mathrm{P} 13$ e $\mathrm{P} 14$.

Analisando as Figura 7.23, 7.24e 7.25 observa-se o alívio de tensões é maior no caso do teste com pressão igual a $3.5 \mathrm{MPa}$, no geral esse teste provoca um alívio de tensões residuais considerável no vaso, sendo extremamente benéfico, no entanto nem sempre esse teste provoca um efeito de alívio, como é o caso da tensão longitudinal do ponto $\mathrm{P} 12$. 
Analisando esses testes hidrostáticos do ponto de vista da norma API 579 FFS-1 [23], os teste com pressão de $1.874 \mathrm{MPa}$ e $2 \mathrm{MPa}$ causam uma tensão circunferencial de membrana no costado cilíndrico do vaso bem abaixo do limite de escoamento do material, assim a redução no nível de tensões é pequena. Já a pressão de $3.5 \mathrm{MPa}$ provoca uma tensão circunferencial de membrana no costado cilíndrico igual ao limite de escoamento, causando uma redução considerável no nível de tensões residuais. 


\section{8 Conclusões e Sugestões para Trabalhos Futuros}

\subsection{Conclusões}

Essa dissertação se baseou em métodos numéricos e experimentais para estudar e estimar o comportamento mecânico de estruturas soldadas após a realização da soldagem e da aplicação de técnicas de alívio de tensões, com principal foco na análise das tensões residuais geradas durante os processos. Diferentes hipóteses foram testadas com o objetivo de se desenvolver uma metodologia para a simulação numérica por elementos finitos da soldagem de qualquer estrutura, independente de seu formato complexo, levando em consideração os parâmetros da soldagem, como: velocidade, calor fornecido, número de passes de solda, e a variação das propriedades do material com a temperatura. Nas medições foram usadas as técnicas do Furo Cego, do Furo Elíptico (uma técnica de seccionamento) e Difração de raios X. Os resultados encontrados foram comparados com os obtidos via MEF e por formulações presentes na literatura.

Em geral as tensões residuais simuladas, medidas e previstas por formulações analíticas apontaram valores altos, da ordem do limite de escoamento do material, na superfície dos cordões de solda na direção longitudinal da maior restrição à expansão e contração do material aquecido.

O perfil das tensões residuais no componente após a soldagem depende de diversos fatores. A velocidade de soldagem, o formato da junta, o número de passos de solda e o material da estrutura têm influência distinta sobre o comportamento das tensões permanentes.

Conclui-se que a aplicação dos testes de alívio de tensões é extremamente benéfica à estrutura. Neste trabalho percebeu-se uma redução considerável nas tensões residuais na direção do maior esforço causado pelo tratamento. Entretanto, não se observou alívio em testes que provocaram esforços iguais ou inferiores a $60 \%$ do SMYS do material. 


\subsection{Sugestões para trabalhos futuros}

Para futuros trabalhos são feitas as seguintes sugestões:

$>$ Consideração dos efeitos das mudanças de fases microestruturais no desenvolvimento do perfil das tensões residuais e na condução do calor dentro do espécime;

Realização de medições experimentais nas juntas do vaso de pressão estudado no Capítulo 7;

Simulação dos componentes soldados sujeitos à esforços produzidos por sua operação continua. 


\section{Referências Bibliográficas}

[1] NOYAN, I. C.; COHEN, J. B.; "Residual stress - Measurement by diffaction and interpretation", Ed. Springer Verlag, 1987, 265p.

[2] RODRIGUES, L. D.; "Medição de tensões residuais em tubos visando a determinação de esforços em dutos enterrados". Dissertação de Mestrado, PUC-Rio, 2007.

[3] MACHERAUCH, E.; "Introduction to residual stress". Advances in surface treatments, 2014.

[4] MACHERAUCH, E., and K. H. Kloos; "Origin, measurement and evaluation of residual stresses." Residual Stresses in Science and Technology, 3-26, 1986.

[5] SHARPE Jr, W. N.; SHARPE, W. N.; "Springer handbook of experimental solid mechanics - Chapter 15". Springer Science \& Business Media, 2008.

[6] LU, J.; "Handbook of measurement of residual stresses, Vol 2". Ed. SEM, 2ed., 2005, 417p.

[7] BARSON, J.; ROLFE, A.; "Fracture and fatigue control in structures". Ed. ASTM, 1999, 515p.

[8] MASUBUCHI, K.; " Analysis of welded structures: Residual stresses, distortion, and their consequences". Elsevier, 1980.

[9] TEBEDGE, N.; ALPSTEN, G.; TALL, L.; "Residual-stress measurement by the sectioning method." Experimental Mechanics, 88-96, 1973.

[10] KÕO, J.; VALGUR, J.; "Layer growing/removing method for determination of residual stresses in orthotropic non-homogeneous cylinders". 2009.

[11] XIANFU, H.; LIU, Z.; XIE, H.; "Recent progress in residual stress measurement techniques." Acta Mechanica Solida Sinica, 570-583, 2013. 
[12] ASTM- E837-13; "Standard Test Method for Determining Residual Stresses by the Hole-Drilling Strain-Gage Method". 2013

[13] MEASUREMENTS, VISHAY MICRO; "Measurement of residual stresses by the hole drilling strain gage method". Tech Note TN-503-6, 2007.

[14] PREVEY, P. S. "X-ray diffraction residual stress techniques". ASM International, ASM Handbook, 380-392, 1986.

[15] KUDRYAVTSEV, Y.; KLEIMAN, J.; "Measurement of Residual Stresses in Welded Elements and Structures by Ultrasonic Method." International Institute of Welding. IIW Document XIII, 2010.

[16] BUTTLE, D. J., V. MOORTHY, and B. SHAW. "Measurement Good Practice Guide No. 88." Determination of Residual Stresses by Magnetic Methods, National Physical Laboratory (2006).

[17] BATHE, KLAUS-JÜRGEN; "Finite element method". Wiley encyclopedia of computer science and engineering, 2008.

[18] TSAI, C. L., S. C. PARK, and W. T. CHENG. "Welding distortion of a thinplate panel structure." Welding Journal, New York, 1999.

[19] MASUBUCHI, K.; MARTIN, D. C.; " Investigation of residual stresses in steel weldments". No. SSC-174 Final Rpt., Nat'l Academy of Sciences, Nat'I Research Council, 1966.

[20] MASUBUCHI, K.; "Analysis of Welded Structures". Pergamon, Elmsford, NY, 1980

[21] SATOH, K.; TERASAKI,T.; "Effect of welding conditions on welding deformations in welded structural materials". Journal of the Japan Welding Society, v. 45, n. 4, p. 302-308, 1976.

[22] BRITISH STANDARD, "B. S. 7910 - Guidance on Methods for Assessing the Acceptability of Flaws in Metallic Structures". 2005.

[23] API "579-1/ASME FFS-1." Fitness-For-Service, 2007. 
[24] PARDOWSKA, A. M.; "Evaluation of residual stress measurements before and after post-weld heat treatment in the weld repairs." Journal of Physics: Conference Series. Vol. 251. No. 1., 2010.

[25] LANCASTER, J. F.; "Metallurgy of Welding". 6aed, Abington Publishing, 1999.

[26] MODENESI, P. J.; MARQUES, P. V.; BRACARENSE, A. Q.; "Soldagemfundamentos e tecnologia". Ed UFMG, 2005.

[27] KODAMA, S.; "Effect of plasma heat source characteristics on nitrogen absorption in gas tungsten arc weld metal”. Welding in the World 925-932, 2013.

[28] TANAKA, M.; TASHIRO, S.; SATOH, T.; MURPHY, A. B.; LOWKE, J. J.; "Influence of shielding gas composition on arc properties in TIG welding". Sci Technol Weld Joining 13:225-231, 2008.

[29] KOU, S.; "Welding metallurgy". New York, 1987.

[30] WENTZ, ANDRÉ VIEGAS. "Simulações de soldagem por arco e resistência elétrica usando o método dos elementos finitos." Dissertação de metrado, UFRGS, 2008.

[31] RODEIRO, P. F.; "Análise de distribuição de temperaturas e tensões residuais em soldas do tipo ring-weld". Dissertação de metrado, USP, 2002.

[32] ANSYS; "ANSYS advanced analysis techniques guide." Ansys Help, 2007.

[33] Melting using element death, Ansys tutorial Alberta University. Disponível em: $\quad<$ http://www.mece.ualberta.ca/tutorials/ansys/at/birthdeath/birthdeath. html> Acessado em: 05/04/2014.

[34] Element birth and death, Ansys Online Manuals. Disponível em: <http://mostreal.sk/html/guide_55/g-adv/GADV6.html>Acessado em: 01/03/2015.

[35] PAIVA, V. E. L.; SANTOS, V. R.; MONTEIRO, M. J.; "Modelagem computacional dos aspectos térmicos na soldagem molhada". $67^{\circ}$ Congresso ABM Internacional, 2012. 
[36] SILVA, R. M. B.; "Uma contribuição à modelagem de processo de soldagem de placas de aço utilizando um modelo constitutivo acoplado". Dissertação de mestrado, CEFET-RJ, 2007.

[37] INCROPERA, F. P.; "Fundamentals of heat and mass transfer". John Wiley \& Sons, 2011.

[38] SHANG, DE-YI.; "Theory of heat transfer with forced convection film flows". Springer Science \& Business Media, 2010.

[39] MARTYNENKO, O. G.; KHRAMTSOV, P. P.; "Free-convective heat transfer: with many photographs of flows and heat exchange". Springer Science \& Business Media, 2005.

[40] SONNTAG, R. E.; BORGNAKKE, C.; VAN WYLEN, G. J.; VAN WYK, S.; "Fundamentals of thermodynamics". Vol. 6, New York, Wiley, 1998.

[41] SIEGEL, R.; HOWELL, J. R.; "Thermal radiation heat transfer". National Aeronautics and Space Administration, Lewis Research Center, 1992.

[42] AVERY, R. E.; "Pay attention to dissimilar-metal welds: guidelines for welding dissimilar metals". Nickel Development Institute, 1991.

[43] CAPRICCIOLI, A.; FROSI, P.; "Multipurpose ANSYS FE procedure for welding processes simulation." Fusion engineering and Design, 546-553, 2009.

[44] Element Solid90, Ansys Online Manuals. Disponível em: <http://mostreal.sk/html/elem_55/chapter4/ES4-90.html> Acessado em: 06/01/2015.

[45] Element Conta170, Ansys Online Manuals. Disponível em: <http://mostreal.sk/html/elem_55/chapter4/ES4-170.html> Acessado em: 06/01/2015.

[46] Element Conta174, Ansys Online Manuals. Disponível em: <http://mostreal.sk/html/elem_55/chapter4/ES4-174.html> Acessado em: 06/01/2015. 
[47] Element Surf152, Ansys Online Manuals. Disponível em: <http://www.ansys.stuba.sk/html/elem_55/chapter4/ES4-152.html> Acessado em 06/01/2015.

[48] ANSYS; "Mechanical ANSYS Mechanical Structural Nonlinearities - Lecture 3, Introduction to Contact". 2010.

[49] DENIS, S.; GAUTIER, E.; SIMON, A.; BECK, G.; "Stress-phasetransformation interactions-basic principles, modelling, and calculation of internal stresses". Materials Science and Technology, 805-814, 1985.

[50] PACHECO, P. M. C. L; "Analise do acoplamento termomecânico em materiais elasto-viscoplasticos". Tese de doutorado, Puc-Rio, 1994.

[51] LUBLINER, J.; "Plasticity Theory". University of California at Berkeley, 2006.

[52] ANSYS; "Mechanical ANSYS Mechanical Structural Nonlinearities - Lecture 5, Rate Independent Plasticity". 2010.

[53] PILIPENKO, A.; "Computer Simulation of Residual Stress and Distortion of Thick Plates in Multielectrode Submerged Arc Welding: Their Mitigation Techniques.". Tese de doutorado, NUST, 2001.

[54] PAIVA, V. E. L.; RODRIGUES, L. D.; FREIRE, J. L.F.; DELGADILLO, G. W. R.; "Simulação da geração e medição de tensões residuais na junta soldada de um tubo API 5L X60". $2^{\circ}$. Congresso de Integridad em Instalaciones em el Upstream y Downstream de Petróleo y Gas, Arg., 2014.

[55] VILA, M. A. V.; "Análise de integridade estrutural de dutos com mossas simples" Dissertação de mestrado, PUC-Rio, 2007.

[56] Element Solid186 Description, Inside Mines. Disponível em: <http://inside.mines.edu/ apetrell/ENME442/Documents/SOLID186.pdf> Acessado em: 23/03/2015.

[57] Alloy 2205, SAND MEYER STEEL COMPANY. Disponível em: <http://www.sandmeyersteel.com/2205.html> Acessado em: 19/08/2014. 
[58] PEET, M. J.; HASAN, H. S.; BHADESHIA, H. K. D. H.; "Prediction of thermal conductivity of steel". The International Journal of Heat and Mass Transfer, Vol. 54, 2602-2608, 2011.

[59] BARRON, R. F.; BARRON, B. R.; "Design for thermal stress”. Wiley, 2011;

[60] PAIVA, V. E. L.; RODRIGUES, L. D.; FREIRE, J. L. F.; “Tensões residuais causadas pelo processo de aquecimento e resfriamento de um disco delgado". 12a Coteq, 2013;

[61] DELGADILLO, G. W. R.; "Medição de tensões residuais em tubos submetidos a esforços combinados". Dissertação de metrado, PUCRio, 2009.

[62] RODAKOSKI, M. R.; "Medição de tensões residuais com holografia eletrônica". Tese de doutorado, UFSC, 1997.

[63] FITZPATRICK, M. E.; FRY, A. T.; HOLDWAY, P.; KANDIL, F. A.; SHACKLETON, J.; SUOMINEN, L.; "Measurement Good Practice Guide No. 52. Determination of Residual Stresses by X-ray Diffraction". 2005.

[64] CULLITY, B. D.; "Elements of X-ray diffraction". 2ed, Wesley Publ. Comp., 1978.

[65] TIMOSHENKO, S. P.; GOODIER, J. N.; "Theory of Elasticity", McGraw-Hill Book Company, 3ed, 1986.

[66] FREIRE, J. L. F.; "Engenharia de dutos”. Rio de Janeiro. ABCM, 2009;

[67] KYRIAKIDES, S.; CORONA, E.; "Mechanics of Offshore Pipelines: Volume 1 Buckling and Collapse". Elsevier Science, 2007;

[68] API SPECIFICATION 5L/ISO3183. Disponível em <http://apispecification.com/psl1.html> Acessado em: 16/02/2015.

[69] TOSCANO, R. G.; RAFFO, J.; FRITZ, M.; SILVA, R. C.; HINES, J.; TIMMS, C.; "Modeling the UOE Pipe Manufacturing Process". ASME 27th International Conference on Offshore Mechanics and Arctic Engineering (pp. 521-528). American Society of Mechanical Engineers, 2008. 
[70] RODRIGUES, L. D.; FREIRE, J.L.F.; VIEIRA, R.D.; "Measurement of residual stresses in UOE-SAW line pipes," Experimental Techniques, p58-62 2008.

[71] RODRIGUES, L. D.; FREIRE, J.L.F. ; VIEIRA, R.D.; "Desenvolvimento e avaliação experimental de uma nova técnica para medição de tensões residuais". Matéria (UFRJ), v. 16, p. 842-856, 2011.

[72] DA SILVA JR, V. F.; "Projeto e estudo da fabricação de vaso de pressão esférico". Dissertação de mestrado, USP, 2011.

[73] MOSS, D. R.; "Pressure vessel design manual". Elsevier, 2004.

[74] TELLES, P. C. S.; "Vasos de pressão". Rio de Janeiro: Livros Técnicos e Científicos, 1996.

[75] JUNIOR, V. M. P.; VALENÇA, A. L. V.; GOMES, F. T. M.; VELOSO, P. V. S. E.; V., WALDÉRIO DOS A E BARBOSA, J. M. A.; " Análise de vaso pressão segundo a ASME VII divisão 1 com recálculo pela divisão 2". 12a Coteq, 2013.

[76] ASTM A516 GRADE 60, MACSTEEL SA. Disponível em: $<$ http://www.macsteel.co.za/files/macsteel_vrn pressure_vessel_steels__astm_a516.pdf> Acessado em: 04/04/2015.

[77] BEDNAR, H. H.; "Pressure Vessel Design Handbook". Van Nostrand Reinhold, New York, 1985.

[78] KU, F. H.; "Evaluation of Residual Stresses in Small Diameter Stainless Steel Pipe Welds by Two-Dimensional and Three-Dimensional Finite Element Analyses". International Journal of Pressure Vessels and Piping, 2014.

[79] DONG, P.; SONG, S.; ZHANG, J.; "Analysis of residual stress relief mechanisms in post-weld heat treatment". International Journal of Pressure Vessels and Piping, v. 122, p. 6-14, 2014.

[80] YAGHI, A. H.; "Finite element simulation of residual stresses induced by the dissimilar welding of a P92 steel pipe with weld metal IN625". International Journal of Pressure Vessels and Piping, v. 111, p. 173-186, 2013. 
[81] KRUTZ, G. W.; SEGERLIND, L. J.; "Finited Element Analysis of Welded Structures". SAE Technical Paper, 1976.

[82] GOLDAK, J.; CHAKRAVARTI, A.; BIBBY, M.; "A new finite element model for welding heat sources". Metallurgical transactions B, 299-305 1984.

[83]XU, S.; WANG, W.; CHANG, Y.; "Using FEM to predict residual stresses in girth welding joint of layered cylindrical vessels". International Journal of Pressure Vessels and Piping, v. 119, p. 1-7, 2014.

[84] LU J.; FLAVENOT, J. F.; "Applications of the Incremental Hole-Drilling Method for Measurement of Residual-Stresses Distribution", Experimental Techniques, pp. 18-24, 1989. 


\section{Bibliografia Sugerida}

RODRIGUES, L. D. ; FREIRE, J. L.; VIEIRA, R. D.; “ Desenvolvimento e avaliação experimental de uma nova técnica para medição de tensões residuais”. Matéria (UFRJ), v. 16, p. 842-856, 2011.

RODRIGUES, L.D.; FREIRE, J. L. F.; VIEIRA, R. D.; "Measurement of Residual Stresses in UOE-SAW Line Pipes". Experimental Techniques (Westport, Conn.), v. 33, p. 58-62, 2008.

DELGADILLO, G.R.; FIORENTINI, F FREIRE, J. L. F. ; VIEIRA, R. D.; "Measurement of Stresses in Pipelines Using Hole Drilling Rosettes". In: Proceedings of Annual Conference in Experimental and Applied Mechanics, Society for Experimental Mechanics, 2010, Indianpolis, IN, EUA. Proceedings of Annual Conference in Experimental and Applied Mechanics, Society for Experimental Mechanics, 2010.

FIORENTINI, F ; DELGADILLO, G.R. ; RODRIGUES, L.D. ; VIEIRA, R. D. ; FREIRE, J. L. F. ; “Medição de Tensões Residuais em Tubos Submetidos a Esforços Combinados”. In: COTEQ 109, Conferência de Tecnologia de Equipamentos, ABENDE, 2009, Salvador. COTEQ 109, Conferência de Tecnologia de Equipamentos, ABENDE, 2009. v. CD. 


\section{Apêndice A -}

Comparação Entre Técnicas Experimentais de Medição de Tensões Residuais

Não existe uma técnica universal para medir tensões residuais, cada técnica apresenta vantagens e desvantagens segundo algum ponto de vista, seja ele técnico, econômico ou até mesmo prático, a Tabela A.1 descrita a seguir compara as diversas técnicas sob diferentes pontos de vista.

Tabela A.1: Comparação entre as principais técnicas de mediação de tensões residuais [2].

\begin{tabular}{|c|c|c|c|c|c|c|c|c|c|}
\hline 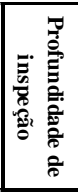 & 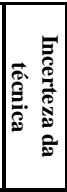 & 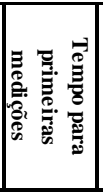 & $\mid$ & 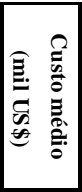 & 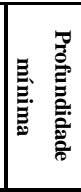 & 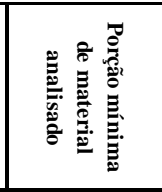 & 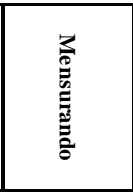 & 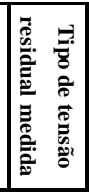 & 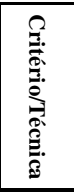 \\
\hline 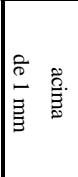 & 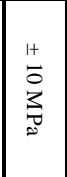 & 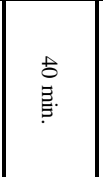 & $\underline{\mid l}$ & $\vec{u}$ & $\begin{array}{l}\overrightarrow{\tilde{N}} \\
\bar{N} \\
\bar{E}\end{array}$ & $\begin{array}{l}\overline{\mathrm{o}} \\
\overline{\mathrm{I}}\end{array}$ & 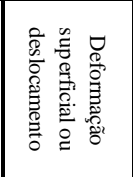 & $\begin{array}{l}z \\
\frac{z}{0} \\
\frac{0}{6}\end{array}$ & 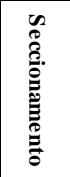 \\
\hline 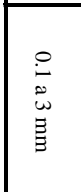 & 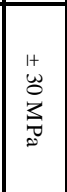 & $\begin{array}{l}\text { 岁 } \\
\text { 音. }\end{array}$ & $z^{\prime \prime}$ & - & $\begin{array}{l}\text { 葆 } \\
\text { 夏 }\end{array}$ & 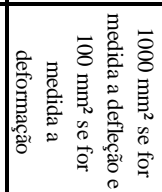 & 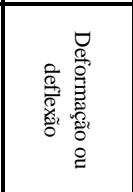 & $\begin{array}{l}\frac{z}{3} \\
\frac{\mathrm{g}}{6}\end{array}$ & 总 \\
\hline 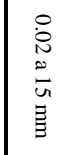 & 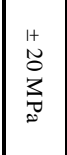 & $\begin{array}{l}\text { to } \\
\text { to }\end{array}$ & $\underline{s}$ & $\begin{array}{l}\overrightarrow{0} \\
\tilde{\omega} \\
u\end{array}$ & $\begin{array}{l}\tilde{\tilde{E}} \\
\underline{\underline{E}}\end{array}$ & $\begin{array}{l}\text { in } \\
\text { 害 }\end{array}$ & 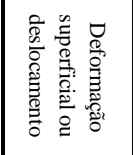 & $\begin{array}{l}3 \\
\frac{3}{0} \\
\frac{0}{6}\end{array}$ & 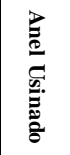 \\
\hline 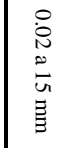 & \begin{tabular}{l}
$1+$ \\
N \\
\multirow{2}{0}{} \\
\multirow{2}{*}{}
\end{tabular} & $\begin{array}{l}\text { to } \\
\text { s. }\end{array}$ & 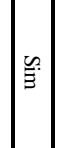 & $\begin{array}{l}\overrightarrow{0} \\
\tilde{\omega} \\
\bar{u}\end{array}$ & $\begin{array}{l}\text { N } \\
\underline{E}\end{array}$ & $\begin{array}{l}\text { in } \\
\text { in }\end{array}$ & 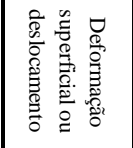 & $\begin{array}{l}\frac{z}{3} \\
\frac{a}{0}\end{array}$ & 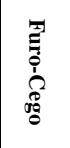 \\
\hline 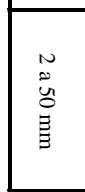 & 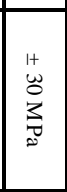 & 蒿 & $\underline{n}$ & $\begin{array}{l}\text { D } \\
\mathbb{N} \\
\mathbb{N}\end{array}$ & 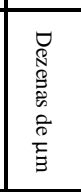 & $\begin{array}{l}\text { in } \\
\text { 害 }\end{array}$ & 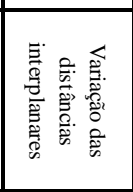 & 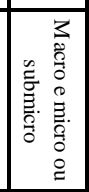 & 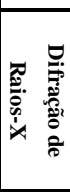 \\
\hline 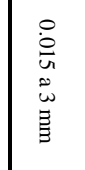 & $\begin{array}{l}1+ \\
+ \\
0 \\
0 \\
\tilde{O} \\
3 \\
0 \\
0\end{array}$ & 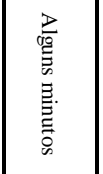 & $\underline{\underline{E}}$ & 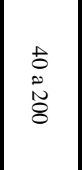 & $\begin{array}{l}\bar{u} \\
\ddot{\tilde{o}} \\
\overline{\mathrm{o}} \\
\overline{\mathrm{z}}\end{array}$ & 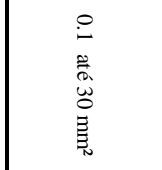 & 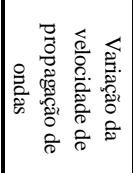 & 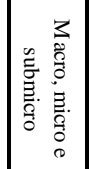 & 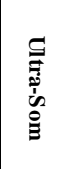 \\
\hline 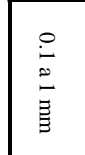 & 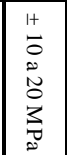 & 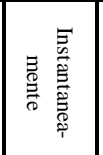 & 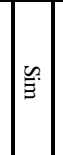 & 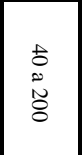 & $\begin{array}{l}\overrightarrow{\mathrm{s}} \\
\overline{\underline{E}}\end{array}$ & 言 & 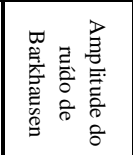 & 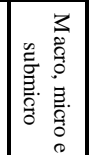 & 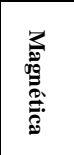 \\
\hline
\end{tabular}




\section{Apêndice B - \\ Modelos Analíticos de Fontes de Calor}

A maioria dos modelos de fontes de calor propostos na literatura utilizam a distribuição normal (gaussiana) para representar a distribuição do fluxo de calor, com os maiores fluxos no centro da distribuição. Os modelos são diferenciados pelas suas dimensões espaciais, fonte pontual, superficial e volumétrica.

\section{B.1 Fonte de Calor Pontual}

O modelo de Rosenthal foi o primeiro a descrever a distribuição de temperatura durante o processo de soldagem, fixando um sistema de coordenadas sobre a fonte de solda. A origem dos eixos foi estabelecida como o ponto de contato entre o eletrodo e a peça soldada e o sistema se move conforme o eletrodo produz o cordão de solda, considerando uma fonte de calor pontual.

A Figura B.1 demostra a fonte de calor pontual posicionada no centro da peça utilizada para o cálculo da distribuição de temperaturas em uma placa soldada pelo processo de soldagem submersa ou popularmente conhecida como soldagem molhada.

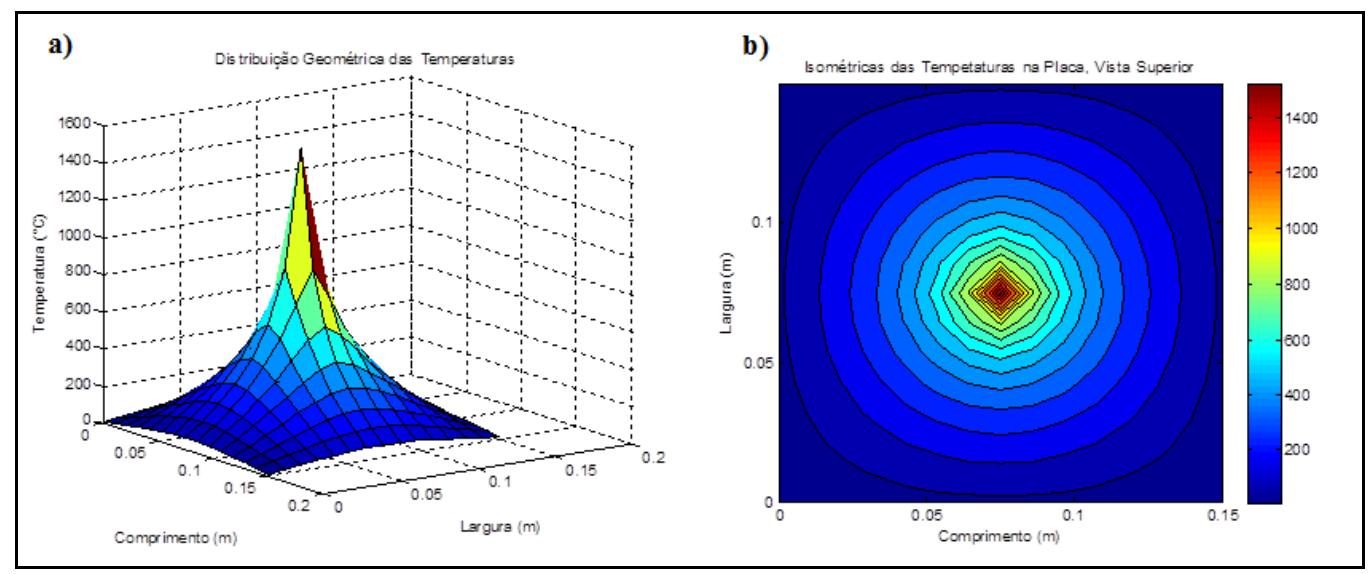

Figura B. 1: a) Distribuição geométrica de temperaturas de uma placa soldada pelo processo de soldagem molhada; b) Isotérmicas das temperaturas da mesma placa [35]. 


\section{B.2 Fonte de Calor Superficial}

O modelo de fonte de superficial, também conhecido por modelo do disco, é mais realístico do que o pontual, porque o fluxo de calor esta representado por uma área na superfície da peça. Esse modelo é bem acurado para descrever o preaquecimento de uma peça, onde o aporte térmico não ocasiona fusão na mesma, Figura B.2.

No modelo do disco, proposto por Pavelic, o fluxo térmico tem uma distribuição gaussiana ou normal no plano z-z:

$$
q(r)=q(0) e^{-C r^{2}}
$$

onde q(r) é o fluxo de calor superficial em um raio r, q(0) é o valor máximo do fluxo de calor no centro da fonte, $\mathrm{C}$ é o coeficiente de concentração e $\mathrm{r}$ a distância radial a partir do centro da fonte de calor.

$\mathrm{O}$ coeficiente $\mathrm{C}$ é relacionado com a largura da fonte, assim o coeficiente $\mathrm{C}$ pode ser assumido como sendo metade do diâmetro da fonte.

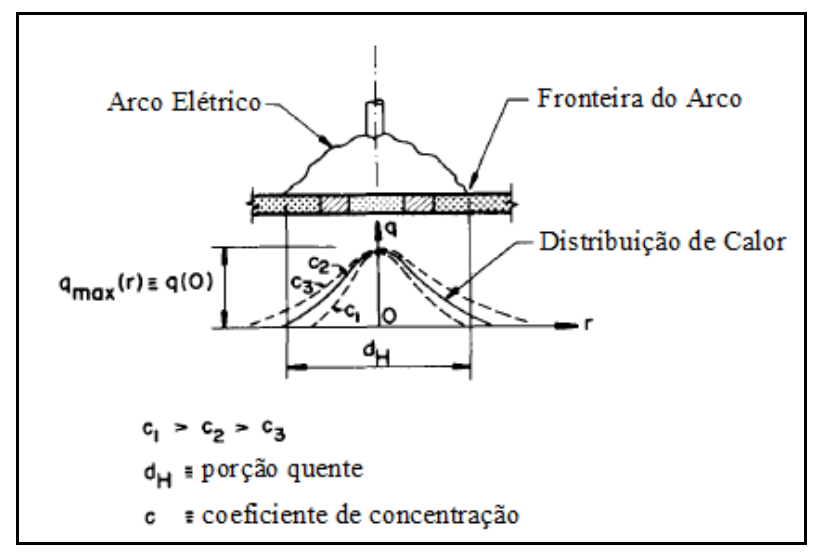

Figura B. 2: Fonte de calor circular. (goldak)

Em [81], Friedman e Krutz sugeriram uma forma alternativa para o modelo do disco, expresso em um sistema de coordenadas que se movimenta com a fonte de calor. Nesse modelo, é considerado um sistema de coordenadas móvel no centro da fonte e um fixo posicionado em um plano de referência, como apresentado na equação a seguir:

$$
q(x, \xi)=\frac{3 Q}{\pi c^{2}} \cdot e^{\frac{-3 x^{2}}{c^{2}}} \cdot e^{\frac{-3 \xi^{2}}{c^{2}}}
$$

onde Q é o aporte de energia, e c é o raio característico da distribuição gaussiana. 
É conveniente introduzir um sistema de coordenadas $(\mathrm{x}, \mathrm{y}, \mathrm{z})$ fixo na peça, onde $\xi$ representa a posição na direção de soldagem em relação a um sistema de coordenadas móvel, localizado no centro da fonte.

$$
\xi=z+v(\tau-t)
$$

onde z é a posição na direção de soldagem em relação ao sistema de coordenadas fixo, $v$ é a velocidade de soldagem, $\tau$ é o fator de atraso da soldagem, representando o tempo necessário para que a tocha, partindo da posição inicial, atinja a superfície de referência e té o tempo.

Para processos de soldagem com baixa penetração, a distribuição superficial proposta pelo modelo de Pavelic, Friedman e Krutz tem sucesso em representar o aporte térmico. No entanto para os casos onde o fluxo de calor para a peça é extremamente elevado esse modelo não leva em consideração os efeitos do arco na espessura. Nesses casos uma distribuição gaussiana hemisférica de calor é um modelo mais condizente com o real, Figura B.3.

A distribuição de calor para uma porção hemisférica pode ser descrita como:

$$
q(x, y, \xi)=\frac{6 \sqrt{3} Q}{c^{3} \pi \sqrt{\pi}} \cdot e^{\frac{-3 x^{2}}{c^{2}}} \cdot e^{\frac{-3 y^{2}}{c^{2}}} \cdot e^{\frac{-3 \xi^{2}}{c^{2}}}
$$

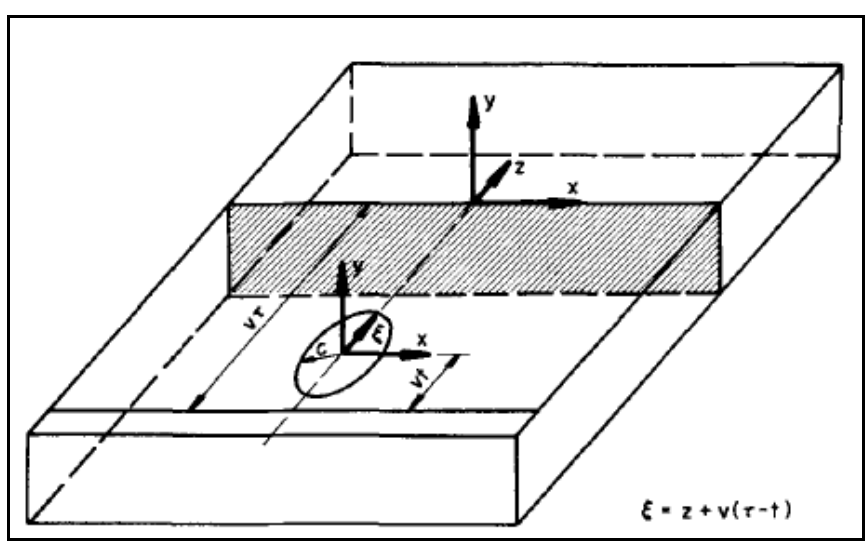

Figura B. 3: Fonte de calor em formato hemisférico, [82].

\section{B.3 Fonte de Calor Volumétrica}

A poça de fusão em muitas soldas não tem formato esférico, logo o modelo da fonte em formato de hemisfério não é apropriado para soldas assimétricas. A fim de solucionar as limitações dos modelos anteriores foi proposto um modelo de fonte de calor em formato de um elipsoide. 
Dentre as diversas formulações, a considerada a mais realista é a composta por duas semi-elipses, chamada de modelo do duplo elipsoide ou modelo de Goldak. A distribuição do fluxo de calor no quadrante frontal do elipsoide é:

$$
q_{f}(x, y, \xi)=\frac{6 \sqrt{3} \cdot f_{f} \cdot Q_{f}}{a \cdot b \cdot c \cdot \pi \sqrt{\pi}} \cdot e^{\frac{-3 x^{2}}{a^{2}}} \cdot e^{\frac{-3 y^{2}}{a^{2}}} \cdot e^{\frac{-3 \xi^{2}}{c^{2}}}
$$

A distribuição do fluxo de calor no quadrante posterior do elipsoide é:

$$
q_{r}(x, y, \xi)=\frac{6 \sqrt{3} \cdot f_{r} \cdot Q_{r}}{a \cdot b \cdot c \cdot \pi \sqrt{\pi}} \cdot e^{\frac{-3 x^{2}}{a^{2}}} \cdot e^{\frac{-3 y^{2}}{a^{2}}} \cdot e^{\frac{-3 \xi^{2}}{c^{2}}}
$$

onde $f_{f}$ e $f_{r}$ são as frações de calor depositados nos quadrantes frontal posterior respectivamente e $f_{f}+f_{r}=2$. "a", "b" e "c" são os semi-eixos paralelos ao sistema de coordenadas $x, y, \xi$. Os valores de "a", "b" e "c" são diferentes para os dois quadrantes. Na Figura B.4 é mostrado o modelo do duplo elipsoide.

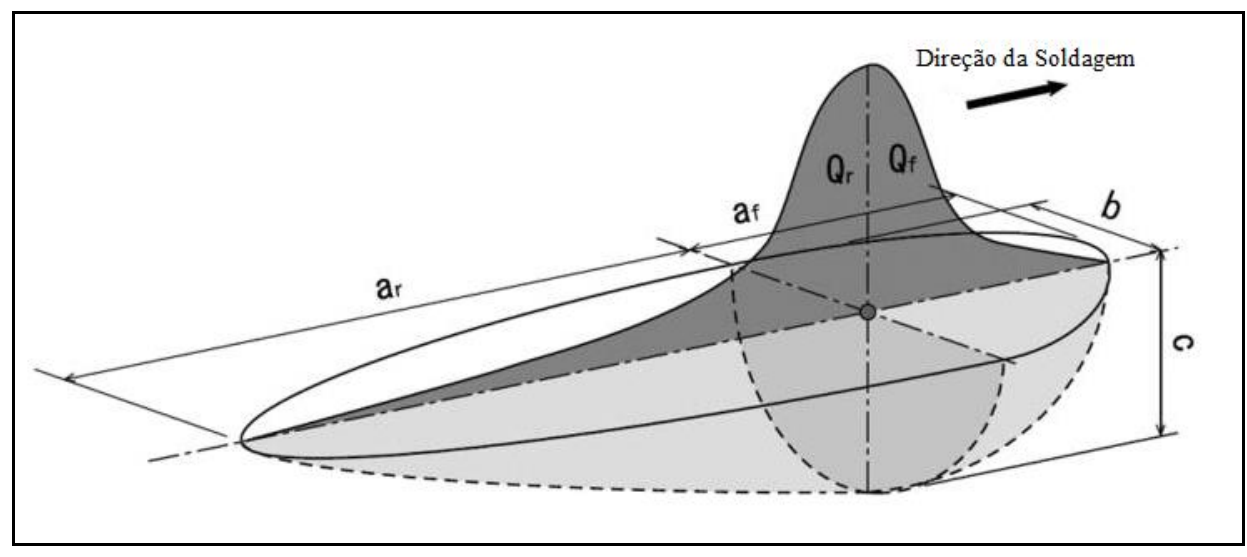

Figura B. 4: Fonte de calor em formato de duplo elipsoide, [82]. 


\section{Apêndice C - \\ Problema da Barra em Flexão Pura}

Este exemplo demonstra o comportamento de uma barra sob ação de dois momentos fletores. Considerou-se que a barra é fabricada a partir de um aço genérico com módulo de Young igual a 187,5 GPa, limite de escoamento igual a $300 \mathrm{MPa}$ e comportamento elasto perfeitamente plástico, como mostrada pelas Figura C.1.

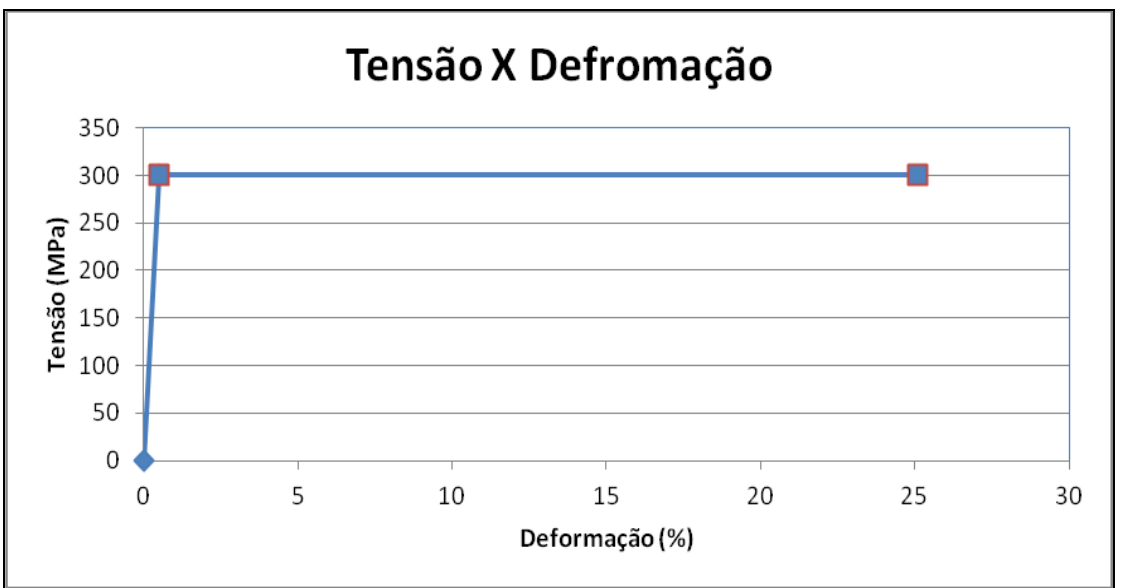

Figura C. 1: Diagrama tensão-deformação elasto perfeitamente plástico.

Os dados utilizados para simulação do problema se encontram discriminados na Tabela C.1e na Figura C.2, abaixo.

Tabela C. 1: Variáveis consideradas na análise.

\begin{tabular}{|c|c|}
\hline Limite de Escoamento $(\mathrm{MPa})$ & 300 \\
\hline Módulo de Elasticidade $(\mathrm{GPa})$ & 187.5 \\
\hline y inicial $(\mathrm{m})$ & 0.025 \\
\hline Coeficiente de Poisson & 0.3 \\
\hline Lado $(\mathrm{m})$ & 0.05 \\
\hline Comprimento $(\mathrm{m})$ & 0.5 \\
\hline Ârea $\left(\mathrm{m}^{2}\right)$ & 0.0025 \\
\hline Momento de Inércia $\left(\mathrm{m}^{4}\right)$ & $5.20833 \mathrm{E}-07$ \\
\hline
\end{tabular}




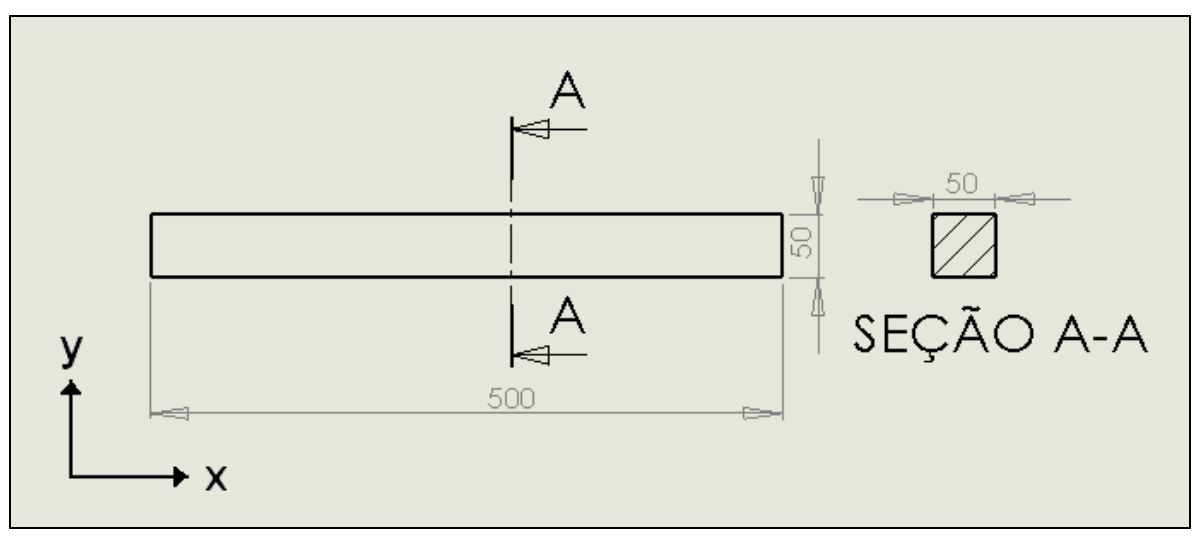

Figura C. 2: Dimensões da barra de seção quadrada.

Quando cargas são aplicadas na barra, seu eixo longitudinal é deformado assumindo a forma de uma curva. As tensões e deformações resultantes estão diretamente relacionadas à curvatura da curva de deflexão.

Tomando como base a linha neutra, que corta a barra em duas partes iguais em relação ao eixo x de referência da barra, pode-se determinar a relação entre tensão e o momento fletor, para situações em que as tensões atingem no máximo o limite de escoamento, como sendo:

$$
\sigma=-\frac{M \cdot y}{I}
$$

onde $\mathrm{M}$ é o momento fletor, y a distancia entre a linha neutra e a região limite de elasticidade, altura do núcleo elástico, e "I" o momento de inércia da estrutura.

O raio de curvatura ( $\rho)$ em geral depende proporcionalmente das deformações longitudinais $\left(\varepsilon_{\mathrm{x}}\right)$ a que a barra está sujeita, e varia linearmente com a distância y, comportando-se segundo a fórmula:

$$
\varepsilon=-\frac{y}{\rho}
$$

Observando a equação (C.2) acima se pode concluir que "as deformações em uma barra em flexão pura variam linearmente com a distância em relação à superfície neutra, independente da forma da curva de tensão-deformação do material." (8) 
A equação (C.1) é válida até a tensão atingir a tensão de escoamento $\sigma_{y}$, ou em tração ou em compressão. Se o momento fletor for aumentado acima do momento de escoamento $\mathrm{M}_{\mathrm{y}}$, as deformações na barra continuam a aumentar e a deformação máxima irá exceder a deformação de escoamento $\varepsilon_{\mathrm{y}}$. No entanto por causa do escoamento perfeitamente plástico, a tensão máxima irá permanecer constante e igual a $\sigma_{\mathrm{y}}$. As regiões externas da barra tornam-se totalmente plásticas enquanto seu núcleo central permanece elástico linear, como mostrado na Figura C.3.

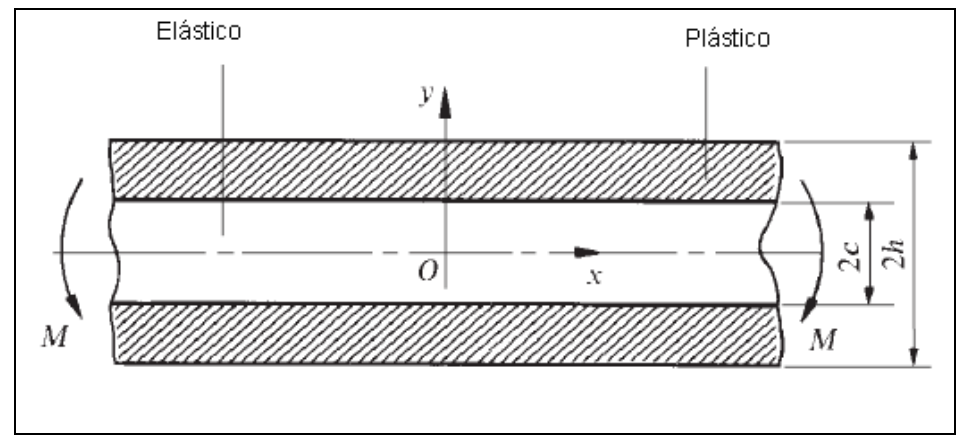

Figura C. 3: Plastificação das regiões externas devido à flexão pura.

Quando o momento aumenta, a região plástica cresce e se move para dentro em direção à linha neutra até que a terceira condição ilustrada na Figura C.4 é atingida. Nesse estágio, a deformação máxima na barra (na maior distância da linha neutra) é em torno de duas vezes a deformação de escoamento e o núcleo elástico quase desaparece. (8)

Dessa forma a barra atingiu o limite de sua capacidade de resistir a momentos, e se pode idealizar a última distribuição de tensão consistindo de duas partes retangulares, caso quatro da Figura C.4. O momento fletor correspondente a essa distribuição de tensão idealizada, chamado de momento plástico, representa o momento máximo que pode ser suportado pelo material elastoplástico. 


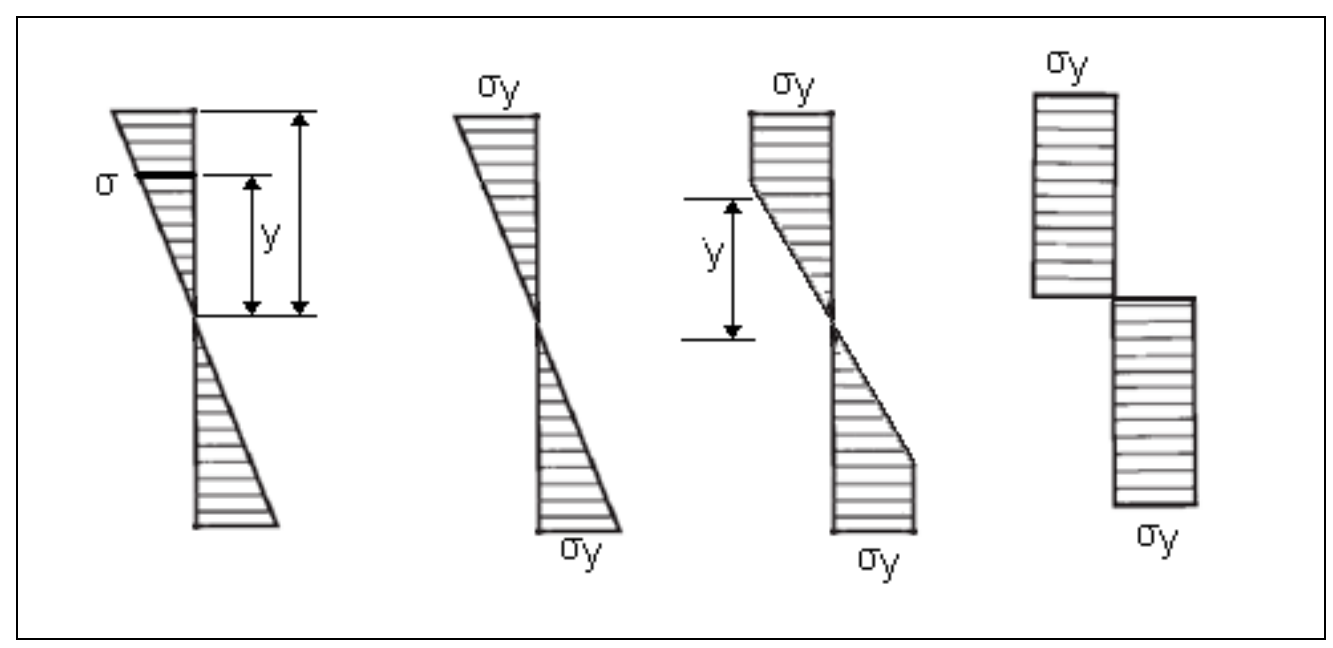

Figura C. 4: Distribuições de tensões em uma barra elastoplástica.

Pode- se definir o momento de colapso plástico em função da geometria da seção transversal da barra e do limite de escoamento, assim o momento máximo de escoamento é definido como: (9)

$$
M_{P}=2 l^{3} \sigma_{y}
$$

onde 1 é o comprimento do lado que forma o perfil quadrado da barra.

As tensões e deformações na região plástica superior a linha neutra tem magnitude igual, mas no sentido oposto as situadas na região inferior. O momento aplicado por unidade de comprimento é,

$$
M=2 \int_{0}^{h} \sigma_{x} y \cdot d y
$$

essa expressão é válida para qualquer relação entre c/h, Figura C.3.

A fim de facilitar a análise do problema, é suficientemente preciso substituir a aplicação do critério de von Mises pelo critério de Tresca modificado, onde $\sigma_{x}= \pm 2 \mathrm{Sy} /(3)^{1 / 2}$. Então a magnitude da tensão longitudinal aumenta de zero na linha neutra até $2 S_{y} /(3)^{1 / 2}$ na fronteira entre as regiões elástica e plástica. Assim o momento é, (5) 


$$
M \cong \frac{2 S_{y}}{\sqrt{3}}\left(h^{2}-\frac{1}{3} c^{2}\right)=\frac{1}{2} M_{y}\left[3-\left(\frac{\rho}{\rho_{y}}\right)^{2}\right]
$$

Analisando a equação proposta acima é possível se determinar a altura, y, do núcleo elástico quando o momento fletor é conhecido. Determina-se y em função do momento fletor, (8)

$$
y=h \sqrt{\frac{1}{2}\left(\frac{3}{2}-\frac{M}{M_{y}}\right)}
$$

onde h é igual a metade da altura do perfil transversal da barra.

No caso estudado, flexão de uma barra, pode-se estimar o momento de escoamento através da fórmula,

$$
M_{y}=0,750 \cdot S_{y} h^{2}
$$

E o raio de curvatura de escoamento como

$$
\rho_{y}=0,977 \cdot \frac{E \cdot h}{S_{y}}
$$

Consideraram-se diferentes momentos, com valores variando de zero até o momento de ruptura. Para valores de momento inferiores ao momento de escoamento, calculado como sendo $6250 \mathrm{~N} / \mathrm{m}$, não há formação de plasticidade e o comportamento da barra segue as equações (C.1) e (C.2).

Para valores de momento que iniciam a plastificação da barra, deve-se calcular o tamanho do núcleo elástico usando a equação (C.6), e depois estimar o raio de curvatura em função do momento e do momento de escoamento através da equação (C.5). Com o raio de curvatura obtém-se a deformação utilizando a equação (C.2) e para obtenção da tensão, deve-se verificar a curva de tensãodeformação do material.

Para que o momento fletor atinge o seu valor máximo igual ao momento de colapso plástico, seu raio de curvatura, $\rho$, deve ser zero. Como é impossível ter um raio de curvatura igual a zero, conclui-se que a barra jamais poderá se plastificar por completo quando sujeita a flexão pura. 
$\mathrm{Na}$ Tabela C.2 estão apresentados os resultados obtidos a partir do emprego das equações propostas acima para diferentes momentos fletores. A linha de valores grifada em amarelo representa a situação onde o momento atinge seu maior valor elástico.

Tabela C. 2: Resultados analíticos da barra sob flexão pura sem descarregamento.

\begin{tabular}{|c|c|c|c|c|}
\hline $\mathbf{M}$ (N.m) & $\boldsymbol{\sigma}(\mathbf{M P a})$ & $\boldsymbol{\varepsilon}$ & $\boldsymbol{\rho}(\mathbf{m})$ & $\mathbf{y}(\mathbf{m})$ \\
\hline 0 & 0.00 & 0 & Infinito & 0.025 \\
\hline 1000 & 48.00 & 0.000256 & 97.65625 & 0.025 \\
\hline 1500 & 72.00 & 0.000384 & 65.10416667 & 0.025 \\
\hline 2000 & 96.00 & 0.000512 & 48.828125 & 0.025 \\
\hline 2500 & 120.00 & 0.00064 & 39.0625 & 0.025 \\
\hline 3000 & 144.00 & 0.000768 & 32.55208333 & 0.025 \\
\hline 3500 & 168.00 & 0.000896 & 27.90178571 & 0.025 \\
\hline 4000 & 192.00 & 0.001024 & 24.4140625 & 0.025 \\
\hline 4500 & 216.00 & 0.001152 & 21.70138889 & 0.025 \\
\hline 5000 & 240.00 & 0.00128 & 19.53125 & 0.025 \\
\hline 5500 & 264.00 & 0.001408 & 17.75568182 & 0.025 \\
\hline 6000 & 288.00 & 0.001536 & 16.27604167 & 0.025 \\
\hline 6250 & 300.00 & 0.001600000 & 15.625 & 0.025 \\
\hline 6350 & 300.00 & 0.001626231 & 15.37296735 & 0.02459 \\
\hline. &. &. & &. \\
\hline. &. &. &. &. \\
\hline 9375 & 300.00 & 0.252525253 & 0.099 & 0 \\
\hline
\end{tabular}

O mesmo problema também foi resolvido utilizando o MEF, a malha utilizada é mostrada na Figura C.5.

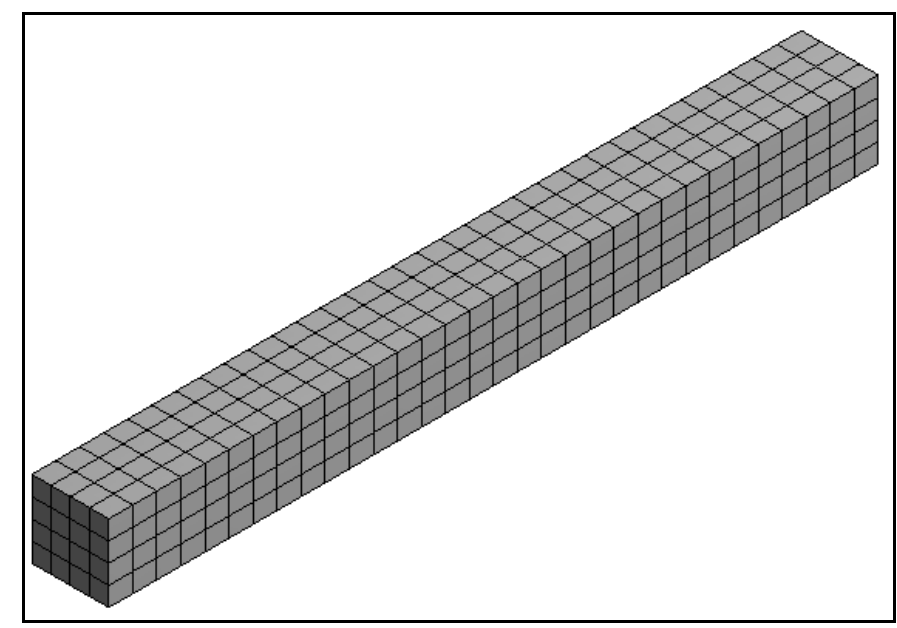

Figura C. 5: Malha utilizada para a simulação da barra. 
A Figura C.6 mostra como se comportam as tensões na barra durante a flexão, na parte superior em tração enquanto na parte inferior em compressão.

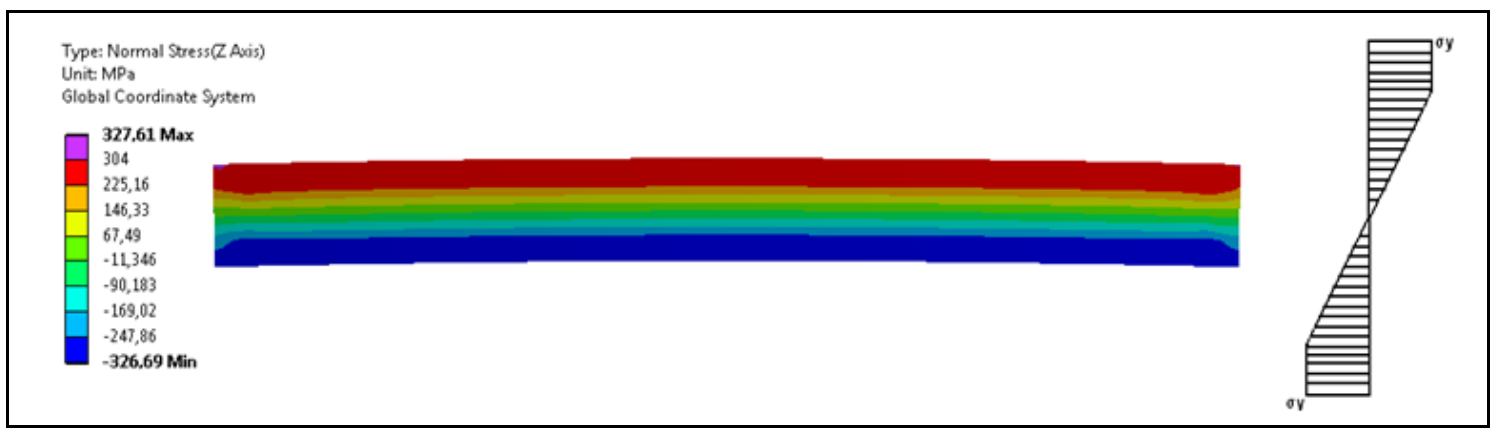

Figura C. 6: Tensões devido à flexão pura atuantes na barra para $M=8000$ N.m.

Na Figura C.7 são mostradas as deformações elásticas na barra fletida, observa-se que a deformação assume seu máximo nos extremos da seção transversal, pois a tração e compressão são maiores nessas regiões. Como as magnitudes das deformações são semelhantes excetuando seu sentido, o ANSYS representa com a mesma cor as mesmas magnitudes de deformação, ou seja, deformações iguais em módulo terão a mesma cor.
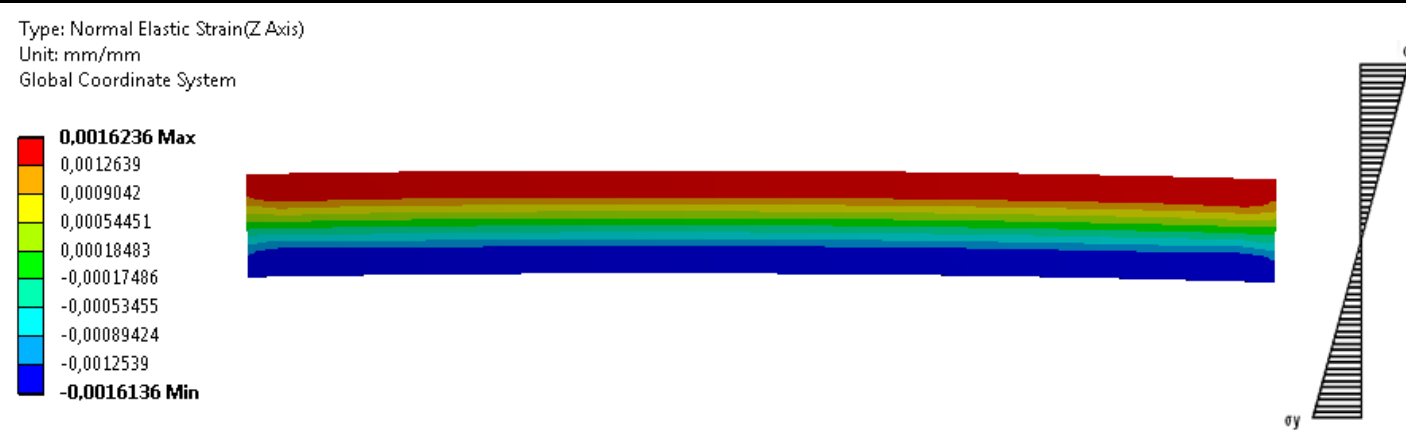

Figura C. 7: Deformações elásticas na barra em flexão.

A seguir serão apresentador os resultados obtidos pelo MEF para o problema em questão.

Tabela C. 3: Resultados obtidos pelo MEF.

\begin{tabular}{|c|c|c|c|}
\hline $\mathbf{M}(\mathbf{N . m})$ & $\mathbf{y}(\mathbf{m})$ & Deformação total & $\begin{array}{c}\text { Tensão Axial } \\
\text { Máxima (MPa) }\end{array}$ \\
\hline 6500 & 0.023515 & 0.0017 & 300 \\
\hline 7000 & 0.016089 & 0.0021 & 301 \\
\hline 8000 & 0.013366 & 0.0028 & 304 \\
\hline 9000 & 0.002723 & 0.0114 & 327 \\
\hline
\end{tabular}


Os resultados obtidos pelo MEF para o momento fletor de 8000 N.m foram plotados na Figura C.8, demonstrando o que foi proposto na Figura C.6 o núcleo elástico está sob a influência de tensões abaixo do limite de escoamento, e a partir de determinada altura, as tensões atuantes produzem deformações plásticas.

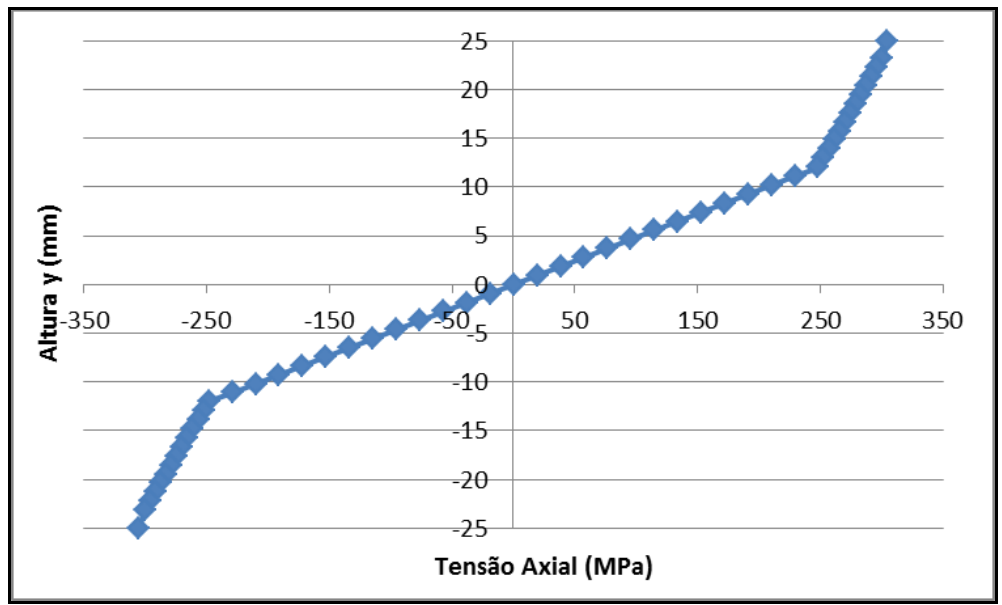

Figura C. 8: Variação da tensão em uma face em função da distância da linha neutra para um momento de 8000 N.m

Após a barra atingir a configuração mostrada na Figura C.8, ela sofre um descarregamento cuja magnitude é mostrada na Figura C.9.

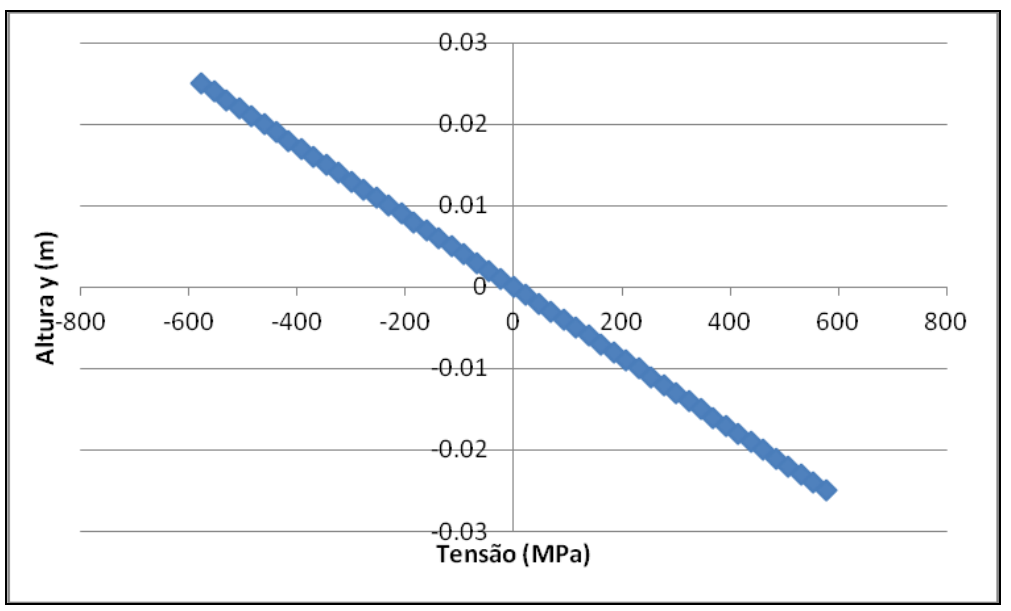

Figura C. 9: Descarregamento aplicado a barra.

Depois da aplicação do descarregamento observa-se a barra apresenta tensões residuais compressivas e trativas ao longo de sua seção transversal, Figura C.10. 
262

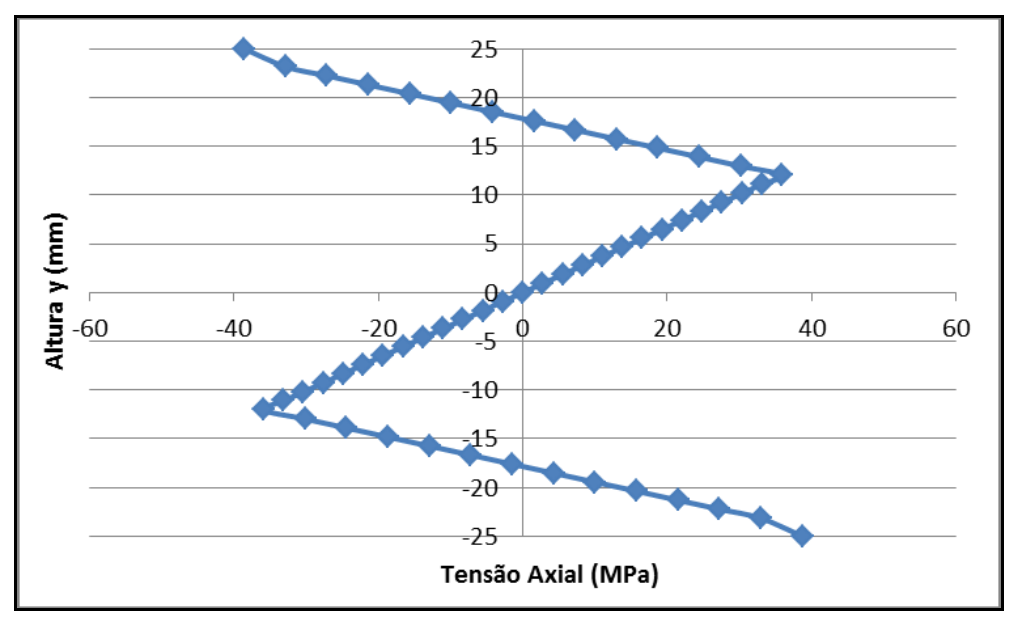

Figura C. 10: Tensões residuais na seção transversal da barra.

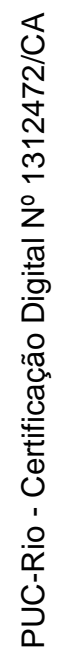




\section{Apêndice D - \\ Comparação Entre as Soluções Analítica e Numérica para o Problema das Três Barras}

Supondo que as três barras são feita do mesmo material, e que esse material tem as seguintes propriedades: limite de escoamento, $S_{\mathrm{Y}}$, igual a $250 \mathrm{MPa}$, deformação de escoamento, $\varepsilon_{Y}$, igual a $0.2 \%$, coeficiente de expansão térmica, $\alpha$, igual a $12.10^{-6}{ }^{\circ} \mathrm{C}$, modulo de elasticidade, E, igual a $200 \mathrm{GPa}$ e sua curva tensão - deformação tem um comportamento bilinear A relação entre áreas é $\mathrm{A}_{2}=2 \mathrm{~A}_{1}$ e a variação de temperatura é $500^{\circ} \mathrm{C}$.

A Figura D.1 apresenta a geometria do modelo numérico estudado.

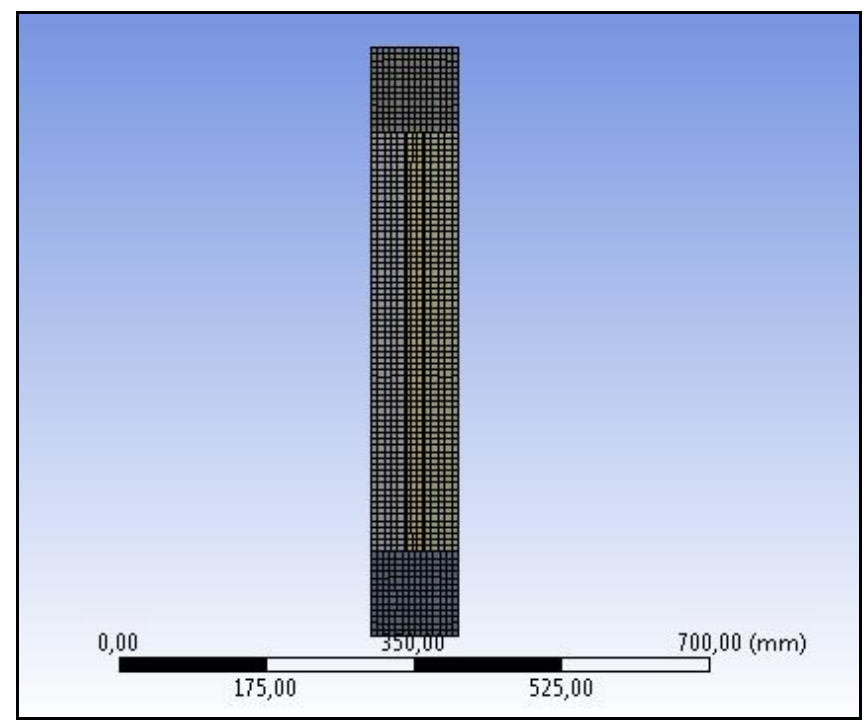

Figura D.1: Geometria do modelo numérico estudado.

Na soldagem o equilíbrio de forças é:

$$
P_{1}{ }^{\prime}+2 P_{2}{ }^{\prime}=0
$$

A compatibilidade de deformações:

$$
\alpha \cdot \Delta T=12 \cdot 10^{-6} \cdot 500=\varepsilon_{1}{ }^{\prime}+\varepsilon_{2}{ }^{\prime}
$$

A relação de áreas é:

$$
2 A_{1}=A_{2}
$$




$$
\left\{\begin{array}{c}
\sigma_{1}{ }^{\prime} \cdot A_{1}-2 \cdot \sigma_{2}{ }^{\prime} \cdot A_{2}=0 \\
\varepsilon_{Y} \cdot E \cdot A_{1}-2 \cdot \varepsilon_{2}{ }^{\prime} \cdot A_{2}=0 \quad \therefore \quad \varepsilon_{2}{ }^{\prime}=\frac{\varepsilon_{Y}}{4} \\
\varepsilon_{1}{ }^{\prime}=\varepsilon_{Y}+\Delta \varepsilon_{1}{ }^{\prime} \\
\varepsilon_{1}{ }^{\prime}+\varepsilon_{2}{ }^{\prime}=\alpha \cdot \Delta T=0.006 \\
\varepsilon_{Y}+\Delta \varepsilon_{1}{ }^{\prime}+\frac{\varepsilon_{Y}}{4}=\alpha \cdot \Delta T
\end{array}\right.
$$

Isolando o termo $\Delta \varepsilon_{1}$, , tem-se:

$$
\Delta \varepsilon_{1}{ }^{\prime}=\alpha \cdot \Delta T-\varepsilon_{Y} \cdot \frac{5}{4}
$$

Assim,

$$
\begin{gathered}
\varepsilon_{1}{ }^{\prime}=\varepsilon_{Y}+\Delta \varepsilon_{1}{ }^{\prime}=0.002+0.006-\frac{5}{4} \cdot 0.002=0.0055 \\
\varepsilon_{2}{ }^{\prime}=\frac{\varepsilon_{Y}}{4}=-0.0005
\end{gathered}
$$

Logo,

$$
\begin{gathered}
\sigma_{1}{ }^{\prime}=250 \mathrm{MPa} \\
\sigma_{2}{ }^{\prime}=-62.5 \mathrm{MPa}
\end{gathered}
$$

A Figura D.2 apresenta as tensões residuais após a soldagem no modelo numérico.

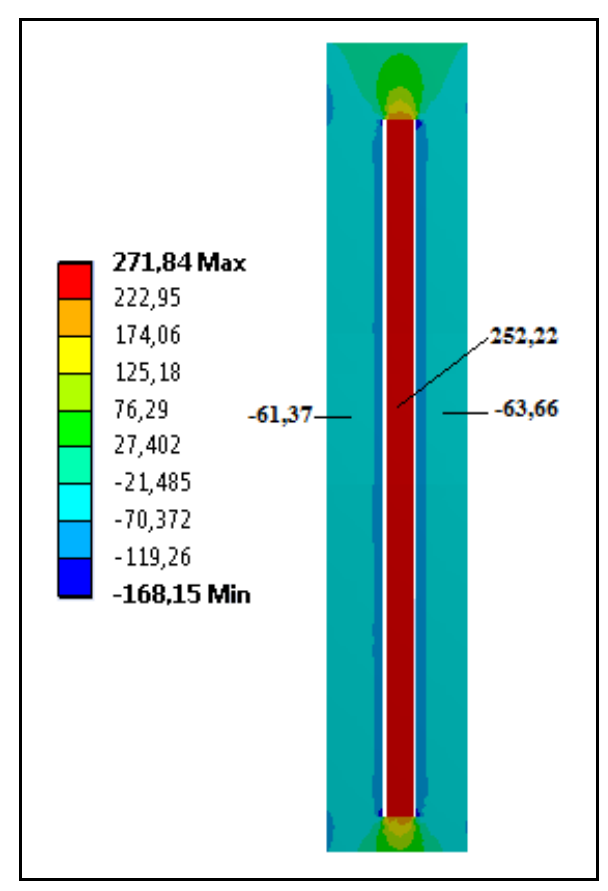

Figura D. 2: Tensões (MPa) após a soldagem calculadas numericamente. 
Aplicando um teste de alívio de tensão.

$$
\begin{gathered}
P_{e x t}=P_{1}{ }^{\prime \prime}+P_{2} "=0+P_{2}^{\prime \prime} \\
\sigma_{2}{ }^{\prime \prime}=\frac{P_{2}{ }^{\prime}}{2 A_{2}}+\sigma_{2}{ }^{\prime}=\frac{P_{e x t}}{2 A_{2}}-S_{Y} \cdot \frac{A_{1}}{2 A_{2}}=S_{Y}=250 \mathrm{MPa} \\
\Delta \varepsilon_{1}{ }^{\prime \prime}=\Delta \varepsilon_{2}{ }^{\prime \prime}=\frac{5}{4} \cdot \varepsilon_{Y}=0.0025 \\
\varepsilon_{2}{ }^{\prime \prime}=\varepsilon_{2}{ }^{\prime}+\Delta \varepsilon_{2}{ }^{\prime}=0.002=\varepsilon_{Y}
\end{gathered}
$$

Logo,

$$
\sigma_{2}{ }^{\prime \prime}=250 M P a
$$

$\mathrm{e}$

$$
\varepsilon_{1} "=0.0055+0.0025=0.0080
$$

Assim,

$$
\sigma_{1}{ }^{\prime \prime}=250 M P a
$$

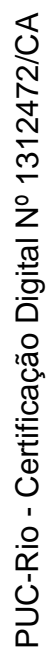

A Figura D.3 apresenta as tensões nas três barras durante a aplicação do teste de alívio de tensões no modelo numérico.

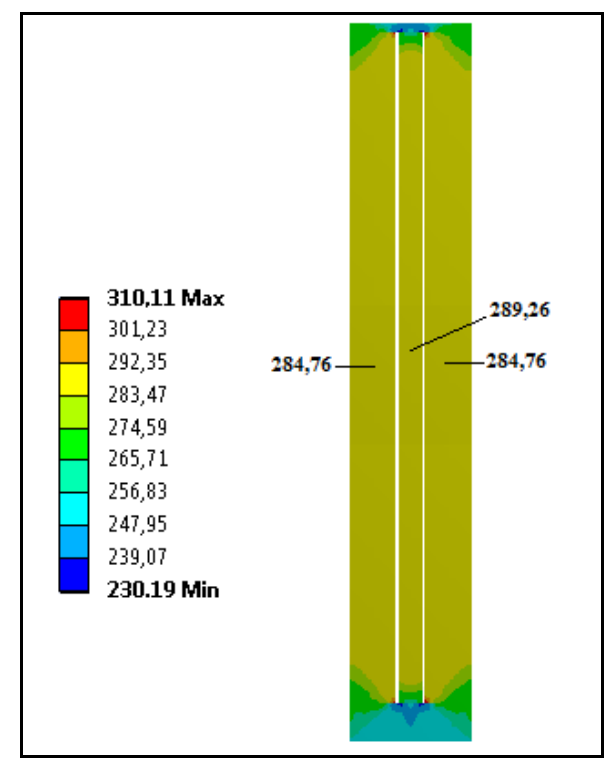

Figura D. 3: Tensões (MPa) durante a aplicação do teste de alívio de tensões no modelo numérico.

Descarregando elasticamente a força do teste de alívio, tem-se:

$$
P_{\text {desc }}=P_{e x t}=P_{\text {desc } 1}+P_{\text {desc } 2}
$$

O descarregamento ocorre segundo iguais deslocamentos (deformações iguais): 


$$
\begin{gathered}
\Delta \varepsilon_{\text {desc } 1}=\Delta \varepsilon_{\text {desc } 2} \\
\frac{\sigma_{\text {desc } 1}}{E}=\frac{\sigma_{\text {desc } 2}}{E} \rightarrow \frac{P_{\text {desc } 1}}{A_{1} \cdot E}=\frac{P_{\text {desc } 2}}{2 \cdot A_{2} \cdot E}
\end{gathered}
$$

Isolando o termo $\mathrm{P}_{\text {desc } 1}$,

$$
\begin{gathered}
P_{\text {desc } 1}=\frac{P_{\text {desc } 2}}{4} \\
P_{\text {desc }}=S_{Y} \cdot 2 A_{2}\left[1+\frac{A_{1}}{2 A_{2}}\right]=P_{d e s c 1}+P_{d e s c 2}=P_{d e s c 2} \cdot \frac{5}{4} \\
\therefore P_{d e s c 2}=4 \cdot S_{Y} \cdot A_{1} \\
\therefore P_{d e s c 1}=S_{Y} \cdot A_{1}
\end{gathered}
$$

Assim,

$$
\begin{aligned}
& \therefore \sigma_{\text {desc } 2}=S_{Y}=250 M P a \rightarrow \Delta \varepsilon_{\text {desc } 1}=\frac{S_{Y}}{E}=0.00125 \\
& \therefore \sigma_{d e s c 1}=S_{Y}=250 M P a \rightarrow \Delta \varepsilon_{\text {desc } 2}=\frac{S_{Y}}{E}=0.00125
\end{aligned}
$$

Então,

$$
\begin{aligned}
& \sigma_{2}{ }^{\prime \prime \prime}=0 M P a \rightarrow \varepsilon_{1}{ }^{\prime \prime \prime}=0.00675 \\
& \sigma_{1}{ }^{\prime \prime \prime}=0 M P a \rightarrow \varepsilon_{2}{ }^{\prime \prime \prime}=0.00075
\end{aligned}
$$

A Figura D.4 apresenta as tensões no modelo numérico após o descarregamento elástico.

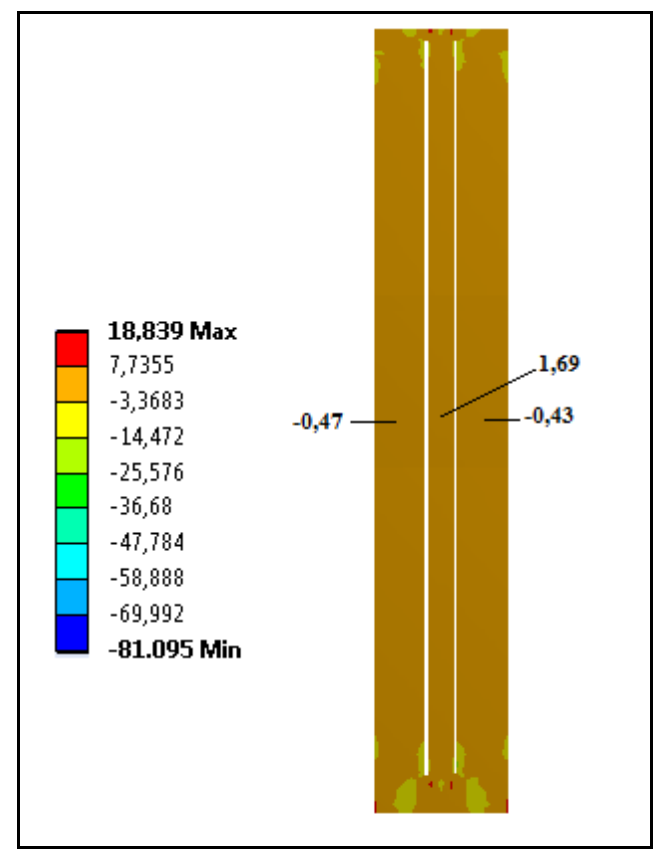

Figura D. 4: Tensões (MPa) após o descarregamento elástico 


\section{Apêndice E - \\ Soldagem de um vaso de pressão considerando uma curva bilinear e um gradiente de temperatura pequeno}

No Capítulo 7 foi simulado o comportamento de um vaso de pressão após a sua fabricação, para essa simulação a curva tensão - deformação foi considerada multilinear e variável com a temperatura. Nesse apêndice será estudado o comportamento do mesmo vaso, mas, no entanto será usada para a simulação uma curva tensão - deformação bilinear com a aplicação de um gradiente de temperatura pequeno, que é capaz de causar deformações plásticas.

As configurações desse modelo são as mesmas apresentadas no Capítulo 7, a geometria do vaso, a malha e a pressão do teste hidrostático são os mesmo. Na Figura E.1 é apresentada a curva do material.

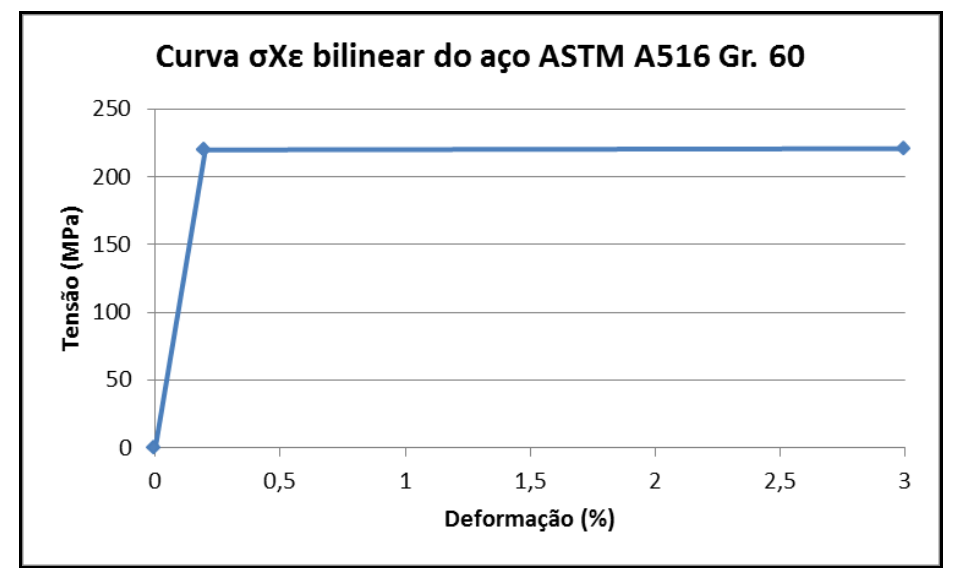

Figura E. 1: Curva tensão-deformação bilinear do material.

As soldagens foram simuladas diretamente como carregamentos térmicos, em uma análise estrutural estática. Todas as juntas soldadas foram simuladas utilizando a hipótese das três barras, não tendo sido considerados os efeitos da velocidade de soldagem e a influência de múltiplos passes de solda nas juntas. Após a soldagem do vaso, foi realizado um teste hidrostático, A pressão de teste hidrostático foi determinada igual $1.874 \mathrm{MPa}$. 
Foram usados 10 passos de tempo para a realização da análise, os primeiros 7 passos representaram os processos de soldagem, realizados em três etapas diferentes e relativas aos cordões de soldas 1 a 5,6 a 9 e 10 a 11. Os três últimos eventos de tempo se referem ao teste hidrostático. A Tabela E.1 correlaciona cada passo de tempo com sua duração e com o evento que ocorre nele para cada hipótese diferente.

Tabela E. 1: Duração de cada passo de tempo.

\begin{tabular}{|c|c|c|c|}
\hline Passo & Duração (s) & $\begin{array}{c}\text { Tempo ao Final do } \\
\text { Passo (s) }\end{array}$ & Evento \\
\hline $1^{0}$ & 1 & 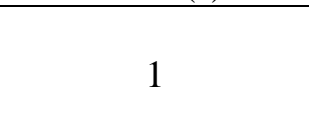 & $\begin{array}{l}\text { Deposição dos cordões } \\
\text { nas juntas } n^{0} 1,2,3,4 \\
\text { e } 5\end{array}$ \\
\hline $2^{0}$ & 1 & 2 & \multirow[t]{2}{*}{ 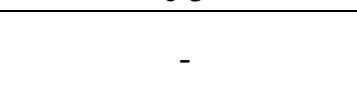 } \\
\hline $3^{0}$ & 1 & 3 & \\
\hline $4^{0}$ & 1 & 4 & $\begin{array}{c}\text { Deposição dos cordões } \\
\text { nas juntas n }{ }^{0} 6,7, \\
8 \text { e } 9\end{array}$ \\
\hline $5^{0}$ & 1 & 5 & \multirow{2}{*}{$x_{1}$} \\
\hline $6^{0}$ & 1 & 6 & \\
\hline $7^{0}$ & 1 & 7 & $\begin{array}{c}\text { Deposição dos cordões } \\
\text { nas juntas } n^{0} 10 \text { e } 11\end{array}$ \\
\hline $8^{0}$ & 1 & 8 & Início do TH \\
\hline $9^{0}$ & 1 & 9 & $\begin{array}{c}\text { Pressão Máxima do } \\
\text { TH }\end{array}$ \\
\hline $10^{0}$ & 1 & 10 & Final do TH \\
\hline
\end{tabular}

Essa análise não tem uma parte térmica, o estudo do comportamento mecânico do vaso de pressão é realizado apenas em uma análise estrutural estática. Os cordões de solda são simulados como se fossem carregamentos de temperatura na análise estrutural, cada cordão de solda é aquecido, em um passo de tempo, até uma temperatura de $500^{\circ} \mathrm{C}$ e depois resfriado até a temperatura ambiente também em um passo de tempo.

As deformações surgem em consequência ao comportamento elastoplástico do material. Não foram simulados os suportes do vaso, entretanto utilizou-se a opção de "Weak Springs", que impede o movimento de corpo rígido. Nos três últimos passos ocorre o teste hidrostático, sendo a pressão máxima atingida no passo do meio. Foi utilizada a pressão de alívio igual a $130 \%$ da pressão de projeto. 
As tensões residuais que surgem nessa análise são consequência do equilíbrio de deformações que deve haver quando se aplica um gradiente térmico que provoca deformações plastificas, como mostrado no item 4.5 do Capítulo 4 .

A Figura E.2 apresenta as distribuições das tensões residuais no vaso após a soldagem de fabricação, no instante de 8 s.

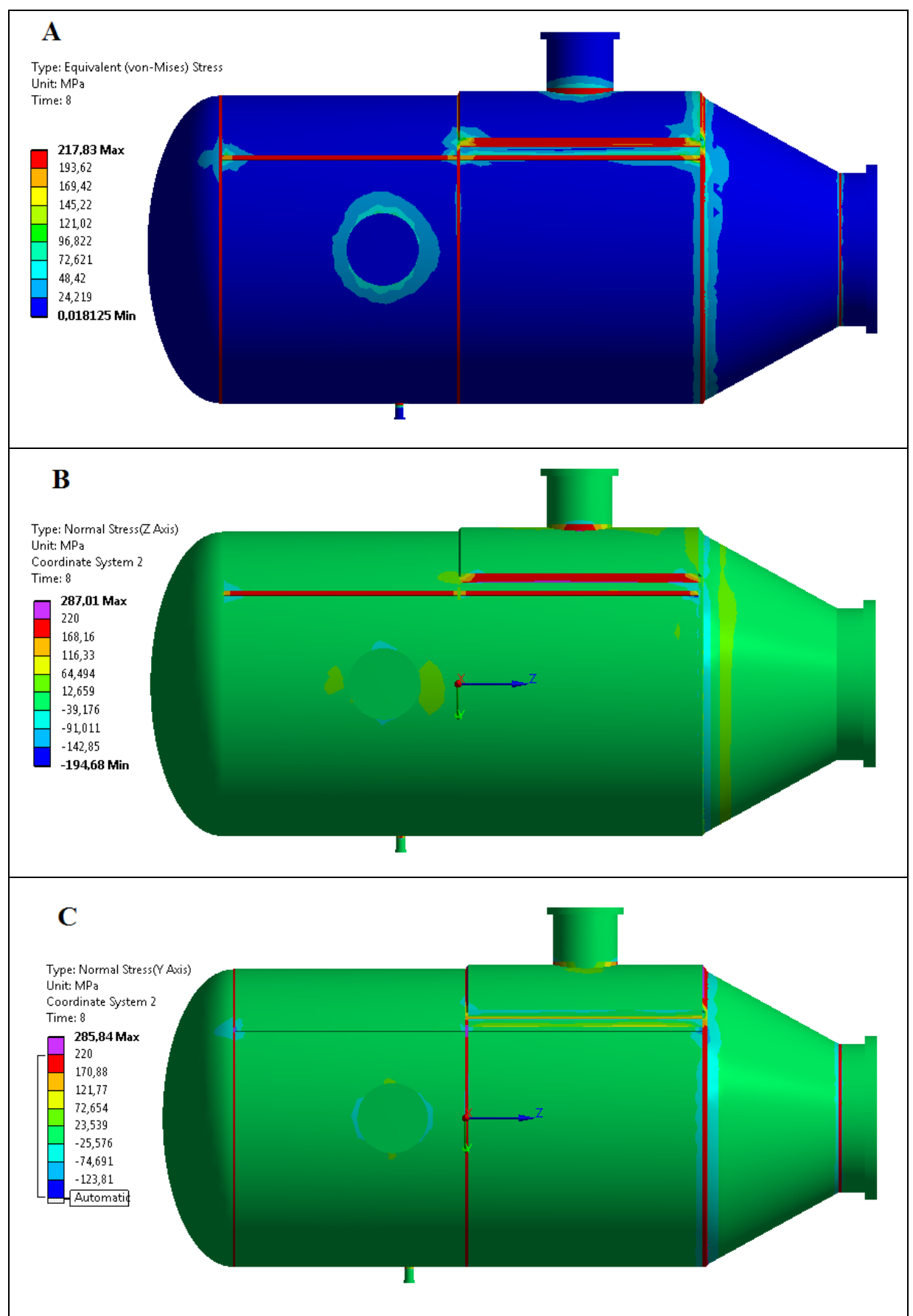

Figura E. 2: Distribuição de tensões residuais: a)Tensões equivalentes; b) Tensões longitudinais; c) Tensões circunferenciais. 
A tensão residual equivalente, Figura E.2a, nos cordões de solda tem magnitude similar ao limite de escoamento do material bilinear. As distorções nas bordas dos cordões provocam mudanças no comportamento das tensões nessas regiões.

As tensões residuais longitudinais e circunferenciais após a soldagem são similares no sentido de que são trativas na superfície dos cordões na direção da maior restrição a deformação, apresentando valores semelhantes ao limite de escoamento do material.

Como os gradientes térmicos nessa análise são localizados e tem curta duração, 1s, o calor não se difunde pelo vaso, as tensões residuais que surgem são localizadas, nas regiões das juntas.

As tensões na direção radial são pequenas e podem ser desprezadas. A contração nessa direção é muito pequena não influenciando no comportamento do vaso.

A Figura E.3 apresenta as distribuições das tensões residuais no vaso ao longo do Caminho 1 após a soldagem de fabricação no instante de 8s.

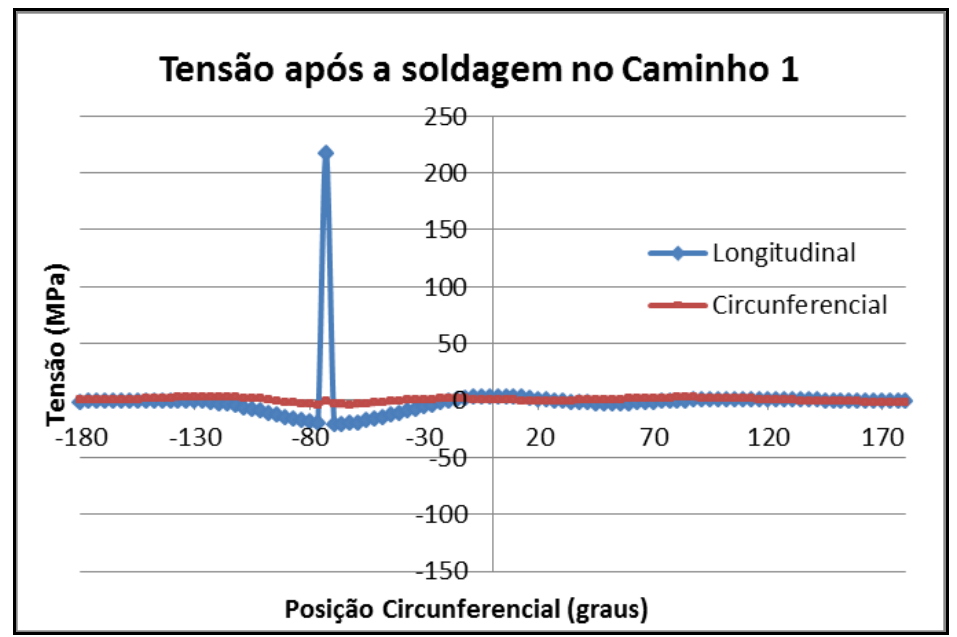

Figura E. 3: Distribuição de tensões residuais no Caminho $1 \mathrm{em} \mathrm{8s.}$

O Caminho 1 corta a junta 1 na posição de -73 graus. Nessa posição a tensão residual longitudinal é máxima trativa, e as tensões nas adjacências são compressivas. As tensões residuais circunferenciais têm magnitudes baixas, variando numa faixa de -4 a $3 \mathrm{MPa}$. 
Após o término das soldagens é aplicado no vaso um teste hidrostático. A pressão de teste é igual a 1.874 MPa. A Figura E.4 apresenta as distribuições de tensões equivalentes no vaso durante a realização do teste hidrostático com pressão igual a $130 \%$ da pressão de projeto.

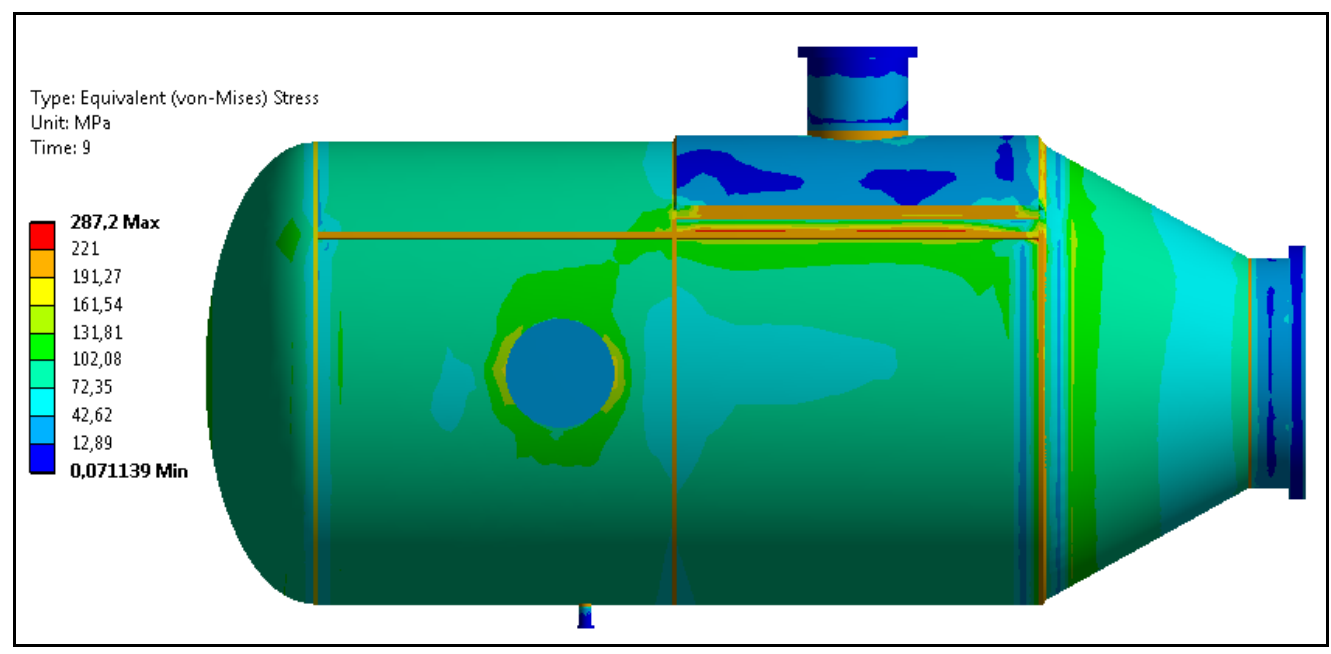

Figura E. 4: Distribuição de tensões residuais equivalentes no vaso durante a realização do $\mathrm{TH}$.

Durante o teste hidrostático a influência da pressão nas demais direções fora a circunferencial é muito pequena; nas regiões nominais do costado cilíndrico o teste hidrostático causa tensões circunferenciais que são duas vezes maiores que as longitudinais.

A Figura E.5 apresenta as distribuições de tensões ao longo do Caminho 1 do vaso durante a realização do teste hidrostático.

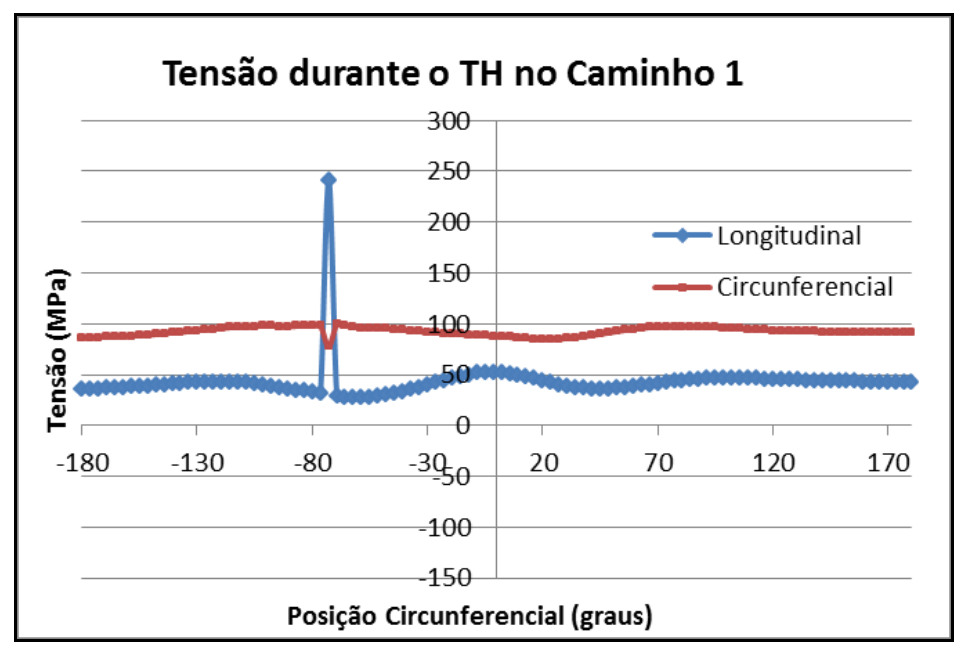

Figura E. 5: Tensões no vaso durante a realização do teste hidrostático. 
Na Figura E.6 são comparadas as distribuições das tensões residuais antes da realização do teste hidrostático e após a despressurização e fim do alívio de tensões no Caminho 1.

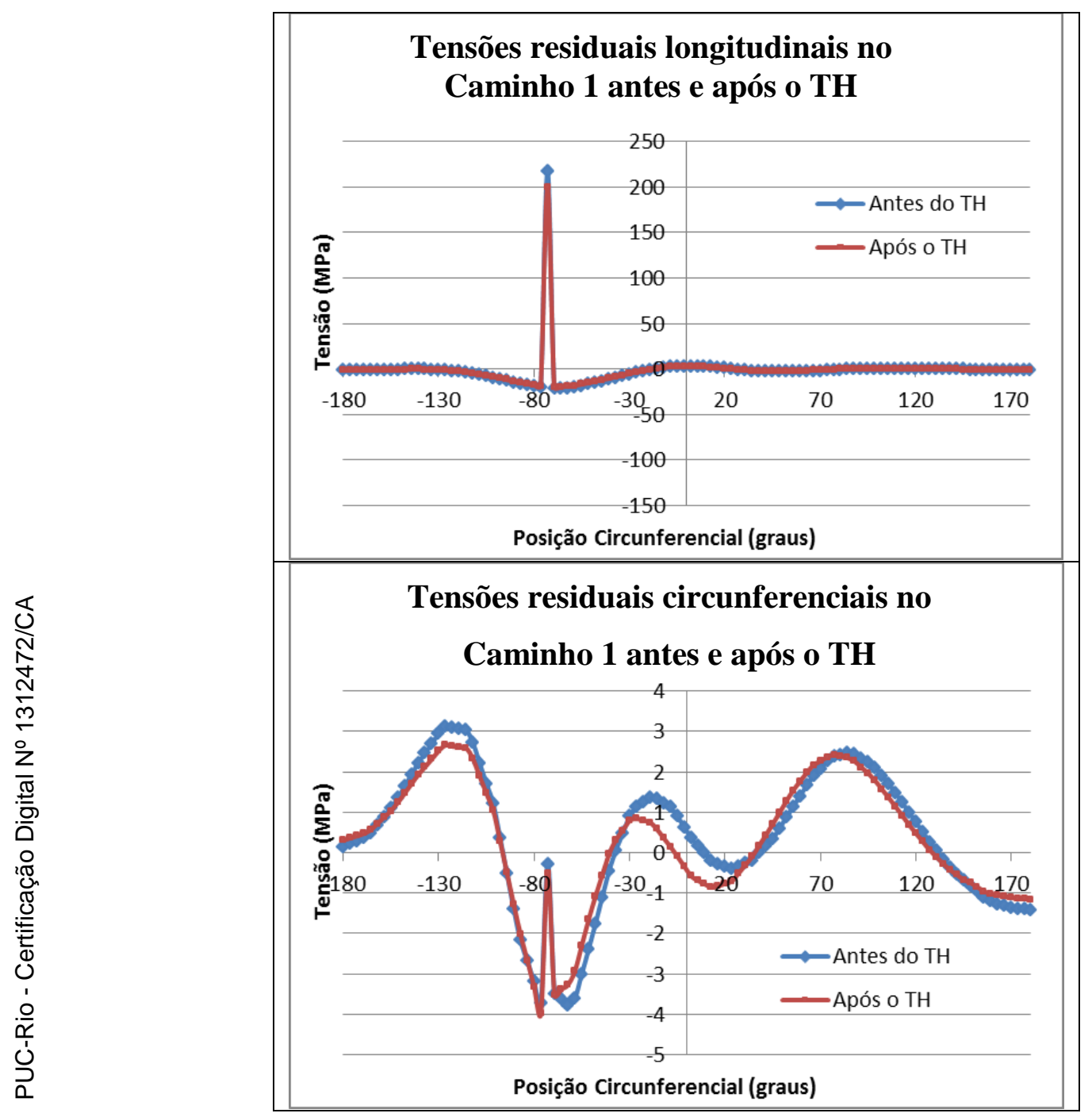

Figura E. 6: Comparação da distribuição de tensões residuais antes e após a realização do TH.

$\mathrm{Na}$ Figura E.7 é apresentada as distribuições das tensões residuais equivalentes após a realização do teste hidrostático. 


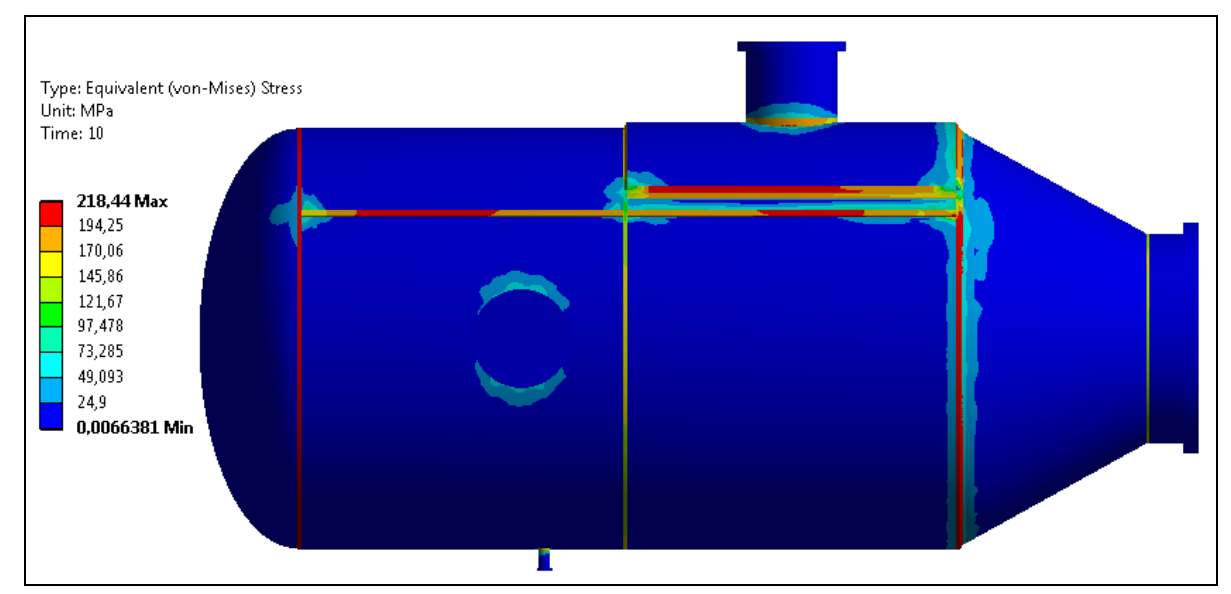

Figura E. 7: Distribuição de tensões residuais equivalentes no vaso após o TH.

Analisando a Figura E.7, observa-se o alívio de tensões é maior nas juntas circunferenciais do que nas longitudinais, no entanto nem todas as juntas circunferenciais sofrem um alívio considerável após a realização do teste hidrostático. Devido à compatibilidade de deslocamentos, que deve existir no vaso durante a pressurização, as tensões nas juntas 6 e 8, regiões de mudança de geometria, não sofrem alteração, continuando as mesma anteriores ao teste hidrostático.

A Tabela E.2 apresenta as tensões residuais antes, durante e após a realização do teste de alívio de tensões nos pontos estudados. As tensões circunferenciais e longitudinais nos pontos localizados nos costados cilíndrico e cônico do vaso foram: direção circunferencial é a direção tangente ao diâmetro do vaso; direção longitudinal é a direção do eixo longitudinal do vaso. As tensões circunferenciais e longitudinais nos pontos localizados nos bocais foram analisadas segundo o seguinte sistema de eixos de referência: direção circunferencial é a direção tangente ao diâmetro do bocal; direção longitudinal é a direção do eixo longitudinal do bocal. 
Tabela E. 2: Tensões nos pontos estudados.

\begin{tabular}{|c|c|c|c|c|c|c|}
\hline \multirow{2}{*}{ Instante } & \multicolumn{2}{|c|}{$\begin{array}{c}\text { Após a } \\
\text { Soldagem }\end{array}$} & \multicolumn{2}{c|}{ Durante o TH } & \multicolumn{2}{c|}{ Após o TH } \\
\hline Ponto/Tensão (MPa) & Circ. & Long. & Circ. & Long. & Circ. & Long. \\
\hline P1 & 0.15 & 217.75 & 78.52 & 242.78 & -0.07 & 196.09 \\
\hline P2 & 6.01 & 202.85 & 102.65 & 249.79 & 5.76 & 197.45 \\
\hline P3 & 212.46 & -2.91 & 212.64 & -3.49 & 192.41 & 3.75 \\
\hline P4 & 192.82 & -42.93 & 231.32 & 31.68 & 128.41 & -34.44 \\
\hline P5 & 199.51 & -28.82 & 221.91 & 6.07 & 161.12 & -18.59 \\
\hline P6 & 204.53 & -22.23 & 215.9 & -4.86 & 151.70 & -9.98 \\
\hline P7 & 182.8 & -53.24 & 191.84 & -42.35 & 136.45 & -30.86 \\
\hline P8 & 177.69 & -60.78 & 232.6 & 38.64 & 38.03 & -21.38 \\
\hline P9 & 209.58 & -15.35 & 196.23 & 23.11 & 209.56 & -15.38 \\
\hline P10 & 209.50 & -15.47 & 234.32 & 37.11 & 141.66 & -10.48 \\
\hline P11 & 199.76 & -30.86 & 140.84 & -99.75 & 194.20 & -29.04 \\
\hline P12 & 206.68 & -19.97 & 234.62 & 39.75 & 144.69 & -13.28 \\
\hline P13 & -14.83 & 204.56 & 2.54 & 216.04 & -11.53 & 189.72 \\
\hline P14 & 219.88 & -2.58 & 219.47 & -2.22 & 184.02 & -1.66 \\
\hline
\end{tabular}

Analisando a tabela acima, pode se verificar que os pontos P1, P2 e P13 apresentam tensões residuais longitudinais após a soldagem com valores próximos ao limite de escoamento do material devido à restrição a expansão nessa direção. Analogamente, os pontos P3, P4, P5, P6, P7, P6, P7, P8, P9, P10, P11, P12 e P14 apresentam tensões circunferenciais com valores próximos ao limite de escoamento do material, pois a restrição à expansão nesses pontos se dá na orientação circunferencial.

Com a aplicação do teste hidrostático há uma alteração nos estados de tensão do vaso, as regiões do vaso tem um acréscimo de deformações trativas. Após a despressurização do vaso as tensões residuais são redistribuídas em novos estados de equilíbrio. Os pontos P9 e P11 não sofrem variações em seus valores de tensões residuais, sendo que esse comportamento se deve as flexões que existem nessas regiões, que tem por finalidade manter a compatibilidade de deslocamentos nas regiões com transição de geometria. Assim, mesmo com a aplicação de um alívio de tensões esse pontos mantem seu valores de tensões residuais inalterados, independente da pressão de teste aplicada. As juntas mais críticas para análise da vida à fadiga são aquelas localizadas em regiões onde a geometria do vaso é variável. 
Os demais pontos localizados em juntas circunferências apresentam uma redução do nível de tensões residuais circunferências em torno de $23 \%$, enquanto que a redução das magnitudes nos pontos situados em juntas longitudinais é de apenas $6 \%$. O teste hidrostático tem pouca influência em outras direções fora a circunferencial, como mostrado na Figura E.8.

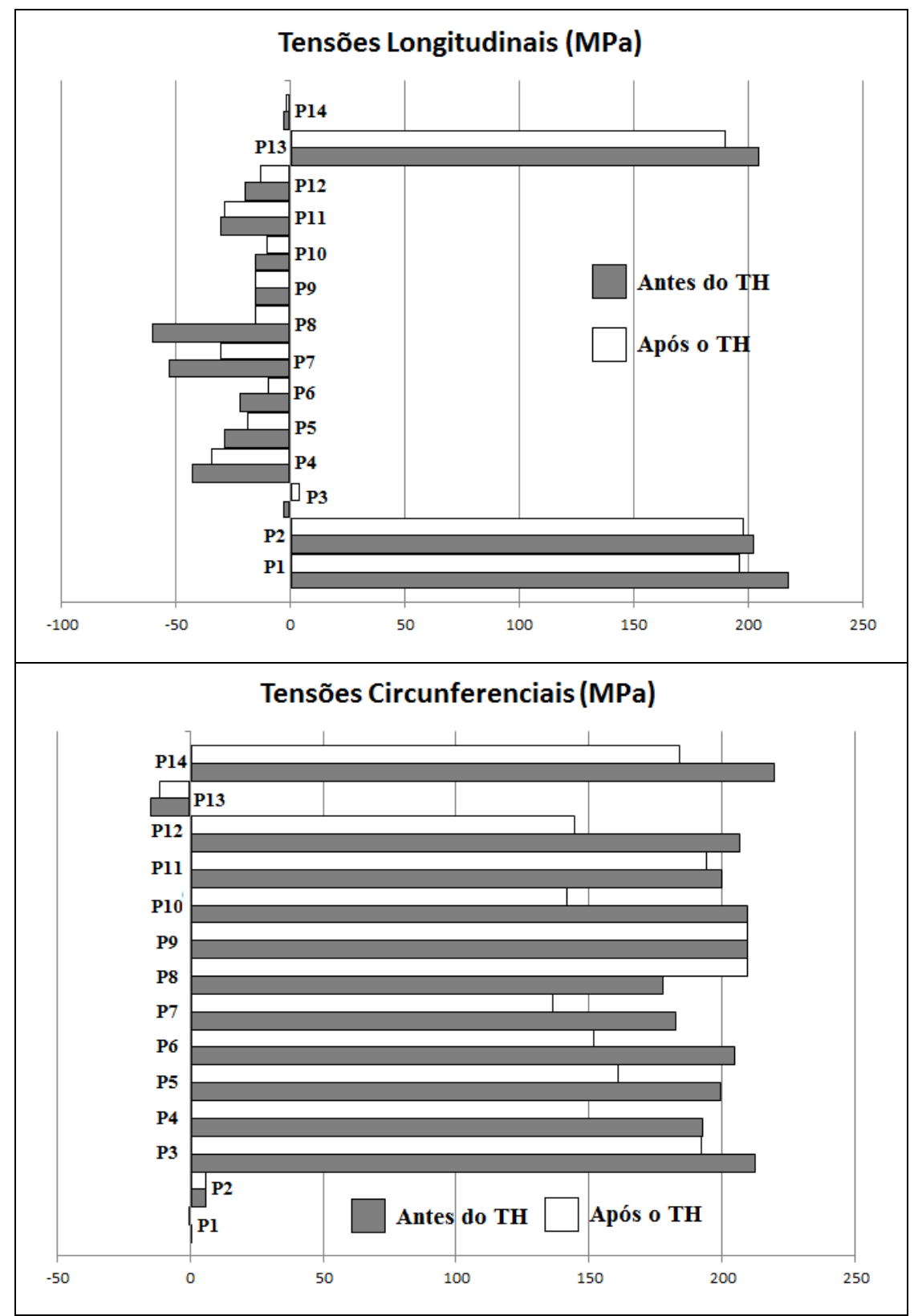

Figura E. 8: Comparação entre as tensões residuais nos pontos estudados antes e após o TH. 